\title{
Numeričko modeliranje međudjelovanja konstrukcije i tekućine kombinacijom metode konačnih elemenata i hidrodinamike izglađenih čestica
}

Sunara Kusić, Marina

Doctoral thesis / Disertacija

2017

Degree Grantor / Ustanova koja je dodijelila akademski / stručni stupanj:

University of Split, Faculty of Civil Engineering, Architecture and Geodesy / Sveučilište u Splitu, Fakultet građevinarstva, arhitekture i geodezije

https://doi.org/10.31534/DocT.042.SunM

Permanent link / Trajna poveznica: https://urn.nsk.hr/urn:nbn:hr:123:860053

Rights / Prava: In copyright/Zaštićeno autorskim pravom.

Download date / Datum preuzimanja: 2023-04-26

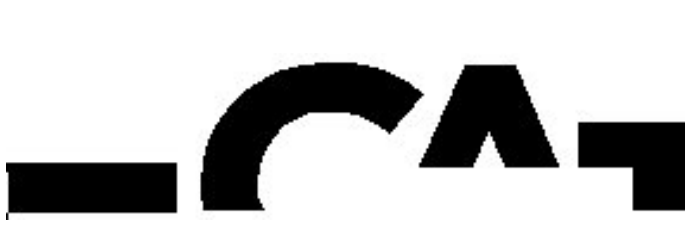

Repository / Repozitorij:

FCEAG Repository - Repository of the Faculty of Civil Engineering, Architecture and Geodesy, University of Split

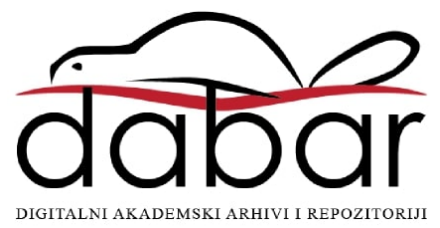




\section{$-\mathrm{CA}_{1}$ \\ SVEUČILIŠTE U SPLITU}

\section{FAKULTET GRAĐEVINARSTVA, ARHITEKTURE I GEODEZIJE}

Marina Sunara Kusić, mag.ing.aedif.

NUMERIČKO MODELIRANJE MEĐUDJELOVANJA KONSTRUKCIJE I TEKUĆINE KOMBINACIJOM METODE KONAČNIH ELEMENATA I HIDRODINAMIKE IZGLAĐENIH ČESTICA

$D$ i s e r t a c i j a

Split, 2017. 
Marina Sunara Kusić, mag.ing.aedif.

Redni broj: 042

Ova disertacija predana je na ocjenu Fakultetu građevinarstva, arhitekture i geodezije Sveučilišta u Splitu u svrhu stjecanja akademskog stupnja doktora tehničkih znanosti u znanstvenom polju građevinarstvo.

Mentor:

Komentor:

Povjerenstvo za ocjenu:

Doc.dr.sc. Davor Bojanić

Prof. dr. sc. Zoran Milašinović

Prof. dr. sc. Violeta Mirčevska

Prof. dr. sc. Jure Radnić

Prof. dr. sc. Alen Harapin 


\section{Povjerenstvo za obranu:}

Doc.dr.sc. Davor Bojanić.

Prof. dr. sc. Zoran Milašinović

Prof. dr. sc. Violeta Mirčevska

Prof. dr. sc. Jure Radnić

Prof. dr. sc. Alen Harapin

Rad je obranjen dana: 29. svibnja, 2017.

Tajnica:

Saša Delić, dipl.iur. 


\section{Rad sadrži:}

178 stranica teksta

143 crteža

10 tablica

138 citiranih referenci 
Mojoj obitelji 
Ovom prigodom izražavam iskrenu zahvalnost:

mentoru prof. dr. sc. Alenu Harapinu za ukazano povjerenje, motivaciju, voditeljstvo $i$ nesebičnu pomoć koja je znatno doprinijela završetku ove disertacije,

komentoru prof. dr. sc. Juri Radniću za podršku, korisne savjete i pomoć tijekom izrade ove disertacije, a posebno pri provedbi eksperimentalnih ispitivanja,

članovima povjerenstva doc. dr. sc. Davoru Bojaniću, prof. dr. sc. Zoranu Milašinoviću i prof. dr. sc. Violeti Mirčevskoj za strpljivo čitanje disertacije i korisne savjete,

kolegicama dr. sc. Mariji Zulim i Tatjani Bojanić na uloženom trudu pri čitanju disertacije, te kolegama doc. dr. sc. Nikoli Grgiću, Anti Buzovu i Ivanu Banoviću za pomoć pri provedbi eksperimentalnih ispitivanja,

i na kraju najveću i neizrecivu zahvalnost dugujem svom suprugu Ivanu, majci Mirjani, ocu Damiru, sestri Mireli i svim prijateljima na podršci i vjeri u moj uspjeh. 
Marina Sunara Kusić, mag.ing.aedif.

\section{NUMERIČKO MODELIRANJE MEĐUDJELOVANJA KONSTRUKCIJE I TEKUĆINE KOMBINACIJOM METODE KONAČNIH ELEMENATA I HIDRODINAMIKE IZGLAĐENIH ČESTICA}

\section{Sažetak}

U okviru ovoga rada razvijen je 3D numerički model za međudjelovanje konstrukcije i tekućine u uvjetima dinamičkog opterećenja. Model se zasniva na pristupu sa zasebnim rješenjima, kod kojega se konstrukcija i tekućina rješavaju odvojeno i različitim metodama. Za analizu konstrukcije korišten je prethodno razvijeni model zasnovan na metodi konačnih elemenata (eng. finite element method - FEM), koji je poboljšan uvođenjem rotacijske krutosti degeneriranog izoparametrijskog konačnog elementa ljuske. $\mathrm{Za}$ analizu tekućine korišten je prethodno razvijeni model zasnovan na metodi hidrodinamike izglađenih čestica (eng. smoothed particle hydrodynamics - SPH), koji je poboljšan uvođenjem dodatne korekcije tlakova tekućine uz rub računalne domene Razvijeni model je primarno namijenjen simulaciji čeličnih konstrukcija koje se mogu opisati elementima ljuske (vodotornjevi, rezervoari i dr.). Modelom je moguće opisati glavne nelinearne značajke konstrukcijskog čelika: tečenje (popuštanje) u tlaku i vlaku i razvoj plastičnosti. Moguće je adekvatno simulirati i osnovne nelinearne karakteristike tekućine (stišljivost, viskoznost i turbulencija). U okviru rada provedena su $\mathrm{i}$ eksperimentalna ispitivanja međudjelovanja otvorenog pravokutnog rezervoara $i$ vode na potresnoj platformi. Eksperimentalna ispitivanja su dala doprinos dodatnim spoznajama o stvarnom ponašanju ljuskastih konstrukcija koje su u doticaju s tekućinom i izložene različitim dinamičkim opterećenjem. Osim toga, stvorena je eksperimentalna baza podataka za provjeru razvijenog numeričkog modela. Numerički testovi provedeni pomoću razvijenog numeričkog modela prikazuju njegovu pouzdanost i mogućnost primjene. Provjera modela izvršena je na primjeru rezultata eksperimentalnih testova provedenih $\mathrm{u}$ okviru rada, ali i numeričkih i eksperimentalnih rezultata iz dostupne literature. Na kraju su navedeni najvažniji zaključci provedenih istraživanja.

Ključne riječi: Numerički model, međudjelovanje konstrukcije i tekućine, dinamičko opterećenje, potres, eksperiment, potresna platforma. 
Marina Sunara Kusić, mag.ing.aedif.

\section{NUMERICAL MODELING OF FLUID STRUCTURE INTERACTION WITH COMBINED FINITE ELEMENT METHOD AND SMOOTHED PARTICLE HYDRODYNAMISC}

\section{Summary}

Within this paper, a 3D numerical model for the fluid structure interaction under dynamic load, has been developed. Partitioned approach has been used, where the construction and fluid are solved separately and by different methods. For the analysis of construction, a previously developed model based on the finite element method (FEM) has been used, which was improved by introducing the drilling stiffness of the degenerated isoparametric final element of the shell. For the analysis of fluid, a previously developed model based on the method of smoothed particle hydrodynamics (SPH) has been used, which was improved by introducing additional correction of fluid pressures values along the boundaries of the computer domain. The model is primarily developed for simulation of steel structures that can be described by shell elements (water tanks, reservoirs, etc.). The model can be used to describe the main nonlinear characteristics of the construction steel: flow (yield) under compression and tension and evolvent of plasticity. It is also possible to simulate the basic nonlinear characteristics of the fluid (compressibility, viscous flow and turbulence). Experimental investigations of the interaction of open rectangular reservoirs and water on the shake table were performed within this paper. Experimental investigations have contributed to additional knowledge of the real behaviour of shell structures that are in contact with the fluid and exposed to different dynamic loads. In addition, an experimental database for verification of the developed numeric model was created. Numerical tests performed by using a developed numerical model show its reliability and application. Model verification was performed on the example of the results of the experimental investigations performed within the paper but also from the numerical and experimental results from available literature. Finally, the most important conclusions of the conducted investigations are listed.

Keywords: Numerical model, fluid structure interaction, dynamic load, earthquake, experiment, shake table. 


\section{SADRŽAJ}

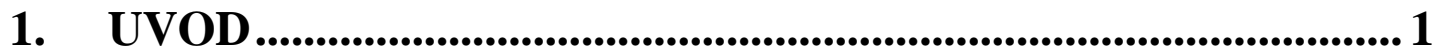

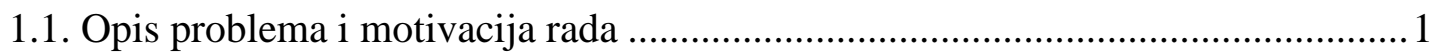

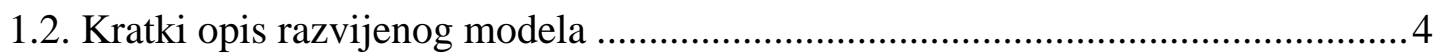

1.3. Pregled literature iz područja istraživanja .......................................................6

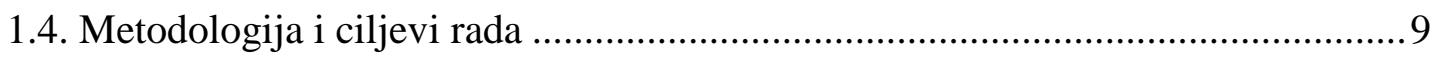

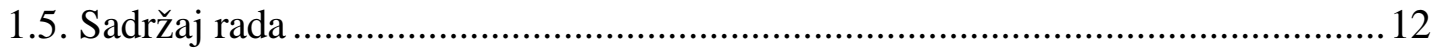

2. NUMERIČKI MODEL ZA KONSTRUKCIJU ............................ 14

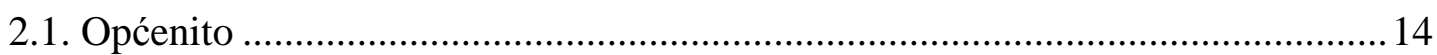

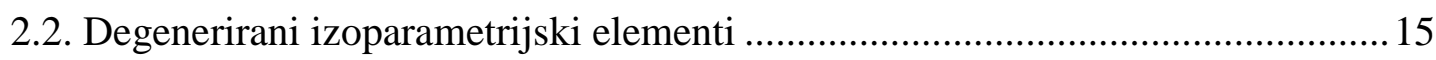

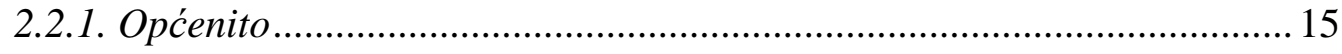

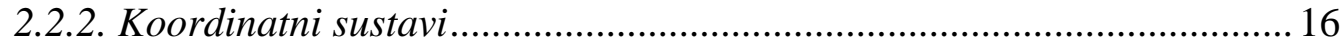

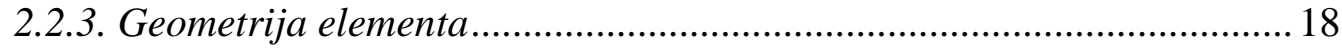

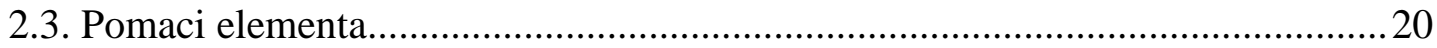

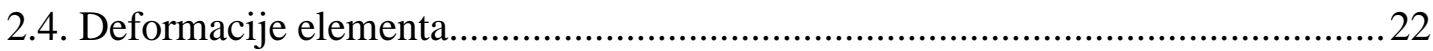

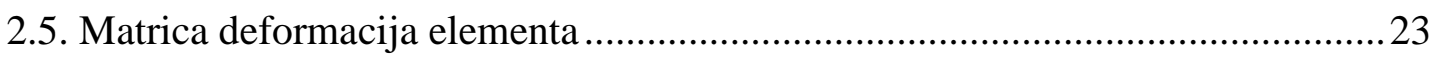

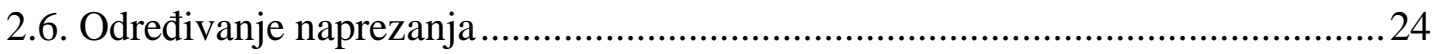

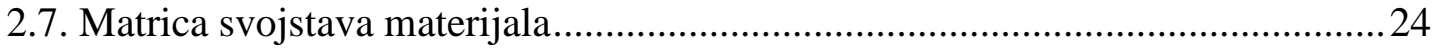

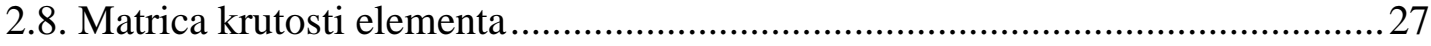

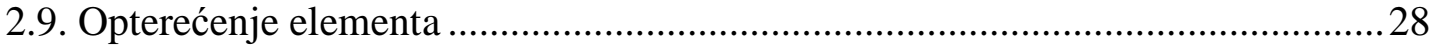

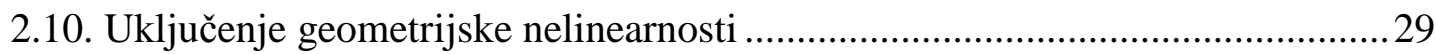

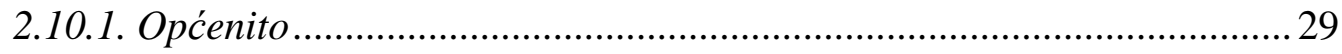

2.10.2. Postupak uključivanja geometrijske nelinearnosti .............................. 29

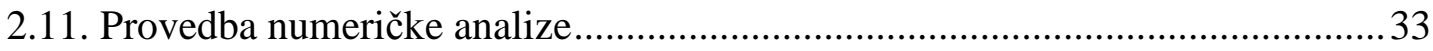

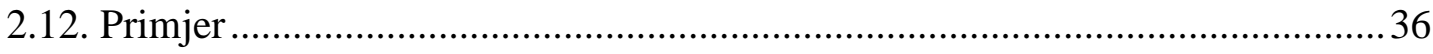

3. NUMERIČKI MODEL ZA TEKUĆINU ......................................... 40

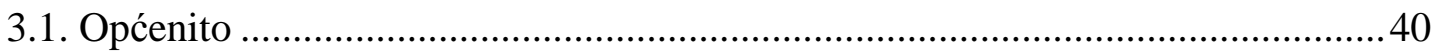

3.2. Osnova metode hidrodinamike izglađenih čestica ..........................................41

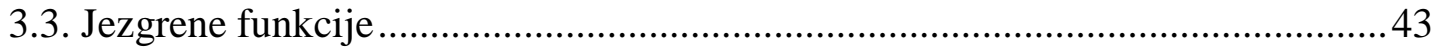

3.4. Osnovne jednadžbe mehanike tekućina ..........................................................47

3.4.1. Jednadžba očuvanja količine gibanja ................................................47 


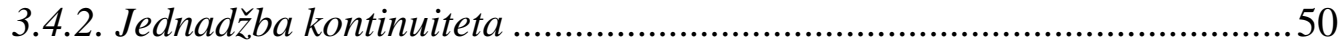

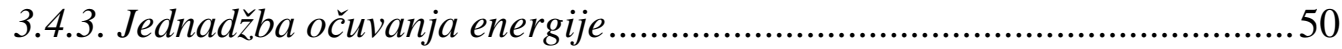

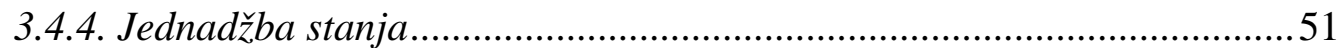

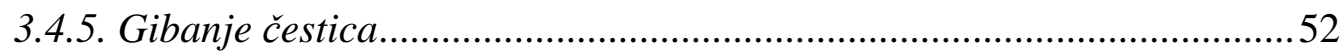

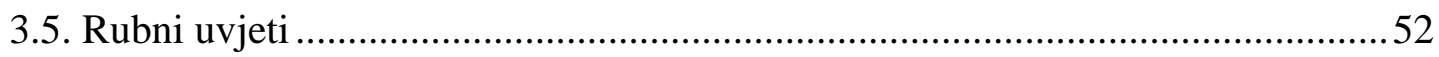

3.5.1. Odbojni rubni uvjeti .......................................................................5

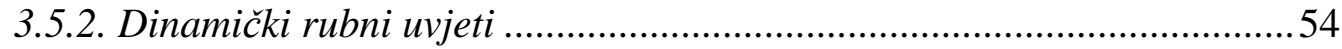

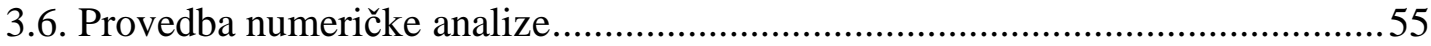

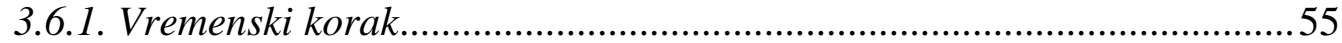

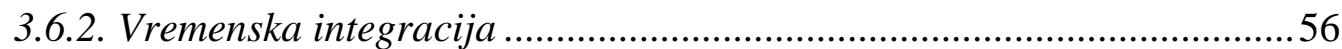

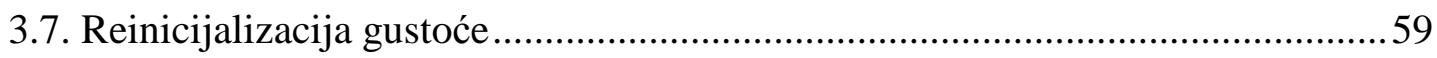

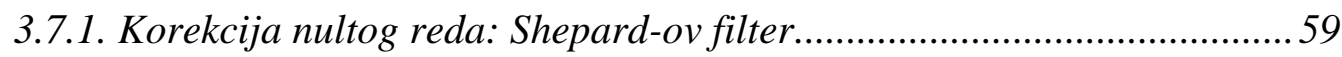

3.7.2. Korekcija prvog reda: MLS korekcija ................................................5 59

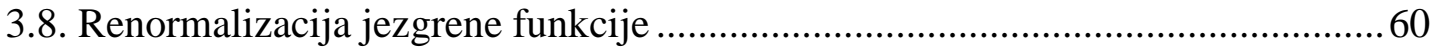

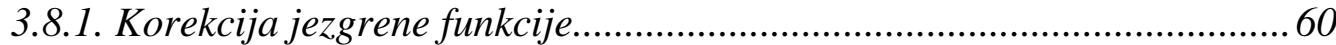

3.8.2. Korekcija gradijenta jezgrene funkcije .................................................61 61

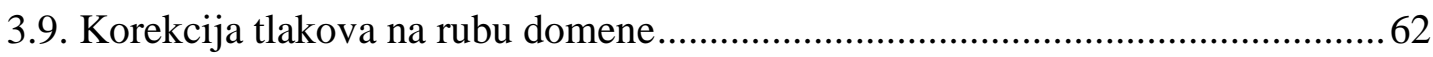

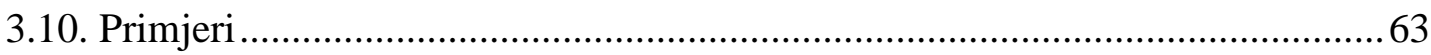

3.10.1. Primjer 1: Kruti rezervoar napunjen vodom izložen harmonijskom ubrzanju. 63

3.10.2. Primjer 2: Kruti rezervoar napunjen vodom izložen djelovanju realnog potresa .. 75

4. NUMERIČKI MODEL ZA MEĐUDJELOVANJE

KONSTRUKCIJE I TEKUĆINE ....................................................84

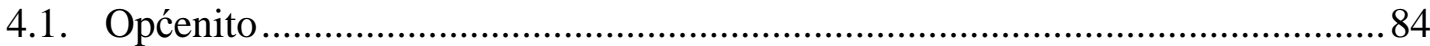

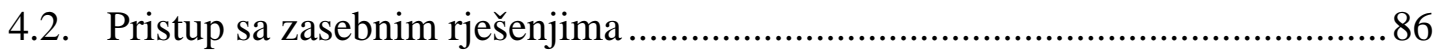

4.2.1. Potpuno povezani algoritmi ....................................................................... 86

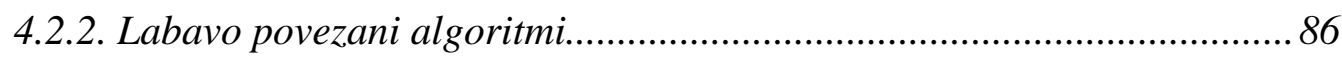

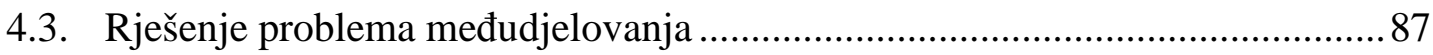

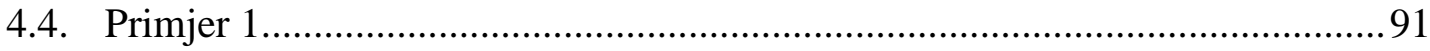

4.4.1. Zapljuskivanje u rezervoaru s krutim stranicama................................ 91

4.4.2. Zapljuskivanje u rezervoaru s elastičnim stranicama............................ 93

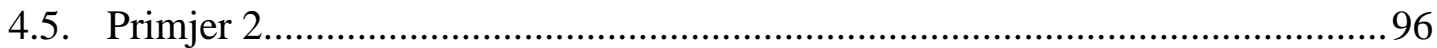

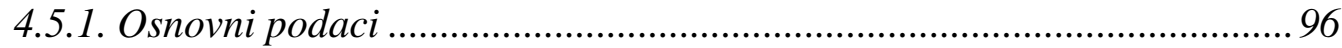

Numeričko modeliranje međudjelovanja konstrukcije i tekućine kombinacijom metode konačnih elemenata i hidrodinamike izglađenih čestica 


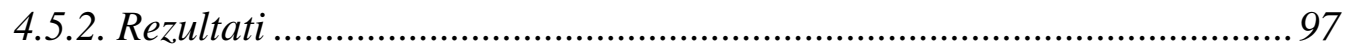

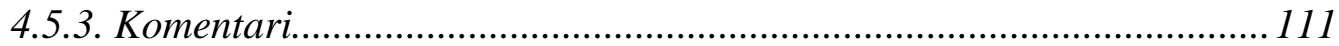

\section{EKSPERIMENTALNA ISPITIVANJA MEĐUDJELOVANJA} KONSTRUKCIJE I TEKUĆINE

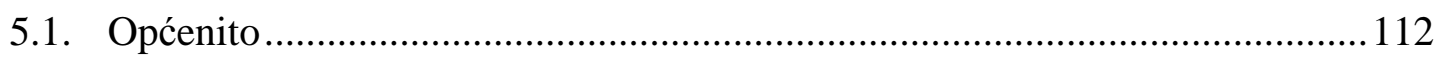

5.2. Podaci o ispitanim uzorcima rezervoara ............................................................114

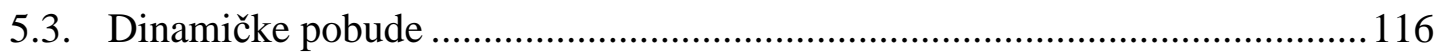

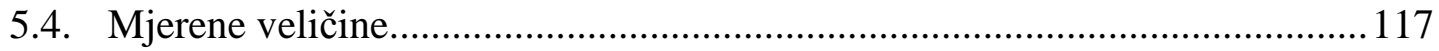

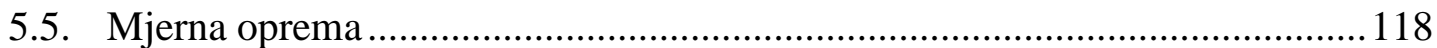

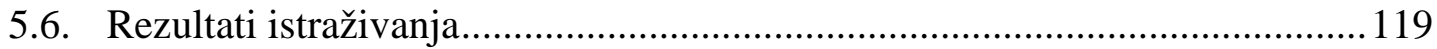

5.6.1. Osnovni periodi slobodnih oscilacija razmatranih rezervoara .............119

5.6.2. Utjecaj tipa/krutosti rezervoara.......................................................... 121

5.6.3. Utjecaj perioda harmonijske pobude ................................................. 125

5.6.4. Utjecaj tipa apliciranog akcelerograma .......................................... 128

5.6.5. Utjecaj visine vode u rezervoaru ........................................................ 132

5.6.6. Utjecaj amplitude harmonijske pobude …………………………….... 136

5.6.7. Utjecaj trajanja harmonijske pobude ……………………………...... 140

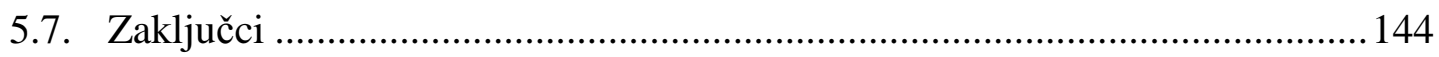

6. PROVJERA RAZVIJENOG NUMERIČKOG MODELA.... 146

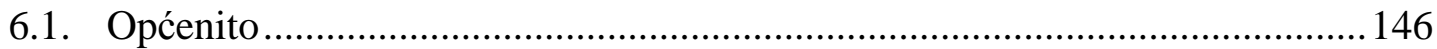

6.2. Osnovni podaci o provedenim numeričkim analizama................................... 147

6.2.1. Prostorna diskretizacija ..................................................................... 147

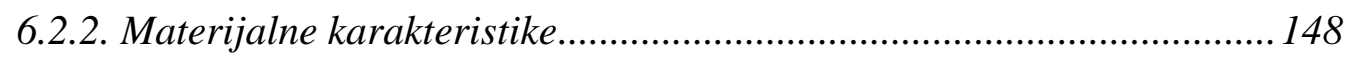

6.3. Usporedba promjene vodnog lica .................................................................. 149

6.4. Usporedba tlakova vode na prednju stijenku rezervoara ................................. 151

6.4.1. Tlakovi na krutu stijenku rezervoara ............................................... 151

6.4.2. Tlakovi na deformabilnu stijenku rezervoara ................................... 155

6.5. Usporedba pomaka stijenke rezervoara ...................................................... 157

6.5.1. Pomaci deformabilne stijenke rezervoara R1 .................................... 157

6.5.2. Pomaci deformabilne stijenke rezervoara $R 2$................................... 160 


\section{ZAKLJUČCI I PRAVCI DALJNJIH ISTRAŽIVANJA ........ 162}

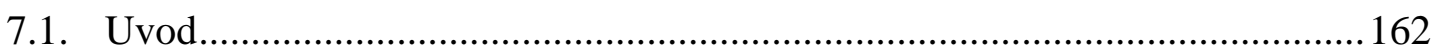

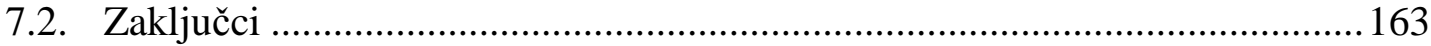

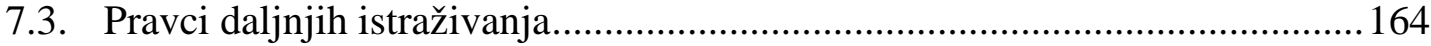

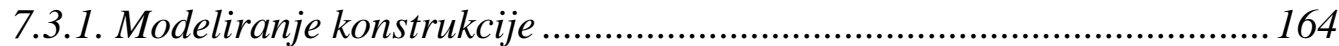

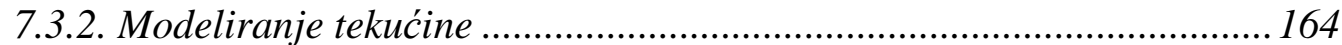

7.3.3. Modeliranje međudjelovanja konstrukcije i tekućine .......................... 165

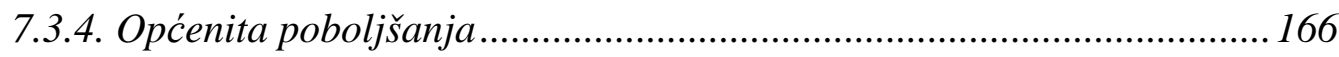

8. LITERATURA ................................................................................. 167 


\section{1}

\section{UVOD}

\subsection{Opis problema i motivacija rada}

Problemi međudjelovanja konstrukcije i tekućine (eng. fluid-structure interaction - FSI) uključuju svaku deformabilnu ili pomičnu konstrukciju koja je u doticaju s tekućinom. Takve primjere uočavamo svuda oko nas, a nalazimo ih u brojnim područjima znanosti i industrije. Strujanje zraka oko krila zrakoplova, gibanje vjetrulje, rotacija propelera broda itd. su samo neki od primjera međudjelovanja konstrukcije i tekućine.

Problemi međudjelovanja konstrukcije i tekućine česti su i u standardnoj graditeljskoj inženjerskoj praksi. Niz je primjera građevinskih konstrukcija koje su u neposrednom doticaju s tekućinama: brane, spremnici različitih tekućina, lukobrani, cjevovodi, preljevne građevine, zapornice ustava, izvanobalne konstrukcije i sl. Neke od njih prikazane su na Slici 1.1. Te konstrukcije moraju i u najekstremnijim situacijama ostati stabilne i uporabljive, jer njihovo rušenje može značiti gubitak brojnih ljudskih života i nemjerljivu materijalnu štetu. Posebno se to odnosi u slučajevima ekstremnih dinamičkih opterećenja, kao na primjer potresa. Rušenje vodotornja može prouzročiti prekid opskrbe vodom i posljedično širenje infekcija. S druge strane, rušenje rezervoara za skladištenje zapaljivih tvari (nafta, ukapljeni plin i dr.) može dovesti do požara i onečišćenje okoliša. 


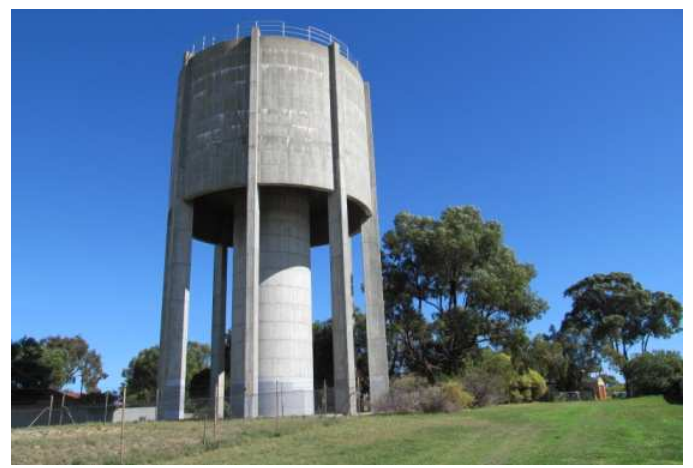

(a) vodotoranj

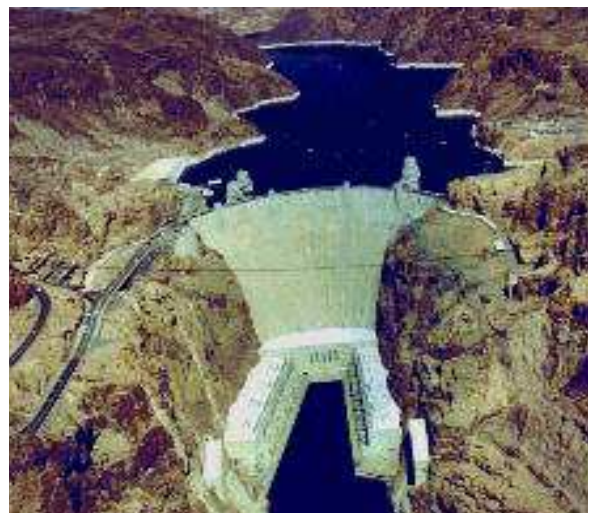

(c) brana

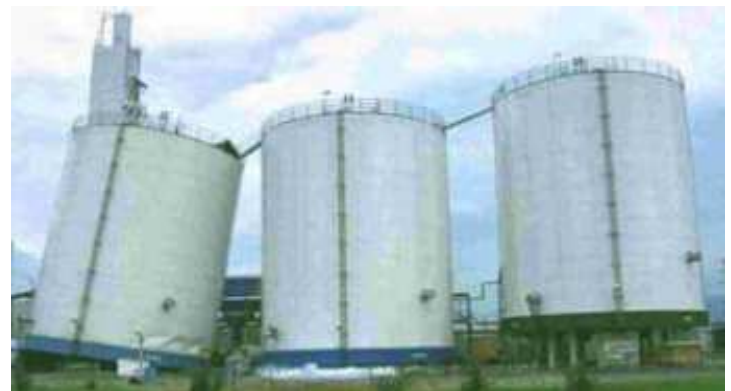

(b) spremnici tekućina

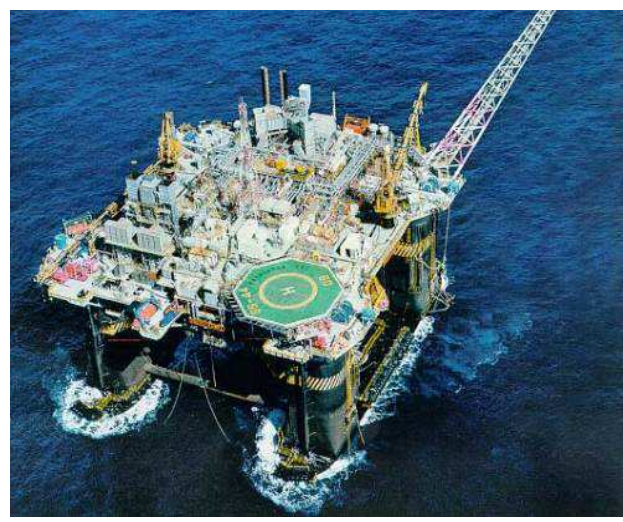

(d) offshore konstrukcije

Slika 1.1. Primjeri konstrukcija koje su u dodiru s tekućinom

Samo u posljednje vrijeme dogodio se niz potresa [1] koji su uzrokovali katastrofalne ili gotovo katastrofalne posljedice na konstrukcijama koje su u direktnom dodiru s tekućinom, pri čemu je upravo tekućina bila uzrokom oštećenja ili rušenja konstrukcije.

Prvi primjer je potres u pokrajini Kocaeli u Turskoj 1999. godine, koji se smatra najrazornijim potresom dvadesetog stoljeća zbog velikog broja izgubljenih ljudskih života. U Turpas rafineriji su oštećeni ili potpuno uništeni brojni spremnici nafte tijekom djelovanja i neposredno nakon djelovanja potresa (Slika 1.2a). Direktni uzrok rušenja je pojava zapljuskivanja (eng. sloshing) u rezervoarima, što je uzrokovalo urušavanje pokrova spremnika, izbočavanje stijenki i konačno zapaljenje tekućine.

Drugi primjer je potres u pokrajini Wenchuan u Kini 2008. godine, tijekom kojega je značajno oštećena brana Zipingpu (Slika 1.2b). Neposredni uzrok oštećenja je silovito djelovanje vode na branu i okolno tlo.

Posljednji primjer je Tohoku potres u Japanu 2011. godine. Tijekom tog potresa spremište ukapljenog plina u Cosmo oil rafineriji je potpuno devastirano, pri čemu je došlo do brojnih eksplozija i nekontroliranog širenja požara (Slika 1.2c). 


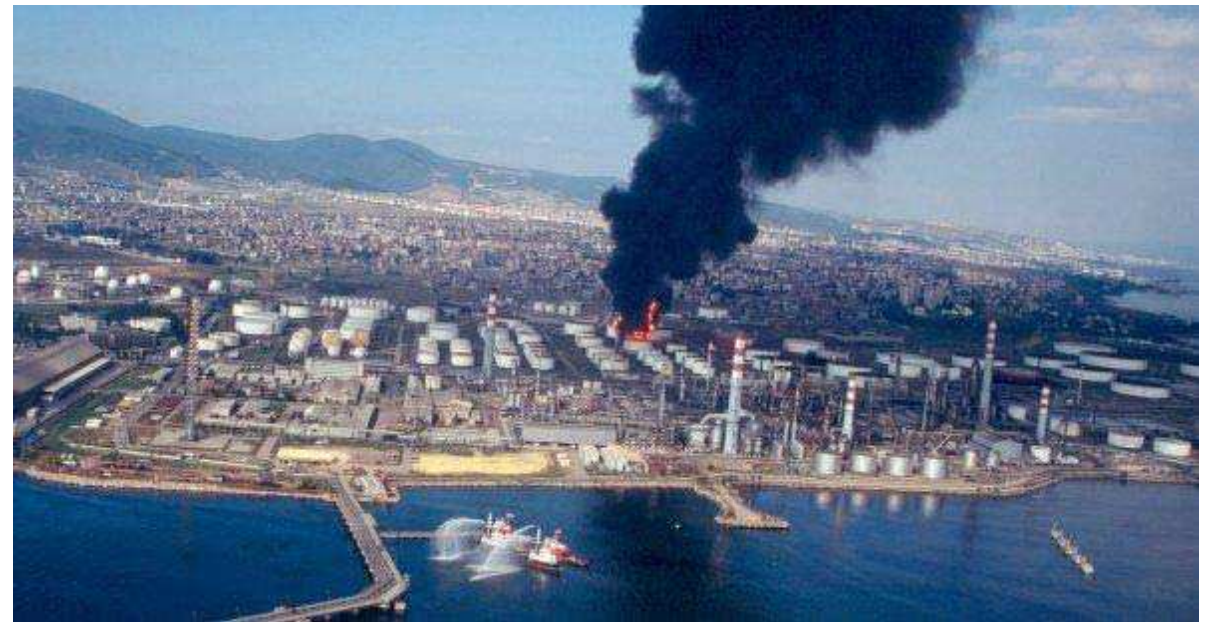

(a) Turpas rafinerija 1999., Turska

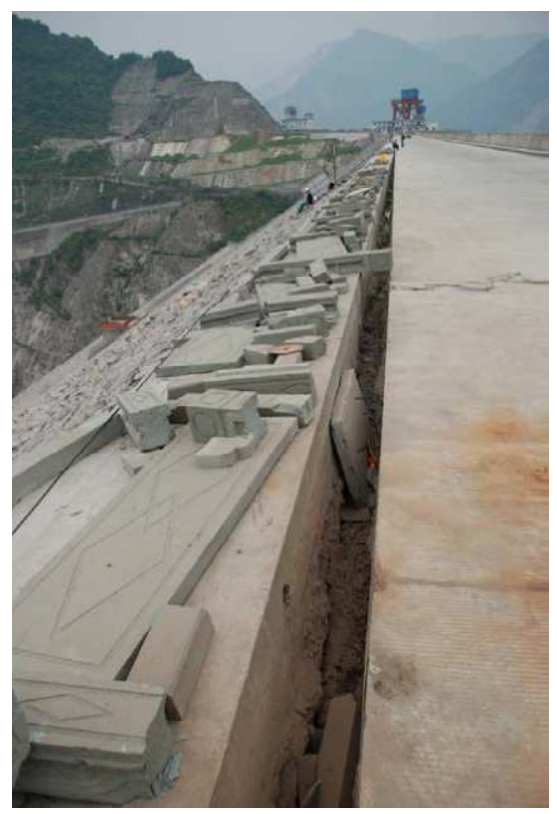

(b) Brana Zipingpu 2008.,Kina

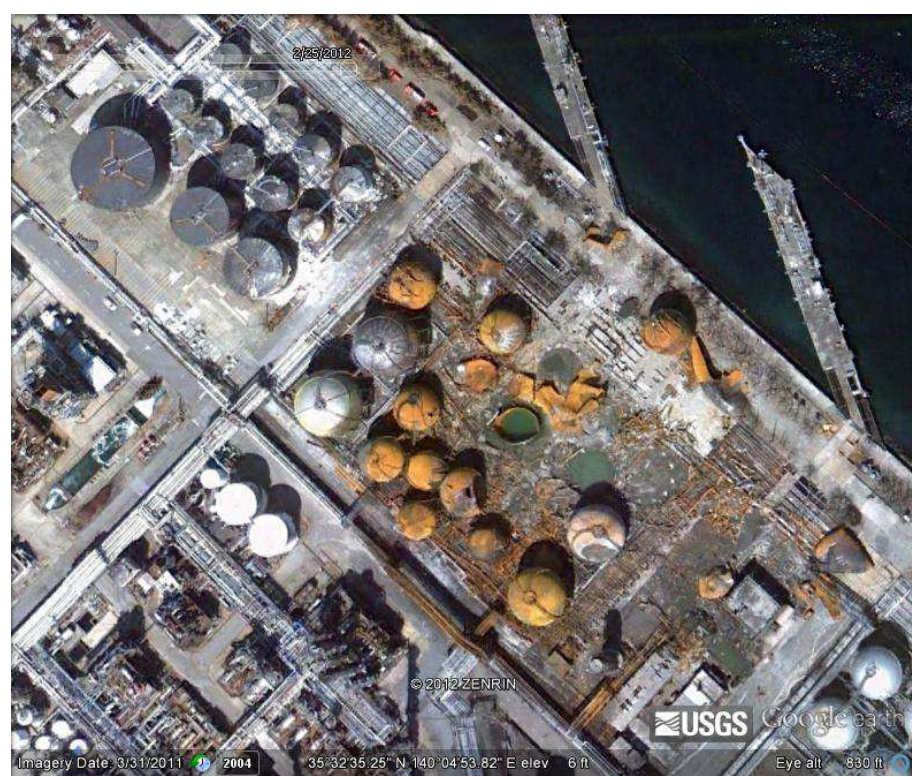

(c) Cosmo oil rafinerija 2011., Japan

Slika 1.2. Oštećenja konstrukcija koje su u doticaju s tekućinama uzrokovanih potresom [1]

Ovakvi i slični primjeri ukazuju na važnost adekvatnog projektiranja i modeliranja konstrukcija koje su u doticaju s tekućinama.

Kod pojednostavljenih metoda proračuna konstrukcija koje su u doticaju s tekućinom, opterećenje izazvano tekućinom zamjenjuje se ekvivalentnim statičkim silama, koje mogu podcijeniti ili precijeniti stvarni utjecaj tekućine. Za mnoge realne probleme međudjelovanja analitičko rješenje je nemoguće iznaći, a fizikalni modeli su ograničeni zbog složenosti i skupoće. S napretkom u razvoju računala, numeričke simulacije i numerički modeli postaju snažan alat za rješavanje problema međudjelovanja. Numeričko modeliranje problema 
međudjelovanja je složen problem zbog svoje multidisciplinarnosti [2,3], te još uvijek predstavlja područje intenzivnog istraživanja velikog broja znanstvenika.

\subsection{Kratki opis razvijenog modela}

U okviru ovoga rada razvijen je 3D numerički model za međudjelovanje konstrukcije i tekućine kojim se može vrlo efikasno simulirati ponašanje konstrukcija koje su u doticaju s tekućinom pri dinamičkom opterećenju (potresu).

Pri simulaciji konstrukcije korišteni su elementi ljuske. Ljuske su konstrukcije koje se mogu pronaći posvuda u prirodi (kornjačin oklop, kućica puža, morska školjka i sl.). Stoga je logično da se te efektne strukturne forme koriste i u građevinarstvu. Veliki broj građevinskih konstrukcija koje su u kontaktu s tekućinama se mogu adekvatno modelirati upravo kao ljuskaste konstrukcije (lučne brane, spremnici tekućina, vodotornjevi i sl).

Kod simulacije tekućine načelno se mogu koristiti dva modela: (i) Euler-ov model koji tekućinu promatra kroz volumen koji zauzima, bez uvida u ponašanje njezine svake čestice i (ii) Lagrange-ov model, koji prati ponašanje svake čestice tekućine. Eulerov-im modelom/pristupom se mogu vrlo dobro opisati globalne pojave (tlakovi, kavitacija i sl.), ali se ne mogu simulirati lokalni efekti (površinski valovi, zapljuskivanje i sl.). Lagrange-ovim modelom se vrlo dobro mogu opisati svi efekti u tekućini, ali je s matematičko/numeričke strane znatno zahtjevniji i proračuni često zahtijevaju moćna računala i znatno više vremena.

Kod realnih problema, kao primjerice analiza gravitacijske brane s akumulacijom, metode bazirane na Eulerov-om principu promatranja polja tekućine su još uvijek u širokoj uporabi. Dva su osnovna razloga za to. Prvi, što kod proračuna brana ponašanje tekućine nas generalno ne zanima, osim njezin utjecaj na konstrukciju, a on se može dovoljno precizno izračunati i jednostavnijim modelom. Drugi, što bi za opisivanje lokalnih utjecaja tekućine na branu pomoću prikladnih Lagranege-ovih metoda, bila potrebna vrlo gusta mreža čestica. To bi znatno vremenski produljilo proračun, a ukupni utjecaj na branu je zanemariv.

No, u slučajevima gibanja tekućine u rezervoarima, vodotornjevima i sl., korištenje metoda baziranih na Lagrange-ovom pristupu pokazuje se neophodnim. Upravo stoga se krenulo u razvijanje matematičkog/numeričkog modela kojim se može simulirati uzdizanje tekućine uz rubove rezervoara, zapljuskivanje i slični efekti. Jedan takav model je upravo model hidrodinamike izglađenih čestica (eng. smoothed particle hydrodynamics - SPH), koji je u biti bezmrežna Lagrange-ova metoda za simulaciju gibanja tekućina. 
Razvijeni numerički model za međudjelovanje nastao je, dakle, povezivanjem modela konačnih elemenata (eng. finite element method - FEM) za simulaciju konstrukcije i modela hidrodinamike izglađenih čestica (SPH) za simulaciju tekućine. U ovom radu naglasak je na problemima međudjelovanja na plohi, tj. problemima kod kojih se polja konstrukcije i tekućine ne prožimaju. Također, naglasak je dan na modeliranje mirne tekućine i konstrukcije izloženih dinamičkoj pobudi, iako načelno razvijeni model može opisati i tečenje.

Model je prvenstveno namijenjen simulaciji čeličnih konstrukcija koje se mogu opisati elementima ljuske i koje su u doticaju s različitim kapljevinama. Modelom su obuhvaćene glavne nelinearne značajke konstrukcijskog čelika (popuštanje u tlaku i vlaku, te razvoj plastičnosti) i osnovne nelinearne karakteristike tekućine (viskoznost, kavitacija, turbulencija i vrtloženje).

U okviru ovoga rada provedena su također i eksperimentalna ispitivanja konstrukcija koje su u doticaju s tekućinom na potresnoj platformi. Svrha provedenih eksperimentalnih ispitivanja je istražiti ponašanje rezervoara pri djelovanju potresa i stvoriti eksperimentalnu bazu podataka za provjeru razvijenog numeričkog modela za međudjelovanje konstrukcije i tekućine. Rezultati numeričkog modela i eksperimentalnih testova su uspoređeni, a dobro slaganje numeričkih i eksperimentalnih rezultata daje dodatnu vjerodostojnost razvijenom modelu.

Vjeruje se da će razvijeni numerički model doprinijeti znatno boljem poznavanju ponašanja konstrukcija u neposrednoj vezi sa tekućinom, posebice u seizmički aktivnim područjima, što je od velikog interesa za širu zajednicu. 


\subsection{Pregled literature iz područja istraživanja}

Istraživanje međudjelovanja konstrukcije i tekućine započinje 1828. godine s Friedrich Besselom i konceptom tzv. hidrodinamičke ili dodatne mase (eng. hydrodynamic or added mass). On je promatrao kretanje njihala u tekućini i shvatio kako njihalo u tekućini ima veći period osciliranja nego u vakuumu i zaključio da okolna tekućina na neki način povećava efektivnu masu sustava [4]. Njegove postavke potvrdio je sir George Gabriel Stokes (1843. godine), koji je istraživao gibanje valjka beskonačne duljine izloženog jednolikom ubrzanju u beskonačnom volumenu tekućine i zaključio da se efektivna masa valjka povećava zbog utjecaja okolne tekućine upravo proporcionalno masi tekućine koju valjak istiskuje. Upravo ovo otkriće se smatra početkom istraživanja problema međudjelovanja konstrukcije i tekućine [4].

Od toga doba probleme međudjelovanja konstrukcije i tekućine obrađivali su brojni autori iz različitih znanstvenih i inženjerskih područja: biomedicine, aeronautike, astrofizike, brodogradnje, strojarstva, pa tako i iz područja građevinarstva. Revolucionarno istraživanje iz područja međudjelovanja brane i akumulacije je objavio Westergaard 1933. godine, u kojemu je dao rješenje za maksimalne hidrodinamičke tlakove na krutu branu tijekom harmonijske pobude koristeći pristup s dodatnim masama [5]. Njegovo rješenje se i danas koristi pri projektiranju konstrukcija koje su u kontaktu s tekućinom za proračun hidrodinamičkih tlakova i sadržano je unutar propisa za projektiranje takvih konstrukcija.

Tijekom povijesti razvijeni su različiti numerički modeli za opisivanje problema međudjelovanja tekućine i konstrukcije. U okviru ovog rada razvijen je numerički model koji primjenjuje metodu konačnih elemenata za opisivanje ponašanja konstrukcije [6-8] i metodu SPH za opisivanje ponašanja tekućine [9-13].

Metoda konačnih elemenata zasigurno je jedna od najzastupljenijih numeričkih metoda zbog svoje točnosti i široke mogućnosti primjene. Može se reći da je standardna metoda za analizu konstrukcija. Pri tome metoda konačnih elemenata je vrlo široki pojam koji uključuje veliki broj različitih elemenata koji se koriste i veliki broj različitih problema koje opisuje (2D, 3D, štapni sustavi i sl.). U ovom radu za opis konstrukcije korišteni su elementi ljuske koji su, kako je ranije navedeno, vrlo široko rasprostranjeni u inženjerskoj praksi, a ujedno vrlo dobro opisuju tipove konstrukcija koji se koriste za potrebe skladištenja tekućina: rezervoari, vodotornjevi, lučne brane i sl. 
Pri projektiranju ljuskastih konstrukcija u prošlosti inženjeri su se uglavnom oslanjali na intuiciju i iskustvo prethodnih graditelja, uz provedbu tek nekoliko jednostavnih proračuna. Analitička rješenja za ljuske ograničena su na vrlo jednostavne i pravilne geometrijske oblike, rubne uvjete i opterećenja, te linearno elastično ponašanje materijala. Kako ovi uvjeti u praksi najčešće nisu ispunjeni, koriste se numerički postupci proračuna. Prve primjene MKE u analizama ploča i ljuski datiraju s početka 60-ih godina 20. stoljeća, a znatniji napredak javlja se početkom 80 -ih godina 20 . stoljeća $[14,15]$.

Globalno gledano, u razvojnom slijedu konačnog elementa ljuske razlikuju se tri pristupa: (i) ravni trokutasti ili kvadrilateralni elementi, (ii) zakrivljeni 3D elementi formulirani na temelju različitih teorija ljuski, (iii) degenerirani 2D elementi izvedeni iz 3D elemenata.

Ravni elementi u numeričkim analizama ljuskastih konstrukcija su jednostavni za korištenje, ali zadovoljavajuće rješenje daju za relativno gustu mrežu elemenata. Kod zakrivljenih 3D elemenata, osnovu čini Kirchoff-Loveyeva hipoteza tankih ljuski. Ovi elementi su također prilično popularni, ali pate od raznih ograničenja zbog složenosti teorija ljuski na kojima se zasnivaju.

$\mathrm{U}$ više pogleda, koncept zasnovan na degeneriranim 2D elementima pokazao se najprikladnijim za uporabu. Razvoj postupka započeo je Ahmad i dr. [16], a poboljšanja su uveli Zienkiewicz i drugi [17]. U osnovi, ovi elementi su izvedeni iz prostornih elemenata. Trodimenzionalne jednadžbe mehanike kontinuuma prilagođene su ponašanju ljuskastih konstrukcija, čime su izbjegnute kompleksnosti opće teorije ljuski. Neovisni translacijski pomaci gornjih i donjih čvorova nadomješteni su s pomacima i zaokretima referentne plohe (što je najčešće srednja ploha elemenata). Pri tome je pretpostavljena nestišljivost elementa $s$ obzirom na srednju plohu. Polja pomaka i zaokreta na elementu su međusobno neovisni što omogućava razmatranje posmičnih deformacija i analizu debelih ljuski. Ovaj koncept primjenjiv je na materijalno i geometrijski nelinearne probleme. Izoparametrijski elementi ljuske također imaju određene nedostatke koji se pokušavaju izbjeći na razne načine. Osnovni Ahmadovi elementi su se pokazali neučinkovitima pri analizi tankih ljuski jer posmični članovi u globalnoj matrici postaju prevladavajući i uzrokuju tzv. posmično blokiranje (eng. shear locking). Taj se problem najčešće rješava selektivnom integracijom.

Model ljuske korišten u ovome radu preuzet je od Figueirasa i Owena [18-21], a nadopunjenim od Huanga [6]. Model je zasnovan na tri vrste konačnih elemenata: osmočvornim (Serendipity), devetočvornim Lagrange-ovim i Heterosis elementima. Ovi 
elementi daju zadovoljavajuće rezultate za debele i tanke ploče, te onemogućavaju tzv. posmično i membransko blokiranje. Ovaj model omogućava zadavanje nehomogenih presjeka i nelinearnih materijala pomoću višeslojne diskretizacije.

Metoda konačnih elemenata često se koristila i za simulaciju tekućina. Pri modeliranju tekućine pomoću metode konačnih elemenata domena je najčešće opisana u Euler-ovom koordinatnom sustavu s nepomičnom mrežom. Međutim, taj pristup je ograničen na probleme gdje nema značajne promjene slobodnog vodnog lica i/ili pomičnih granica. Zasigurno jedan od najpoznatiji pristupa za rješavanje problema sa značajnim promjenama slobodnog vodnog lica i/ili pomičnih granica je tzv. proizvoljni Lagrange-Euler-ov pristup (eng. arbitrary Lagrangian-Eulerian formulation - ALE), kod kojega je moguća promjena mreže konačnih elemenata tekućine neovisno od gibanja čestice tekućine. Taj pristup se počeo primjenjivati 60-tih godina prošlog stoljeća u okviru metode konačnih razlika i volumena [22,23], a kasnije i u okviru metode konačnih elemenata [24,25]. ALE formulacija je i danas aktualna za numeričko modeliranje problema međudjelovanja [26,27], kao i neke druge metode kojima je osnova metoda konačnih elemenata (Least Squares Finite Element Method (LSFEM) [28] i Particle Finite Element Method (PFEM) [29,30]).

Snažan poticaj razvoju brojnih numeričkih modela za simulaciju gibanja tekućine, time i za probleme međudjelovanja konstrukcije i tekućine, svakako je i razvitak bez-mrežnih metoda. Jedna od najstarijih, a vjerojatno i najpoznatijih je metoda hidrodinamike izglađenih čestica (SPH), koju su 1977. originalno razvili Monaghan [31] i Lucy [32] za opisivanje problema u astrofizici. Danas se uspješno primjenjuje za rješavanje različitih problema hidromehanike [10,33-43].

I niz drugih bez-mrežnih metoda su razvijene i primjenjuju se u hidromehanici: Diffuse element method - DEM (1992.); Dissipative particle dynamics - DPD (1992.); Element-free Galerkin method - EFG / EFGM (1994.); Moving particle semi-implicit method - MPS (1996.); Finite pointset method - FPM (1998.); Finite mass method - FMM (2000.); Smoothed point interpolation method - S-PIM (2005.); Meshfree local radial point interpolation method - RPIM; Local radial basis function collocation Method - LRBFCM; Viscous vortex domains method - VVD; Discrete least squares meshless method - DLSM (2006.); Optimal Transportation Meshfree method - OTM (2010.); Repeated replacement method - RRM (2012.), i dr. [9,44]. Bez-mrežne metode su uglavnom Lagrangeove metode kod kojih se kontinuum diskretizira s konačnim brojem pokretnih čestica. Ovim metodama mogu se dobro opisati problemi kod kojih dolazi do značajne distorzije mreže tijekom 
simulacije, što ih čini izrazito pogodnima pri modeliranju probleme tečenja tekućine. Osim modeliranja tekućina, ovim metodama se vrlo uspješno simuliraju i razni problemi plastičnog tečenja materijala kod mehanike kontinuuma i sl. Nedostatak svih ovih metoda je potreba za moćnim računalima i dugo vrijeme trajanja proračuna.

Attaway [45] je začetnik u povezivanju bez-mrežnih čestičnih metoda i metode konačnih elemenata, pri čemu je koristio tzv. master-slave algoritam za rješavanje problema međudjelovanja. Sličan pristup koristili su i drugi autori [46,47]. Povezivanje metode konačnih elemenata i metode hidrodinamike izglađenih čestica (i drugih bez-mrežnih metoda) [48-58] aktualno je posljednjeg desetljeća. Takvi modeli koriste se za rješavanje problema međudjelovanja konstrukcije i tekućine i primjenjuju se u različitim granama znanosti. Kombinaciju FEM-SPH koristili su Vuyst i dr. [59] u udarnim problemima međudjelovanja konstrukcije i tekućine, Groenenboom and Cartwright [60] i Fourey i dr. [61-63] za međudjelovanje tekućine sa slobodnim vodnim licem i elastične konstrukcije, Yang i dr. $[64,65]$ i Jian [66] za međudjelovanje tekućine sa slobodnim vodnim licem i elastične konstrukcije unutar rezervoara, Du i dr. [67] i Ming i dr. [68] za modeliranje ljuskastih konstrukcija izloženih podvodnoj eksploziji. Najizraženija razlika između tih modela je u načinu modeliranju kontaktne sile na konstrukciju na plohi spoja s tekućinom.

\subsection{Metodologija i ciljevi rada}

Za većinu realnih problema međudjelovanja konstrukcije i tekućine analitička rješenja je nemoguće dobiti. Eksperimentalna istraživanja ograničena su zbog svoje složenosti i skupoće, iako se uz suvremene precizne mjerne instrumente mogu dobiti vrlo pouzdani rezultati. Zahvaljujući performansama računala u današnje vrijeme, složeni problemi međudjelovanja konstrukcije i tekućine najčešće se rješavaju pomoću numeričkih modela. Numerički modeli se verificiraju pomoću eksperimentalnih istraživanja, kako bi se mogli pouzdano koristiti u analizi različitih problema u praksi.

Numerički postupak rješavanja problema međudjelovanja konstrukcije i tekućine u uvjetima dinamičkog opterećenja općenito se može podijeliti na dva pristupa: monolitni pristup i pristup sa zasebnim rješenjima [69-72].

Monolitni pristup tretira konstrukciju i tekućinu u okviru istog matematičkog opisa (okvira) i formira jedinstveni sustav jednadžbi koji opisuje cjelokupni problem i koji se rješava istovremeno jedinstvenim algoritmom. Ovaj pristup obično daje veću točnost, ali 
zahtijeva veće resurse i posebna znanja za razvoj jedinstvenog koda za svaki pojedini problem.

$\mathrm{U}$ ovom radu se koristi pristup sa zasebnim rješenjima koji tretira tekućinu i konstrukciju kao dva polja koji se mogu riješiti odvojeno, pri čemu svako polje ima svoju diskretizaciju i svoj numerički algoritam. Razdvojeni pristup čuva modularnost računalnog programa, samo se postojeći solveri za tekućinu i konstrukciju vezuju na način da izmjenjuju informacije. Štoviše, razdvojeni pristup olakšava rješavanje jednadžbi gibanja tekućine i jednadžbi konstrukcije, jer se one mogu rješavati razdvojeno, često sa učinkovitijim tehnikama koje su posebno razvijene za rješavanje pojedinačnih polja tekućine ili konstrukcije.

Konstrukcija se analizira pomoću metode konačnih elemenata (FEM), a tekućina pomoću metode hidrodinamike izglađenih čestica (SPH). U svakom vremenskom koraku računaju se sile kojima tekućina djeluje na konstrukciju i koje uzrokuju deformacije konstrukcije, nakon čega se ažuriraju rubni uvjeti za polje tekućine te analizira ponašanje konstrukcije. Načelni algoritam rješenja problema prikazan je na Slici 1.3.

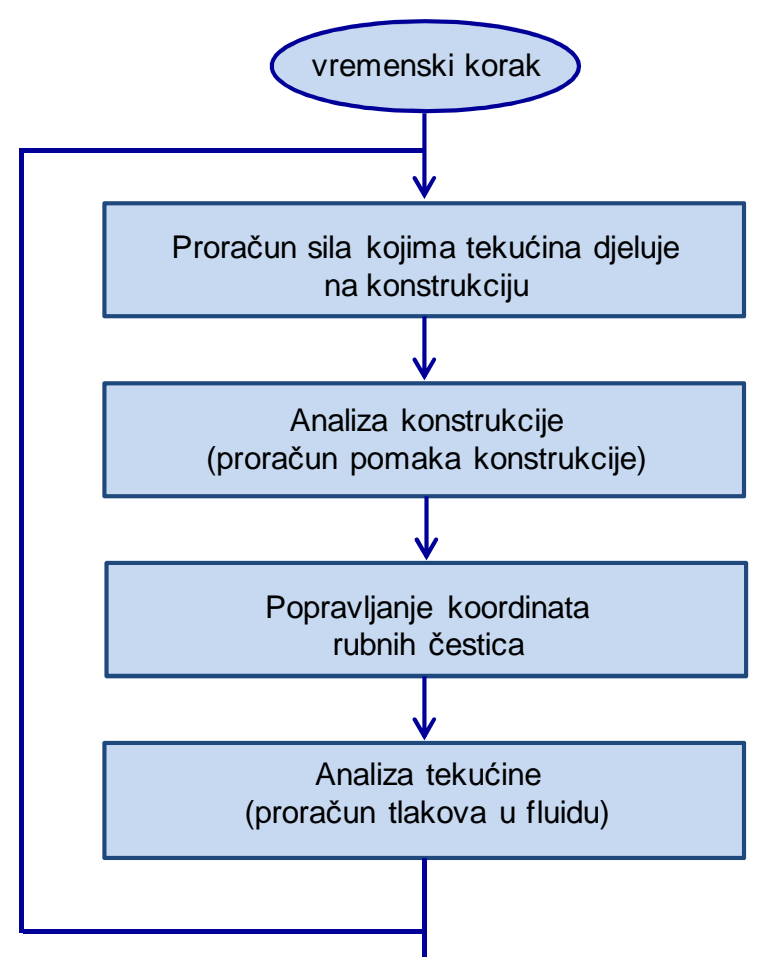

Slika 1.3. Načelni algoritam rješenja problema međudjelovanja konstrukcije i tekućine Razvijeni algoritam prvo je testiran na nekim primjerima iz literature. 
Zatim su izvršena eksperimentalna ispitivanja na potresnoj platformi kojima se istražilo ponašanja rezervoara ispunjenih vodom izloženih različitim eksitacijama podloge. Na temelju mjerenih podataka provjerena je pouzdanost razvijenog numeričkog modela za međudjelovanje konstrukcije i tekućine.

Ciljevi ovog rada bili su:

- Priprema, poboljšanje i provjera pouzdanosti postojećeg numeričkog modela za analizu ljuskastih konstrukcija pod dinamičkim opterećenjem koji se temelji na metodi konačnih elemenata. Poboljšanje modela se odnosi na uvođenje rotacijske krutosti konačnog elementa ljuske oko normale na srednju plohu i poboljšanju modela za opis nelinearnog ponašanja materijala.

- Priprema, poboljšanje i provjera pouzdanosti postojećeg numeričkog modela za simulaciju ponašanja tekućine koji se temelji na metodi hidrodinamike izglađenih čestica. Istražena je mogućnost primjene ovoga modela za razvoj novog modela za međudjelovanje konstrukcije i tekućine, u okviru pouzdanosti proračuna tlakova kojima tekućina djeluje na konstrukciju. Poboljšanje postojećeg numeričkog modela za simulaciju ponašanja tekućine odnosi se na mogućnost zadavanja složene geometrije i vanjske ekscitacije podloge, a sve sa ciljem kako bi model za tekućinu bio primjenjiv za razvoj novog modela za međudjelovanje.

- Povezivanje modela za konstrukciju i modela za tekućinu u jedinstveni numerički model za opisivanje međudjelovanja konstrukcije i tekućine u uvjetima dinamičkog opterećenja.

- Provedba eksperimentalnih istraživanja pomoću potresne platforme kojima je istraženo ponašanje otvorenih rezervoara ispunjenih vodom i izloženih različitim ekscitacijama podloge. Istražen je utjecaj krutosti stijenke rezervoara, razine punjenja, tipa dinamičke pobude, te perioda, amplitude i duljine trajanja harmonijske pobude.

- Provjera razvijenog numeričkog modela za međudjelovanje konstrukcije i tekućine. 


\subsection{Sadržaj rada}

Rad je podijeljen u osam poglavlja.

1. Uvod

U ovom poglavlju prikazana je osnovna motivacija za izradu ovog rada, definiran je problem i predmet istraživanja, prikazana su dosadašnja postignuća iz područja istraživanja, prikazana je metodologija i navedeni su ciljevi rada. Na kraju je kratko prikazan sadržaj rada po poglavljima.

\section{Numerički model za konstrukciju}

U drugom poglavlju prikazan je model za dinamičku analizu ljuskastih konstrukcija kod kojeg se koriste degenerirani izoparametrijski konačni elementi ljuske sa šest stupnjeva slobode u svakom čvoru. Prikazan je usvojeni model materijala kojim se opisuje elastoplastično ponašanje anizotropnog materijala. Prikazana je osnova ovog numeričkog modela, podaci o prostornoj i vremenskoj diskretizaciji, modeliranju krutosti, mase, opterećenja i prigušenja, kriterij konvergencije iterativnih postupaka i sl. Na kraju je prikazan numerički test kojim je istražena pouzdanost i točnost modela za konstrukciju.

\section{Numerički model za tekućinu}

U trećem poglavlju prikazan je model za simulaciju ponašanja tekućine koji se temelji na metodi hidrodinamike izglađenih čestica. Modelom se opisuje gibanje realne tekućine sa slobodnim vodnim licem. Prikazana je osnova numeričkog modela, podaci o prostornoj i vremenskoj diskretizaciji, mogućnosti modeliranja viskoznosti, kriterij konvergencije analiza i sl. Na kraju su prikazani numerički testovi kojima je istražena pouzdanost i prikladnost ovog numeričkog modela tekućinu za korištenje pri izradi novog numeričkog modela za simulaciju međudjelovanja.

\section{Numerički model za međudjelovanje konstrukcije i tekućine}

U ovom poglavlju numerički modeli prikazani u drugom i trećem poglavlju povezani su u jedinstveni model za simulaciju međudjelovanja konstrukcije i tekućine. Prikazan je algoritam rješenja ovog složenog problema. Na kraju su prikazani rezultati numeričkih testova provedenih pomoću razvijenog numeričkog modela i usporedba nekih rezultata s rezultatima iz dostupne literature. 
5. Eksperimentalna ispitivanja međudjelovanja konstrukcije i tekućine

$\mathrm{U}$ petom poglavlju prikazan je program provođenja eksperimentalnih istraživanja međudjelovanja otvorenog pravokutnog rezervoara i tekućine na potresnoj platformi. Prikazani su korišteni mjerni uređaji i njihov raspored. Na kraju su prikazani rezultati eksperimentalnih ispitivanja.

\section{Provjera razvijenog numeričkog modela}

U šestom poglavlju je prikazana usporedba rezultata dobivenih razvijenim numeričkim modelom za simulaciju međudjelovanja konstrukcije $i$ tekućine $s$ dobivenim eksperimentalnim rezultatima iz Poglavlja 5.

\section{Zaključci i pravci daljnjih istraživanja}

Najvažniji zaključci provedenih istraživanja i smjernice za buduća istraživanja prikazani su u sedmom poglavlju.

\section{Literatura}




\section{2 \\ NUMERIČKI MODEL ZA KONSTRUKCIJU}

\subsection{Općenito}

Za modeliranje konstrukcije u ovome radu je korišten model ljuski. Ljuske su zakrivljene tanke plošne konstrukcije koje opterećenje preuzimaju savojnim i membranskim djelovanjem. Model ljuski je odabran jer se brojne konstrukcije u građevinarstvu, koje su u kontaktu s tekućinama, mogu adekvatno modelirati upravo kao ljuskaste konstrukcije.

U ovome poglavlju je prikazan prethodno razvijen i provjeren model za dinamičku analizu ljuskastih konstrukcija s degeneriranim izoparametrijskim konačnim elementima sa pet stupnjeva slobode u svakom čvoru. Model je izvorno preuzet od Huanga [6] i nadopunjen od Harapina [73], pri čemu je svaki čvor konačnog elementa imao pet stupnjeva slobode. Šesti stupanj slobode (rotacijska krutost oko normale na srednju plohu ljuske) je dodan prema Kozulić [74].

Model je namijenjen prvenstveno simulaciji tankih čeličnih konstrukcija koje opterećenje preuzimaju kao ljuskaste konstrukcije. Usvojeni model materijala može opisati glavne nelinearne značajke konstrukcijskog čelika (popuštanje u tlaku, popuštanje u vlaku i razvoj plastičnosti). Osim materijalne nelinearnosti, model uključuje i geometrijsku nelinearnost preko teorije velikih pomaka. 
Vremenska integracija jednadžbi dinamičke ravnoteže izvršena je metodom konačnih diferencija pomoću Newmarkovog implicitnog algoritma.

\subsection{Degenerirani izoparametrijski elementi}

\subsubsection{Općenito}

U ovom radu korišteni su degenerirani izoparametrijski konačni elementi ljuske sa šest stupnjeva slobode u svakom čvoru. Njihov razvoj je započeo Ahmad i dr. [16], a poboljšani su od Zienkiewicza i dr. [17]. Kod izoparametrijskih elemenata, kakvi se koriste u ovome radu, upotrebljavaju se iste bazne funkcije za opisivanje geometrije i izračunavanje nepoznatih pomaka konstrukcije. Izoparametrijski $\mathrm{C}^{0}$ elementi ljuske $\mathrm{s}$ kvadratnim polinomima za polje pomaka izvedeni su iz trodimenzionalnih elemenata (Slika 2.1). Trodimenzionalne jednadžbe mehanike kontinuuma prilagođene su ponašanju ljuskastih konstrukcija, čime su izbjegnute kompleksnosti opće teorije ljuske. Elementi korišteni u ovom radu su preuzeti od Owena i Figueirasa [18-21] i nadopunjeni od Huanga [6].
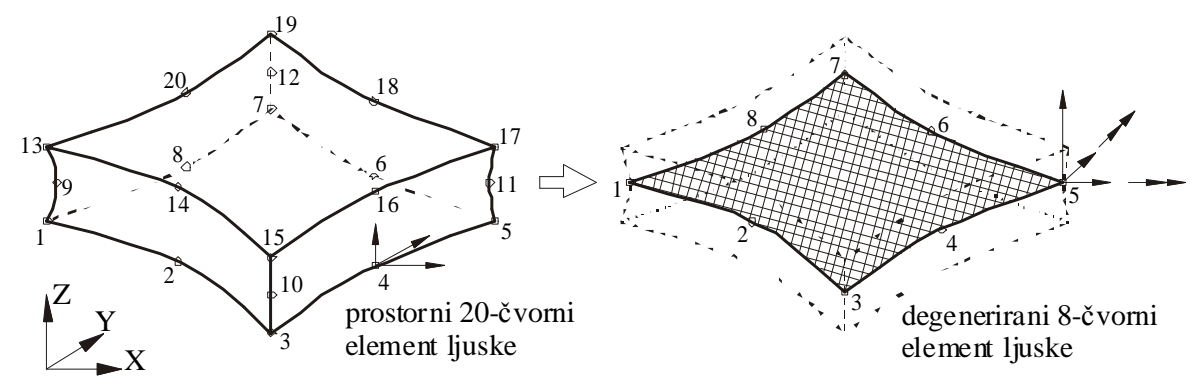

Slika 2.1. 8-čvorni element ljuske izveden iz 20-čvornog prostornog elementa ljuske

Dvije su osnovne pretpostavke u ovom pristupu [21]:

- Normala na srednju plohu konačnog elementa ljuske ostaje u pravacu i nakon deformiranja;

- Zanemareno je naprezanje okomito na srednju plohu konačnog elementa ljuske.

Usvojena je pretpostavka o nezavisnosti pomaka i rotacija normale na srednju plohu konačnog elementa ljuske prema Ressner-Mindlin-ovoj teoriji. Zbog neovisnosti polja pomaka i zaokreta, omogućava se uzimanje u obzir poprečnih posmičnih deformacija jer zaokreti nisu povezani s nagibom srednje ravnine nego samo ovisni o zaokretu normale (Slika 2.2). 


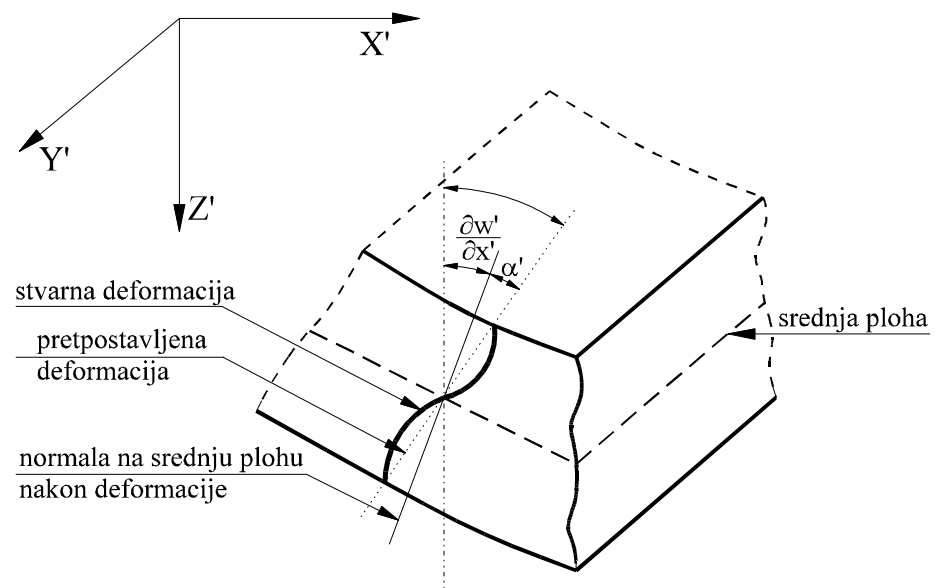

Slika 2.2. Deformacija presjeka ljuske

Degenerirani elementi ljuske ovoga modela mogu imati osam (serendipity) ili devet čvorova (Lagrange-ovi i Heterosis elementi) (Slika 2.3).

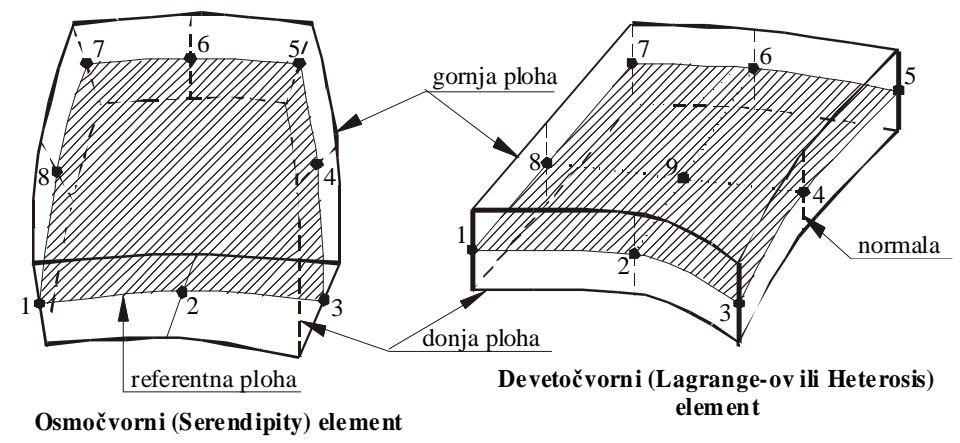

Slika 2.3. Elementi ljuske

\subsubsection{Koordinatni sustavi}

Četiri koordinatna sustava koriste se u formulaciji degeneriranog elementa ljuske:

(a) Globalni koordinatni sustav $(\mathrm{X}, \mathrm{Y}, \mathrm{Z})$

U globalnom koordinatnom sustavu su definirane koordinate čvorova elemenata i pomaci čvorova.

(b) Prirodni koordinatni sustav $(\xi, \eta, \zeta)$

Bazne funkcije $\mathrm{N}_{\mathrm{i}}$ su opisane $\mathrm{u}$ prirodnom ili krivolinijskom koordinatnom sustavu. Srednja ploha elementa ljuske je definirana pomoću $\xi$ i $\eta$ koordinata. Smjer $\zeta$ je okomit na srednju plohu ljuske.

(c) Č vorni koordinatni sustav $\left(\mathrm{X}_{\underline{k}}, \underline{\mathrm{Y}}_{\underline{k}}, \mathrm{Z}_{\underline{k}}\right)$

Čvorni koordinatni sustav je lokalni Kartezijev koordinatni sustav pridružen svakom čvoru elementa ljuske. To je referentni sustav za rotacije i određen je s tri vektora $\bar{v}_{1}^{k}, \bar{v}_{2}^{k} i \bar{v}_{3}^{k}$. 
Vektor $\overline{\mathrm{v}}_{3}^{\mathrm{k}}$ je određen normalom na srednju plohu ljuske.. Vektor $\overline{\mathrm{v}}_{1}^{\mathrm{k}}$ je okomit na $\overline{\mathrm{v}}_{3}^{\mathrm{k}}$ i paralelan s ravninom XZ. Vektor $\overline{\mathrm{v}}_{2}^{\mathrm{k}}$ je okomit na ravninu definiranu s $\overline{\mathrm{v}}_{1}^{\mathrm{k}}$ i $\overline{\mathrm{v}}_{3}^{\mathrm{k}}$ (Slika 2.4).

(d) Lokalni koordinatni sustav $(\mathrm{x}, \mathrm{y}, \mathrm{z})$

U lokalnom koordinatnom sustavu definirana su naprezanja i deformacije u nekoj točki ljuske. Lokalni koordinatni sustav je određen s tri vektora, a za njegove koordinate se upotrebljavaju sljedeće oznake:

$$
\mathrm{x}_{1}=\mathrm{x}, \quad \mathrm{x}_{2}=\mathrm{y}, \quad \mathrm{x}_{3}=\mathrm{z}
$$

Smjer $\mathrm{x}_{3}$ je okomit na srednju plohu i izračunava se kao vektorski produkt tangentnih vektora u smjeru $\xi$ i $\eta$ koordinatnih osi. Ostala dva vektora $x_{1}$ i $x_{2}$ određuju se kao $\bar{v}_{1}^{k}$ i $\bar{v}_{2}^{k}$ kod čvornog koordinatnog sustava.

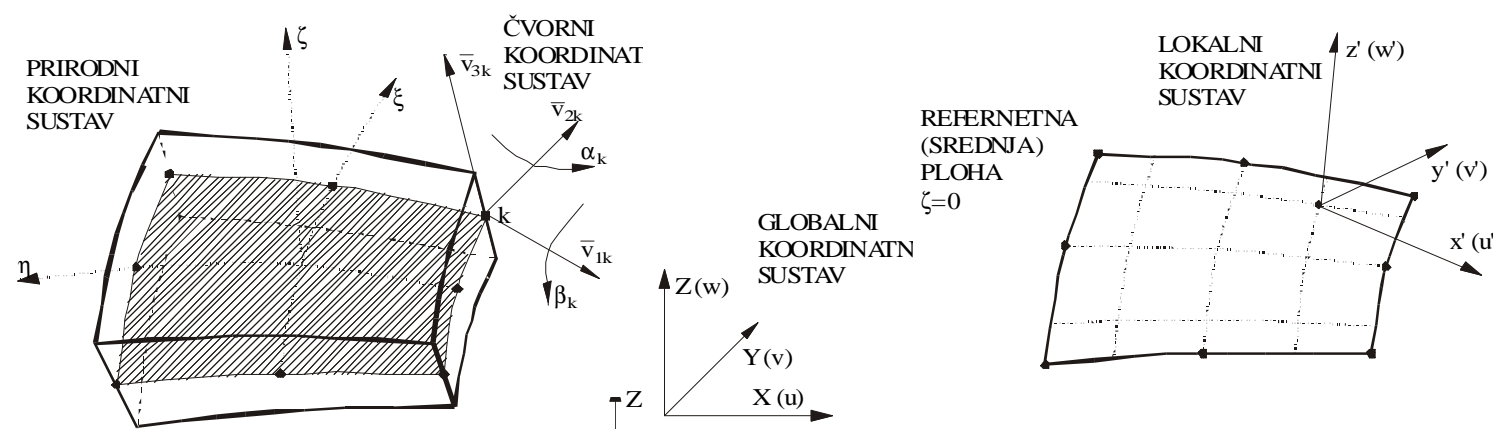

Slika 2.4. Koordinatni sustavi za degenerirani element ljuske 


\subsubsection{Geometrija elementa}

Koordinate u nekoj proizvoljnoj točki ljuske mogu se dobiti iz koordinata čvorova na srednjoj plohi s pripadajućom debljinom ljuske i smjerovima normala (Slika 2.5):

$$
\mathrm{X}_{\mathrm{i}}=\sum_{\mathrm{k}=1}^{\mathrm{n}} \mathrm{N}_{\mathrm{k}}^{\zeta=0}+\sum_{\mathrm{k}=1}^{\mathrm{n}} \mathrm{N}_{\mathrm{k}} \frac{\mathrm{h}_{\mathrm{k}}}{2} \zeta \overline{\mathrm{v}}_{3}^{\mathrm{ki}}
$$

gdje su: $\mathrm{X}_{\mathrm{i}}=$ koordinate u globalnom koordinatnom sustavu neke točke elementa $(\mathrm{i}=1,2,3$ se odnosi na globalne koordinatne osi X,Y, i Z), $\mathrm{N}_{\mathrm{k}}(\xi, \eta)$ je dvodimenzionalna interpolacijska funkcija za čvor $k, \mathrm{~h}_{\mathrm{k}}$ je debljina ljuske u čvoru $k$, dok su $\xi$, $\eta \mathrm{i} \zeta$ su krivolinijske koordinate promatrane točke elementa.

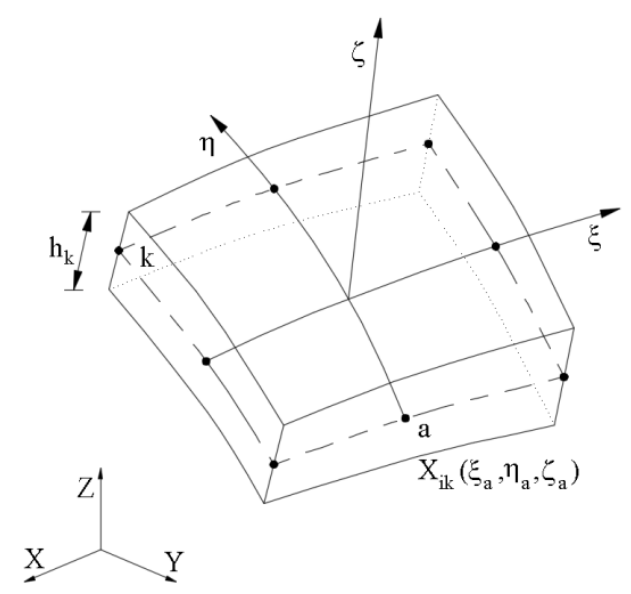

Slika 2.5. Geometrija elementa ljuske

Bazne (interpolacijske) funkcije za konačni element ljuske koje su korištene u ovome radu su prikazane na Slici 2.6. 


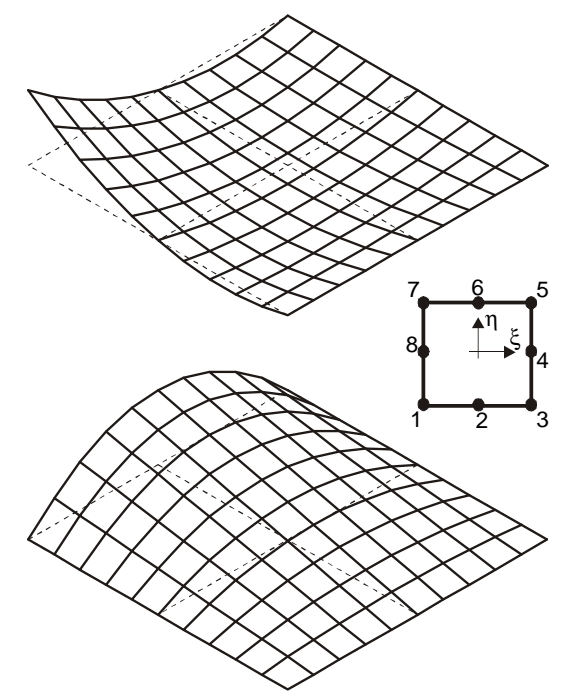

Bazne funkcije 8-čvornog degeneriranog konačnog elementa ljuske

$$
\begin{gathered}
\mathrm{N}_{\mathrm{i}}=\frac{1}{4}\left(1+\xi_{\mathrm{i}} \xi\right)\left(1+\eta_{\mathrm{i}} \eta\right)\left(\xi_{\mathrm{i}} \xi+\eta_{\mathrm{i}} \eta-1\right) \\
\text { za i }=1,3,5,7 \\
\mathrm{~N}_{\mathrm{i}}=\frac{\xi_{\mathrm{i}}^{2}}{2}\left(1+\xi_{\mathrm{i}} \xi\right)\left(1-\eta^{2}\right)+\frac{\eta_{\mathrm{i}}^{2}}{2}\left(1+\eta_{\mathrm{i}} \eta\right)\left(1-\xi^{2}\right) \\
\text { za i }=2,4,6,8
\end{gathered}
$$

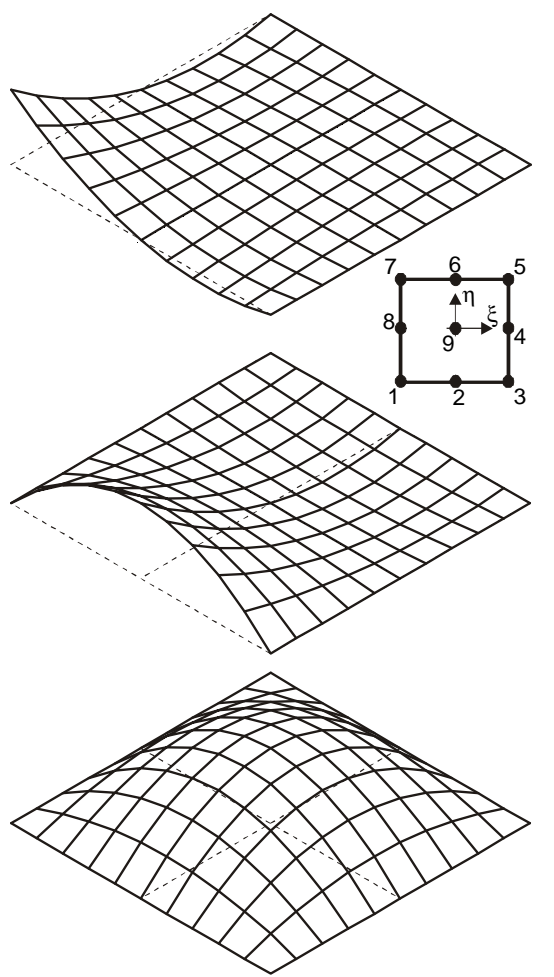

Bazne funkcije 9-čvornog degeneriranog konačnog elementa ljuske

$$
\begin{array}{r}
\mathrm{N}_{\mathrm{i}}=\frac{1}{4} \xi \eta\left(\xi+\xi_{\mathrm{i}}\right)\left(\eta+\eta_{\mathrm{i}}\right) \\
\text { za i }=1,3,5,7
\end{array}
$$

$\mathrm{N}_{\mathrm{i}}=\frac{\xi_{\mathrm{i}}^{2 \xi}}{2}\left(\xi+\xi_{\mathrm{i}}\right)\left(1-\eta^{2}\right)+\frac{\eta_{\mathrm{i}}^{2} \eta^{2}}{2}\left(\eta+\eta_{\mathrm{i}}\right)\left(1-\xi^{2}\right)$

$$
\text { za } \mathrm{i}=2,4,6,8
$$

$$
\begin{gathered}
\mathrm{N}_{\mathrm{i}}=\left(1-\eta^{2}\right)\left(1-\xi^{2}\right) \\
\text { za i }=9
\end{gathered}
$$

Slika 2.6. Bazne funkcije za 8-čvorni i 9-čvorni degenerirani element ljuske 


\subsection{Pomaci elementa}

Pomaci u nekoj proizvoljnoj točki elementa ljuske definirani su pomoću tri komponente čvornih pomaka srednje plohe ljuske (definiranih u globalnom koordinatnom sustavu) i tri zaokreta normale oko vektora čvornog koordinatnog sustava označenih s $\alpha_{k}, \beta_{k} \mathrm{i}$ $\gamma_{k}($ Slika 2.7).

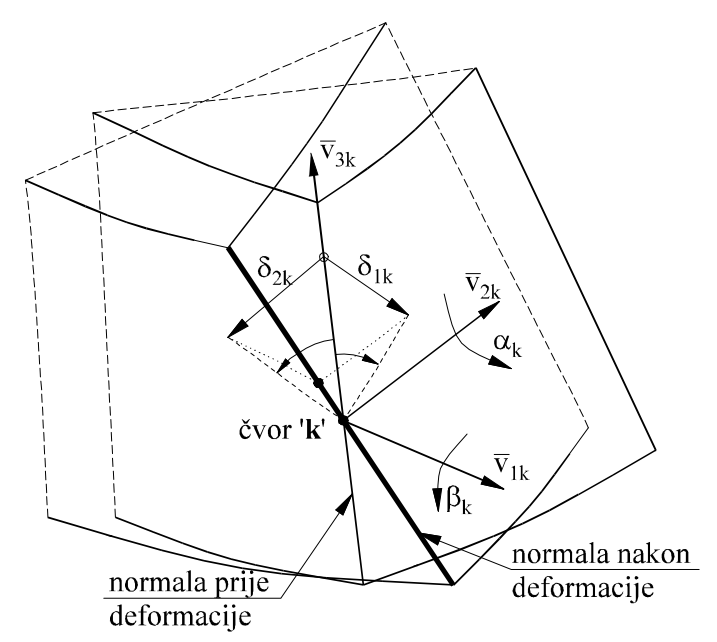

Slika 2.7. Veza između zaokreta normale i pomaka

Pomaci točke na normali u čvoru $k$, uz pretpostavku malih zaokreta, dobivaju se pomoću linearne veze:

$$
\begin{aligned}
& \delta_{1 \mathrm{k}}=\zeta \frac{\mathrm{h}_{\mathrm{k}}}{2} \alpha_{\mathrm{k}} \\
& \delta_{2 \mathrm{k}}=\zeta \frac{\mathrm{h}_{\mathrm{k}}}{2} \beta_{\mathrm{k}}
\end{aligned}
$$

gdje je $\delta_{1 \mathrm{k}}$ pomak u smjeru vektora $\overline{\mathrm{v}}_{1}^{\mathrm{k}}$, a $\delta_{2 \mathrm{k}}$ pomak u negativnom smjeru vektora $\overline{\mathrm{v}}_{2}^{\mathrm{k}}$. Komponente vektora pomaka, nastalih zbog zaokreta, su:

$$
\begin{aligned}
& \left(\mathbf{U}_{\mathrm{ik}}\right)_{\alpha_{\mathrm{k}}}=\delta_{1 \mathrm{k}} \overline{\mathrm{V}}_{1}^{\mathrm{ki}} \\
& \left(\mathbf{U}_{\mathrm{ik}}\right)_{\beta_{\mathrm{k}}}=\delta_{2 \mathrm{k}}\left(-\overline{\mathrm{v}}_{2}^{\mathrm{ki}}\right)
\end{aligned}
$$

Utjecaj kuta zaokreta $\gamma_{\mathrm{k}}$ oko normale na srednju plohu u čvoru $k$ na pomak bilo koje točke elementa egzaktno je izražen pomoću baznih funkcija višeg stupnja. Promatra li se deformacija 8-čvornog elementa za jedinični zaokret oko normale na srednju plohu, može se uočiti da iako su pomaci svih čvorova jednaki nuli, postoje pomaci svih ostalih točaka (Slika 2.8). Takvi pomaci trebali bi biti opisani baznim funkcijama koji su polinomi najmanje trećeg stupnja [74]. 


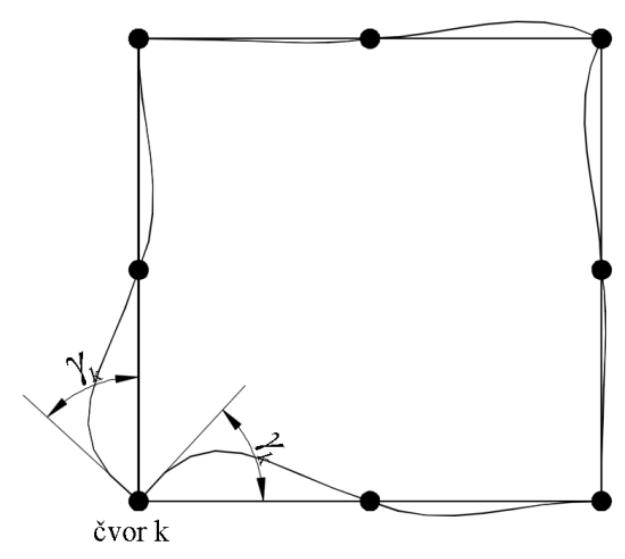

Slika 2.8. Deformacija 8-čvornog elementa uslijed jediničnog zaokreta $\gamma_{k}$

Međutim, mnogo je jednostavnije sve stupnjeve slobode opisivati istim baznim funkcijama i nije potrebno uvođenje novih baznih funkcija za zaokret $\gamma_{k}$ jer je njegov utjecaj integralno uzet u obzir kao rotacija krutog tijela [74].

Zanemarujući doprinos zaokreta $\gamma_{k}$ pomacima proizvoljne točke unutar elementa, doprinos čvora $k$ pomacima proizvoljne točke unutar elementa je:

$$
\mathbf{u}=\left[\begin{array}{c}
\mathrm{u} \\
\mathrm{v} \\
\mathrm{w}
\end{array}\right]=\left[\begin{array}{cccccc}
\mathrm{N}_{\mathrm{k}} & 0 & 0 & \mathrm{~N}_{\mathrm{k}} \frac{\mathrm{h}_{\mathrm{k}}}{2} \zeta \overline{\mathrm{v}}_{1 \mathrm{k}}^{\mathrm{X}} & -\mathrm{N}_{\mathrm{k}} \frac{\mathrm{h}_{\mathrm{k}}}{2} \zeta \overline{\mathrm{v}}_{2 \mathrm{x}}^{\mathrm{x}} & 0 \\
0 & \mathrm{~N}_{\mathrm{k}} & 0 & \mathrm{~N}_{\mathrm{k}} \frac{\mathrm{h}_{\mathrm{k}}}{2} \zeta \overline{\mathrm{v}}_{1 \mathrm{k}}^{\mathrm{Y}} & -\mathrm{N}_{\mathrm{k}} \frac{\mathrm{h}_{\mathrm{k}}}{2} \zeta \overline{\mathrm{v}}_{2 \mathrm{k}}^{\mathrm{Y}} & 0 \\
0 & 0 & \mathrm{~N}_{\mathrm{k}} & \mathrm{N}_{\mathrm{k}} \frac{\mathrm{h}_{\mathrm{k}}}{2} \zeta \overline{\mathrm{v}}_{1 \mathrm{k}}^{\mathrm{Z}} & -\mathrm{N}_{\mathrm{k}} \frac{\mathrm{h}_{\mathrm{k}}}{2} \zeta \overline{\mathrm{v}}_{2 \mathrm{k}}^{\mathrm{Z}} & 0
\end{array}\right]\left[\begin{array}{c}
\mathrm{U}_{\mathrm{k}} \\
\mathrm{V}_{\mathrm{k}} \\
\mathrm{W}_{\mathrm{k}} \\
\alpha_{\mathrm{k}} \\
\beta_{\mathrm{k}} \\
\gamma_{\mathrm{k}}
\end{array}\right]
$$

ili

$$
\mathbf{u}_{\mathrm{k}}=\mathrm{N}_{\mathrm{k}} \mathbf{U}_{\mathrm{k}}
$$

Pomaci proizvoljne točke unutar elementa, kada se u obzir uzmu doprinosi pomaka svih čvorova toga elementa, su:

$$
\mathbf{u}=\mathrm{NU}
$$




\subsection{Deformacije elementa}

Komponente deformacija se određuju u lokalnom koordinatnom sustavu $\left(\mathrm{x}_{1}=\mathrm{x}, \mathrm{x}_{2}=\right.$ $\mathrm{y}, \mathrm{x}_{3}=\mathrm{z}$ ), gdje ravnina $\mathrm{x}-\mathrm{y}$ tangira srednju plohu ljuske, a $\mathrm{x}_{3}$ je okomit na promatranu plohu ljuske ( $\zeta=$ konst.). Vektor deformacija definiran je sa:

$$
\boldsymbol{\varepsilon}^{\prime}=\left[\begin{array}{c}
\varepsilon_{\mathrm{x}^{\prime}} \\
\varepsilon_{\mathrm{y}^{\prime}} \\
\gamma_{\mathrm{x}^{\prime} \mathrm{y}^{\prime}} \\
\gamma_{\mathrm{x}^{\prime} \mathrm{z}^{\prime}} \\
\gamma_{\mathrm{y}^{\prime} z^{\prime}} \\
\varphi_{\mathrm{z}^{\prime}}
\end{array}\right]=\left[\begin{array}{c}
\partial \mathrm{u}^{\prime} / \partial \mathrm{x}^{\prime} \\
\partial \mathrm{v}^{\prime} / \partial \mathrm{y}^{\prime} \\
\partial \mathrm{u}^{\prime} / \partial \mathrm{y}^{\prime}+\partial \mathrm{v}^{\prime} / \partial \mathrm{x}^{\prime} \\
\partial \mathrm{w}^{\prime} / \partial \mathrm{x}^{\prime}+\alpha^{\prime} \\
\partial \mathrm{w}^{\prime} / \partial \mathrm{y}^{\prime}+\beta^{\prime} \\
-\frac{1}{2} \partial \mathrm{u}^{\prime} / \partial \mathrm{y}^{\prime}+\frac{1}{2} \partial \mathrm{v}^{\prime} / \partial \mathrm{x}^{\prime}-\gamma^{\prime}
\end{array}\right]
$$

Vektor deformacija $\varepsilon^{\prime}$ ima šest komponenti: $\varepsilon_{x}, \varepsilon_{y^{\prime}}, \gamma_{x^{\prime} y^{\prime}}, \gamma_{x^{\prime} z^{\prime}}, \gamma_{y^{\prime} z^{\prime}} i \varphi_{z^{\prime}}$. Kod toga su $\gamma_{i j}$ inženjerske posmične deformacije $\left(2 \varepsilon_{i j}=\gamma_{i j}\right)$. Posljednja komponenta vektora deformacija $\varphi_{z^{\prime}}$ posljedica je krutosti oko normale na srednju plohu ljuske i proizvodi je antisimetrični dio posmičnog naprezanja [74].

Derivacije lokalnih pomaka u', $\mathrm{v}^{\prime} \mathrm{i} \mathrm{w}^{\prime}$ po lokalnim koordinatama transformiraju se u derivacije globalnih pomaka u, v i w pomoću standardnih operacija:

$$
\left[\begin{array}{lll}
\partial u^{\prime} / \partial x^{\prime} & \partial v^{\prime} / \partial x^{\prime} & \partial w^{\prime} / \partial x^{\prime} \\
\partial u^{\prime} / \partial y^{\prime} & \partial v^{\prime} / \partial y^{\prime} & \partial w^{\prime} / \partial y^{\prime} \\
\partial u^{\prime} / \partial z^{\prime} & \partial v^{\prime} / \partial z^{\prime} & \partial w^{\prime} / \partial z^{\prime}
\end{array}\right]=\Theta^{T}\left[\begin{array}{lll}
\partial u / \partial X & \partial v / \partial X & \partial w / \partial X \\
\partial u / \partial Y & \partial v / \partial Y & \partial w / \partial Y \\
\partial u / \partial Z & \partial v / \partial Z & \partial w / \partial Z
\end{array}\right] \Theta
$$

gdje je $\Theta$ matrica transformacije oblika:

$$
\boldsymbol{\Theta}=\left[\begin{array}{lll}
\partial \mathrm{x} / \partial \mathrm{x}^{\prime} & \partial \mathrm{x} / \partial \mathrm{y}^{\prime} & \partial \mathrm{x} / \partial \mathrm{z}^{\prime} \\
\partial \mathrm{y} / \partial \mathrm{x}^{\prime} & \partial \mathrm{y} / \partial \mathrm{y}^{\prime} & \partial \mathrm{y} / \partial \mathrm{z}^{\prime} \\
\partial \mathrm{z} / \partial \mathrm{x}^{\prime} & \partial \mathrm{z} / \partial \mathrm{y}^{\prime} & \partial \mathrm{z} / \partial \mathrm{z}^{\prime}
\end{array}\right]
$$

Globalne derivacije pomaka u, v, w određuju se pomoću izraza:

$$
\left[\begin{array}{lll}
\partial \mathrm{u} / \partial \mathrm{X} & \partial \mathrm{v} / \partial \mathrm{X} & \partial \mathrm{w} / \partial \mathrm{X} \\
\partial \mathrm{u} / \partial \mathrm{Y} & \partial \mathrm{v} / \partial \mathrm{Y} & \partial \mathrm{w} / \partial \mathrm{Y} \\
\partial \mathrm{u} / \partial \mathrm{Z} & \partial \mathrm{v} / \partial \mathrm{Z} & \partial \mathrm{w} / \partial \mathrm{Z}
\end{array}\right]=\mathbf{J}^{-1}\left[\begin{array}{lll}
\partial \mathrm{u} / \partial \xi & \partial \mathrm{v} / \partial \xi & \partial \mathrm{w} / \partial \xi \\
\partial \mathrm{u} / \partial \eta & \partial \mathrm{v} / \partial \eta & \partial \mathrm{w} / \partial \eta \\
\partial \mathrm{u} / \partial \zeta & \partial \mathrm{v} / \partial \zeta & \partial \mathrm{w} / \partial \zeta
\end{array}\right]
$$

gdje je J Jacobijeva matrica u točki srednje plohe elementa. Pojedini članovi Jacobijeve matrice su derivacije globalnih koordinata po krivolinijskim koordinatama. 
Lokalni zaokret $\alpha^{\prime}, \beta^{\prime}$ i $\gamma^{\prime}$ dobiju se prema izrazima:

$$
\left[\begin{array}{l}
\alpha^{\prime} \\
\beta^{\prime}
\end{array}\right]=\sum_{\mathrm{k}=1}^{\mathrm{n}} \mathrm{N}_{\mathrm{k}}\left[\begin{array}{ll}
\psi_{22} & \psi_{21} \\
\psi_{12} & \psi_{11}
\end{array}\right]\left[\begin{array}{l}
\alpha_{\mathrm{k}} \\
\beta_{\mathrm{k}}
\end{array}\right] ; \quad \gamma^{\prime}=\sum_{\mathrm{k}=1}^{\mathrm{n}} \mathrm{N}_{\mathrm{k}} \gamma_{\mathrm{k}}
$$

gdje su $\psi_{\mathrm{ij}}(\mathrm{i}, \mathrm{j}=1,2)$ članovi transformacijske matrice iz čvornog u lokalni koordinatni sustav.

\subsection{Matrica deformacija elementa}

Matrica deformacija B, koja povezuje komponente deformacija u lokalnom koordinatnom sustavu s čvornim nepoznanicama elementa, može se dobiti iz:

$$
\boldsymbol{\varepsilon}^{\prime}=\sum_{\mathrm{k}=1}^{\mathrm{n}} \mathbf{B}_{\mathrm{k}} \mathbf{U}_{\mathrm{k}}
$$

gdje su $\mathbf{U}_{\mathrm{k}}$ i $\varepsilon^{\prime}$ definirani u (2.6) i (2.8), a matrica $\mathbf{B}_{\mathbf{k}}$ ima šest redaka i broj stupaca koji odgovara broju čvornih varijabli elementa (ukupan broj stupnjeva slobode elementa).

Doprinos pojedinog čvora $k$ matrici deformacija $\mathbf{B}$ za cijeli element može se prikazati u obliku:

$$
\mathbf{B}_{k}=\left[\begin{array}{llllll}
b_{1 u^{\prime}} & b_{1 v^{\prime}} & b_{1 w^{\prime}} & b_{1 \alpha^{\prime}} & b_{1 \beta^{\prime}} & 0 \\
b_{2 u^{\prime}} & b_{2 v^{\prime}} & b_{2 w^{\prime}} & b_{2 \alpha^{\prime}} & b_{2 \beta^{\prime}} & 0 \\
b_{3 u^{\prime}} & b_{3 v^{\prime}} & b_{3 w^{\prime}} & b_{3 \alpha^{\prime}} & b_{3 \beta^{\prime}} & 0 \\
b_{4 u^{\prime}} & b_{4 v^{\prime}} & b_{4 w^{\prime}} & b_{4 \alpha^{\prime}} & b_{4 \beta^{\prime}} & 0 \\
b_{5 u^{\prime}} & b_{5 v^{\prime}} & b_{5 w^{\prime}} & b_{5 \alpha^{\prime}} & b_{5 \beta^{\prime}} & 0 \\
b_{6 u^{\prime}} & b_{6 v^{\prime}} & b_{6 w^{\prime}} & 0 & 0 & b_{6 \gamma^{\prime}}
\end{array}\right]
$$

Članovi matrice B su derivacije baznih funkcija po lokalnim koordinatama. Kako su bazne funkcije ovisne o krivolinijskim koordinatama, mora se odrediti matrica $\mathbf{J}^{-1}$ koja ima oblik:

$$
\overline{\mathbf{J}}^{-1}=\left[\begin{array}{lll}
\partial \xi / \partial x^{\prime} & \partial \eta / \partial x^{\prime} & \partial \zeta / \partial x^{\prime} \\
\partial \xi / \partial y^{\prime} & \partial \eta / \partial y^{\prime} & \partial \zeta / \partial y^{\prime} \\
\partial \xi / \partial z^{\prime} & \partial \eta / \partial z^{\prime} & \partial \zeta / \partial z^{\prime}
\end{array}\right]
$$




\subsection{Određivanje naprezanja}

Komponente vektora naprezanja vezane su s komponentama vektora deformacija preko matrice elastičnih konstanti D. Vektor naprezanja u lokalnom koordinatnom sustavu može se napisati u obliku:

$$
\sigma=\left[\begin{array}{c}
\sigma_{\mathrm{x}^{\prime}} \\
\sigma_{\mathrm{y}^{\prime}} \\
\tau_{\mathrm{x}^{\prime} \mathrm{y}^{\prime}}^{\mathrm{s}} \\
\tau_{\mathrm{x}^{\prime} \mathrm{z}^{\prime}} \\
\tau_{\mathrm{y}^{\prime} \mathrm{z}^{\prime}} \\
\tau_{\mathrm{x}^{\prime} \mathrm{y}^{\prime}}
\end{array}\right]=\mathbf{D}\left[\begin{array}{c}
\varepsilon_{\mathrm{x}^{\prime}}+\mathrm{z}^{\prime} \mathrm{K}_{\mathrm{x}^{\prime}} \\
\varepsilon_{\mathrm{y}^{\prime}}+\mathrm{z}^{\prime} \mathrm{K}_{\mathrm{y}^{\prime}} \\
\gamma_{\mathrm{x}^{\prime} \mathrm{y}^{\prime}}+\mathrm{z}^{\prime} \mathrm{K}_{\mathrm{x}^{\prime} \mathrm{y}^{\prime}} \\
\gamma_{\mathrm{x}^{\prime} \mathrm{z}^{\prime}} \\
\gamma_{\mathrm{y}^{\prime} \mathrm{z}^{\prime}} \\
\varphi_{\mathrm{Z}^{\prime}}
\end{array}\right]+\left[\begin{array}{c}
\sigma_{\mathrm{x}^{\prime}}^{0} \\
\sigma_{\mathrm{y}^{\prime}}^{0} \\
0 \\
0 \\
0 \\
0
\end{array}\right]
$$

gdje su $\sigma_{x^{\prime}}^{0}$ i $\sigma_{y^{\prime}}^{0}$ početna naprezanja, $\tau_{x^{\prime} y^{\prime}}{ }^{s}$ je simetrični dio posmičnih naprezanja a $\tau_{x^{\prime} y^{\prime}}{ }^{A}$ antisimetrični dio posmičnih naprezanja koji proizvodi lokalnu rotaciju krutog tijela $\varphi_{Z^{\prime}}$.

\subsection{Matrica svojstava materijala}

Matrica elastičnih konstanti D predstavlja poopćeni Hook-ov zakon i za usvojeni konačni element je reda 6x6. U ovom radu je uzet Green-ov model za anizotropno hiperelastično tijelo. Pod anizotropijom se kod ljuske podrazumijeva ortotropija $\mathrm{s}$ tri međusobno okomite ravnine simetrije. Kada se glavne osi ortotropije $(1,2,3)$ podudaraju s lokalnim koordinatnim osima (x', y', z'), matrica D ima oblik:

$$
\mathbf{D}=\left[\begin{array}{cccccc}
\mathrm{d}_{11} & \mathrm{~d}_{12} & 0 & 0 & 0 & 0 \\
\mathrm{~d}_{21} & \mathrm{~d}_{22} & 0 & 0 & 0 & 0 \\
0 & 0 & \mathrm{~d}_{33} & 0 & 0 & 0 \\
0 & 0 & 0 & \mathrm{~d}_{44} & 0 & 0 \\
0 & 0 & 0 & 0 & \mathrm{~d}_{55} & 0 \\
0 & 0 & 0 & 0 & 0 & \mathrm{~d}_{66}
\end{array}\right]
$$

gdje su:

$$
\begin{array}{ll}
\mathrm{d}_{11}=\mathrm{E}_{1} /\left(1-\mathrm{v}_{12} \mathrm{v}_{21}\right) & \mathrm{d}_{33}=\mathrm{d}_{66}=\mathrm{G}_{12} \\
\mathrm{~d}_{22}=\mathrm{E}_{2} /\left(1-\mathrm{v}_{12} \mathrm{v}_{21}\right) & \mathrm{d}_{44}=\mathrm{K}_{1}^{*} \mathrm{G}_{13} \\
\mathrm{~d}_{12}=\mathrm{E}_{2} \mathrm{v}_{12} /\left(1-\mathrm{v}_{12} \mathrm{v}_{21}\right) & \mathrm{d}_{55}=\mathrm{K}_{2}^{*} \mathrm{G}_{23}
\end{array}
$$

Poisson-ovi koeficijenti su povezani jednadžbom:

$$
v_{21}=v_{12} E_{2} / E_{1}
$$


Ako se glavne osi ortotropije 1, 2 i 3 ne podudaraju sa smjerovima lokalnih osi x', y' i z', već su zarotirane za kut $\omega$, matrica $\mathbf{D}$ se treba transformirati prije određivanja matrice krutosti elementa. Kod toga transformacijska matrica T ima oblik:

$$
\mathbf{T}=\left[\begin{array}{cccccc}
\cos ^{2} \omega & \sin ^{2} \omega & \sin \omega \cos \omega & 0 & 0 & \sin \omega \cos \omega \\
\sin ^{2} \omega & \cos ^{2} \omega & -\sin \omega \cos \omega & 0 & 0 & -\sin \omega \cos \omega \\
-2 \sin \omega \cos \omega & 2 \sin \omega \cos \omega & \cos ^{2} \omega-\sin ^{2} \omega & 0 & 0 & 0 \\
0 & 0 & 0 & \cos \omega & \sin \omega & 0 \\
0 & 0 & 0 & -\sin \omega & \cos \omega & 0 \\
-2 \sin \omega \cos \omega & 2 \sin \omega \cos \omega & 0 & 0 & 0 & \cos ^{2} \omega-\sin ^{2} \omega
\end{array}\right]
$$

Koeficijenti $\mathrm{K}_{1}^{*}$ i $\mathrm{K}_{2}^{*}$ su korekcijski faktori za posmik u 1-3 i 2-3 ravnini. U formulaciji usvojenog elementa ljuske, usvojena je pretpostavka da normala na srednju plohu ostaje ravna (ne nužno okomita) i nakon deformiranja elementa. Ova pretpostavka ima za posljedicu konstantnu raspodjelu poprečnih posmičnih deformacija po debljini elementa, što je gruba aproksimacija stvarnog stanja (čak i za homogene poprečne presjeke). Poprečne posmične deformacije se u energetskom smislu aproksimiraju pomoću korekcijskih posmičnih faktora [6,22]. Taj faktor je određen kao kvocijent posmične deformacijske energije kod pretpostavljene konstantne deformacije i posmične deformacijske energije kod stvarne parabolične raspodjele. Za homogene presjeke uzima se $\mathrm{K}^{*}=5 / 6$.

Korišteni model materijala prvenstveno je namijenjen modeliranju ljuski od konstrukcijskog čelika, pri čemu se pretpostavlja njegovo elastoplastično ponašanje. Pretpostavljeno je elastično ponašanje dok se ne dosegne granica popuštanja, nakon čega se materijal ponaša potpuno plastično. Ponašanje materijala je opisano pomoću uvjeta početka tečenja, pravila tečenja i pravila ojačanja.

U ovom modelu koristi se Huber-Mises-ov uvjet tečenja, koji definira funkciju F koja predstavlja uvjet plastičnog popuštanja [6]:

$$
F(\sigma, H)=f(\sigma)-Y(H)=0
$$

gdje je $\mathrm{f}(\sigma)$ funkcija invarijanti devijatorskog naprezanja (2.22), a $\mathrm{Y}(\mathrm{H})$ granica tečenja koja može biti funkcija parametra očvršćenja H. Funkcija invarijanti devijatorskog naprezanja je dana sa:

$$
f(\sigma)=\bar{\sigma}=\sqrt{a_{11} \sigma_{1}^{2}+2 a_{12} \sigma_{11} \sigma_{22}+a_{22} \sigma_{2}^{2}+a_{33} \tau_{12}^{2}+a_{44} \tau_{13}^{2}+a_{55} \tau_{23}^{2}}=\sqrt{\boldsymbol{\sigma}_{1,2,3}^{\mathrm{T}} \mathbf{A}_{1,2,3} \boldsymbol{\sigma}_{1,2,3}}
$$


gdje je $\mathbf{A}_{1,2,3}$ matrica anizotropije čiji parametri se određuju eksperimentalno na temelju šest nezavisnih testova tečenja $[6,22]$ :

$$
\mathbf{A}_{1,2,3}=\left[\begin{array}{rlccc}
\mathrm{a}_{11} & \mathrm{a}_{12} & 0 & 0 & 0 \\
\mathrm{a}_{21} & \mathrm{a}_{22} & 0 & 0 & 0 \\
0 & 0 & \mathrm{a}_{33} & 0 & 0 \\
0 & 0 & 0 & \mathrm{a}_{44} & 0 \\
0 & 0 & 0 & 0 & \mathrm{a}_{55}
\end{array}\right]
$$

Ukupni prirast deformacija de definiran je kao zbroj elastične i plastične komponente:

$$
\mathrm{d} \boldsymbol{\varepsilon}=\mathrm{d} \boldsymbol{\varepsilon}^{\mathrm{e}}+\mathrm{d} \boldsymbol{\varepsilon}^{\mathrm{p}}
$$

gdje je d $\varepsilon^{\mathrm{e}}$ prirast elastičnih deformacija, a d $\boldsymbol{\varepsilon}^{\mathrm{p}}$ prirast plastičnih deformacija koji se dobiju na temelju pravila tečenja. Ako se pretpostavi pridružena plastičnost, odnosno okomitost vektora toka deformacija na krivulju plastičnog popuštanja, prirast plastičnih deformacija je:

$$
\mathrm{d} \boldsymbol{\varepsilon}^{\mathrm{p}}=\mathrm{d} \lambda \frac{\partial \mathrm{F}}{\partial \boldsymbol{\sigma}}
$$

gdje je d $\lambda$ pozitivni skalar, a gradijent funkcije $\mathrm{F}$ definira smjer koji je okomit na krivulju plastičnog popuštanja. Izraz (2.21) u diferencijalnom obliku je:

$$
\mathbf{a}^{\mathrm{T}} \mathrm{d} \boldsymbol{\sigma}-\operatorname{Hd} \lambda=0
$$

gdje je vektor tečenja a definiran:

$$
\mathbf{a}=\left[\frac{\partial \mathrm{F}}{\partial \sigma_{x}}, \frac{\partial \mathrm{F}}{\partial \sigma_{y}}, \frac{\partial \mathrm{F}}{\partial \tau_{x y}}, \frac{\partial \mathrm{F}}{\partial \tau_{x z}}, \frac{\partial \mathrm{F}}{\partial \tau_{y z}}\right]^{\mathrm{T}}
$$

Veza naprezanja i deformacija u diferencijalnom obliku je definirana kao:

$$
\mathrm{d} \boldsymbol{\sigma}=\mathbf{D}_{\mathrm{ep}} \mathrm{d} \boldsymbol{\varepsilon}
$$

gdje je $\mathbf{D}_{\mathrm{ep}}$ matrica elastoplastičnosti:

$$
\mathbf{D}_{\text {ep }}=\mathbf{D}-\frac{\mathbf{D} \mathbf{a} \mathbf{a}^{\mathrm{T}} \mathbf{D}}{\mathrm{H}+\mathbf{a}^{\mathrm{T}} \mathbf{D a}}
$$




\subsection{Matrica krutosti elementa}

Matrica krutosti elemenata $\mathbf{K}_{\mathbf{e}}$ ima $(6 \times n) \times(6 \times n)$ članova, pri čemu je $n$ broj čvorova elementa. Sastavljena je od podmatrica $\mathbf{K}_{\mathbf{i j}}$ veličine $6 \times 6$, koje povezuju dva čvora $i$ i $j$. Izračunava se integriranjem po srednjoj plohi ljuske pomoću:

$$
\mathbf{K}_{\mathrm{ij}}=\int_{-1}^{+1} \int_{-1}^{+1} \mathbf{B}_{\mathrm{i}}^{\mathrm{T}} \mathbf{D} \mathbf{B}_{\mathrm{j}} \operatorname{det} \mathbf{J}(\xi, \eta) \mathrm{d} \xi \mathrm{d} \eta
$$

U ovome pristupu moguće je modelirati ljusku koja se sastoji od više slojeva različitog materijala i različitih debljina, pri čemu se koristi Gaussova numerička integracija [75] za izračunavanje doprinosa krutosti svakoga sloja. Ako su po debljini ljuske raspoređeni različiti materijali, može se svaki pojedini materijal predstaviti kao sloj elementa ljuske čija je debljina poznata. Nehomogenost elementa po debljini uzima se u obzir pomoću matrice $\mathbf{D}$, koja je dana jednadžbom (2.17). Prirodna koordinata $\zeta$ smještena je u sredini svake lamele i komponente deformacija i naprezanja, kao i doprinosi krutosti za svaku lamelu, računaju se u sredini svake lamele (Slika 2.9).

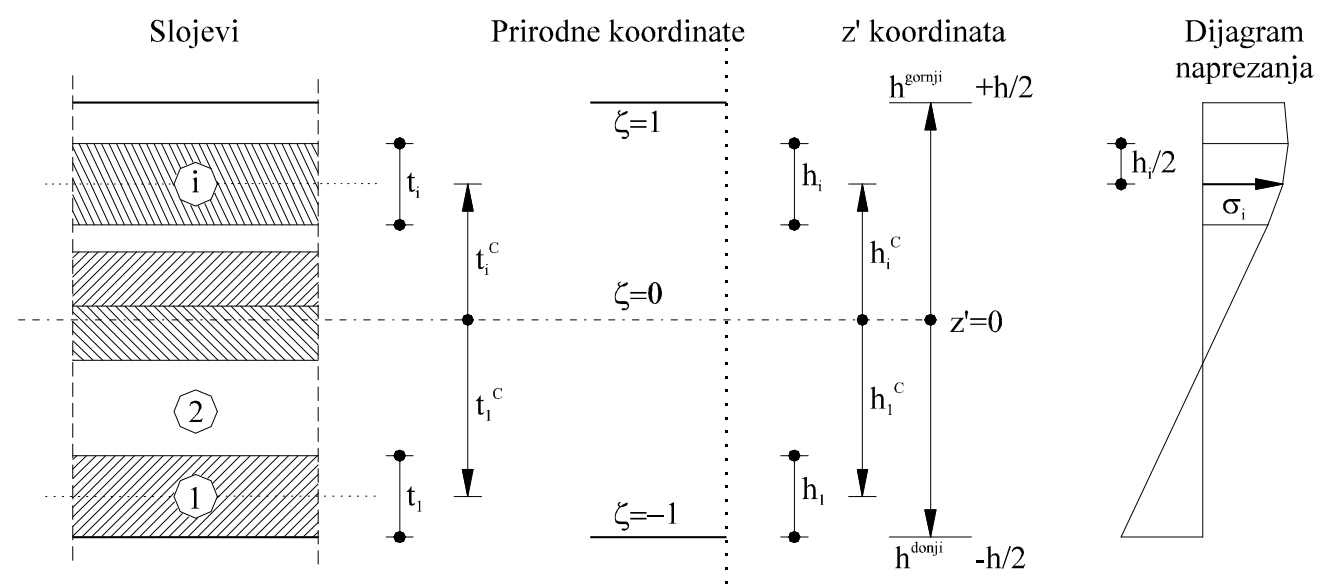

Slika 2.9. Uslojenost elementa ljuske

Kada se pri analizi tankih ljuski koristi puna integracija za izračunavanje matrice krutosti, koja ima m×m Gauss-ovih integracijskih točaka (Slika 2.10.b), dolazi do povećanja poprečnih posmičnih komponenti u matrici krutosti koje nazivamo posmično ukrućivanje (eng. shear locking), te povećanja membranskih komponenti koje nazivamo membransko ukrućivanje (eng. membrane locking). Bolje rezultate daje reducirana integracija koja ima (m1)×(m-1) Gaussovih integracijskih točaka (Slika 2.10.a). Kod ovog integracijskog postupka mogu se u nekim primjerima javiti nulti energijski oblici, što se eliminira uporabom selektivne integracije. Tehnikom selektivne integracije se dio matrice krutosti (posmični dio) integrira po reduciranom pravilu. 


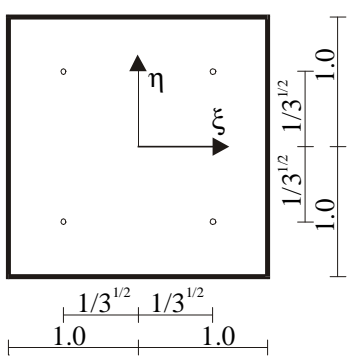

a) reducirana integracija $(2 \times 2)$

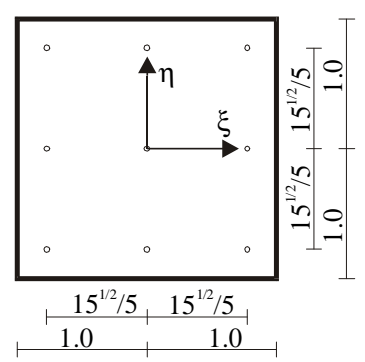

b) puna integracija $(3 \times 3)$

Slika 2.10. Položaj integracijskih točaka

Konačni degenerirani izoparametrijski elementi ljuske koji se koriste u ovom radu i razvijenom numeričkom modelu [73] oslobođeni su utjecaja posmičnog i membranskog ukrućivanja. Detaljan opis rješenja za eliminaciju ovog utjecaja može se naći u [6].

\subsection{Opterećenje elementa}

Element ljuske može biti opterećen čvornim, površinskim i volumenskim silama:

$$
\mathrm{F}_{\mathrm{e}}=\mathrm{F}_{\mathrm{crv}}+\mathrm{F}_{\mathrm{pov}}+\mathrm{F}_{\mathrm{vol}}
$$

Principom virtualnog rada za vektor opterećenja elementa dobiva se sljedeći izraz:

$$
\mathrm{F}_{\mathrm{e}}=\mathrm{F}_{\check{c ̌ v}}+\int_{\mathrm{A}_{\mathrm{el}}} \mathrm{N}^{\mathrm{T}} \mathrm{pdA}+\int_{\mathrm{V}_{\mathrm{el}}} \mathrm{N}^{\mathrm{T}} \mathrm{fdV}
$$

gdje je p površinsko opterećenje, f volumensko opterećenje $\mathrm{i} \mathrm{A}_{\text {el }}$ površina srednje plohe elementa.

Volumen elementa određuje se jednadžbom:

$$
\mathrm{V}_{\mathrm{el}}=\int_{\mathrm{V}_{\mathrm{el}}} \mathrm{dV}=\int_{-1}^{1} \int_{-1}^{1} 2 \operatorname{det} \mathrm{J} \mathrm{d} \xi \mathrm{d} \eta=\sum_{\mathrm{i}=1}^{\mathrm{n}} \sum_{\mathrm{j}=1}^{\mathrm{n}} 2 \mathrm{w}_{\mathrm{i}} \mathrm{w}_{\mathrm{j}} \operatorname{det} \mathrm{J}\left(\xi_{\mathrm{i}}, \eta_{\mathrm{i}}\right)
$$

gdje je integracija po prirodnim koordinatama zamijenjena numeričkom (Gaussovom) integracijom $n \times n$. Kod toga je $n$ broj Gaussovih točaka u $\xi$ i $\eta$ smjeru, a $w_{i}$ i $w_{j}$ su integracijske težine [75]. Determinanta Jacobijeve matrice se mora izračunati u svakoj integracijskoj točki na srednjoj plohi ljuske.

Dakle, vektor opterećenja čvora konačnog elementa ima 6 komponenti:

$$
\mathbf{F}_{\mathrm{k}}=\left\{\begin{array}{llllll}
\mathrm{F}_{\mathrm{k}}^{\mathrm{X}} & \mathrm{F}_{\mathrm{k}}^{\mathrm{Y}} & \mathrm{F}_{\mathrm{k}}^{\mathrm{Z}} & \mathbf{M}_{\mathrm{k}}^{\overline{\mathrm{v}}_{2}} & \mathrm{M}_{\mathrm{k}}^{\overline{\mathrm{v}}_{1}} & \mathbf{M}_{\mathrm{k}}^{\overline{\mathrm{v}}_{3}}
\end{array}\right\}
$$


Komponente $F_{k}^{X}, F_{k}^{Y}$ i $F_{k}^{Z}$ su u globalnom koordinatnom sustavu, a $M_{k}^{\bar{v}_{1}}, \quad M_{k}^{\bar{v}_{2}}$ i $M_{k}^{\bar{v}_{3}} u$ čvornom koordinatnom sustavu i predstavljaju sile i momente u čvoru k uslijed djelovanja čvornih, površinskih i volumenskih sila.

\subsection{Uključenje geometrijske nelinearnosti}

\subsubsection{Općenito}

Geometrijska nelinearnost konstrukcije je posljedica utjecaja promjene geometrije konstrukcije i nelinearnog odnosa između deformacija i pomaka. Kada su pomaci konstrukcije veliki, zadovoljavanje jednadžbi ravnoteže na nedeformiranom sustavu daje pogrešne rezultate. Stoga je pri velikim pomacima konstrukcije nužno uzeti u obzir utjecaj promjene geometrije i rješavati jednadžbe ravnoteže na deformiranom sustavu.

Odnos deformacija i pomaka je linearan kada su deformacije konstrukcije male. Linearna veza deformacija i pomaka prihvatljiva je za probleme s malim deformacijama (npr. analiza konstrukcija kod kojih su uporabne i lomne deformacije relativno male) [76].

U ovome radu usvojen je model geometrijske nelinearnosti za probleme s velikim pomacima (eng. large displacement) i malim deformacijama (eng. small strains).

\subsubsection{Postupak uključivanja geometrijske nelinearnosti}

Za rješenje problema koristi se tzv. ažurirani Lagrange-ov postupak, koji se temelji na sljedećim postavkama [77]:

1. Vanjsko opterećenje se aplicira u inkrementima. Za svaki inkrement opterećenja se provodi iteracijski postupak proračuna sve dok vektor neuravnoteženih sila ne bude dovoljno malen. Nakon što je zadovoljen kriterij konvergencije, vektor neuravnoteženih sila pridodaje se idućem inkrementu vanjskog opterećenja i iteracijski postupak se ponovno nastavlja.

2. U okviru svakog iteracijskog koraka koristi se klasični Lagrange-ov postupak: stanje varijabli se definira u odnosu na stanje na početku promatranog iteracijskog koraka.

3. Na kraju svakog iteracijskog koraka, stanje varijabli se ažurira u odnosu prema stanju na kraju promatranog iteracijskog koraka.

Prvo će se razmotriti stanje na početku promatranoga iteracijskog koraka. U Lagrangeovom opisu, prostorni položaj tijela izražen u Kartezijevu koordinatnom sustavu $\mathbf{X}_{\mathrm{i}}$ definiran je izrazom: 


$$
\mathbf{X}_{\mathrm{i}}=\mathbf{X}_{\mathrm{i}}\left(\boldsymbol{\Theta}^{\alpha}\right)
$$

gdje je materijalna točka tijela jedinstveno definirana u pridruženom krivolinijskom koordinatnom sustavu $\Theta^{\alpha}$ (Slika 2.10).

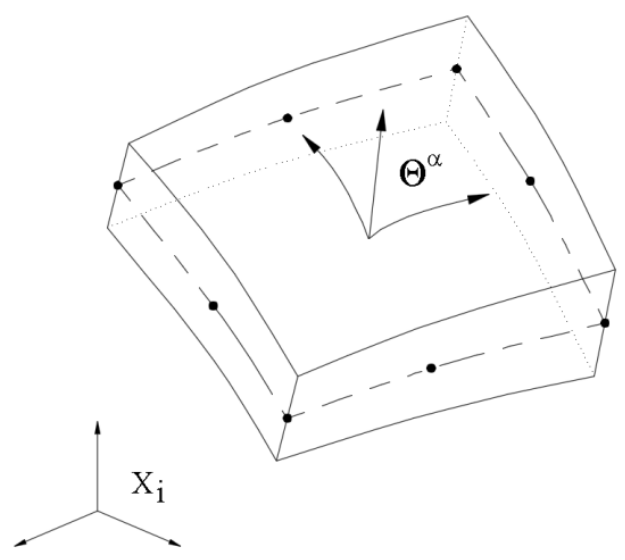

Slika 2.10. Prostorni položaj konstrukcije

Ravnoteža tijela izražava se jednadžbom virtualnog rada $\mathrm{s}$ komponentama $\mathrm{u}$ Kartezijevu koordinatnom sustavu, ili s komponentama u pridruženom krivolinijskom koordinatnom sustavu:

$$
\int_{V} \sigma_{i j} \delta \varepsilon_{i j} d V=\int_{S} \mathbf{q}_{i} \delta u_{i} d S ; \int_{V} \sigma_{\alpha \beta} \delta \varepsilon_{\alpha \beta} d V=\int_{S} \mathbf{q}_{i} \delta u_{i} d S
$$

gdje su $\sigma_{\mathrm{ij}}$ i $\boldsymbol{\sigma}_{\alpha \beta}$ Cauchy-evo naprezanje, $\delta \boldsymbol{\varepsilon}_{\mathrm{ij}}$ i $\delta \boldsymbol{\varepsilon}_{\alpha \beta}$ mali prirast (inkrement) deformacije, $\mathbf{q}_{\mathrm{i}}$ površinsko opterećenje, $\mathrm{V}$ volumen tijela i S ploha tijela.

Integracija jednadžbi (2.36) se obavlja preko tekućeg stanja tijela. Kontravarijantne komponente Cauchy-eva naprezanja $\sigma_{\alpha \beta}$ su jednake kontravarijantnim komponentama drugih Piola-Kirchhoff-ovih naprezanja $\mathbf{S}_{\alpha \beta}$. Kovarijantne komponente prirasta deformacija povezane su s Kartezijevim komponentama prirasta pomaka $\delta \mathbf{u}$ preko:

$$
\delta \boldsymbol{\varepsilon}_{\alpha \beta}=\frac{1}{2}\left(\mathbf{X}_{\mathrm{k}, \alpha} \delta \mathbf{u}_{\mathrm{k}, \beta}+\mathbf{X}_{\mathrm{k}, \beta} \delta \mathbf{u}_{\mathrm{k}, \alpha}\right)
$$

Koristeći se simetrijom $\sigma_{\alpha \beta}$, jednadžba virtualnog rada može se napisati u obliku:

$$
\int_{\mathrm{V}} \mathbf{S}_{\alpha \beta} \mathbf{X}_{\mathrm{k}, \alpha} \delta \mathbf{u}_{\mathrm{k}, \beta} \mathrm{dV}=\int_{\mathrm{S}} \mathbf{q}_{\mathrm{i}} \delta \mathbf{u}_{\mathrm{i}} \mathrm{dS}
$$

Na kraju promatranoga iteracijskog koraka, prostorni položaj tijela opisan je sa:

$$
\mathbf{x}_{\mathrm{i}}=\mathbf{x}_{\mathrm{i}}\left(\boldsymbol{\Theta}_{\alpha}\right)=\mathbf{x}_{\mathrm{i}}\left(\boldsymbol{\Theta}_{\alpha}\right)+\Delta \mathrm{u}_{\mathrm{i}}\left(\boldsymbol{\Theta}_{\alpha}\right)
$$


gdje je $\mathbf{x}_{\mathrm{i}}$ prostorni položaj točke tijela na početku promatranoga iteracijskog koraka, a $\Delta \mathbf{u}_{\mathrm{i}}$ inkrement pomaka.

Jednadžba virtualnog rada na kraju promatranog iteracijskog koraka ima oblik:

$$
\int_{\mathrm{V}}\left(\mathbf{S}_{\alpha \beta}+\Delta \mathbf{S}_{\alpha \beta}\right) \delta \mathbf{E}_{\alpha \beta} \mathrm{dV}=\int_{\mathrm{S}}\left(\mathbf{q}_{\mathrm{i}}+\Delta \mathbf{q}_{\mathrm{i}}\right) \delta \mathbf{u}_{\mathrm{i}} \mathrm{d} \mathrm{S}
$$

gdje $\delta \mathbf{E}_{\alpha \beta}$ označava prirast Green-ovih deformacija, koji se može izračunati iz prirasta pomaka s pomoću:

$$
\delta \mathbf{E}_{\alpha \beta}=\frac{1}{2}\left[\left(\mathbf{X}_{\mathrm{k}, \alpha}+\Delta \mathbf{u}_{\mathrm{k}, \alpha}\right) \delta \mathbf{u}_{\mathrm{k}, \beta}+\left(\mathbf{X}_{\mathrm{k}, \beta}+\Delta \mathbf{u}_{\mathrm{k}, \beta}\right) \delta \mathbf{u}_{\mathrm{k}, \alpha}\right]
$$

Integracija jednadžbe (2.40) vrši se u odnosu na stanje tijela na početku iteracijskog koraka i $\Delta \mathbf{S}_{\alpha \beta}$ je inkrement drugih Piola-Kirchhoff-ovih naprezanja.

Koristeći se simetrijom $\mathbf{S}_{\alpha \beta}$ i $\Delta \mathbf{S}_{\alpha \beta}$, jednadžba ravnoteže u funkciji pomaka ima oblik:

$$
\int_{\mathrm{V}}\left(\mathbf{S}_{\alpha \beta}+\Delta \mathbf{S}_{\alpha \beta}\right)\left(\mathbf{X}_{\mathrm{k}, \alpha}+\Delta \mathbf{u}_{\mathrm{k}, \alpha}\right) \delta \mathbf{u}_{\mathrm{k}, \beta} \mathrm{dV}=\int_{\mathrm{S}}\left(\mathbf{q}_{\mathrm{i}}+\Delta \mathbf{q}_{\mathrm{i}}\right) \delta \mathbf{u}_{\mathrm{i}} \mathrm{d} \mathrm{S}
$$

Integracija u (2.38) i (2.42) provodi se prema istom stanju tijela.

Kraćenjem jednadžbe (2.42), dobiva se jednadžba inkrementalnoga virtualnog rada koja se također označava kao jednadžba neprekinute (kontinuirane) ravnoteže:

$$
\int_{\mathrm{V}}\left(\Delta \mathbf{S}_{\alpha \beta} \mathbf{X}_{\mathrm{k}, \alpha}+\mathbf{S}_{\alpha \beta} \Delta \mathbf{u}_{\mathrm{k}, \alpha}+\Delta \mathbf{S}_{\alpha \beta} \Delta \mathbf{u}_{\mathrm{k}, \alpha}\right) \delta \mathbf{u}_{\mathrm{k}, \beta} \mathrm{dV}=\int_{\mathrm{S}}\left(\mathbf{q}_{\mathrm{i}}+\Delta \mathbf{q}_{\mathrm{i}}\right) \delta \mathbf{u}_{\mathrm{i}} \mathrm{d} \mathbf{S}
$$

Prirast naprezanja, odnosno tekući konstitutivni model materijala, može se napisati u obliku:

$$
\Delta \mathbf{S}_{\alpha \beta}=\mathbf{C}_{\alpha \beta \gamma \delta} \Delta \mathbf{E}_{\gamma \delta}
$$

gdje $\mathbf{C}_{\alpha \beta \gamma \delta}$ označava tekuću funkcijsku vezu između prirasta naprezanja i prirasta deformacija. Inkrement Green-ovih deformacija može se izračunati iz prirasta pomaka s pomoću:

$$
\Delta \mathbf{E}_{\gamma \delta}=\frac{1}{2}\left(\mathbf{X}_{\mathrm{k}, \gamma} \Delta \mathbf{u}_{\mathrm{k}, \delta}+\mathbf{X}_{\mathrm{k}, \delta} \Delta \mathbf{u}_{\mathrm{k}, \gamma}+\Delta \mathbf{u}_{\mathrm{k}, \gamma} \Delta \mathbf{u}_{\mathrm{k}, \delta}\right)
$$

Budući da je $\mathbf{C}_{\alpha \beta \gamma \delta}$ simetričan u odnosu na dva posljednja indeksa, kombinacijom jednadžbi (2.44) i (2.45) dobije se izraz za proračun inkremenata naprezanja u funkciji inkremenata pomaka:

$$
\Delta \mathbf{S}_{\alpha \beta}=\mathbf{C}_{\alpha \beta \gamma \delta}\left(\mathbf{X}_{\mathrm{k}, \gamma} \Delta \mathbf{u}_{\mathrm{k}, \delta}+\frac{1}{2} \Delta \mathbf{u}_{\mathrm{k}, \gamma} \Delta \mathbf{u}_{\mathrm{k}, \delta}\right)
$$


Izrazi (2.43) i (2.46) temeljne su jednadžbe promatranoga iteracijskog koraka. Ako je koordinatni sustav Kartezijev, (2.43) i (2.46) pojednostavljuju se na:

$$
\begin{gathered}
\int_{\mathrm{V}}\left(\Delta \mathbf{S}_{\mathrm{ij}} \delta_{\mathrm{ki}}+\mathbf{S}_{\mathrm{ij}} \Delta \mathbf{u}_{\mathrm{k}, \mathrm{i}}+\Delta \mathbf{S}_{\mathrm{ij}} \Delta \mathbf{u}_{\mathrm{k}, \mathrm{i}}\right) \delta \mathbf{u}_{\mathrm{k}, \mathrm{j}} \mathrm{dV}=\int_{\mathrm{S}} \mathbf{q}_{\mathrm{i}} \delta \mathbf{u}_{\mathrm{i}} \mathrm{d} S \\
\Delta \mathbf{S}_{\mathrm{ij}}=\mathbf{C}_{\mathrm{ijkl}}\left(\Delta \mathbf{u}_{\mathrm{k}, \mathrm{j}}+\frac{1}{2} \Delta \mathbf{u}_{\mathrm{m}, \mathrm{k}} \Delta \mathbf{u}_{\mathrm{m}, \mathrm{l}}\right)
\end{gathered}
$$

gdje je $\delta_{\text {ki }}$ Kronecher-ov simbol.

Na kraju tekućeg iteracijskog koraka potrebno je ažurirati stanje varijabli. Pri tome se razlikuje formulacija preko općega krivolinijskog koordinatnog sustava i pridruženog koordinatnog sustava koji je Kartezijev koordinatni sustav na početku iteracijskog koraka.

Za zakrivljeni sustav, kontravarijantne komponente drugog Piola-Kirchhoff-ova naprezanja treba korigirati za promjene volumena kako bi postale kontravarijantne komponente Cauchy-eva naprezanja:

$$
\boldsymbol{\sigma}_{\alpha \beta}=\left(\mathbf{S}_{\alpha \beta}+\Delta \mathbf{S}_{\alpha \beta}\right) / \mathrm{J}
$$

gdje je J jakobijana inkrementa deformacije. Ako je materijal približno nestišljiv, transformacija nije potrebna.

Za početni Katrezijev sustav, drugo Piola-Kirchhoff-ovo naprezanje treba transformirati u stvarno (Cauchy-evo) naprezanje u Kartezijevu koordinatnom sustavu:

$$
\sigma_{\mathrm{ij}}=\left(\delta_{\mathrm{ik}}+\Delta \mathrm{u}_{\mathrm{i}, \mathrm{k}}\right)\left(\mathrm{S}_{\mathrm{kl}}+\Delta \mathrm{S}_{\mathrm{kl}}\right)\left(\delta_{\mathrm{jl}}+\Delta \mathrm{u}_{\mathrm{j}, 1}\right) / \mathrm{J}
$$

Pritom opet jakobijana treba biti jednaka jedinici ako je materijal približno nestišljiv.

Prethodno prikazanim postupkom, utjecaj promjene geometrije sustava obuhvaćen je transformacijama komponenata pomaka i sila (naprezanja) između globalnog i lokalnog koordinatnog sustava. Uz pretpostavku da je prirast pomaka unutar svakoga iteracijskog koraka malen, može se usvojiti da je odnos između deformacija i pomaka linearan. Na ovaj se način proračun značajno pojednostavljuje i skraćuje. Primjena lokalnog koordinatnog sustava za definiranje konstitutivnog zakona materijala također pojednostavljuje analizu za slučajeve s anizotropnim svojstvima materijala. 


\subsection{Provedba numeričke analize}

Linearna diferencijalna jednadžba dinamičke ravnoteže sustava dana je izrazom:

$$
\mathbf{M}_{\mathrm{s}} \ddot{\mathbf{u}}+\mathbf{C}_{\mathrm{s}} \dot{\mathbf{u}}+\mathbf{R}(\mathrm{u})=\mathbf{f}_{\mathrm{s}}
$$

gdje je $\mathbf{M}_{\mathrm{s}}$ matrica masa, $\mathbf{C}_{\mathrm{s}}$ matrica prigušenja, $\mathbf{R}(\mathrm{u})$ vektor unutrašnjih sila, $\mathbf{f}_{\mathrm{s}}$ je vektor vanjskih čvornih sila konstrukcije, u je nepoznati pomak konstrukcije.

Za vremensku integraciju jednadžbe (2.51) koristi se metoda konačnih diferencija i to Newmarkov implicitno iterativni algoritam. Promatrano vremensko područje podijeljeno je u vremenske korake $\Delta \mathrm{t}$. Potrebno je izračunati nepoznate varijable u vremenu $\mathrm{t}_{\mathrm{n}+1}=\mathrm{t}_{\mathrm{n}}+\Delta \mathrm{t}$, kod čega su poznati svi rezultati $u$ vremenu $t_{0}=0$ do vremena $t_{n}$. Prema Newmarkovom algoritmu, kojega je u iterativnom obliku kasnije razvio Hughes [78,79], jednadžbu dinamičke ravnoteže treba zadovoljiti $\mathrm{u}$ vremenu $\mathrm{t}_{\mathrm{n}+1}=\mathrm{t}_{\mathrm{n}}+\Delta \mathrm{t}=(\mathrm{n}+1) \Delta \mathrm{t}$, odnosno $\mathrm{u} \quad(\mathrm{n}+1)$ vremenskom inkrementu:

$$
\mathbf{M} \ddot{u}_{n+1}+\mathbf{R}\left(\mathrm{u}_{\mathrm{n}+1}, \dot{\mathrm{u}}_{\mathrm{n}+1}\right)=\mathbf{f}_{\mathrm{n}+1}
$$

pri čemu su:

$$
\begin{gathered}
\mathrm{u}_{\mathrm{n}+1}=\overline{\mathrm{u}}_{\mathrm{n}+1}+\beta \Delta \mathrm{t}^{2} \ddot{\mathrm{u}}_{\mathrm{n}} \\
\dot{\mathrm{u}}_{\mathrm{n}+1}=\overline{\mathrm{u}}_{\mathrm{n}+1}+\beta \Delta \mathrm{t}_{\mathrm{u}} \\
\overline{\mathrm{u}}_{\mathrm{n}+1}=\mathrm{u}_{\mathrm{n}}+\Delta \mathrm{t} \dot{\mathrm{u}}_{\mathrm{n}}+0.5(1-2 \beta) \Delta \mathrm{t}^{2} \ddot{\mathrm{u}}_{\mathrm{n}} \\
\dot{\dot{\mathrm{u}}}_{\mathrm{n}+1}=\dot{\mathrm{u}}_{\mathrm{n}}+(1-\gamma) \Delta \mathrm{t} \ddot{\mathrm{u}}_{\mathrm{n}}
\end{gathered}
$$

U gornjim izrazima $\overline{\mathrm{u}}_{\mathrm{n}+1} \mathrm{i} \overline{\mathrm{u}}_{\mathrm{n}+1}$ su pretpostavljene, $\mathrm{u}_{\mathrm{n}+1} \mathrm{i} \dot{\mathrm{u}}_{\mathrm{n}+1}$ korigirane vrijednosti pomaka, odnosno brzina, a $\ddot{\mathrm{u}}_{\mathrm{n}+1}$ su ubrzanja. Pretpostavljene vrijednosti vektora pomaka i brzina ovise o vrijednostima izračunatih varijabli iz prethodnog vremenskog koraka.

Parametri $\beta$ i $\gamma$ određuju stabilnost i točnost metode. Praktično bezuvjetna stabilnost postiže se za $\gamma \geq 0.5$ i $\beta=0.25(\gamma+0.5)^{2}$. Problem stabilnosti implicitnih metoda detaljnije je prikazan primjerice u [78]. Parametar $\gamma$ odražava numeričko prigušenje u sustavu. Za $\gamma=0.5$, nema prigušenja. Newmarkova familija metoda, kao poseban slučaj (za određene vrijednosti parametara $\beta$ i $\gamma$ ), uključuje mnoge poznate metode [79]. Jedna od najefikasnijih i najčešće korištenih je metoda srednjeg ubrzanja $(\beta=0.25, \gamma=0.5)$.

Uvrštenjem (2.53) u (2.52) i uvođenjem inkrementalno-iterativnog postupka rješavanja općeg nelinearnog problema, dobiva se tzv. efektivni statički problem: 


$$
\mathbf{K}_{\tau}^{*} \Delta \mathrm{u}^{\mathrm{i}}=\left(\mathbf{f}^{*}\right)^{\mathrm{i}}
$$

gdje je matrica efektivne tangentne krutosti $\mathrm{K}_{\tau}^{*}$, proračunata u vremenu $\tau$, definirana s:

$$
\mathbf{K}_{\tau}^{*}=\frac{\mathbf{M}}{\beta \Delta \mathrm{t}^{2}}+\gamma \frac{\mathbf{C}}{\beta \Delta \mathrm{t}}+\mathbf{K}_{\tau}
$$

a vektor efektivnog opterećenja s:

$$
\mathbf{f}^{*}=\mathbf{f}_{\mathrm{n}+1}-\mathbf{M} \ddot{\mathrm{u}}_{\mathrm{n}+1}^{\mathrm{i}}-\mathbf{R}\left(\mathrm{u}_{\mathrm{n}+1}^{\mathrm{i}}, \dot{\mathrm{u}}_{\mathrm{n}+1}^{\mathrm{i}}\right)
$$

U gornjim izrazima $n$ označava vremenski korak, $i$ iteracijski korak, a $\Delta u$ vektor prirasta pomaka. Kao što je ranije navedeno, rješenje nelinearnog problema izvršeno je metodom Newton-Raphson.

$\mathrm{Na}$ početku proračunskog postupka, za poznate početne vrijednosti vektora pomaka $\mathrm{u}_{0} \mathrm{i}$ vektora brzina $\dot{\mathrm{u}}_{0}$, vektor početnog ubrzanja $\ddot{\mathrm{u}}_{0}$ dobije se prema (2.52), tj.:

$$
\ddot{\mathrm{u}}_{0}=\mathbf{M}^{-1} \mathbf{f}-\mathbf{R}\left(\mathrm{u}_{0}, \dot{\mathrm{u}}_{0}\right)
$$

Ako je matrica masa dijagonalna, što je najčešći slučaj u praksi, rješenje (2.58) je jednostavno.

U ovom radu je korištena metoda srednjeg ubrzanja, a algoritam rješenja u svakom vremenskom koraku prikazan je u Tablici 2.1. 
Tablica 2.1. Newmarkov implicitno iterativni algoritam

\begin{tabular}{|c|c|}
\hline (1) & Za vremenski korak $(n+1)$, staviti iteracijski korak $\mathrm{i}=1$ \\
\hline (2) & $\begin{array}{l}\text { Izračunati vektore pretpostavljenih pomaka, brzina } i \text { ubrzanja na početku } \\
\text { vremenskog koraka s pomoću poznatih vrijednosti iz prethodnih vremenskih } \\
\text { koraka: } \\
\qquad \begin{array}{l}\mathrm{u}_{\mathrm{n}+1}^{1} \\
=\overline{\mathrm{u}}_{\mathrm{n}+1} \\
\qquad \dot{\mathrm{u}}_{\mathrm{n}+1}^{1}=\overline{\dot{\mathrm{u}}}_{\mathrm{n}+1} \\
\qquad \ddot{\mathrm{u}}_{\mathrm{n}+1}^{1}=\left(\mathrm{u}_{\mathrm{n}+1}^{1}-\overline{\mathrm{u}}_{\mathrm{n}+1}\right) /\left(\beta \Delta \mathrm{t}^{2}\right)\end{array}\end{array}$ \\
\hline (3) & $\begin{array}{l}\text { Izračunati efektivne rezidualne sile }\left(\mathbf{f}^{*}\right)^{\mathrm{i}} \text { : } \\
\qquad\left(\mathbf{f}^{*}\right)^{\mathrm{i}}=\mathbf{f}_{\mathrm{n}+1}{ }^{\mathrm{i}}-\mathbf{M} \ddot{\mathrm{u}}_{\mathrm{n}+1}^{\mathrm{i}}-\mathbf{R}\left(\mathrm{u}_{\mathrm{n}+1}^{\mathrm{i}}, \dot{\mathrm{u}}_{\mathrm{n}+1}^{\mathrm{i}}\right)\end{array}$ \\
\hline (4) & $\begin{array}{l}\text { Izračunati matricu efektivne krutosti } \mathbf{K}_{\tau}^{*} \text { (ako je potrebno): } \\
\qquad \mathbf{K}_{\tau}^{*}=\frac{\mathbf{M}}{\beta \Delta \mathrm{t}^{2}}+\gamma \frac{\mathbf{C}}{\beta \Delta \mathrm{t}}+\mathbf{K}_{\tau}\end{array}$ \\
\hline (5) & $\begin{array}{l}\text { Izračunati vektor prirasta pomaka } \Delta \mathrm{u}^{\mathrm{i}} \text { : } \\
\qquad \mathbf{K}_{\tau}^{*} \Delta \mathrm{u}^{\mathrm{i}}=\left(\mathbf{f}^{*}\right)^{\mathrm{i}}\end{array}$ \\
\hline (6) & $\begin{array}{l}\text { Korigirati pretpostavljene vrijednosti pomaka, brzina i ubrzanja: } \\
\qquad \begin{aligned} \mathrm{u}_{\mathrm{n}+1}^{\mathrm{i}+1} & =\mathrm{u}_{\mathrm{n}+1}^{\mathrm{i}}+\Delta \mathrm{u}_{\mathrm{n}+1}^{\mathrm{i}} \\
\ddot{\mathrm{u}}_{\mathrm{n}+1}^{\mathrm{i}+1} & =\left(\mathrm{u}_{\mathrm{n}+1}^{\mathrm{i}+1}-\overline{\mathrm{u}}_{\mathrm{n}+1}\right) /\left(\beta \Delta \mathrm{t}^{2}\right) \\
\dot{\mathrm{u}}_{\mathrm{n}+1}^{\mathrm{i}+1} & =\dot{\mathrm{u}}_{\mathrm{n}+1}^{\mathrm{i}}+(\gamma \Delta \mathrm{t}) \ddot{\mathrm{u}}_{\mathrm{n}+1}^{\mathrm{i}+1}\end{aligned}\end{array}$ \\
\hline (7) & $\begin{array}{l}\text { Kontrolirati konvergenciju postupka: } \\
\text { - Ako } \Delta \mathrm{u}^{\mathrm{i}} \text { zadovoljava kriterij konvergencije: } \\
\qquad\left\|\Delta \mathrm{u}^{\mathrm{i}}\right\| /\left\|\mathrm{u}_{\mathrm{n}+1}^{\mathrm{i}+1}\right\| \leq \varepsilon_{\mathrm{n}} \\
\text { prelazi se na sljedeći vremenski korak (zamijeni se " } \mathrm{n} \text { " s “ } \mathrm{n}+1 \text { " i ide na korak } \\
\text { rješenja (1)). Rješenje u vremenu } \mathrm{t}_{\mathrm{n}+1} \text { je: } \\
\qquad \mathrm{u}_{\mathrm{n}+1}=\mathrm{u}_{\mathrm{n}+1}^{\mathrm{i}+1} \\
\dot{\mathrm{u}}_{\mathrm{n}+1}=\dot{\mathrm{u}}_{\mathrm{n}+1}^{\mathrm{i}+1} \\
\qquad \ddot{\mathrm{u}}_{\mathrm{n}+1}=\ddot{\mathrm{u}}_{\mathrm{n}+1}^{\mathrm{i}+1}\end{array}$ \\
\hline
\end{tabular}




\subsection{Primjer}

Poboljšanje prethodno razvijenog numeričkog modela za analizu ljuskastih konstrukcija, koje se odnosi na uvođenje rotacijske krutosti konačnog elementa ljuske oko normale na srednju plohu, provjereno je na jednom jednostavnom primjeru naborane ljuske. Analizirana konstrukcija se sastoji od tri ravninske ljuske, kako je prikazano na Slici 2.11. Ploče su na rubu zglobno vezane za dijafragmu, a u polovici raspona ojačane rebrom. Rebro je modelirano ljuskastim elementima. Konstrukcija je opterećena vertikalnim raspodijeljenim opterećenjem. Usvojeno je linearno elastično ponašanje materijala. Analizirana je četvrtina konstrukcije zbog simetričnosti sustava. Korišteni su devetočvorni konačni elementi.
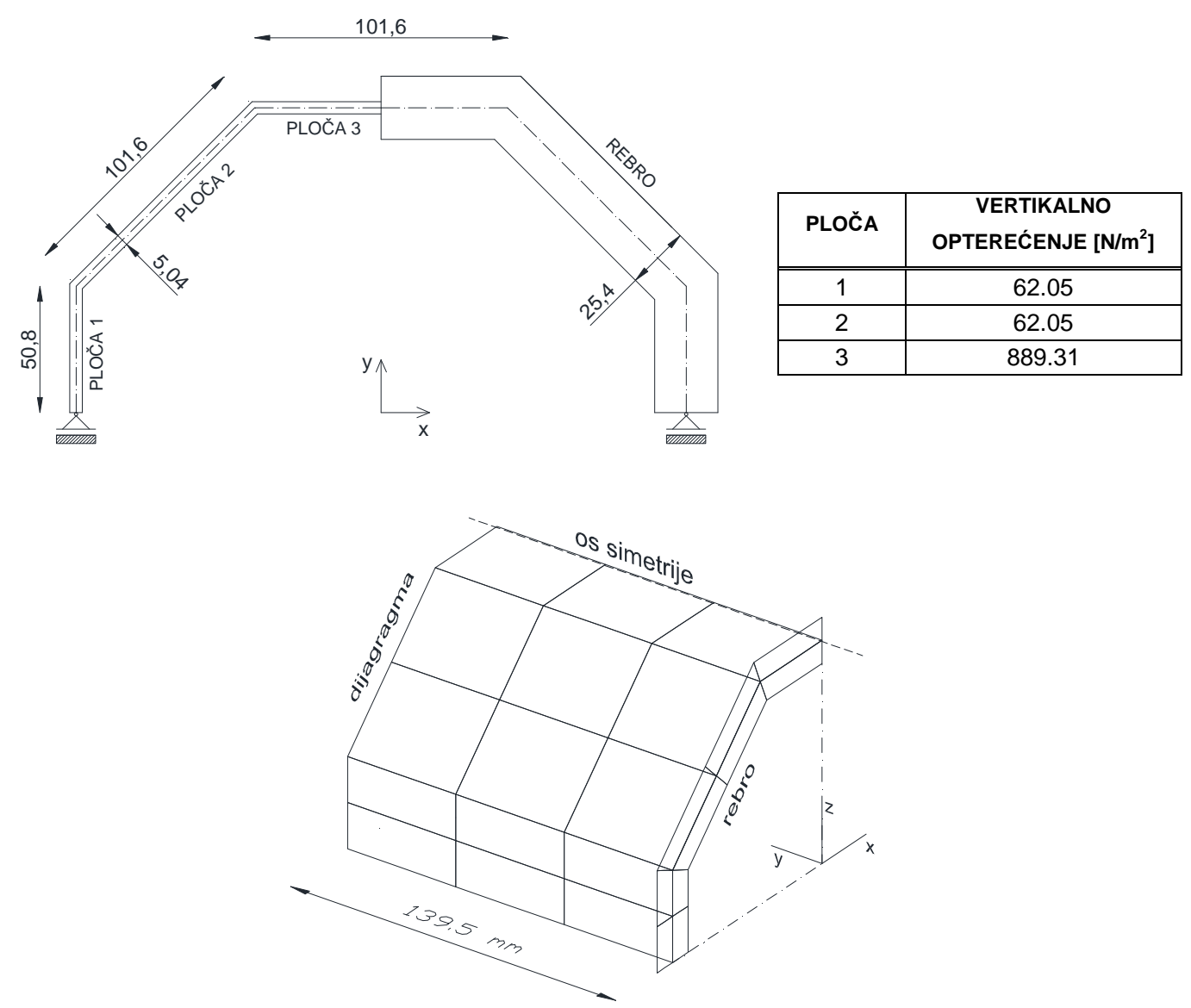

Slika 2.11. Geometrija i opterećenje naborane konstrukcije i geometrija modela

Pomaci i naprezanja konstrukcije analizirane pomoću poboljšanog numeričkog modela prikazani su na Slikama 2.12 i 2.13. 


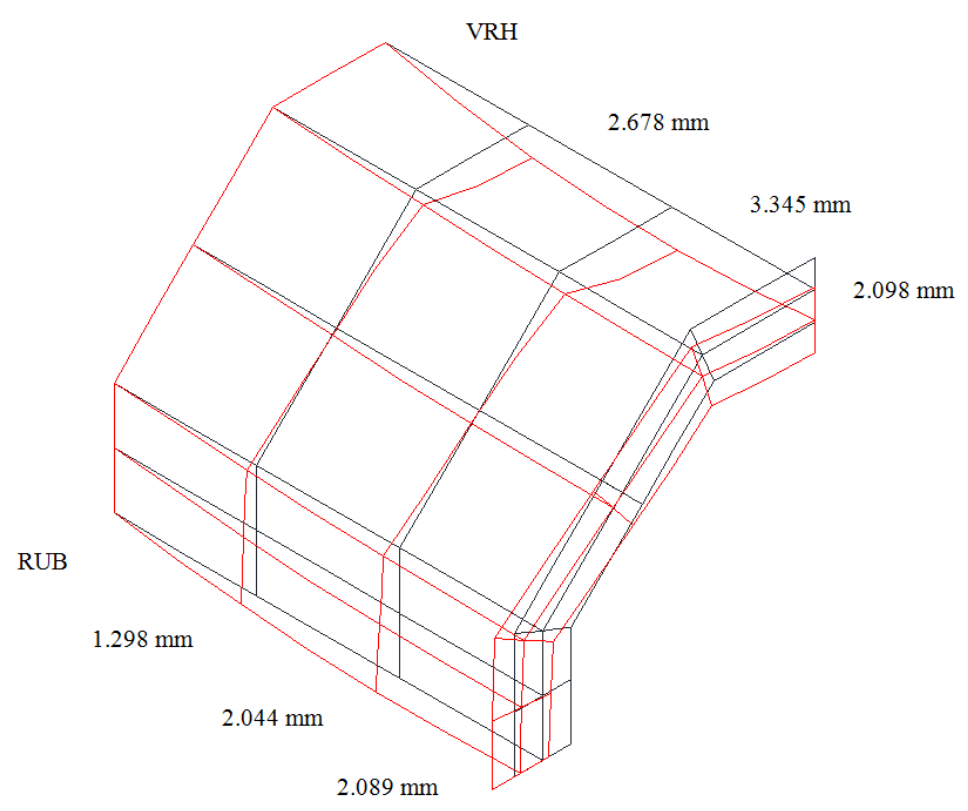

Slika 2.12. Pomaci konstrukcije
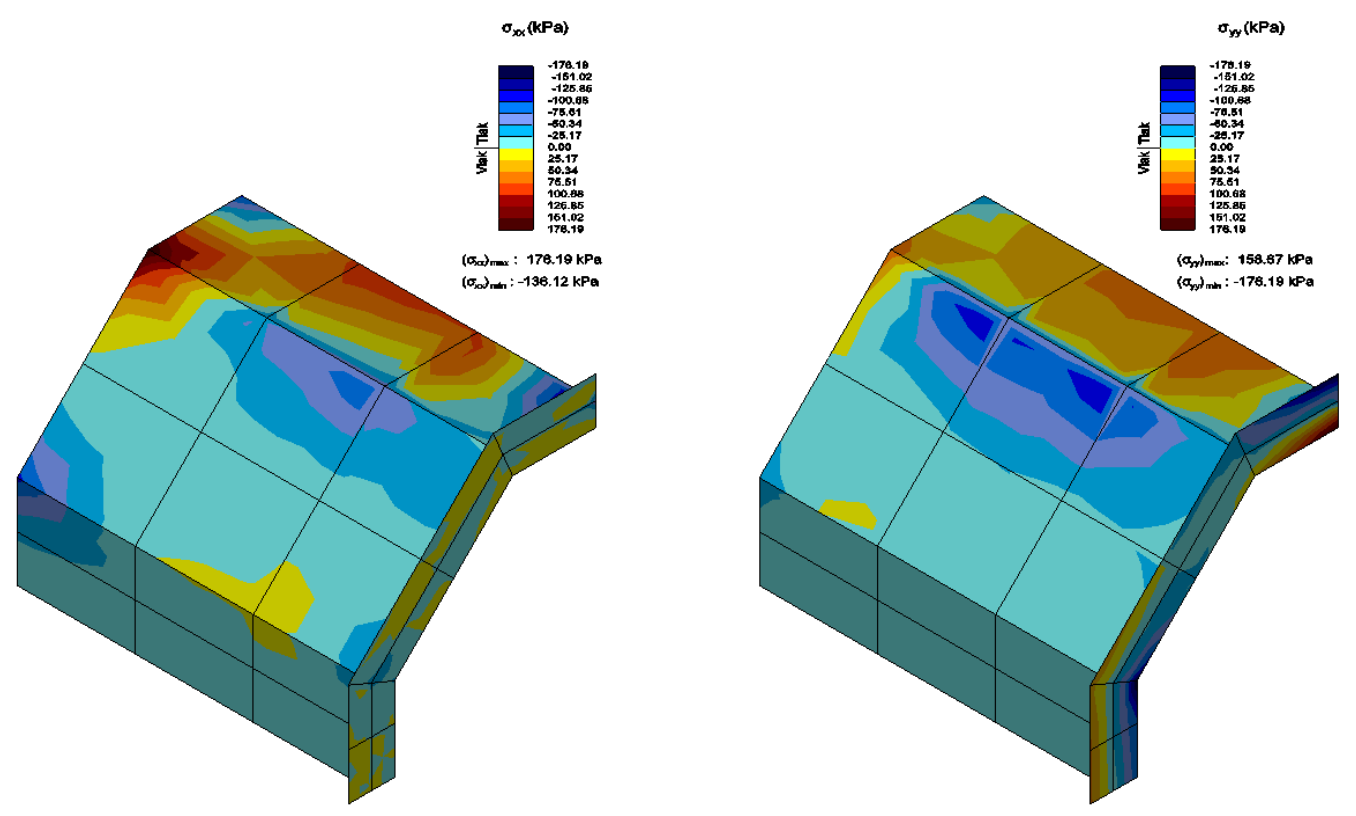

Slika 2.13. Naprezanja u konstrukciji

Obzirom da analitičko rješenje ovoga problema nije poznato, rezultati analize dobivenih pomoću poboljšanog modela su uspoređeni s eksperimentalnim rezultatima [80] i numeričkim analizama drugih autora $[74,81]$. Radi usporedbe dobivenih rezultata, izvršena je $\mathrm{i}$ analiza konstrukcije s izoparametrijskim elementima s pet stupnjeva slobode $\mathrm{u}$ svakom čvoru. Usporedbe rezultata prikazane su na Slikama 2.14 i 2.15 i u Tablicama 2.2 i 2.3. 


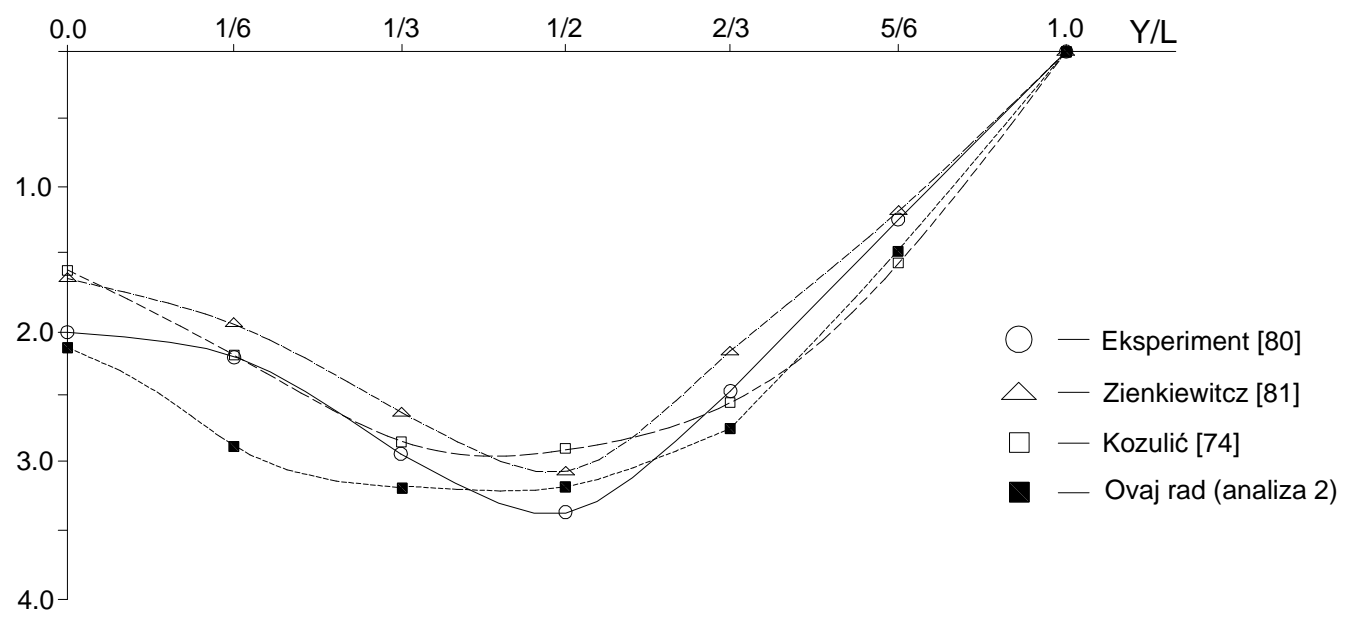

Slika 2.14. Pomaci na vrhu

Tablica 2.2. Pomaci na vrhu [mm]

\begin{tabular}{cccccccc}
\hline $\mathbf{Y / L}$ & $\begin{array}{c}\text { Eksperiment Zienkiewitcz } \\
{[\mathbf{8 0}]}\end{array}$ & $\begin{array}{c}\text { Koz1] } \\
\text { [74] }\end{array}$ & $\begin{array}{c}\text { Ovaj rad } \\
\text { analiza 1 } \\
\text { (5 stupnjeva) }\end{array}$ & $\begin{array}{c}\text { Relativna } \\
\text { pogreška* } \\
(\mathbf{\%})\end{array}$ & $\begin{array}{c}\text { Ovaj rad } \\
\text { analiza 2 } \\
(\mathbf{6} \text { stupnjeva) }\end{array}$ & $\begin{array}{c}\text { Relativna } \\
\text { pogreška* } \\
(\%)\end{array}$ \\
\hline $\mathbf{0 . 0}$ & 2.050 & 1.653 & 1.601 & 2.336 & 13.9 & 2.098 & 2.3 \\
$\mathbf{1 / 6}$ & 2.234 & 1.989 & 2.215 & 3.070 & 37.4 & 2.856 & 27.8 \\
$\mathbf{2 / 6}$ & 2.938 & 2.632 & 2.854 & 3.497 & 19.0 & 3.345 & 13.9 \\
$\mathbf{1 / 2}$ & 3.366 & 3.060 & 2.903 & 3.309 & 1.7 & 3.240 & 3.7 \\
$\mathbf{2 / 3}$ & 2.479 & 2.173 & 2.545 & 2.693 & 8.6 & 2.678 & 8.0 \\
$\mathbf{5 / 6}$ & 1.224 & 1.163 & 1.543 & 1.429 & 16.7 & 1.518 & 24.0 \\
$\mathbf{1 . 0}$ & 0.000 & 0.000 & 0.000 & 0.000 & 0 & 0.000 & 0 \\
\hline
\end{tabular}

*relativna pogreška u odnosu na rezultate ekperimenta [80]

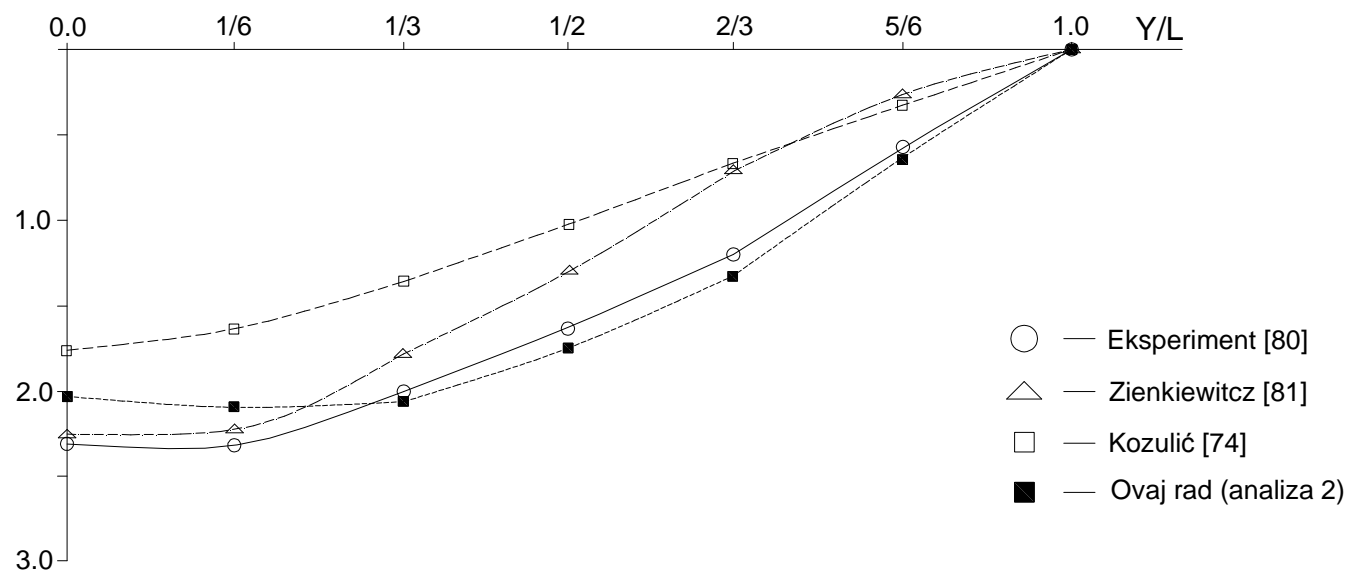

Slika 2.15. Pomaci na rubu 
Tablica 2.3. Pomaci na rubu [mm]

\begin{tabular}{|c|c|c|c|c|c|c|c|}
\hline $\mathrm{Y} / \mathrm{L}$ & $\begin{array}{c}\text { Eksperiment } \\
{[80]}\end{array}$ & $\begin{array}{c}\text { Zienkiewitcz } \\
{[81]}\end{array}$ & $\begin{array}{c}\text { Kozulić } \\
{[74]}\end{array}$ & $\begin{array}{c}\text { Ovaj rad } \\
\text { analiza } 1 \\
\text { (5 stupnjeva) }\end{array}$ & $\begin{array}{c}\text { Relativna } \\
\text { pogreška* } \\
(\%) \\
\end{array}$ & $\begin{array}{c}\text { Ovaj rad } \\
\text { analiza } 2 \\
\text { (6 stupnjeva) }\end{array}$ & $\begin{array}{c}\text { Relativna } \\
\text { pogreška* } \\
(\%)\end{array}$ \\
\hline 0.0 & 2.310 & 2.265 & 1.771 & 1.995 & 13.6 & 2.089 & 9.6 \\
\hline $1 / 6$ & 2.326 & 2.234 & 1.646 & 2.124 & 8.7 & 2.138 & 8.1 \\
\hline $2 / 6$ & 2.019 & 1.806 & 1.358 & 2.073 & 2.7 & 2.044 & 1.2 \\
\hline $1 / 2$ & 1.653 & 1.316 & 1.040 & 1.716 & 3.8 & 1.753 & 6.0 \\
\hline $2 / 3$ & 1.224 & 0.764 & 0.704 & 1.107 & 9.6 & 1.298 & 6.0 \\
\hline $5 / 6$ & 0.612 & 0.306 & 0.365 & 0.357 & 41.7 & 0.691 & 12.9 \\
\hline 1.0 & 0.000 & 0.000 & 0.000 & 0.000 & 0 & 0.000 & 0 \\
\hline
\end{tabular}

Rezultati provedene analize poboljšanog numeričkog modela s elementima ljuske sa šest stupnjeva slobode u svakom čvoru se dobro slažu s rezultatima eksperimenta [80]. Ako se usporede rezultati te analize s rezultatima analize u kojoj su korišteni elementi ljuske s pet stupnjeva slobode u svakom čvoru, može se uočiti da su rezultati dobiveni pomoću novog modela bliži eksperimentalnim rezultatima iz literature. 


\section{NUMERIČKI MODEL ZA TEKUĆINU}

\subsection{Općenito}

Tekućina je tvar čije molekularne strukture ne pružaju otpor vanjskim posmičnim silama i koja se pod utjecajem tih sila kontinuirano deformira i mijenja svoj oblik. Tekućine dijelimo na kapljevine i plinove. Iako postoje bitne razlike između kapljevina i plinova, obje vrste tekućine se ponašaju po istim zakonima gibanja.

Najvažnija svojstva tekućine su gustoća i viskoznost. Ostala svojstva, kao što su Prandtl-ov broj, specifična toplina i površinska napetost, utječu na gibanje tekućine u određenim uvjetima. Na svojstva tekućine utječe i brzina toka tekućine. Pri dovoljno malim brzinama inercija tekućine je zanemariva i takav tok nazivamo "puzajućim"; povećavanjem brzine toka iznos inercije postaje relevantan i putanja toka je glatka trajektorija za svaku česticu fluida, što se naziva laminaranim tokom. Daljnjim povećanjem brzine tok postaje turbulentan i karakterizira ga izrazito nestacionarno strujanje s miješanjem i vrtloženjem tekućine.

Gibanje tekućine može se opisati korištenjem dvaju pristupa:

- Euler-ov pristup (kod kojega se prati promjena fizikalnih veličina u vremenu u unaprijed određenim točkama prostora),

- Lagrange-ov pristup (kod kojega se prati promjena fizikalnih veličina u vremenu jedne i/ili više čestica tekućine). 
S aspekta numeričkog modeliranja ponašanja tekućina, Euler-ov pristup je vezan za numeričke metode koje zahtijevaju unaprijed definiranu mrežu točaka (npr. metoda konačnih volumena ili metoda konačnih elemenata), dok je Lagrange-ov pristup vezan za bezmrežne numeričke metode.

U ovome radu za opisivanje ponašanja tekućine koristi se Lagrange-ov pristup i bezmrežna numerička metoda: metoda hidrodinamike izglađenih čestica, čija je prednost $u$ odnosnu na standardne mrežne metode mogućnost rješavanja problema s promjenama slobodnog vodnog lica.

\subsection{Osnova metode hidrodinamike izglađenih čestica}

Metoda hidrodinamike izglađenih čestica (SPH) je originalno smišljena 70-tih godina prošlog stoljeća za opisivanje pojedinih pojava u astrofizici $[31,32]$. Najviše se primjenjuje za rješavanje problema hidromehanike i aeromehanike. U posljednje vrijeme se razvija velikom brzinom i primjenu nalazi u brojnim područjima i poljima znanosti.

SPH metoda predstavlja interpolacijsku metodu modeliranja gibanja tekućine kao skupine pokretnih čestica. Svaka čestica zauzima vlastiti dio prostora i sadrži podatke o vlastitim fizičkim odrednicama, kao što su masa, gustoća, tlak i sl. Matematički model metode SPH se temelji na integralnoj interpolaciji nekog svojstva tekućine $A(\vec{r})$ :

$$
A(\vec{r})=\int_{\Omega} A\left(\vec{r}^{\prime}\right) \delta\left(\vec{r}-\vec{r}^{\prime}\right) d \vec{r}^{\prime}
$$

gdje je $\Omega$ domena fluida, $A(\vec{r})$ je neka skalarna funkcija ovisna o vektoru položaja, a $\delta(\vec{r})$ je Diracova delta funkcija koja se može okarakterizirati kao funkcija čiji je iznos uvijek nula osim u ishodištu:

$$
\delta\left(r-r^{\prime}\right):=\left\{\begin{array}{lll}
1 & z a & r=r^{\prime} \\
0 & z a & r \neq r^{\prime}
\end{array}\right.
$$


Zamjenjujući Diracovu delta funkciju prikladnom jezgrenom ili težinskom funkcijom (eng. kernel function, smoothing kernel function, kernel), funkcija $A(\vec{r})$ se može aproksimirati sljedećim izrazom (eng. kernel approximation):

$$
A(\vec{r})=\int_{\Omega} A\left(\vec{r}^{\prime}\right) W\left(\vec{r}-\vec{r}^{\prime}, h\right) d \vec{r}^{\prime}
$$

gdje je $h$ utjecajna duljina (eng. smoothing length), a $W\left(\vec{r}-\vec{r}^{\prime}, h\right)$ je jezgrena funkcija [31]. Dakle, svojstva pojedine čestice dobivaju se težinskim zbrajanjem svojstava okolnih čestica, odnosno onih čestica koje se nalaze unutar prostorne udaljenosti $h$ (Slika 3.1).

U SPH metodi, čitav sustav je prikazan konačnim brojem čestica koje imaju masu i zauzimaju određeni prostor. Kontinuirani integralni prikaz se može pretvoriti u diskretni (čestični) prikaz kao suma nad $\mathrm{N}$ čestica koje se nalaze unutar utjecajne domene čestice $j$. Utjecajna domena je kružna radijusa $\kappa h$.

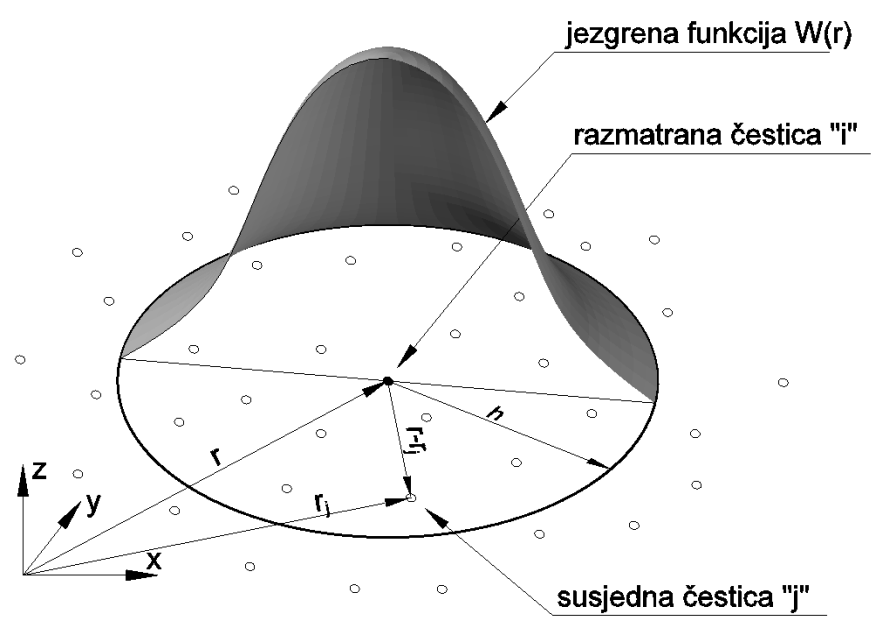

Slika 3.1. Čestična aproksimacija unutar utjecajne domene pomoću jezgrenih funkcija $W$

Ako se infinitezimalni volumen $d x^{\prime}$ na mjestu čestice $j$ zamijeni s konačno malim volumenom čestice $\Delta V_{j}$ koji je povezan s masom čestice $m_{j}$ dobije se izraz:

$$
m_{j}=\Delta V_{j} \rho_{j}
$$

gdje je $\rho_{j}(\mathrm{j}=1,2, \ldots, \mathrm{N})$ gustoća čestice, a $\mathrm{N}$ je broj čestica koje se nalaze unutar utjecajne domene. 
Kontinuirani integralni prikaz svojstva $A(\vec{r})$ se može zapisati u diskretnom obliku koristeći čestičnu aproksimaciju (eng. particle approximation):

$$
\begin{aligned}
A(\vec{r}) & =\int_{\Omega} A\left(\vec{r}^{\prime}\right) W\left(\vec{r}-\vec{r}^{\prime}, h\right) d \vec{r}^{\prime} \\
& \cong \sum_{j=1}^{N} A\left(\vec{r}_{j}\right) W\left(\vec{r}-\vec{r}_{j}, h\right) \Delta V_{j} \\
& =\sum_{j=1}^{N} A\left(\vec{r}_{j}\right) W\left(\vec{r}-\vec{r}_{j}, h\right) \frac{m_{j}}{\rho_{j}}
\end{aligned}
$$

gdje je $\vec{r}$ vektor položaja promatrane čestice, $\vec{r}_{j}$ je vektor položaja susjedne čestice, a $N$ je ukupan broj susjednih čestica.

Gradijent svojstva A predstavlja izraz (3.6), a laplasijan svojstva A izraz (3.7).

$$
\begin{aligned}
\nabla A(\vec{r}) & =\sum_{j=1}^{N} A\left(\vec{r}_{j}\right) \nabla W\left(\vec{r}-\vec{r}_{j}, h\right) \frac{m_{j}}{\rho_{j}} \\
\nabla^{2} A(\vec{r}) & =\sum_{j=1}^{N} A\left(\vec{r}_{j}\right) \nabla^{2} W\left(\vec{r}-\vec{r}_{j}, h\right) \frac{m_{j}}{\rho_{j}}
\end{aligned}
$$

Greška aproksimacije jednadžbe (3.3) jednadžbom (3.5) ovisi o poremećenosti čestica i najčešće je $\mathrm{O}\left(\mathrm{h}^{2}\right)$ [82].

\subsection{Jezgrene funkcije}

Različite jezgrene funkcije se koristite u SPH metodi, pri čemu njihov odabir utječe na točnost aproksimacije i na učinkovitost proračuna. Jezgrena funkcija mora zadovoljiti nekoliko uvjeta [9]:

1. Pozitivnost (osigurava da je aproksimacija funkcije preko sume formirana od osrednjenih vrijednosti u razmatranim točkama):

$$
W\left(\vec{r}-\vec{r}^{\prime}, h\right) \geq 0
$$

2. Normaliziranost (osigurava egzaktnu aproksimaciju integrala željene konstante funkcije - konzistentnosti nultog reda):

$$
\int W\left(\vec{r}-\vec{r}^{\prime}, h\right) d \vec{r}=1
$$


3. Kompaktnost (utjecajna domena funkcije definirana je kao kugla čiji je polumjer jednak produktu $\kappa h)$ :

$$
W\left(\vec{r}-\vec{r}^{\prime}, h\right)=0, \quad z a\left|\vec{r}-\vec{r}^{\prime}\right|>\kappa h, \quad \kappa \ldots \text { faktor razmjera }
$$

4. Svojstvo delta funkcije (smanjivanjem utjecajne duljine $h$ funkcija se približava Diracovoj delta funkciji kako bi se aproksimacija približavala željenoj funkciji):

$$
\lim _{h \rightarrow 0} W\left(\vec{r}-\vec{r}^{\prime}, h\right)=\delta\left(\vec{r}-\vec{r}^{\prime}\right)
$$

5. Padajuća monotonost (osigurava da utjecaj međudjelovanja parova čestica opada $s$ porastom njihove međusobne udaljenosti);

6. Kontinuiranost druge derivacije (osigurava točniju aproksimaciju funkcije i manju osjetljivost na nepravilan raspored čestica);

7. Parnost (osigurava da sve jednako razmaknute čestice jednakih utjecajnih duljina imaju jednako međudjelovanje).

Bilo koja funkcija koja zadovoljava ove uvjete može se koristiti kao jezgrena funkcija.

U nastavku su prikazane neke od najčešće korištenih jezgrenih funkcija.

(i) Gaussova funkcija

$$
W(r, h)=\alpha_{d} e^{-q^{2}}
$$

gdje je $\alpha_{d}=1 / \pi h^{2}$ u 2D i $\alpha_{d}=1 / \pi^{3 / 2} h^{3} \quad$ u 3D. Na Slici 3.2 je prikazana Gaussova funkcija i njene prve dvije derivacije podijeljene s dimenzionalnim faktorom $\alpha_{d}$.

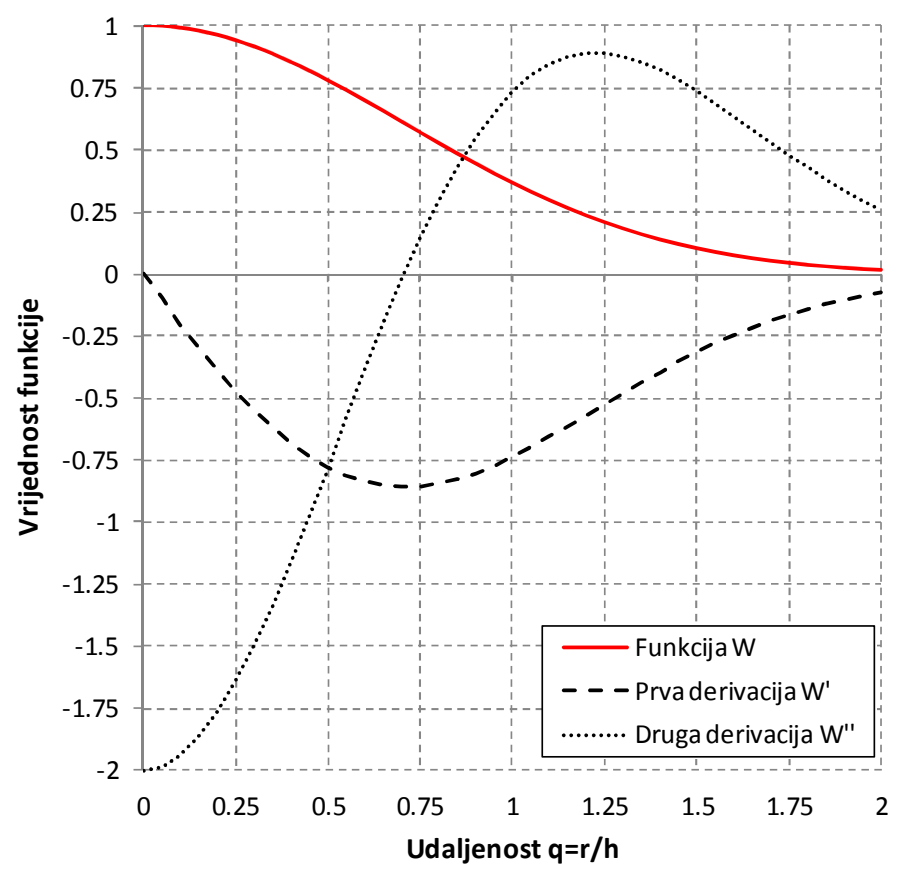

Slika 3.2. Gausova funkcija i njene prve dvije derivacije 
U literaturi se navodi da je za fizikalnu interpretaciju jednadžbi SPH metode najbolje usvojiti Gaussovu funkciju za jezgrenu funkciju [31]. Gaussova funkcija je dovoljno derivabilna, vrlo stabilna i točna čak za vrlo nepravilno razmještene čestice. To je čini vrlo pogodnom za jezgrenu funkciju.

(ii) Kvadratna funkcija

$$
W(r, h)=\alpha_{d}\left[\frac{3}{16} q^{2}-\frac{3}{4} q+\frac{3}{4}\right]
$$

gdje je $\alpha_{d}=2 / \pi h^{2} \quad$ u 2D i $\quad \alpha_{d}=5 / 4 \pi h^{3} \quad$ u 3D. Na Slici 3.3 je prikazana kvadratna funkcija i njene prve dvije derivacije podijeljene s dimenzionalnim faktorom $\alpha_{d}$.

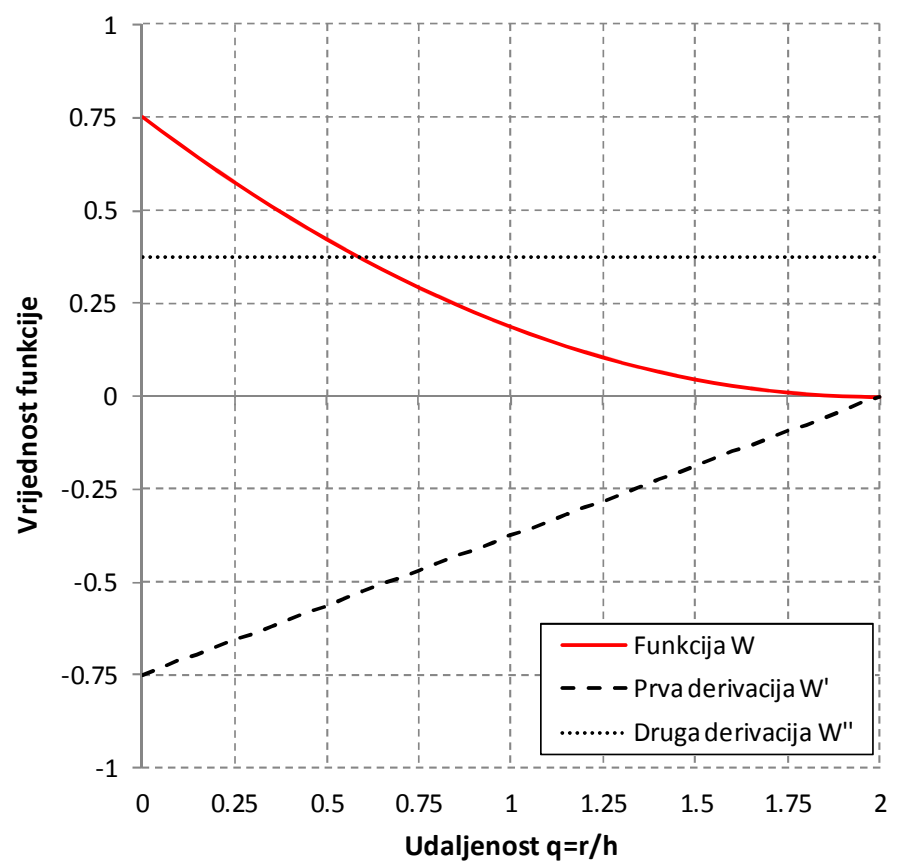

Slika 3.3. Kvadratna funkcija i njene prve dvije derivacije

(iii)Kubični spline

$$
W(r, h)=\alpha_{d}\left\{\begin{array}{cl}
\frac{2}{3}-q^{2}+\frac{1}{2} q^{3} & 0 \leq q<1 \\
\frac{1}{6}(2-q)^{3} & 1 \leq q<2 \\
0 & q \geq 2
\end{array}\right.
$$

gdje je $\alpha_{d}=15 / 7 \pi h^{2}$ u 2D i $\alpha_{d}=3 / 2 \pi h^{3}$ u 3D. Na Slici 3.4 je prikazan kubični spline i njegove prve dvije derivacije podijeljene s dimenzionalnim faktorom $\alpha_{d}$. 


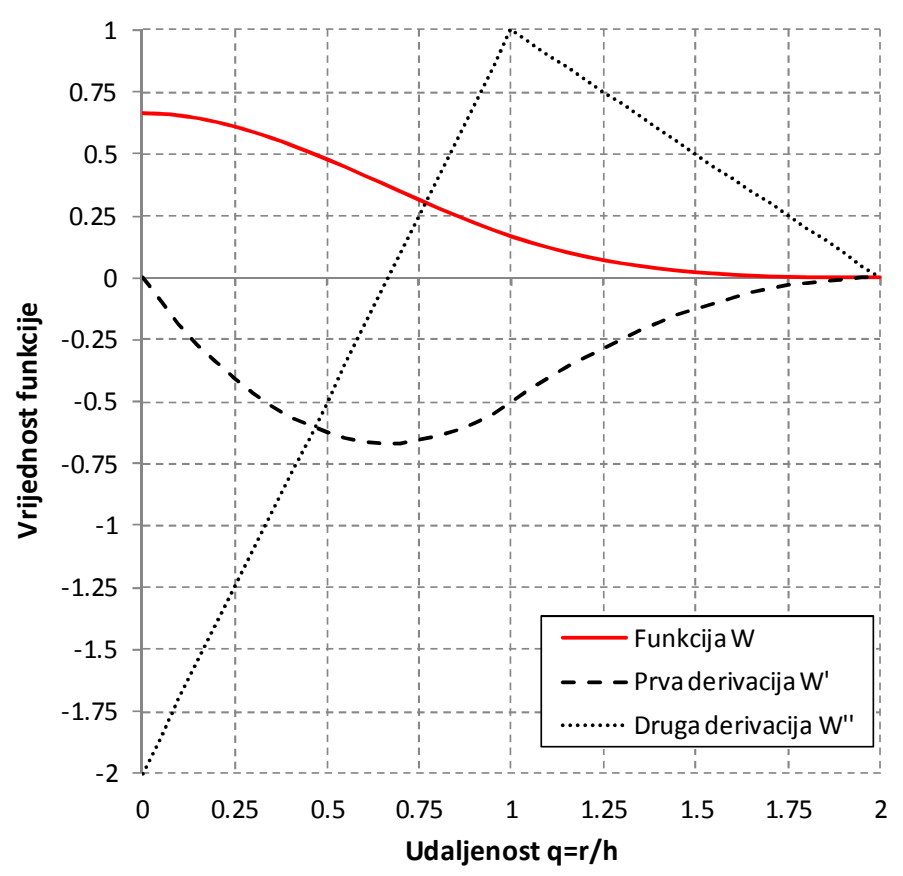

Slika 3.4. Kubični spline i njegove prve dvije derivacije

(iv)Kvintalni spline

$$
W(r, h)=\alpha_{d}\left(1-\frac{q}{2}\right)^{4} \cdot(2 q+1) \quad 0 \leq q \leq 2
$$

gdje je $\alpha_{d}=7 / 4 \pi h^{2}$ u 2D i $\alpha_{d}=21 / 16 \pi h^{3}$ u 3D. Na Slici 3.5 je prikazan kvintalni spline i njegove prve dvije derivacije podijeljene s dimenzionalnim faktorom $\alpha_{d}$.

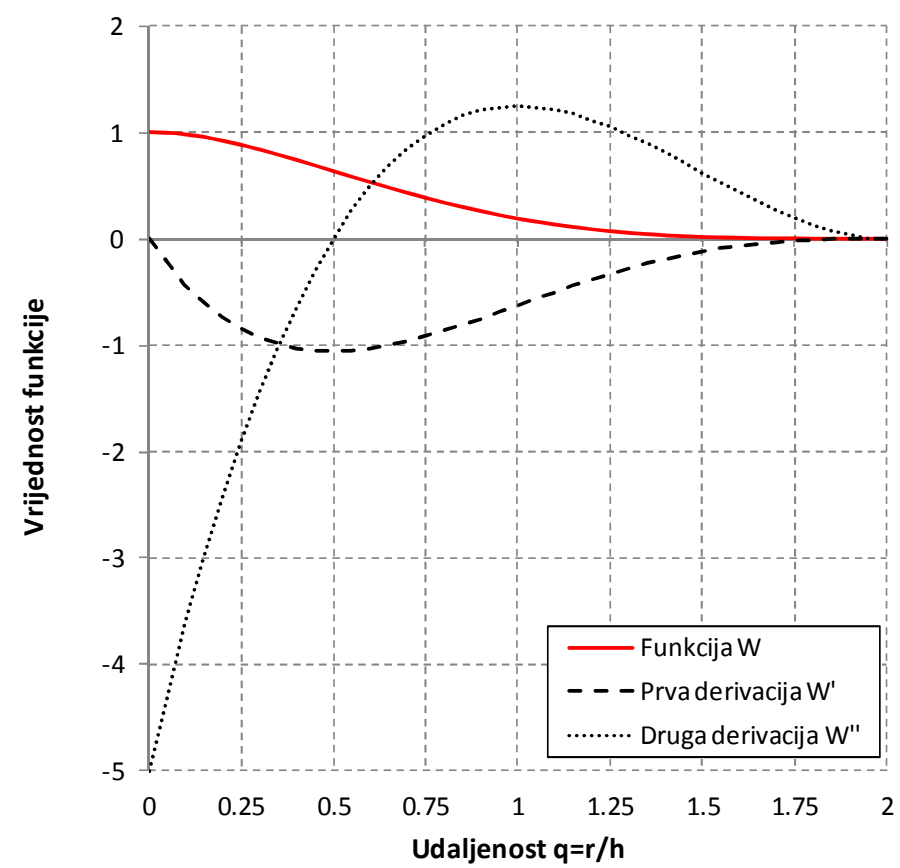

Slika 3.5. Kvintalni spline i njegove prve dvije derivacije 


\subsection{Osnovne jednadžbe mehanike tekućina}

Mehanika tekućina je dio znanosti koja se bavi gibanjem tekućina, odnosno općim načelima strujanja tekućina. Osnovne jednadžbe gibanja tekućina su izvedene iz zakona očuvanja konzervativnih svojstava. To su zakon očuvanja momenta količine gibanja, zakon očuvanja mase i zakon očuvanja energije. Ova tri zakona u potpunosti opisuju ponašanje određenog sustava uz dodatne informacije o prirodi same tekućine.

\subsubsection{Jednadžba očuvanja količine gibanja}

Jednadžba očuvanja količine gibanja predstavlja dinamičku jednadžbu strujanja tekućine. U svojoj osnovi ona predstavlja 2. Newton-ov zakon za tekućinu i može se zapisati kao:

$$
\frac{d v}{d t}=-\frac{1}{\rho} \nabla p+\Theta+f
$$

gdje je $\rho$ gustoća tekućine, $\Theta=v \nabla^{2} v$ izraz za viskoznu silu, $v$ je kinematička viskoznost tekućine i $f$ su vanjske sile koje djeluju na tekućinu. Izraz za difuziju opisuje koliko brzo se poništi razlika u brzinama unutar tekućine koje okružuju zadanu točku.

(i) Neviskozna tekućina

Ukoliko se tekućina smatra neviskoznom, izraz za difuziju iščezava i jednadžba (3.16) postaje:

$$
\frac{d v}{d t}=-\frac{1}{\rho} \nabla p+f
$$

Primjenom izraza (3.6), gradijent tlaka može se zapisati kao

$$
\rho_{a} \nabla P_{a}=\sum_{b} m_{b}\left(P_{b}-P_{a}\right) \nabla_{\mathrm{a}} \mathrm{W}_{\mathrm{ab}}
$$

gdje je $\rho_{a}$ gustoća promatrane čestice $a, P_{a}, P_{b}$ tlak promatrane čestice $a$, odnosno $b, m_{b}$ je masa susjedne čestice $b$, a $\nabla_{\mathrm{a}} \mathrm{W}_{\mathrm{ab}}$ gradijent odabrane jezgrene funkcije. Gradijent tlaka $\mathrm{u}$ simetričnoj formi se može zapisati kao:

$$
\frac{\nabla P}{\rho}=\nabla\left(\frac{P}{\rho}\right)+\frac{P}{\rho^{2}} \nabla \rho
$$

Tada jednadžba očuvanja količine gibanja za česticu $a$ primjenom SPH čestične aproksimacije postaje:

$$
\frac{d v_{a}}{d t}=-\sum_{b} m_{b}\left(\frac{P_{b}}{\rho_{b}^{2}}+\frac{P_{a}}{\rho_{a}^{2}}\right) \nabla_{a} W_{a b}+\mathrm{g}
$$


Međutim, pri nedostatku fizikalne viskoznosti javljaju se problemi pri iznalaženju numeričkog rješenja jednadžbe (3.20). Uvođenjem umjetne viskoznosti (eng. artificial viscosity) omogućava se računsko rješavanje problema. Ona je dodana u jednadžbe hidrodinamike kao umjetna viskoznost tlaka [83]. Jednadžba očuvanja momenta (3.20) postaje:

$$
\frac{d v_{a}}{d t}=-\sum_{b} m_{b}\left(\frac{P_{b}}{\rho_{b}{ }^{2}}+\frac{P_{a}}{\rho_{a}{ }^{2}}+\Pi_{a b}\right) \nabla_{a} W_{a b}+\mathrm{g}
$$

gdje je $\Pi_{a b}$ najčešće korišteni Monaghan-ov izraz za umjetnu viskoznost. Monaghan-ov izraz za umjetnu viskoznost definiran je izrazom [9]:

$$
\Pi_{a b}=\left\{\begin{array}{cc}
\frac{-\alpha \bar{c}_{a b} \mu_{a b}+\beta \mu_{a b}{ }^{2}}{\bar{\rho}_{a b}} & v_{a b} \cdot x_{a b}<0 \\
0 & v_{a b} \cdot x_{a b} \geq 0
\end{array}\right.
$$

gdje je:

$$
\begin{gathered}
\mu_{a b}=\frac{h_{a b} v_{a b} \cdot x_{a b}}{\left|x_{a b}\right|^{2}+\eta^{2}} \\
c_{a b}=\frac{c_{a}+c_{b}}{2} \\
\bar{\rho}_{a b}=\frac{\rho_{a}+\rho_{b}}{2} \\
h_{a b}=\frac{h_{a}+h_{b}}{2} \\
v_{a b}=v_{a}-v_{b} ; x_{a b}=x_{a}-x_{b}
\end{gathered}
$$

Parametri $\alpha$ i $\beta$ su konstante i trebali bi biti približno $\alpha=1 ; \beta=2$ [9]. Parametar $\eta$ spriječava singularnost i najčešće se uzima $\eta^{2}=0.01 h^{2}$. Osim što osigurava potrebnu disipaciju kako bi se kinetička energija pretvorila u toplinsku u zoni udarnih valova, parametar $\eta$ onemogućava nefizikalno prodiranje čestica jedne u drugu [84].

\section{(ii) Laminarna viskoznost}

Jednadžba očuvanja momenta s laminarnim viskoznim naprezanjima dana je izrazom

$$
\frac{d v}{d t}=-\frac{1}{\rho} \nabla p+v_{0} \nabla^{2} v+g
$$

Izraz za viskoznu silu $\left(v_{0} \nabla^{2} v\right)$ je pojednostavljen [85]:

$$
\left(v_{0} \nabla^{2} v\right)=\sum_{\mathrm{b}} \mathrm{m}_{\mathrm{b}}\left(\frac{4 v_{0} r_{a b} \nabla_{a} W_{a b}}{\left(\rho_{a}+\rho_{b}\right)\left|r_{a b}\right|^{2}}\right) v_{a b}
$$


gdje je $v_{0}$ kinematička viskoznost laminarnog tečenja $\left(v_{0}=10^{-6} \mathrm{~m}^{2} / \mathrm{s}\right)$, a $r_{a b}$ je udaljenost između dviju čestica $a$ i $b$. U SPH formulaciji izraz (3.29) postaje:

$$
\frac{d v_{a}}{d t}=-\sum_{b} m_{b}\left(\frac{P_{b}}{\rho_{b}{ }^{2}}+\frac{P_{a}}{\rho_{a}{ }^{2}}\right) \nabla_{a} W_{a b}+\sum_{b} m_{b}\left(\frac{4 v_{0} r_{a b} \nabla_{a} W_{a b}}{\left(\rho_{\mathrm{a}}+\rho_{\mathrm{b}}\right)\left|r_{a b}\right|^{2}}\right) v_{a b}+\mathrm{g}
$$

(iii) Laminarna viskoznost s uključenjem turbulencija

Mnogi problemi nestišljivog tečenja tekućina koji se rješavaju SPH metodom uključuju i razvoj turbulencije. Primjeri takvog problema su lom brane (eng. dam break) kod kojeg je tečenje tekućine laminarno dok ne udari o prepreku, kada dolazi do loma valova i zapljuskivanja (eng. sloshing) tekućine u rezervoaru koji oscilira. U ovome radu se koristi koncept simulacije velikih vrtloga (eng. Large Eddy Simulation - LES) za opisivanje nestacionarnih turbulentnih strujanja [86, 87]. Kod ove metode se velika nestacionarna turbulentna gibanja, na koje utječe geometrija toka i koja nisu univerzalna, računaju eksplicitno, dok su utjecaji gibanja manjih razmjera (koja u određenoj mjeri imaju univerzalni karakter) prikazani jednostavnim pod-mrežnim modelom (eng. Sub-Grid Scale -SGS) [88]. Pristup simulacije velikih vrtloga na bezmrežene metode prvi su primjenili Goth i ostali [89], koristeći pod-čestični model (eng. Sub-Particle Scale - SPS).

Jednadžba očuvanja momenta s laminarnim viskoznim naprezanjima i SPS naprezanjima $\tau$ dana je izrazom

$$
\frac{d v}{d t}=-\frac{1}{\rho} \nabla p+v_{0} \nabla^{2} v+\frac{1}{\rho} \nabla \tau+g
$$

gdje $\tau$ predstavlja pod-čestični (SPS) tenzor naprezanja, koji proizlazi iz rezidualne komponente brzine koja predstavlja gibanja manjih razmjera. Primjenjujući Favre-ovo osrednjavanje vrijednosti, kako bi se uzela u obzir stišljivost tekućine, SPS tenzor naprezanja postaje

$$
\frac{\tau_{\mathrm{ij}}}{\rho}=v_{t}\left(2 \mathrm{~S}_{\mathrm{ij}}-\frac{2}{3} \mathrm{k} \delta_{\mathrm{ij}}\right)-\frac{2}{3} \mathrm{C}_{\mathrm{I}} \nabla^{2} \delta_{\mathrm{ij}}\left|\mathrm{S}_{\mathrm{ij}}\right|^{2}
$$

gdje je $v_{t}=\left[\mathrm{C}_{\mathrm{s}} \Delta \mathrm{l}\right]^{2}|S|$ vrtložna viskoznost turbulencije, $C_{S}$ je Smagorinsky-eva konstanta i iznosi $0.12, \Delta l$ je početna prostorna udaljenost između čestica, $|S|=\sqrt{2 S_{i j} S_{i j}}$, gdje je $S_{i j}$ element SPS tenzora naprezanja ( $i, j$ označavaju smjerove koordinatnih osi), $k$ predstavlja SPS kinetičku energiju turbulencije, a $C_{I}$ konstanta koja iznosi 0.00666 .

SPS tenzor naprezanja primjenom simetrične formulacije može se zapisati kao [90]: 


$$
\frac{\tau_{\mathrm{ij}}}{\rho}=\sum_{j} m_{j}\left(\frac{\tau_{\mathrm{i}}}{\rho_{\mathrm{i}}^{2}}+\frac{\tau_{\mathrm{j}}}{\rho_{\mathrm{j}}^{2}}\right) \nabla_{i} W_{i j}
$$

Tada izraz (3.31) u SPH zapisu izgleda [91]:

$$
\begin{gathered}
\frac{d v_{a}}{d t}=-\sum_{b} m_{b}\left(\frac{P_{b}}{\rho_{b}{ }^{2}}+\frac{P_{a}}{\rho_{a}{ }^{2}}\right) \nabla_{a} W_{a b}+\sum_{b} m_{b}\left(\frac{4 v_{0} r_{a b} \nabla_{a} W_{a b}}{\left(\rho_{\mathrm{a}}+\rho_{\mathrm{b}}\right)\left|r_{a b}\right|^{2}}\right) v_{a b} \\
+\sum_{b} m_{b}\left(\frac{\tau_{a}}{\rho_{a}^{2}}+\frac{\tau_{\mathrm{b}}}{\rho_{b}^{2}}\right) \nabla_{a} W_{a b}+\mathrm{g}
\end{gathered}
$$

\subsubsection{Jednadžba kontinuiteta}

Jednadžba kontinuiteta predstavlja zakon očuvanja mase i u Lagrange-ovom obliku je:

$$
\frac{d \rho_{a}}{d t}=-\nabla \rho v
$$

Generalizirajući prethodni izraz za derivaciju i aproksimirajući $\nabla v$ pomoću (3.6), dobije se:

$$
\frac{d \rho_{a}}{d t}=\rho_{b} \sum_{b} \frac{m_{b}}{\rho_{b}} v_{a b} \nabla_{a} W_{a b}
$$

iz čega slijedi:

$$
\frac{d \rho_{a}}{d t}=\sum_{b} m_{b} v_{a b} \nabla_{a} W_{a b}
$$

Jednadžba (3.35) se može prikazati i kao težinska suma masa okolnih čestica:

$$
\rho_{a}=\sum_{b} m_{b} W_{a b}
$$

Često se u analizama pomoću SPH metode koristi izraz (3.38). Međutim, pokazalo se da korištenje tog izraza ima za posljedicu umjetno smanjenje gustoće dijela tekućine koji se nalazi na rubu domene, a time i netočne iznose tlakova u tekućini uz rub. Korištenjem izraza (3.37) taj se nedostatak izbjegava, ali njime očuvanje mase nikada nije u potpunosti zadovoljeno [85].

\subsubsection{Jednadžba očuvanja energije}

Prvi zakon termodinamike može se shvatiti kao jednu formulaciju zakona o očuvanja energije, prema kojemu je toplina tek jedan oblik energije, za koju vrijedi zakon o očuvanju.

$$
\begin{aligned}
T d s & =d u-P d V \\
& =d u-\frac{P}{\rho^{2}} d \rho
\end{aligned}
$$

gdje je $s$ entropija, a $u$ je termalna energija. 
Jednadžba promjene toplinske energije po jedinici mase može se zapisati u sljedeća dva oblika:

$$
\frac{d u}{d t}=\frac{P}{\rho^{2}} \frac{d \rho}{d t}-\left(\frac{P}{\rho^{2}}\right) \nabla v
$$

ili

$$
\frac{d u}{d t}=-\nabla\left(\frac{P v}{\rho}\right)+v \nabla\left(\frac{P}{\rho}\right)
$$

Jednadžbe (3.40) i (3.41) zapisane pomoću čestične SPH aproksimacije su:

$$
\frac{d u_{a}}{d t}=\left(\frac{P_{a}}{\rho_{a}^{2}}\right) \sum_{b} m_{b} v_{a b} \nabla_{a} W_{a b}
$$

odnosno

$$
\frac{d u_{a}}{d t}=\sum_{b} m_{b}\left(\frac{P_{b}}{\rho_{b}^{2}}\right) v_{a b} \nabla W_{a b}
$$

Aritmetičkim uprosječivanjem jednadžbi (3.42) i (3.43), uz dodavanje Monaghan-ovog izraza za umjetnu viskoznost, dobije se jednadžba [84]:

$$
\frac{d u_{a}}{d t}=\frac{1}{2} \sum_{b} m_{b}\left(\frac{P_{b}}{\rho_{b}{ }^{2}}+\frac{P_{a}}{\rho_{a}{ }^{2}}+\Pi_{a b}\right) v_{a b} \cdot \nabla_{a} W_{a b}
$$

\subsubsection{Jednadžba stanja}

Tekućina se u SPH formalizmu tretira kao slabo stišljiva, pri čemu se koristi jednadžba stanja za određivanje tlakova. Najčešće korištenu jednadžbu stanja za vodu je predložio Cole [92], odnosno Batchelor [93]:

$$
P=B\left[\left(\frac{\rho}{\rho_{0}}\right)^{\gamma}-1\right]
$$

gdje je za vodu parametar $\gamma=7, \rho_{0}=1000 \mathrm{~kg} / \mathrm{m}^{3}$. Parametar $B$, kojim se korigira stvarna brzina zvuka u vodi, definiran je izrazom:

$$
B=c_{0}^{2} \rho_{0} / \gamma
$$

gdje je $c_{0}=c\left(\rho_{0}\right)=\left.\sqrt{P \partial / \partial \rho}\right|_{\rho_{0}}$.

Prema Courant-Fredrich-Levy uvjetu, koristeći stvarnu vrijednost brzine zvuka u vodi, u numeričkoj analizi treba odabrati vrlo mali vremenski korak [94]. Monaghan je pokazao da se brzina zvuka može umjetno umanjiti, posebno za tekućine na čije tečenje to neće utjecati, kako bi vremenski korak numeričke analize bio prihvatljivo mali. Također se predlaže da 
minimalna brzina zvuka bude oko deset puta veća od maksimalne brzine strujanja tekućine [95].

\subsubsection{Gibanje čestica}

Kod SPH metode čestice se gibaju prema izrazu [85]:

$$
\frac{d r_{a}}{d t}=v_{a}
$$

Koristeći čestičnu aproksimaciju i prepravljajući brzine čestica, tako da su što bliže prosječnoj brzini gibanja okolnih čestica (XSPH varijanta gibanja čestica), jednadžba (3.47) postaje [96]:

$$
\frac{d r_{a}}{d t}=v_{a}+\varepsilon \sum_{b} v_{b a}\left(\frac{m_{b}}{\bar{\rho}_{a b}}\right) W_{a b}
$$

gdje je $\bar{\rho}_{a b}=\left(\rho_{a}+\rho_{b}\right) / 2$, a $\varepsilon$ je konstanta za koju vrijedi $0 \leq \varepsilon \leq 1$. Ovom popravkom se postiže veća pravilnost u rasporedu čestica i pri velikim brzinama je izbjegnuto prodiranje jedne čestice u drugu.

\subsection{Rubni uvjeti}

Zbog Lagrange-ove prirode SPH metode, implementacija rubnih uvjeta na granicama nije izravna kao kod metoda s definiranom mrežom. Granica slobodnog lica ne zahtjeva posebno definiranje jer su preko jednadžbi (3.45) i (3.47) zadovoljeni kinematički i dinamički rubni uvjeti. Međutim, definiranje krutih granica u SPH metodi još uvijek predstavlja izazov. Uobičajeni način opisivanja krutih granica je upotrebom algoritama koji koriste različite vrste rubnih čestica na rubu računalne domene tekućine. U ovome modelu implementirana su dva pristupa u modeliranju krutih granica.

\subsubsection{Odbojni rubni uvjeti}

Ovaj pristup je prvi uveo Monghan [95], a temelji se na postavljanju odbojnih čestica (koje se u literaturi nazivaju i virtualne čestice - tip I) na granicu (Slika 3.6). Te čestice predstavljaju granicu stvarajući jake odbojne sile na čestice tekućine, analogno međumolekulskim silama. Ovaj tip rubnih uvjeta osigurava da čestice tekućine ne mogu prijeći granicu krutog tijela.

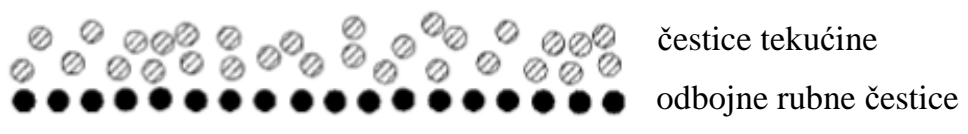

Slika 3.6. Odbojni rubni uvjeti 
Dakle, sila po jedinici mase između rubne čestice i čestice tekućine, koje su na udaljenosti $r$, dana je Leonard-Jones-ovim potencijalom. Prema [87], sila uzrokovana česticama tekućine $\vec{f}$ djeluje okomito na granicu i dana je izrazom:

$$
\vec{f}=\vec{n} R(\Psi) P(\xi) \varepsilon\left(z, u_{\perp}\right)
$$

gdje je $\vec{n}$ normala na granicu, a $R(\Psi)$ je odbojna funkcija ovisna o okomitoj udaljenosti čestice tekućine od granice $\Psi$. Ona se izračunava u ovisnosti o normaliziranoj vrijednosti udaljenosti od granice $q=\Psi / 2 \mathrm{~h}$ prema:

$$
R(\Psi)=A \frac{1}{\sqrt{q}}(1-q)
$$

gdje je koeficijent $A$

$$
A=\frac{1}{h} 0.01 c_{i}^{2}
$$

kod čega je $c_{i}$ je brzina zvuka za odgovarajuću česticu $i$.

Funkcija $P(\xi)$ je izabrana tako da čestica tekućine ima konstantnu odbojnu silu dok se giba paralelno s granicom

$$
P(\xi)=\frac{1}{2}\left(1+\cos \left(\frac{2 \pi \xi}{\Delta \mathrm{b}}\right)\right)
$$

gdje je $\xi$ projekcija interpolirane lokacije $\xi_{i}$ na spojnicu dvije susjedne čestice, a $\Delta \mathrm{b}$ je udaljenost između bilo koje dvije susjedne granične čestice. Konačno, funkcija $\varepsilon\left(z, u_{\perp}\right)$ je modificirani originalni prijedlog Monaghan-a i Kos-a [33] kako bi se podesila veličina sile prema lokalnoj dubini vode i brzinama čestica tekućine okomito na granicu. Ovisna je o položaju promatrane čestice $z$ i brzini čestice tekućine projicirane na normalu $u_{\perp}$ :

$$
\varepsilon\left(z, u_{\perp}\right)=\varepsilon(z)+\varepsilon\left(u_{\perp}\right)
$$

gdje je

$$
\varepsilon(z)=\left\{\begin{array}{cc}
0.02 & z \geq 0 \\
\left|z / h_{0}\right|+0.02 & 0>z>-h_{0} \\
1 & \left|z / h_{0}\right|>1
\end{array}\right.
$$




$$
\varepsilon\left(u_{\perp}\right)=\left\{\begin{array}{cc}
0 & u_{\perp}>0 \\
\left|20 u_{\perp}\right| / c_{0} & \left|2 O u_{\perp}\right|<c_{0} \\
1 & \left|2 O u_{\perp}\right|>c_{0}
\end{array}\right.
$$

U jednadžbama (3.53)-(3.55), $z$ je visina iznad lokalne razine tekućine $h_{0}$, $u_{\perp}=\left(v_{W P}-v_{B P}\right) \vec{n}$, gdje se $v_{W P}$ odnosi na brzinu čestice tekućine, a $v_{B P}$ na brzinu čestice na granici: $c_{0}=\sqrt{B \gamma / \rho_{0}}$ je brzina zvuka.

\subsubsection{Dinamički rubni uvjeti}

U ovom pristupu, čestice na granici trebaju zadovoljiti iste jednadžbe (3.20), (3.37), (3.44) i (3.45) kao i čestice tekućine (Slika 3.7). Ne gibaju se po jednadžbi (3.48), jer im je položaj u prostoru nepromjenjiv (ukoliko se radi o nepomičnim granicama) ili se gibaju prema zadanoj funkcijama (ukoliko se radi o nekim objektima koji se gibaju, kao npr. generatori valova). Ideju o ovakvom pristupu su prvi iznijeli Liu i Liu [9], a Dalrymple i Knio [97] su je prvi uspješno implementirali. Virtualne čestice su najčešće postavljene u nekoliko redova, kako bi uvjet normaliziranosti jezgrene funkcije za čestice tekućine bio što manje narušen.

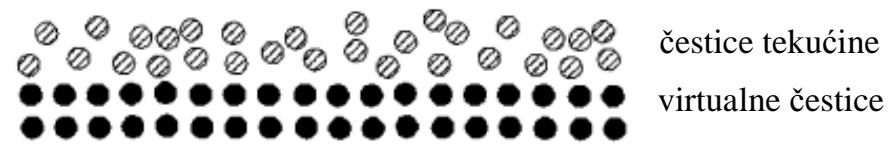

Slika 3.7. Dinamički rubni uvjeti

Kada se čestica tekućine približava granici, virtualnoj čestici na granici se povećava gustoća prema izrazu (3.38), uzrokujući povećanje tlaka prema izrazu (3.45). Dakle, sila na česticu tekućine se povećava obzirom na izraz $\left(P / \rho^{2}\right)$ u jednadžbi za očuvanje momenta.

Prednost ovog tipa rubnih uvjeta, u računalnom smislu, je da svojstva virtualnih čestica mogu biti izračunata unutar iste petlje kao i čestice tekućine, što značajno smanjuje vrijeme proračuna. Pokazalo se je da ovaj pristup ima određene nedostatke po pitanju točnosti polja tlakova. Gong and Liu [98] su predložili određena poboljšanja kojim se otklanja problem oscilacija u polju tlakova. 


\subsection{Provedba numeričke analize}

Jednadžbe prikazane u poglavlju 3.4. rješavaju se eksplicitnim integracijskim shemama. Stabilnost numeričke analize uvelike ovisi o veličini vremenskog koraka i odabranoj metodi vremenske integracije. U nastavku je prikazan način odabira vremenskog koraka i metode vremenske integracije koje se koriste u ovome modelu.

\subsubsection{Vremenski korak}

Stabilnost numeričke analize ovisi o veličini vremenskog koraka, definiranog CourantFriedrichs-Lewy (CFL) uvjetom [94]. Njime se osigurava da je vremenski korak dovoljno malen da informacije ne bi putovale brže nego je to fizikalno moguće. U ovom uvjetu također stoji da vremenski korak mora biti proporcionalan najmanjoj prostornoj rezoluciji čestice, što u SPH metodi predstavlja najmanju utjecajnu duljinu $h$ :

$$
\Delta t=\min \left(\frac{h}{c}\right)
$$

Monaghan $[85,96]$ daje dva izraza kojima se uzima CFL uvjet i uvjet viskoznosti:

$$
\begin{gathered}
\Delta t_{c v}=\min \left(\frac{h}{c_{i}+0.6\left(\alpha_{\Pi} c_{i}+\beta_{\Pi} \max \left(\phi_{i j}\right)\right.}\right)=\min _{a}\left(\frac{h}{c_{s}+\max _{b}\left|\frac{h v_{a b} r_{a b}}{r_{a b}{ }^{2}}\right|}\right) \\
\Delta t_{f}=\min _{a} \sqrt{\frac{h}{\left|f_{a}\right|}}
\end{gathered}
$$

Kombinirajući jednadžbe (3.57) i (3.58) s određenim koeficijentima sigurnosti $\lambda_{1}$ i $\lambda_{2}$, tipični vremenski korak je:

$$
\Delta t=\min \left(\lambda_{1} \Delta t_{c v}, \lambda_{2} \Delta t_{f}\right)
$$

pri čemu Monaghan predlaže: $\lambda_{1}=0.4$ i $\lambda_{2}=0.25$ [85]. 


\subsubsection{Vremenska integracija}

Stabilnost numeričkih analiza ovisi u velikoj mjeri o odabranoj metodi integracije. U ovome numeričkom modelu implementirane su četiri različite metode vremenske integracije, koje su prikazane u nastavku.

Uzimajući u obzir jednadžbu očuvanja količine gibanja (3.20), jednadžbu kontinuiteta (3.37), jednadžbu položaja (3.48) i jednadžbu očuvanja energije (3.44), može se zapisati:

$$
\begin{aligned}
\frac{d \boldsymbol{v}_{a}}{d t} & =\boldsymbol{F}_{a} \\
\frac{d \rho_{a}}{d t} & =D_{a} \\
\frac{d \boldsymbol{r}_{a}}{d t} & =\boldsymbol{V}_{a} \\
\frac{d e_{a}}{d t} & =E_{a}
\end{aligned}
$$

gdje $\boldsymbol{V}_{a}$ predstavlja doprinos brzine susjednih čestica na brzinu čestice $a$ (XSPH korekcija).

(i) Prediktor-korektor shema

U ovoj shemi pretpostavljaju se vrijednosti u vremenu prema sljedećim izrazima:

$$
\begin{aligned}
& \boldsymbol{v}_{a}^{n+1 / 2}=\boldsymbol{v}_{a}^{n}+\frac{\Delta t}{2} \boldsymbol{F}_{a}^{n} \\
& \rho_{a}^{n+1 / 2}=\rho_{a}^{n}+\frac{\Delta t}{2} D_{a}^{n} \\
& \boldsymbol{r}_{a}^{n+1 / 2}=\boldsymbol{r}_{a}^{n}+\frac{\Delta t}{2} \boldsymbol{V}_{a}^{n} \\
& e_{a}^{n+1 / 2}=e_{a}^{n}+\frac{\Delta t}{2} E_{a}^{n}
\end{aligned}
$$

uzimajući $P_{a}^{n+1 / 2}=f\left(\rho_{a}^{n+1 / 2}\right)$ prema jednadžbi (3.45).

Jednadžbe (3.64)-(3.67) se zatim prepravljaju vrijednostima promjene polja brzina, gustoće, položaja i energije (3.60) - (3.63) u pola vremenskog koraka:

$$
\begin{aligned}
& \boldsymbol{v}_{a}^{n+1 / 2}=\boldsymbol{v}_{a}^{n}+\frac{\Delta t}{2} \boldsymbol{F}_{a}^{n+1 / 2} \\
& \rho_{a}{ }^{n+1 / 2}=\rho_{a}^{n}+\frac{\Delta t}{2} D_{a}^{n+1 / 2}
\end{aligned}
$$




$$
\begin{aligned}
& \boldsymbol{r}_{a}^{n+1 / 2}=\boldsymbol{r}_{a}^{n}+\frac{\Delta t}{2} \boldsymbol{V}_{a}^{n+1 / 2} \\
& e_{a}^{n+1 / 2}=e_{a}^{n}+\frac{\Delta t}{2} E_{a}^{n+1 / 2}
\end{aligned}
$$

Konačno, vrijednosti se računaju na kraju vremenskog koraka prema:

$$
\begin{aligned}
& \boldsymbol{v}_{a}^{n+1}=2 \boldsymbol{v}_{a}{ }^{n+1 / 2}-\boldsymbol{v}_{a}^{n} \\
& \rho_{a}{ }^{n+1}=2 \rho_{a}{ }^{n+1 / 2}-\rho_{a}^{n} \\
& \boldsymbol{r}_{a}^{n+1}=2 \boldsymbol{r}_{a}{ }^{n+1 / 2}-\boldsymbol{r}_{a}^{n} \\
& e_{a}^{n+1}=2 e_{a}{ }^{n+1 / 2}-e_{a}^{n}
\end{aligned}
$$

Tlak se izračunava prema $P_{a}^{n+1}=f\left(\rho_{a}^{n+1}\right)$.

(ii) Verlet shema

Karakteristika Verlet sheme [99] jest stabilnost i očuvanje fizikalnih svojstava, kao što su reverzibilnost i homogenost prostora. Verlet integracija se naziva i Störmerova metoda, prema Carlu Störmeru, koji ju je koristio kod računanja trajektorija gibanja čestica u magnetskom polju.

Ovaj algoritam, kojim se diskretiziraju jednadžbe (3.60) - (3.63), je podijeljen u dva dijela. Općenito, varijable se računaju prema:

$$
\begin{gathered}
\boldsymbol{v}_{a}^{n+1}=\boldsymbol{v}_{a}^{n}+2 \Delta t \boldsymbol{F}_{a}^{n} \\
\rho_{a}^{n+1}=\rho_{a}^{n}+2 \Delta t D_{a}^{n} \\
\boldsymbol{r}_{a}^{n+1}=\boldsymbol{r}_{a}^{n}+\Delta t \boldsymbol{V}_{a}^{n}+0.5 \Delta t^{2} \boldsymbol{F}_{a}^{n} \\
e_{a}^{n+1}=e_{a}^{n}+2 \Delta t E_{a}^{n}
\end{gathered}
$$

Nakon svakih $m$ vremenskih koraka, varijable se računaju prema:

$$
\begin{gathered}
\boldsymbol{v}_{a}^{n+1}=\boldsymbol{v}_{a}^{n}+\Delta t \boldsymbol{F}_{a}^{n} \\
\rho_{a}^{n+1}=\rho_{a}^{n}+\Delta t D_{a}^{n} \\
\boldsymbol{r}_{a}^{n+1}=\boldsymbol{r}_{a}^{n}+\Delta t \boldsymbol{V}_{a}^{n}+0.5 \Delta t^{2} \boldsymbol{F}_{a}^{n} \\
e_{a}^{n+1}=e_{a}^{n}+\Delta t E_{a}^{n}
\end{gathered}
$$


(iii) Symplectic shema

Symplectic vremenska integracija je vremenski reverzibilna u slučaju nedostatka trenja ili viskoznih učinaka [100] i stoga predstavlja vrlo atraktivnu opciju za uporabu kod bezmrežnih čestičnih metoda. Kod ove metode, prvo se izračunavaju vrijednosti gustoće i ubrzanja u polovici vremenskog koraka:

$$
\begin{aligned}
& \rho_{a}^{n+1 / 2}=\rho_{a}^{n}+\frac{\Delta t}{2} \frac{d \rho_{a}^{n}}{d t} \\
& \boldsymbol{r}_{a}^{n+1 / 2}=\boldsymbol{r}_{a}^{n}+\frac{\Delta t}{2} \frac{d \boldsymbol{r}_{a}^{n}}{d t}
\end{aligned}
$$

gdje $n$ označava vremenski korak, a vrijeme je $t=n \Delta t$. Tlak $P_{a}^{n+1 / 2}$ se izračunava koristeći jednadžbu stanja. U drugom koraku $d\left(\omega_{i} \rho_{i} v_{i}\right)^{n+1 / 2} / d t$ daje podatke o brzini, a time i položaju čestice na kraju vremenskog koraka:

$$
\begin{gathered}
\left(\omega_{i} \rho_{i} v_{i}\right)^{n+1}=\left(\omega_{i} \rho_{i} v_{i}\right)^{n+1 / 2}+\frac{\Delta t}{2} \frac{d\left(\omega_{i} \rho_{i} v_{i}\right)^{n+1 / 2}}{d t} \\
\boldsymbol{r}_{a}^{n+1}=\boldsymbol{r}_{a}^{n+1 / 2}+\frac{\Delta t}{2} \boldsymbol{v}_{a}^{n+1}
\end{gathered}
$$

Na kraju vremenskog koraka $d \rho_{a}{ }^{n+1} / d t$ se izračunava koristeći ažuriranu vrijednost $\boldsymbol{v}_{a}^{n+1} \mathrm{i}$ $\boldsymbol{r}_{a}^{n+1}[101]$.

(iv) Beeman shema

Beeman algoritam koristi Beeman prediktor i Adams-Bashforth-Moulton korektor. Ova metoda ima točnost $\mathrm{O}\left(\Delta t^{4}\right)$.

Predviđanje vrijednosti varijable po Beeman metodi [102] definirano je s:

$$
\begin{gathered}
\boldsymbol{v}_{a}{ }^{n+1 / 2}=\boldsymbol{v}_{a}^{n}+1.5 \Delta t \boldsymbol{F}_{a}^{n}-0.5 \Delta t \boldsymbol{F}_{a}^{n-1} \\
\rho_{a}^{n+1 / 2}=\rho_{a}^{n}+1.5 \Delta t D_{a}^{n}-0.5 \Delta t D_{a}^{n-1} \\
\boldsymbol{r}_{a}^{n+1 / 2}=\boldsymbol{r}_{a}^{n}+\Delta t \boldsymbol{V}_{a}^{n}+\frac{2}{3} \Delta t^{2} \boldsymbol{F}_{a}^{n}-\frac{1}{6} \Delta t^{2} \boldsymbol{F}_{a}^{n-1} \\
e_{a}{ }^{n+1 / 2}=e_{a}^{n}+1.5 \Delta t E_{a}^{n}-0.5 \Delta t E_{a}^{n-1}
\end{gathered}
$$

uzimajući $P_{a}^{n+1 / 2}=f\left(\rho_{a}^{n+1 / 2}\right)$ prema jednadžbi (3.45).

Korekcija vrijednosti dana je izrazima:

$$
\boldsymbol{v}_{a}^{n+1}=\boldsymbol{v}_{a}^{n}+\frac{5}{12} \Delta t \boldsymbol{F}_{a}^{n+1 / 2}+\frac{8}{12} \Delta t \boldsymbol{F}_{a}^{n}-\frac{1}{12} \Delta t \boldsymbol{F}_{a}^{n-1}
$$




$$
\begin{gathered}
\rho_{a}^{n+1}=\rho_{a}^{n}+\frac{5}{12} \Delta t D_{a}^{n+1 / 2}+\frac{8}{12} \Delta t D_{a}^{n}-\frac{1}{12} \Delta t D_{a}^{n-1} \\
\boldsymbol{r}_{a}^{n+1}=\boldsymbol{r}_{a}^{n}+\Delta t \boldsymbol{V}_{a}^{n}+\frac{1}{6} \Delta t^{2} \boldsymbol{F}_{a}^{n+1 / 2}-\frac{1}{3} \Delta t^{2} \boldsymbol{F}_{a}^{n} \\
e_{a}^{n+1}=e_{a}^{n}+\frac{5}{12} \Delta t E_{a}^{n+1 / 2}+\frac{8}{12} \Delta t E_{a}^{n}-\frac{1}{12} \Delta t E_{a}^{n-1}
\end{gathered}
$$

Tlak se izračuna prema $P_{a}^{n+1}=f\left(\rho_{a}^{n+1}\right)$.

\subsection{Reinicijalizacija gustoće}

Korištena metoda u kojoj se tekućina tretira kao slabo stišljiva (eng. weakly compressible SPH method - WCSPH) se pokazala prilično pouzdana za simulaciji gibanja tekućine. Međutim u polju tlakova se javljaju neprirodne oscilacije kao posljedica korištenja jednadžbe stanja [103]. Postoji i tzv. nestišljiva formulacija SPH metode (eng. incompressible SPH method - ISPH), kod koje se koristi Poisson-ova jednadžba koja sprječava problem oscilacije tlakova. Da bi se smanjio problem oscilacije polja tlakova, u okviru WCSPH metode provodi se reinicijalizacija gustoće. Reinicijalizacija se provodi filtrima preko polja gustoće čestica i ponovnom dodjeljivanju gustoće svakoj čestici [10].

\subsubsection{Korekcija nultog reda: Shepard-ov filter}

Shepard-ov filter [104] je jednostavna korekcija kojom se gustoća čestica povremeno reinicijalizira izrazom:

$$
\tilde{\rho}_{a}=\sum_{b} \rho_{b} \widetilde{W}_{a b} \frac{m_{b}}{\rho_{b}}=\sum_{b} m_{b} \widetilde{W}_{a b}
$$

gdje je

$$
\widetilde{W}_{a b}=\frac{W_{a b}}{\sum_{b} \widetilde{W}_{a b} \frac{m_{b}}{\rho_{b}}}
$$

\subsubsection{Korekcija prvog reda: MLS korekcija}

Kod ovoga pristupa gustoća čestica se reinicijalizira koristeći aproksimaciju standardnom linearnom metodom najmanjih kvadrata. (eng. Moving Least Squares- MLS) [105]. Kao kod Shepard-ovog filtra, gustoća se povremeno reinicijalizira izrazom:

$$
\tilde{\rho}_{a}=\sum_{b} \rho_{b} W_{a b}^{M L S} \frac{m_{b}}{\rho_{b}}=\sum_{b} m_{b} W_{a b}^{M L S}
$$


gdje je korigirana jezgrena funkcija u 3D dana sa:

$$
W_{a b}^{M L S}=\left[\beta_{0}\left(\vec{r}_{a}\right)+\beta_{1 x}\left(\vec{r}_{a}\right)\left(x_{a}-x_{b}\right)+\beta_{1 y}\left(\vec{r}_{a}\right)\left(y_{a}-y_{b}\right)+\beta_{1 z}\left(\vec{r}_{a}\right)\left(z_{a}-z_{b}\right)\right] W_{a b}
$$

Vektor korekcije $\beta$ je:

$$
\begin{gathered}
\beta=\left[\begin{array}{l}
\beta_{0} \\
\beta_{1 x} \\
\beta_{1 y} \\
\beta_{1 z}
\end{array}\right]=A^{-1}\left[\begin{array}{l}
1 \\
0 \\
0 \\
0
\end{array}\right], \quad \text { gdje je } \boldsymbol{A}=\sum_{b} W_{b}\left(\vec{r}_{a}\right) \widetilde{A} V_{b} \\
\widetilde{\boldsymbol{A}}=\left[\begin{array}{cccc}
1 & \left(x_{a}-x_{b}\right) & \left(y_{a}-y_{b}\right) & \left(z_{a}-z_{b}\right) \\
\left(x_{a}-x_{b}\right) & \left(x_{a}-x_{b}\right)^{2} & \left(y_{a}-y_{b}\right)\left(x_{a}-x_{b}\right) & \left(z_{a}-z_{b}\right)\left(x_{a}-x_{b}\right) \\
\left(y_{a}-y_{b}\right) & \left(x_{a}-x_{b}\right)\left(y_{a}-y_{b}\right) & \left(y_{a}-y_{b}\right)^{2} & \left(z_{a}-z_{b}\right)\left(y_{a}-y_{b}\right) \\
\left(z_{a}-z_{b}\right) & \left(x_{a}-x_{b}\right)\left(z_{a}-z_{b}\right) & \left(y_{a}-y_{b}\right)\left(z_{a}-z_{b}\right) & \left(z_{a}-z_{b}\right)^{2}
\end{array}\right]
\end{gathered}
$$

Ovaj postupak se primjenjuje svakih $m$ vremenskih koraka (npr. svaki trideseti korak) i malo produljuje vrijeme računanja (najviše zbog računanja inverzne matrice $\boldsymbol{A}^{-1}$ ). Ovom korekcijom postiže se konzistentnost mase i gustoće na promatranom području, pravilnija raspodjela tlakova i očuvanje ukupne energije [10].

\subsection{Renormalizacija jezgrene funkcije}

$\mathrm{Na}$ rubu računalne domene čestice tekućine imaju skraćenu jezgrenu funkciju, odnosno smanjenu utjecajnu duljinu zbog odsutnosti susjednih čestica (npr. čestice u blizini granice slobodnog lica ili krute granice), čime su uvjeti normaliziranosti i kompaktnosti jezgrene funkcije narušeni. Smanjenje pogreške u ovome modelu se postiže korekcijom jezgrene funkcije i/ili njezinog gradijenta.

\subsubsection{Korekcija jezgrene funkcije}

Metodu korekcije jezgrene funkcije prvi su predložili Liu [106] i Bonet [107], a u ovom radu korekcija jezgrene funkcije dana je u sljedećem obliku:

$$
\overrightarrow{f_{a}}=\frac{\sum_{b} \frac{m_{b}}{\rho_{b}} \overrightarrow{f_{b}} W_{a b}}{\sum_{b} \frac{m_{b}}{\rho_{b}} W_{a b}}
$$

Jednadžba (3.102) predstavlja poseban slučaj linearne korekcije kojom se postiže potpuno točna interpolacija funkcije nultog stupnja i njenog gradijenta. Ovu vrstu korekcije testirao je Bonet [107] i pokazao da značajno poboljšava interpolaciju gradijenta polja brzine. 


\subsubsection{Korekcija gradijenta jezgrene funkcije}

Kod ove korekcije prepravljeni gradijent jezgrene funkcije $\widetilde{\nabla} W_{a b}$ se koristi za proračun sila u jednadžbi gibanja umjesto uobičajenog gradijenta jezgrene funkcije $\nabla W_{a b}$, Prepravljeni gradijent jezgrene funkcije $\widetilde{\nabla} W_{a b}$ definiran je izrazom [107]:

$$
\widetilde{\nabla} W_{a b}=\boldsymbol{L}_{a} \nabla W_{a b}
$$

pri čemu je $\boldsymbol{L}_{a}$ matrica korekcije.

Prema tome, gradijent brzine se izračunava kao:

$$
\nabla v_{a}=\sum_{b=1}^{N} \frac{m_{b}}{\rho_{b}}\left(\boldsymbol{v}_{a}-\boldsymbol{v}_{b}\right) \otimes \widetilde{\nabla} W_{a b}=\sum_{b=1}^{N} \frac{m_{b}}{\rho_{b}}\left(\boldsymbol{v}_{a}-\boldsymbol{v}_{b}\right) \otimes \boldsymbol{L}_{a} \nabla W_{a b}
$$

Prepravljeni gradijent jezgrene funkcije mora zadovoljiti uvjet normaliziranosti:

$$
\sum_{b=1}^{N} \frac{m_{b}}{\rho_{b}}\left(\boldsymbol{r}_{a}-\boldsymbol{r}_{b}\right) \otimes \nabla W_{a b}=\boldsymbol{I}
$$

Iz čega slijedi

$$
\sum_{b}^{N} \frac{m_{b}}{\rho_{b}}\left(\boldsymbol{r}_{a}-\boldsymbol{r}_{b}\right) \otimes \widetilde{\nabla} W_{a b}=\left(\sum_{b=1}^{N} \frac{m_{b}}{\rho_{b}}\left(\boldsymbol{r}_{a}-\boldsymbol{r}_{b}\right) \otimes \nabla W_{a b}\right) \boldsymbol{L}_{a}^{T}=\boldsymbol{I}
$$

Iz izraza (3.106) se dobije matrica korekcije $\boldsymbol{L}_{a}$ :

$$
\boldsymbol{L}_{a}=\boldsymbol{M}_{a}^{-1} ; \quad \boldsymbol{M}_{a}=\sum_{b=1}^{N} \frac{m_{b}}{\rho_{b}} \nabla W_{a b} \otimes\left(\boldsymbol{r}_{a}-\boldsymbol{r}_{b}\right)
$$

gdje je $\mathrm{N}$ broj čestica koje su u interakciji s česticom $a$. 


\subsection{Korekcija tlakova na rubu domene}

Pokazalo se da su korištenjem reinicijalizacije gustoće i renormalizacije jezgrene funkcije oscilacije u tlakovima tekućine uz rub domene smanjene, ali nisu potpuno izbjegnute. Oscilacije u tlakovima nemaju velik utjecaj na globalnu sliku gibanja tekućine [108, 109]. Različite vrste korekcija predložene su kako bi se problem oscilacije tlakova umanjio u okviru stišljive formulacije SPH metode [12,110,111].

U ovome radu je usvojena originalna korekcija tlakova na rubovima domene. Nakon izračuna tlakova čestica prema izrazu (3.45), tlakovi čestica tekućine uz rub su korigirani prema sljedećem izrazu:

$$
P(a)=\frac{\sum_{b} \frac{P(b)}{\left(\overrightarrow{r_{b}}-\overrightarrow{r_{a}}\right)}}{\sum_{b} \frac{1}{\left(\overrightarrow{r_{b}}-\overrightarrow{r_{a}}\right)}}
$$

gdje oznaka $a$ predstavlja promatranu rubnu česticu, dok $b$ predstavlja čestice tekućine koje se nalaze u neposrednoj blizini čestice $a$ (odnosno unutar utjecajne domene čestice). Uprosječivanjem tlakova tekućine uz rub domene neprirodne oscilacije tlakova su značajno smanjene, što će biti prikazano u primjerima u nastavku. 


\subsection{Primjeri}

Pomoću prethodno prikazanog numeričkog modela za simulaciju ponašanja tekućine, analizirani su tlakovi koje tekućina stvara na krute pregrade rezervoara izloženih vanjskim ekscitacijama podloge. U ovim primjerima ispitana je pouzdanost i prikladnost numeričkog modela za simulaciju ponašanja tekućine pri izradi novog numeričkog modela za simulaciju međudjelovanja tekućine i konstrukcije.

\subsubsection{Primjer 1: Kruti rezervoar napunjen vodom izložen harmonijskom ubrzanju}

U ovom primjeru analizirana je raspodjela tlakova koje stvara voda na stranice krutog rezervoara izloženog djelovanju horizontalnog ubrzanja. Usvojene su različite geometrije rezervoara: pravokutni rezervoar s uspravnim stranicama, pravokutni rezervoar s jednom nagnutom stranicom i valjkasti rezervoar. Rezervoari su otvorenog tipa i djelomično su ispunjeni vodom. U svim numeričkim testovima usvojena je početna gustoća vode $\rho_{0}=1000 \mathrm{~kg} / \mathrm{m}^{3}$.

(i) Pravokutni rezervoar s uspravnim stranicama

Rezervoar je dimenzija $3.0 \mathrm{~m}$ x $1.0 \mathrm{~m}$ x $1.5 \mathrm{~m}$, a razina vode u rezervoaru je $1.0 \mathrm{~m}$ (Slika 3.8). Izložen je harmonijskom ubrzanju podloge $a$, sa maksimalnim ubrzanjem $a_{0}$ i periodom $T_{p}$ (Slika 3.9).

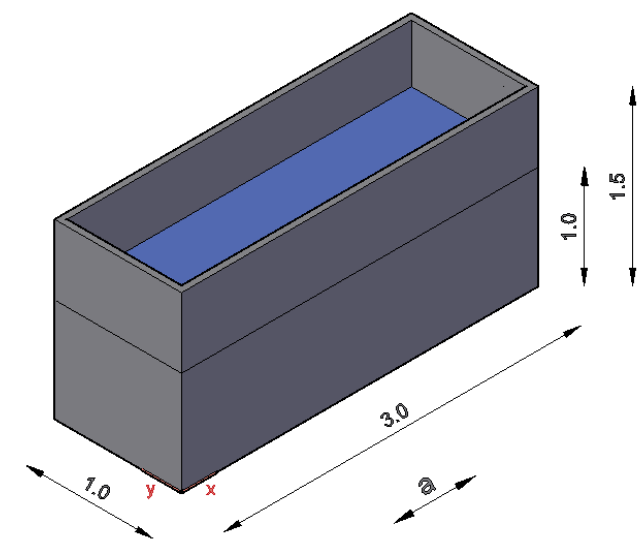

Slika 3.8. Geometrija rezervoara

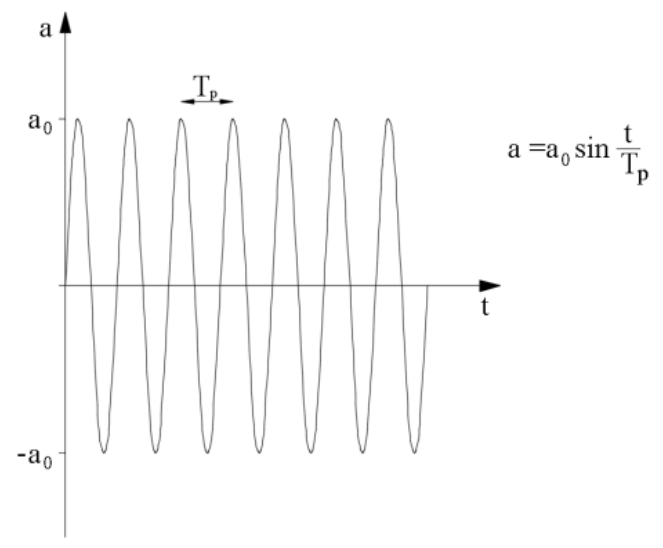

Slika 3.9. Usvojeno ubrzanje podloge

Početni razmak čestica je $0.05 \mathrm{~m}$ i jednoliko su raspoređene (Slika 3.10). Ukupan broj čestica, uključujući i rubne čestice, je 38170. 


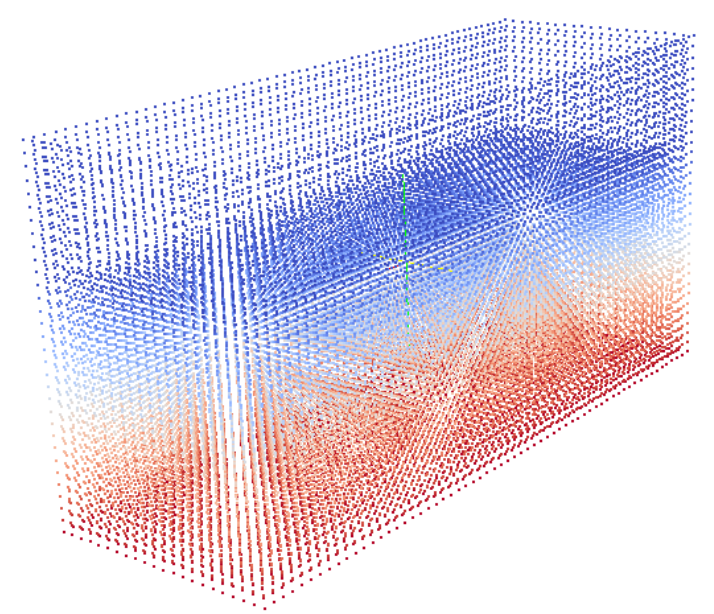

Slika 3.10. Početni razmještaj čestica

U svim testovima usvojeno maksimalno ubrzanje podloge je $0.5 \mathrm{~g}$. Razmatrane su dvije različite harmonijske ekscitacije podloge. $U$ prvoj je period pobude $T_{p}=0.03 \mathrm{~s}$, koji je oko deset puta veći od osnovnog rezonantnog perioda za tlakove u vodi $\mathrm{T}_{1}$. On se prema [112] može izračunati prema izrazu:

$$
\mathrm{T}_{1}=\frac{4 \mathrm{~h}}{\mathrm{c}_{\mathrm{p}}}
$$

gdje je $h$ dubina vode u rezervoaru, a $c_{p}$ brzina zvuka u vodi $(1430 \mathrm{~m} / \mathrm{s})$. Za usvojene dimenzije rezervoara i razinu vode, prema izrazu (3.109) osnovni rezonantni period za tlakove iznosi oko $0.0028 \mathrm{~s}$. Period $\mathrm{T}_{\mathrm{p}}=0.03 \mathrm{~s}$ je odabran kako bi se raspodjela hidrodinamičkih tlakova pomoću ovoga numeričkog modela mogla usporediti sa dobro poznatim Westergaardovim analitičkim rješenjem [5] jer ne uzrokuje značajne pomake vode u rezervoaru i nije blizak osnovnom rezonantnom periodu za tlakove za razmatrani rezervoar. Njegovo analitičko rješenje za maksimalne tlakove vode na branu je dano izrazom:

$$
\mathrm{p}_{\mathrm{d}}=\frac{8 \mathrm{a}_{0} \rho \mathrm{h}}{\pi^{2}} \sum_{1,3,5}^{\mathrm{n}} \frac{1}{\mathrm{n}^{2} \mathrm{c}_{\mathrm{n}}} \sin \frac{\mathrm{n} \pi \mathrm{y}}{2 \mathrm{~h}}
$$

gdje je je $\rho$ gustoća vode, $h$ je dubina vode u rezervoaru, $y$ je dubina vode mjerena od slobodnog vodnog lica, a vrijednost $\mathrm{c}_{\mathrm{n}}$ se izračunava kao:

$$
c_{n}=\sqrt{1-\frac{16 \rho g H^{2}}{n^{2} g k T_{p}^{2}}}
$$

gdje je $k$ modul elastičnosti vode. 
Jednadžba (3.110) ima fizikalno značenje dok je $c_{n}$ realan broj, što se postiže za pobude sa periodom $T_{p}$ većim od osnovnog rezonantnog perioda za tlakove. Maksimalni hidrodinamički tlakovi na krutu pregradu tijekom harmonijske pobude mogu se razmatrati kao dodatna inercijalna sila, koju bi stvorila i masa raspodijeljena na tijelo pregrade, ako pretpostavimo nestišljivu tekućinu $\left(\mathrm{k}, \mathrm{c}_{\mathrm{n}} \rightarrow \infty\right)$. U tom slučaju njegovo analitičko rješenje $\mathrm{u}$ pojednostavljenom obliku dano je izrazom:

$$
\mathrm{p}_{\mathrm{d}}=\frac{7}{8} \rho \mathrm{a}_{0} \sqrt{\mathrm{h}(\mathrm{h}-\mathrm{y})}
$$

Prema izrazu (3.112) raspodjela hidrodinamičkih tlakova ne ovisi o periodu pobude, nego o maksimalnom ubrzanju pobude. Ova pretpostavka je opravdana ako je odnos dubine vode i perioda pobude dovoljno mali [112].

Raspodjela maksimalnih hidrodinamičkih tlakova na vertikalnu stranicu rezervoara okomitu na smjer djelovanja pobude je prikazana na Slici 3.11. Koeficijent hidrodinamičkog tlaka $k_{p}$ je definiran kao:

$$
\mathrm{k}_{\mathrm{p}}=\frac{\mathrm{p}_{\mathrm{d}}}{\rho \mathrm{a}_{0} \mathrm{~h}}
$$

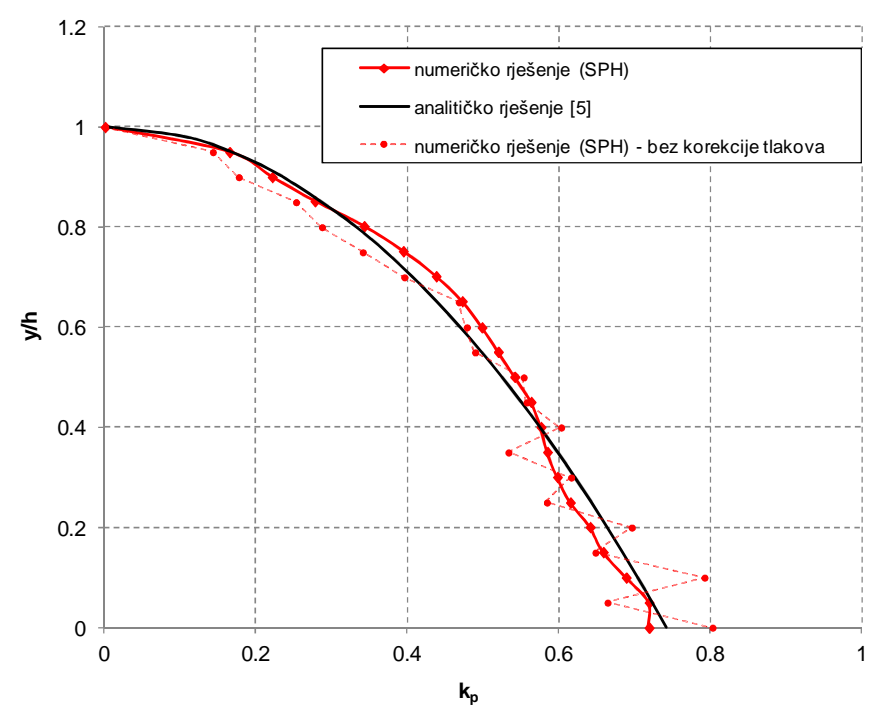

Slika 3.11. Hidrodinamički tlakovi na krutu stranicu rezervoara za $T_{p}=0.03 \mathrm{~s}$

Osim usporedbe na Slici 3.11, odstupanja između numeričkih i analitičkih rješenja procijenjena su pomoću srednje kvadratne greške koja iznosi $0.0411(8.6 \%)$ kada se ne koristi korekcija tlakova. Međutim, koristeći dodatnu korekciju tlakova prema izrazu (3.108), srednja kvadratna greška između numeričkih i analitičkih rješenje iznosi 0.02 (4.1\%). 
Numerički rezultati dobiveni modelom na temelju SPH se dobro podudaraju s Westergaard-ovim analitičkim rješenjem. Manja odstupanja između numeričkog i analitičkog rješenja su vidljiva na Slici 3.11. Iako harmonijska pobuda s periodom $T_{p}=0.03 \mathrm{~s}$ ne uzrokuje značajan pomak čestica vode, one osciliraju oko svog ravnotežnog položaja, što vodi do promjene u gustoći vode. Male promjene u gustoći mogu izazvati velike oscilacije u polju tlakova prema (3.45), tako da su takva odstupanja očekivana. Također, ova odstupanja djelomično proizlaze iz različitih pretpostavki između analitičkih i numeričkih rješenja. U numeričkim analizama usvojen je rezervoar konačnih dimenzija, dok je analitičko rješenje izvedeno za beskonačno dug i širok rezervoar.

Ukupni tlakovi $\mathrm{u}$ vodi za harmonijsko ubrzanje podloge $\mathrm{s}$ periodom $\mathrm{T}_{\mathrm{p}}=0.03 \mathrm{~s}$ prikazani su u nekim vremenima na Slici 3.12.

$\mathrm{t}=0.060 \mathrm{~s}$

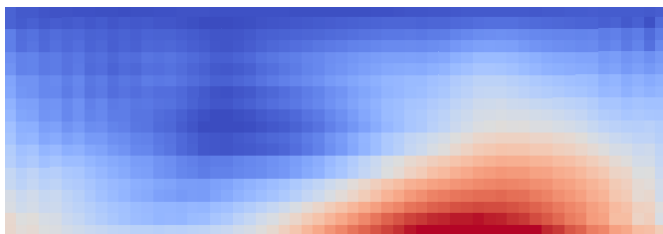

$\mathrm{t}=0.079 \mathrm{~s}$

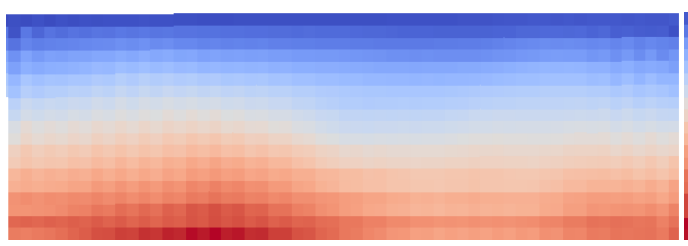

$\mathrm{t}=0.090 \mathrm{~s}$

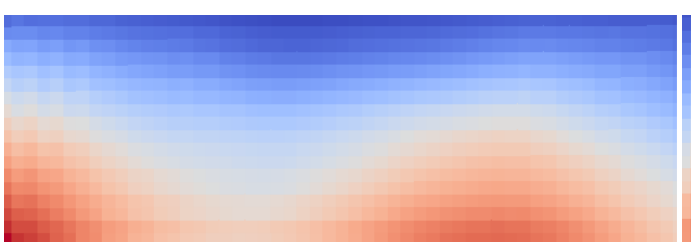

$\mathrm{t}=0.072 \mathrm{~s}$

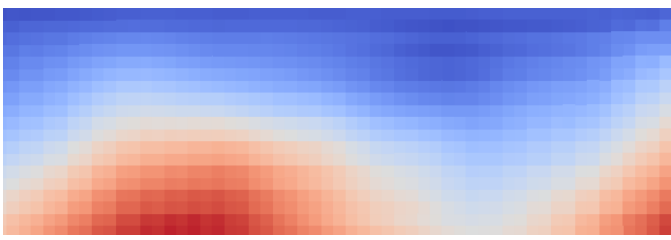

$\mathrm{t}=0.082 \mathrm{~s}$

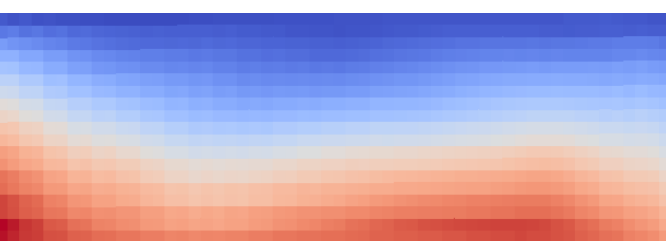

$\mathrm{t}=0.132 \mathrm{~s}$

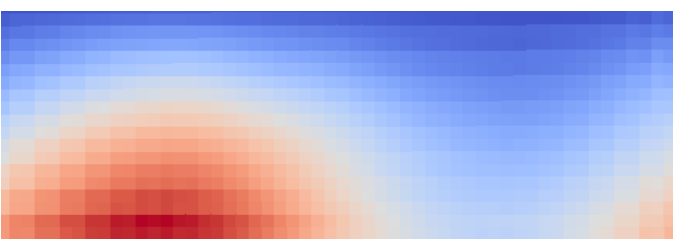

Slika 3.12. Ukupni tlakovi u vodi za harmonijsku pobudu s periodom $T_{p}=0.03 \mathrm{~s}$

U drugom numeričkom testu, prikazani rezervoar je izložen harmonijskom ubrzanju podloge $\mathrm{s}$ periodom $\mathrm{T}_{\mathrm{p}}=1.0 \mathrm{~s}$. Usvojeni period je značajno veći od osnovnog rezonantnog perioda za tlakove, ali manji od rezonantnog perioda za pomake, koji za usvojenu razinu vode u rezervoaru iznosi oko 2s [113]. Ova pobuda uzrokuje značajno valovanje vode u rezervoaru (Slika 3.13 i 3.14). Na Slici 3.13 je prikazana raspodjela ukupnih tlakova (hidrostatički i hidrodinamički) za pobudu $\mathrm{s}$ periodom $\mathrm{T}_{\mathrm{p}}=1.0 \mathrm{~s}$ u srednjem presjeku rezervoara u nekim odabranim trenucima. Obzirom na značajne pomake vode tijekom ove pobude, raspodjela 
tlakova se ne može usporediti sa Westergaard-ovim rješenjem koje vrijedi uz pretpostavku o malom valovanju vode. Tijekom ove pobude dolazi do značajnih promjena vodnog lica, uz zapljuskivanje valova na stranice rezervoara, što dovodi do različitih raspodjela tlakova na stranice rezervoara (Slika 3.13).
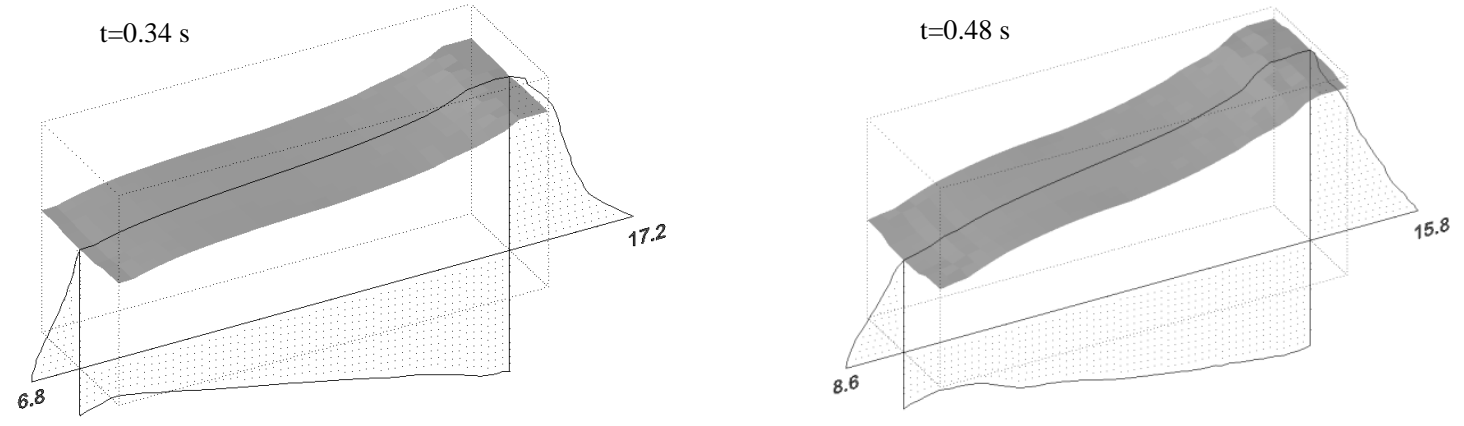

$\mathrm{t}=1.0 \mathrm{~s}$
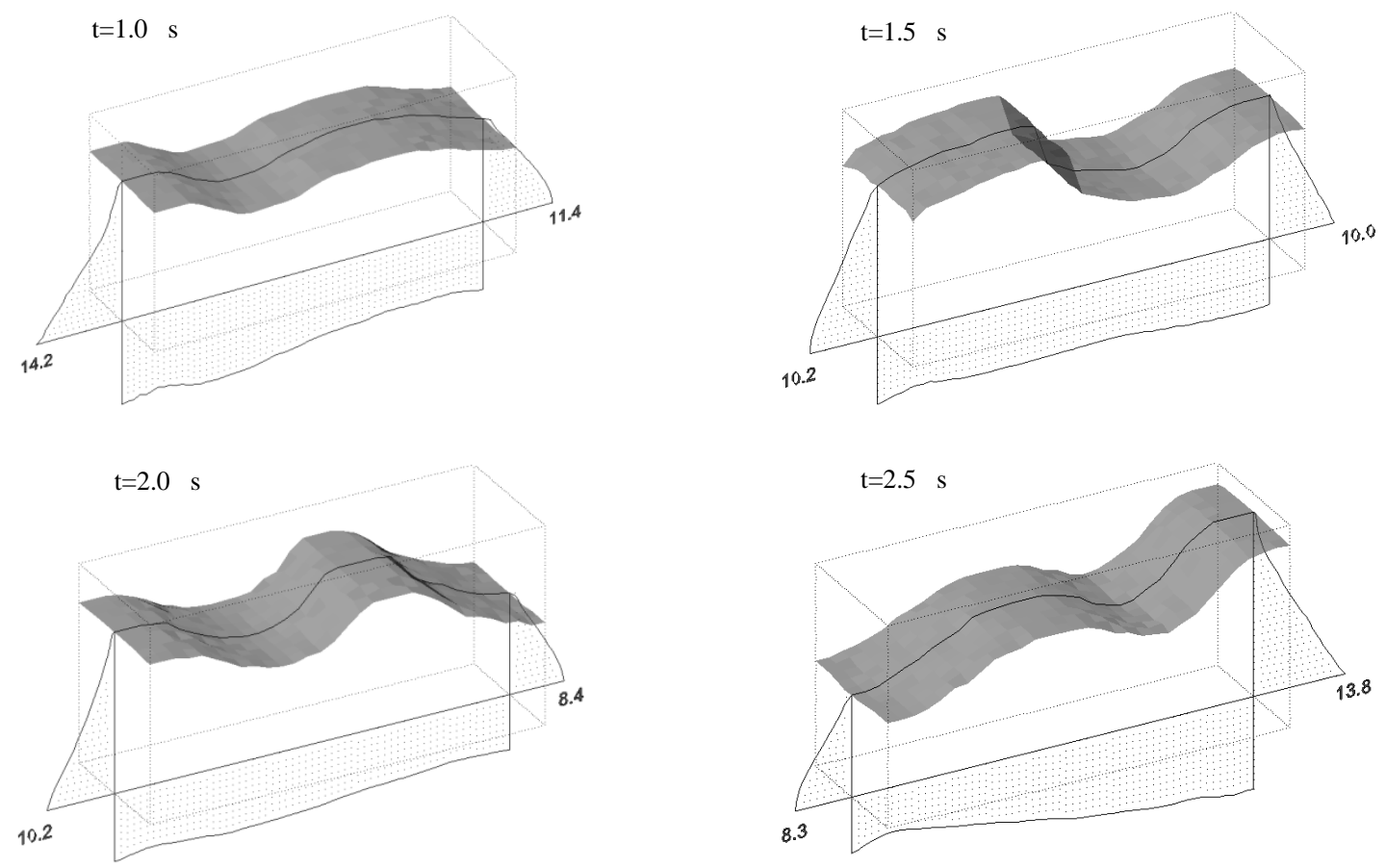

Slika 3.13. Vodno lice i raspodjela ukupnih tlakova na stranice rezervoara $[\mathrm{kPa}] \mathrm{za} \mathrm{T}_{\mathrm{p}}=1.0 \mathrm{~s}$ 
$\mathrm{t}=0.48 \mathrm{~s}$

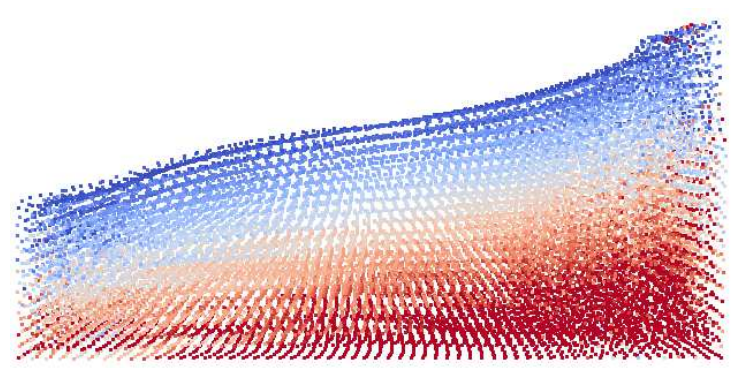

$\mathrm{t}=1.0 \mathrm{~s}$

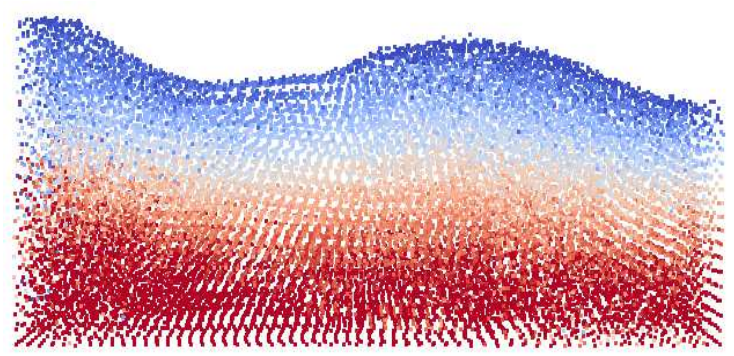

$\mathrm{t}=2.0 \mathrm{~s}$

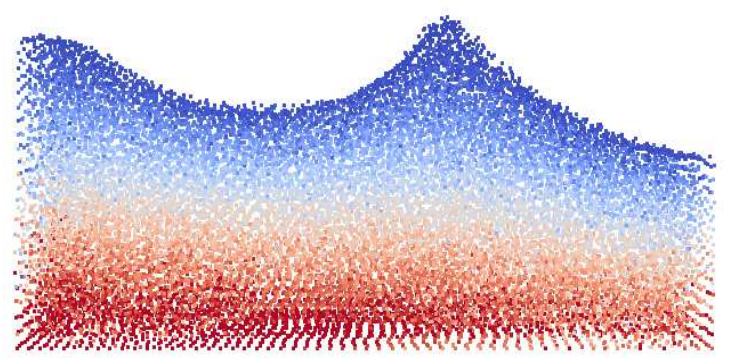

$\mathrm{t}=0.80 \mathrm{~s}$

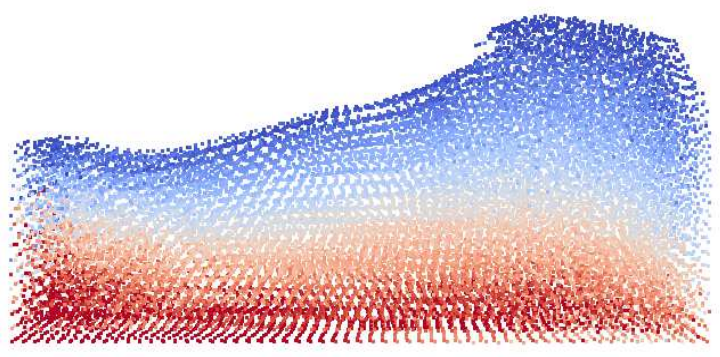

$\mathrm{t}=1.5 \mathrm{~s}$

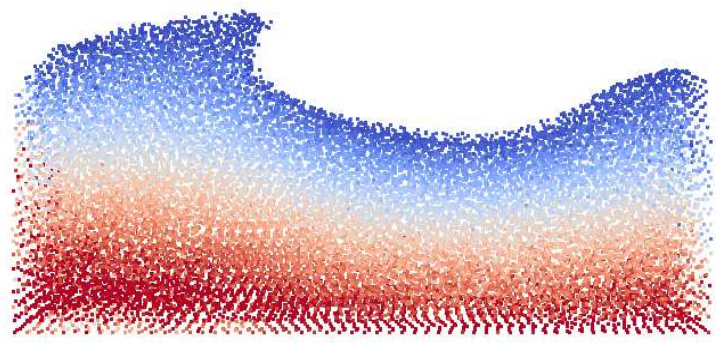

$\mathrm{t}=2.5 \mathrm{~s}$

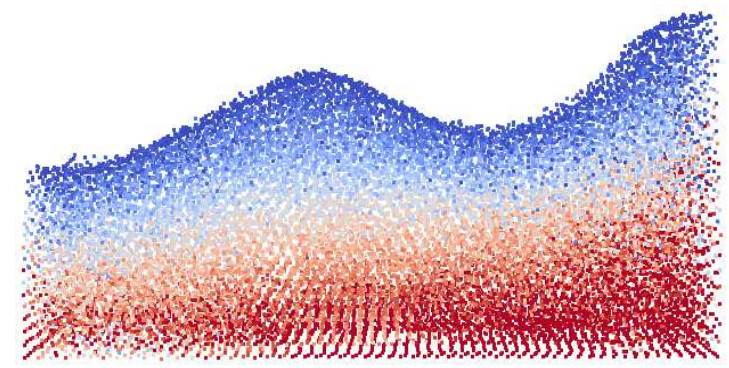

Slika 3.14. Ukupni tlakovi u vodi za harmonijsku pobudu sa periodom $T_{p}=1.0 \mathrm{~s}$ 
(ii) Pravokutni rezervoar sa stranicom u nagibu

Ovdje je analizirana raspodjela hidrodinamičkih i ukupnih tlakova na nagnutu stranicu krutog rezervoara. Dimenzije rezervoara su kao u prethodnim primjerima, osim što je jedna stranica pod nagibom od $15^{\circ}, 30^{\circ}$ i $45^{\circ}$ (Slika 3.15). Početni razmak čestica je $0.05 \mathrm{~m}$ (Slika 3.16). Rezervoari su izloženi harmonijskom ubrzanju podloge s periodima $T_{p}=0.03 \mathrm{~s}$ i $T_{p}=1.0$ s (Slika 3.9). Maksimalno ubrzanje podloge je $0.5 \mathrm{~g}$.
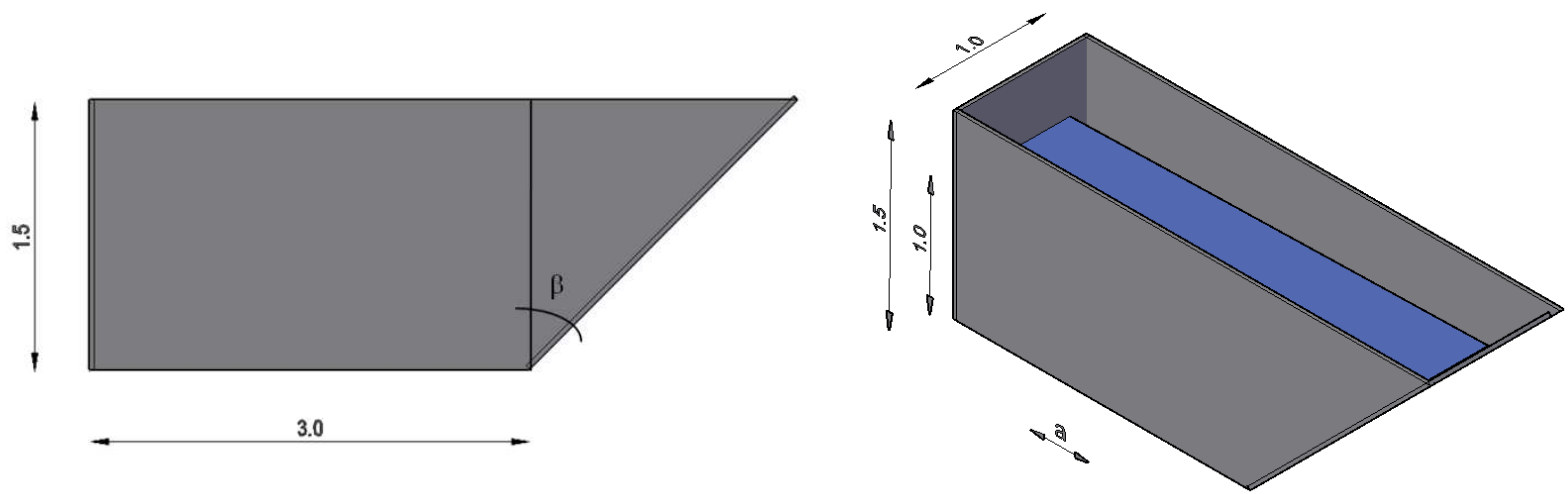

Slika 3.15. Geometrija rezervoara s nagnutom stranicom

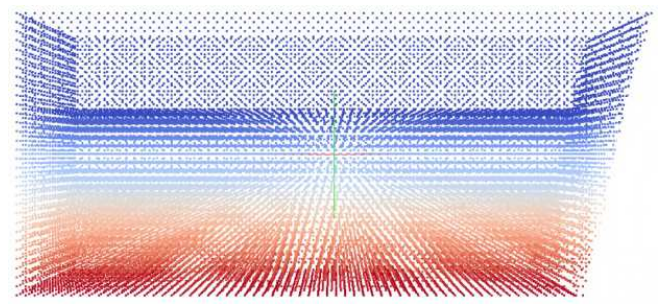

(a) $15^{\circ}$

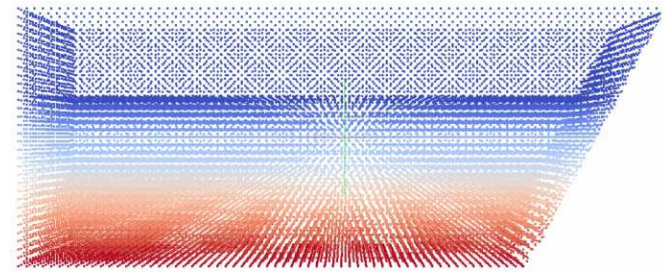

(b) $30^{\circ}$

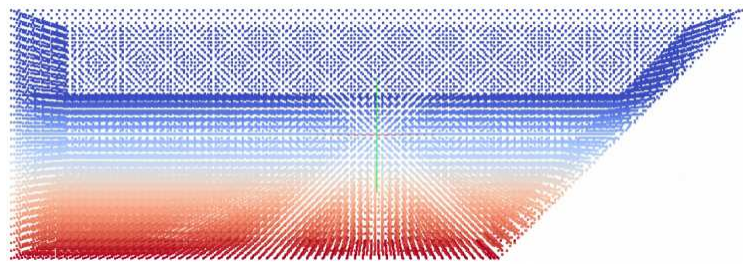

(c) $45^{\circ}$

Slika 3.16. Početni razmještaj čestica u rezervoaru s nagnutom stranicom

Raspodjela tlakova na nagnutu stranicu rezervoara za pobudu s periodom $T_{p}=0.03 \mathrm{~s}$ prikazana je na Slici 3.17. Raspodjele tlakova dobivene numeričkim modelom uspoređene su s Chwang-ovim analitičkim rješenjem [114]. Ono vrijedi za beskonačno dugi i široki rezervoar ispunjen neviskoznom i nestišljivom tekućinom, pri pobudama koje ne uzrokuju 
značajnu promjenu vodnog lica. Na Slici 3.17 uočava se vrlo dobro podudaranje numeričkih i analitičkih rezultata, posebno pri korištenju dodatne korekcije tlakova prema izrazu (3.108). Međutim, može se uočiti da su odstupanja numeričkih rezultata od analitičkih nešto veća nego u primjeru s vertikalnom stanicom rezervoara. To se može objasniti utjecajem nejednolike početne raspodjele čestica na nagnutoj stranici rezervoara, što je izazvalo još veće oscilacije u gustoći i tlakovima.

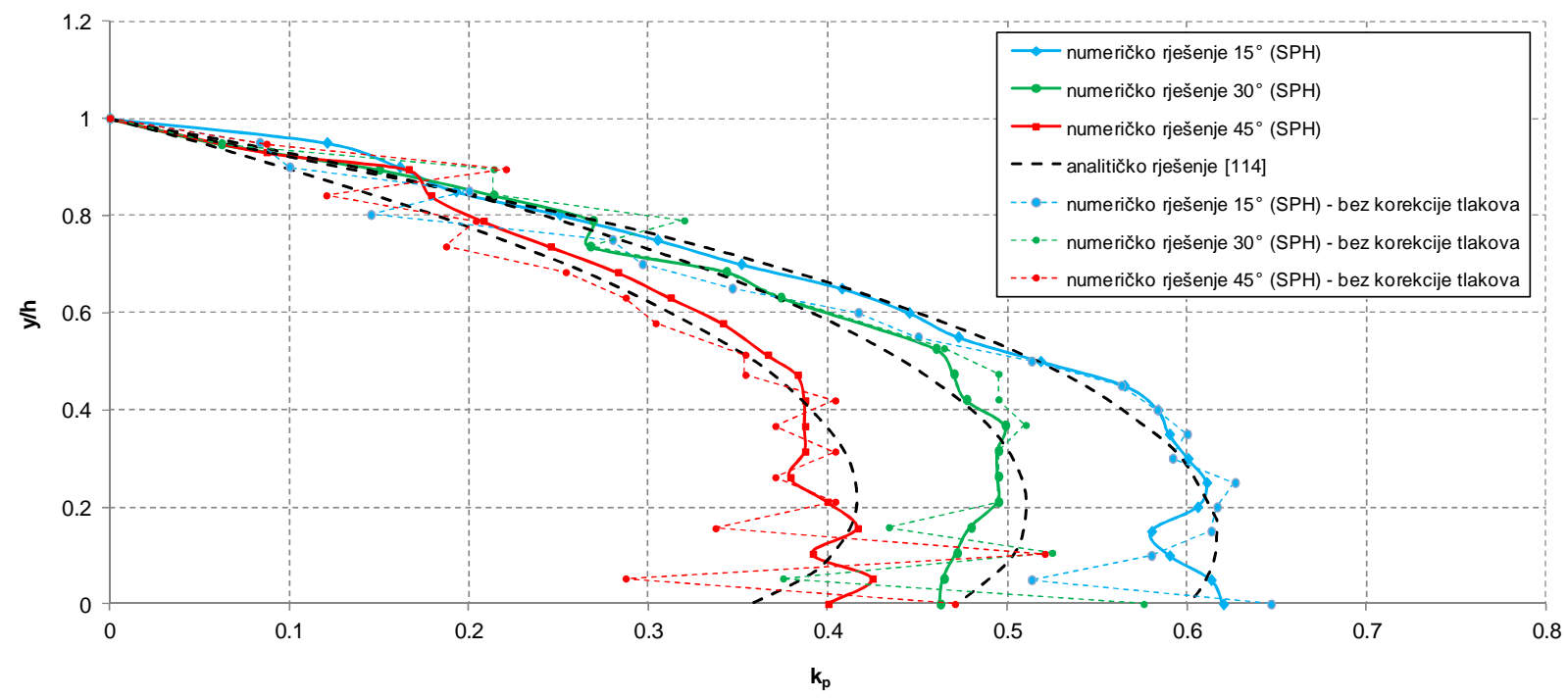

Slika 3.17. Hidrodinamički tlakovi na krutu nagnutu stranicu rezervoara za $T_{p}=0.03 \mathrm{~s}$

Raspodjela ukupnih tlakova (hidrostatičkih i hidrodinamičkih) u srednjem presjeku rezervoara za harmonijsko ubrzanje podloge $\mathrm{s}$ periodom $\mathrm{T}_{\mathrm{p}}=1.0 \mathrm{~s}$ u nekim vremenima prikazana je na Slici 3.18. Obzirom da postoje značajni pomaci čestica vode tijekom ove pobude, raspodjela tlakova se ne može usporediti s Chwang-ovim rješenjem koje vrijedi uz pretpostavku o malom valovanju vode. Tijekom ove pobude dolazi do značajnih promjena vodnog lica, uz zapljuskivanje valova na stranice rezervoara, što dovodi do različitih raspodjela tlakova na stranice rezervoara (Slika 3.18). 

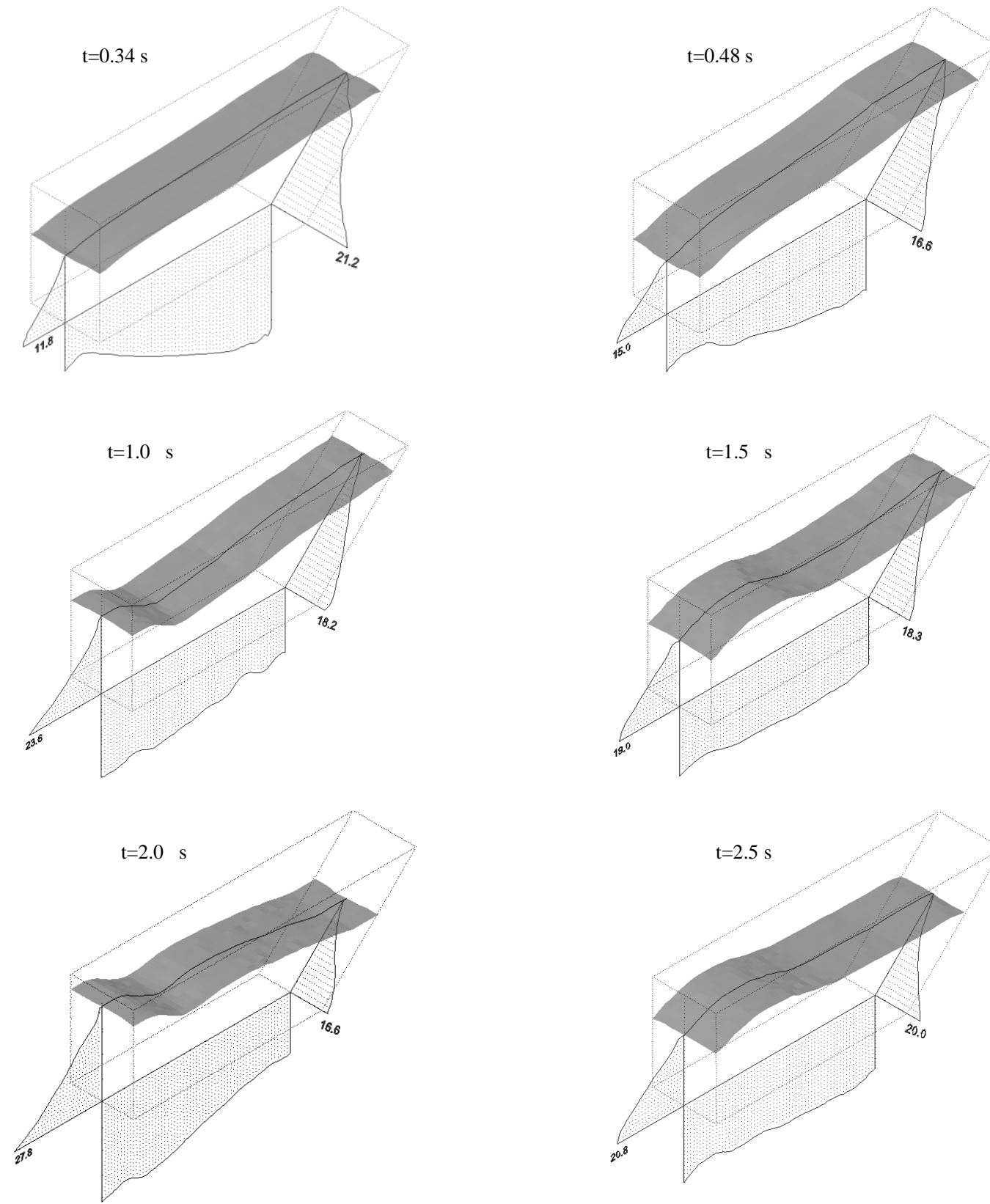

Slika 3.18. Vodno lice i raspodjela ukupnih tlakova na nagnutu stranicu rezervoara $[\mathrm{kPa}] \mathrm{za}_{\mathrm{p}}=1.0 \mathrm{~s}$ 


\section{(iii)Valjkasti rezervoar}

Ovdje je analizirana raspodjela hidrodinamičkih i ukupnih tlakova na stranice krutog valjkastog rezervoara (Slika 3.19). Rezervoar je promjera $2.0 \mathrm{~m}$, visine $1.0 \mathrm{~m}$ i napunjen je vodom do visine od $0.6 \mathrm{~m}$. Izložen je harmonijskom ubrzanju podloge prema Slici 3.9. Maksimalno ubrzanje u svim testovima je $0.5 \mathrm{~g}$. Početni razmještaj čestica vode u rezervoaru prikazan je na Slici 3.20, pri čemu su čestice na početnom razmaku od $0.05 \mathrm{~m}$.

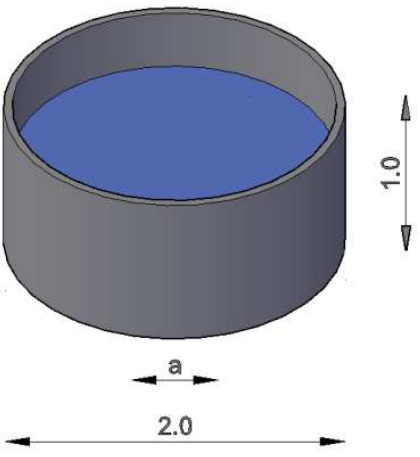

Slika 3.19. Dimenzije rezervoara

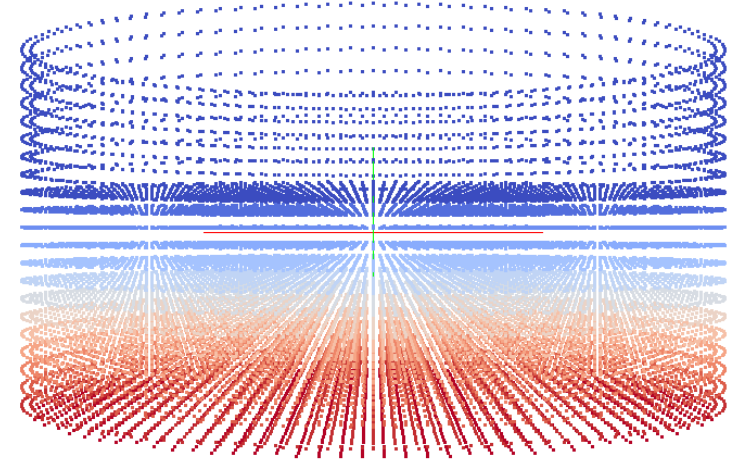

Slika 3.20. Početni razmještaj čestica

Prvo je razmatrana raspodjela hidrodinamičkih tlakova na vertikalnu stranicu valjkastog rezervoara u srednjoj ravnini pri djelovanju harmonijskog ubrzanja podloge $\mathrm{s}$ periodom $T_{p}=0.02 \mathrm{~s}$. Ovaj period pobude je veći od osnovnog rezonantnog perioda za tlakove, koji iznosi 0.00167 s za ovaj rezervoar. Ovakva pobuda ne uzrokuje značajnu promjenu vodnog lica i pomaci čestica vode su beznačajni. Stoga se raspodjela tlakova dobivena numeričkim modelom može usporediti s analitičkim rezultatima autora Petrov i Moiseev [115]. Njihovo rješenje vrijedi za valjkaste rezervoare djelomično ispunjene neviskoznom i nestišljivom tekućinom, a dano je jednadžbama (3.114) i (3.115), uz simbole definirane na Slici 3.21.

$$
\begin{gathered}
\mathrm{p}_{\mathrm{w}}=\rho_{\mathrm{w}} \ddot{\mathrm{a}}_{0} \mathrm{~h}\left[\sqrt{3} \cos \phi^{\prime}\left(\left(\frac{\mathrm{y}}{\mathrm{h}}\right)-\frac{1}{2}\left(\frac{\mathrm{y}}{\mathrm{h}}\right)^{2}\right) \operatorname{th}\left(\sqrt{3} \frac{\mathrm{R}}{\mathrm{h}}\right)\right] \\
\mathrm{p}_{\mathrm{b}}=\rho_{\mathrm{w}} \ddot{\mathrm{a}}_{0} \mathrm{~h}\left[\frac{\sqrt{3}}{2} \cos \phi^{\prime} \frac{\left.\operatorname{sh}\left(\sqrt{3} \frac{\mathrm{r}}{\mathrm{h}}\right)\right] ;}{\left.\operatorname{ch}\left(\sqrt{3} \frac{\mathrm{R}}{\mathrm{h}}\right)\right] ;} \quad\left[\begin{array}{c}
0 \leq \mathrm{r} \leq \mathrm{R} \\
0 \leq \phi^{\prime} \leq 2 \pi \\
0 \leq \mathrm{y} \leq \mathrm{h}
\end{array}\right]\right.
\end{gathered}
$$



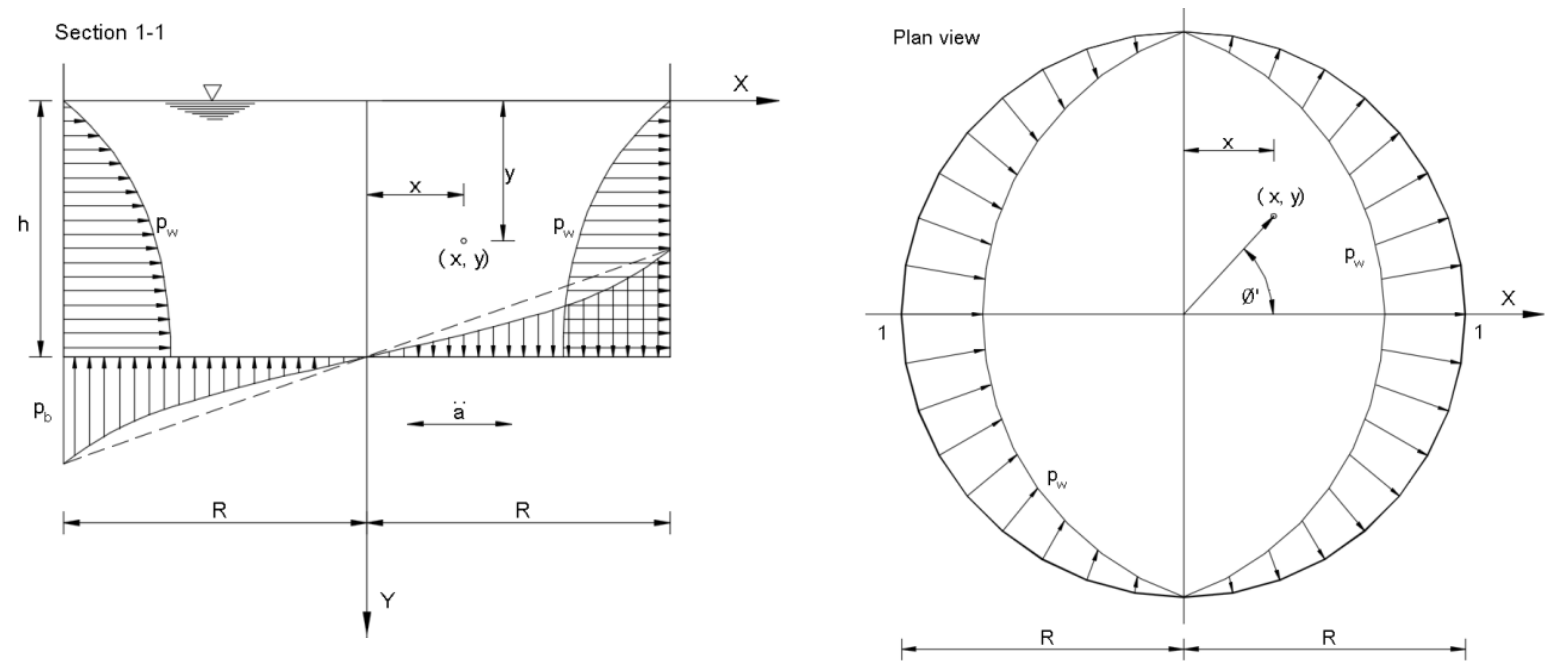

Slika 3.21. Raspodjela hidrodinamičkih tlakova na kružni rezervoar [115]

Raspodjela maksimalnih hidrodinamičkih tlakova na uspravnu stranicu valjkastog rezervoara $\mathrm{u} \mathrm{x}-\mathrm{z}$ ravnini, dobivena numeričkim modelom je uspoređena $\mathrm{s}$ analitičkim rezultatima na Slici 3.22. Na istoj slici je prikazana i usporedba s numeričkim modelom koji se temelji na metodi konačnih elemenata [116]. Može se uočiti vrlo dobro podudaranje rezultata i s analitičkim i drugim numeričkim rezultatima.

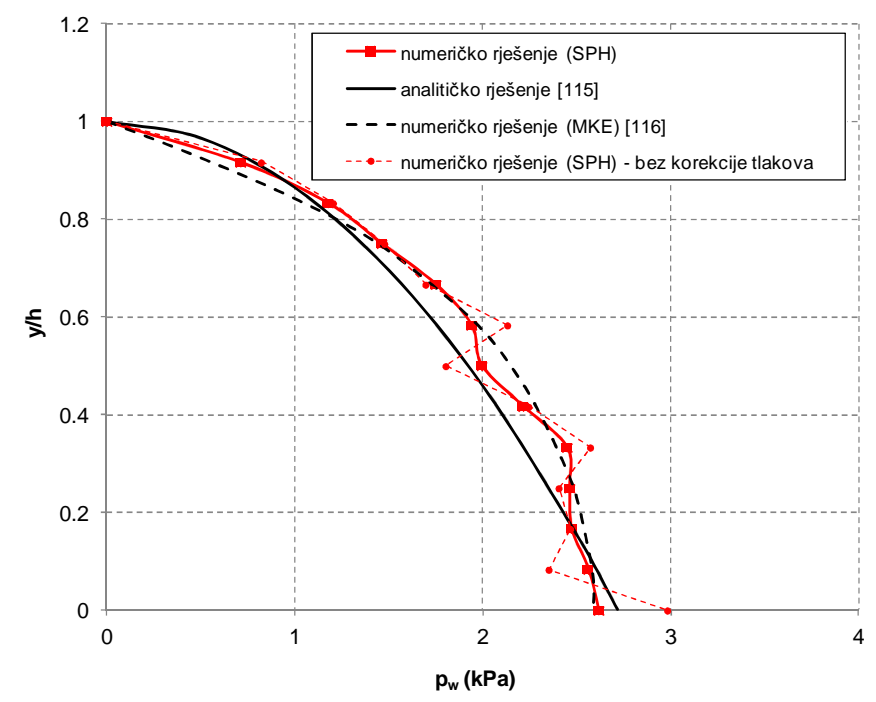

Slika 3.22. Hidrodinamički tlakovi na krutu stranicu kružnog rezervoara za $T_{p}=0.02 \mathrm{~s}$

Osim vizualne usporedbe na Slici 3.22, odstupanja između numeričkih i analitičkih rješenja procijenjena su pomoću srednje kvadratne greške. Srednja kvadratna greška između rezultata dobivenih numeričkim modelom za tekućinu iz ovoga rada i analitičkih rezultata iznosi $0.1271 \mathrm{kPa}(7.0 \%)$, dok srednja kvadratna greška između rezultata dobivenih numeričkim modelom koji se temelji na metodi konačnih elemenata $\mathrm{i}$ analitičkih rezultata iznosi $0.1871 \mathrm{kPa}(10.1 \%)$. Nešto lošije podudaranje s analitičkim rezultatima u odnosnu na 
pravilni pravokutni rezervoar je očekivano zbog nejednolike raspodjele volumena vode koji pripada rubnim česticama.

Raspodjela ukupnih tlakova (hidrostatički i hidrodinamičkih) na stranice valjkastog rezervoara $\mathrm{u} x-\mathrm{z}$ ravnini za harmonijsko ubrzanje podloge $\mathrm{s}$ periodom $\mathrm{T}_{\mathrm{p}}=0.7 \mathrm{~s}$ u nekim vremenima prikazana je na Slici 3.23. Obzirom da postoje značajni pomaci čestica vode tijekom ove pobude, raspodjela tlakova se ne može usporediti s analitičkim rješenjem [115], koje vrijedi uz pretpostavku o malom valovanju vode. Tijekom ove pobude dolazi do značajnih promjena vodnog lica, uz zapljuskivanje valova na stranice rezervoara, što dovodi do različitih raspodjela tlakova na stranice rezervoara (Slika 3.23).

$\mathrm{t}=0.25 \mathrm{~s}$
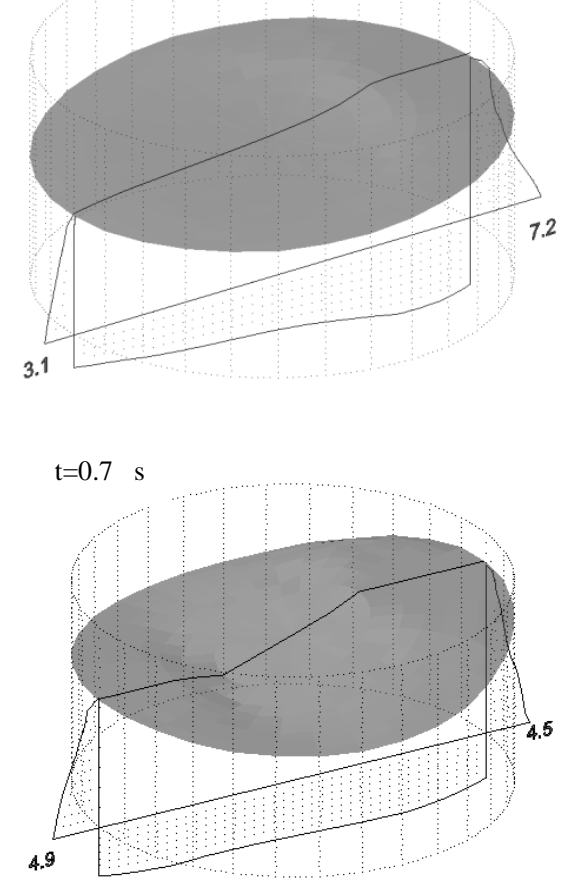

$\mathrm{t}=1.4 \mathrm{~s}$

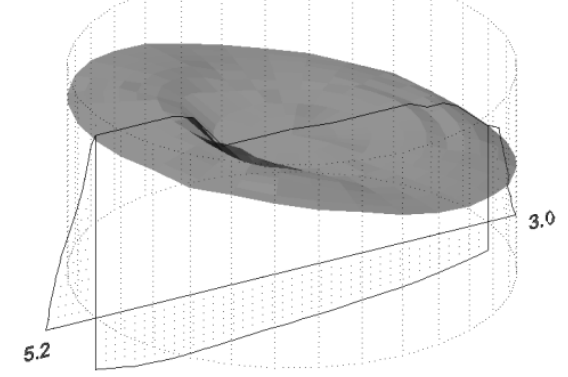

$\mathrm{t}=0.52 \mathrm{~s}$

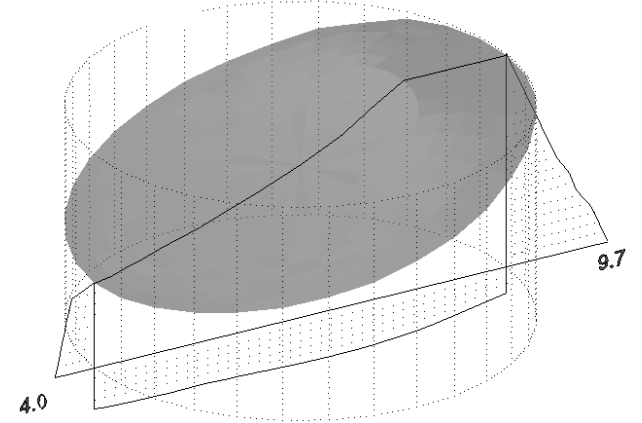

$\mathrm{t}=1.0 \mathrm{~s}$

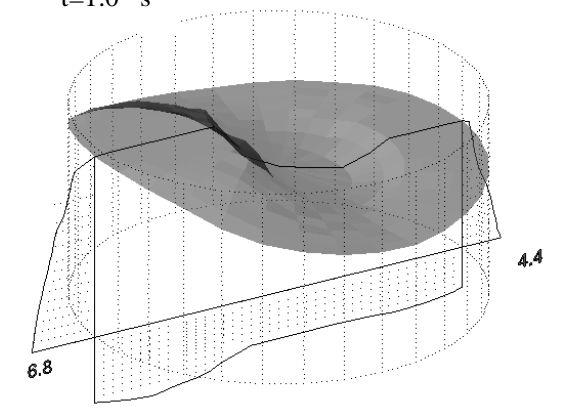

$\mathrm{t}=2.3 \mathrm{~s}$

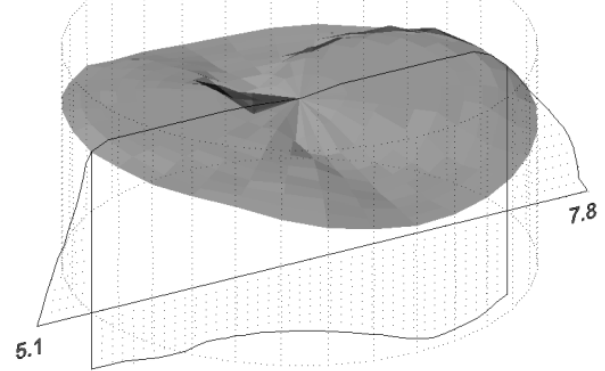

Slika 3.23. Vodno lice i raspodjela ukupnih tlakova na stranice valjkastog rezervoara $[\mathrm{kPa}]$ za $\mathrm{T}_{\mathrm{p}}=0.7 \mathrm{~s}$ 


\subsubsection{Primjer 2: Kruti rezervoar napunjen vodom izložen djelovanju realnog potresa}

U ovom primjeru analizirani su pomaci vode u rezervoaru zatvorenog tipa i raspodjela tlakova na stranice rezervoara izloženog djelovanju realnog potresa. Usvojene su dvije geometrije rezervoara: kockasti i valjkasti (Slika 3.24). Visina oba rezervoara je $3.0 \mathrm{~m}$, a dimenzije baze rezervoara su odabrane iz uvjeta jednakih površina, kako bi za određenu razinu punjenja volumen tekućine u oba rezervoara bio isti.

Rezervoari su ispunjeni vodom do visine 2.0 m (67\% ispunjen vodom) i do visine 2.85 m (95\% ispunjen vodom). Početni međusobni razmak čestica vode je $0.05 \mathrm{~m}$. U kockastom rezervoaru voda je simulirana s 139240 čestica za ispunjenost rezervoara 67\%, odnosno s 198417 čestica za ispunjenost rezervoara 95\% (Slika 3.25). U valjkastom rezervoaru voda je simulirana s 151280 čestica za ispunjenost rezervoara 67\%, odnosno s 215574 čestica za ispunjenost rezervoara 95\% (Slika 3.26). U svim numeričkim testovima usvojena je početna gustoća vode $\rho_{0}=1000 \mathrm{~kg} / \mathrm{m}^{3}$.
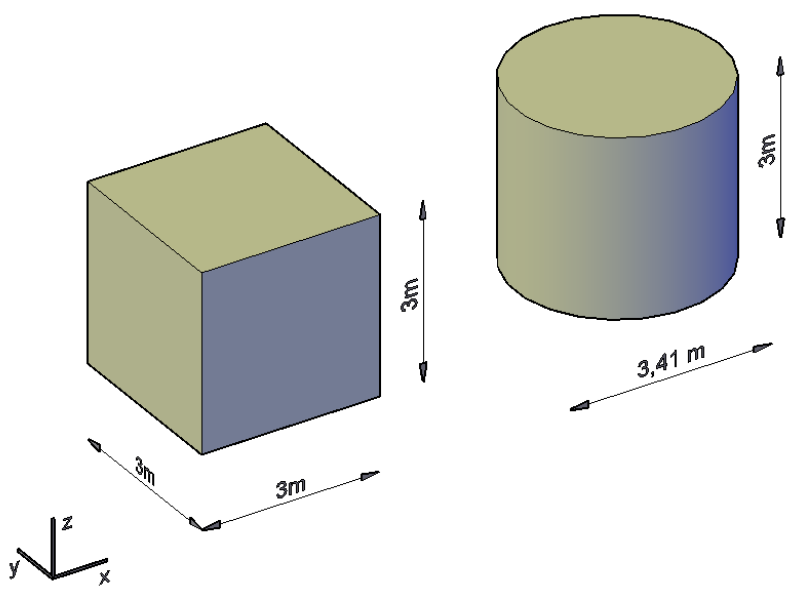

Slika 3.24. Geometrija rezervoara

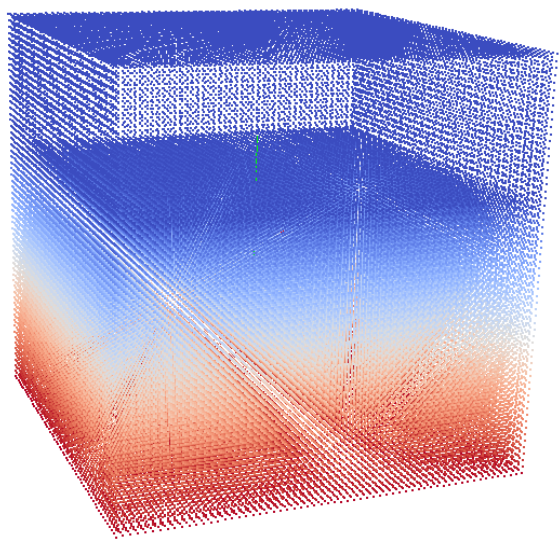

(a) $\mathrm{h}=2.0 \mathrm{~m}$

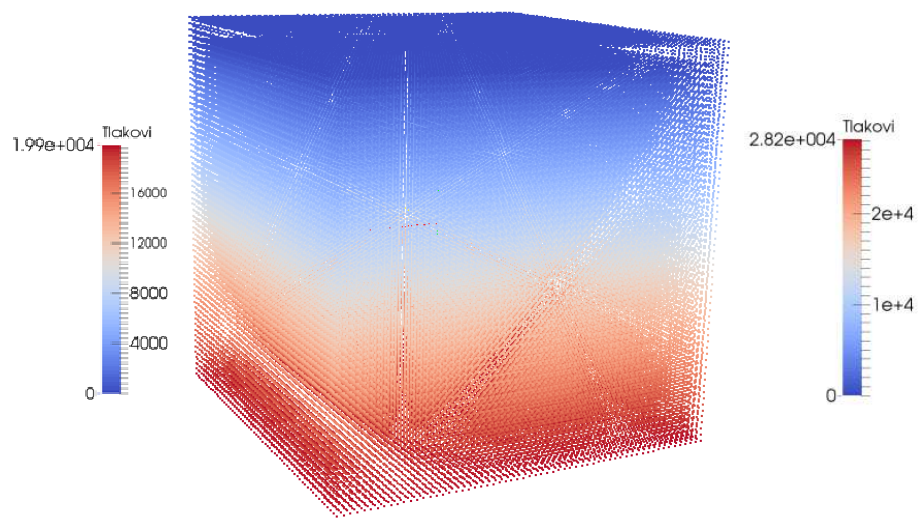

(b) $\mathrm{h}=2.85 \mathrm{~m}$

Slika 3.25. Početni razmještaj čestica i početni tlakovi za kockasti rezervoar 


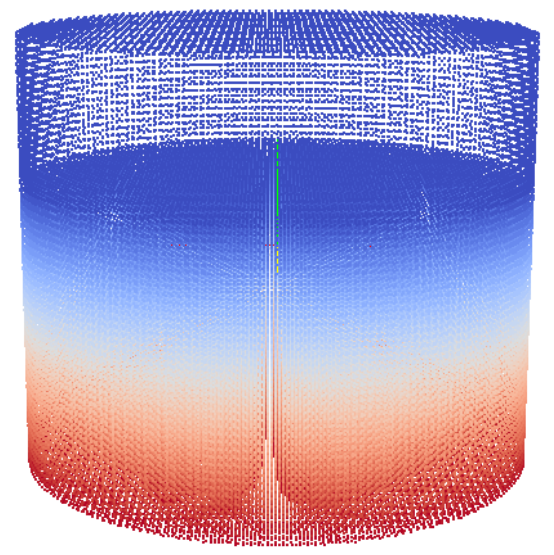

(a) $\mathrm{h}=2.0 \mathrm{~m}$
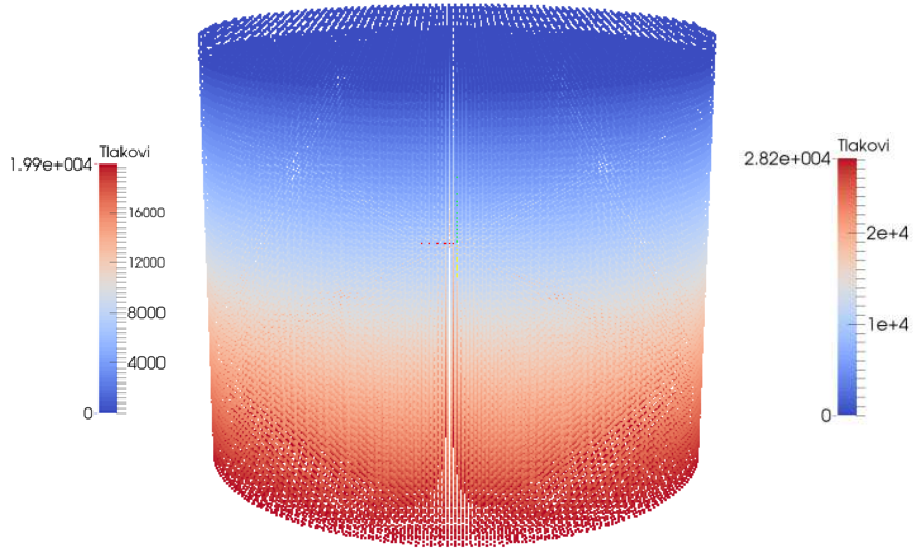

(b) $\mathrm{h}=2.85 \mathrm{~m}$

Slika 3.26. Početni razmještaj čestica i početni tlakovi za valjkasti rezervoar

Rezervoari su izloženi djelovanju horizontalne komponente ubrzanja četiri realna potresa: Northridge, Kobe, Ston i Banja Luka. Vremenski zapisi horizontalne komponente ubrzanja za svaku pobudu prikazani su na Slici 3.27. Odabrani potresi izvorno imaju različito vrijeme trajanja, maksimalno ubrzanje i predominantni period. Akcelelogrami svih usvojenih potresa su skalirani na $0.6 \mathrm{~g}$, zbog jednostavnije interpretacije rezultata numeričkih testova.
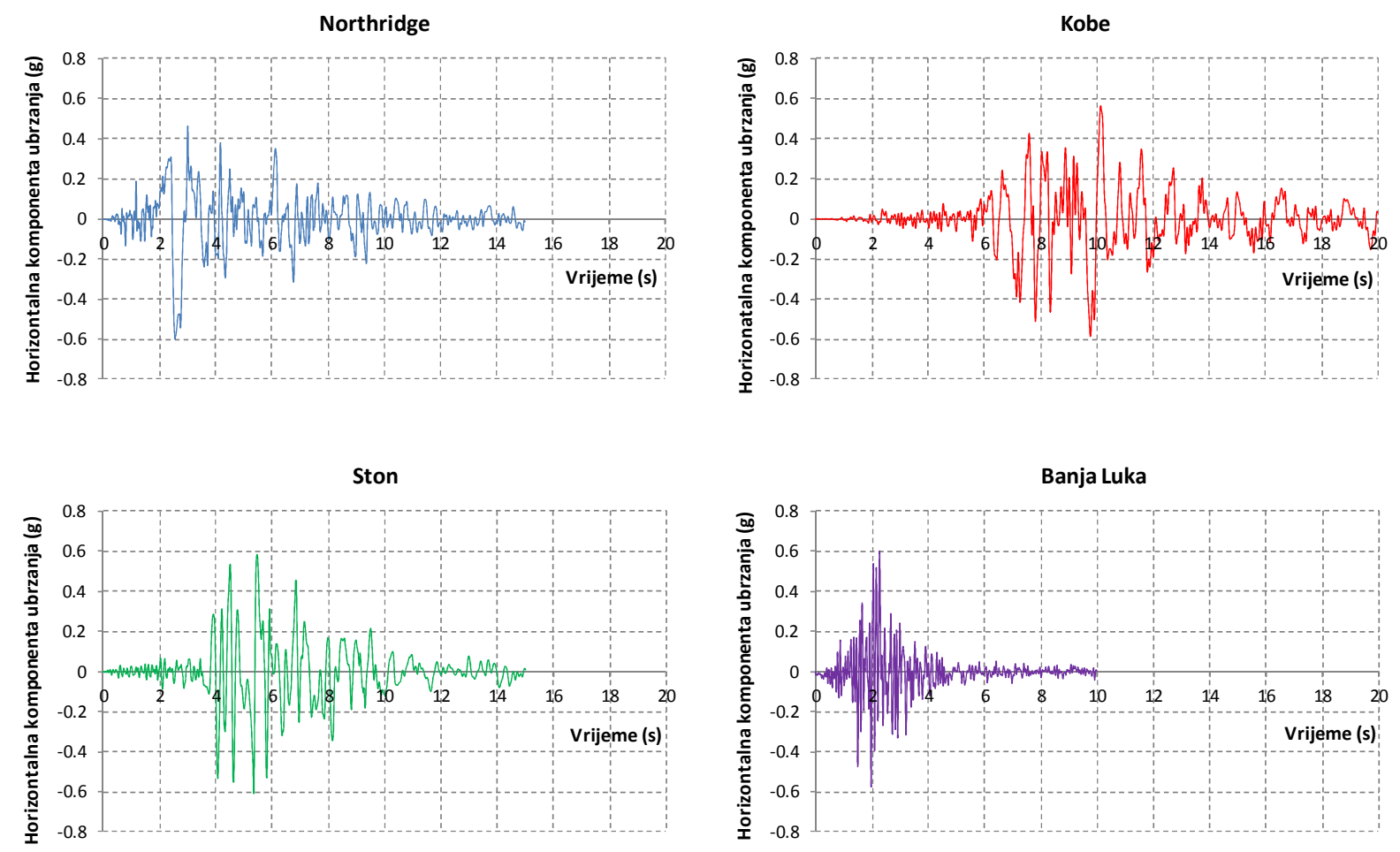

Slika 3.27. Usvojeni akcelelogrami realnih potresa

Za usvojene pobude sa Slike 3.27 izračunata su njihova spektralna ubrzanja i spektralni pomaci (za prigušenje od $5 \%$ ), koji su prikazani na Slici 3.28. 


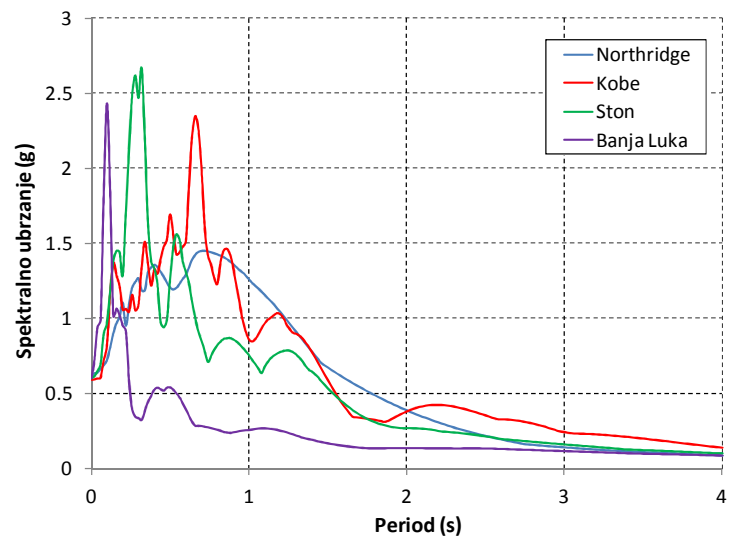

a) Spektar ubrzanja

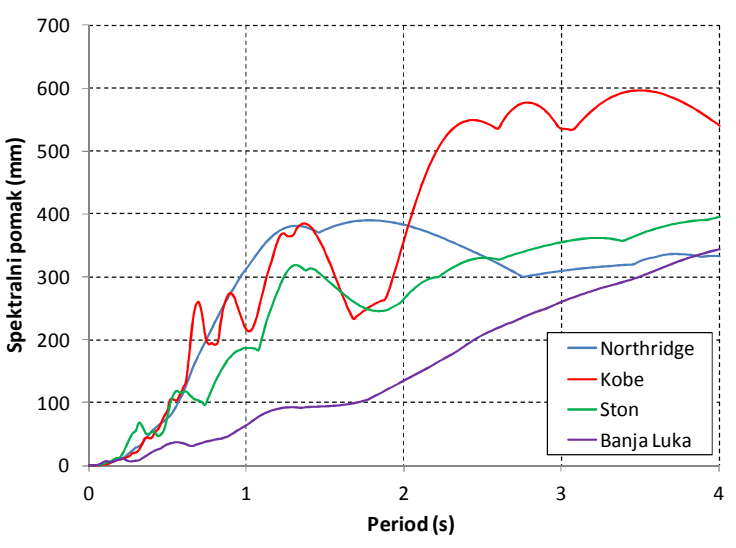

b) Spektar pomaka

Slika 3.28. Spektar ubrzanja i pomaka za usvojene akcelelograme realnih potresa
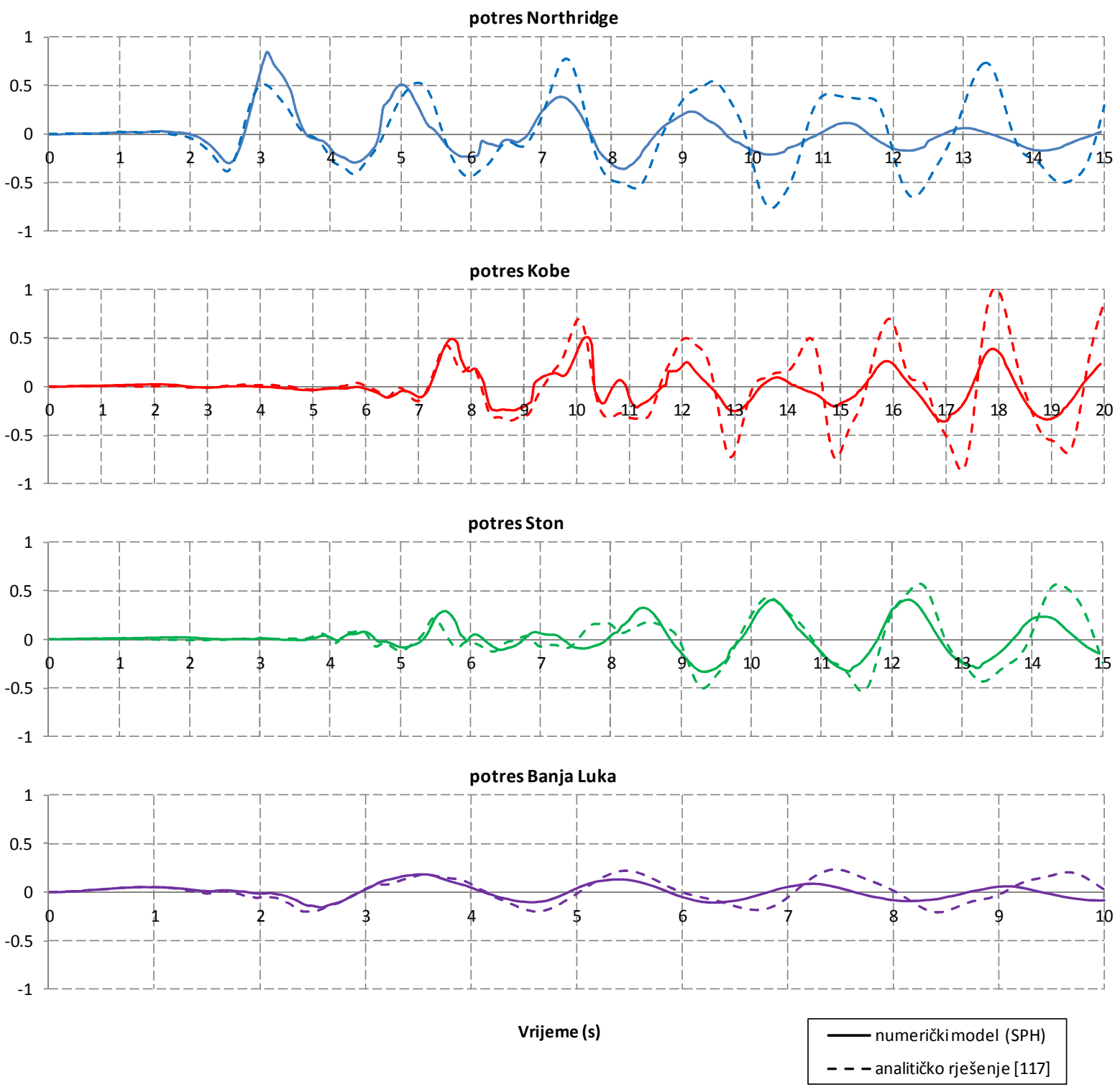

Slika 3.29. Pomaci slobodnog vodnog lica za kockasti rezervoar 

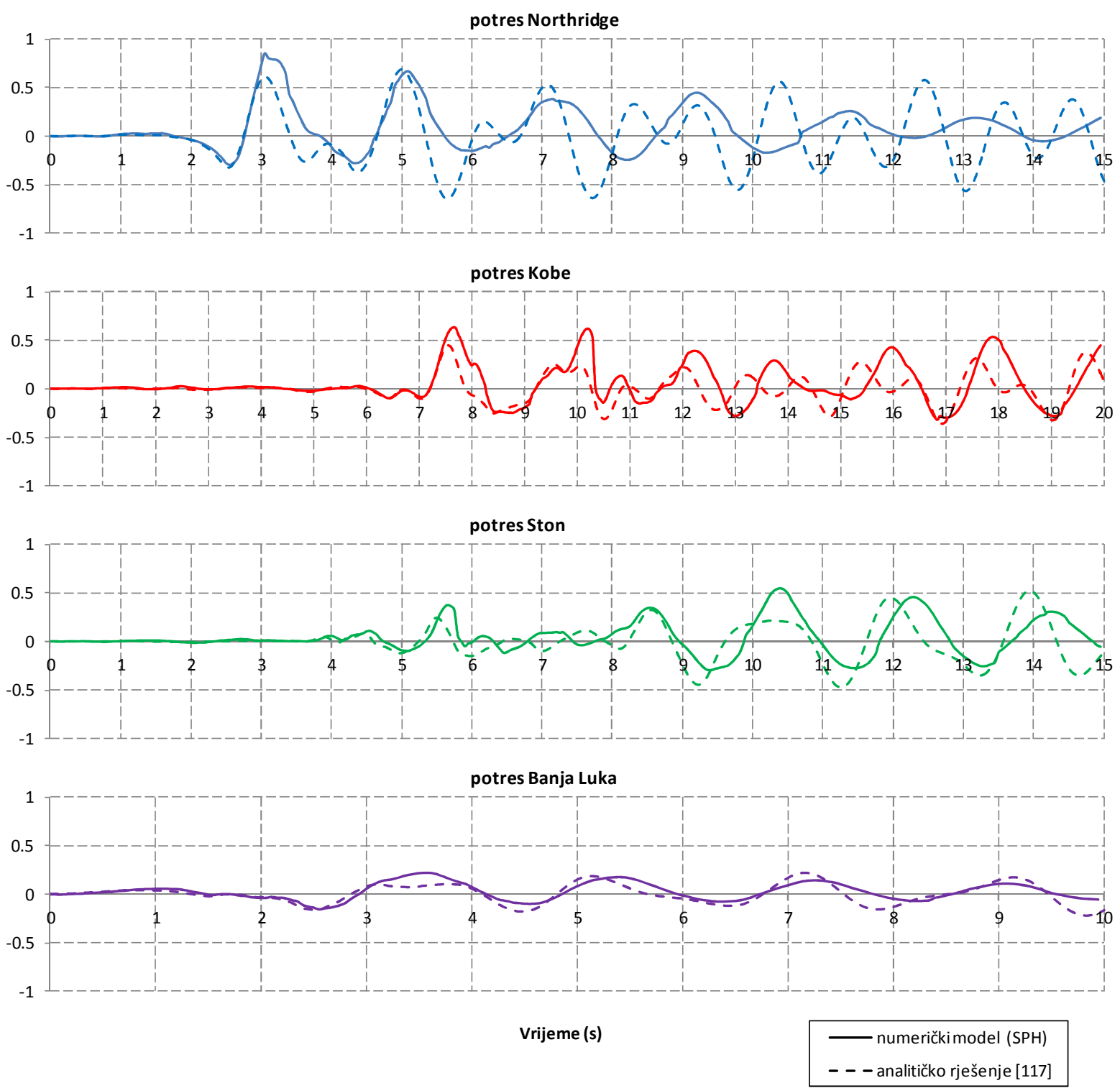

Slika 3.30. Pomaci slobodnog vodnog lica za valjkasti rezervoar

Vremenska promjena pomaka uslijed zapljuskivanja, promatrana na uspravnoj stranici $\mathrm{u} \mathrm{x}-\mathrm{Z}$ ravnini prikazana je na Slici 3.29 za kockasti rezervoar, a na Slici 3.30 za valjkasti rezervoar (ispunjenost rezervoara 67\%). Rezultati dobiveni numeričkim modelom temeljenim na SPH metodi su uspoređeni s Veletsos-ovim analitičkim rješenjem [117]. Sa Slike 3.29 i Slike 3.30 može se uočiti vrlo dobro podudaranje numeričkih i analitičkih rezultata sa stanovišta maksimalnih pomaka. Nešto lošije podudaranje u periodu osciliranja vode u rezervoaru posebno je izraženo s povećanjem vremena izloženosti pobude. Takva odstupanja su logična jer analitičko rješenje vrijedi za nestišljivo, neviskozano i bezvrtložno tečenje.

Osim vizualne usporedbe numeričkih i analitičkih rezultata na Slikama 3.29 i 3.35, odstupanja između numeričkih i analitičkih rješenja procijenjena su pomoću Pearsonovih koeficijenata korelacije prikazanih u Tablici 3.1. 
Tablica 3.1. Koeficijenti korelacije između numeričkih i analitičkih rezultata

\begin{tabular}{lcc}
\hline & Kockasti rezervoar & Valjkasti rezervoar \\
\hline Northridge & 0.7517 & 0.3919 \\
\hline Kobe & 0.8232 & 0.5674 \\
\hline Ston & 0.8118 & 0.6144 \\
\hline Banja Luka & 0.8199 & 0.6577 \\
\hline
\end{tabular}

Može se zaključiti da je bolja korelacija između numeričkih i analitičkih rezultata za kockasti rezervoar, nego za valjkasti. Najniži koeficijent korelacije dobiven je za pomake uzrokovane potresom Northridge. On uzrokuje izrazito nelinearno ponašanje tekućine, koje nije obuhvaćeno analitičkim rješenjem. Stoga je nizak koeficijent korelacije očekivan.

Kada je frekvencija pobude bliska osnovnoj rezonantnoj frekvenciji tekućine $\mathrm{u}$ rezervoaru, javljaju se velike amplitude zapljuskivanja, odnosno značajni pomaci slobodnog vodnog lica. Za usvojenu geometriju i određenu razinu punjenja rezervoara, frekvencije slobodnih osciliranja tekućine mogu se izračunati prema linearnoj teoriji $[118,119]$. Za prizmatični rezervoar, slobodna frekvencija osciliranja izračunava se prema:

$$
\omega_{\mathrm{n}}^{2}=\mathrm{g} \frac{\mathrm{n} \pi}{\mathrm{L}} \tanh \left(\frac{\mathrm{n} \pi}{\mathrm{L}} \mathrm{D}\right)
$$

gdje je $g$ gravitacijska konstanta, $L$ je duljina rezervoara, $D$ je dubina vode u rezervoaru, a $n$ je broj moda osciliranja. Prema gornjem izrazu postoji beskonačno mnogo slobodnih frekvencija osciliranja. Osnovni period slobodnih oscilacija vode u rezervoaru za različite razine punjenja su prikazani u Tablici 3.2.

Tablica 3.2. Osnovni periodi osciliranja vode za različite razine punjenja

Osnovni period osciliranja vode u rezervoaru [s]

\begin{tabular}{ccc}
\hline Razina punjenja [\%] & Kockasti rezervoar & Valjkasti rezervoar \\
\hline \hline 33 & 2.218 & 2.205 \\
\hline 67 & 1.997 & 1.981 \\
\hline 85 & 1.978 & 1.961 \\
\hline 95 & 1.974 & 1.957 \\
\hline
\end{tabular}

Osnovni period slobodnih oscilacija vode za ispunjenost rezervoara $67 \%$ iznosi približno 2 s [120,121]. Prema dijagramu spektralnih pomaka i ubrzanja prikazanih na Slici 3.28, spektralni pomaci i ubrzanje pri $\mathrm{T}=\mathrm{T}_{1}=2.0 \mathrm{~s}$ su najveći u slučaju potresa Northridge. 
Stoga je za očekivati da taj potres uzrokuje najveće pomake vode u rezervoaru i da je općenito najnepovoljniji. Takva očekivanja su i potvrđena na Slikama 3.29. i 3.30.

Vizualizacija zapljuskivanja vode u kockastom rezervoaru tijekom djelovanja potresa Northridge prikazana je na Slici 3.31.

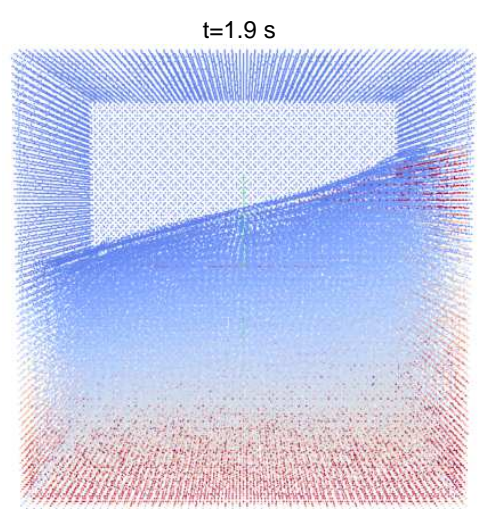

$t=3.0 s$

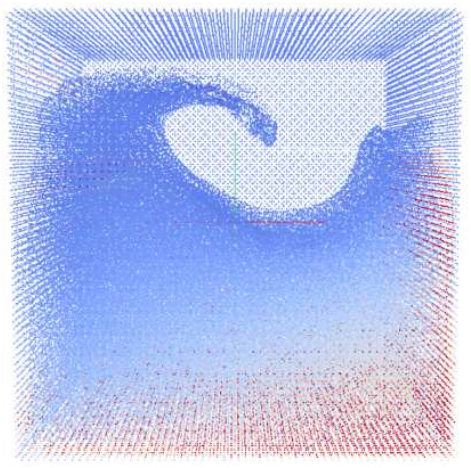

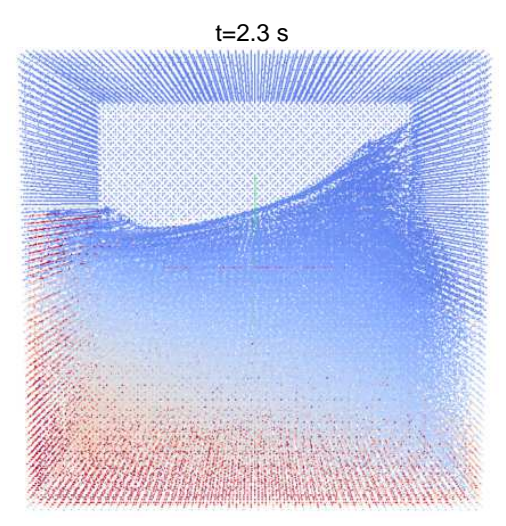

$\mathrm{t}=3.5 \mathrm{~s}$

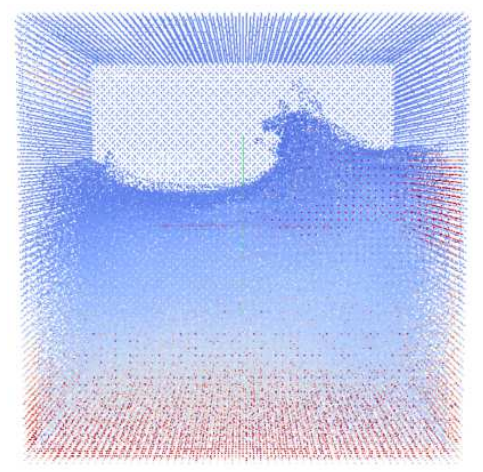

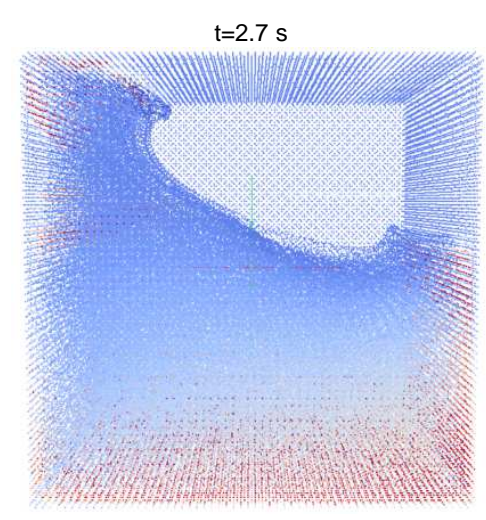

$t=4.2 \mathrm{~s}$

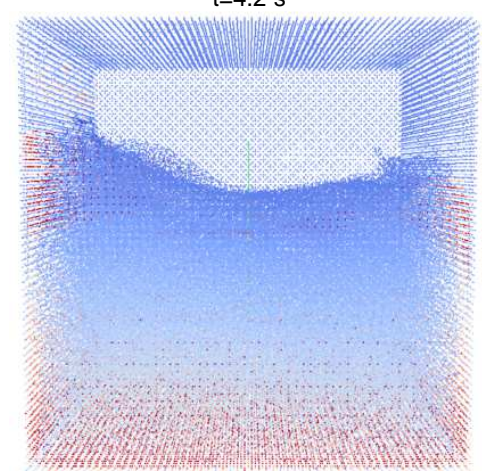

Slika 3.31. Zapljuskivanje vode u kockastom rezervoaru ispunjenog $67 \%$ za potres

\section{Northridge}

Udarna sila u vremenu na gornju (pokrovnu) stranicu rezervoara napunjenog 95\% prikazana je na Slici 3.32 za kockasti rezervoar, a na Slici 3.33 za valjkasti rezervoar.

Udarna sila na gornju stranicu rezervoara je posljedica zapljuskivanja vode $\mathrm{u}$ rezervoaru. Ona dominantno ovisi o vrijednosti spektralnog pomaka za usvojene pobude pri osnovnom periodu slobodnih oscilacija vode u rezervoaru. Osnovni period slobodnih oscilacija iznosi oko $1.98 \mathrm{~s}$ za rezervoar napunjen 95\%. Za taj period, najveći spektralni pomak ima potres Northridge, nešto manji spektralni pomak imaju potresi Kobe i Ston, dok potres Banja Luka ima najmanji spektralni pomak (Slika 3.28). Sukladno tome, najveća udarna sila na gornju stranicu rezervoara se javlja u slučaju potresa Northridge i iznosi oko $250 \mathrm{kN}$, što gotovo dostiže težinu vode u rezervoaru. Nešto manja udarna sila se javlja za potres Kobe i Ston, a najmanja u slučaju potresa Banja Luka. Nešto veće udarne sile se javljaju za valjkasti rezervoar, u odnosu na kockasti rezervoar. 

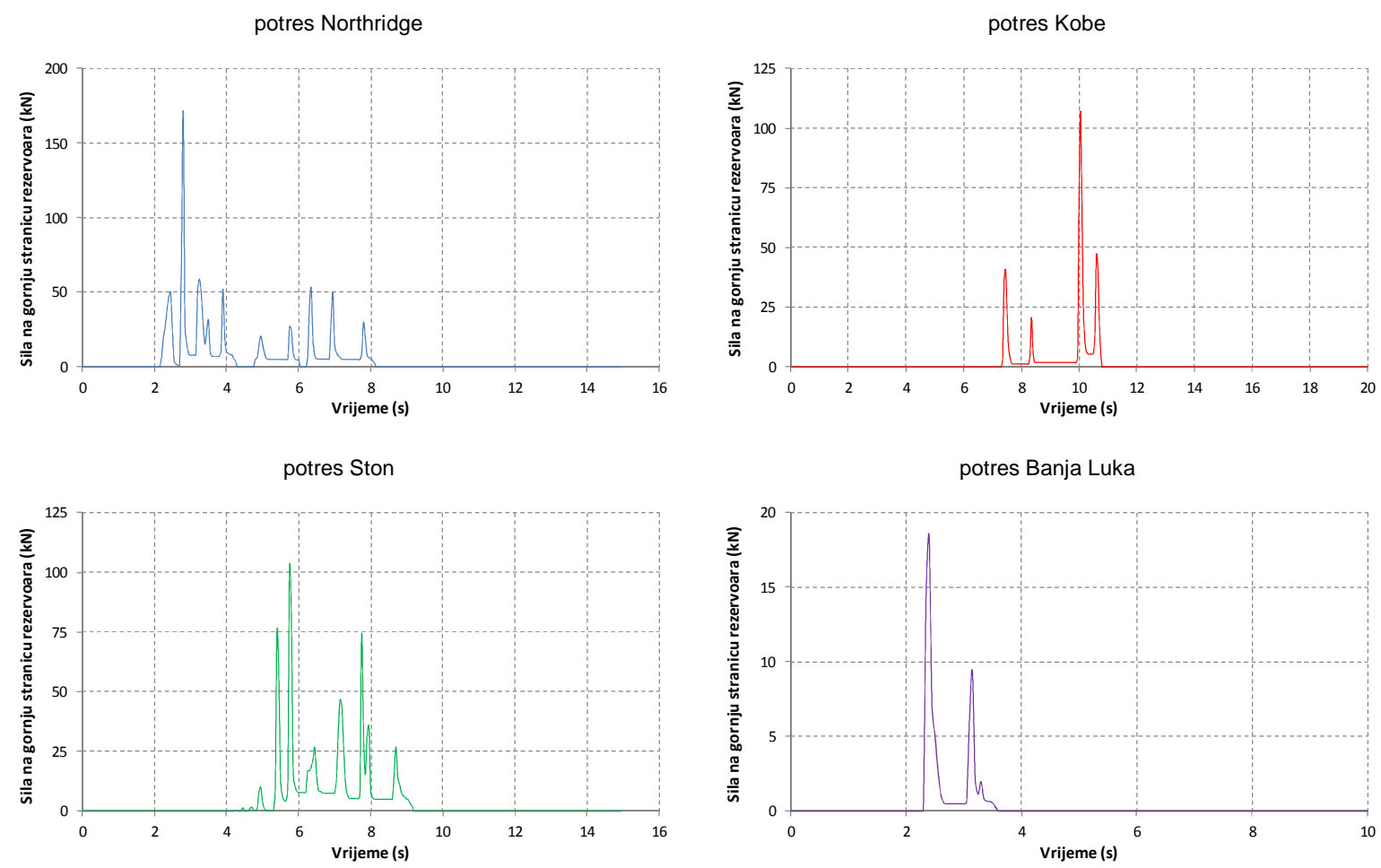

Slika 3.32. Udarna sila na gornju stranicu kockastog rezervoara
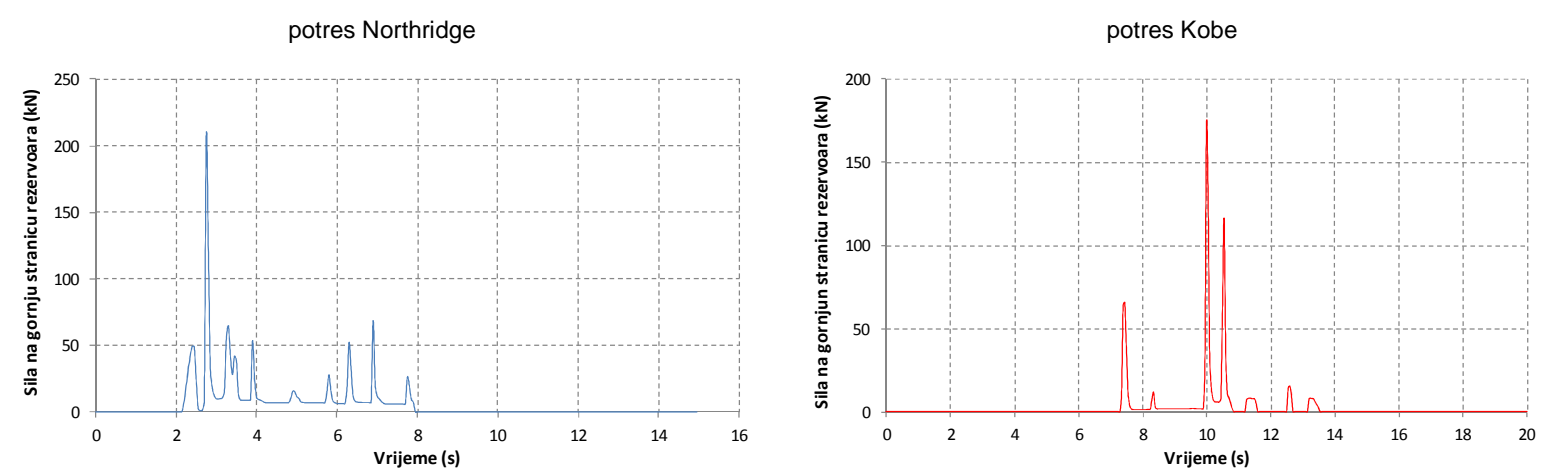

potres Ston
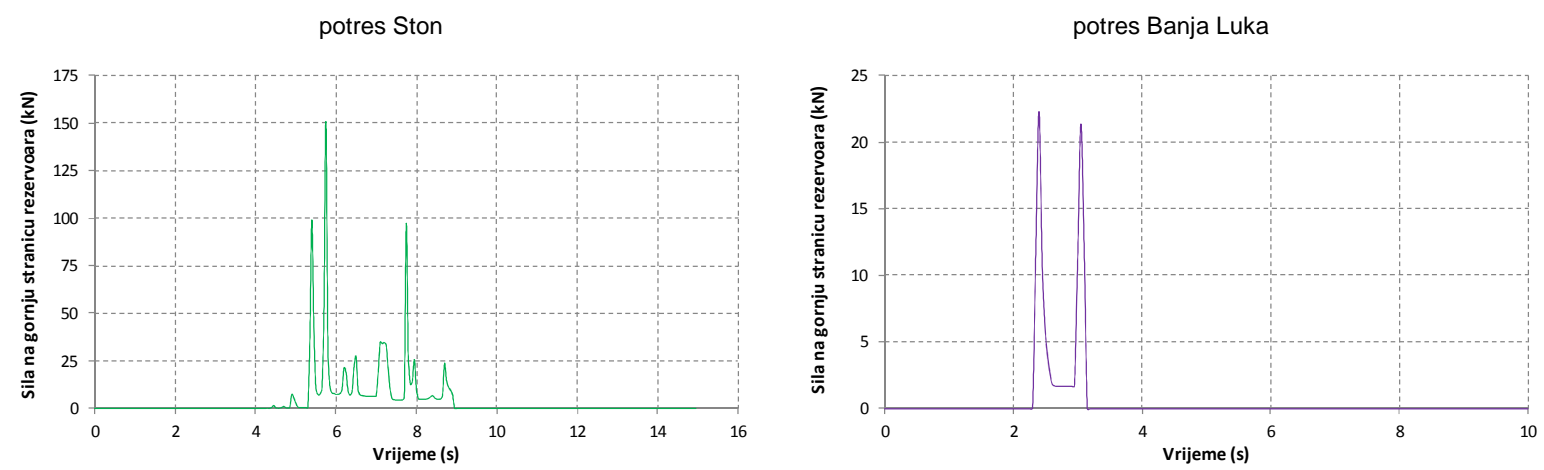

Slika 3.33. Udarna sila na gornju stranicu valjkastog rezervoara

Raspodjele ukupnih tlakova $\mathrm{u} \mathrm{x}-\mathrm{z}$ ravnini na stranice rezervoara u slučaju potresa Northridge su prikazane na Slici 3.34 za kockasti rezervoar, a na Slici 3.35 za valjkasti rezervoar. Hidrodinamički tlakovi koji se javljaju prilikom zapljuskivanja vode u rezervoaru 
tijekom djelovanja pobude se mogu podijeliti na dvije komponente: impulsnu i ne-impulsnu [122]. Ne-impulsna komponenta tlaka je ekvivalentna hidrodinamičkom tlaku tekućine koja oscilira u rezervoaru. Raspodjela ukupnih tlakova (hidrostatički + ne-impulsna komponenta hidrodinamičkog tlaka) ima oblik sličan raspodjeli hidrostatičkog tlaka, pogotovo u slučaju kada ne-impulsna komponenta nije dominantna kao na Slikama 3.34 i 3.35 u vremenima $\mathrm{t}=2.3 \mathrm{~s}$ i $\mathrm{t}=3.0 \mathrm{~s}$.

Impulsna komponenta tlaka je posljedica tlačnog impulsa između tekućine i stranica rezervoara i povezana je s hidrauličkim skokovima. Ta komponenta je izrazito lokalizirana $i$ karakteriziraju je ekstremno velike vrijednosti tlakova. Značajni impulsni tlakovi se mogu uočiti na Slikama 3.34 i 3.35 , osobito za t=2.7 s.
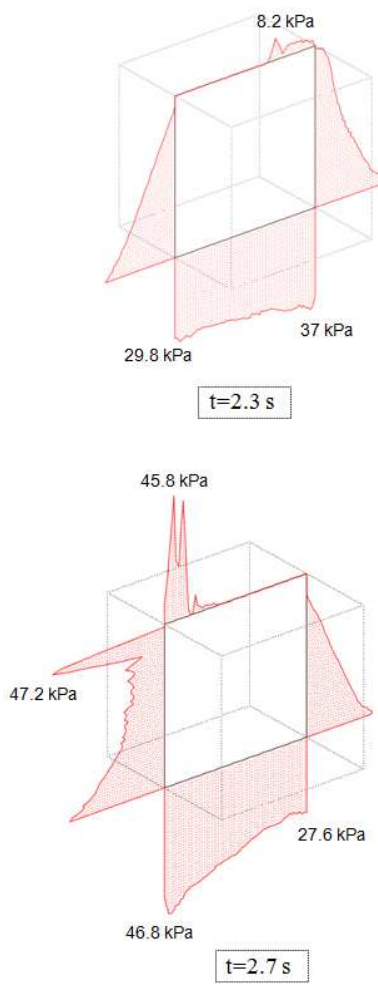
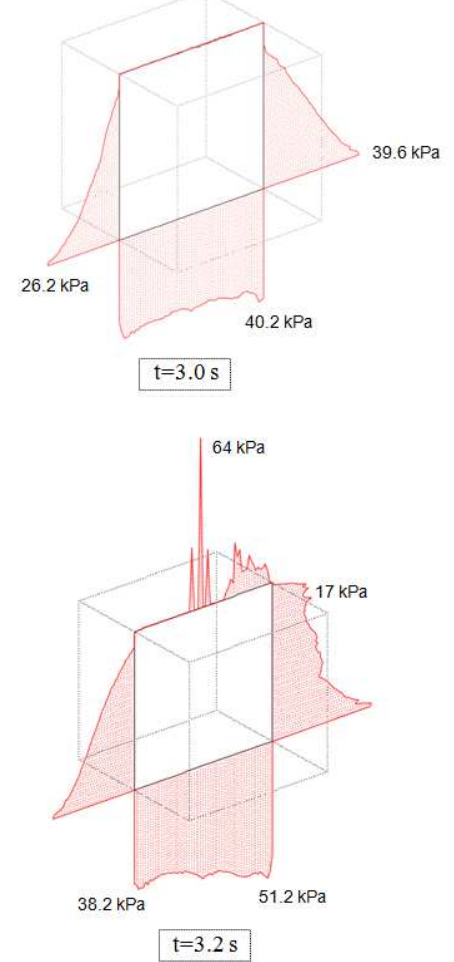
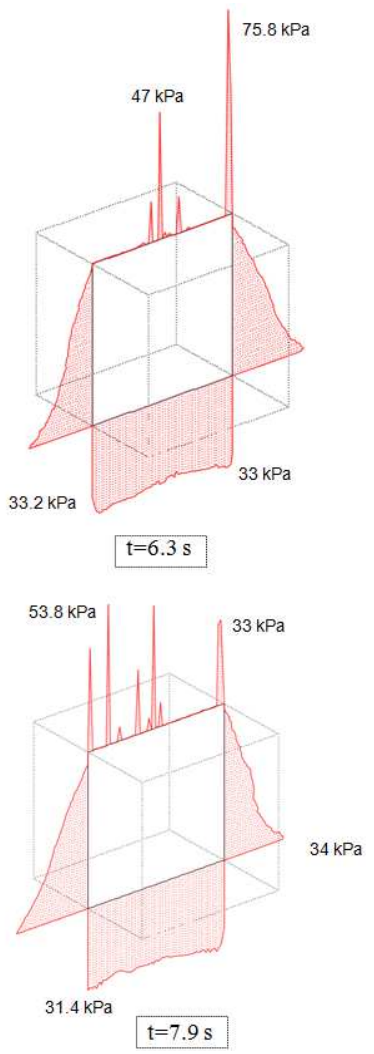

Slika 3.34. Raspodjela tlakova na stranice kockastog rezervoara za potres Northridge 

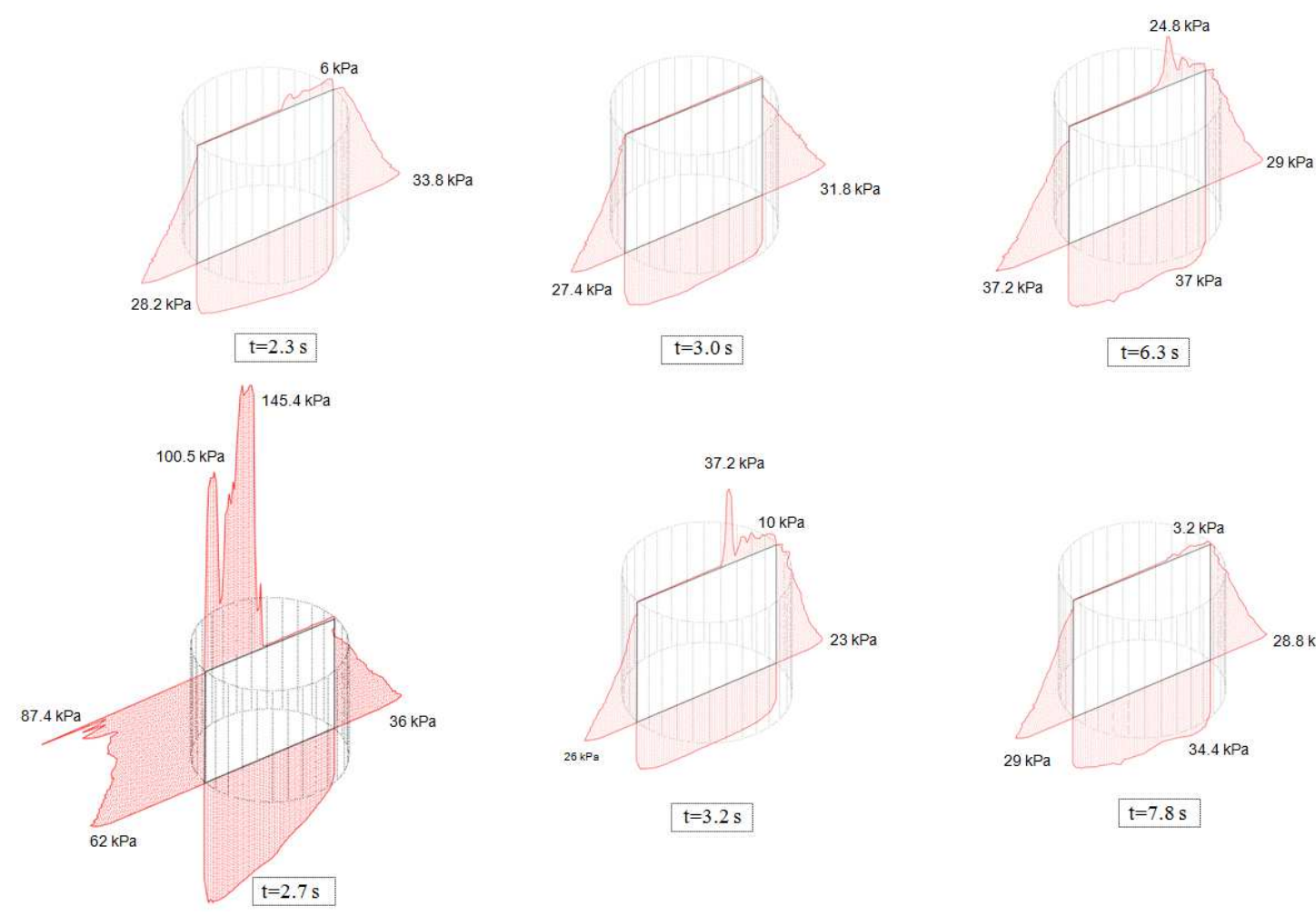

Slika 3.35. Raspodjela tlakova na stranice valjkastog rezervoara za potres Northridge 


\section{4}

\section{NUMERIČKI MODEL ZA MEĐUDJELOVANJE KONSTRUKCIJE I TEKUĆINE}

\subsection{Općenito}

Problem međudjelovanja konstrukcije i tekućine podrazumijeva deformabilnu konstrukciju u doticaju s tekućinom u gibanju. Takvi problemi postoje u brojnim područjima znanosti i industrije. Stoga ne čudi da je taj problem predmet interesa brojnih istraživača. Za većinu problema međudjelovanja konstrukcije i tekućine analitička rješenja ne postoje, a eksperimentalna istraživanja pojedinih problema su često složena i skupa. Stoga se najveći broj istraživanja međudjelovanja konstrukcije i tekućine temelji na numeričkim modelima.

Modeliranje međudjelovanja konstrukcije i tekućine je složen problem zbog svoje multidisciplinarnosti: uključuje probleme mehanike krutih tijela i mehanike fluida. $S$ razvojem računalne tehnologije, simulacija različitih problema međudjelovanja postala je sve sofisticiranija i složenija [123].

Rješavanje problema međudjelovanja konstrukcije i tekućine se može izvršiti na dva načina (Slika 4.1): monolitnim pristupom (eng. monolithic approach) i pristupom sa zasebnim rješenjima (eng. partitioned approach) [123]. 


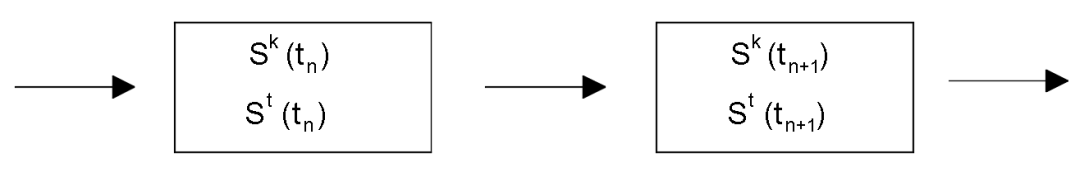

(a) monolitni pristup

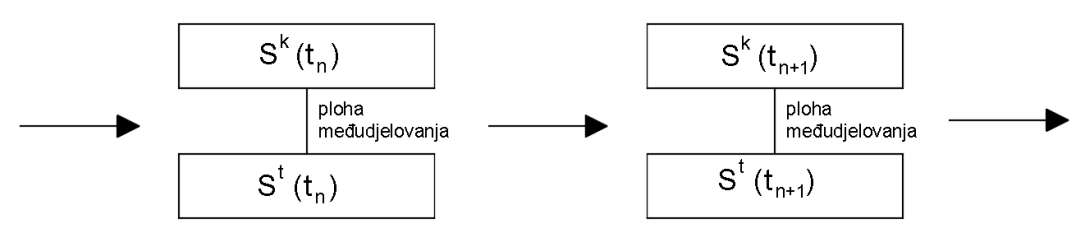

(b) pristup sa zasebnim rješenjima

Slika 4.1. Shematski prikaz pristupa rješavanju problema međudjelovanja, pri čemu $S^{k}$ i $S^{t}$ označavaju rješenje konstrukcije i rješenje tekućine

Kod monolitnog pristupa [124,125], gibanje konstrukcije i tekućine se opisuje u okviru jedinstvenog matematičkog modela. Dakle, formira se jedinstveni sustav jednadžbi koji opisuje ponašanje cjelokupnog problema i koji se rješava istovremeno jedinstvenim algoritmom. Ovim pristupom se postiže veća točnost rješenja. Međutim, ovaj pristup zahtijeva veće računalne resurse i stručnost istraživača za razvoj i održavanje takvih specijaliziranih kodova. Kod pristupa sa zasebnim rješenjima, jednadžbe kojima se opisuje ponašanje konstrukcije i tekućine rješavaju se odvojeno, izmjenjujući informacije na plohi međudjelovanja.

U ovom radu se koristi pristup sa zasebnim rješenjima, kojemu je prednost mogućnost korištenja prethodno razvijenih numeričkih modela za pojedinačna polja. U okviru ovoga rada, model za konstrukciju temeljen na metodi konačnih elemenata (Poglavlje 2) i model za tekućinu temeljen na metodi hidrodinamike izglađenih čestica (Poglavlje 3) povezan je u jedan jedinstveni model za simulaciju ponašanja međudjelovanja konstrukcije i tekućine u uvjetima dinamičkog opterećenja. 


\subsection{Pristup sa zasebnim rješenjima}

Pri rješavanju problema međudjelovanja konstrukcije i tekućine pomoću pristupa sa zasebnim rješenjima, konstrukcija i tekućina se rješavaju odvojeno. Stoga je moguće koristiti različite diskretizacije i algoritme, posebno razvijene za rješavanje pojedinog polja. Uvjeti kompatibilnosti brzina i sila na plohi međudjelovanja nisu implicitno uzeti u obzir kao kod monolitnog pristupa. Uvjeti kompatibilnosti brzina i sila između konstrukcije i tekućine koji moraju biti zadovoljeni na plohi međudjelovanja dani su sa:

$$
v_{k}=v_{t}, f_{k t}=f_{t k}
$$

gdje je $v_{k}$ brzina konstrukcije na plohi međudjelovanja, $v_{t}$ brzina tekućine na plohi međudjelovanja, $f_{k t}$ sila kojom konstrukcija djeluje na tekućinu i $f_{t k}$ sila kojom tekućina djeluje na konstrukciju.

U ovom pristupu uvjeti kompatibilnosti sadržani su unutar rubnih uvjeta na plohi međudjelovanja i zadovoljavaju se asinkrono. Općenito, u okviru pristupa sa zasebnim rješenjima algoritmi mogu biti (po)vezani na dva načina: labavo (eng. loosely/weakly coupled) ili potpuno (eng. fully/strongly coupled) [126].

\subsubsection{Potpuno povezani algoritmi}

Kod ovoga načina povezivanja, konstrukcija i tekućina se rješavaju odvojeno u svakom vremenskom koraku, uz iterativni postupak rješenja na plohi međudjelovanja između dva vremenska koraka $t_{n}$ i $t_{n+1}$ (Slika 4.2) [127].

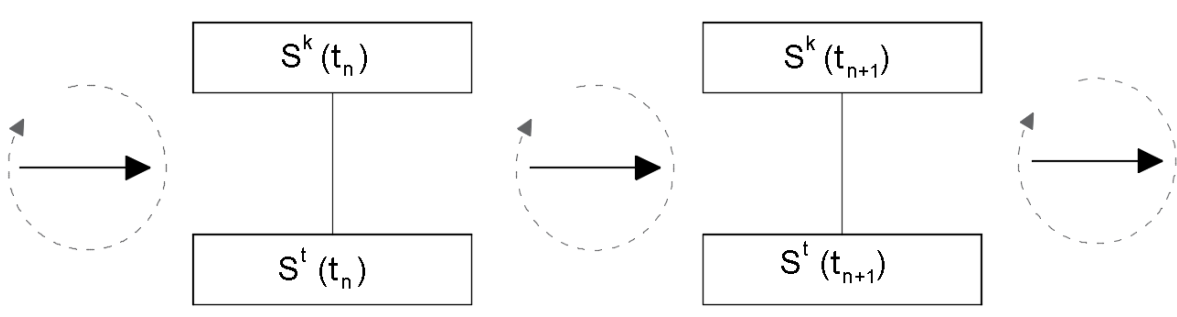

Slika 4.2. Potpuno povezani algoritmi

Obzirom da postoji iterativni postupak rješenja na plohi međudjelovanja, problemi stabilnosti numeričkog postupka su manje izraženi nego kod labavo povezanih algoritama.

\subsubsection{Labavo povezani algoritmi}

Kod ovoga načina povezivanja, konstrukcija i tekućina se rješavaju odvojeno i jednom u svakom vremenskom koraku $t_{n}$ (Slika 4.3). Dakle, konvergencija rješenja na plohi međudjelovanja ovim pristupom se ne uzima u obzir, čime se uvodi greška pri povezivanja u 
problemu međudjelovanja. Ukoliko se radi o problemima međudjelovanja kod kojih se javljaju male deformacije konstrukcije, ova greška je zanemariva.

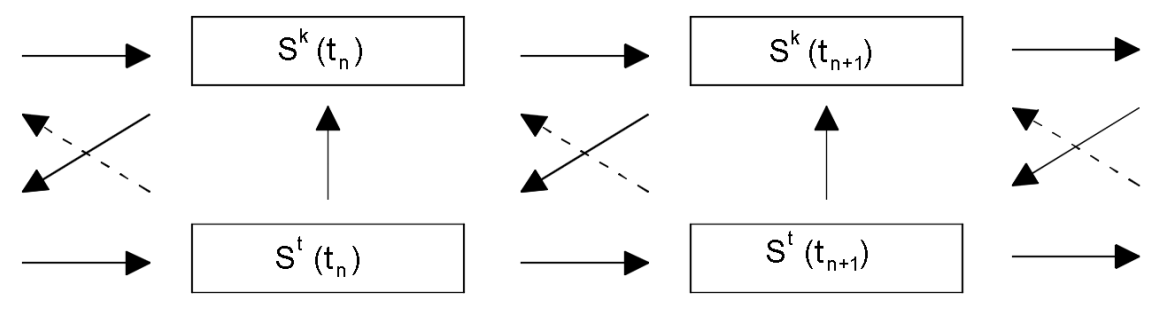

Slika 4.3. Labavo povezani algoritmi

U odnosu na smjer izmjene informacija među algoritmima na plohi međudjelovanja, razlikujemo jednosmjerno ili dvosmjerno povezane algoritme. Dvosmjerno povezani algoritmi su oni kod kojih se na plohi međudjelovanja izmjenjuju informacije o tlakovima kojima tekućina djeluje na konstrukciju, ali i o pomacima konstrukcije koji mijenjaju strujanje tekućine.

\subsection{Rješenje problema međudjelovanja}

Međudjelovanje konstrukcije i tekućine u uvjetima dinamičkog opterećenja očituje se na način da gibanje tekućine uzrokuje sile na konstrukciju, koja se uslijed njih deformira.

Deformiranjem konstrukcije dolazi do promjene računalne domene tekućine, odnosno do promjene u gibanju tekućine. Time se mijenjaju i sile na konstrukciju u odnosu na prvotno stanje, što stvara jedan ponavljajući uzročno-posljedični proces (Slika 4.4).
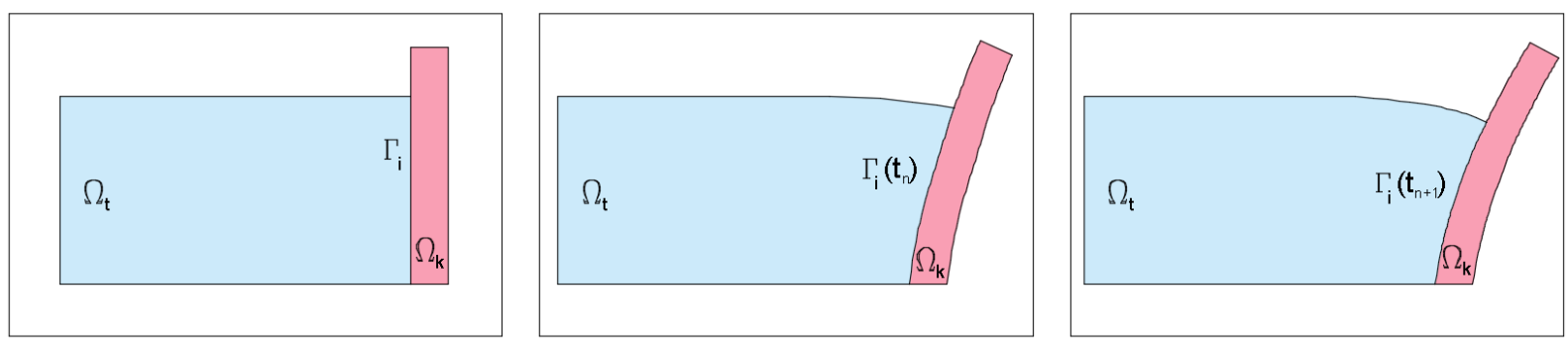

Slika 4.4. Međudjelovanje konstrukcije i tekućine

Sile kojima tekućina djeluje na konstrukciju izračunavaju se za svaki čvor konstrukcije prema izrazu:

$$
f_{t k}=-Q P
$$

gdje je $P$ tlak tekućine, a $\boldsymbol{Q}$ matrica međudjelovanja koja definira plohu međudjelovanja i uključuje integraciju na plohi međudjelovanja $\Gamma_{i}$ : 


$$
\boldsymbol{Q}=\int_{\Gamma_{\mathrm{i}}} \boldsymbol{N}^{T} \vec{n} \boldsymbol{N} d \Gamma_{\mathrm{i}}
$$

pri čemu su $\boldsymbol{N}$ bazne funkcije, a $\vec{n}$ je vanjska normala na konstrukciju (ljusku) na plohi međudjelovanja i definirana je vektorskim produktom:

$$
\vec{n}=\overrightarrow{e_{1}} \times \overrightarrow{e_{2}}=\left[\begin{array}{lll}
\overrightarrow{e_{1}^{0}} & \overrightarrow{e_{2}^{0}} & \overrightarrow{e_{3}^{0}} \\
\frac{\partial X}{\partial \xi} & \frac{\partial Y}{\partial \xi} & \frac{\partial Z}{\partial \xi} \\
\frac{\partial X}{\partial \eta} & \frac{\partial Y}{\partial \eta} & \frac{\partial Z}{\partial \eta}
\end{array}\right]=n_{x} \overrightarrow{e_{1}^{0}}+n_{y} \overrightarrow{e_{2}^{0}}+n_{z} \overrightarrow{e_{3}^{0}}
$$

gdje su $\overrightarrow{e_{1}^{0}}, \overrightarrow{e_{1}^{0}}, \overrightarrow{e_{1}^{0}}$ jedinični vektori u smjeru osi krivolinijskog koordinatnog sustava (Slika 4.5)

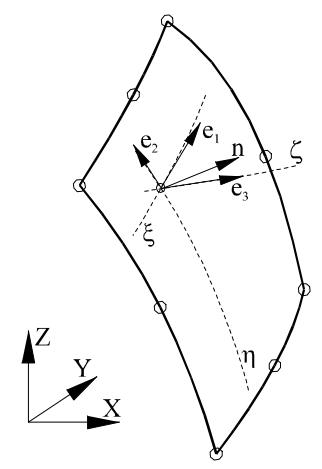

Slika 4.5. Normala na konstrukciju na plohi međudjelovanja

Sile $f_{t k}$ su posljedica tlakova $P$ u tekućini i izračunavaju se na temelju vrijednosti tlakova u česticama tekućine koje se nalaze u neposrednoj blizini plohe međudjelovanja. Odnosno, izračunavaju se na temelju vrijednosti tlakova u česticama tekućine koje se nalaze unutar prostorne udaljenosti $2 h$ od promatranog čvora konstrukcije (Slika 4.6). U ovome radu tlakovi tih čestica tekućine uprosječuju se pomoću izraza (3.108).

Uprosječivanjem tlakova tekućine postiže se znatno bolje približenje tlakova analitičkim vrijednostima, što je vrlo važno pri određivanju sila kojima tekućina djeluje na konstrukciju, a što je prikazano u Primjeru 1 (Poglavlje 3).

Čvorne sile $f_{t k}$, izračunate prema izrazu (4.2), predstavljaju dio efektivnog vektora opterećenja na konstrukciju, čiji se nepoznati pomaci proračunavaju numeričkim modelom na temelju metode konačnih elemenata. 


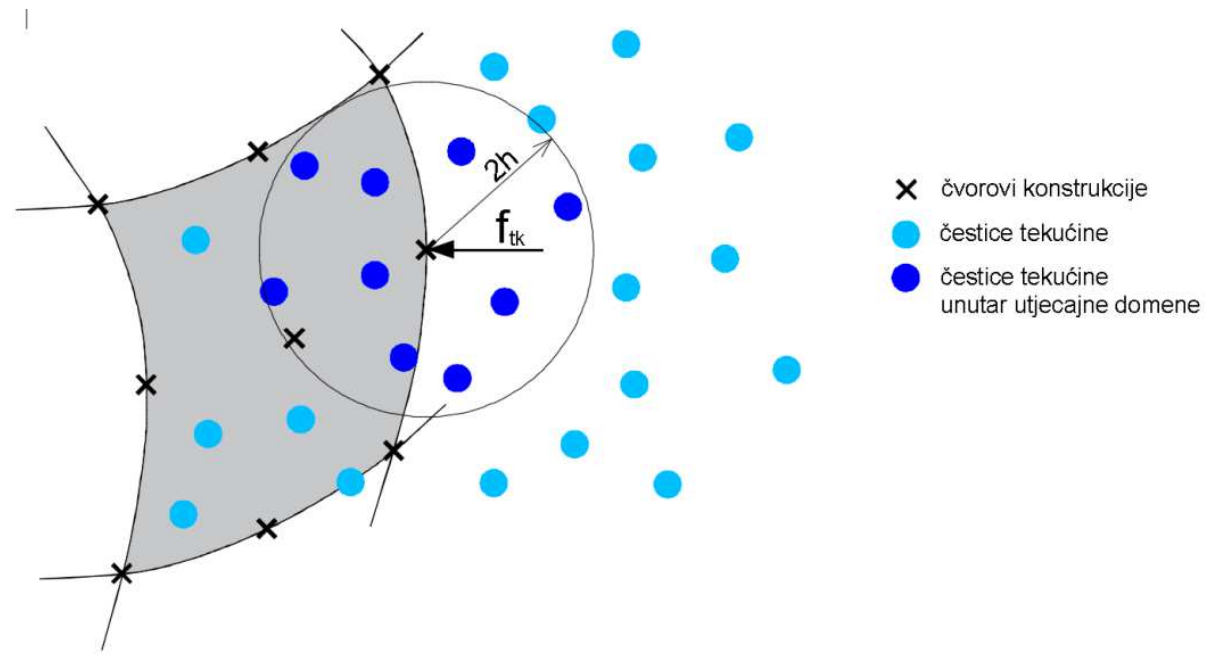

Slika 4.6. Sile tekućine na konstrukciju

Kako je već rečeno, rub domene tekućine simulira se nizom rubnih čestica, na način kako je prikazano u poglavlju 3.5. U ovome radu, na plohi međudjelovanja između konstrukcije i tekućine su postavljene tzv. virtualne čestice u više redova (dinamički rubni uvjeti). Pri tome, prvi red rubnih čestica poklapa se s gornjom (ili donjom) plohom ljuskaste konstrukcije (Slika 4.7).

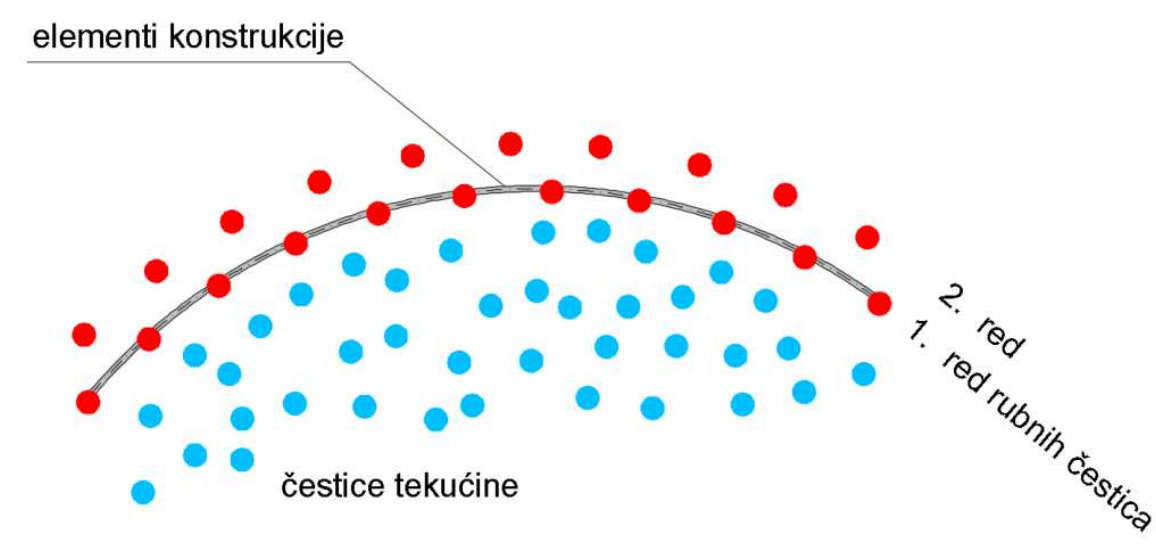

Slika 4.7. Virtualne čestice na plohi međudjelovanja

Nakon proračuna nepoznatih čvornih pomaka konstrukcije, virtualne rubne čestice na plohi međudjelovanja mijenjaju svoj položaj sukladno izračunatim pomacima konstrukcije. Ovakvim pristupom na plohi međudjelovanja između konstrukcije i tekućine u potpunosti je zadovoljen uvjet kompatibilnosti pomaka. 
Prepravljanjem koordinata virtualnih rubnih čestica na plohi međudjelovanja, mijenjaju se rubni uvjeti za tekućinu. Zatim slijedi analiza tekućine i proračun tlakova numeričkim modelom na temelju metode hidrodinamike izglađenih čestica. Ovaj postupak se ponavlja za svaki vremenski korak analize, do isteka ukupnog vremena proračuna. Shematski prikaz rješavanja problema međudjelovanja konstrukcije i tekućine u ovome modelu je prikazan u Tablici 4.1 .

Tablica 4.1. Shematski prikaz rješavanja problema međudjelovanja

\begin{tabular}{|c|c|c|}
\hline & & $\mathrm{U}$ svakom $\Delta \mathrm{t}$ vremenskom koraku \\
\hline \multirow{5}{*}{ 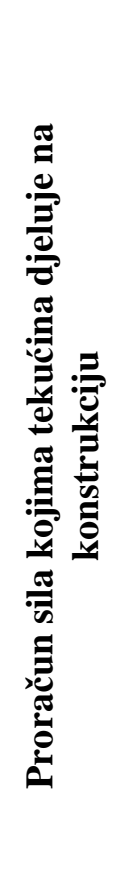 } & (1) & $\begin{array}{l}\text { Izračunati vrijednosti tlakova na kraju vremenskog koraka prema jednadžbi } \\
\text { stanja (3.46): } \\
\qquad \mathrm{P}_{\mathrm{n}+1}=\mathrm{f}\left(\mathrm{P}_{\mathrm{n}+1}\right)\end{array}$ \\
\hline & (2) & $\begin{array}{l}\text { Za svaki čvor konstrukcije } a \text { (koji je u kontaktu s tekućinom) pronaći čestice } \\
b_{i} \text { tekućine koje se nalaze unutar prostorne udaljenosti od } 2 h \text {. }\end{array}$ \\
\hline & (3) & $\begin{array}{l}\text { Korekcija tlakova čestica tekućine prema jednadžbi (3.108): } \\
\qquad P_{a}=\frac{\sum_{b} P\left(b_{i}\right) /\left(\overrightarrow{r_{b_{l}}}-\overrightarrow{r_{a}}\right)}{\sum_{b} 1 /\left(\overrightarrow{r_{b_{l}}}-\overrightarrow{r_{a}}\right)}\end{array}$ \\
\hline & (4) & $\begin{array}{l}\text { Definirati matricu međudjelovanja: } \\
\qquad \boldsymbol{Q}=\int_{\Gamma_{\mathrm{i}}} \boldsymbol{N}^{T} \vec{n} \boldsymbol{N} d \Gamma_{\mathrm{i}}\end{array}$ \\
\hline & (5) & $\begin{array}{l}\text { Izračunati čvorne sile na konstrukciju od tlaka (raspodijeljeno površinsko } \\
\text { opterećenje definirano u svakom čvoru konstrukcije): } \\
\qquad f_{t k}=-Q P\end{array}$ \\
\hline 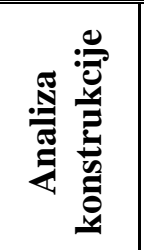 & (6) & $\begin{array}{l}\text { Izračunati vrijednosti pomaka čvorova konstrukcije } k \text { (Poglavlje 2, Tablica } \\
\text { 2.1) u } n+1 \text { vremenskom koraku: } \\
\qquad u_{n+1}^{k}=u_{n}^{k^{i+1}}\end{array}$ \\
\hline 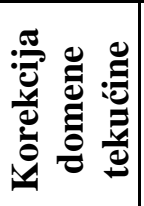 & (7) & $\begin{array}{l}\text { Položaj virtualnih rubnih čestica koje se nalaze na plohi međudjelovanja se } \\
\text { mijenja prema izračunatim pomacima konstrukcije. } \\
\qquad u_{n+1}^{v}=u_{n}^{v}+u_{n+1}^{k}\end{array}$ \\
\hline
\end{tabular}




\subsection{Primjer 1}

Pomoću prethodno prikazanog numeričkog modela za međudjelovanje konstrukcije i tekućine izvršena je analiza zapljuskivanja vode u rezervoarima s krutim i deformabilnim stranicama prema primjerima iz literature [128]. Njima se može opisati većina mogućnosti razvijenog numeričkog modela za međudjelovanje. Prvo je analizirano zapljuskivanje u rezervoaru s krutim stranicama, a zatim zapljuskivanje u rezervoaru s deformabilnim stranicama.

Rezervoari su izloženi harmonijskom ubrzanju podloge $a$, definiranim izrazom:

$$
a=a_{0} \sin \omega_{f} t
$$

gdje je $a_{0}$ amplituda pobude (u svim numeričkim testovima iznosi $0.05 \mathrm{~g}$ ), a $\omega_{f}$ je frekvencija pobude. U svim numeričkim testovima usvojena je početna gustoća vode $\rho_{0}=1000 \mathrm{~kg} / \mathrm{m}^{3} \mathrm{i}$ kinematička viskoznost laminarnog tečenja $v_{0}=10^{-6} \mathrm{~m}^{2} / \mathrm{s}$.

\subsubsection{Zapljuskivanje u rezervoaru s krutim stranicama}

Rezervoar je dimenzija $0.8 \mathrm{~m}$ x $0.5 \mathrm{~m}$ x $0.7 \mathrm{~m}$, s razinom vode u rezervoaru je $0.3 \mathrm{~m}$ (Slika 4.8), i izložen je harmonijskom ubrzanju podloge prema izrazu (4.6). Početni razmak čestica je $0.025 \mathrm{~m}$ i jednoliko su raspoređene (Slika 4.9). Ukupan broj čestica, uključujući i rubne čestice, je 15001.

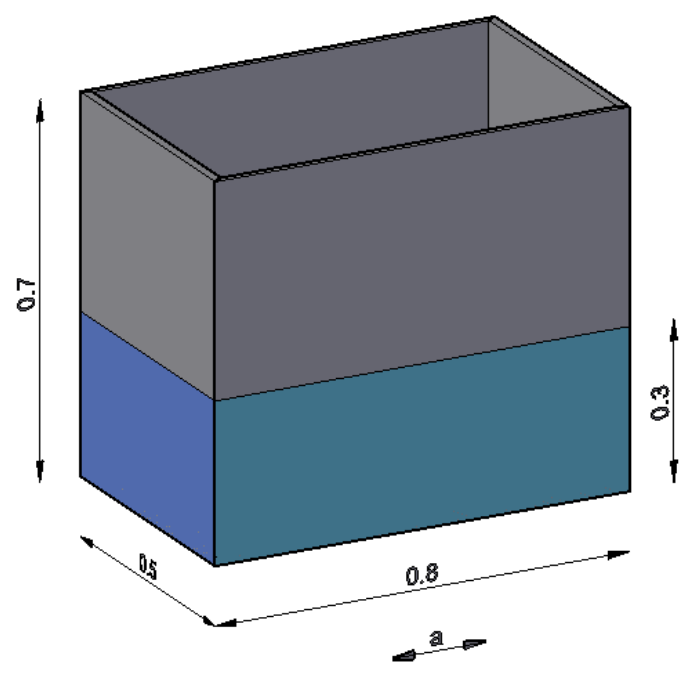

Slika 4.8. Geometrija rezervoara

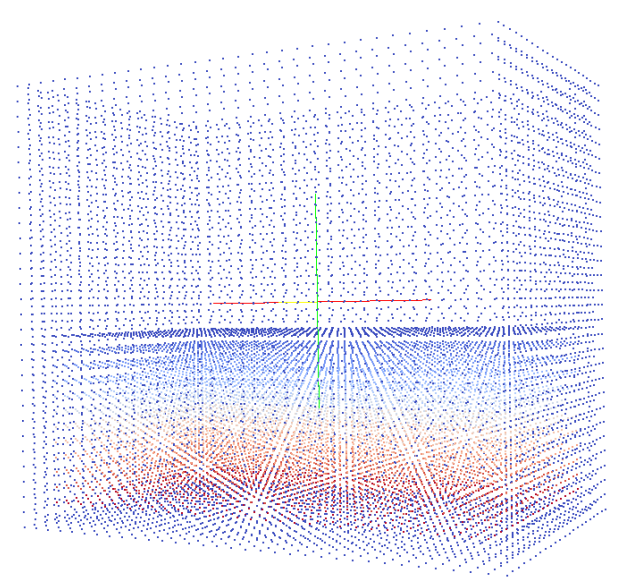

Slika 4.9. Početni razmještaj čestica

Teorijska prirodna frekvencija prvog moda osciliranja vode u ovome rezervoaru iznosi $\omega_{1}=0.89 \mathrm{~Hz}$ [118]. Pomoću prethodno prikazanog numeričkog modela, analizirano je ponašanje vode $u$ rezervoaru pri pobudi čija frekvencija odgovara prirodnoj frekvenciji rezervoara $\left(\omega_{f}=\omega_{1}\right)$, ali i pri pobudama čije su frekvencije bliske prirodnoj frekvenciji rezervoara (Slika 4.10). 
Na Slici $4.10 A_{\max }$ je najveće uzdizanje vode na desnoj stranici rezervoara u odnosu na početnu razinu vode, $w$ je duljina rezervoara $(0.8 \mathrm{~m})$. Rezultati analiza su uspoređeni $\mathrm{s}$ rezultatima $2 \mathrm{D}$ numeričkog modela i eksperimentalnim rezultatima dostupnim iz literature [128].

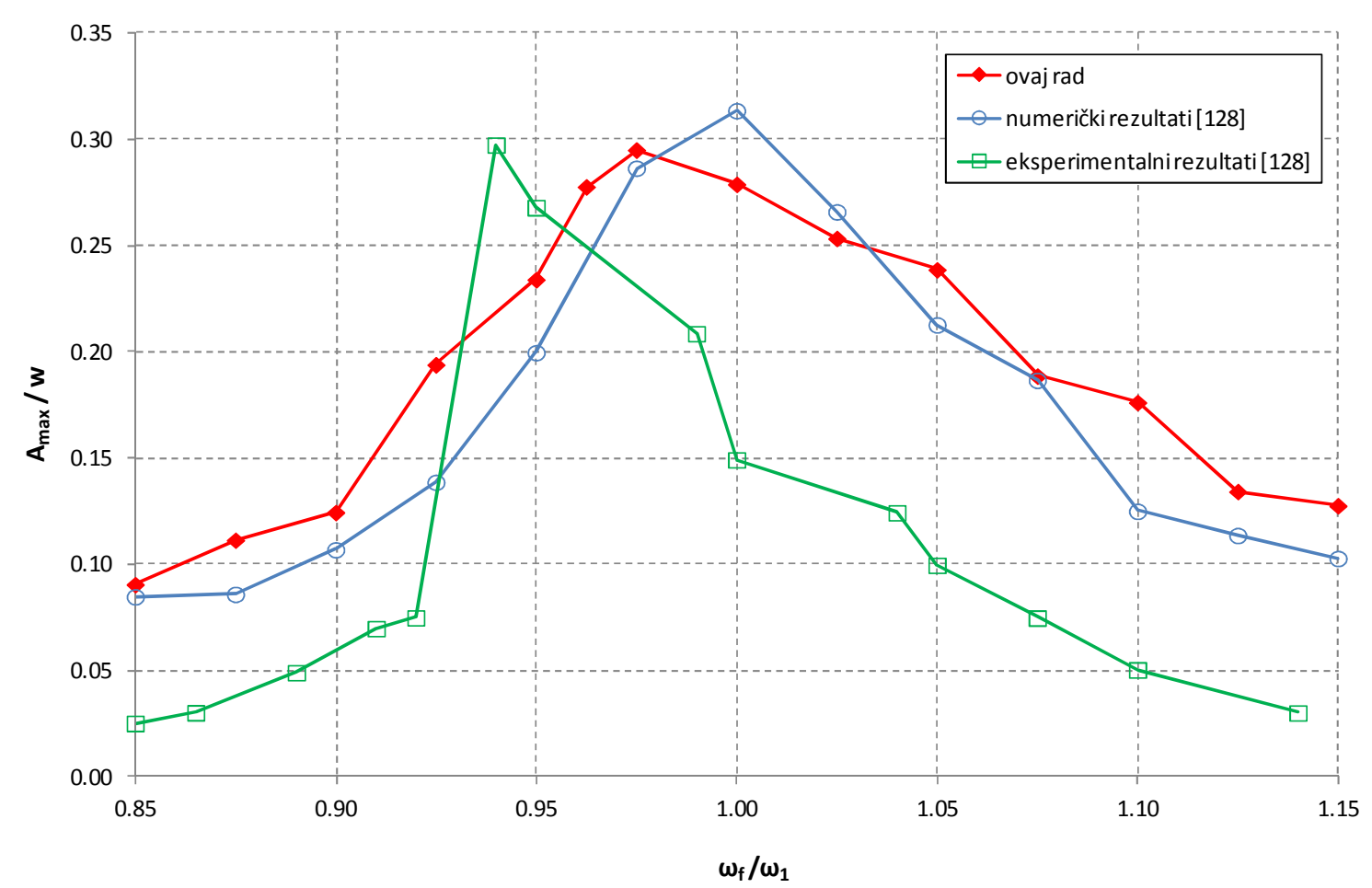

Slika 4.10. Rezonantni odgovor rezervoara s krutim stranicama

Iz Slike 4.10 je vidljivo da je vrijednost maksimalnog uzdizanje vode $A_{\max }=0.24 \mathrm{~m}$ i da se ta vrijednost poklapa s eksperimentalnim rezultatima iz [128]. Maksimalno uzdizanje vode u rezervoaru $A_{\max }$ je dobiveno za pobudu s frekvencijom nešto manjom od teorijski rezonantne frekvencije $\left(\omega_{f}=0.975 \omega_{1}\right)$. Dakle, slično eksperimentalnim rezultatima, rezonantna frekvencija za promatrani rezervoar je nešto manja od teorijske rezonantne frekvencije $\omega_{1}$.

Iz priloženih rezultata je vidljivo da se pomoću ovoga numeričkog modela može realno simulirati ponašanje vode $\mathrm{u}$ rezervoaru $\mathrm{s}$ krutim stranicama tijekom rezonantne pobude.

Na Slici 4.11 b je prikazan rezervoar u trenutku u kojemu je došlo do maksimalnog uzdizanja vode na desnoj stranici rezervoara, a na Slikama 4.11a i 4.11c neposredno prije i nakon tog trenutka. 


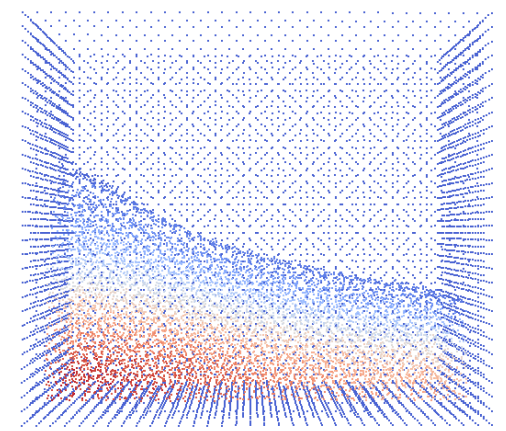

(a)

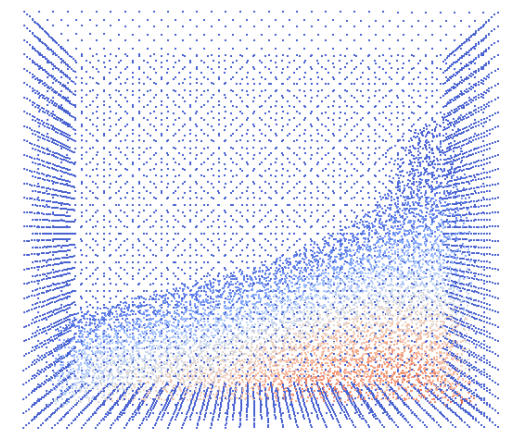

(b)

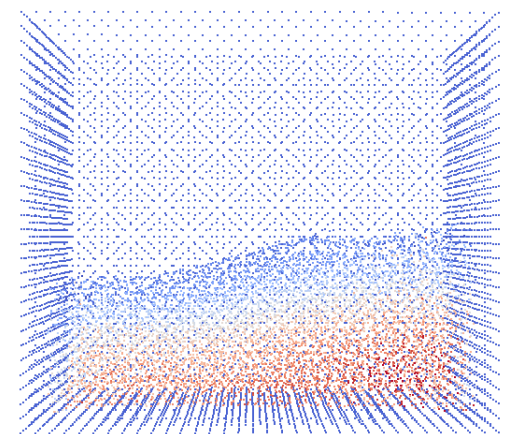

(c)

Slika 4.11. Maksimalno uzdizanje vode u rezervoaru za $\omega_{f}=0.975 \omega_{1}$

\subsubsection{Zapljuskivanje u rezervoaru s elastičnim stranicama}

Rezervoar je dimenzija $5.0 \mathrm{~m}$ x $5.0 \mathrm{~m}$ x $8.0 \mathrm{~m}$, s razinom vode u rezervoaru je $4.0 \mathrm{~m}$ (Slika 4.12). Izložen je harmonijskom ubrzanju podloge prema izrazu (4.6). Početni razmak čestica je $0.2 \mathrm{~m}$ i jednoliko su raspoređene (Slika 4.13). Ukupan broj čestica, uključujući i rubne čestice, je 18230.

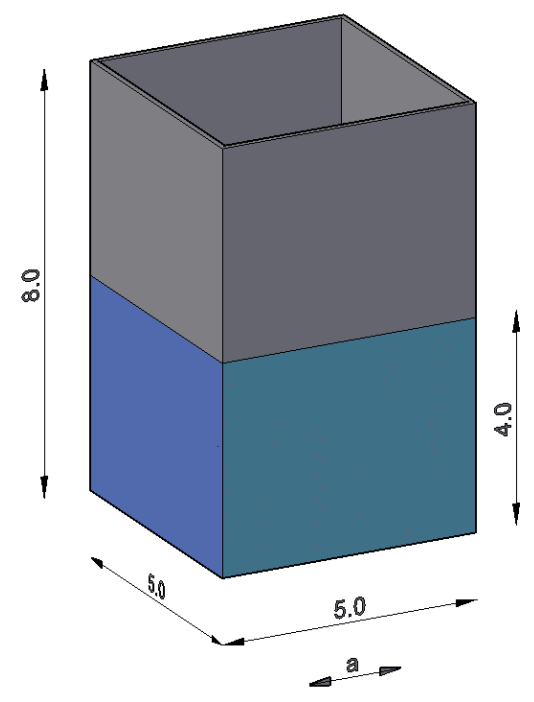

Slika 4.12. Geometrija rezervoara

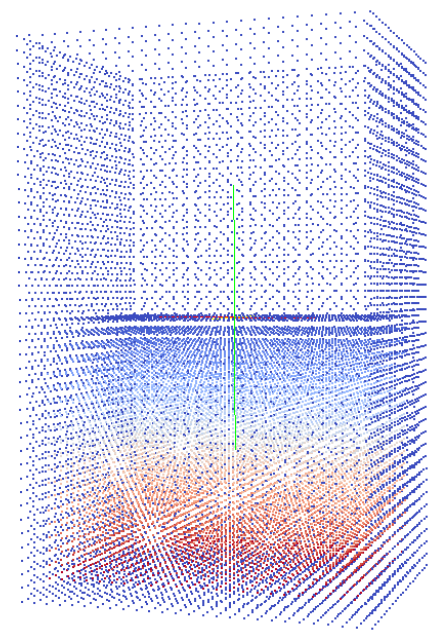

Slika 4.13. Početni razmještaj čestica

Teorijska prirodna frekvencija prvog moda osciliranja vode u rezervoaru iznosi $\omega_{1}=0.39 \mathrm{~Hz}$ [118]. Pomoću prethodno prikazanog numeričkog modela analizirano je ponašanje vode u rezervoaru pri pobudi čija frekvencija odgovara prirodnoj frekvenciji rezervoara $\left(\omega_{f}=\omega_{1}\right)$, ali i pri pobudama čije su frekvencije bliske prirodnoj frekvenciji rezervoara (Slika 4.14).

U prvom numeričkom testu usvojeno je da su sve stranice rezervoara krute. U drugom numeričkom testu je usvojeno je da su dvije nasuprotne stranice (koje su okomite na smjer djelovanja pobude) deformabilne ljuske, s materijalnim karakteristikama prikazanima u Tablici 4.2, dok su ostale stranice krute. 
Tablica 4.2. Materijalne karakteristike deformabilne stranice rezervoara

\begin{tabular}{|l|c|}
\hline Modul elastičnosti [GPa] & 5.0 \\
\hline Poissonov koeficijent & 0.3 \\
\hline Gustoća $\left[\mathrm{kg} / \mathrm{m}^{3}\right]$ & 7860 \\
\hline Debljina[m] & 0.11034 \\
\hline
\end{tabular}

Na Slici $4.14 A_{\max }$ je najveće uzdizanje vode na desnoj stranici rezervoara u odnosu na početnu razinu vode u rezervoaru, a $w$ je duljina rezervoara $(5.0 \mathrm{~m})$. Rezultati analiza su uspoređeni s numeričkim rezultatima dostupnim iz literature [128].

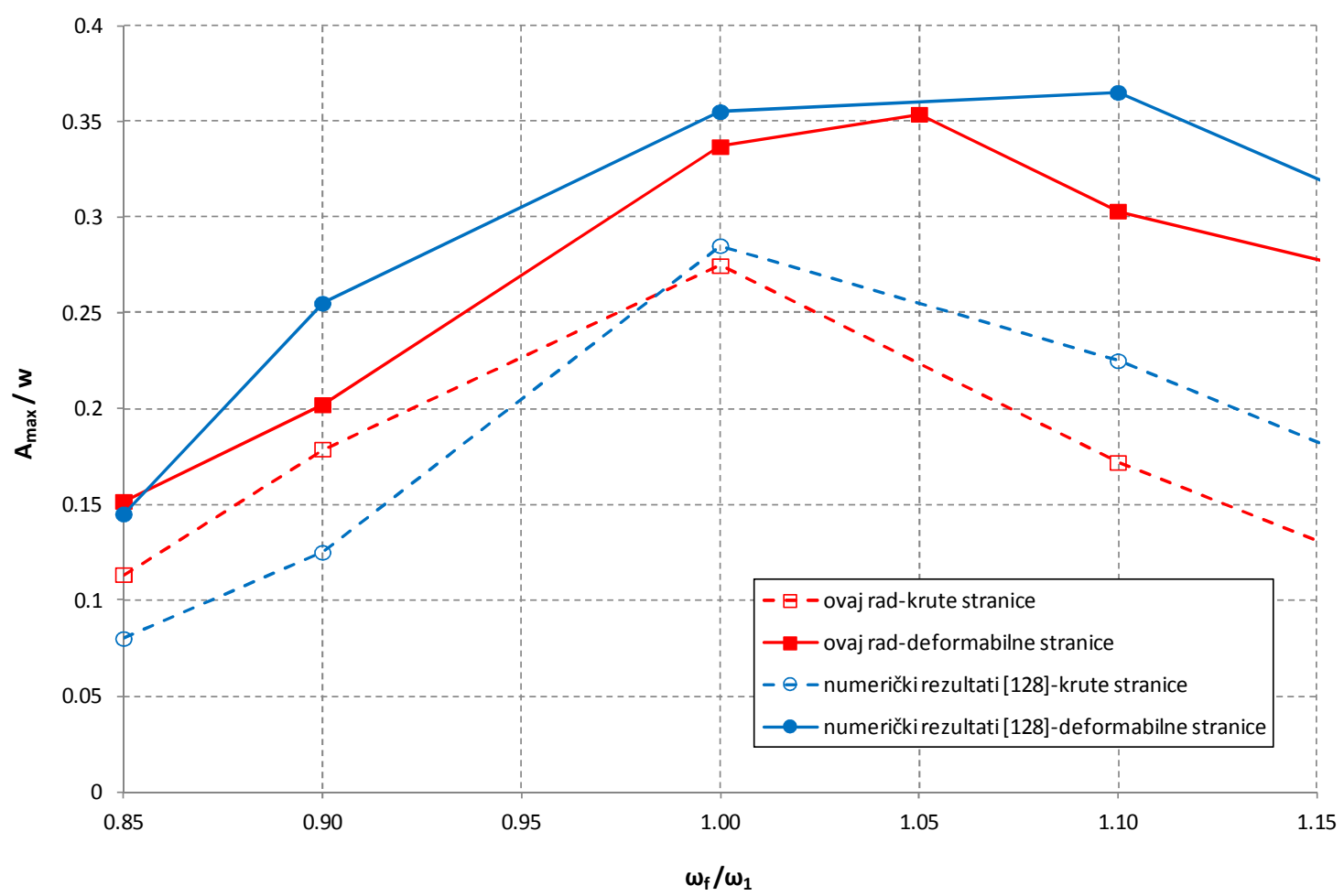

Slika 4.14. Rezonantni odgovor rezervoara s deformabilnim stranicama

Prikazani su pomaci vrha deformabilne konstrukcije u vremenu (Slika 4.15). Vidi se da pomaci osciliraju oko vrijednosti pomaka za početno hidrostatičko opterećenje. 


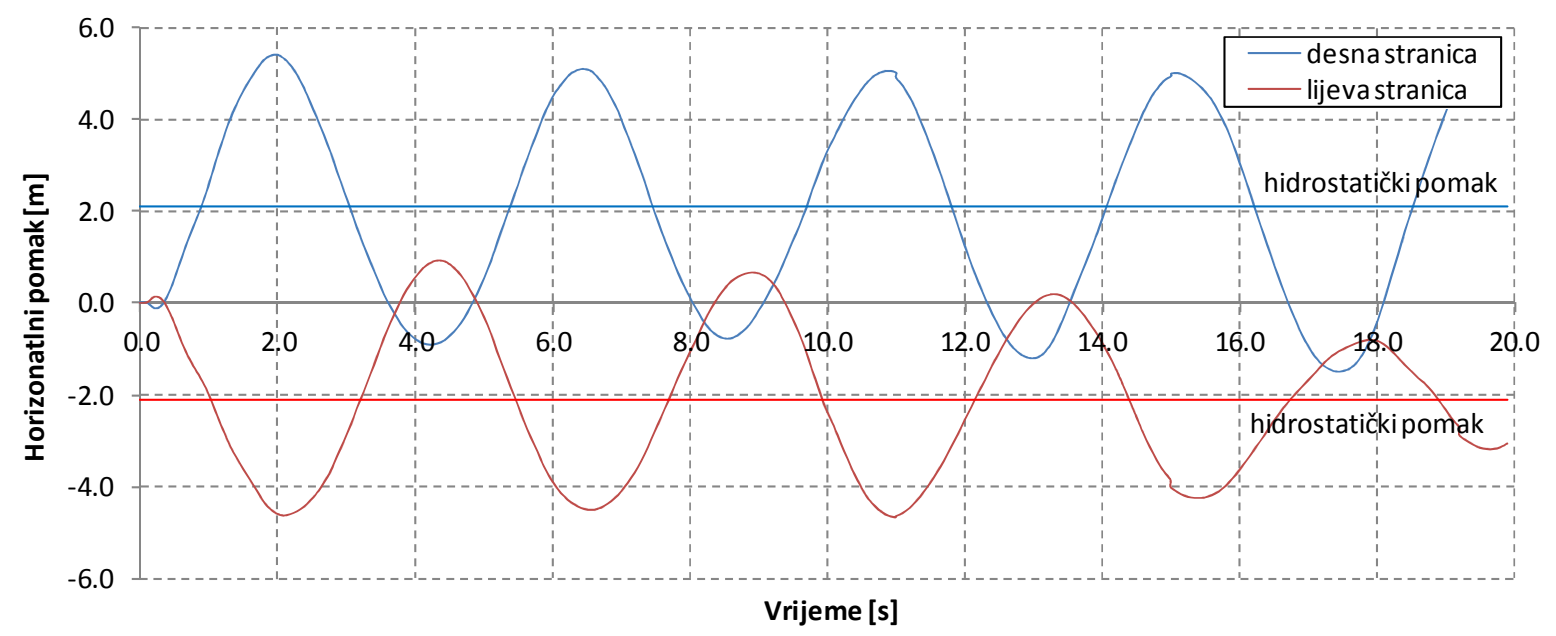

Slika 4.15. Pomaci vrha ljuske u vremenu

$\mathrm{Na}$ Slici 4.16b prikazan je kruti rezervoar u trenutku u kojemu je došlo do maksimalnog uzdizanja vode na desnoj stranici rezervoara, a na Slikama 4.16a i 4.16c neposredno prije i nakon tog trenutka. Na Slici $4.17 \mathrm{~b}$ prikazan je deformabilni rezervoar $\mathrm{u}$ trenutku u kojemu je došlo do maksimalnog uzdizanja vode na desnoj stranici rezervoara, a na Slikama 4.17a i 4.17c neposredno prije i nakon tog trenutka.

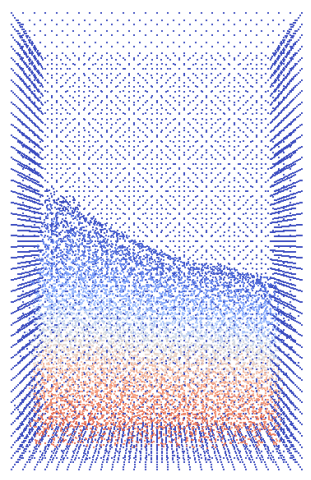

(a)

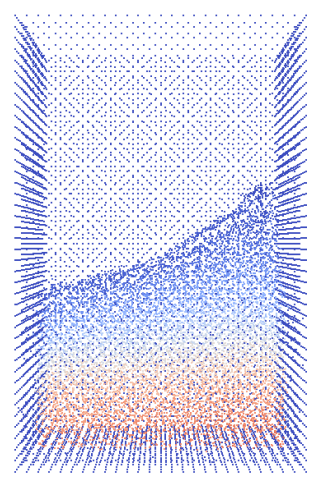

(b)

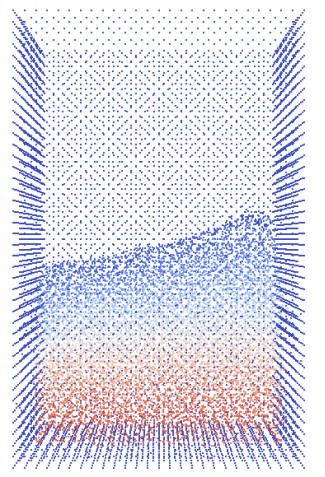

(c)

Slika 4.16. Rezonantni odgovor rezervoara s krutim stranicama

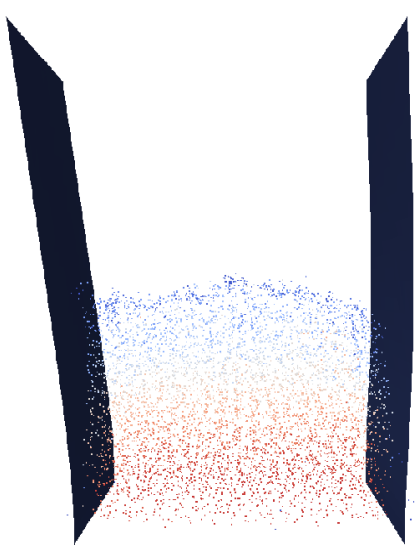

(a)

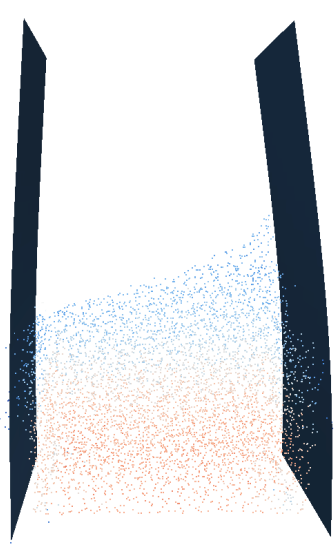

(b)

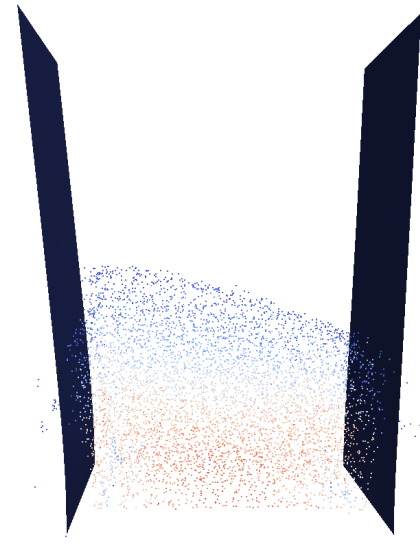

(c)

Slika 4.17. Rezonantni odgovor rezervoara s deformabilnim stranicama 


\subsection{Primjer 2}

\subsubsection{Osnovni podaci}

U nastavku je obrađen problem u literaturi poznat kao „dam-break“ problem (problem popuštanja brane) s jednom deformabilnom stranicom/pregradom. Osnovna geometrija i početni položaj stupca tekućine prikazani su na Slici 4.18.
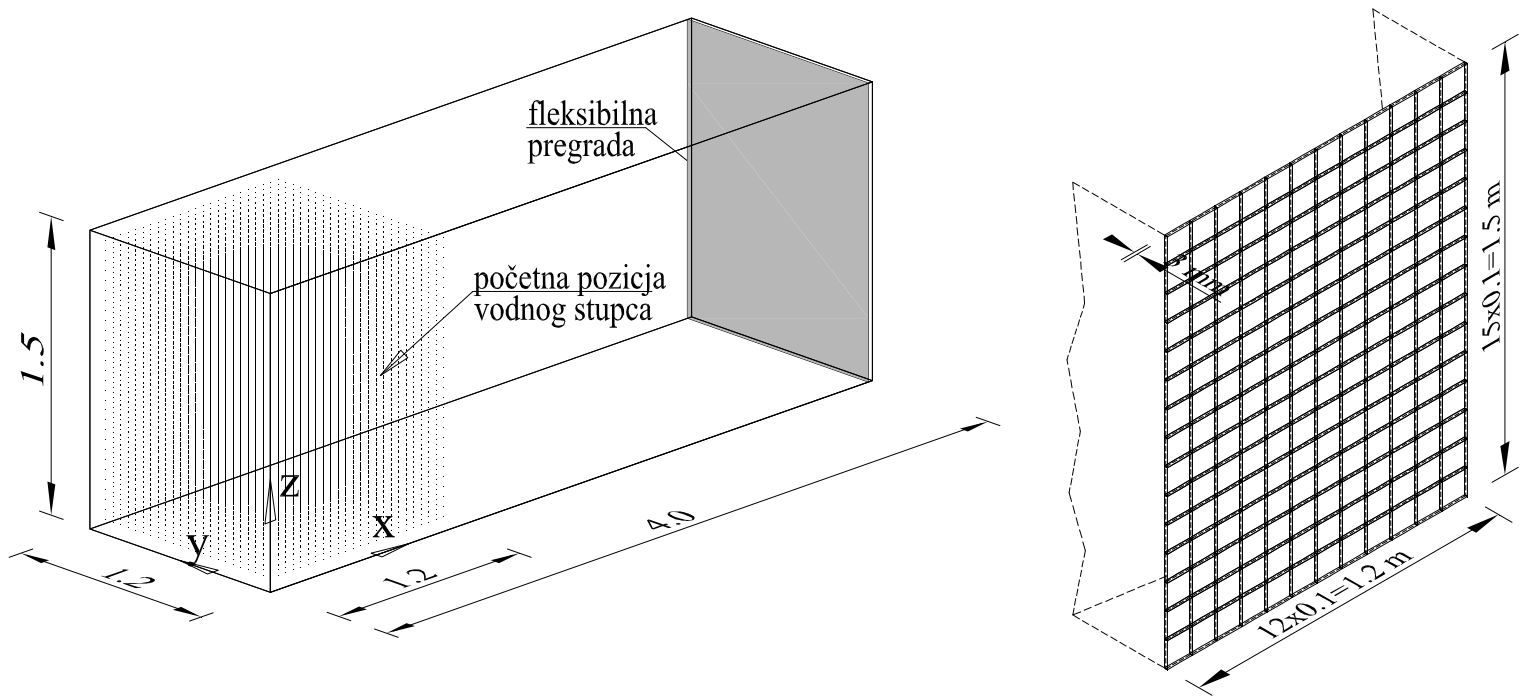

Slika 4.18. Osnovna geometrija problema i početni položaj stupca vode

„Dam-break“ problem podrazumijeva inicijalnu poziciju stupca tekućine koju u tom položaju pridržava nevidljiva barijera, koja u trenutku $\mathrm{t}=0$ nestaje i stupac tekućine se urušava u posudu. Tekućina korištena u ovom primjeru je čista voda gustoće $\rho_{0}=1000 \mathrm{~kg} / \mathrm{m}^{3}$. Voda se smatra neviskozna i slabo stišljiva.

U prikazanom primjeru (Slika 4.18) sve stranice rezervoara su krute osim nizvodne stranice koja je deformabilna i koja je na Slici 4.18. prikazana kao siva ploha. Ova stranica je čelična ploča debljine $t_{s 1}=3 \mathrm{~mm}$, fiksirana na tri strane (upeta čvrsto): dolje, lijevo i desno, dok je vrh pregrade slobodan.

Materijalne karakteristike vode (tekućine) i konstrukcije (čelik) prikazane su u Tablici 4.3. Čelik je tretiran kao elastičan materijal do dosezanja granice popuštanja $\left(f_{y}\right)$, a nakon dosezanja granice popuštanja kao potpuno plastičan. 
Tablica 4.3. Materijalne karakteristike

\begin{tabular}{|l|l|}
\hline Tekućina - voda & Konstrukcija - čelična pregrada \\
\hline & $\mathrm{E}_{\mathrm{s}}=200.0 \mathrm{GN} / \mathrm{m}^{2}$ \\
$\rho_{\mathrm{v}}=1000.0 \mathrm{~kg} / \mathrm{m}^{3}$ & $\mathrm{f}_{\mathrm{y}} / \mathrm{f}_{\mathrm{u}}=240.0 / 370.0 \mathrm{MN} / \mathrm{m}^{2}$ \\
$\mathrm{c}=1430.0 \mathrm{~m} / \mathrm{s}$ & $\mathrm{v}_{\mathrm{s}}=0.3$ \\
& $\rho_{\mathrm{s}}=7850.0 \mathrm{~kg} / \mathrm{m}^{3}$ \\
\hline
\end{tabular}

U tablici su korištene sljedeće oznake: c - brzina zvuka u vodi, $\mathrm{f}_{\mathrm{y}}$ - granica popuštanja čelika $\mathrm{i} \mathrm{f}_{\mathrm{u}}$ - lomna čvrstoća čelika. Ostali parametri su dobro znani modul elastičnosti (Youngov modul) čelika $\left(E_{\mathrm{s}}\right)$, Poissonov koeficijent za čelik $\left(v_{\mathrm{s}}\right)$, te gustoća vode $\left(\rho_{\mathrm{v}}\right)$ i gustoća čelika $\left(\rho_{\mathrm{s}}\right)$

Čestice vode su inicijalno postavljene u kvadar dimenzija 1.2×1.2×1.5 m (Slika 4.18). Broj pomičnih čestica (čestice tekućine) je 16560, a broj rubnih čestica (virtualne čestice) je 17641, što ukupno čini 34201 čestica. Na slikama u nastavku su, zbog jasnoće prikaza, prikazivane samo pomične čestice tekućine. Inicijalno, čestice su postavljene na razmaku 0.05 m. Početni vremenski korak je $\Delta \mathrm{t}=0.0005 \mathrm{~s}$, a ukupno vrijeme simulacije je $\mathrm{t}_{\mathrm{tot}}=8.0 \mathrm{~s}$.

Početni tlakovi na deformabilnu čeličnu pregradu su 0.0 , jer u inicijalnom položaju voda nije u doticaju sa pregradom. Prvi kontakt vode na pregradu događa se u vremenu $t=0.62 \mathrm{~s}$.

\subsubsection{Rezultati}

"Dam break" problem podrazumijeva da zamišljena pregrada, koja drži stupac vode u početnoj poziciji, nestaje u trenutku $\mathrm{t}=0$. $\mathrm{U}$ tom trenutku započinje slobodno gibanje vode prema fleksibilnoj pregradi na suprotnoj strani rezervoara. Na Slici 4.19 prikazani su početni pomaci stupca vode koji se obrušava prema fleksibilnoj pregradi u trenutcima: $t=0.15 \mathrm{~s} ; 0.30$ s, $0.45 \mathrm{~s}$ i $0.6 \mathrm{~s}$. Tlakovi u česticama iskazani su u paskalima. U vremenu $\mathrm{t}=0.62 \mathrm{~s}$, stupac vode dolazi do deformabilne pregrade i počinje djelovati na nju. 


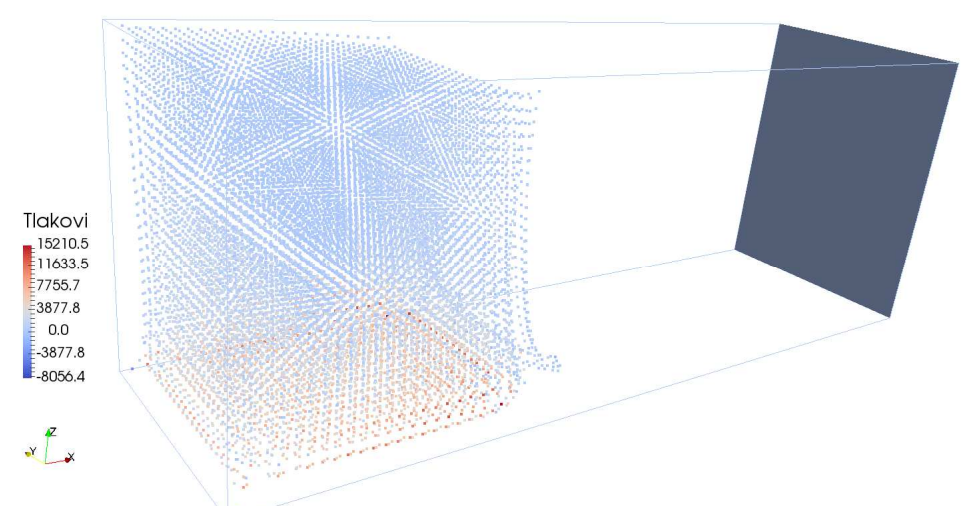

(a) $\mathrm{t}=0.15 \mathrm{~s}$ (vrijeme prije nego stupac vode dotakne pregradu)

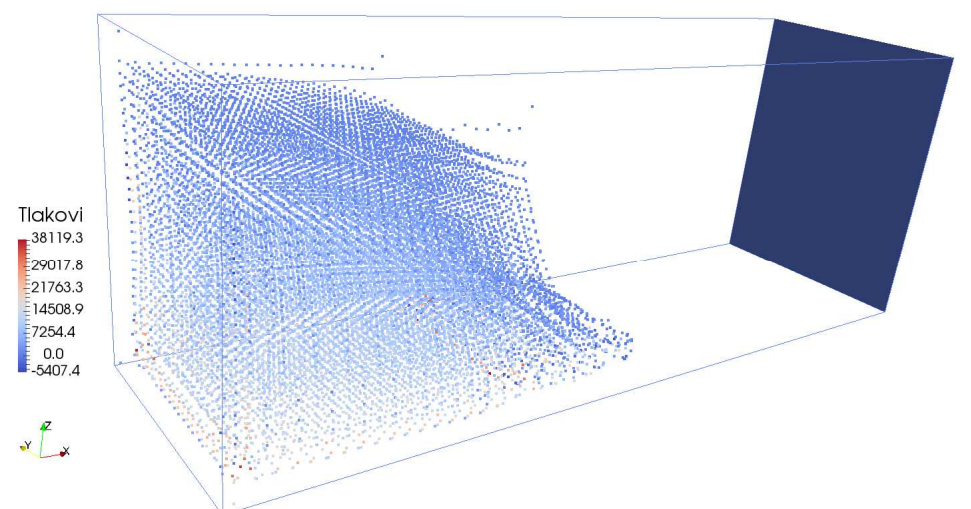

(b) $\mathrm{t}=0.30 \mathrm{~s}$ (vrijeme prije nego stupac vode dotakne pregradu)

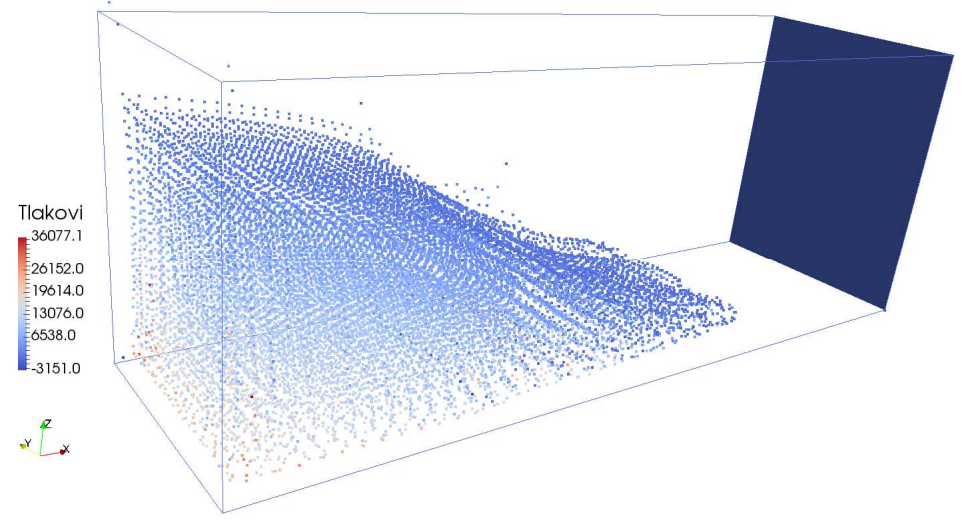

(c) $\mathrm{t}=0.45 \mathrm{~s}$ (vrijeme prije nego stupac vode dotakne pregradu)

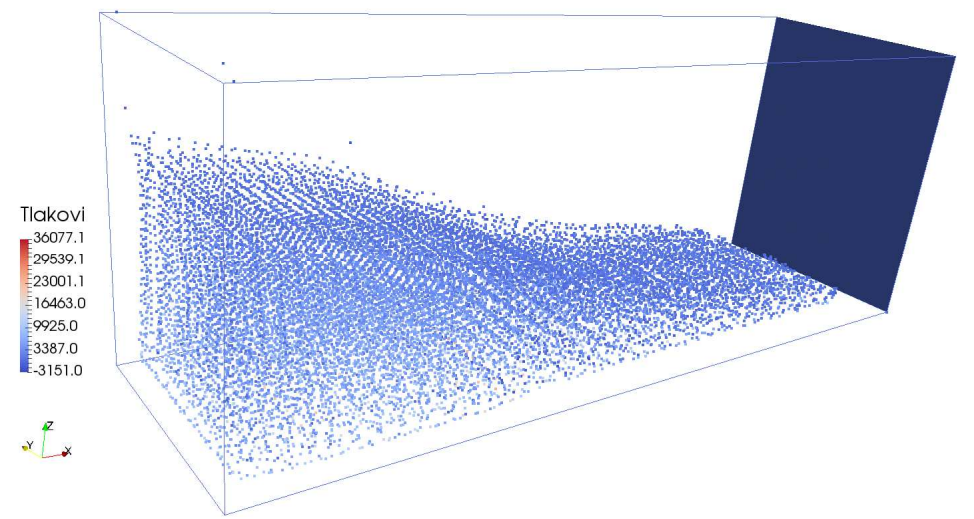

(d) $\mathrm{t}=0.60 \mathrm{~s}$ (vrijeme prije nego stupac vode dotakne pregradu)

Slika 4.19. Gibanje čestica vode prije doticaja pregrade i vode 
Potrebno je uočiti da je početni hidrostatički tlak na dnu rezervoara $\mathrm{u}$ trenutku $\mathrm{t}=0$, $14.7 \mathrm{kPa}$. Konačni hidrostatički tlak nakon smirivanja vode (nivo vode je $0.375 \mathrm{~m}$ ) je $3.7 \mathrm{kPa}$.

$\mathrm{U}$ trenutku $\mathrm{t}=0.65 \mathrm{~s}$, dolazi do silovitog udara vode na deformabilnu pregradu. Tlakovi u vodi rastu čak do $162.6 \mathrm{kPa}$, a tlakovi vode na deformabilnu pregradu do $71.2 \mathrm{kPa}$ (oko 5 puta veći od početnih hidrostatičkih). Primjećuje se pojava i manjih negativnih tlakova na vrhu vodenog mlaza (Slika 4.20). Pomaci fleksibilne pregrade na slikama su uvećani 5 puta.

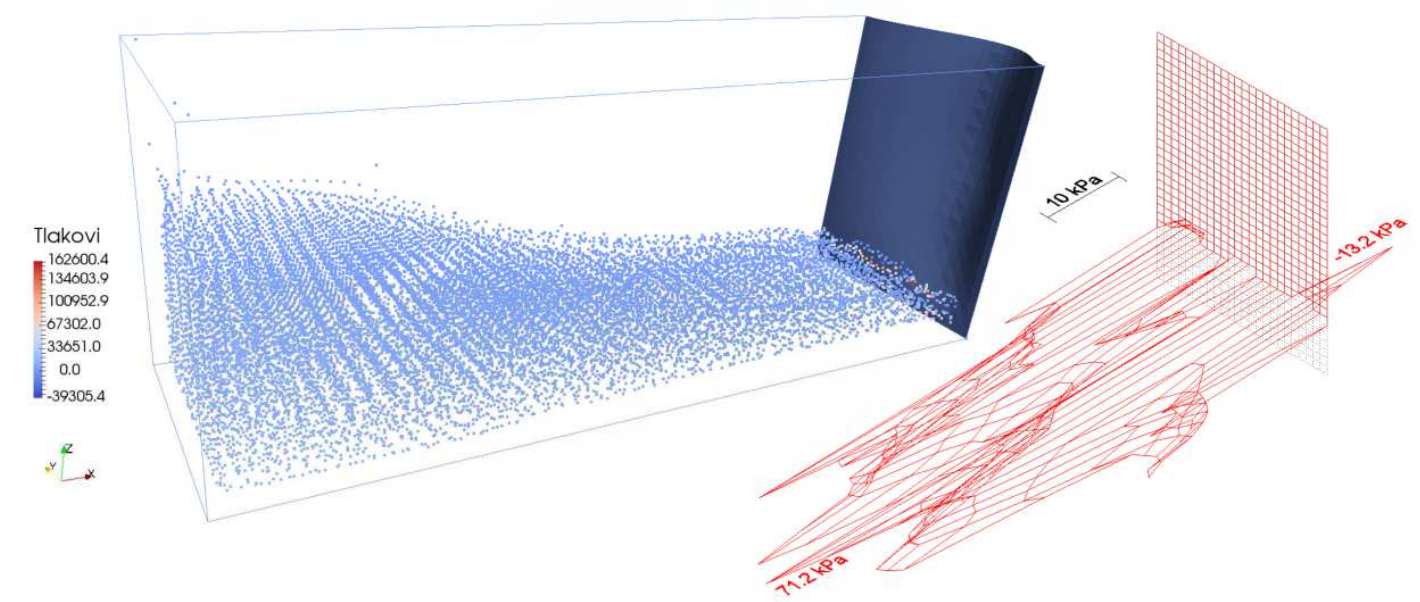

Slika 4.20. Pomak čestica vode i tlakovi na pregradu u trenutku $t=0.65 \mathrm{~s}$

Ovi tlakovi su siloviti, kratkotrajni i vrlo brzo se smanjuju kako stupac vode skače u vis. Na Slici 4.21. prikazani su daljnji rezultati numeričke analize: pomaci čestica vode $\mathrm{i}$ tlakovi vode na deformabilnu pregradu u vremenskim trenutcima: $t=0.70 \mathrm{~s} ; 0.75 \mathrm{~s}, 0.80 \mathrm{~s} \mathrm{i}$ 0.85 s. Svi rezultati su vizualizirani AutoCAD-om (tlakovi) i Paraview-om (pomaci čestica). Različite boje čestica definiraju različite tlakove, pri čemu crvena boja predstavlja velike tlakove, a plava male. Na sljedećim slikama je vidljivo kako tlakovi nakon udara i odbijanja vodenog mlaza rapidno padaju na relativno normalne vrijednosti, od oko 17-20 kPa. 

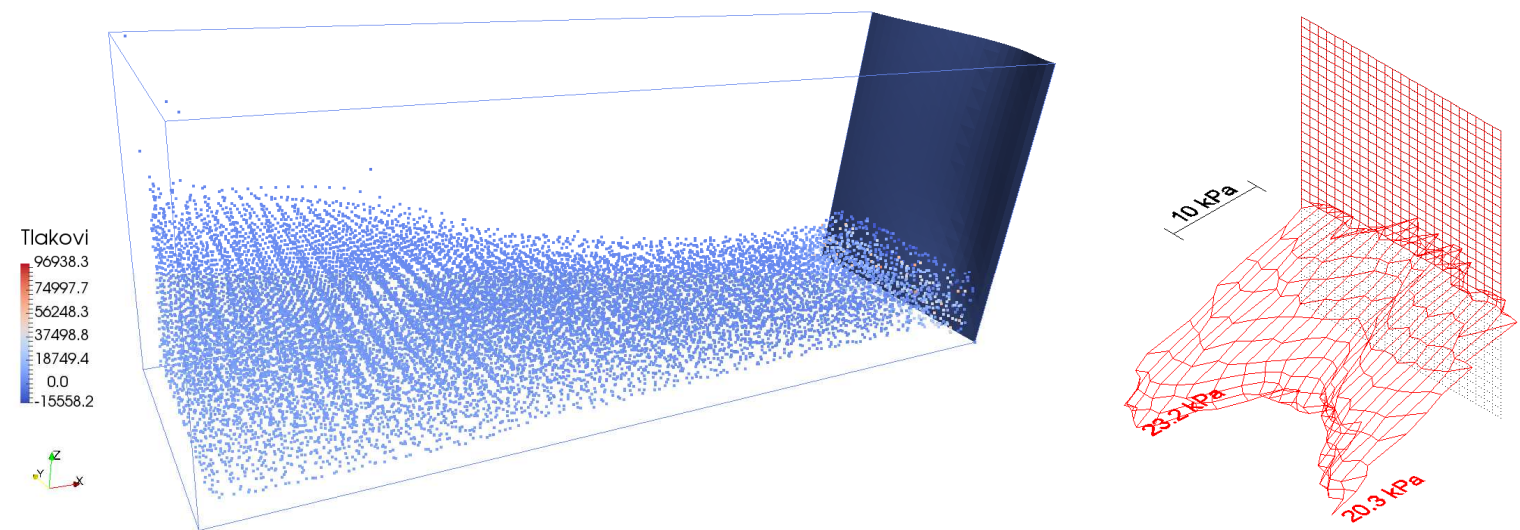

(a) $\mathrm{t}=0.70 \mathrm{~s}$
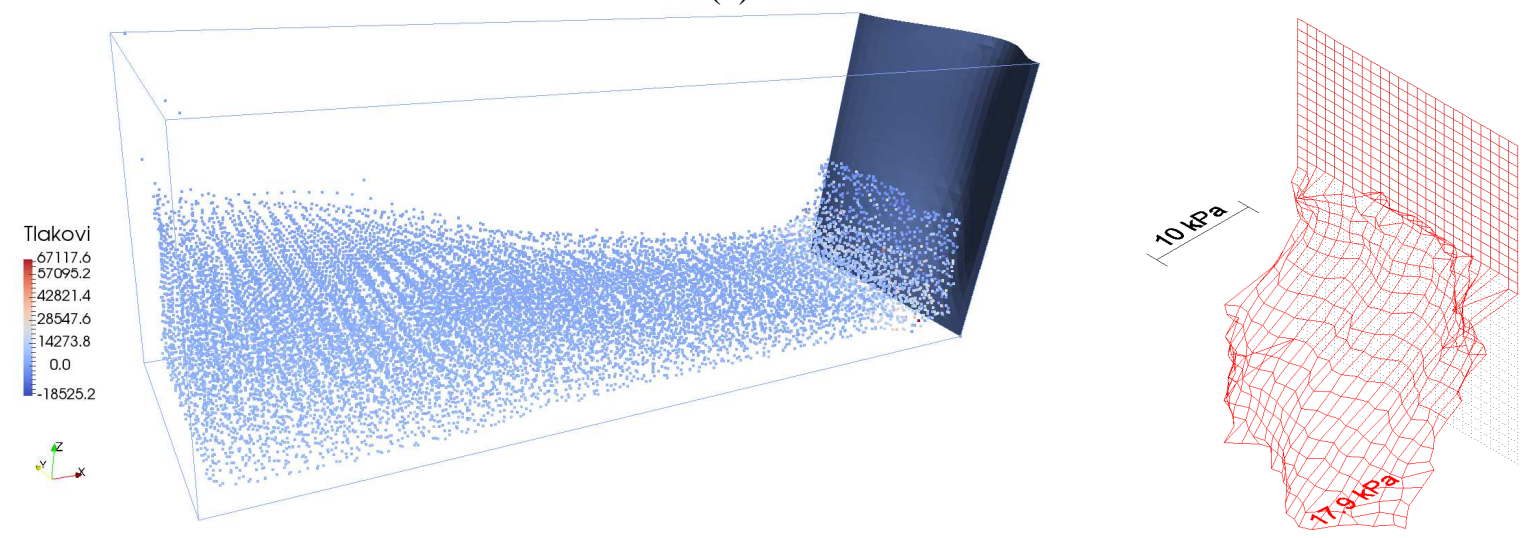

(b) $\mathrm{t}=0.75 \mathrm{~s}$
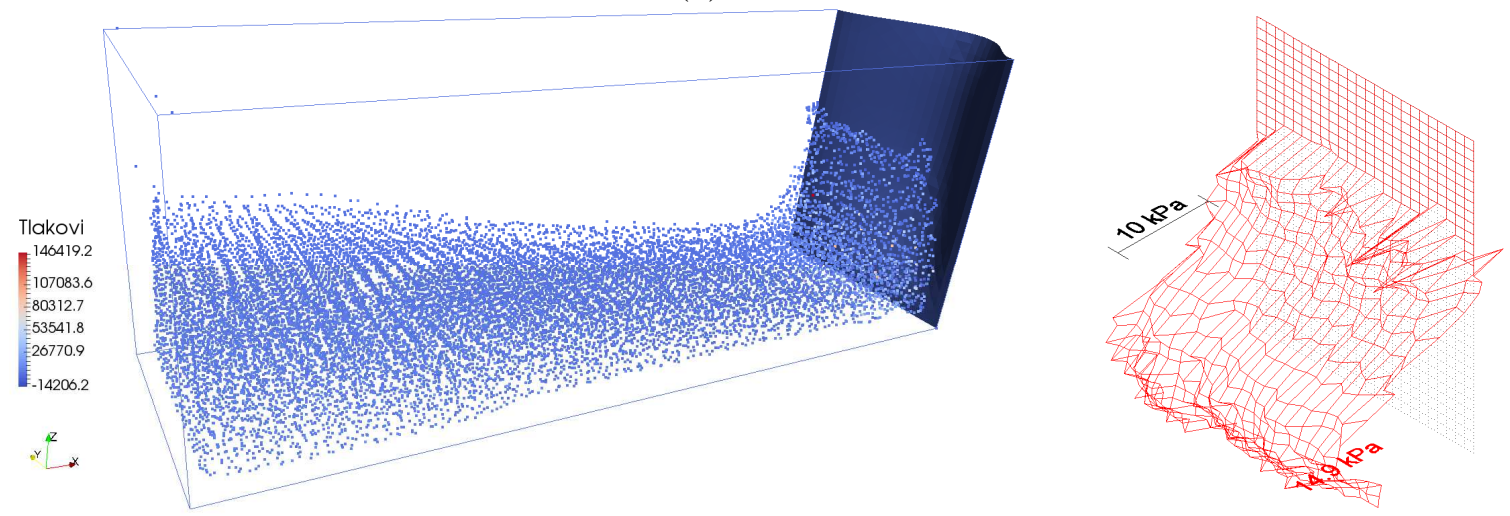

(c) $\mathrm{t}=0.80 \mathrm{~s}$
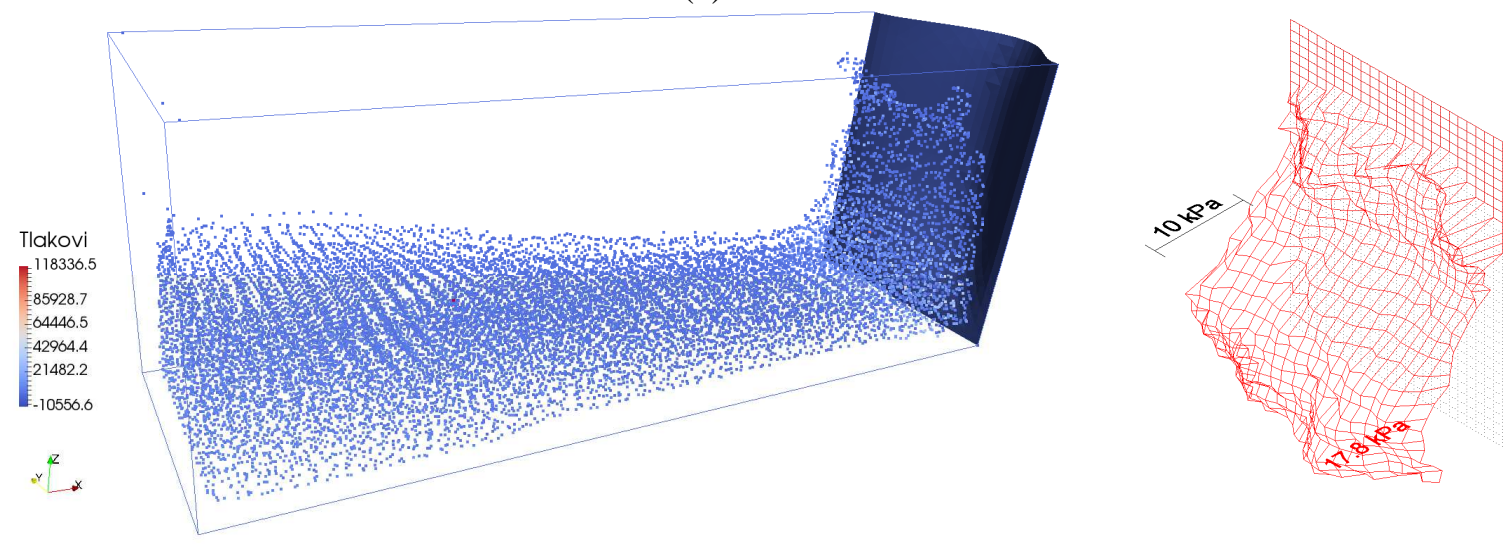

(d) $\mathrm{t}=0.85 \mathrm{~s}$

Slika 4.21. Gibanje čestica vode i tlakovi vode na pregradu 
$\mathrm{U}$ trenutku $\mathrm{t}=0.65 \mathrm{~s}$ ukupna horizontalna sila je najveća i iznosi $\mathrm{P}=11.95 \mathrm{kN}$, međutim ima relativno nisko hvatište: $\mathrm{z}=0.158 \mathrm{~m}$. $\mathrm{U}$ trenutku $\mathrm{t}=0.85 \mathrm{~s}$ horizontalna sila uzrokovana tlakom vode je nešto manja, $\mathrm{P}=11.33 \mathrm{kN}$, sa relativno visokim hvatištem $\mathrm{z}=0.374 \mathrm{~m}$. $\mathrm{U}$ tom trenutku deformabilna pregrada ima najveće deformacije i naprezanja (Slika 4.22-4.23).
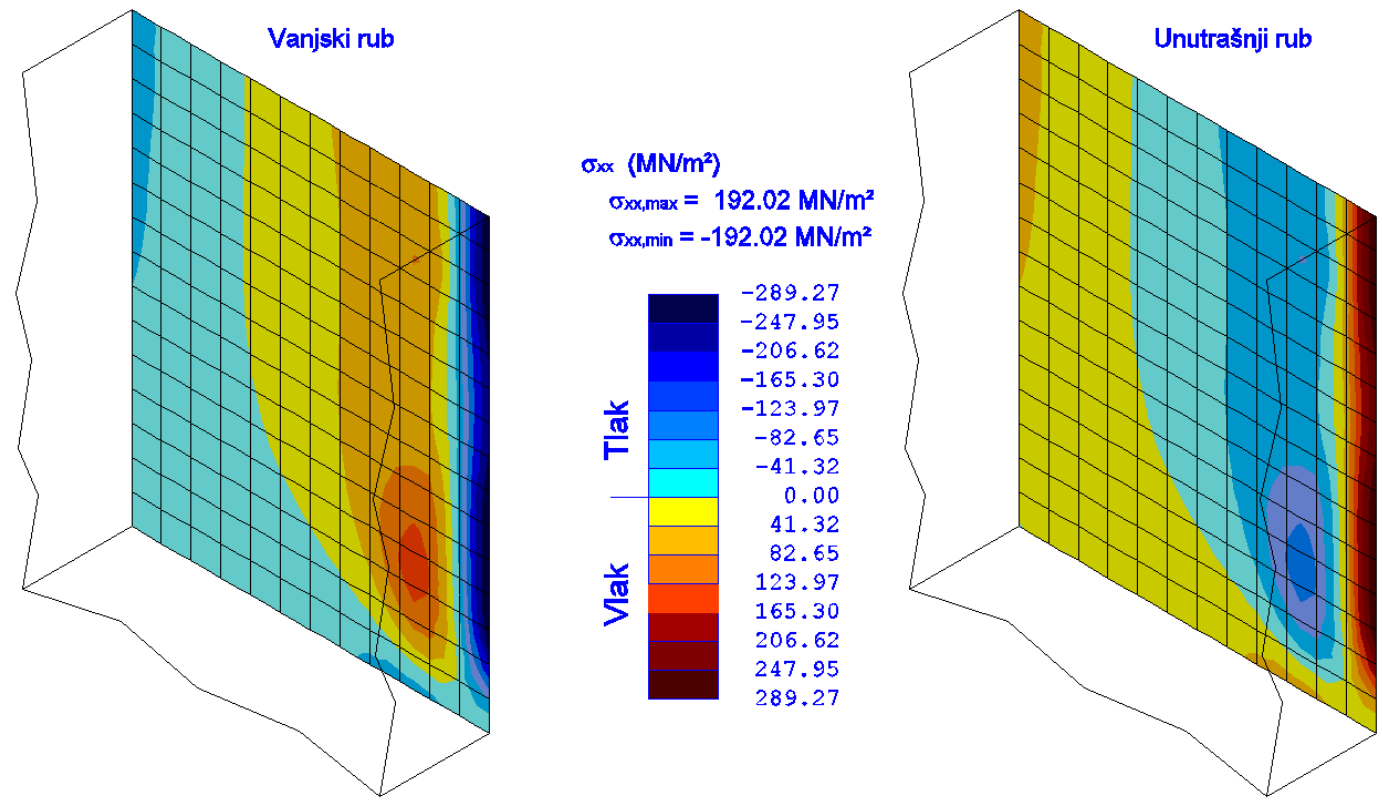

Slika 4.22. Naprezanja $\sigma_{\mathrm{xx}}$ deformabilne pregrade $\mathrm{u}$ trenutku $\mathrm{t}=0.85 \mathrm{~s}$
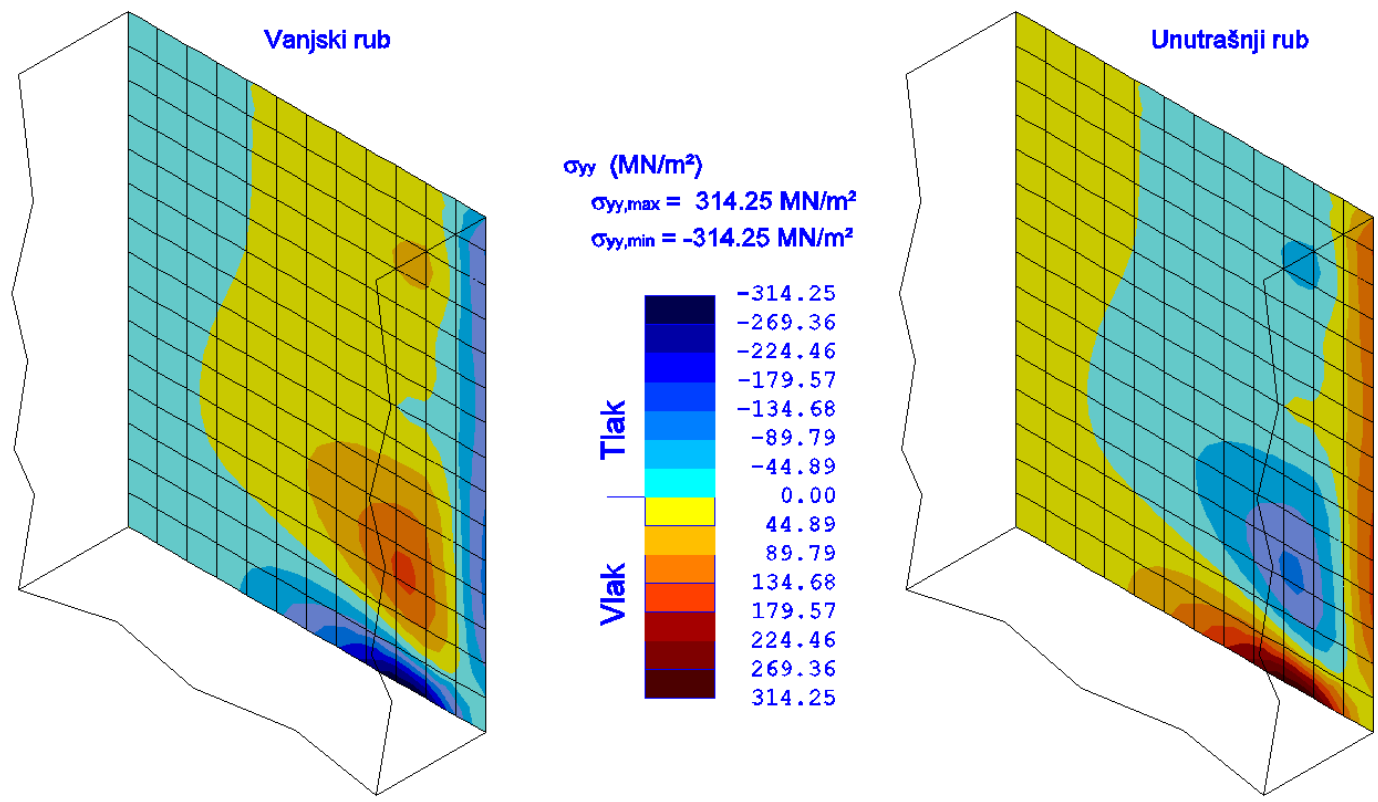

Slika 4.23. Naprezanja $\sigma_{y y}$ deformabilne pregrade $u$ trenutku $\mathrm{t}=0.85 \mathrm{~s}$

Zbog neravnomjerne raspodjele tlakova, desna strana pregrade doživljava veća naprezanja, što je vidljivo na Slikama 4.22-4.23. Naprezanja $\sigma_{x x}$ i $\sigma_{y y}$ prelaze granicu tečenja $\left(\mathrm{f}_{\mathrm{y}}=240 \mathrm{MN} / \mathrm{m}^{2}\right)$, te se javlja plastifikacije uz upete rubove. 
U daljnjim vremenskim trenutcima: $\mathrm{t}=0.90 \mathrm{~s}, \mathrm{t}=0.95 \mathrm{~s}$ i $\mathrm{t}=1.0 \mathrm{~s}$, tlakovi još više padaju i poprimaju pravilan oblik, što je vidljivo sa Slike 4.24.
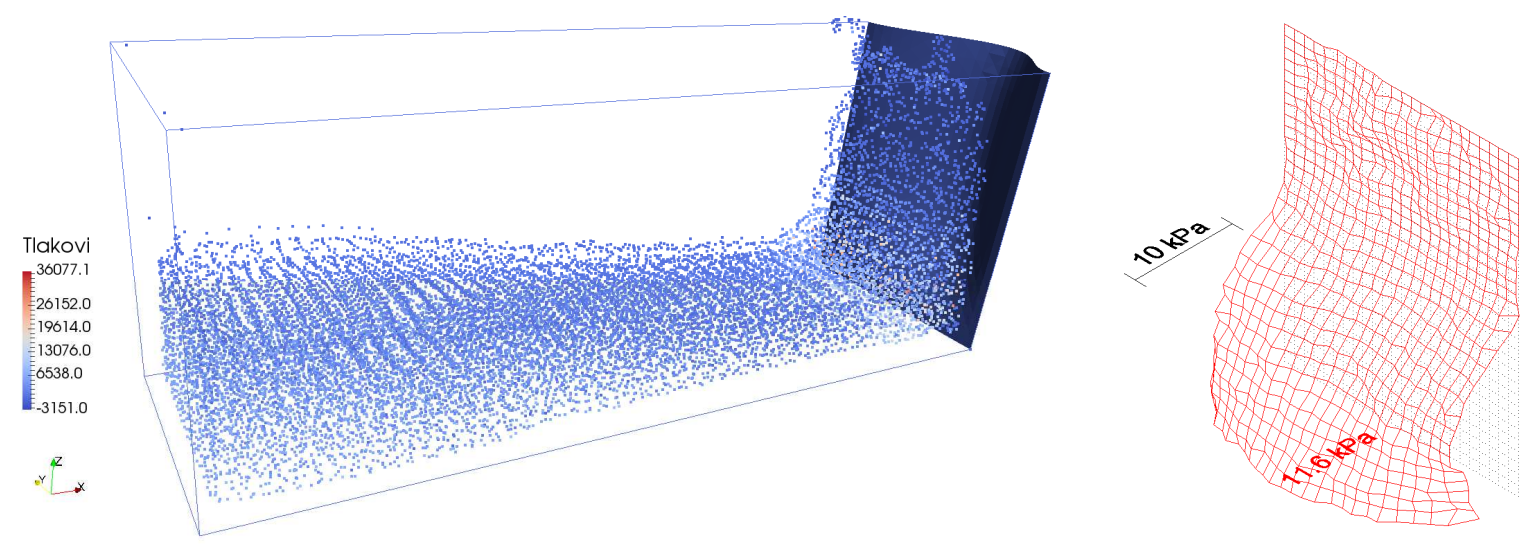

(a) $\mathrm{t}=0.90 \mathrm{~s}$
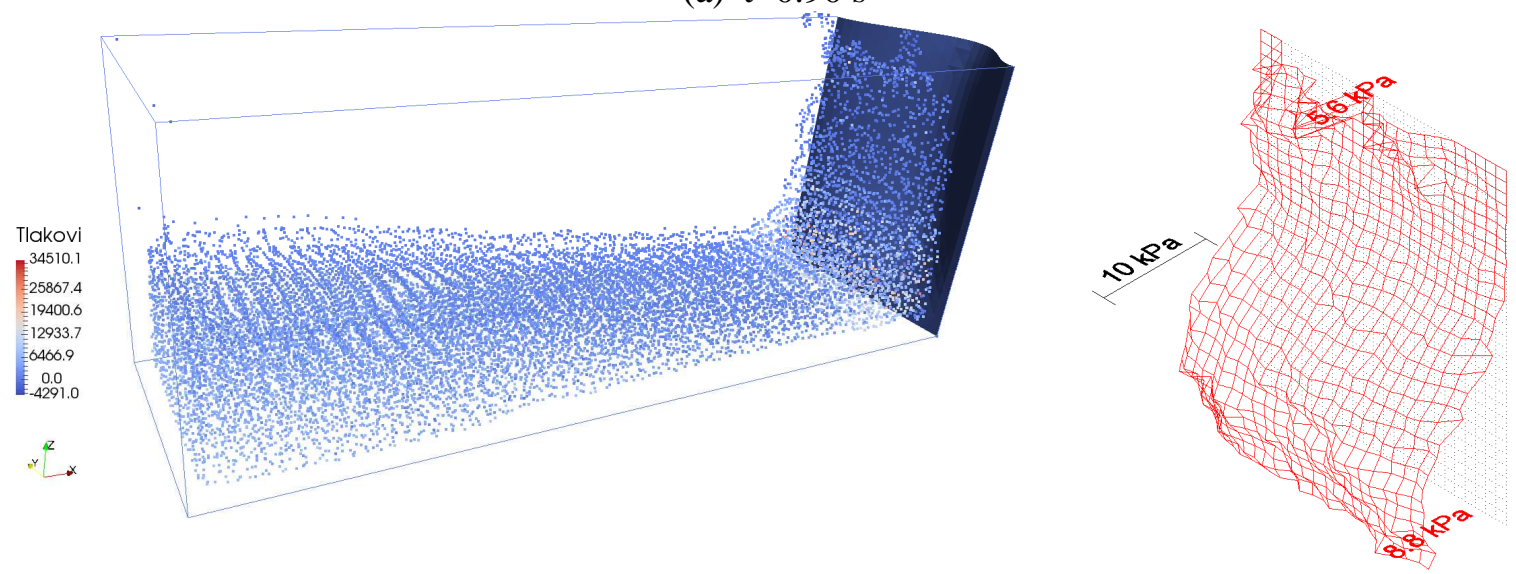

(b) $\mathrm{t}=0.95 \mathrm{~s}$
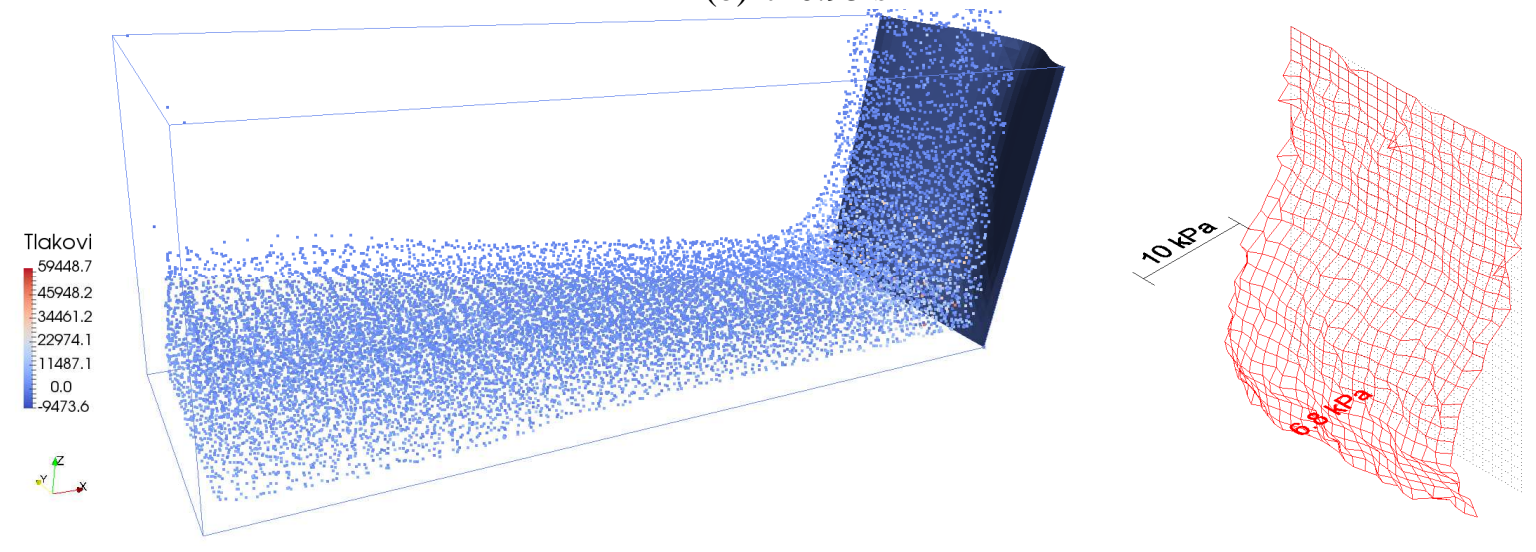

(c) $\mathrm{t}=1.00 \mathrm{~s}$

Slika 4.24. Gibanje čestica vode i tlakovi na pregradu

U daljnjim toku analize, oscilacija nivoa vode uzrokuje rast i pad tlakova na pregradu, što je prikazano sa Slici 4.25. Ove oscilacije su sada relativno male i na plohi tlakova nema skokova. 


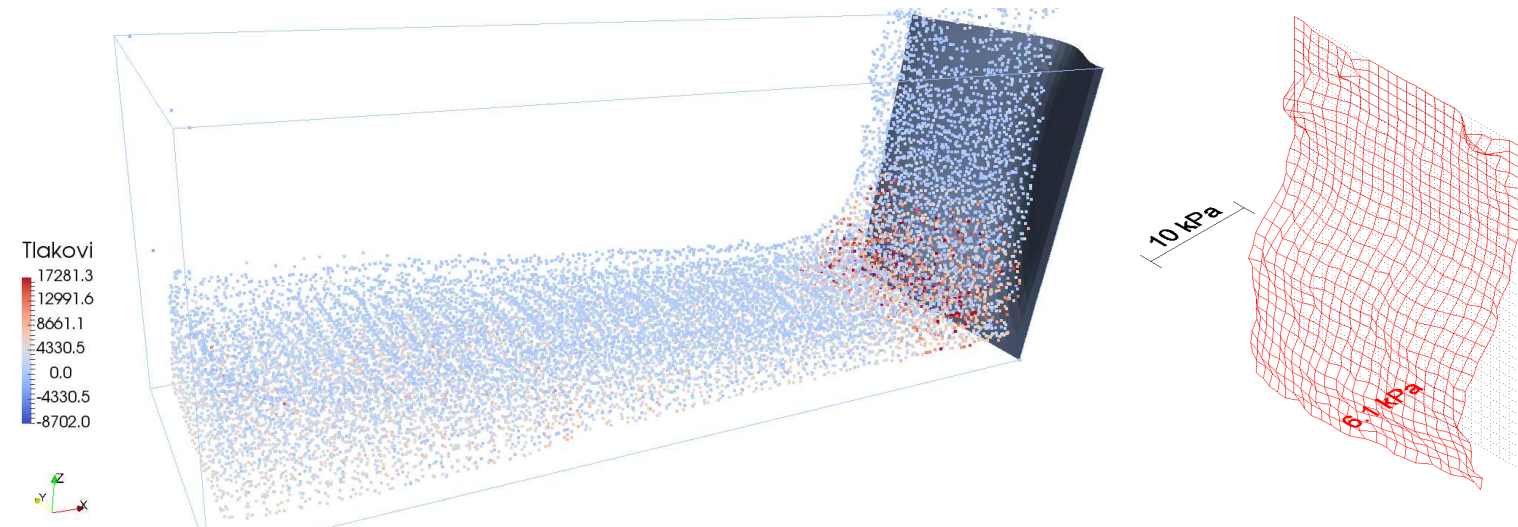

(a) $\mathrm{t}=1.10 \mathrm{~s}$

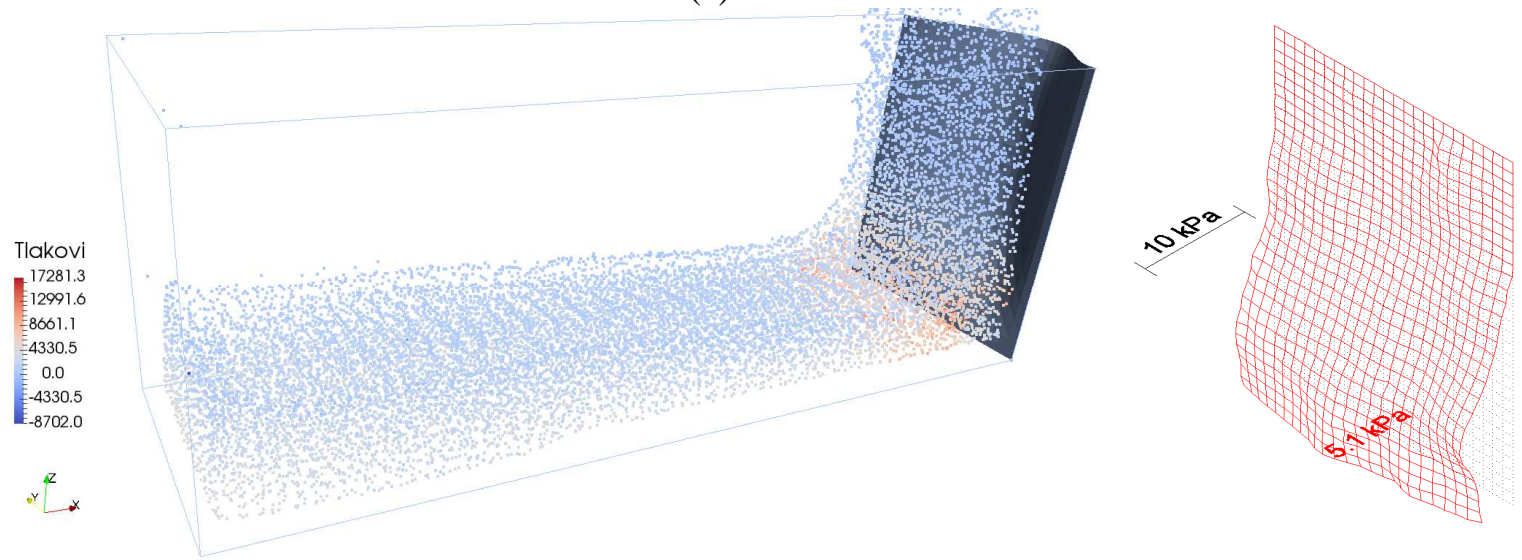

(b) $\mathrm{t}=1.20 \mathrm{~s}$

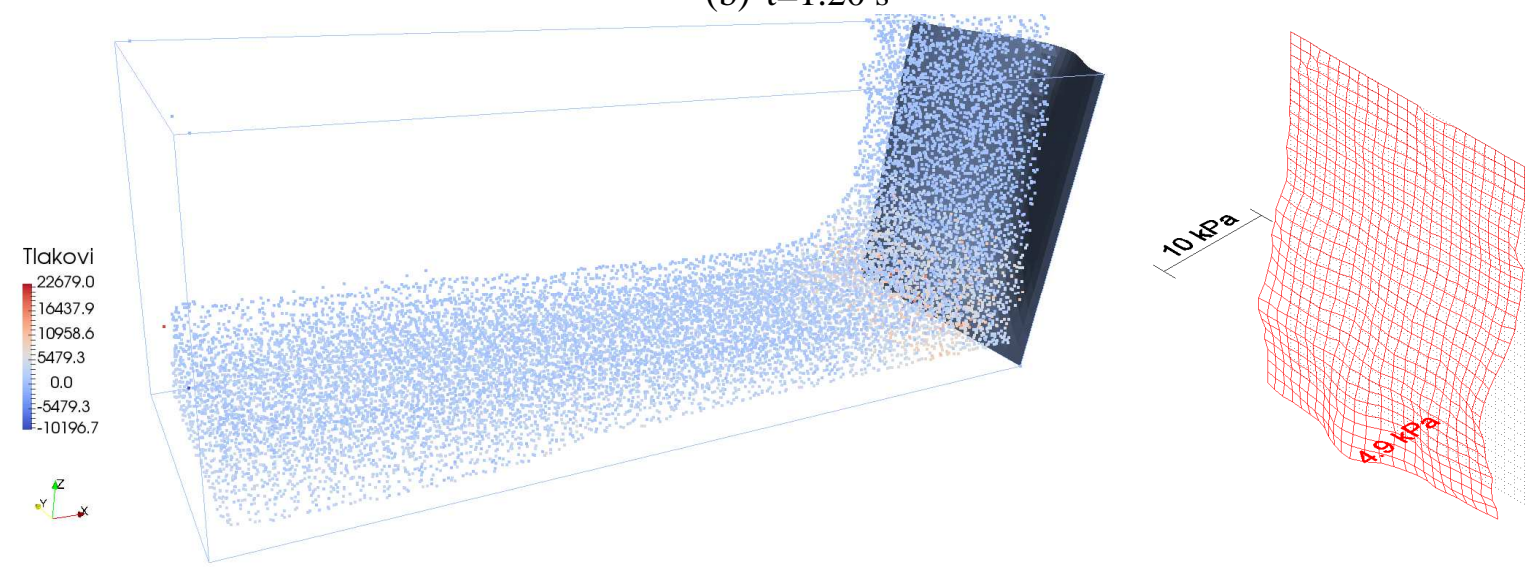

(c) $\mathrm{t}=1.30 \mathrm{~s}$ 

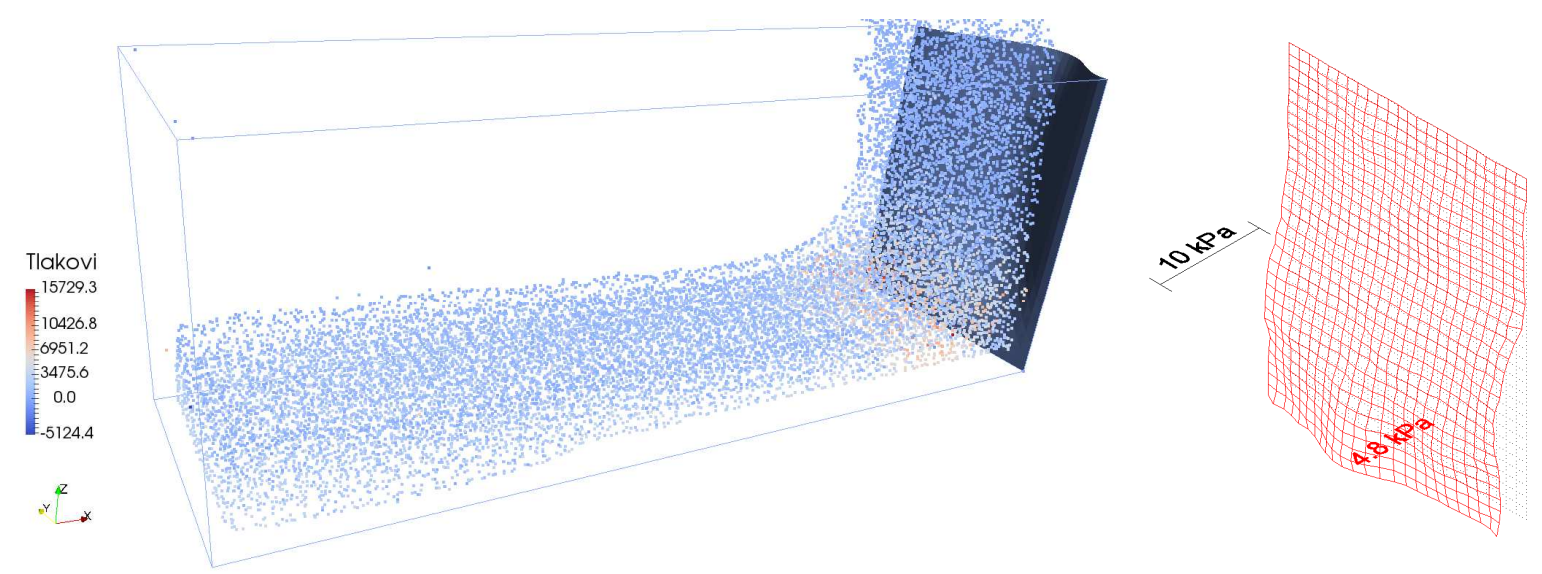

(d) $\mathrm{t}=1.40 \mathrm{~s}$

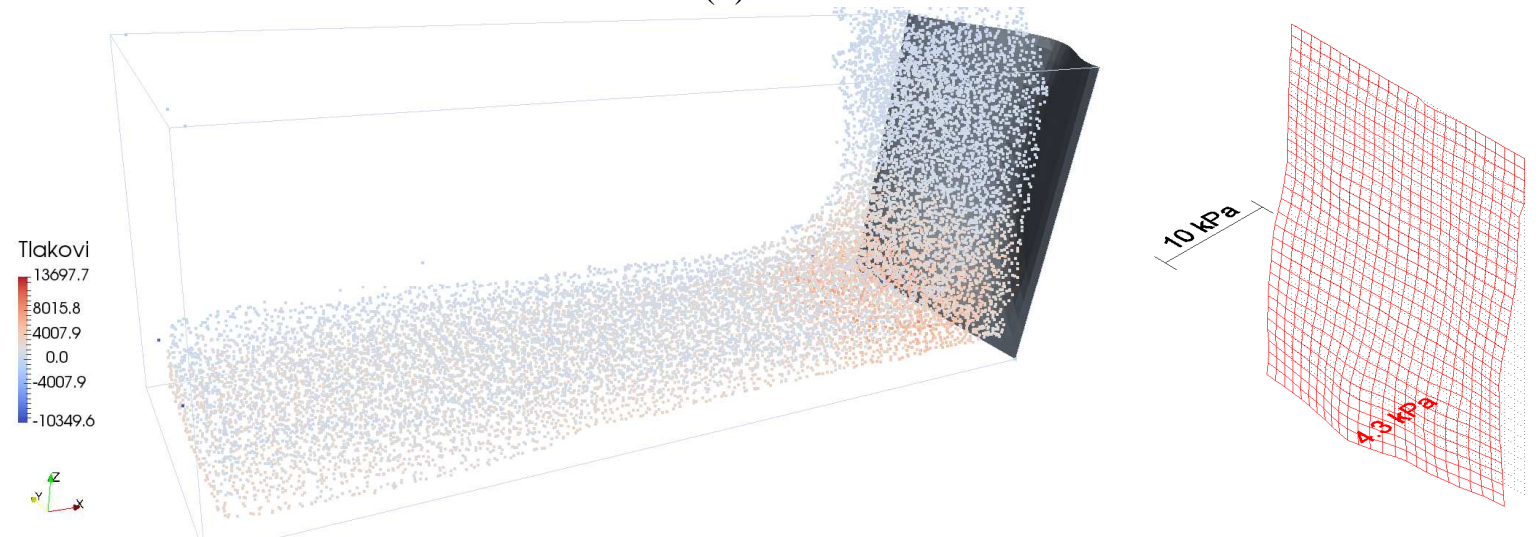

(e) $\mathrm{t}=1.50 \mathrm{~s}$

Slika 4.25. Gibanje čestica vode i tlakovi na pregradu

$\mathrm{U}$ trenutku oko $\mathrm{t}=1.5 \mathrm{~s}$ voda se počinje povlačiti natrag. Dolazi do laganog rasterećenja deformabilne pregrade, iako pregrada generalno zadržava deformirani oblik zbog plastifikacije. Ukupna naprezanja u trenutku t=1.5 s prikazana su na Slikama 4.26-4.27. Vidljivo je da su svi rubovi u plastičnom području. Granične deformacije su uzete vrlo daleko, tako da ne dolazi do loma materijala. 

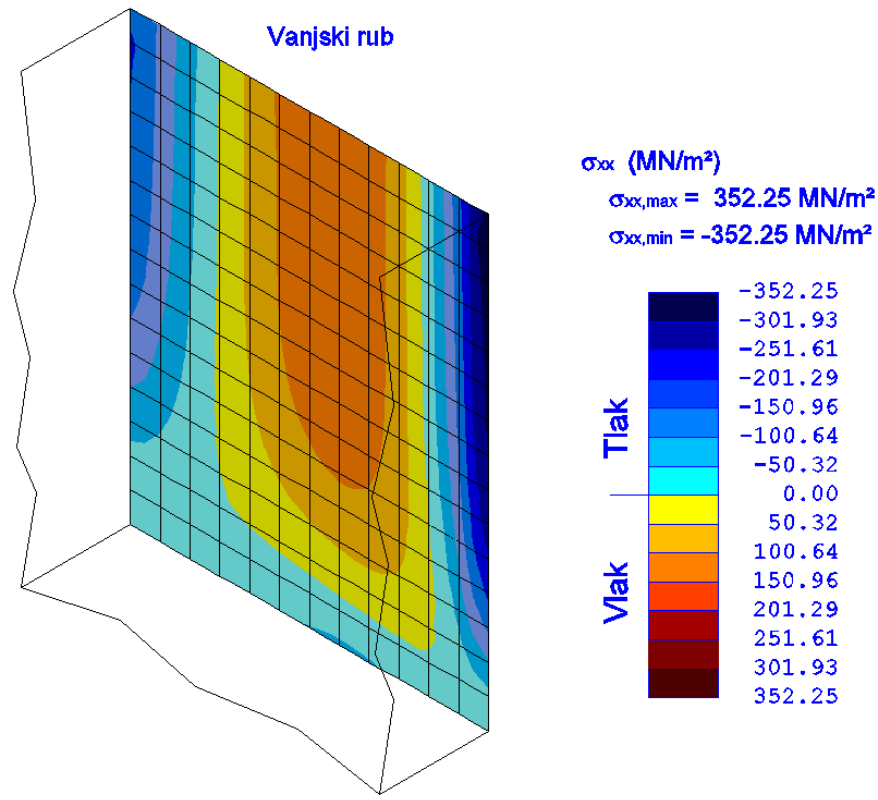

$\sigma x x, \min =-352.25 \mathrm{MN} / \mathrm{m}^{2}$

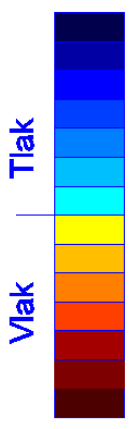

$-352.25$ $-301.93$ $-251.61$ $-201.29$ $-150.95$ $-100.64$ $-50.32$ 0.00 50.32 100.64 150.96

201.29

251.61

301.93

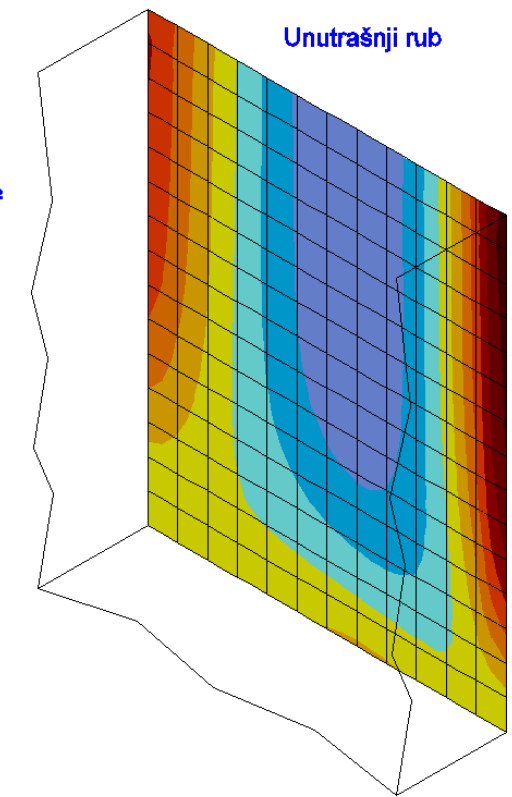

Slika 4.26. Naprezanja $\sigma_{x x}$ deformabilne pregrade $u$ trenutku $t=1.50 \mathrm{~s}$

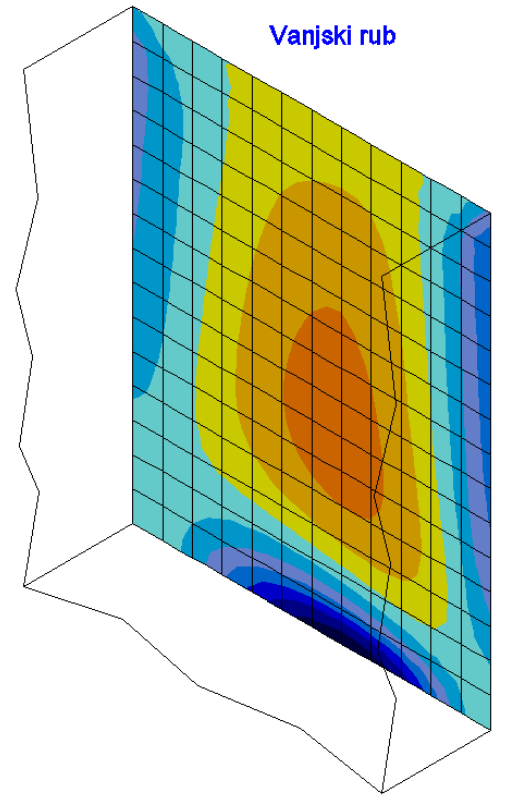

$$
\begin{aligned}
& \sigma_{\mathrm{y}}\left(\mathrm{MN} / \mathrm{m}^{2}\right) \\
& \sigma_{y, \max }=364.28 \mathrm{MN} / \mathrm{m}^{2} \\
& \sigma_{y y, m i n}=-364.28 \mathrm{MN} / \mathrm{m}^{2}
\end{aligned}
$$

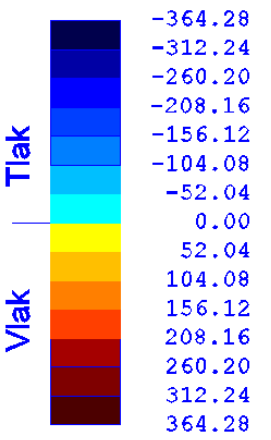

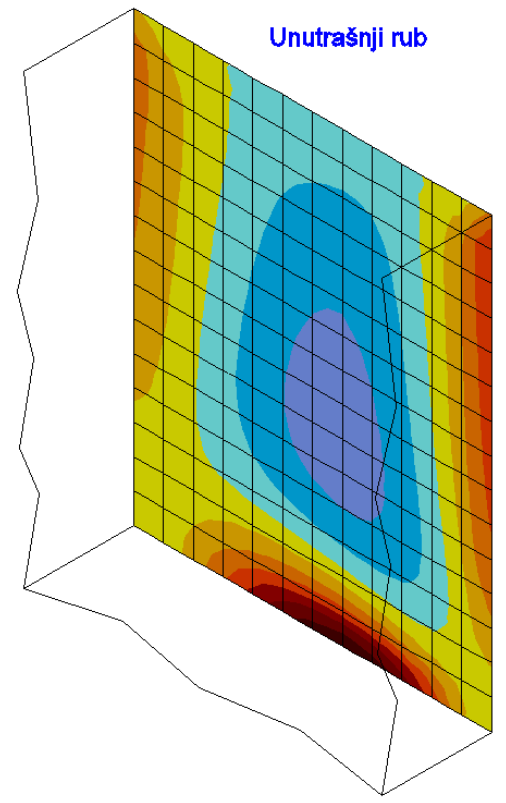

Slika 4.27. Naprezanja $\sigma_{y y}$ deformabilne pregrade $u$ trenutku $t=1.50 \mathrm{~s}$

U periodu od $2.0 \mathrm{~s}$ do kraja numeričkog testa $(8.0 \mathrm{~s})$ voda u rezervoaru se smiruje, a fleksibilna pregrada ostaje u deformiranom položaju (Slika 4.28). 

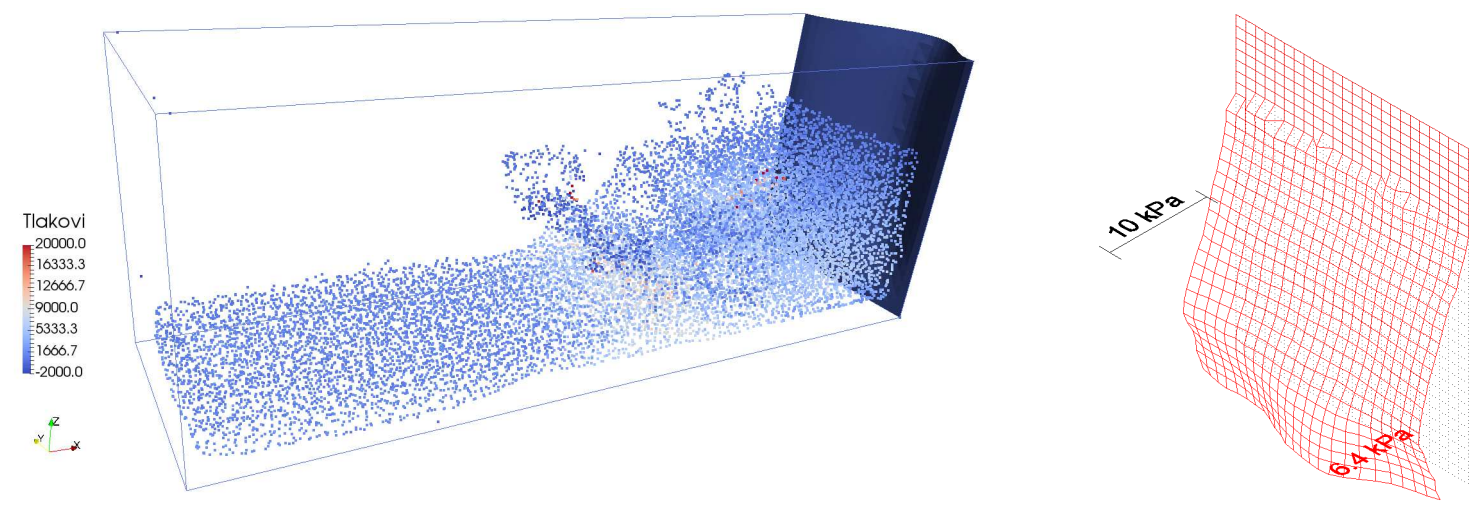

(a) $\mathrm{t}=2.00 \mathrm{~s}$
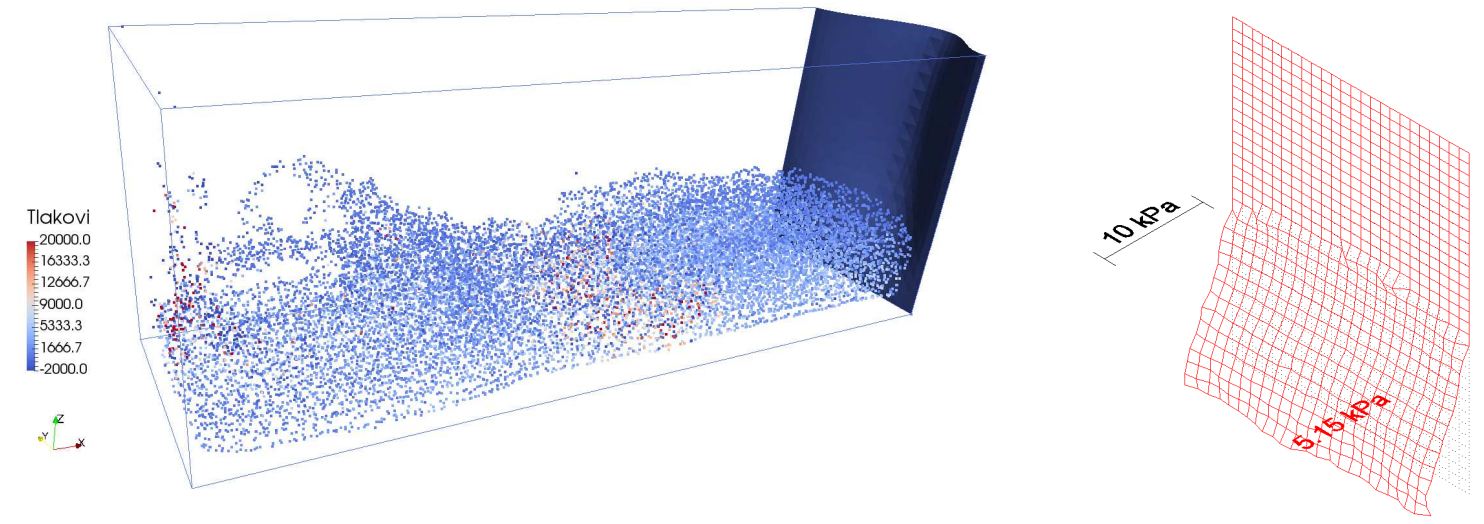

(b) $\mathrm{t}=2.50 \mathrm{~s}$
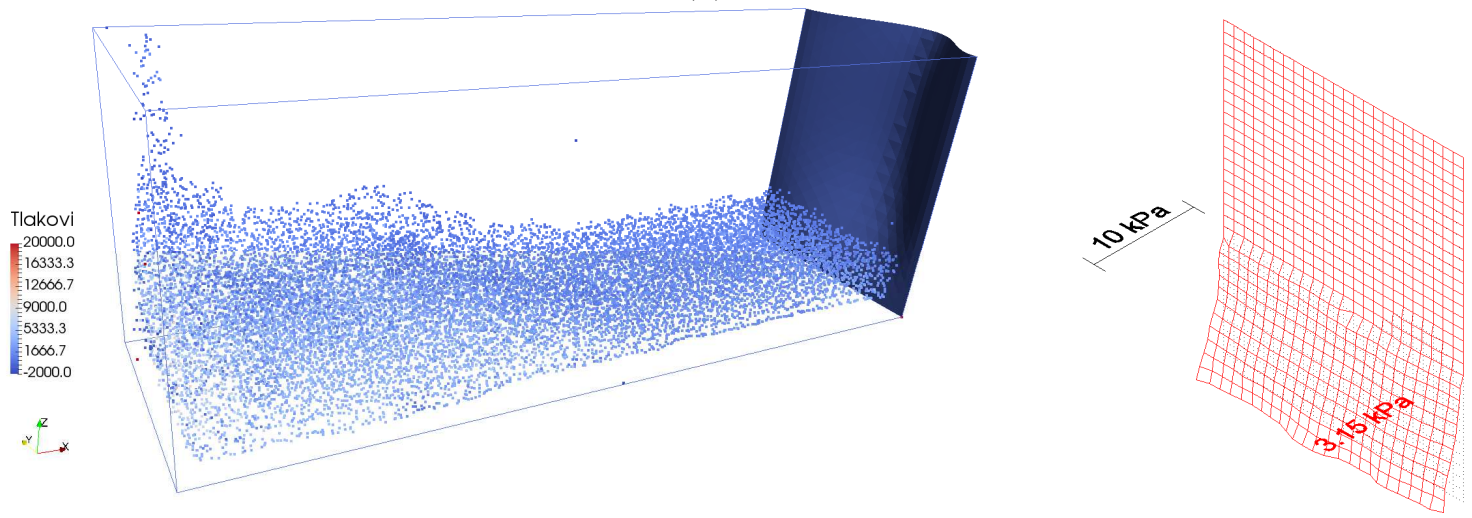

(c) $\mathrm{t}=3.00 \mathrm{~s}$
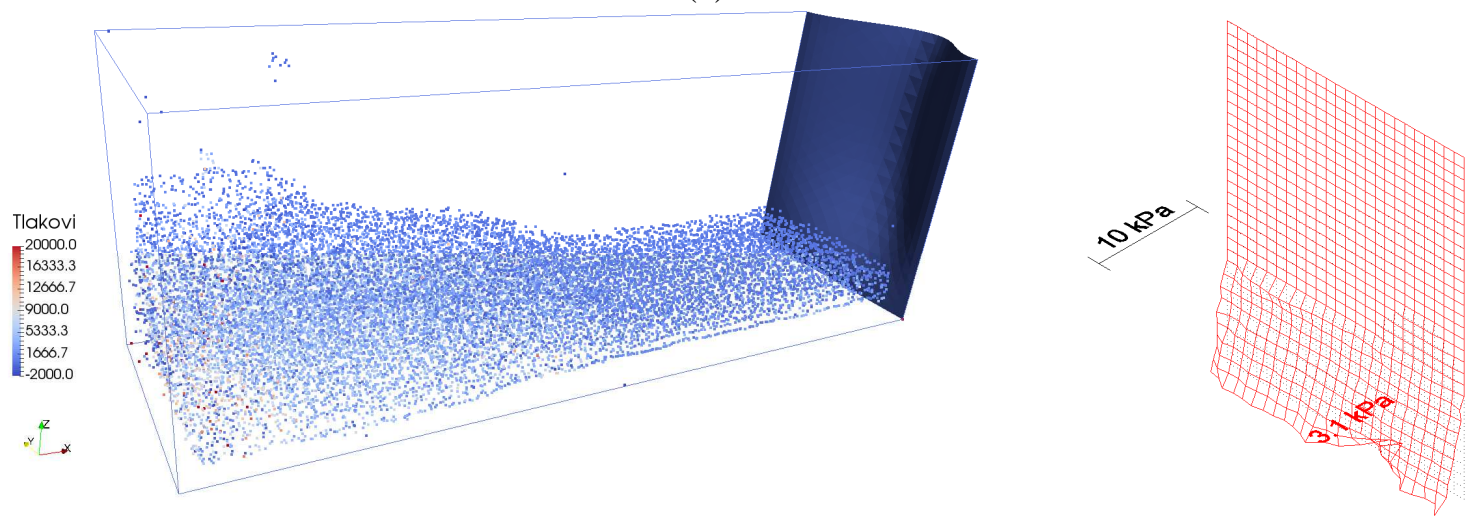

(d) $\mathrm{t}=3.50 \mathrm{~s}$ 

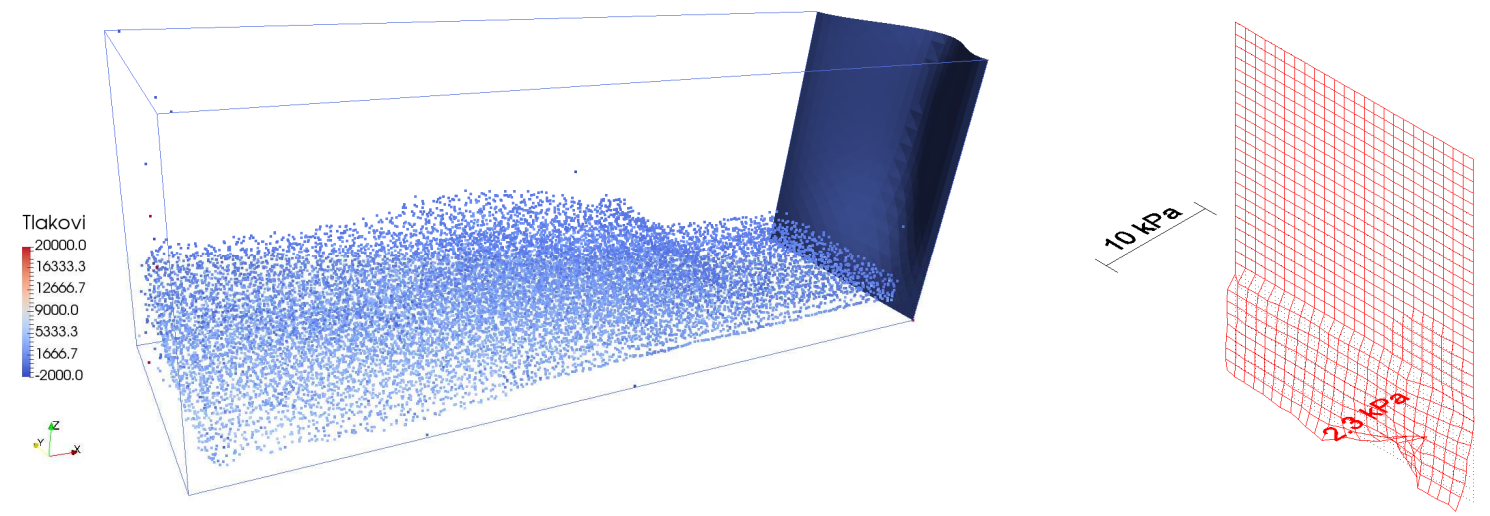

(e) $\mathrm{t}=4.00 \mathrm{~s}$
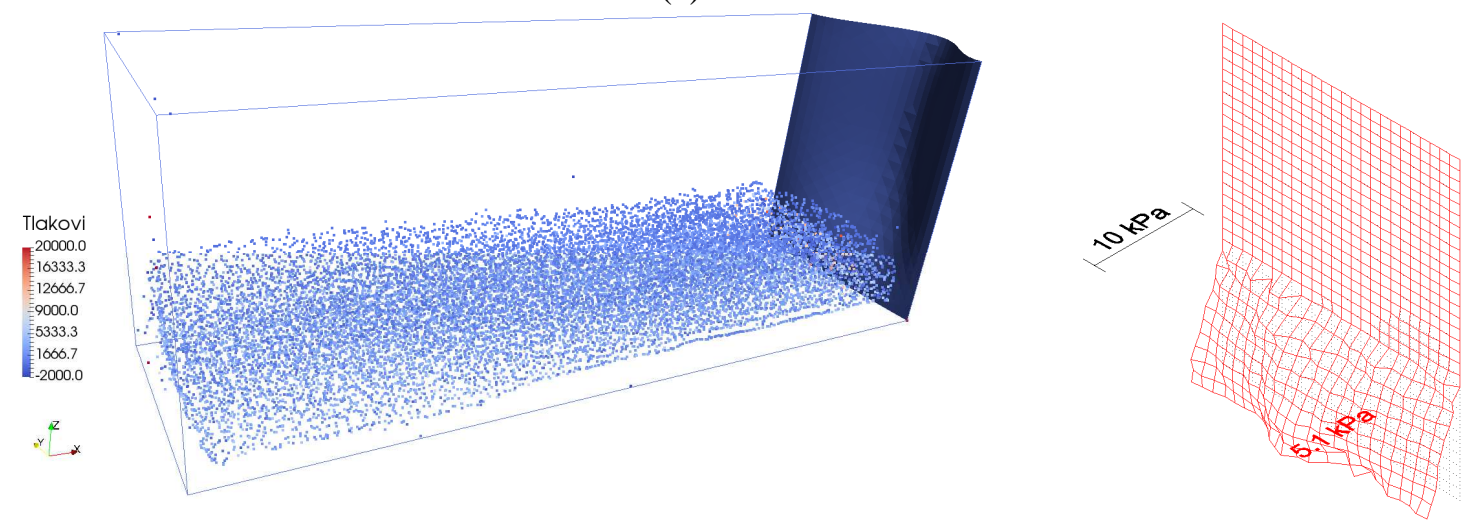

(f) $\mathrm{t}=4.50 \mathrm{~s}$
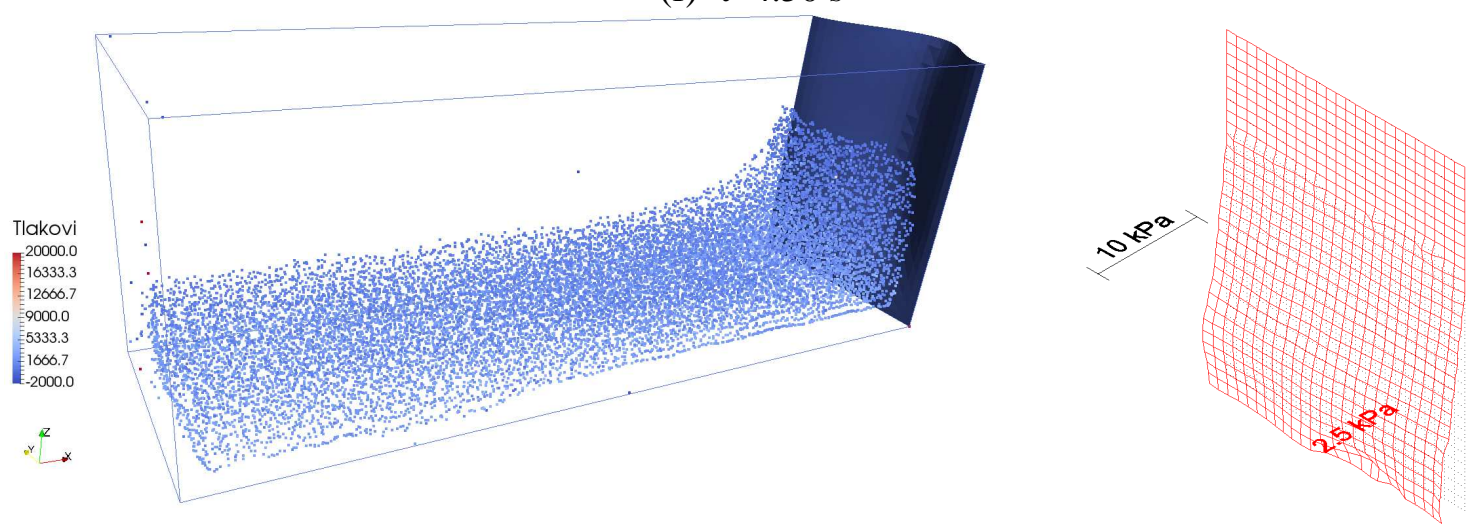

(g) $\mathrm{t}=5.00 \mathrm{~s}$
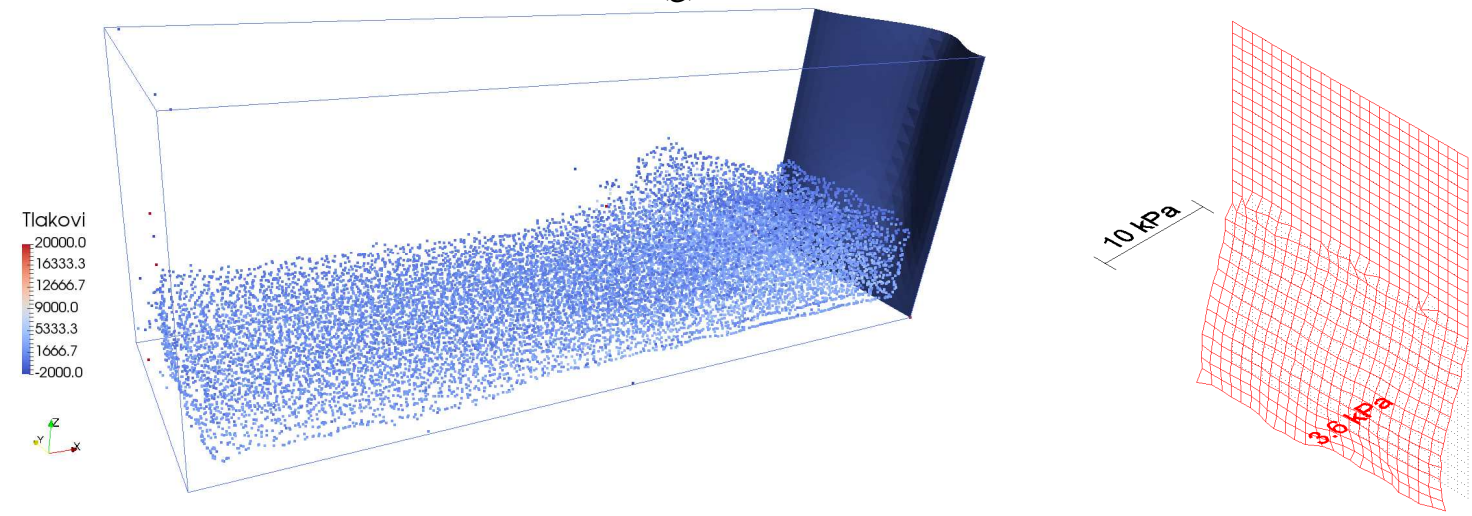

(h) $\mathrm{t}=5.50 \mathrm{~s}$ 

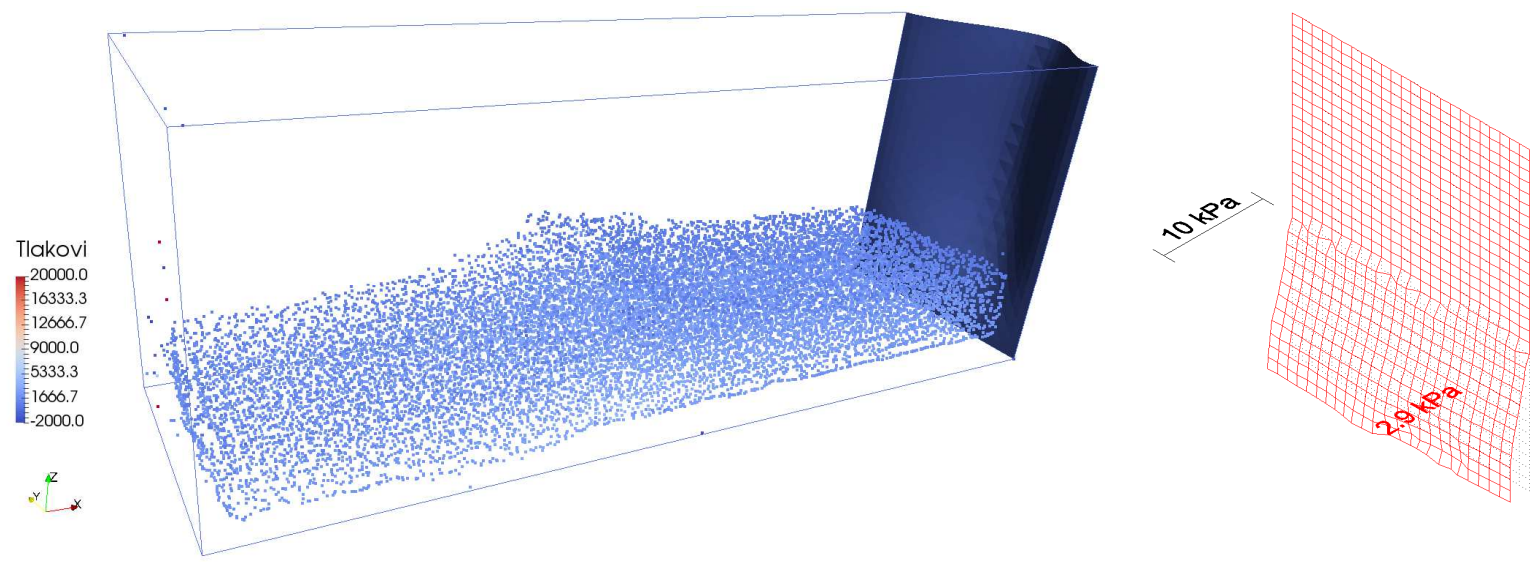

(i) $\mathrm{t}=6.00 \mathrm{~s}$

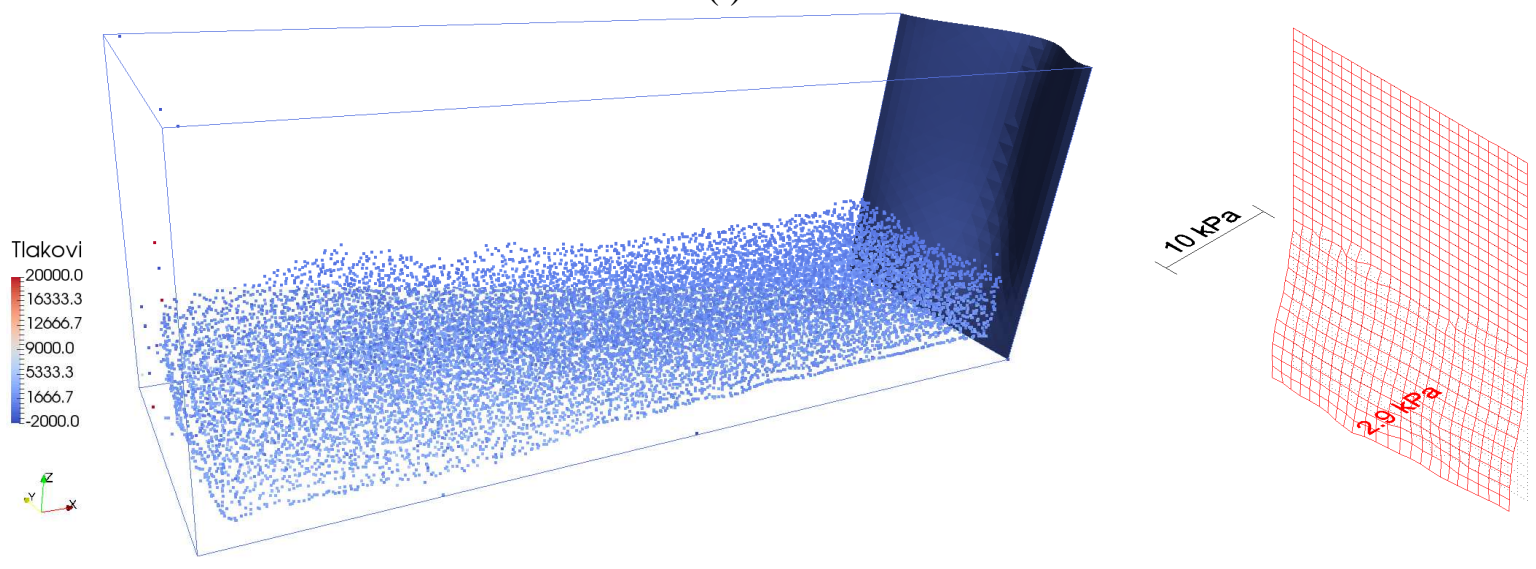

(j) $\mathrm{t}=6.50 \mathrm{~s}$

Slika 4.28. Gibanje čestica vode i tlakovi na pregradu

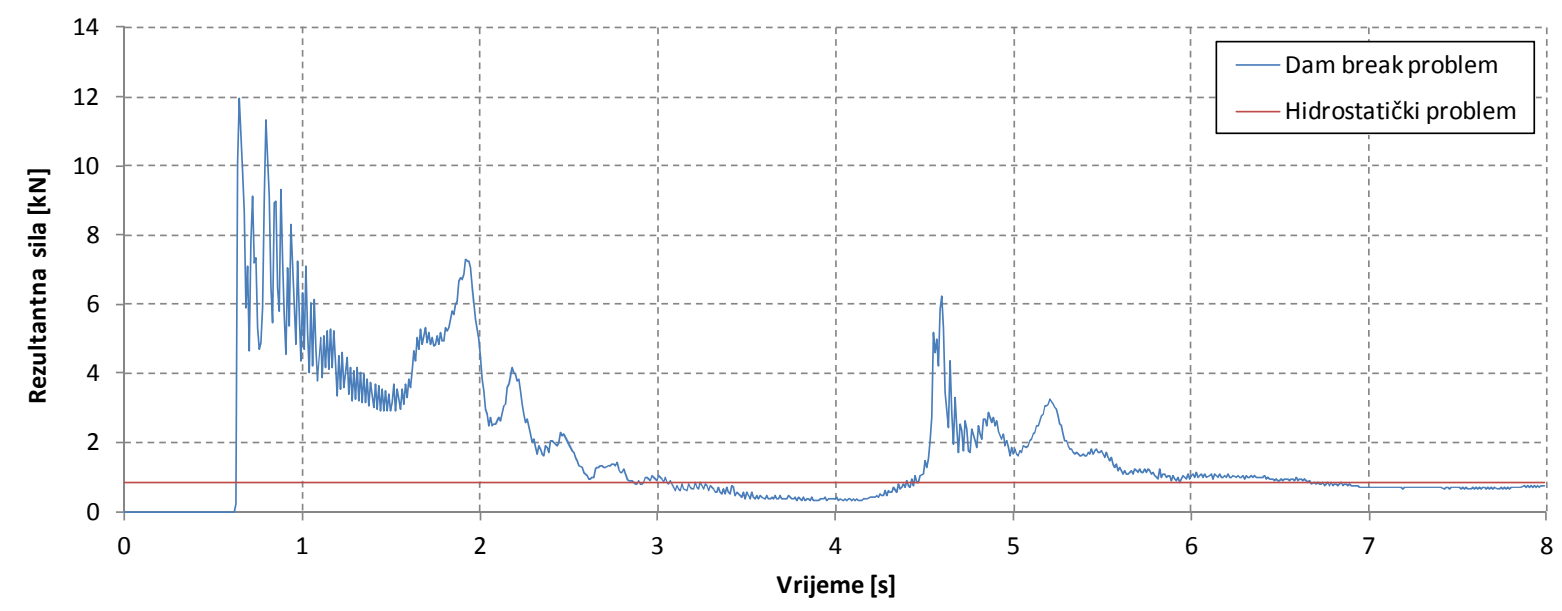

Slika 4.29. Rezultantna sila na deformabilnu pregradu 


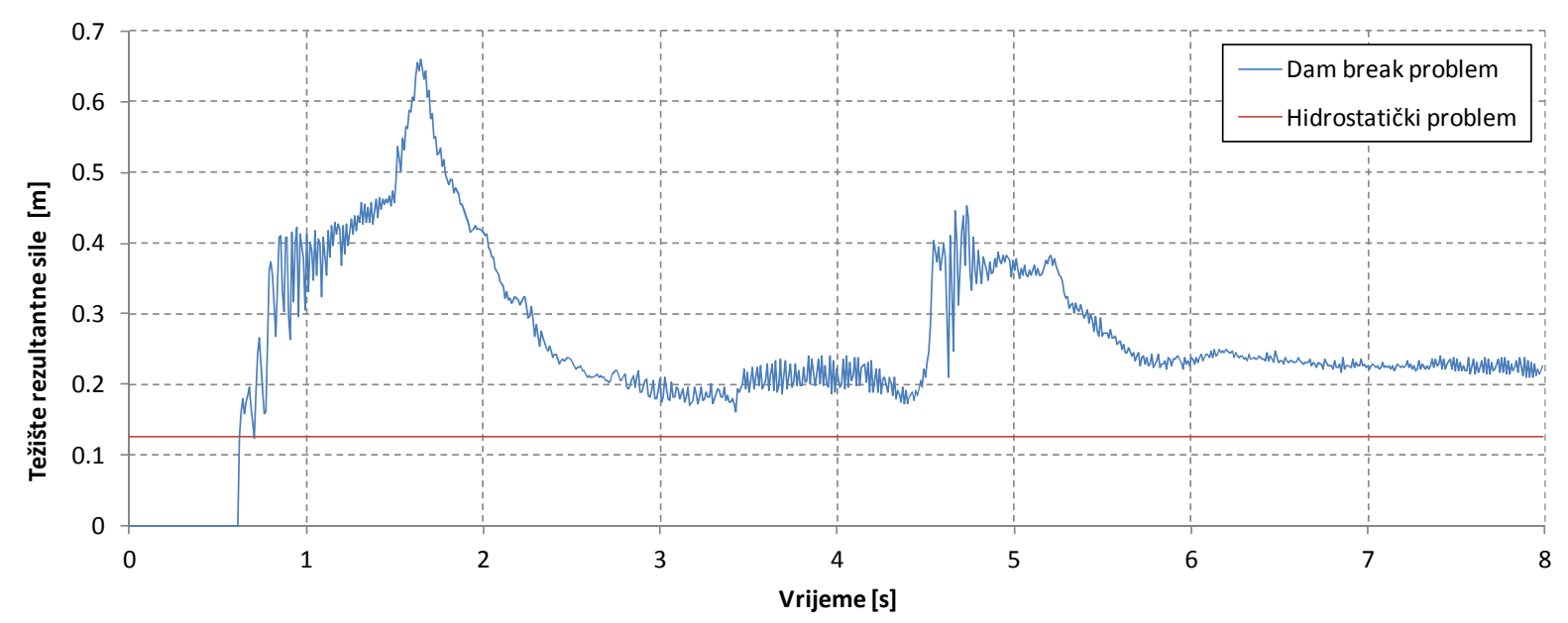

Slika 4.30. Položaj težišta rezultantne sile na pregradu u vremenu

Promjena rezultantne sile na pregradu u vremenu prikazana je na Slici 4.29, a položaj težišta rezultantne sile na Slici 4.30. Ako se uzme u obzir da je razina smirivanja vode na $\mathrm{h}=0.375 \mathrm{~m}$, te da je ukupna sila od hidrostatičkog opterećenja $0.843 \mathrm{kN}$ (težištem na 0.125 $\mathrm{m})$, primjećuje se da iznos rezultantne sile i položaj težišta sa dijagrama 4.29 i 4.30 konvergiraju prema hidrostatičkom stanju. Valja primijetiti da se u trenutku $t=8.0 \mathrm{~s}$ (kraj numeričkog testa) voda u rezervoaru još nije u potpunosti umirila.

Na Slici 4.31 su prikazani pomaci deformabilne pregrade (u milimetrima) u odabranim vremenskim trenutcima i uvećani su pet puta kako bi deformirani oblik pregrade bio vidljiviji. Na Slici 4.32 su prikazani pomaci nekih točaka deformabilne pregrade u vremenu. Odabrane točke se nalaze na sredini pregrade, a njihov točan položaj je označen na Slici 4.31. 

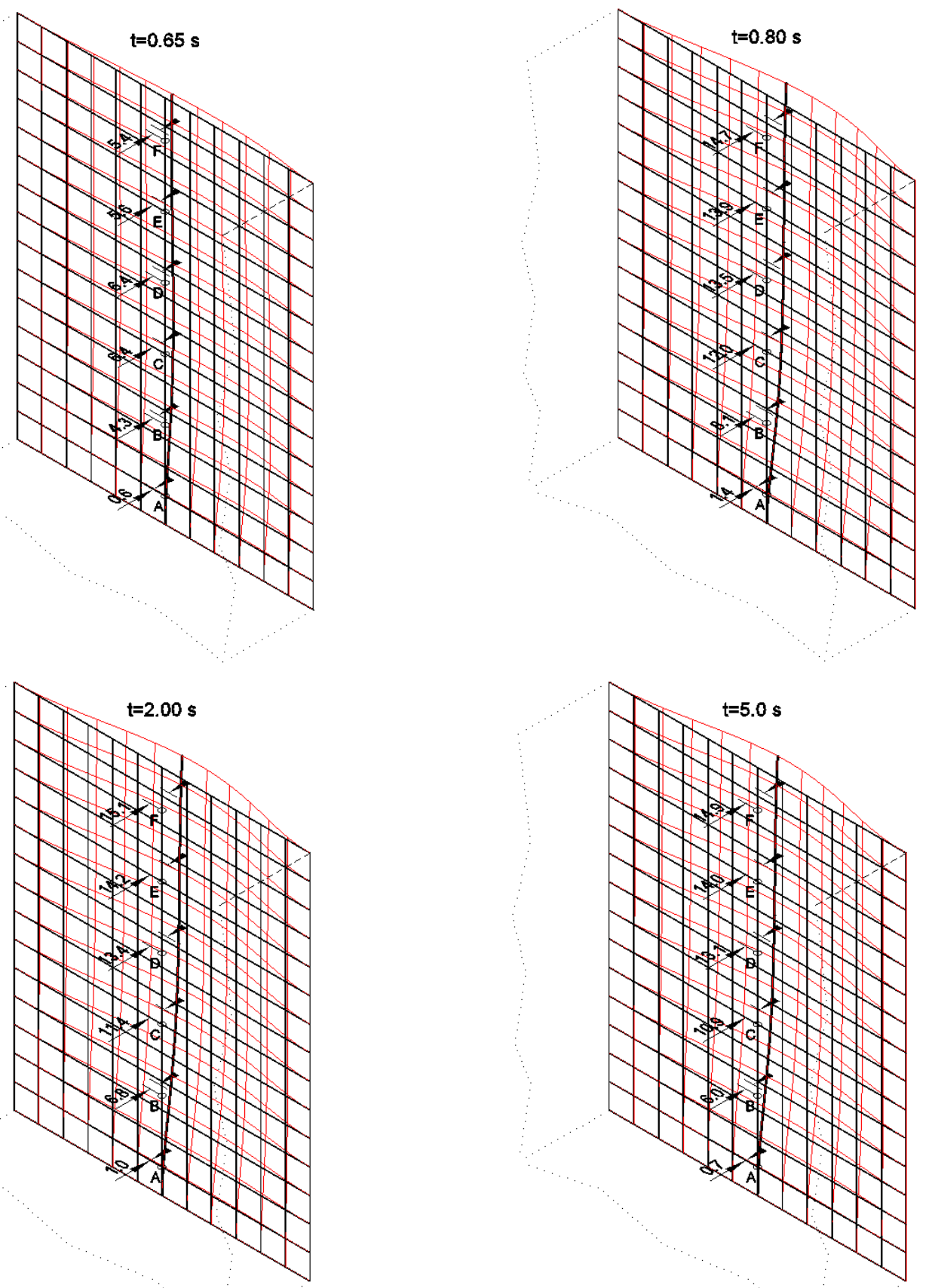

Slika 4.31. Pomaci deformabilne pregrade u odabranim vremenskim trenutcima 


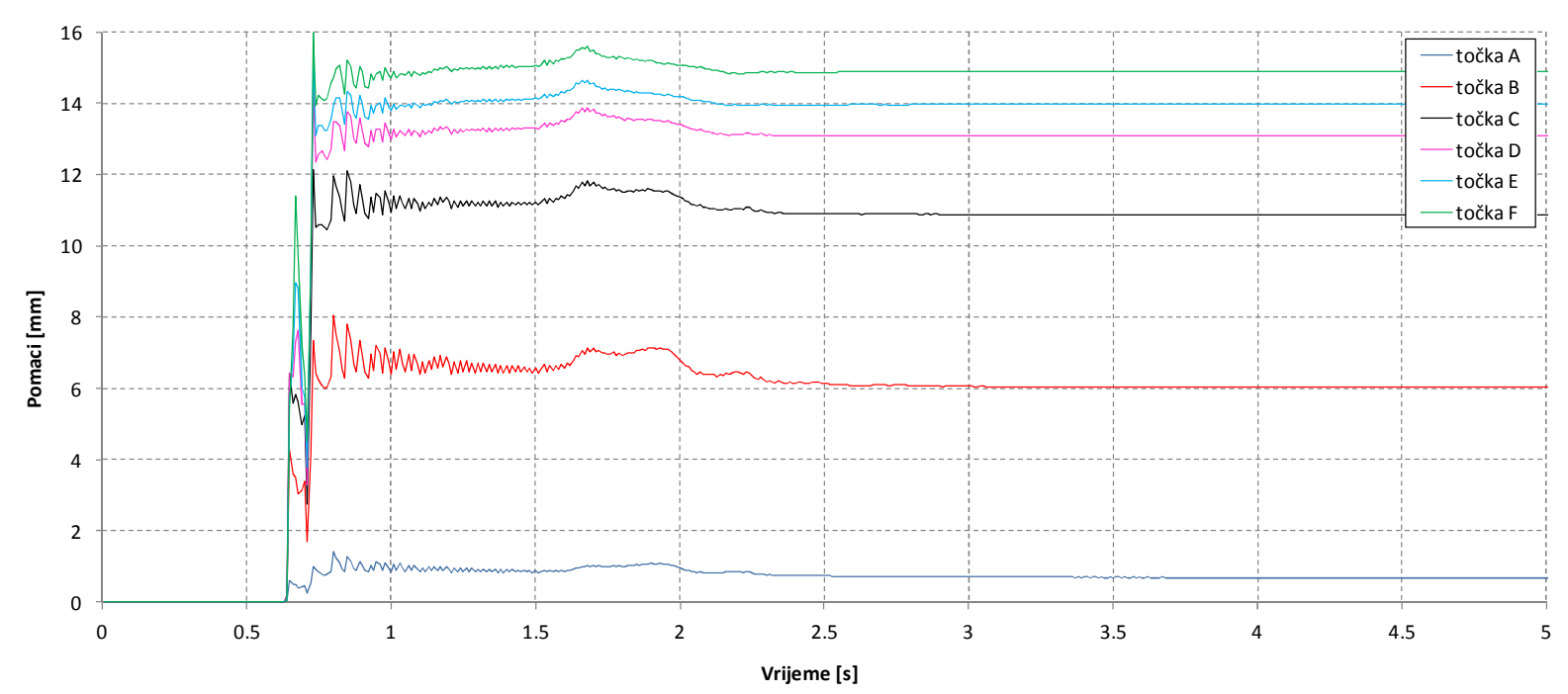

Slika 4.32. Pomaci deformabilne pregrade u vremenu

\subsubsection{Komentari}

Nakon prvog doticaja vode sa fleksibilnom pregradom $(\mathrm{t}=0.62 \mathrm{~s})$, slijedi glavni udar vodene mase u pregradu ( $\mathrm{t}=0.65 \mathrm{~s})$ koji stvara i relativno veliku deformaciju pregrade. $\mathrm{Na}$ dnu pregrade stvaraju se manje zone plastifikacije. Glavni udar vode se odbija visoko u zrak, pri čemu se jedan dio vode prelijeva preko stranica rezervoara, a pregrada se relaksira. Povratkom stupca vode u rezervoar nastaje sekundarni udar koji dodatno deformira (oslabljenu) pregradu, povećava deformaciju i proširuje plastične zone, nakon čega slijedi smirivanje vode u rezervoaru. 


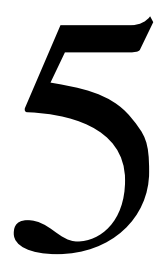

\section{EKSPERIMENTALNA ISPITIVANJA} MEĐUDJELOVANJA KONSTRUKCIJE I TEKUĆINE

\subsection{Općenito}

Eksperimentalna ispitivanja međudjelovanja konstrukcije i tekućine, koja su provedena u okviru ovoga rada, prvenstveno se odnose na rezervoare ispunjene tekućinom. Rezervoari su građevine koje se koriste u vodoopskrbnim sustavima, industriji nafte i plina, nuklearnim postrojenjima itd. Ponašanje takvih konstrukcija pri potresu još uvijek nije sasvim jasno zbog složenog relativnog gibanja tekućine $u$ odnosu na rezervoar i pojave zapljuskivanja, te dinamičkog međudjelovanja konstrukcije, tekućine i tla vezanog nelinearnog sustava. Sigurnost rezervoara pri djelovanju potresa je izuzetno važna zbog mogućih katastrofalnih posljedica njihovog rušenja. Stoga su eksperimentalna istraživanja takvih konstrukcija još uvijek dobrodošla.

Dok su dosadašnja teorijska/numerička istraživanja vezana za ponašanje i sigurnost rezervoara s tekućinom prilično zastupljena, eksperimentalna ispitivanja njihova ponašanja pri dinamičkoj pobudi su rjeđa. Najveći broj postojećih eksperimentalnih ispitivanja odnosi se na krute rezervoare različitih geometrijskih karakteristika izložene dinamičkim pobudama [129]. U nastavku su kratko prikazana neka dostupna eksperimentalna istraživanja deformabilnih rezervoara s tekućinom pri dinamičkoj pobudi.

Cho i Cho [130] su istražili ponašanje deformabilnog čeličnog rezervoara pri djelovanju potresa. Chiba [131] je istražio utjecaj elastičnog dna rezervoara na osnovne 
periode osciliranja tekućine u rezervoaru. De Angelis i dr. [132] su istražili utjecaj izolacije baze rezervoara na ponašanje rezervoara pri dinamičkoj pobudi pomoću potresne platforme. Burkacki D., Jankowski [133] su eksperimentalno istražili ponašanje skaliranog modela postojećeg čeličnog rezervoara iz Poljske. Park i dr. [134] su istražili dinamičke karakteristike kružnog deformabilnog rezervoara pri horizontalnoj dinamičkoj pobudi.

Rezervoari za tekućine u pravilu imaju veliki prvi period slobodnih oscilacija, koji je dominantno posljedica svojstava tekućine, pa su gibanja tla s velikim periodima i dugog trajanja za njih obično najnepovoljnija. Čak i pri niskim amplitudama ubrzanja, takvi potresi mogu izazvati velike pomake tekućine unutar rezervoara, formiranje valova u rezervoaru i značajnu promjenu slobodnog vodnog lica tekućine, odnosno mogu rezultirati velikim tlakovima tekućine na stijenke rezervoara koji mogu izazvati kolaps konstrukcije.

U ovom su poglavlju prikazani rezultati eksperimentalnog ispitivanja ponašanja otvorenog pravokutnog rezervoara s vodom pri potresu pomoću potresne platforme. Istražen je utjecaj krutosti stijenki rezervoara, visine vode u rezervoaru, tipa dinamičke eksitacije podloge, te perioda, amplitude i duljine trajanja harmonijske pobude. Provedena su ukupno 54 različita testa, a za svakog od njih je mjerena raspodjela tlakova na prednju stijenku rezervoara, pomaci i deformacije prednje stijenke rezervoara, te je snimano gibanje vode $\mathrm{i}$ rezervoara kamerom tijekom dinamičke eksitacije podloge. Grafički je prikazan dio rezultata istraživanja, koji su kratko diskutirani. Na kraju su navedeni najvažniji zaključci istraživanja.

Glavni cilj provedenog istraživanja je doprinos poznavanju ponašanja otvorenog pravokutnog rezervoara pri potresima kod kojih dolazi do značajnog gibanja vode u rezervoaru, tj. do pojave zapljuskivanja. Jedan od ciljeva provedenih eksperimentalnih ispitivanja je i stvaranje eksperimentalne baze podataka za provjeru razvijenog numeričkog modela za simulaciju ponašanja međudjelovanja konstrukcije i tekućine u dinamičkim uvjetima. 


\subsection{Podaci o ispitanim uzorcima rezervoara}

Testirana su tri skalirana otvorena pravokutna rezervoara s različitim stijenkama (Slika 5.1). Rezervoari R1 i R2 imaju prednju stijenku od tankog čeličnog lima, dok su im ostale sijenke krute. Rezervoar R3 ima sve stijenke krute. Debljina lima prednje stijenke rezervoara R1 je $1 \mathrm{~mm}$, a prednje stijenke rezervoara R2 $2 \mathrm{~mm}$. Dakle, odnos krutosti ovih stijenki na uzdužnu silu iznosi 1:2, a na savijanje 1:8. Krute stijenke svih rezervoara su debljine $10 \mathrm{~cm}$. Izvedene su od betona visoke čvrstoće i armirane obostrano s visokim postotkom armature. Unutrašnje dimenzije svih rezervoara su jednake: dužina $2400 \mathrm{~mm}$, širina $800 \mathrm{~mm}$ i visina 1000 mm. Rezervoar R3 je simetričan, dok su rezervoari R1 i R2 uzdužno nesimetrični.

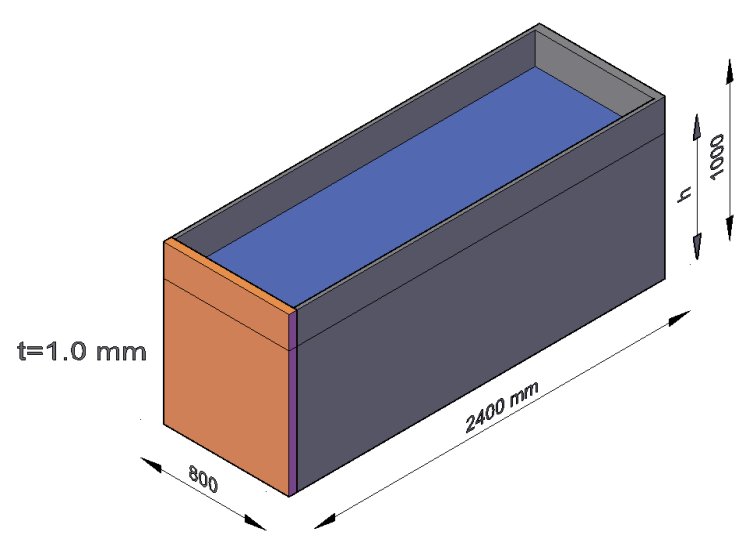

(a) Rezervoar R1

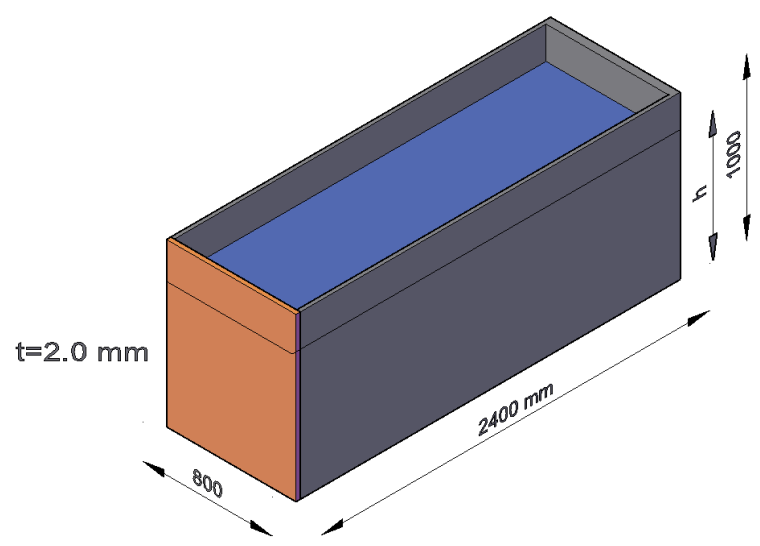

(b) Rezervoar R2

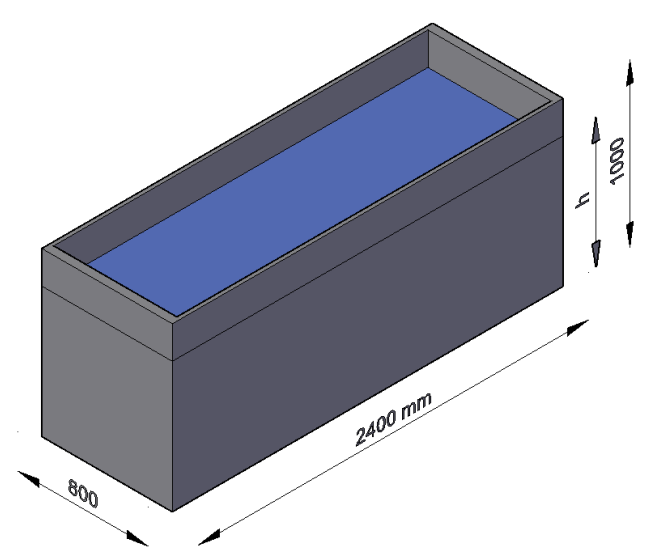

(c) Rezervoar R3

Slika 5.1. Testirani rezervoari

Rezervoari su ispunjeni vodom $\mathrm{u}$ visini h i ispitivani su na ubrzanje podloge $\mathrm{u}$ smjeru duže stijenke rezervoara. Prednja stijenka rezervoara je usvojena s različitim krutostima, kako bi se istražio utjecaj međudjelovanja vode s deformabilnom konstrukcijom. Čelična stijenka je kruto uklještena u betonske stijeke rezervoara. Sve unutarnje plohe stijenki rezervoara su ravne i glatke. Dno rezervoara je fiksirano za vrh potresne platforme. 
Ispitana jednoosna vlačna čvrstoća čeličnog lima iznosi $365 \mathrm{MPa}$, granica tečenje 245 MPa i modul elastičnosti $205 \mathrm{GPa}$ [135]. Prilikom svih ispitivanja, naprezanja čeličnog lima su bila u elastičnom području. Korištena je voda iz gradskog vodovoda, čija je temperatura prilikom ispitivanja iznosila prosječno oko $22{ }^{\circ} \mathrm{C}$. Fotografija rezervoara R2 spremnog za ispitivanje prikazana je na Slici 5.2.

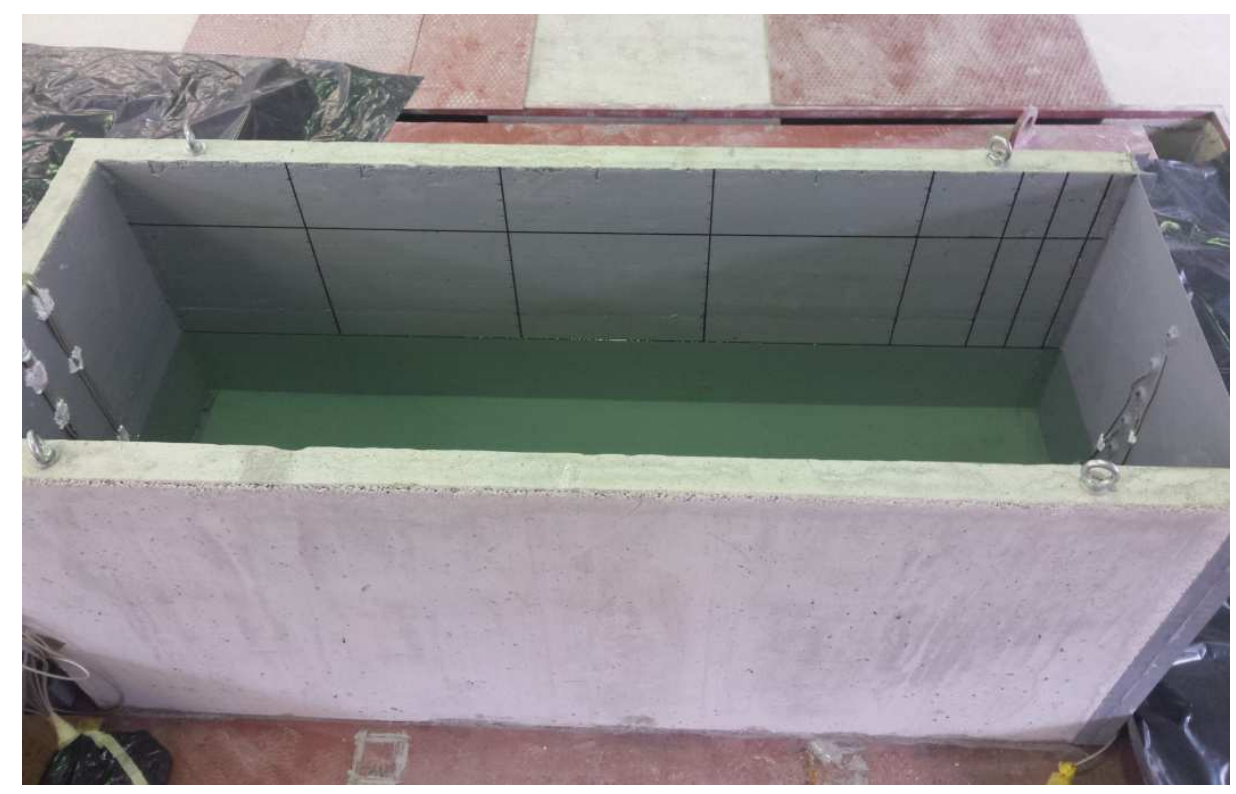

Slika 5.2. Fotografija rezervoara $R 2$ spremnog za ispitivanje 


\subsection{Dinamičke pobude}

Rezervoari su ispitivani na tri različita ubrzanja potresne platforme (Slika 5.3). Harmonijsko ubrzanje (Slika 5.3a) je tijekom vremena $\mathrm{T}_{e}=\mathrm{nT}_{\mathrm{p}}$ definirano s klasičnom sinusnom funkcijom $a=a_{0} \sin \left(t / T_{p}\right)$, gdje je a ubrzanje $u$ vremenu $t, T_{p}$ period pobude, $T_{e}$ trajanje pobude, $n$ prirodni broj $\mathrm{i} \mathrm{a}_{0}$ maksimalno ubrzanje. Od vremena $\mathrm{t}_{0}$ do $\mathrm{t}_{\mathrm{a}}$ maksimalno ubrzanje $\mathrm{a}_{0}$ raste, a od vremena $\mathrm{t}_{\mathrm{b}}$ do $\mathrm{t}_{\mathrm{c}}$ pada po kubnoj funkciji. Umjetni akcelerogram (Slika 5.3b) s maksimalnim ubrzanjem $a_{0}$ konstruiran je za elastični spektar odgovora prema [136], za tlo kategorija A. N-E akcelerogram potresa Petrovac, Crna Gora [137] skaliran je na maksimalno ubrzanje $\mathrm{a}_{0}$ (Slika 5.3c).

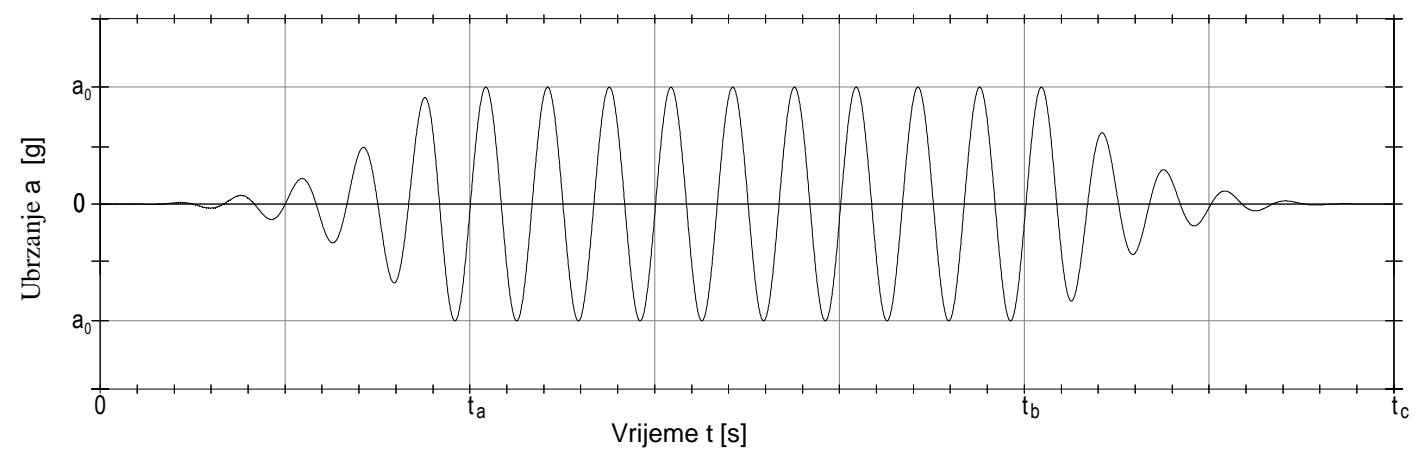

(a) Harmonijsko ubrzanje

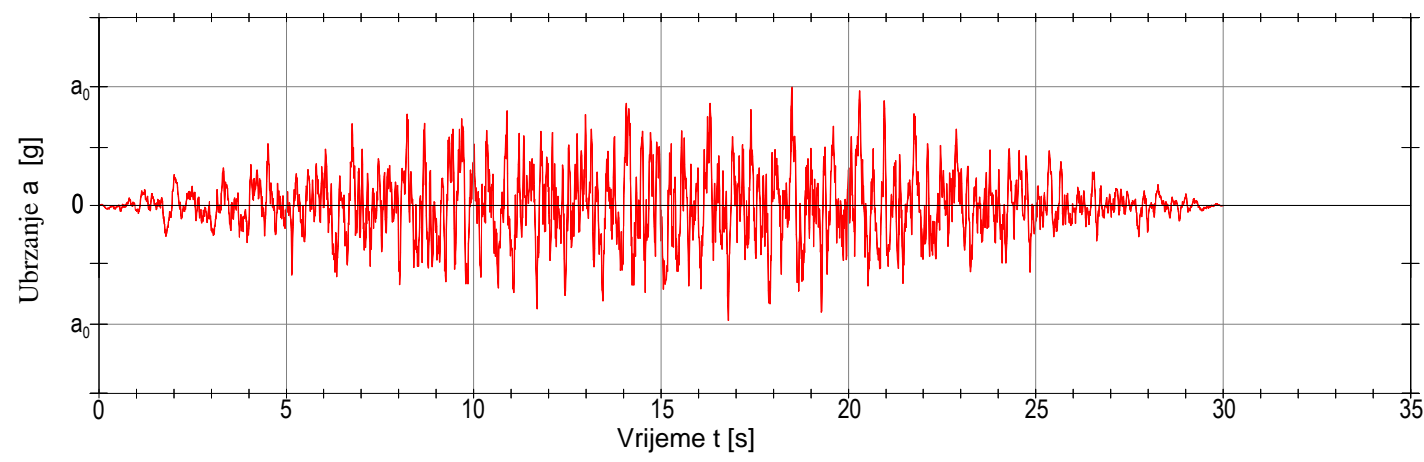

(b) Umjetni akcelerogram [136]

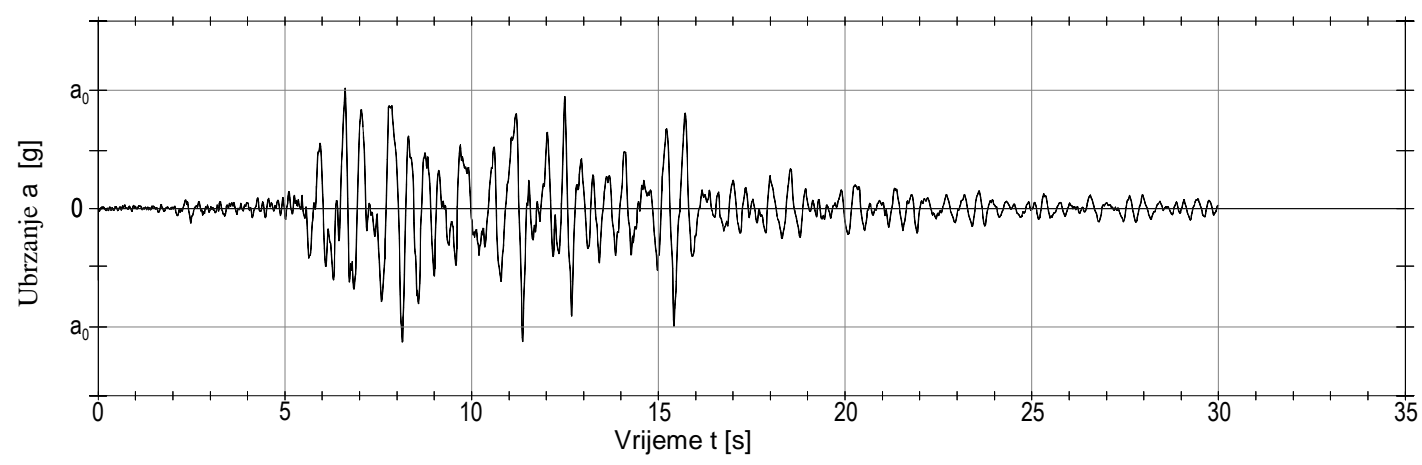

(c) N-E akcelerogram potresa Petrovac [137]

Slika 5.3. Razmatrana ubrzanja podloge 


\subsection{Mjerene veličine}

Za svaki test, mjereni su ukupni tlakovi vode p (statički i dinamički) na prednju stijenku rezervoara u deset točaka po visini rezervoara (Slika 5.4a), horizontalni pomaci čeličnog lima u dvije točke po visini prednje stijenke (Slika 5.4b), te poprečne horizontalne deformacije čeličnog lima u dvije točke po visini prednje stijenke (Slika 5.4c). S dvije digitalne kamere snimano je gibanje sustava voda-rezervoar za svaki test, odnosno praćena je promjena razine vode u rezervoaru (Slika 5.4d).

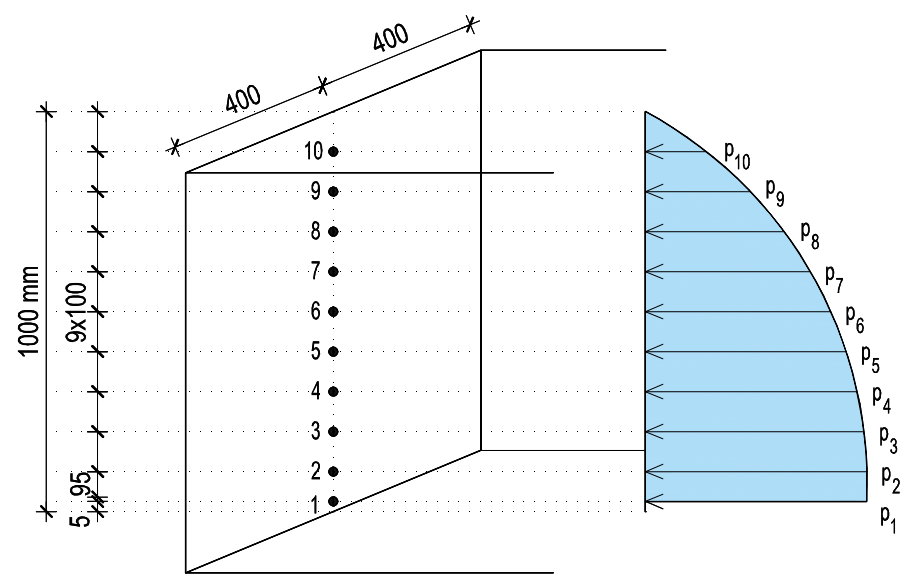

(a) Tlakovi vode na prednju stijenku $\mathrm{p}_{1}-\mathrm{p}_{10}$

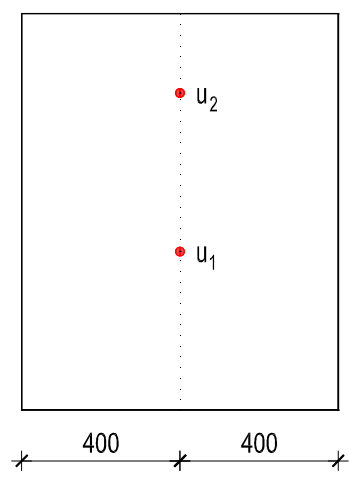

(b) Pomaci lima $\mathrm{u}_{1}, \mathrm{u}_{2}$

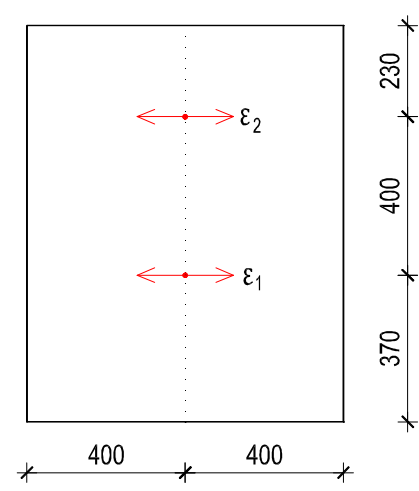

(c) Deformacije lima $\varepsilon_{1}, \varepsilon_{2}$

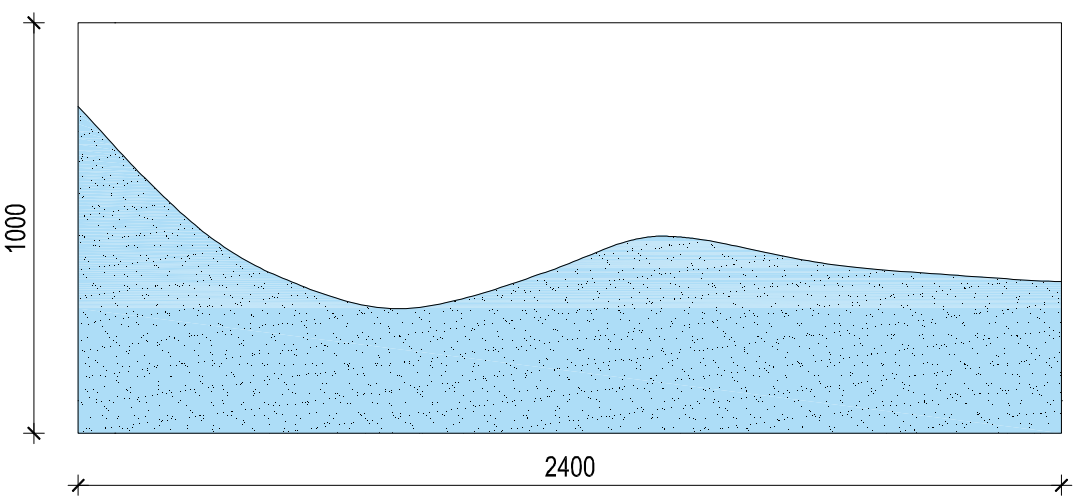

(d) Razina vode

Slika 5.4. Mjerene veličine 
Iz izmjerenih tlakova vode $\mathrm{p}_{1}-\mathrm{p}_{10}$ izračunata je rezultantna sila vode na prednju stijenku rezervoara $H_{w}$ i njen položaj $\eta$ u odnosu na visinu vode u rezervoaru pri mirovanju $h$ (Slika 5.5). $H_{w}$ i $\eta$ su izračunati u osi rezervoara na širini $100 \mathrm{~mm}$, uz pretpostavku linearne interpolacije/ekstrapolacije između izmjerenih tlakova vode. Podaci vezani za $\mathrm{H}_{w}$ i $\eta$ su važni s inženjerskog stajališta jer definiraju ukupnu silu vode na pregradu i njeno težište djelovanja, tj. definiraju odnose hidrodinamičkog stanja prema početnom hidrostatičkom stanju.

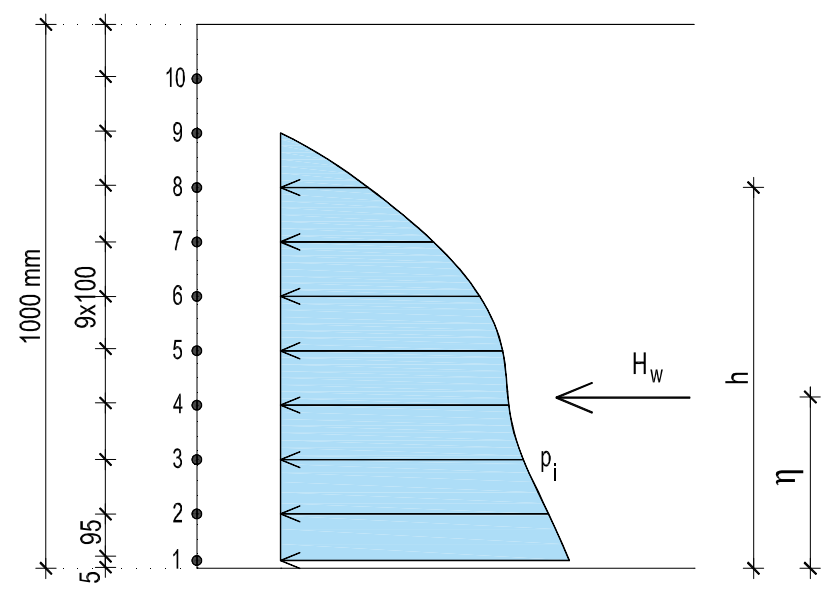

Slika 5.5. Rezultantna sila na čeonu stijenku $\left(\mathrm{H}_{\mathrm{w}}\right)$ i njeno težište $(\eta)$

\subsection{Mjerna oprema}

Ispitivanje rezervoara obavljeno je pomoću potresne platforme na Sveučilištu u Splitu, Fakultet građevinarstva, arhitekture i geodezije.

Tlakovi vode su mjereni s elektrootpornim mjeračima tlaka, tip 1451, proizvođača DSPM Industria (Slika 5.6).

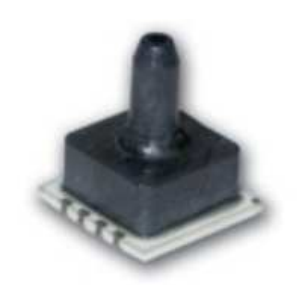

Slika 5.6. Senzor tlaka

Pomaci su mjereni pomoću analognih senzora pomaka - potenciometra (eng. analog displacement sensor) tip PB-25-S10-N0S-10C proizvođača Uni Measure, raspona $640 \mathrm{~mm}$ (Slika 5.7). 


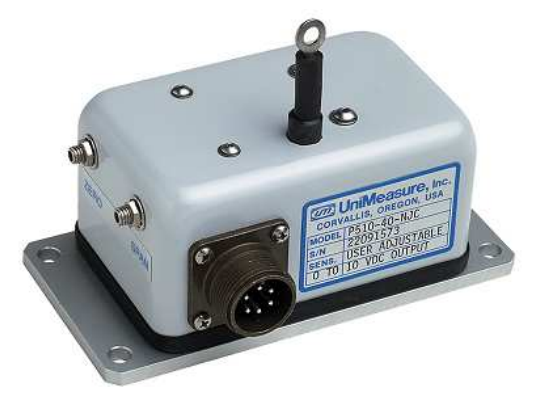

Slika 5.7. Senzori pomaka

Deformacije čeličnog lima su mjerene s elektrootpornim mjernim trakama (tenzometrima) s dužinom baze $6 \mathrm{~mm}$, tip 6/120 LY11 proizvođača HBM (Slika 5.8). Korištene mjerne trake su početnog električnog otpora $120 \Omega$, a maksimalno izduženje im je $\pm 5 \%( \pm 50000 \mu \mathrm{m} / \mathrm{m})$.

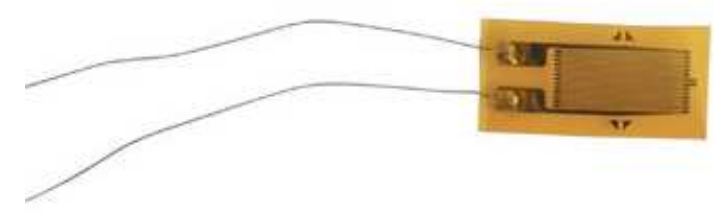

Slika 5.8. Senzori deformacija

Gibanje vode i rezervoara snimano je s dvije digitalne kamere.

\subsection{Rezultati istraživanja}

Prikazani su samo neki rezultati istraživanja, koji su ukratko diskutirani. Rezultati su prikazani prema istraživanim utjecajima. Zbog nakane za što većim brojem grafičkih priloga i što konciznijeg prikaza rada, neki su crteži morali biti umanjeni i smanjene preglednosti.

\subsubsection{Osnovni periodi slobodnih oscilacija razmatranih rezervoara}

Kao što je prethodno navedeno, glavni cilj ovog ispitivanja je istraživanje tlaka vode na stijenke fiksnog rezervoara pri velikim pomacima vode u rezervoaru. Pomaci su najveći pri djelovanju rezonantnih ubrzanja tla. Zato su za analizirane rezervoare prema Slici 5.1, s visinama vode $\mathrm{h}=0.8 \mathrm{~m}, 0.6 \mathrm{~m}$ i $0.4 \mathrm{~m}$, najprije eksperimentalno utvrđena prva tri perioda slobodnih oscilacija sustava voda-rezervoar pomoću mjerenja tlaka vode na prednjoj stijenki rezervoara (Tablica 5.1). Izmjerene vrijednosti za slučaj krutog rezervoara R3 se vrlo dobro slažu s teorijskim vrijednostima [138] navedenim u zagradama. Rezervoari R1 i R2 s deformabilnom prednjom stijenkom imaju samo neznatno veće periode slobodnih oscilacija 
od rezervoara R3, što je posljedica daleko manje krutosti vode u odnosu na krutost prednje stijenke rezervoara.

Tablica 5.1. Periodi slobodnih oscilacija sustava voda - rezervoar

\begin{tabular}{ccccc}
\hline Rezervoar & Visina vode $\mathrm{h}[\mathrm{m}]$ & $\mathrm{T}_{1}[\mathrm{~s}]$ & $\mathrm{T}_{2}[\mathrm{~s}]$ & $\mathrm{T}_{3}[\mathrm{~s}]$ \\
\hline \hline $\mathrm{R} 1$ & 0.4 & 2.58 & 1.44 & 1.10 \\
& 0.6 & 2.22 & 1.36 & 1.06 \\
& 0.8 & 2.03 & 1.31 & 1.03 \\
\hline $\mathrm{R} 2$ & 0.4 & 2.55 & 1.42 & 1.08 \\
& 0.6 & 2.18 & 1.32 & 1.05 \\
& 0.8 & 2.01 & 1.28 & 1.04 \\
$\mathrm{R} 3$ & 0.4 & $2.54\left(2.53^{*}\right)$ & $1.40\left(1.40^{*}\right)$ & $1.07\left(1.06^{*}\right)$ \\
& 0.6 & $2.17\left(2.16^{*}\right)$ & $1.30\left(1.39^{*}\right)$ & $1.04\left(1.02^{*}\right)$ \\
& 0.8 & $2.00\left(1.98^{*}\right)$ & $1.27\left(1.26^{*}\right)$ & $1.02\left(1.01^{*}\right)$ \\
\hline
\end{tabular}

(*) teorijske vrijednosti [138]

Kad se rezervoar s vodom izloži eksitaciji podloge čiji je period blizak nekom od prvih perioda sustava, dolazi do rezonantnog gibanja vode u rezervoaru. Naime, dolazi do formiranja visokih valova koji zapljuskuju stijenke rezervoara. Već pri relativno malim ubrzanjima i uz čak nisku razinu vode h, može doći do izdizanja vrha zapljuskujućeg vodnog vala visoko iznad vrha rezervoara i izlijevanje vode iz rezervoara. Ovo je osobito izraženo za pobude $\mathrm{s}$ periodom bliskim $\mathrm{T}_{1}$. Za razmatrane visine vode $\mathrm{h} \mathrm{u}$ rezervoaru, $\mathrm{u}$ provedenim eksperimentima su odabrane takve frekvencije i ubrzanja podloge, koje su osigurale velike pomake vode i njeno visoko uzdizanje bez prelijevanja rezervoara (osim u slučaju navedenom u točki 5.6.3). Zbog male viskoznosti vode i malog trenja između vode i stijenki rezervoara, izraženo je vrlo sporo prigušenje gibanja vode u rezervoaru za rezonantne eksitacije podloge.

Analizirani skalirani rezervoari imaju visok $\mathrm{T}_{1}$, koji je kod realnih rezervoara još veći. Realni akcelerogrami potresa $\mathrm{u}$ vremenskom intervalu najvećih ubrzanja redovito imaju značajno niži predominantni period od $\mathrm{T}_{1}$. Međutim, $\mathrm{u}$ seizmičkim područjima $\mathrm{s}$ debelim naslagama mekog tla i osobito nakon najjačih ubrzanja, predominantni period potresa može biti blizak nekom od prvih perioda slobodnih oscilacija sustava tekućina-rezervoar. 


\subsubsection{Utjecaj tipa/krutosti rezervoara}

Jedan od ciljeva ovoga rada je istraživanje utjecaja deformabilnosti stijenki rezervoara na veličinu i raspodjelu hidrodinamičkih tlakova vode na rezervoar. Zato su pored krutog rezervoara R3 razmatrani i rezervoari R1, R2 s deformabilnom prednjom stijenkom. Utjecaj razmatranih parametara u Potpoglavljima 5.6.3.-5.6.7. također je analiziran na svim tipovima rezervoara. U nastavku su prikazani rezultati samo za jednu visinu vode $\mathrm{H}$ i jednu eksitaciju podloge. Odabrana je visina vode $\mathrm{h}=0.4 \mathrm{~m}$ i harmonijsko ubrzanje (Slika 5.3a) s a $\mathrm{a}_{0}=0.1 \mathrm{~g}$, $\mathrm{T}_{\mathrm{p}}=1 \mathrm{~s}$ i $\mathrm{T}_{\mathrm{e}}=10 \mathrm{~s}$.

Najveći prirast tlakova vode na prednju stijenku rezervoara bio je za kruti rezervoar R3 (Slika 5.9). Povećanje tlaka $\mathrm{p}_{1}$ pri dnu rezervoara u odnosu na hidrostatički tlak za R3 iznosi oko $45 \%$, za R2 oko $41 \%$ i za R1 oko $20 \%$. Očito je da se sa smanjenjem krutosti stijenke rezervoara smanjuju hidrodinamički tlakovi vode koji na njih djeluju.

Ukupna sila od tlaka vode $\mathrm{H}_{\mathrm{w}}$ (statička i dinamička) na prednju stijenku rezervoara (Slika 5.10), tj. integral tlaka vode po visini rezervoara, zornije ilustrira prethodnu konstataciju. U odnosu na statičku silu, hidrodinamička sila na rezervoar R3 maksimalno je povećana za oko $52 \%$, za rezervoara R2 oko $43 \%$ i za rezervoar R1 oko $31 \%$. Najveće oscilacije sile bile su također kod rezervoara R3.

Težište ukupne sile vode $\eta$ na prednju stijenku rezervoara (Slika 5.11) pokazuje da pri dinamičkoj pobudi dolazi do njegovog značajnog izdizanja u odnosu na težište hidrostatičke sile. Kod rezervoara R2 izdizanje težišta ukupne sile je iznosilo oko 40\%, kod R3 oko 36\% i kod R1 oko $35 \%$ u odnosu na težište hidrostatičke sile.

Horizontalni pomaci rezervoara $\mathrm{u}_{1}, \mathrm{u}_{2}$ (Slika 5.12) su veći za rezervoar $\mathrm{R} 1$ nego za rezervoar R2, pri čemu je ta razlika izraženija kod $\mathrm{u}_{2}$. Maksimalni horizontalni pomak $\mathrm{u}_{1} \mathrm{za}$ rezervoar R1 povećan je za oko $38 \%$ u odnosu na pomak od statičkog tlaka vode, a za rezervoar R2 također oko 38\%. Maksimalni horizontalni pomak $\mathrm{u}_{2}$ za rezervoar R1 povećan je za oko $180 \%$ u odnosu na pomak od hidrostatičkog tlaka vode, a za rezervoar R2 oko $48 \%$.

Dijagrami deformacija $\varepsilon_{1}, \varepsilon_{2}$ (Slika 5.13) su po obliku analogni dijagramima pomaka $\mathrm{u}_{1}, \mathrm{u}_{2}$. Deformacija $\varepsilon_{1}$ je veća kod rezervoara R2 nego kod rezervoara R1, dok je deformacija $\varepsilon_{2}$ veća kod rezervoara R1 nego kod rezervoara R2. 


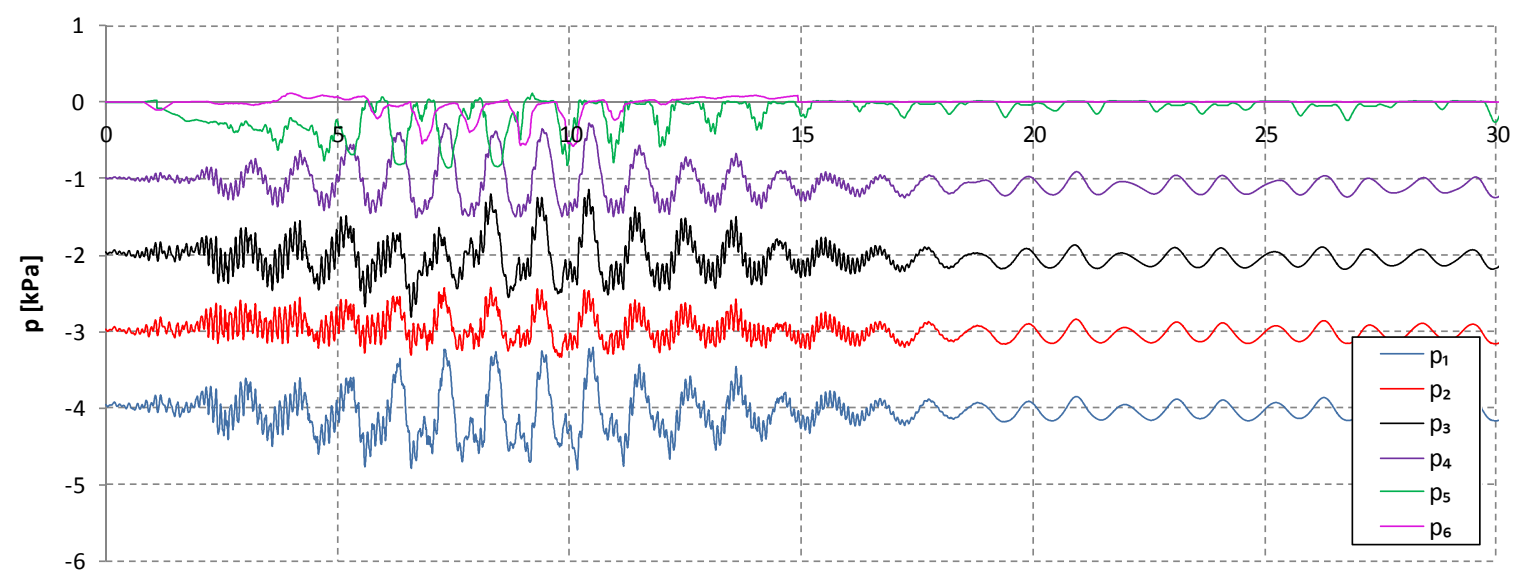

$t[s]$

(a) Rezervoar $\mathrm{R}_{1}$

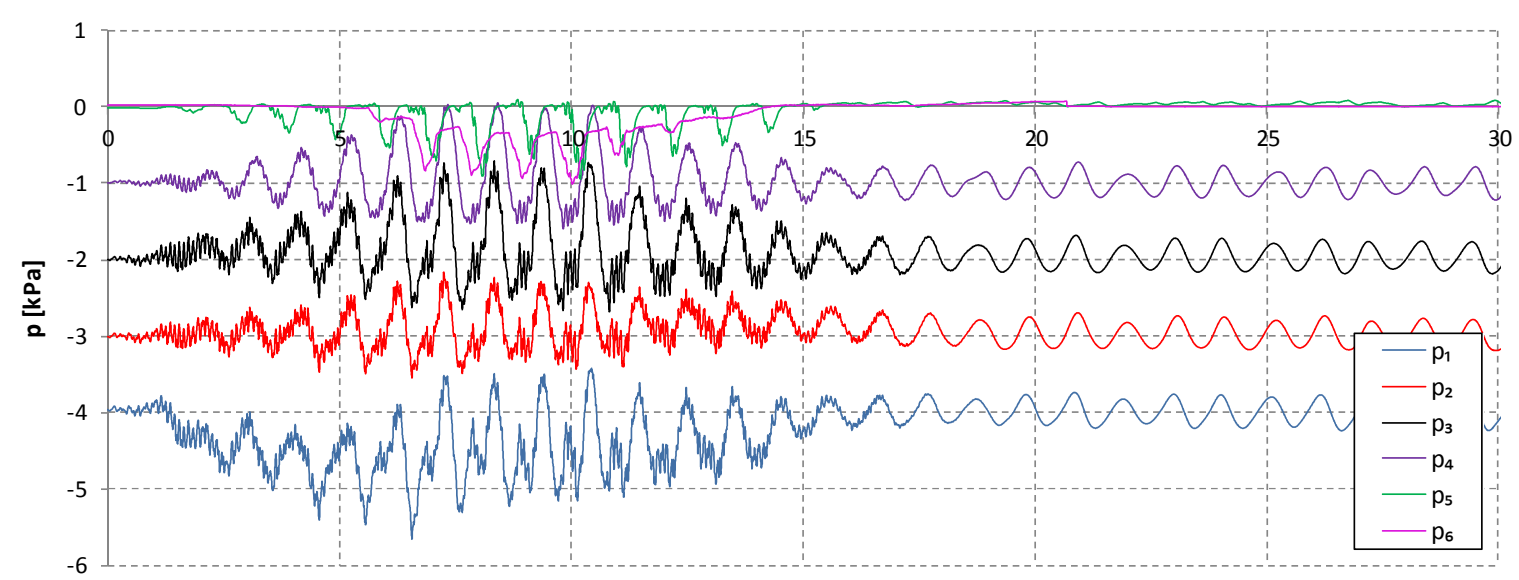

$\mathrm{t}[\mathrm{s}]$

(b) Rezervoar $\mathrm{R}_{2}$

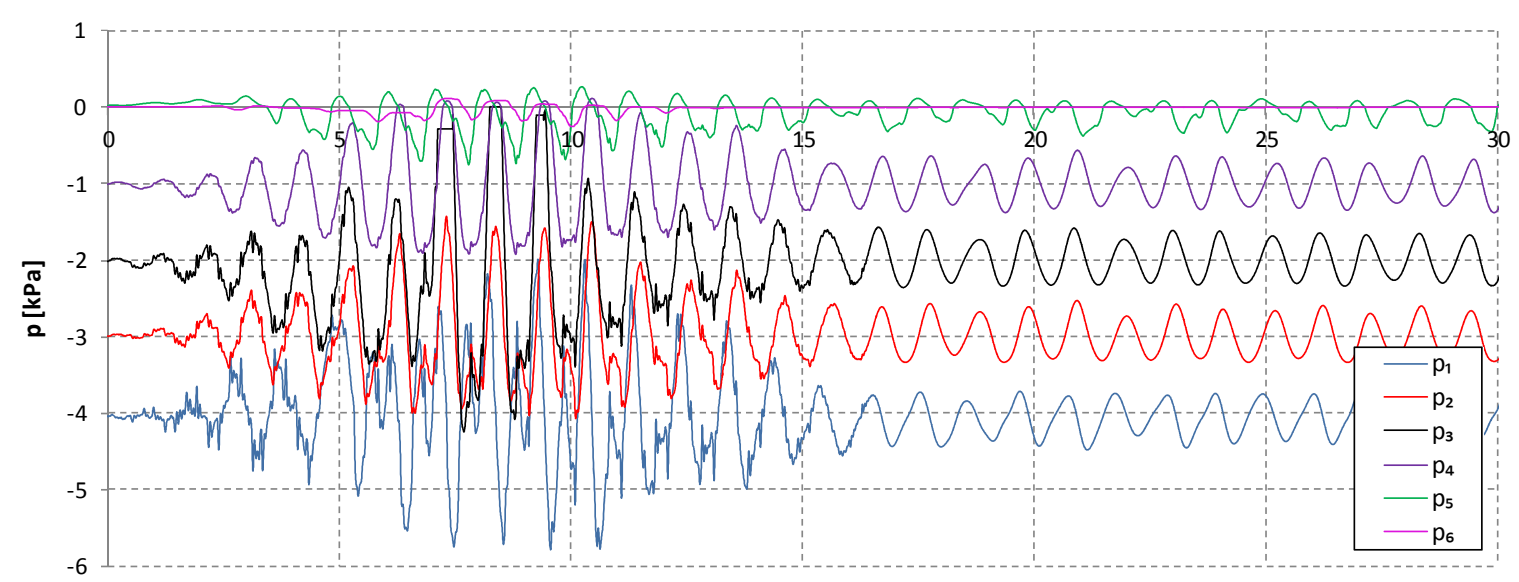

$t[s]$

(c) Rezervoar $\mathrm{R}_{3}$

Slika 5.9. Tlakovi vode na prednju stijenku rezervoara 


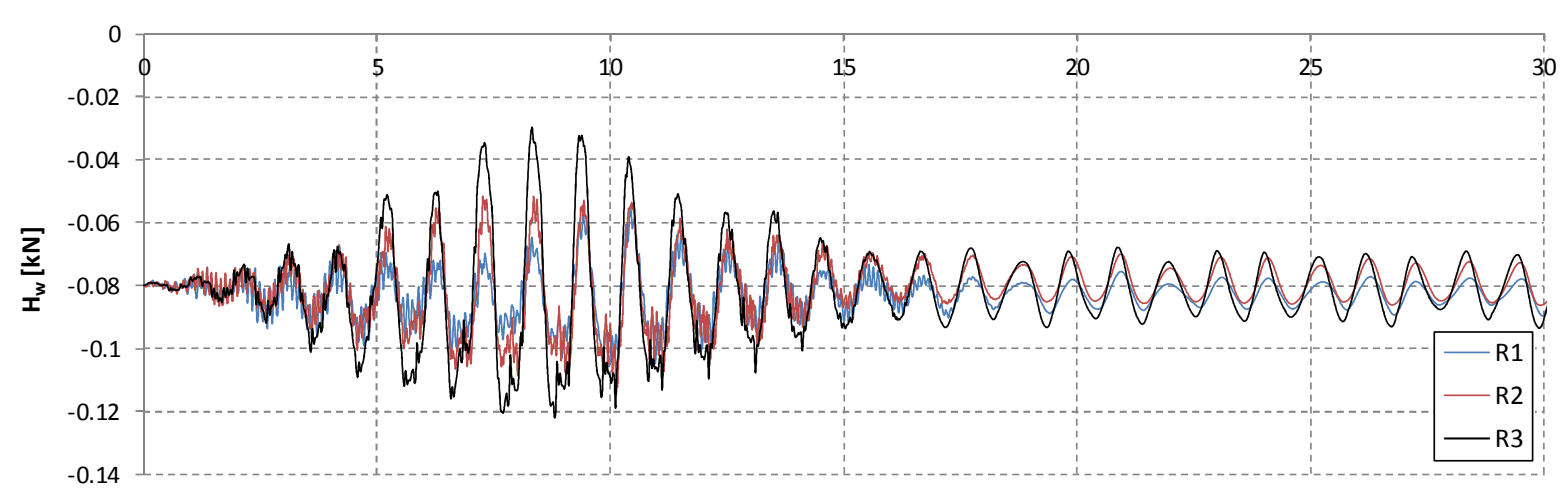

$\mathrm{t}[\mathrm{s}]$

Slika 5.10. Rezultantna sila vode na prednju stijenku rezervoara

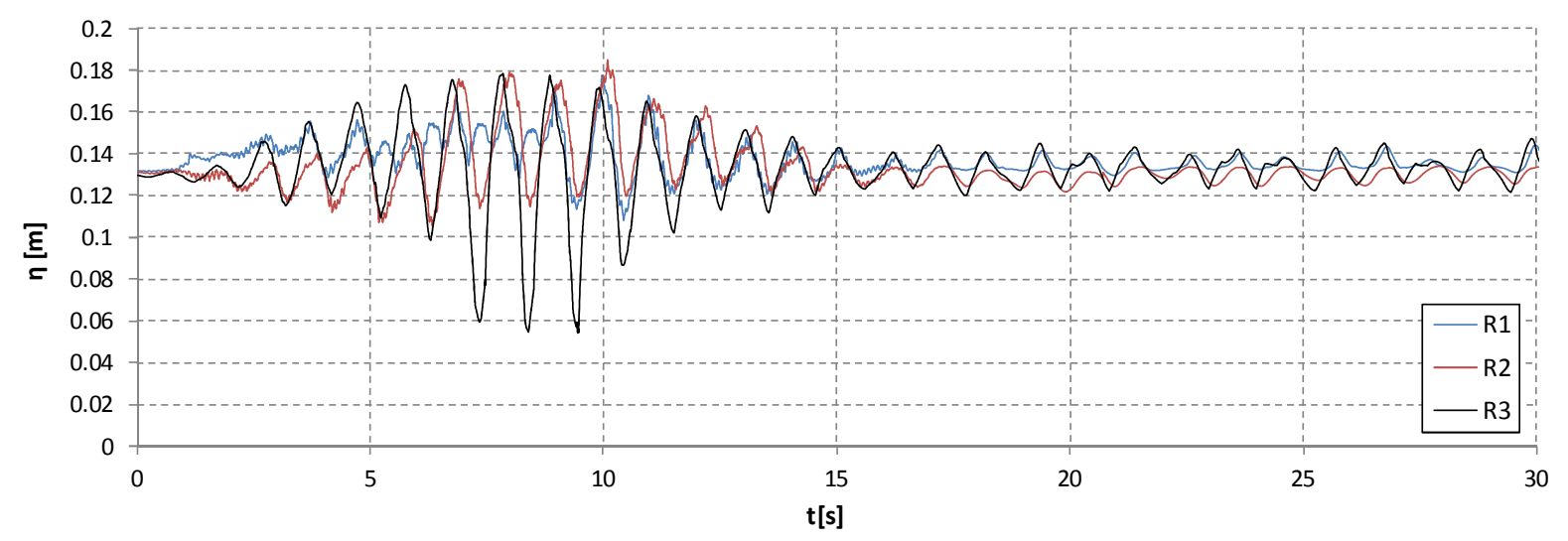

Slika 5.11. Težište rezultantne sile na prednju stijenku rezervoara 


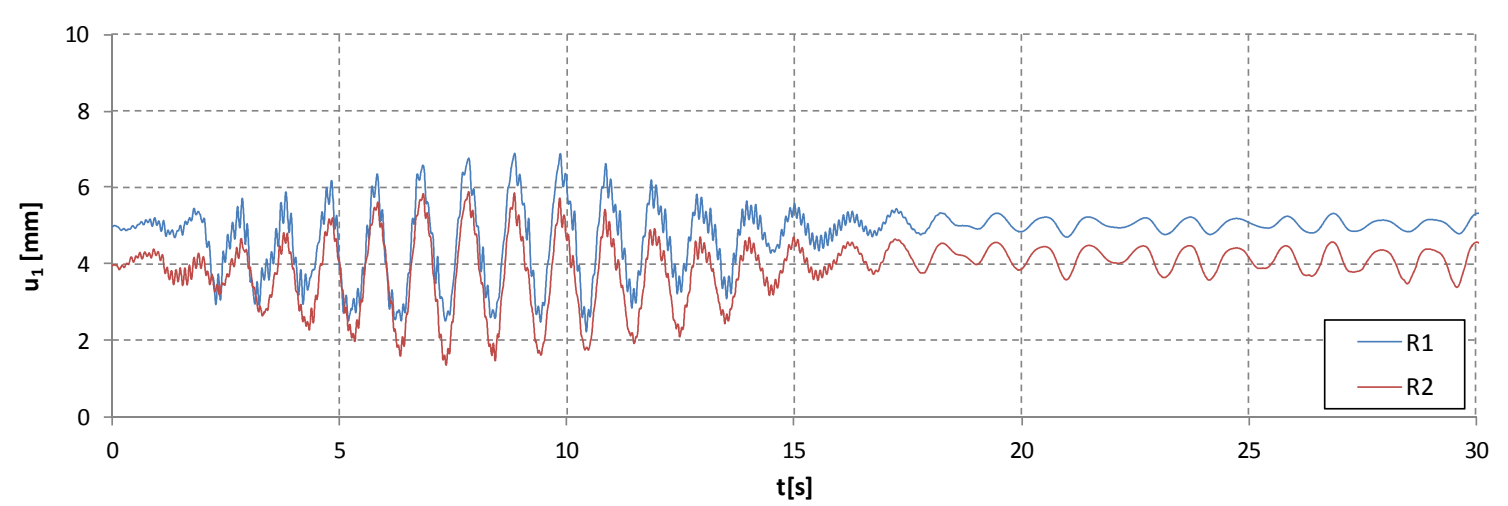

(a) Pomak $u_{1}$

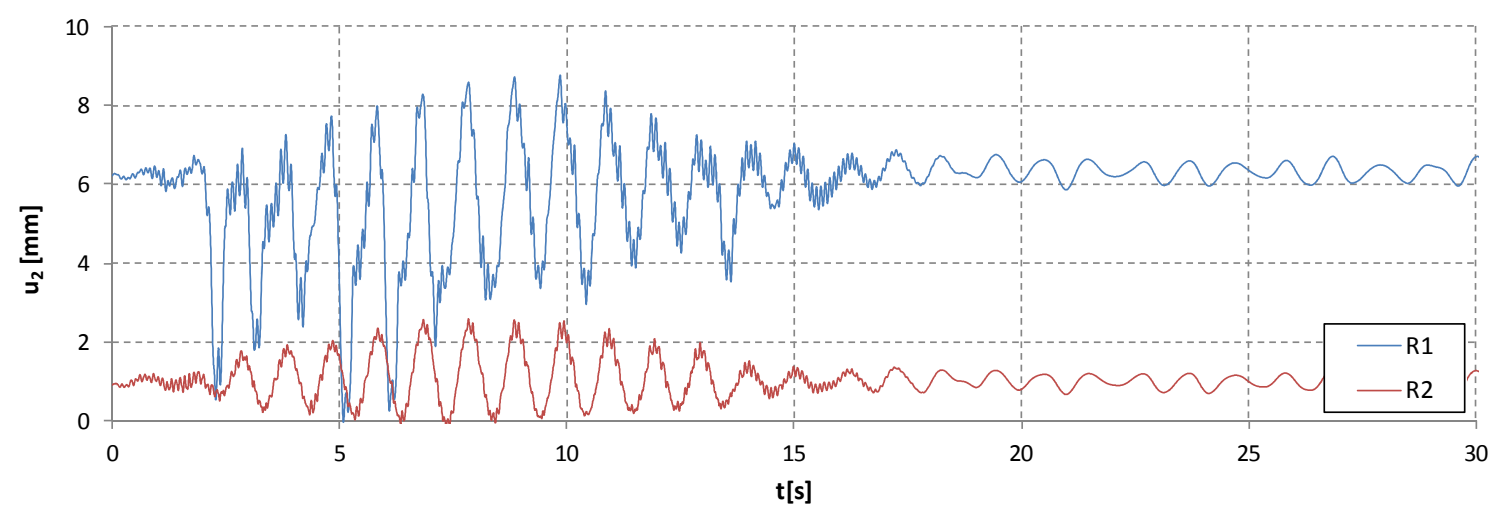

(b) Pomak $\mathrm{u}_{2}$

Slika 5.12. Horizontalni pomak prednje stijenke rezervoara

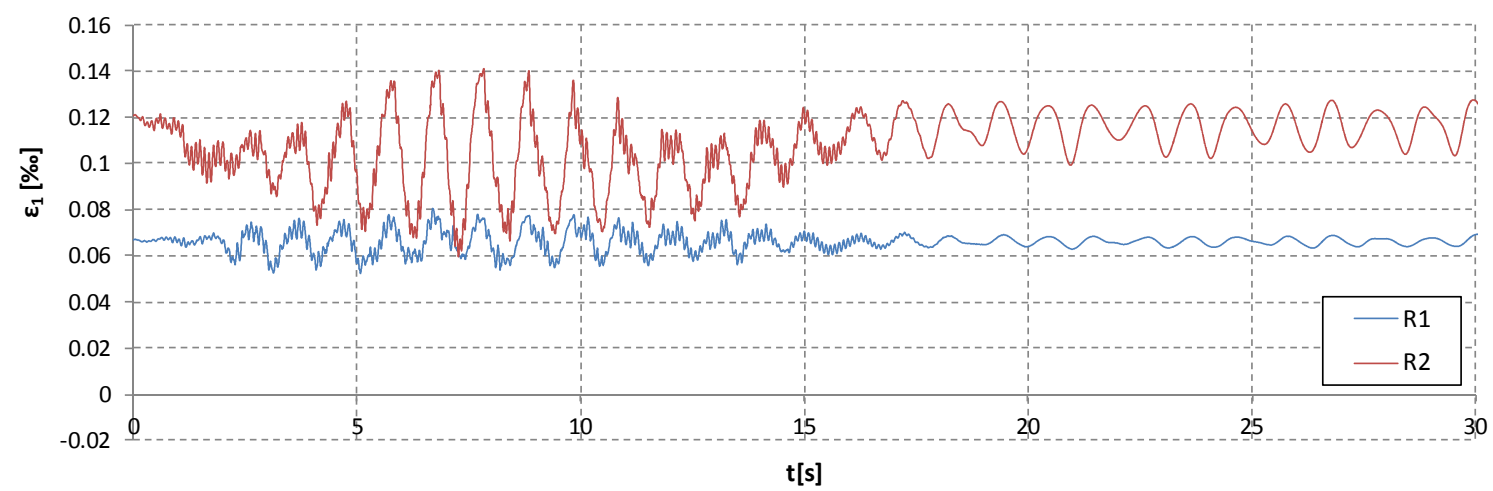

(a) Deformacija $\varepsilon_{1}$

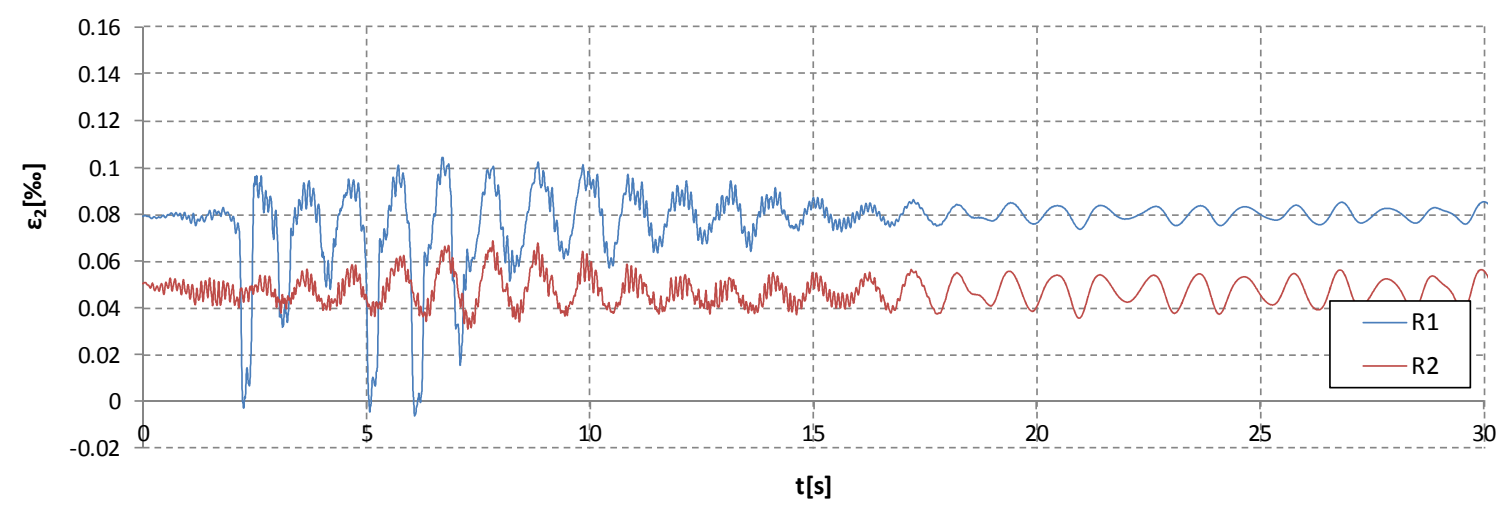

(b) Deformacija $\varepsilon_{2}$

Slika 5.13. Deformacija prednje stijenke rezervoara 


\subsubsection{Utjecaj perioda harmonijske pobude}

Prikazani su samo rezultati za kruti rezervoar $\mathrm{R} 3 \mathrm{~s}$ visinom vode $\mathrm{h}=0.4 \mathrm{~m}$, koji je izložen harmonijskoj pobudi prema Slici 5.3. sa $\mathrm{a}_{0}=0.5 \mathrm{~g}$ i $\mathrm{T}_{\mathrm{e}}=10 \mathrm{~T}_{\mathrm{p}}$. Varirana su tri perioda pobude: $T_{p}=0.5 \mathrm{~s}, T_{p}=1.0 \mathrm{~s}$ i $T_{p}=2.5 \mathrm{~s}$. Pri tome je $T_{p}=2.5 \mathrm{~s}$ gotovo jednak $T_{1}$, a $T_{p}=1.0 \mathrm{~s} \mathrm{je}$ blizak $\mathrm{T}_{3}$ za ovaj rezervoar (Tablica 5.1). Usvojena je niska razina vode u rezervoaru $\mathrm{i}$ vrlo malo maksimalno ubrzanje harmonijske pobude jer je pri tome za $\mathrm{T}=2.5 \mathrm{~s}$ očekivan visoki vodni val u rezervoaru, čak i za ovo stanje. Kako je za $T_{p}=2.5 \mathrm{~s}$ zaista vrlo brzo došlo do vrlo visokog uzdizanja vode i njenog prelijevanja preko rezervoara, potresna platforma je isključena prije $\mathrm{T}_{\mathrm{e}}=10 \mathrm{~T}_{\mathrm{p}}, \mathrm{tj}$. $\operatorname{kod} \mathrm{t}=6 \mathrm{~s}$.

Tlakovi vode na prednju stijenku rezervoara su prikazani na Slici 5.14. Za $\mathrm{T}_{\mathrm{p}}=0.5 \mathrm{~s}$ tlakovi vode vrlo malo osciliraju oko hidrostatičkih tlakova (Slika 5.14a). Nakon prestanka pobude gibanje vode se brzo prigušuje.

Za $\mathrm{T}_{\mathrm{p}}=1.0 \mathrm{~s}$ tlakovi vode su veći i osciliraju više oko hidrostatičkih vrijednosti nego za $\mathrm{T}_{\mathrm{p}}=0.5 \mathrm{~s}$ (Slika 5.14b). Pri tome se odnos ukupnog tlaka i hidrostatičkog tlaka povećava od dna prema vrhu vode u rezervoaru. Maksimalna visina vode ne doseže točku 6 na prednjoj stijenki rezervoara (Slika 5.14b), tj. nije registriran tlak vode u ovoj točki koja je $100 \mathrm{~mm}$ iznad početne razine vode. Nakon prestanka pobude gibanje vode se sporo prigušuje.

$\mathrm{Za} \mathrm{T}_{\mathrm{p}}=2.5 \mathrm{~s}$ pomaci vode su vrlo veliki i dolazi do uzdizanja udarnog vodnog vala iznad vrha rezervoara. Maksimalni tlak vode pri dnu rezervoara $\mathrm{p}_{1}$ je dvostruko veći od hidrostatičkog tlaka u toj točki. Odnos ukupnog tlaka i hidrostatičkog tlaka vode povećava se od dna prema vrhu rezervoara. U točki 6 registriran je maksimalni tlak od oko -5.6 kPa, što je veće od hidrostatičkog tlaka na dnu rezervoara (oko -4.0 kPa). Hidrodinamički tlakovi vode su registrirani u svim točakama 1-10 na prednjoj stijenki rezervoara (Slika 5.14c).

Položaj vodnog lica u rezervoaru za $\mathrm{T}_{\mathrm{p}}=2.5 \mathrm{~s}$ u nekim diskretnim vremenima prikazan je na Slici 5.15. Pri t=9.4 s i t=12.2 s vidljivo je uzdizanje zapljuskujućeg vodnog vala visoko iznad vrha rezervoara.

Rezultantna sila vode na prednju stijenku rezervoara (Slika 5.16) potvrđuje njenu drastičnu ovisnost o periodu harmonijske pobude. $\mathrm{Za} \mathrm{T}_{\mathrm{p}}=0.5 \mathrm{~s}$ ona vrlo malo oscilira oko hidrostatičku sile. $\mathrm{Za} \mathrm{T}_{\mathrm{p}}=1.0 \mathrm{~s}$ ona oscilira do oko $25 \% \mathrm{u}$ odnosu na hidrostatičku silu. $\mathrm{Za}$ $\mathrm{T}_{\mathrm{p}}=2.5 \mathrm{~s}$ maksimalna sila je oko 3.7 puta veća od hidrostatičke sile.

Položaj rezultantne sile vode $\mathrm{H}_{\mathrm{w}}$ (Slika 5.16) također drastično ovisi o $\mathrm{T}_{\mathrm{p}}$. Za $\mathrm{T}_{\mathrm{p}}=0.5 \mathrm{~s}$ težište ukupne sile podudara se $\mathrm{s}$ težištem hidrostatičke sile. Za $\mathrm{T}_{\mathrm{p}}=1.0 \mathrm{~s}$ težište ukupne sile se 
podiže do oko $22 \%$ u odnosu na težište hidrostatičke sile. Za $\mathrm{T}_{\mathrm{p}}=2.5 \mathrm{~s}$ težište ukupne sile je do oko 2.85 puta više nego za hidrostatičku silu, tj. približava se početnoj visini vode $\mathrm{h}=0.4 \mathrm{~m}$.

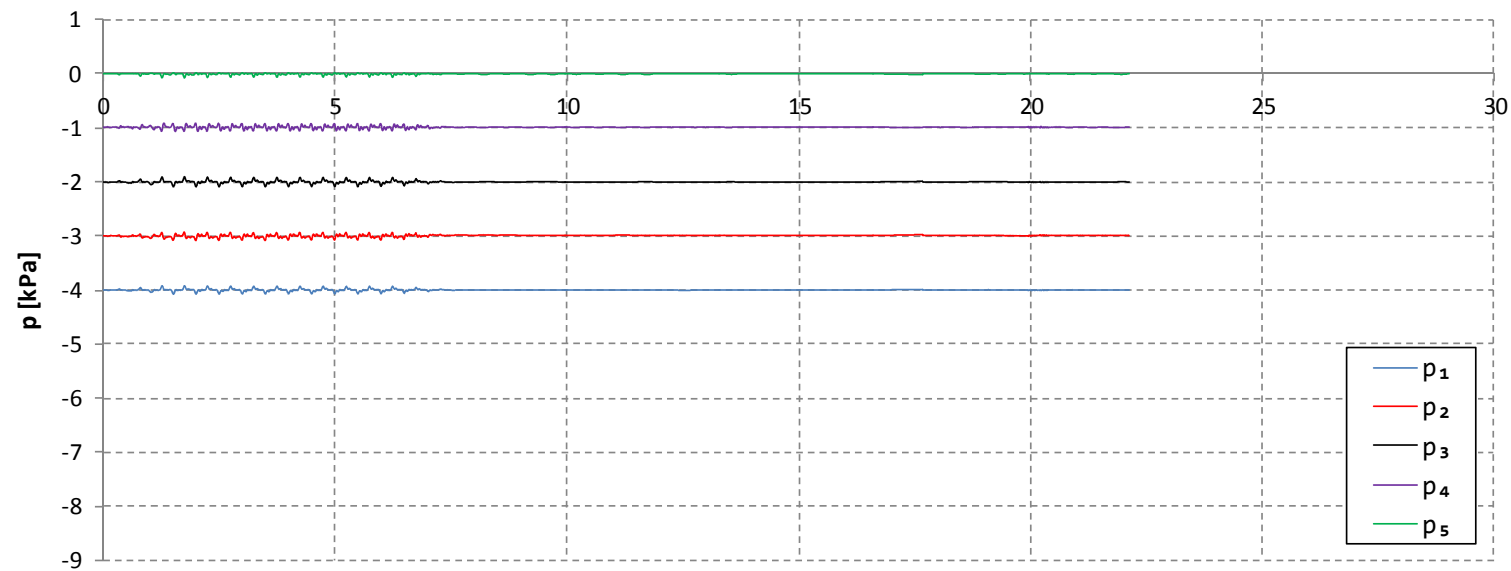

$\mathrm{t}[\mathrm{s}]$

(a) $\mathrm{T}_{\mathrm{p}}=0.5 \mathrm{~s}$

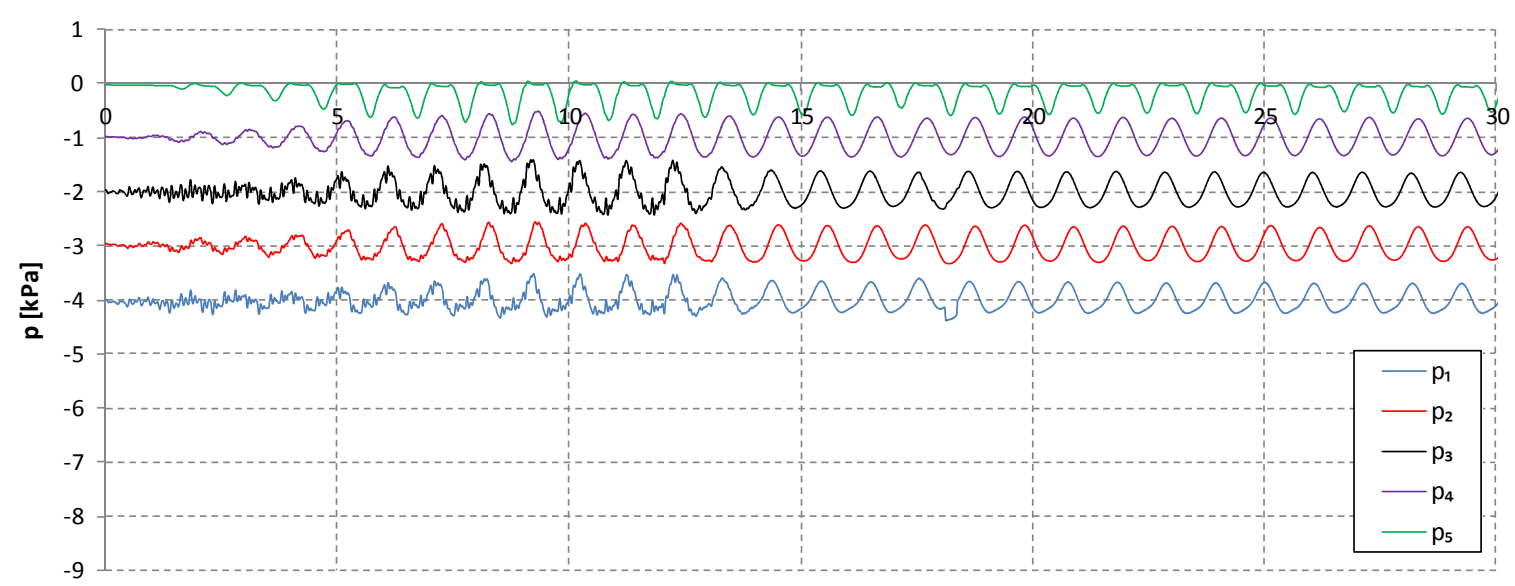

$\mathrm{t}[\mathrm{s}]$

(b) $\mathrm{T}_{\mathrm{p}}=1.0 \mathrm{~s}$

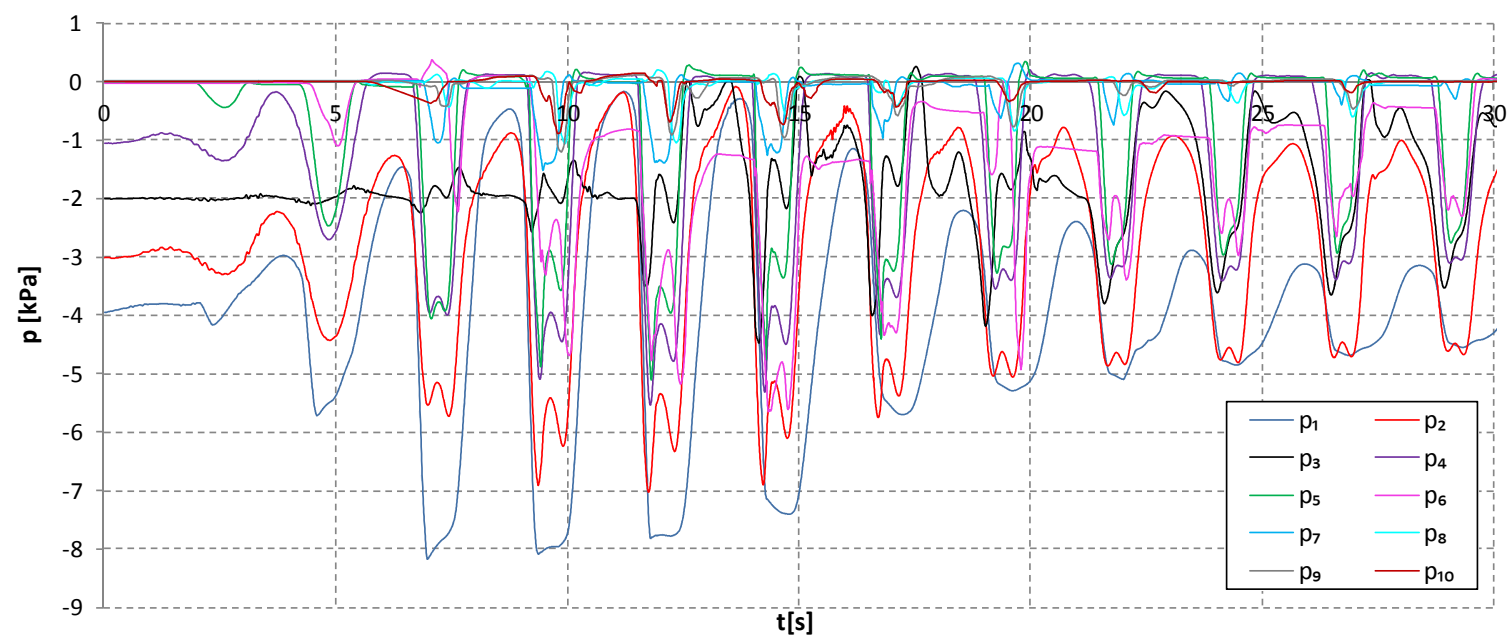

(c) $\mathrm{T}_{\mathrm{p}}=2.5 \mathrm{~s}$

Slika 5.14. Tlakovi vode na prednju stijenku rezervoara R3 


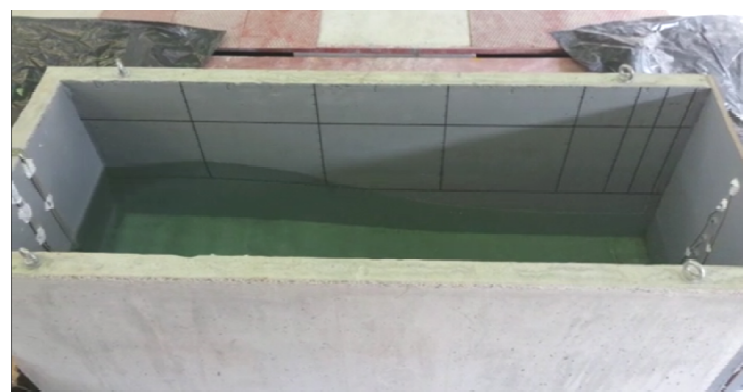

(a) $\mathrm{t}=4.0$

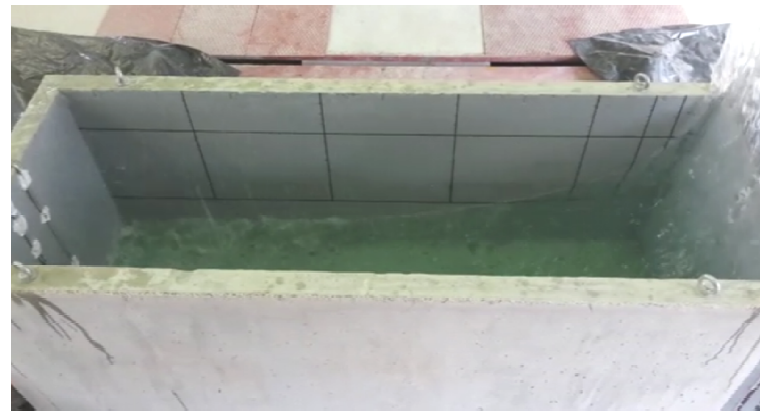

(c) $\mathrm{t}=9.5 \mathrm{~s}$

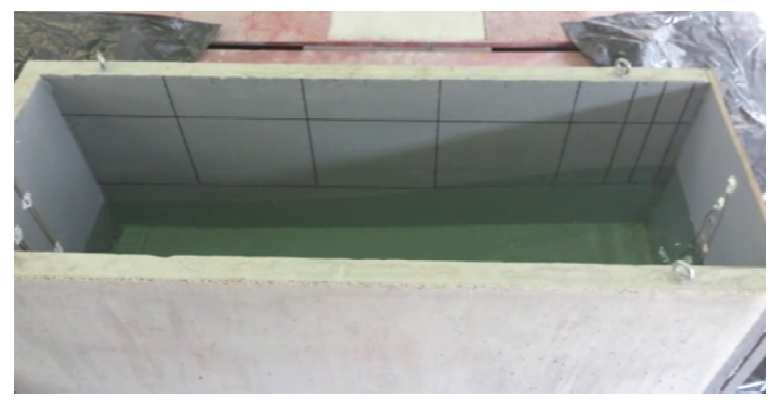

(b) $\mathrm{t}=4.5 \mathrm{~s}$

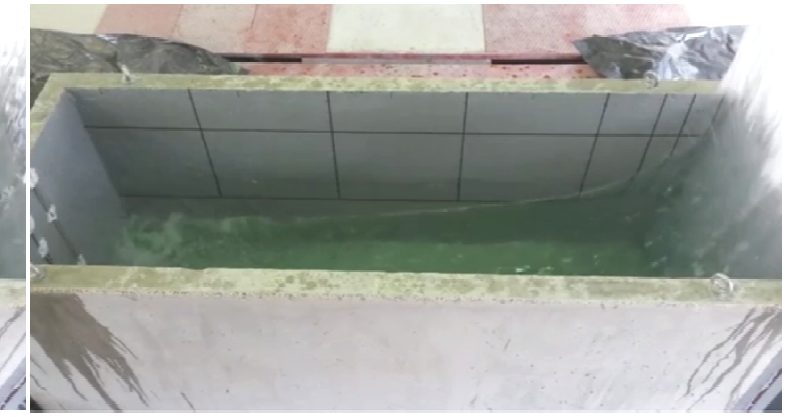

(d) $\mathrm{t}=12.0 \mathrm{~s}$

Slika 5.15. Položaj vodnog lica

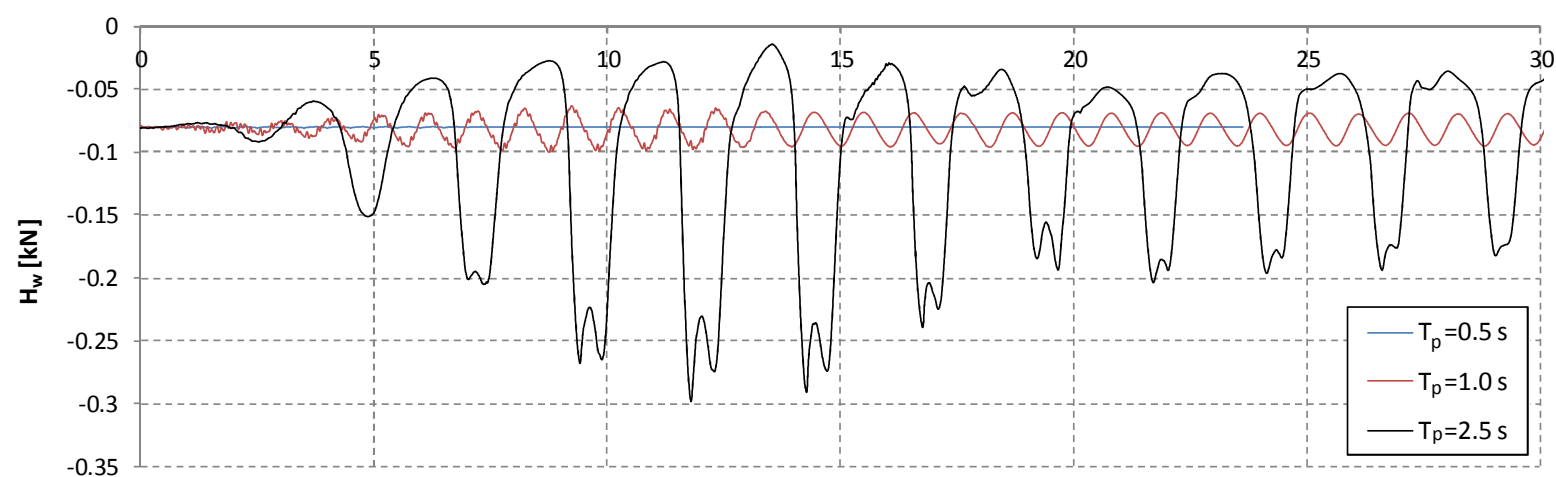

$t[s]$

Slika 5.16. Rezultantna sila vode na prednju stijenku rezervoara R3

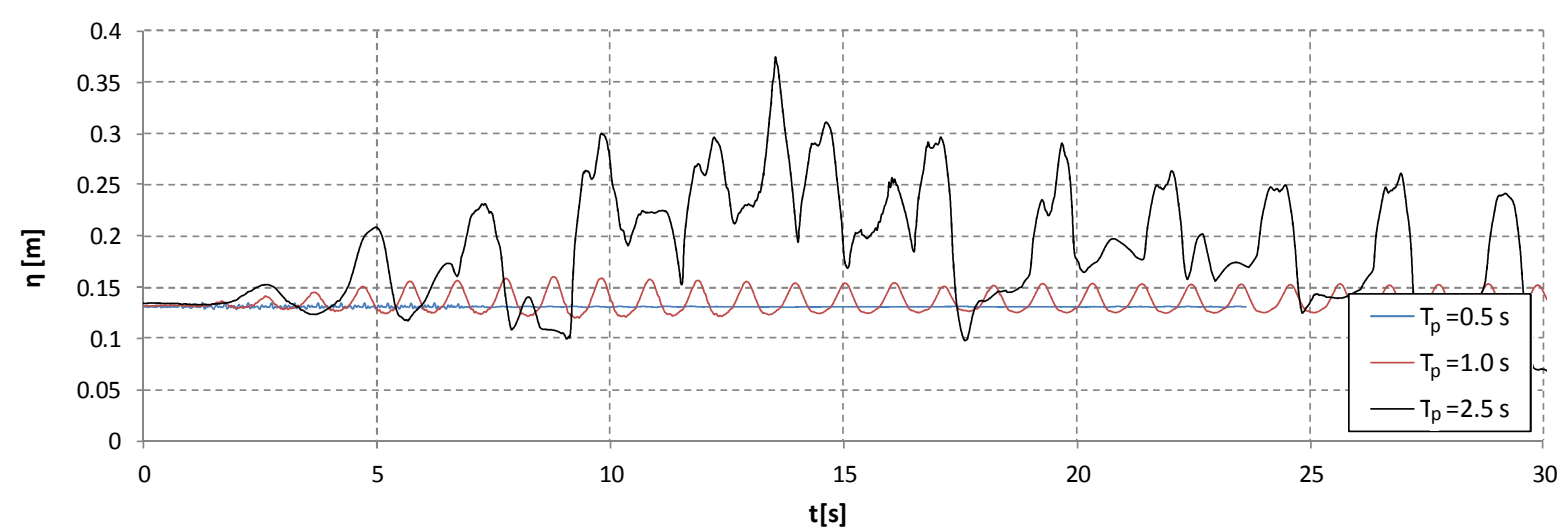

Slika 5.17. Težište rezultantne sile na prednju stijenku rezervoara R3 


\subsubsection{Utjecaj tipa apliciranog akcelerograma}

Prikazani su rezultati samo za rezervoar R1 s visinom vode $\mathrm{H}=0.4 \mathrm{~m}$. Aplicirana su tri tipa ubrzanja podloge prema Potpoglavlju 5.3 i Slici 5.3: harmonijsko ubrzanje, umjetni akcelerogram i akcelerogram potresa Petrovac. Usvojeno maksimalno ubrzanje za sve tipove akcelerograma je $\mathrm{a}_{0}=0.16 \mathrm{~g}$. Za harmonijsku pobudu usvojeno je $\mathrm{T}_{\mathrm{p}}=1.0 \mathrm{~s}$ i $\mathrm{T}_{\mathrm{e}}=10 \mathrm{~s}$. Prema navedenom u Potpoglavlju 5.6.1, očito je da bi najnepovoljnije bile harmonijske pobude sa $\mathrm{T}_{\mathrm{p}}$ bliskim $\mathrm{T}_{1}$ za ovaj rezervoar (Tablica 5.1). Nažalost, za $\mathrm{a}_{0}=0.16 \mathrm{~g}$ došlo bi do velikog prelijevanja vode preko rezervoara za takve harmonijske pobude pa one nisu usvojene.

Tlakovi vode na prednju stijenku rezervoara prikazani su na Slici 5.18. Najveći ukupni tlak vode pri dnu rezervoara bio je za umjetni akcelerogram i iznosio je oko -5.6 kPa, odnosno bio je veći za oko $40 \%$ u odnosu na hidrostatički tlak. Najmanji tlak $\mathrm{p}_{1}$ bio je za usvojeno harmonijsko ubrzanje. Najveće oscilacije maksimalnih tlakova i najslabije prigušenje oscilacija bili su za umjetni akcelerogram. Prema zabilježenom tlaku $\mathrm{p}_{7}$, očito je da je pri apliciranim dinamičkim pobudama došlo do izdizanja razine vode u rezervoaru za najmanje $0.2 \mathrm{~m}$ u odnosu na početnu razinu $\mathrm{h}=0.4 \mathrm{~m}$.

Iz dijagrama rezultantne sile vode na prednju stijenku rezervoara $\mathrm{H}_{\mathrm{w}}$ (Slika 5.19) vidljivo je da je ona najveća za umjetni akcelerogram, a najmanja za usvojenu harmonijsku pobudu. Najveće povećanje $\mathrm{H}_{\mathrm{w}} \mathrm{u}$ odnosu hidrostatičku silu za umjetni akcelerogram je oko $69 \%$, za potres Petrovac oko $61 \%$ i za harmonijsko ubrzanje oko $42 \%$.

Težište $\eta$ rezultantne sile $\mathrm{H}_{\mathrm{w}}$ (Slika 5.20) u odnosu na težište hidrostatičke sile uzdiže se do oko $70 \%$ za umjetni akcelerogram, do oko $50 \%$ za potres Petrovac i do oko $47 \%$.za harmonijsko ubrzanje podloge.

Najveći pozitivni pomaci $\mathrm{u}_{1}, \mathrm{u}_{2}$ (u smjeru pomaka od hidrostatičkog tlaka) bili su također za umjetni akcelerogram, a najmanji za potres Petrovac (Slika 5.21). Najveće povećanje pomaka $\mathrm{u}_{1} \mathrm{u}$ odnosu na pomak za hidrostatički tlak vode za umjetni akcelerogram iznosilo je oko $81 \%$, a pomaka $\mathrm{u}_{2}$ oko $95 \%$.

Najveće deformacije (Slika 5.22) bile su za umjetni akcelerogram. Najveće vlačne deformacije $\varepsilon_{2}$ bile su također za umjetni akcelerogram (oko 0.13\%o), a najveće tlačne deformacije za harmonijsko ubrzanje (oko $0.05 \%$ ). Oscilacija deformacija oko početne deformacije od hidrostatičkog tlaka bila je za $\varepsilon_{2}$ značajno veća nego za $\varepsilon_{1}$.

Nakana je bila da se eksperimentalno potvrdi da za uobičajeni stvarni i umjetni akcelerogram potresa može doći do značajnih pomaka vode u rezervoaru i do generiranja 
visokih hidrodinamičkih tlakova vode na stijenke rezervoara čak i za relativno nisko maksimalno ubrzanje podloge.

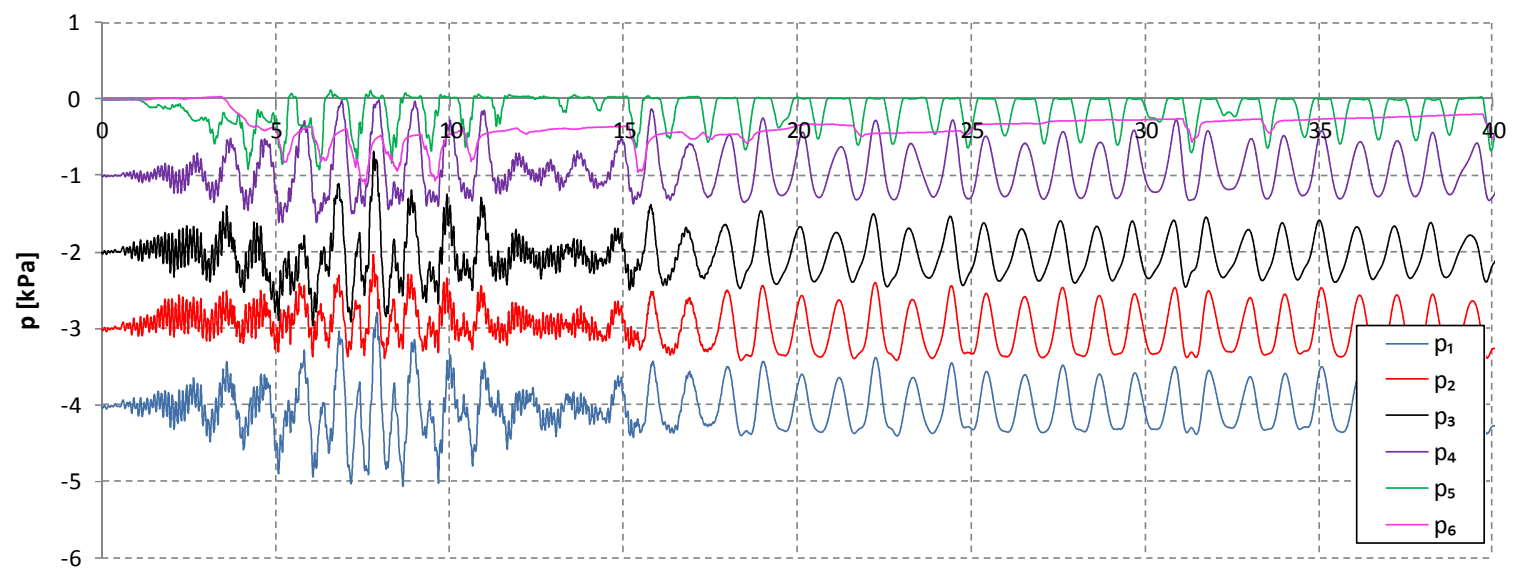

$\mathrm{t}[\mathrm{s}]$

(a) Harmonijsko ubrzanje

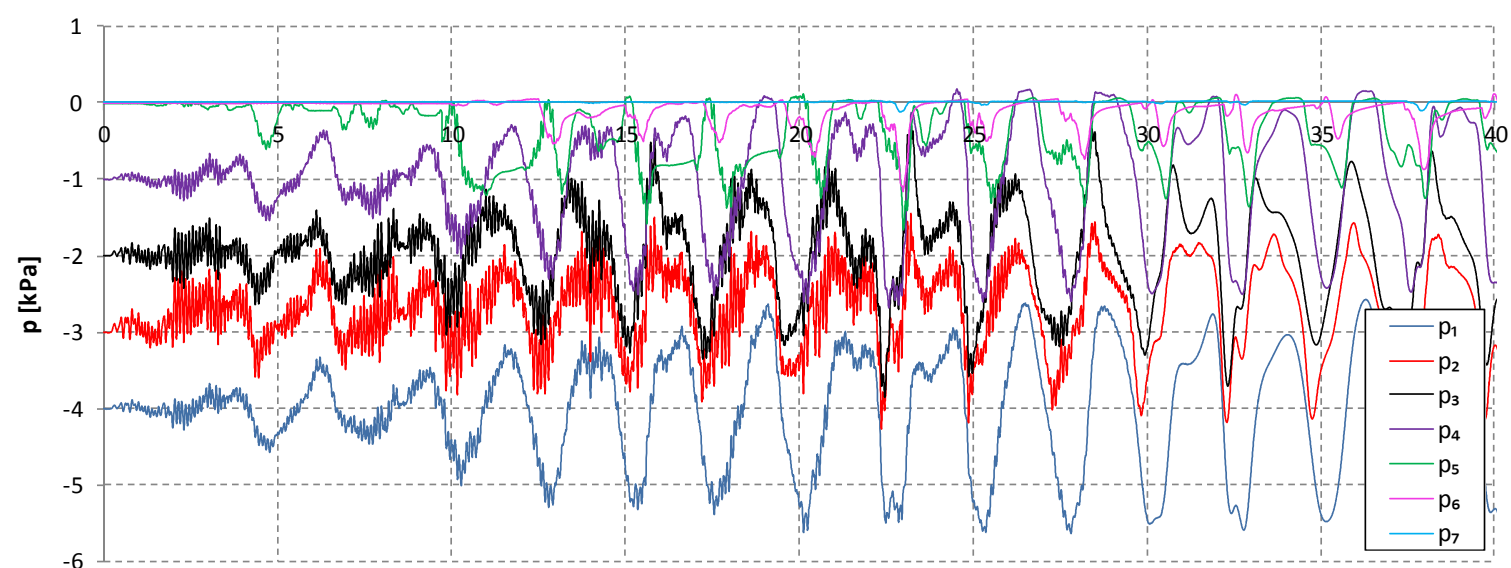

$\mathrm{t}[\mathrm{s}]$

(b) Umjetni akcelerogram

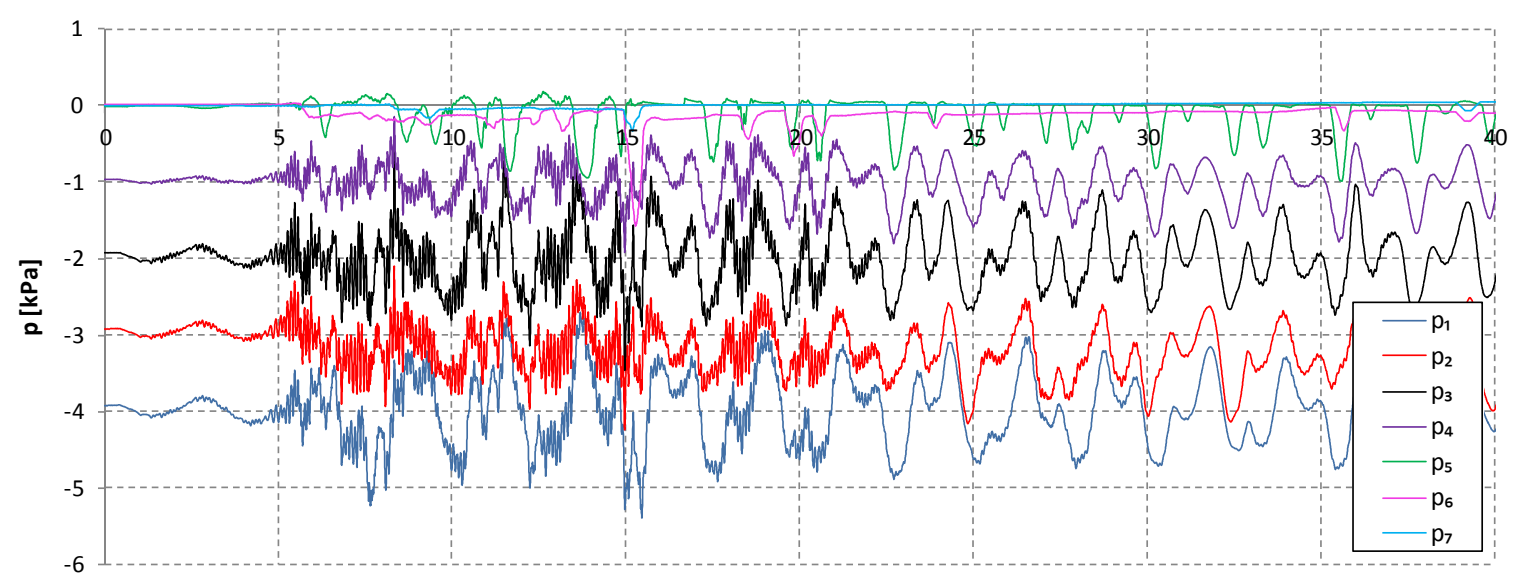

$\mathrm{t}[\mathrm{s}]$

(c) Potres Petrovac

Slika 5.18. Tlakovi vode na prednju stijenku rezervoara R1 


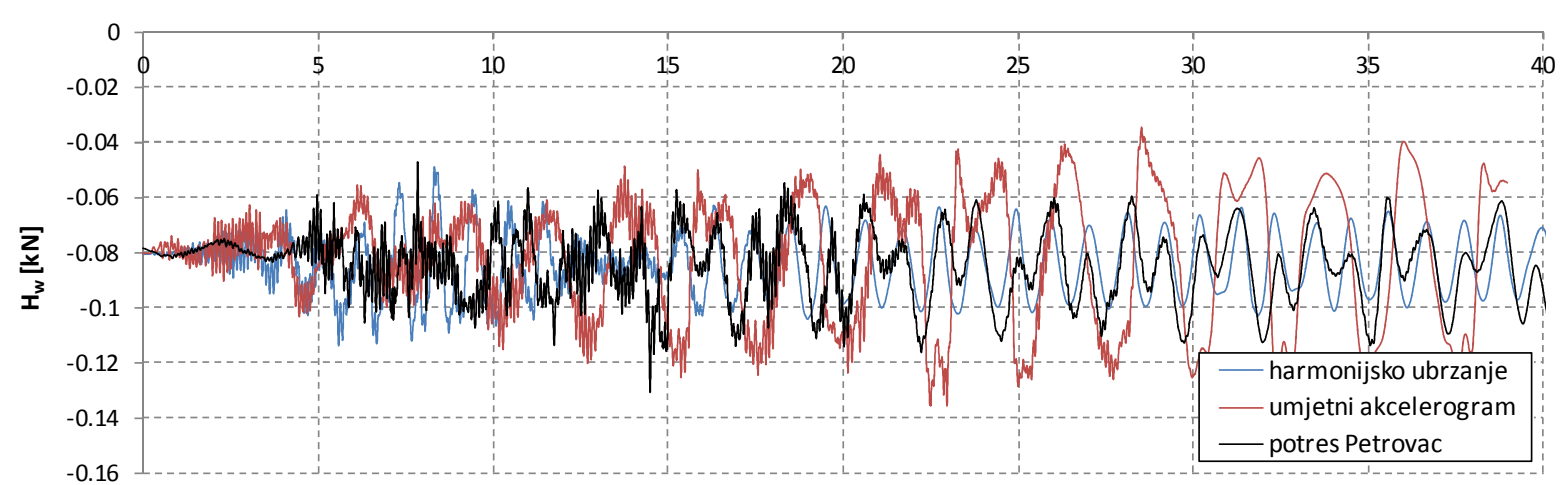

$t[s]$

Slika 5.19. Rezultantna sila vode na prednju stijenku rezervoara R1

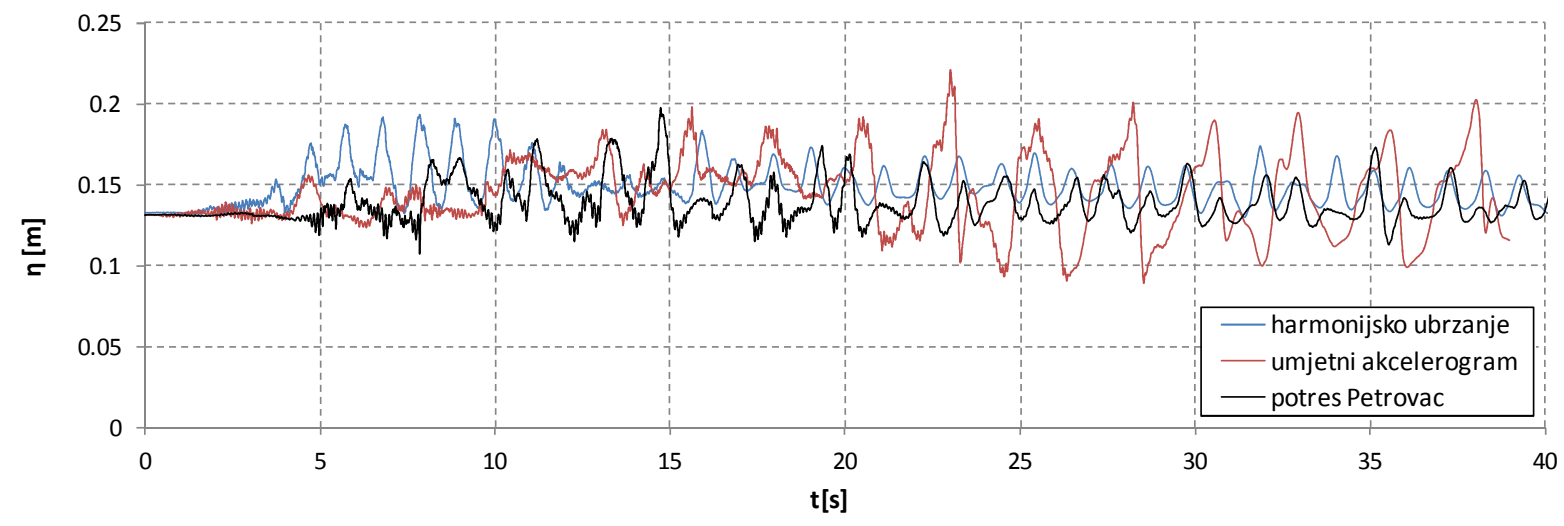

Slika 5.20. Težište rezultantne sile na prednju stijenku rezervoara $R 1$

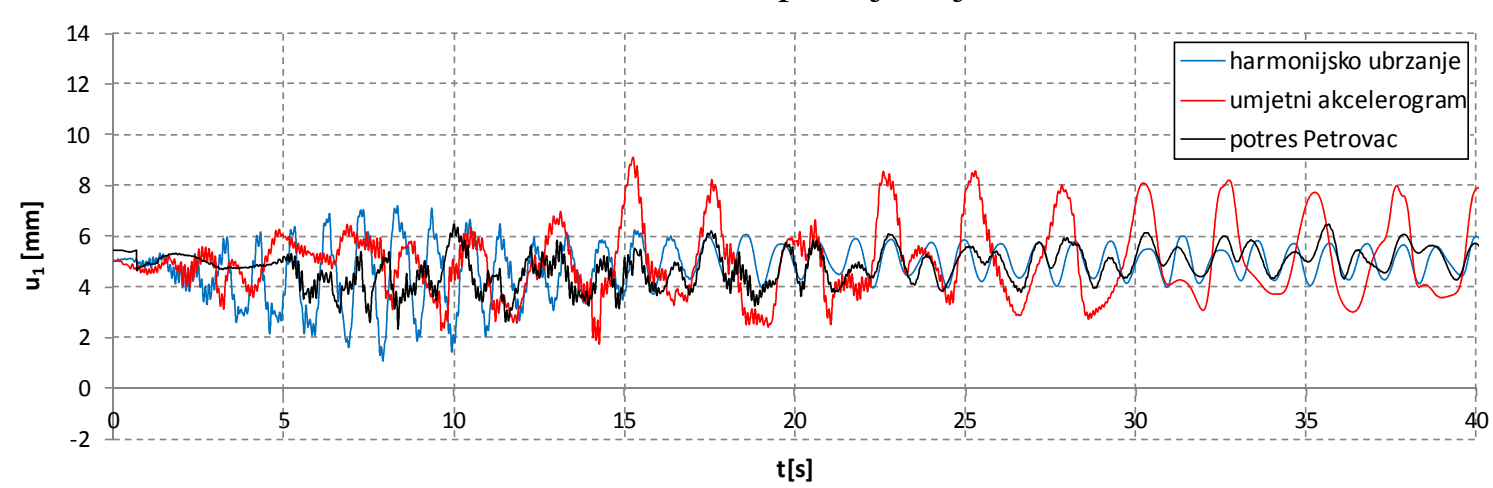

(a) Pomak $u_{1}$

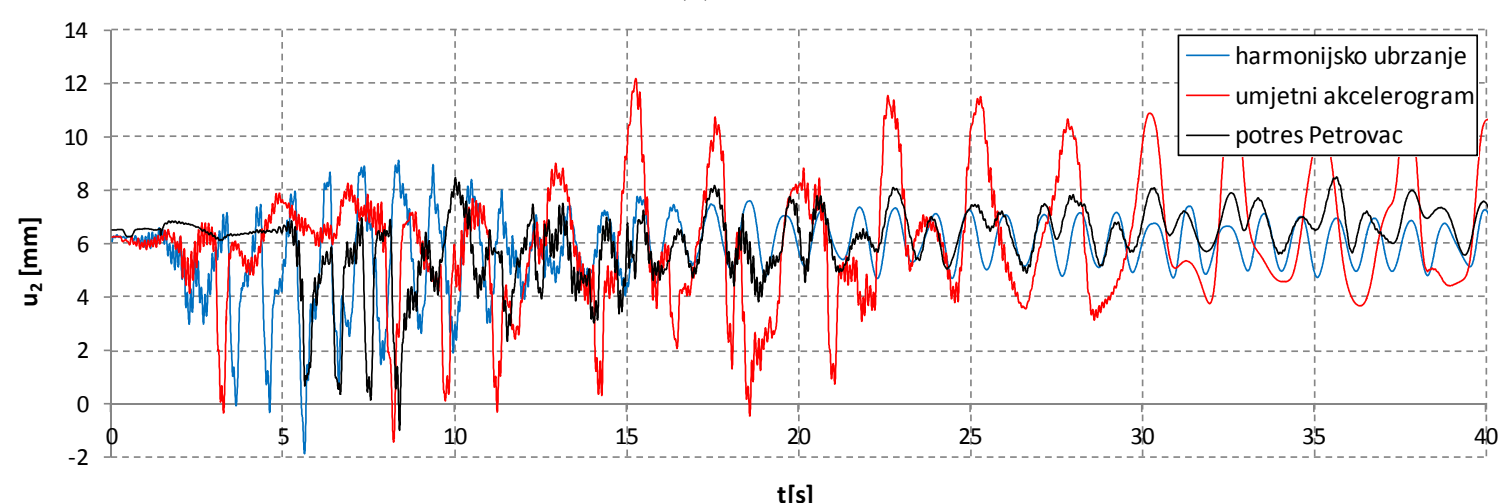

(b) Pomak $\mathrm{u}_{2}$

Slika 5.21. Horizontalni pomak prednje stijenke rezervoara R1 


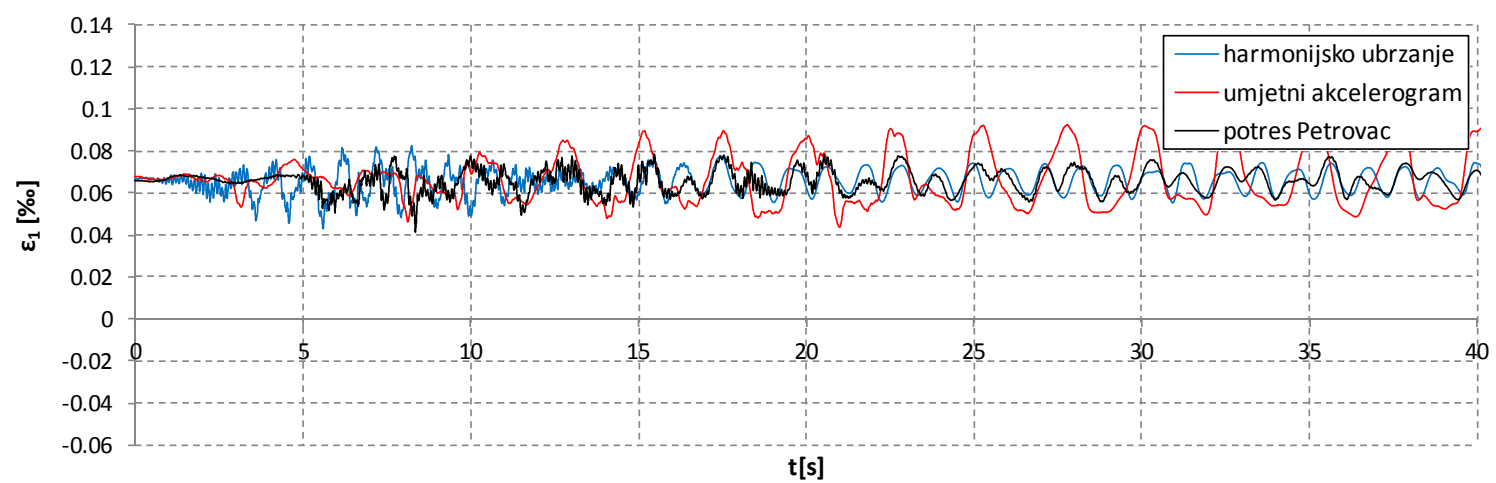

(a) Deformacija $\varepsilon_{1}$

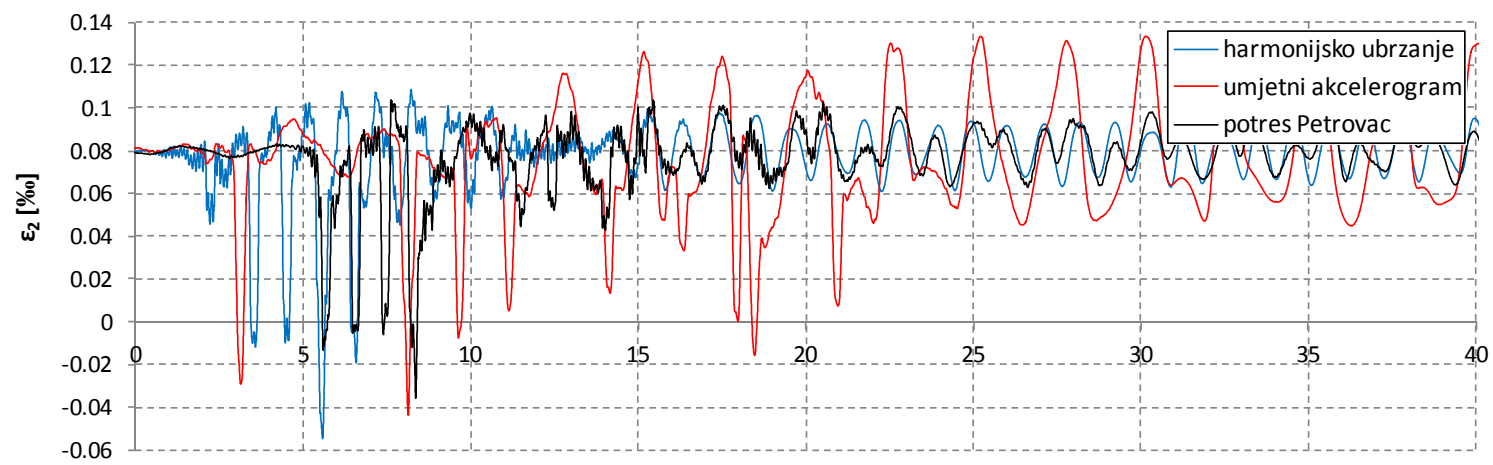

$t[s]$

(b) Deformacija $\varepsilon_{2}$

Slika 5.22. Deformacija prednje stijenke rezervoara R1 


\subsubsection{Utjecaj visine vode u rezervoaru}

Prikazani su samo rezultati za rezervoar R2 izložen harmonijskoj pobudi prema Slici $5.2 \mathrm{sa} \mathrm{T}_{\mathrm{p}}=1 \mathrm{~s}, \mathrm{a}_{0}=0.1 \mathrm{~g}$ i $\mathrm{T}_{\mathrm{e}}=10 \mathrm{~s}$. Varirane visine vode su bile $\mathrm{h}=0.4 \mathrm{~m}, \mathrm{~h}=0.6 \mathrm{~m} \mathrm{i} \mathrm{h=0.8} \mathrm{m}$.

Ukupni tlakovi vode rastu s visinom vode u rezervoaru (Slika 5.23). U odnosu na hidrostatički tlak, najveći tlak $\mathrm{p}_{1}$ pri dnu rezervoara $\mathrm{za} \mathrm{h}=0.4 \mathrm{~m}$ povećan je za oko $40 \%$, za $\mathrm{h}=0.6 \mathrm{~m}$ oko $39 \%$ i za h=0.8 m oko $22 \%$. Prigušenje gibanja vode nakon prestanka djelovanja pobude se smanjuje sa smanjenjem visine vode u rezervoaru. Prema zabilježenim tlakovima na mjernim mjestima, maksimalno izdizanje razine vode u rezervoaru za $\mathrm{h}=0.4 \mathrm{~m}$ i za $\mathrm{h}=0.6 \mathrm{~m}$ iznosilo je preko $0.2 \mathrm{~m}$ i za h=0.8 $\mathrm{m}$ oko $0.1 \mathrm{~m}$.

Rezultantna sila vode $\mathrm{H}_{\mathrm{w}}$ (Slika 5.24) u odnosu na hidrostatičku silu za h=0.4 m povećana je do oko $41 \%$, za h=0.6 $\mathrm{m}$ do oko $46 \%$ i za h=0.8 $\mathrm{m}$ do oko $39 \%$.

Položaj $\eta$ rezultantne sile vode $\mathrm{H}_{\mathrm{w}}$ (Slika 5.25) u odnosu na položaj hidrostatičke sile $\mathrm{za} \mathrm{h}=0.4 \mathrm{~m}$ podiže se do oko $41 \%$, za h=0.6 $\mathrm{m}$ do oko $25 \% \mathrm{i}$ za $\mathrm{h}=0.8 \mathrm{~m}$ do oko $20 \%$. Dakle, $\mathrm{s}$ povećanjem $H$ smanjuje se visina težišta sile $H_{w} u$ odnosu na visinu težišta hidrostatičke sile.

Maksimalni horizontalni pomak $\mathrm{u}_{1}$ (Slika 5.26a) za $\mathrm{h}=0.6 \mathrm{~m}$ je veći nego za $\mathrm{h}=0.8 \mathrm{~m}$. $\mathrm{U}$ odnosu na hidrostatički pomak, najveće oscilacije pomaka $\mathrm{u}_{1}$ su za $\mathrm{h}=0.4 \mathrm{~m}$. Maksimalni horizontalni pomak $\mathrm{u}_{2}$ (Slika 5.26b) raste $\mathrm{s}$ visinom vode $\mathrm{h}$. Najveće oscilacije pomaka $\mathrm{u}_{2} \mathrm{u}$ odnosu na hidrostatički pomak su također za $\mathrm{h}=0.4 \mathrm{~m}$.

Maksimalne deformacije $\varepsilon_{1}, \varepsilon_{2}$ (Slika 5.27) rastu s povećanjem h. Najveća deformacija lima ne prelazi $0.35 \%$, tj. naprezanja lima su u elastičnom području. 


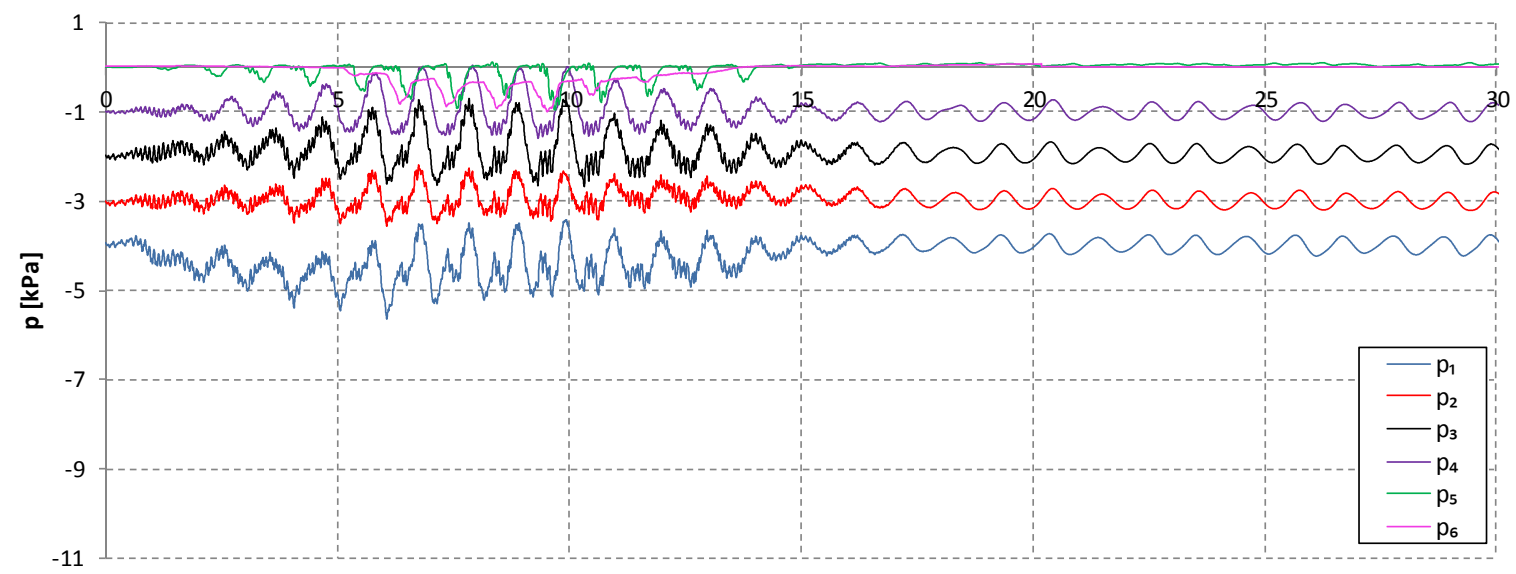

$\mathrm{t}[\mathrm{s}]$

(a) $\mathrm{H}=0.4 \mathrm{~m}$

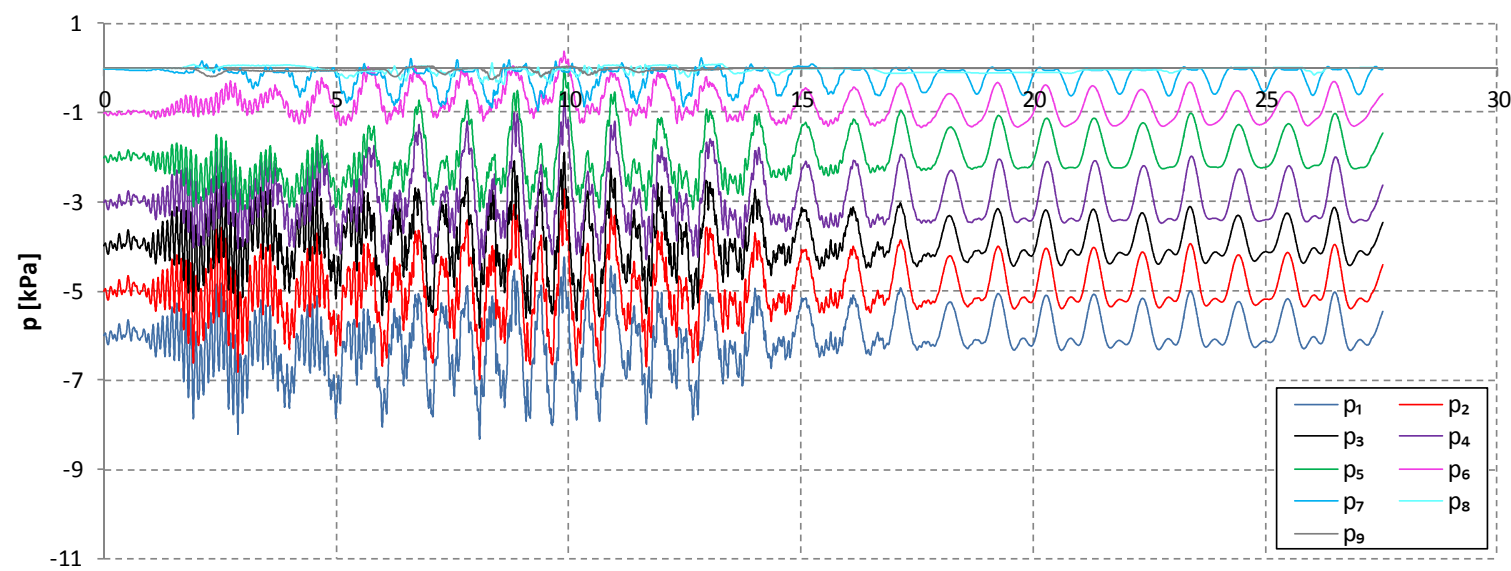

$\mathrm{t}[\mathrm{s}]$

(b) $\mathrm{H}=0.6 \mathrm{~m}$

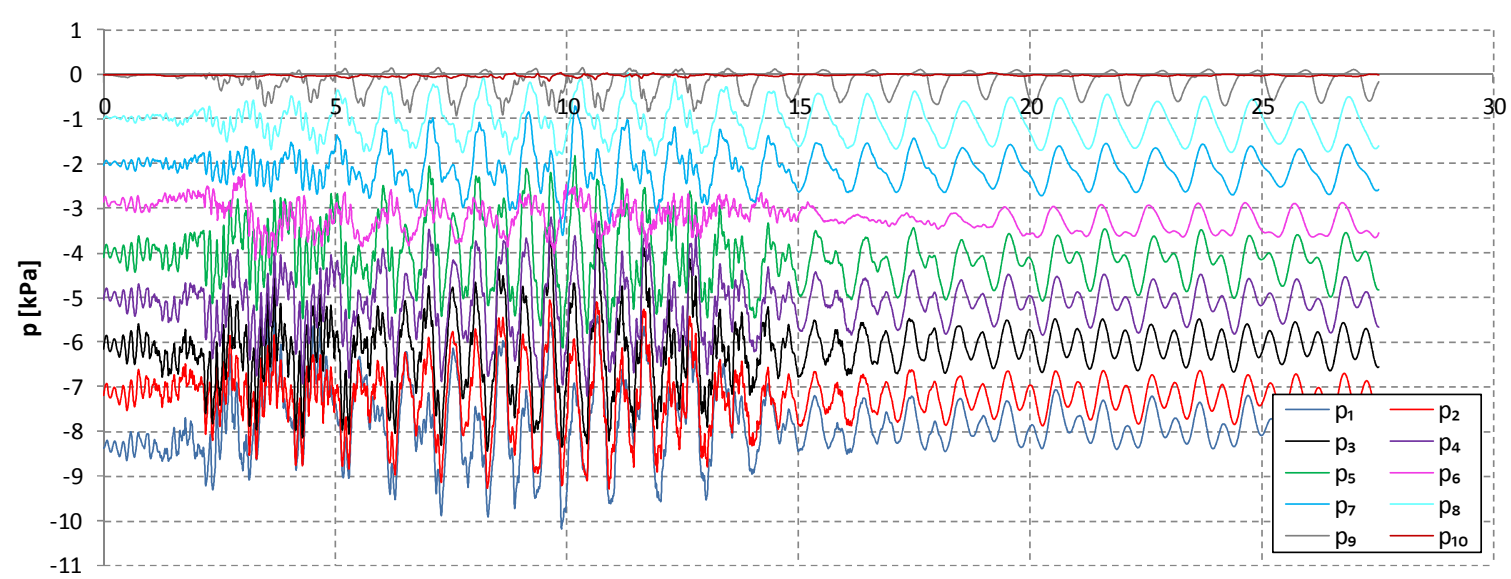

$\mathrm{t}[\mathrm{s}]$

(c) $\mathrm{H}=0.8 \mathrm{~m}$

Slika 5.23. Tlakovi vode na prednju stijenku rezervoara R2 


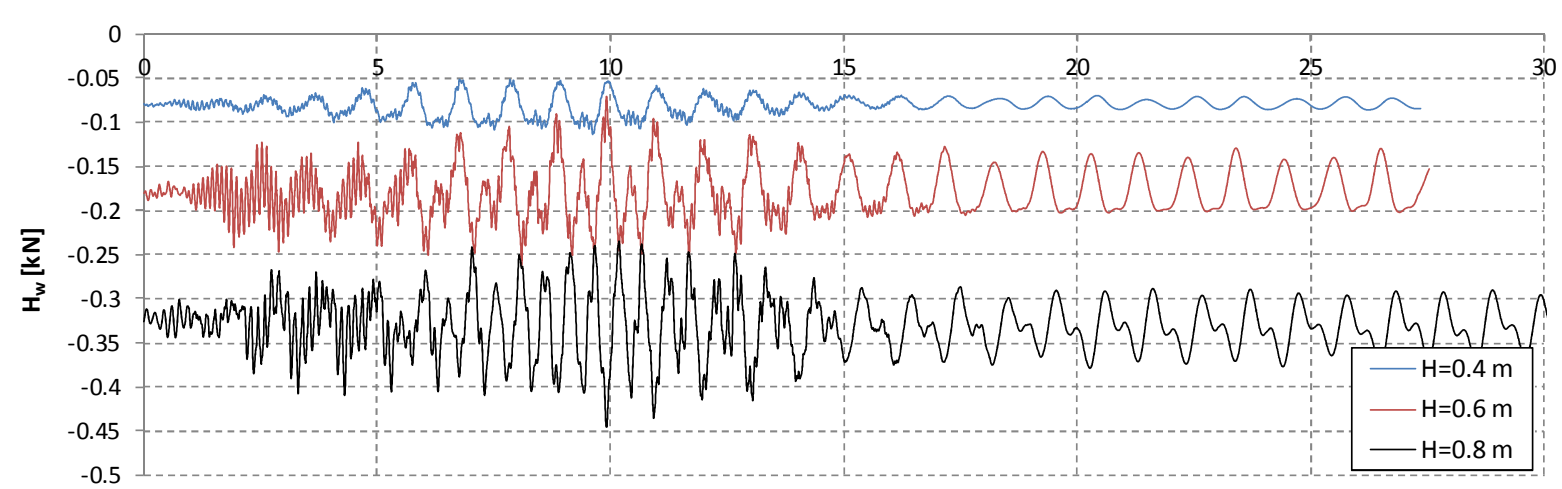

$t[s]$

Slika 5.24. Rezultantna sila vode na prednju stijenku rezervoara R2

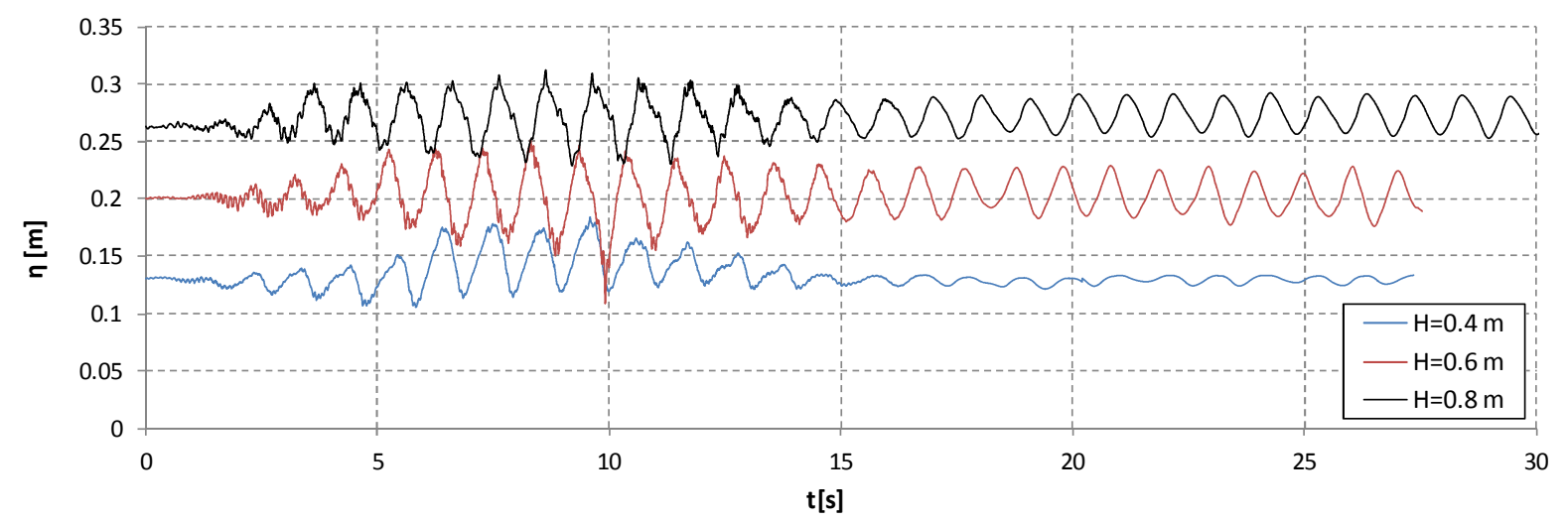

Slika 5.25. Težište rezultantne sile na prednju stijenku rezervoara R2

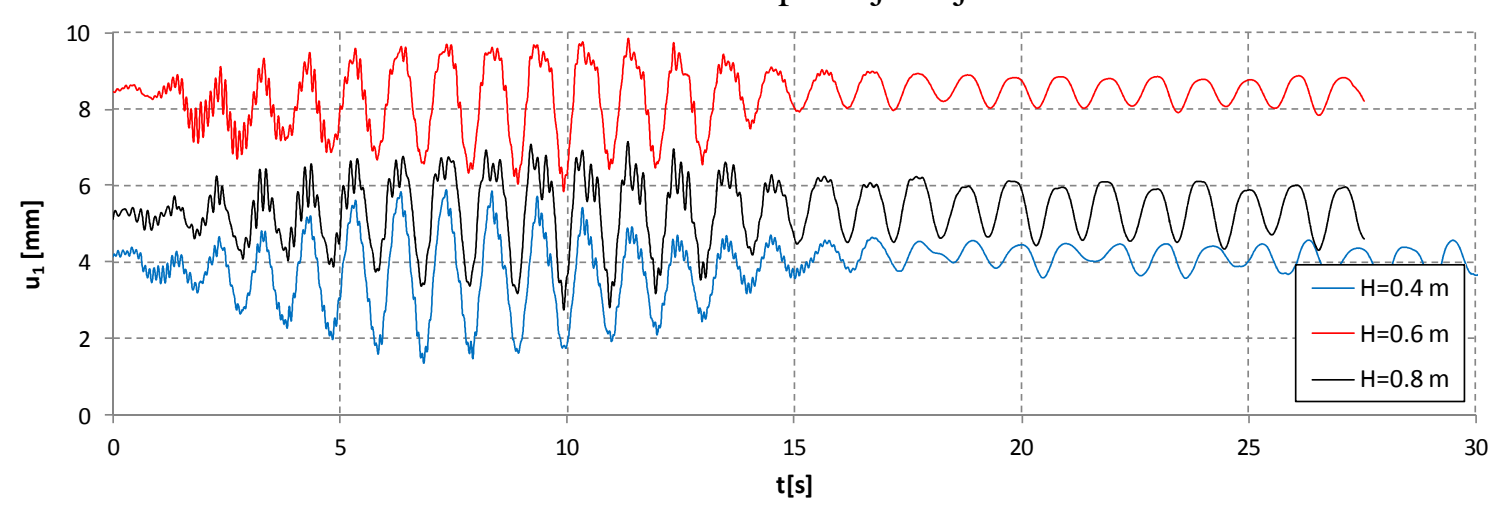

(a) Pomak $\mathrm{u}_{1}$

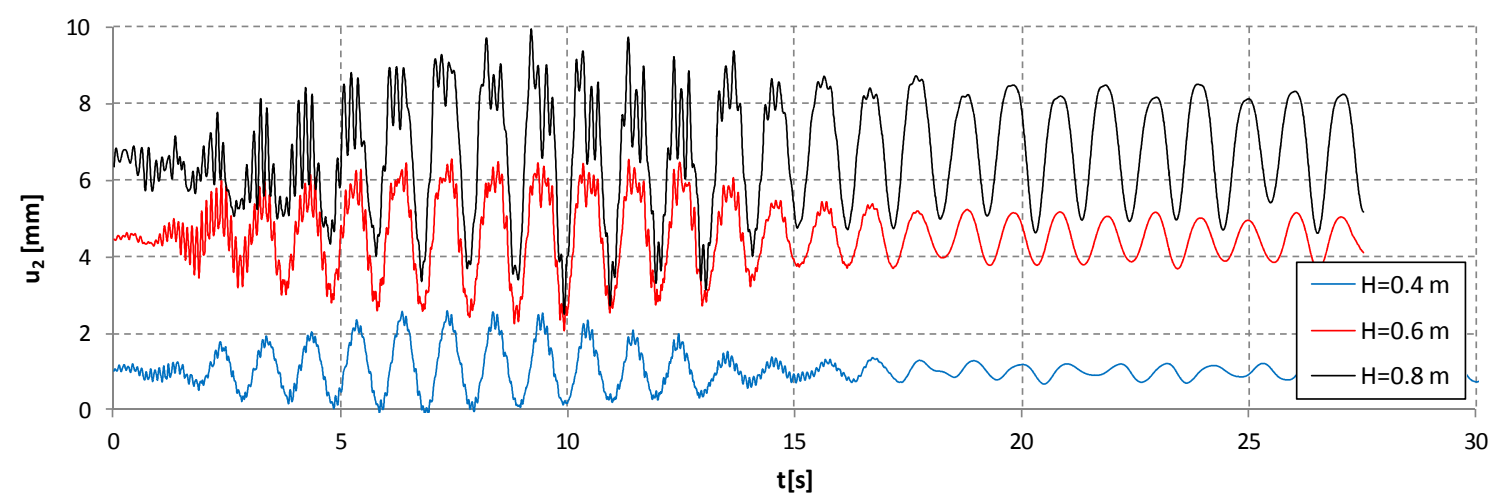

(b) Pomak $\mathrm{u}_{2}$

Slika 5.26. Horizontalni pomak prednje stijenke rezervoara $R 2$ 


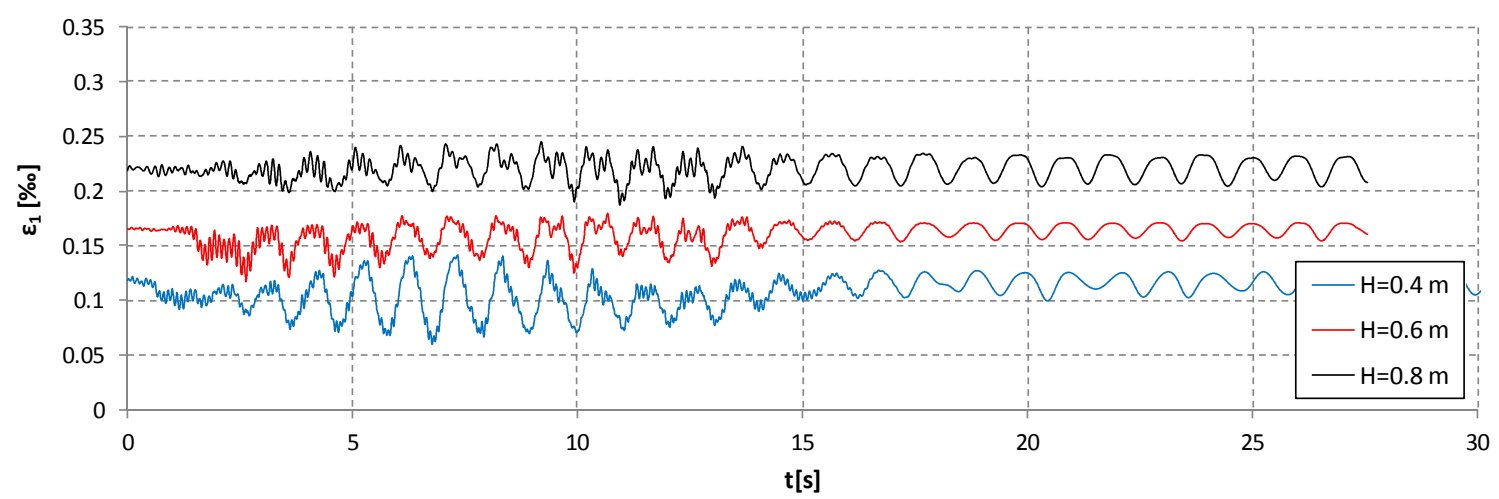

(a) Deformacija $\varepsilon_{1}$

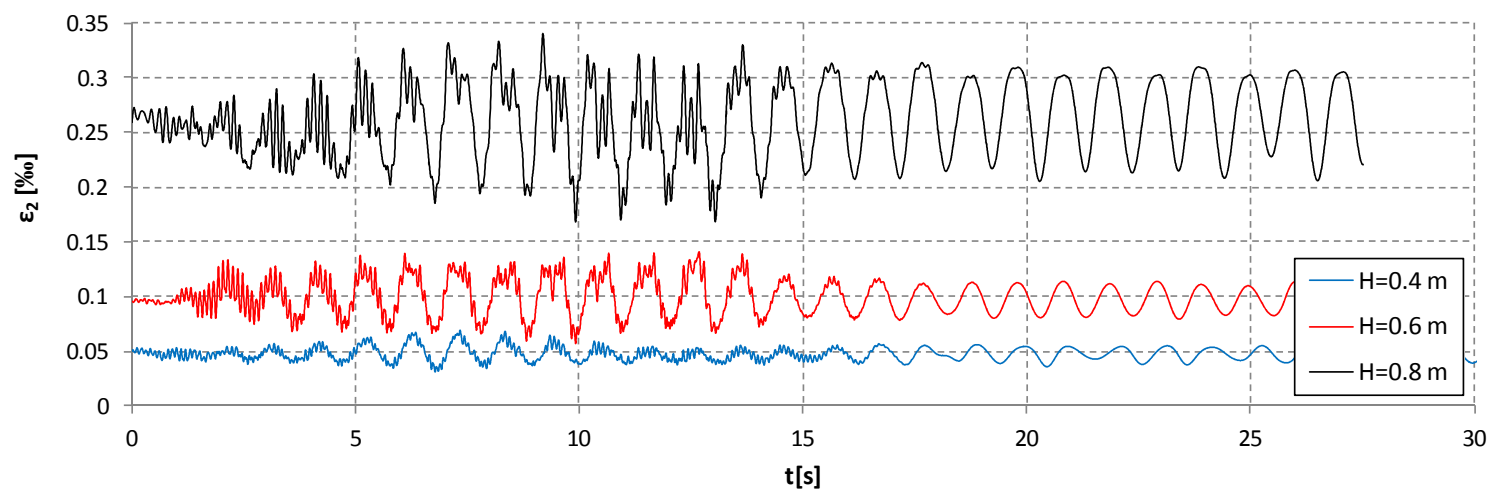

(b) Deformacija $\varepsilon_{2}$

Slika 5.27. Deformacija prednje stijenke rezervoara R2 


\subsubsection{Utjecaj amplitude harmonijske pobude}

Prikazani su rezultati samo za rezervoar R2 s visinom vode $\mathrm{h}=0.4 \mathrm{~m}$, za harmonijsku pobudu (Slika 5.3a) s periodom $T_{p}=0.3 \mathrm{~s}$ i trajanjem $T_{e}=10 \mathrm{~s}$. Varirana maksimalna ubrzanja podloge bila su $\mathrm{a}_{0}=0.1 \mathrm{~g}, \mathrm{a}_{0}=0.2 \mathrm{~g}$ i $\mathrm{a}_{0}=0.5 \mathrm{~g}$. Odabran je nešto niži $\mathrm{T}_{\mathrm{p}}$ kakao bi se na raspoloživoj dinamičkoj platformi mogao postići što veći $\mathrm{a}_{0}$. Odabrani $\mathrm{T}_{\mathrm{p}}$ još uvijek osigurava relativno velike pomake vode $\mathrm{u}$ rezervoaru.

Veličina ukupnih tlakova vode (Slika 5.28) se povećava s povećavanjem maksimalnog ubrzanja $\mathrm{a}_{0}$, ali ne proporcionalno njemu. Povećanje maksimalnog tlaka na dnu rezervoara $\mathrm{p}_{1}$ $\mathrm{u}$ odnosu na hidrostatički tlak za $\mathrm{a}_{0}=0.1 \mathrm{~g}$ iznosi oko $10 \%$, za $\mathrm{a}_{0}=0.2 \mathrm{~g}$ oko $12 \%$ i za $\mathrm{a}_{0}=0.5 \mathrm{~g}$ oko $15 \%$. Hidrodinamički tlak po visini vode u rezervoaru se malo mijenja.

Prema zabilježenim tlakovima $\mathrm{u}$ mjernim točkama za $\mathrm{a}_{0}=0.1 \mathrm{~g}$ praktično nema izdizanja vode $\mathrm{u}$ rezervoaru. $\mathrm{Za} \mathrm{a}_{0}=0.2 \mathrm{~g}$ izdizanje vode iznosi do oko $0.1 \mathrm{~m}$, a za $\mathrm{a}_{0}=0.5 \mathrm{~g}$ do oko $0.25 \mathrm{~m}$.

Povećanje maksimalne rezultante sile vode $\mathrm{H}_{\mathrm{w}}$ (Slika 5.29) u odnosu na hidrostatičku silu za $\mathrm{a}_{0}=0.1 \mathrm{~g}$ iznosi oko $19 \%$, za $\mathrm{a}_{0}=0.2 \mathrm{~g}$ oko $22 \%$ i za $\mathrm{a}_{0}=0.5 \mathrm{~g}$ oko $29 \%$. Dakle, s povećanjem $\mathrm{a}_{0}$ povećava se odnos $\mathrm{H}_{\mathrm{w}} \mathrm{i}$ hidrostatičke sile vode, ali ne proporcionalno njemu.

Izdizanje težišta $\eta$ sile $H_{w} u$ odnosu na težište hidrostatičke sile vode (Slika 5.30) se također povećava s povećanjem $\mathrm{a}_{0}$. $\mathrm{Za} \mathrm{a}_{0}=0.5 \mathrm{~g}$ ono iznosi maksimalno oko $17 \%$. Relativno malo izdizanje $\eta$ je posljedica relativno niskog perioda harmonijske pobude $\left(\mathrm{T}_{\mathrm{p}}=0.3 \mathrm{~s}\right)$.

Pomaci $\mathrm{u}_{1}, \mathrm{u}_{2}$ (Slika 5.31) tijekom apliciranih ubrzanja osciliraju oko vrijednosti koja je niža od pomaka za hidrostatički tlak vode. Nakon prestanka pobude, pomaci teže pomacima $\mathrm{u}_{1}, \mathrm{u}_{2}$ od hidrostatičkog tlaka vode. Ovo je još izraženije za drugi deformabilni rezervoar R1 što ovdje nije grafički prikazano. Pomaci lima u odnosu na početne pomake od hidrostatičkog tlaka vode rastu s povećanjem $\mathrm{a}_{0}$. Prigušenje osciliranja lima počinje ranije kod nižih $\mathrm{a}_{0}$ zbog unesene manje energije aplicirane pobude u rezervoar.

Dijagrami deformacija $\varepsilon_{1}, \varepsilon_{2}$ (Slika 5.32) analogni su dijagramima pomaka $\mathrm{u}_{1}, \mathrm{u}_{2}$. Najveće smanjenje deformacije od one za hidrostatički tlak vode bilo je za najveći aplicirani $\mathrm{a}_{0}$. 


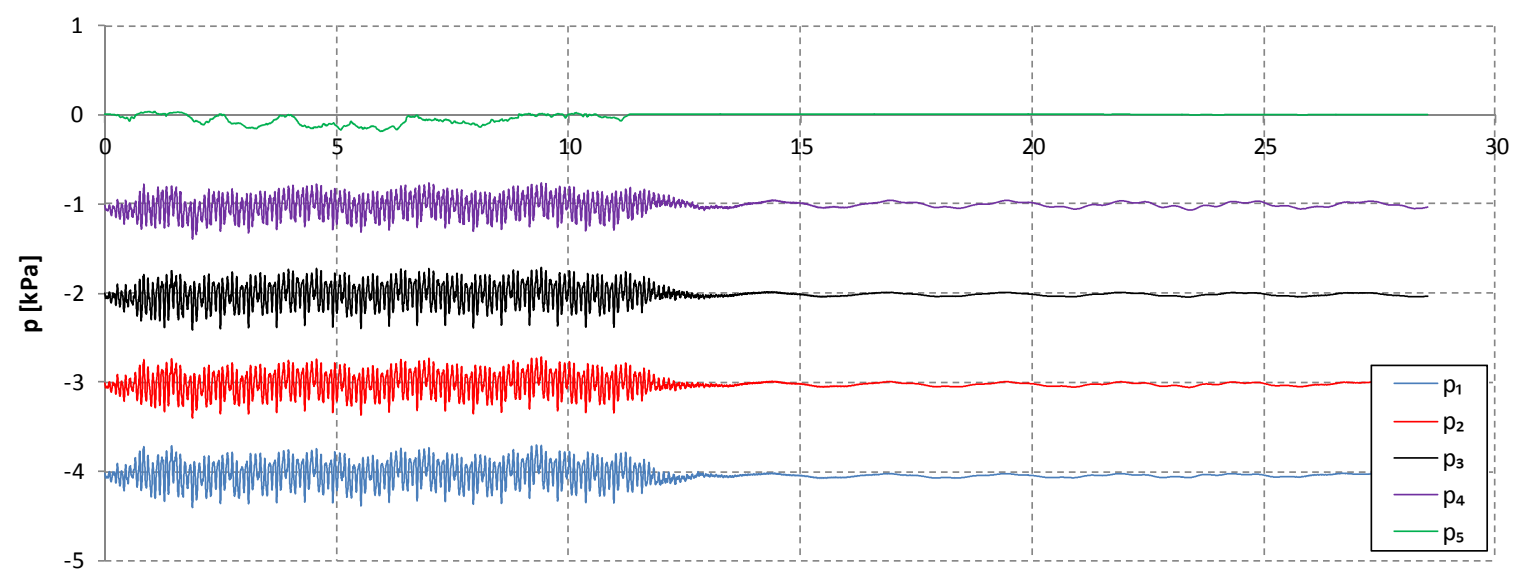

$\mathrm{t}[\mathrm{s}]$

(a) $\mathrm{a}_{0}=0.1 \mathrm{~g}$

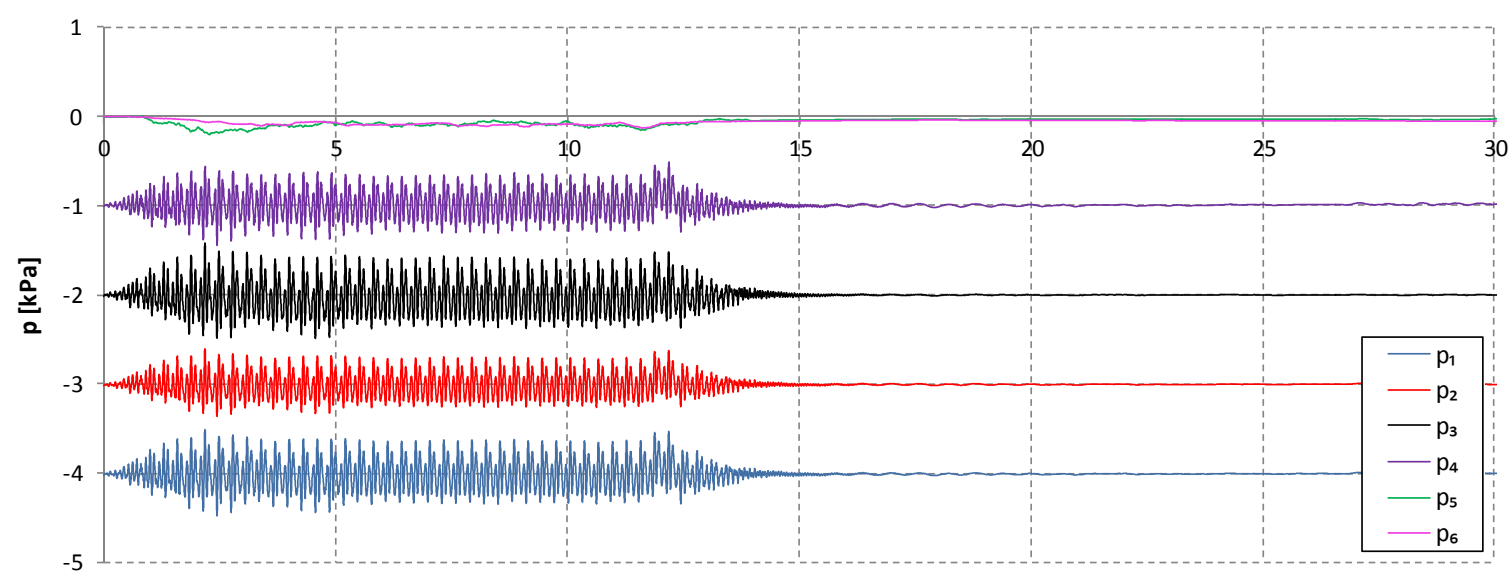

$t[s]$

(b) $\mathrm{a}_{0}=0.2 \mathrm{~g}$

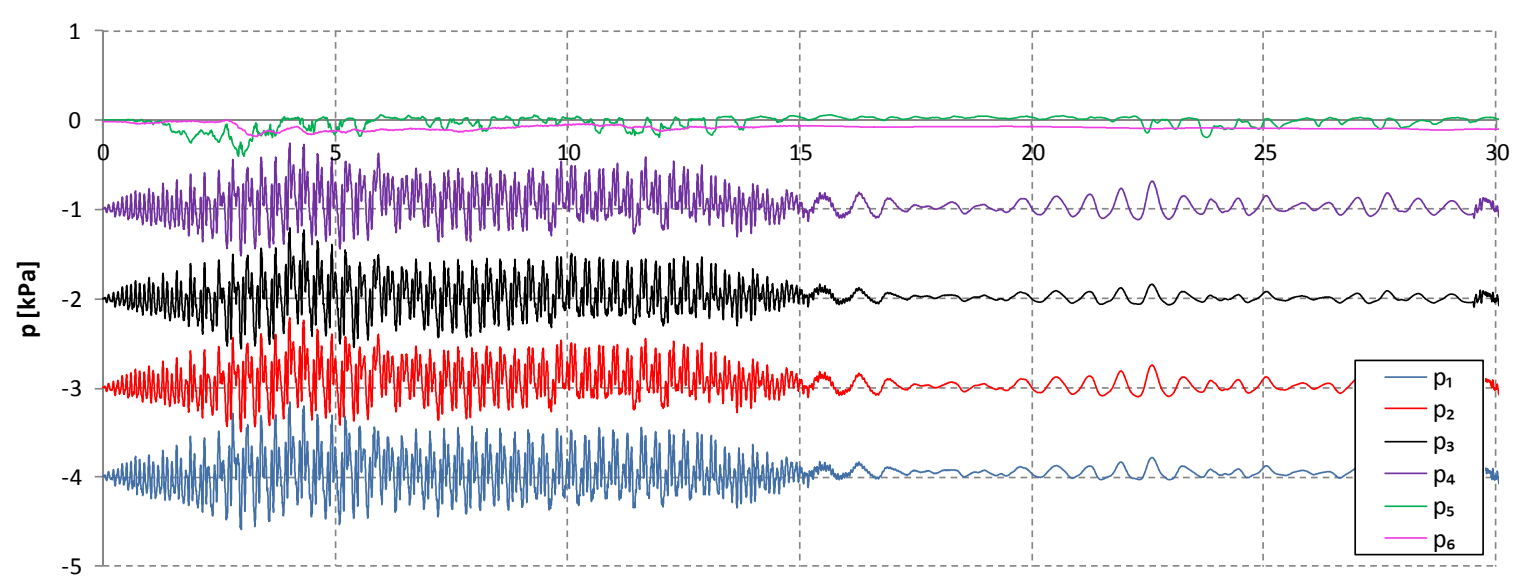

$\mathrm{t}[\mathrm{s}]$

(c) $\mathrm{a}_{0}=0.5 \mathrm{~g}$

Slika 5.28. Tlakovi vode na prednju stijenku rezervoara R2 


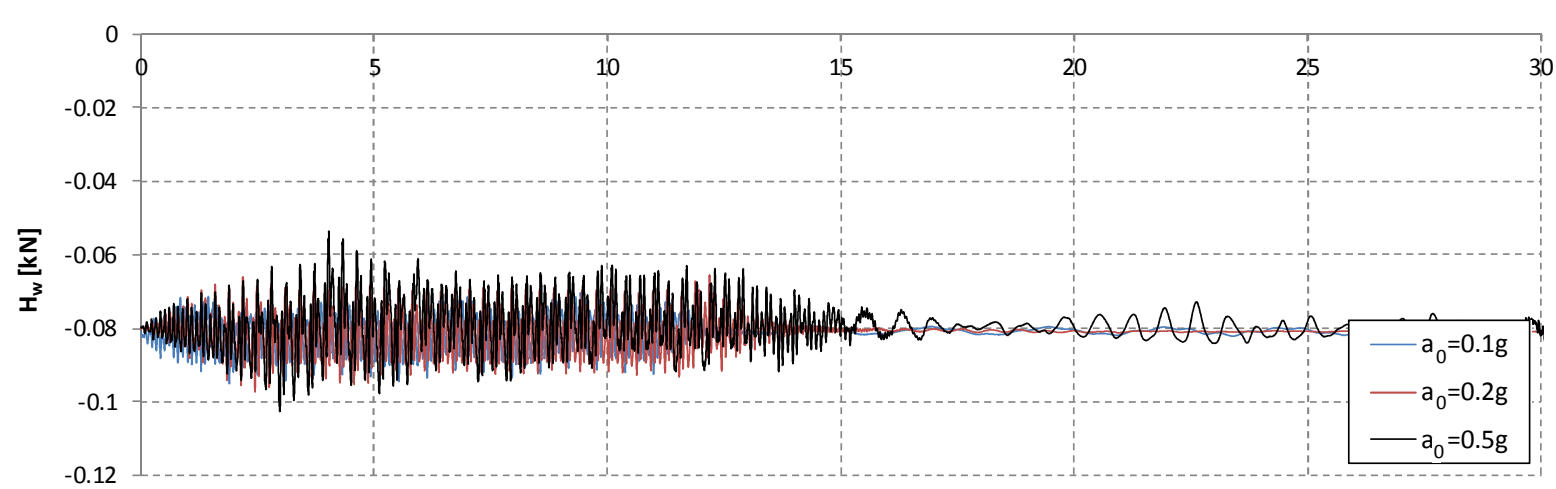

$\mathrm{t}[\mathrm{s}]$

Slika 5.29. Rezultantna sila vode na prednju stijenku rezervoara $R 2$

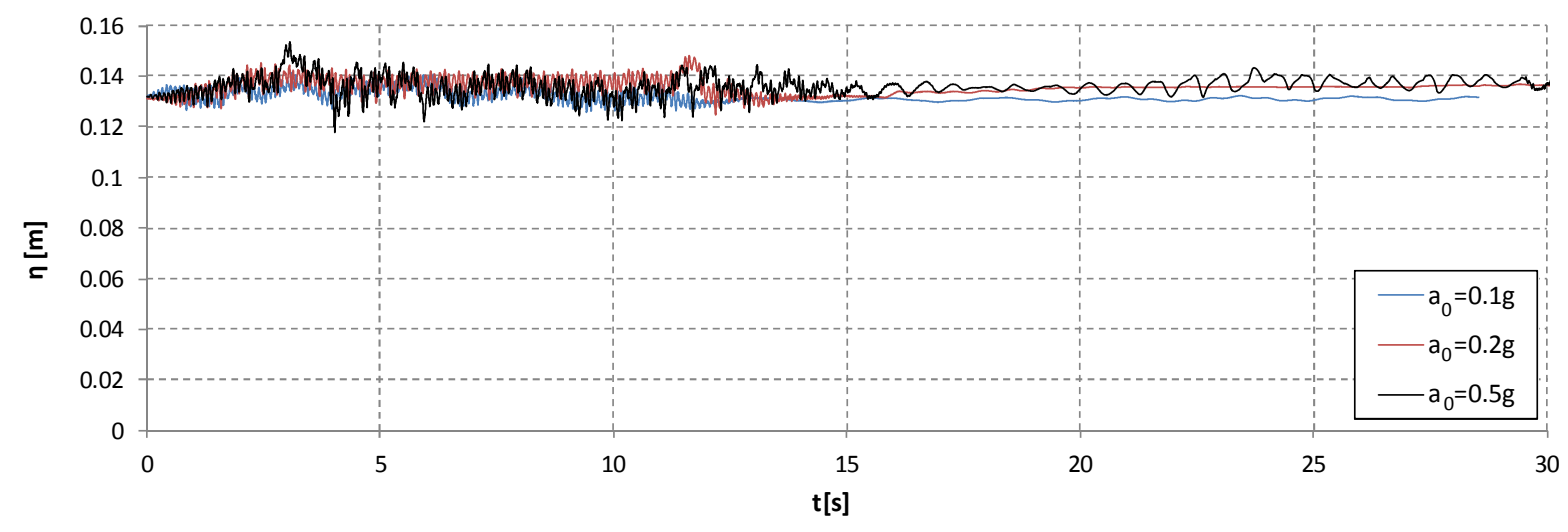

Slika 5.30. Težište rezultantne sile na prednju stijenku rezervoara R2

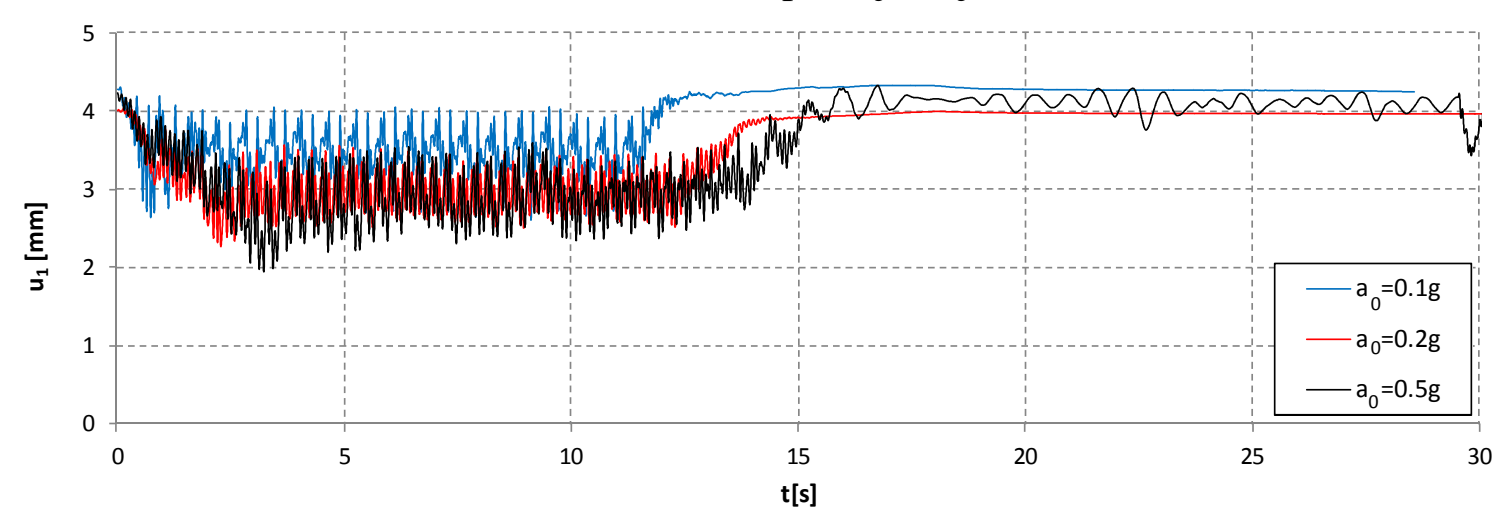

(a) Pomak $u_{1}$

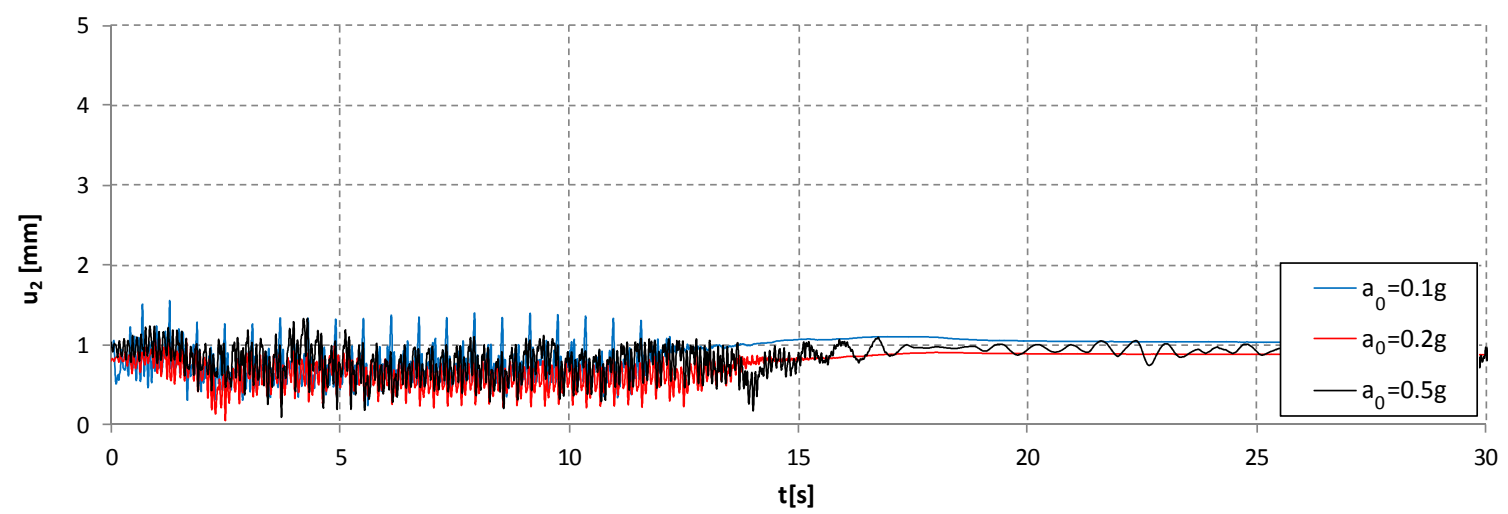

(b) Pomak $\mathrm{u}_{2}$

Slika 5.31. Horizontalni pomak prednje stijenke rezervoara R2 


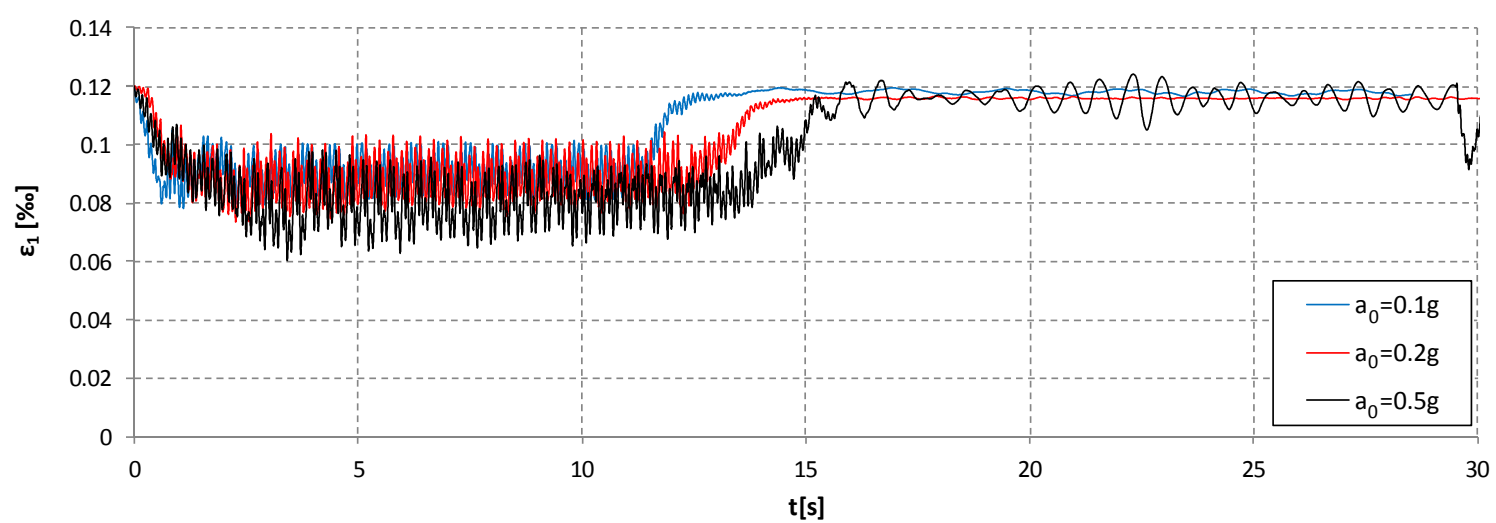

(a) Deformacija $\varepsilon_{1}$

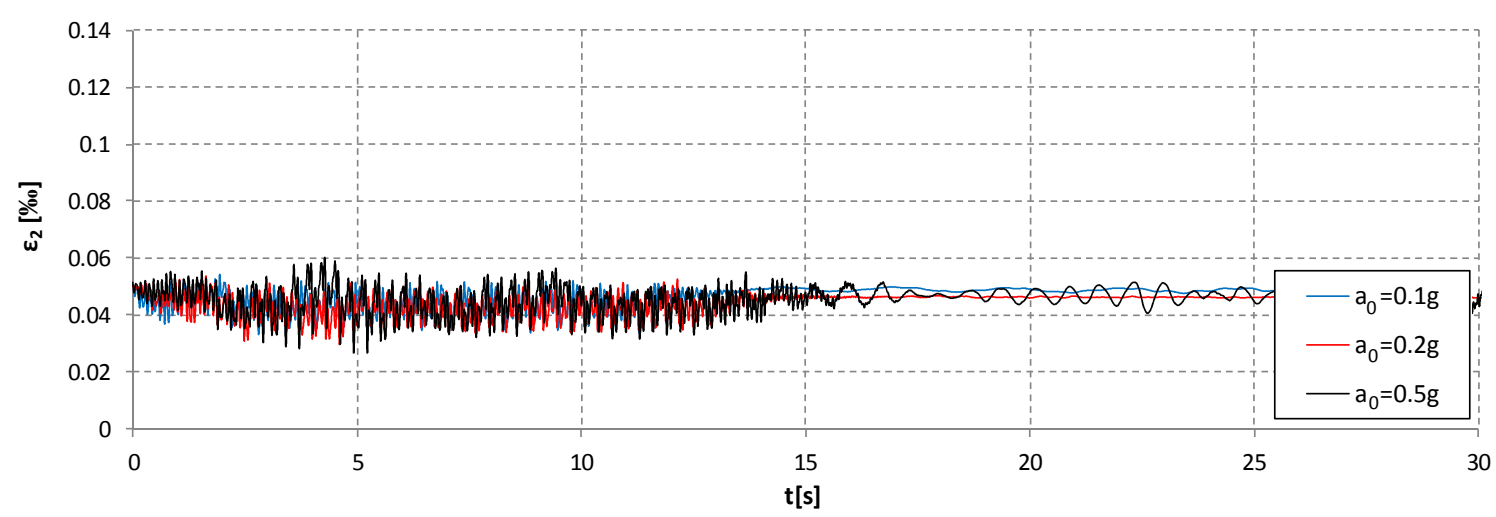

(b) Deformacija $\varepsilon_{2}$

Slika 5.32. Deformacija prednje stijenke rezervoara $R 2$ 


\subsubsection{Utjecaj trajanja harmonijske pobude}

Rezultati su prikazani samo za rezervoar $\mathrm{R} 1 \mathrm{~s} \mathrm{~h}=0.4 \mathrm{~m}, \mathrm{~s}$ pobudom $\mathrm{a}_{0}=0.16 \mathrm{~g}$ i $\mathrm{T}_{\mathrm{p}}=1 \mathrm{~s}$ (Slika 5.3a). Varirane su tri duljine trajanja pobude: $\mathrm{T}_{\mathrm{e}}=10 \mathrm{~s}, \mathrm{~T}_{\mathrm{e}}=5 \mathrm{~s}$ i $\mathrm{T}_{\mathrm{e}}=2 \mathrm{~s}$.

Iz dijagrama tlakova vode na prednju stijenku rezervoara (Slika 5.33) vidljivo je da je najveći tlak na dnu rezervoara $\mathrm{p}_{1}$ za $\mathrm{T}_{\mathrm{e}}=5 \mathrm{~s}$ i iznosi oko $-6.0 \mathrm{kPa}$. Za $\mathrm{T}_{\mathrm{e}}=2 \mathrm{~s}$ i $\mathrm{T}_{\mathrm{e}}=10 \mathrm{~s}$ najveći $\mathrm{p}_{1}$ je podjednak. Najveće prigušenje pomaka nakon prestanka pobude bilo je za $\mathrm{T}_{\mathrm{e}}=10 \mathrm{~s}$. Vrlo slični rezultati su dobiveni za rezervoar R2, uz ostale jednake parametre, što ovdje nije grafički prikazano. Očito je da za usvojeni $T_{p}=1 \mathrm{~s}$ i trajanje pobude $T_{e}=10 \mathrm{~s}$ prigušenje gibanja vode u rezervoaru je najveće. Maksimalne vrijednosti izmjerenih tlakova javljaju se znatno prije $\mathrm{T}_{\mathrm{e}}=10 \mathrm{~s}$, pa je to razlog da je za $\mathrm{T}_{\mathrm{e}}=5 \mathrm{~s}$ dobiveno nepovoljnije stanje tlakova. $\mathrm{Za}$ $\mathrm{T}_{\mathrm{e}}=5 \mathrm{~s}$ najnepovoljnije stanje je nakon prestanka pobude.

Dijagram rezultantne sile vode $\mathrm{H}_{\mathrm{w}}$ na prednju stijenku rezervoara (Slika 5.34) potvrđuje prethodno navedeno za tlakove vode. Naime, najveće vrijednosti i najveće amplitude oscilacija $\mathrm{H}_{\mathrm{w}}$ ima za $\mathrm{T}_{\mathrm{e}}=5 \mathrm{~s}$. $\mathrm{Za} \mathrm{T}_{\mathrm{e}}=10 \mathrm{~s}$ one su malo veće nego za $\mathrm{T}_{\mathrm{e}}=2 \mathrm{~s}$. Odnos maksimalne sile $\mathrm{H}_{\mathrm{w}}$ i hidrostatičke sile za $\mathrm{T}_{\mathrm{e}}=5 \mathrm{~s}$ iznosi oko $88 \%$, za $\mathrm{T}_{\mathrm{e}}=2 \mathrm{~s}$ oko $38 \%$ i za $\mathrm{T}_{\mathrm{e}}=10 \mathrm{~s}$ oko $43 \%$.

Najveće izdizanje težišta $\eta$ sile $H_{w}$ (Slika 5.35) bilo je za $T_{e}=5$ s. Za $T_{e}=2 s$ maksimalni položaj težišta $\eta$ je značajno manji nego za $T_{e}=5 \mathrm{~s} \mathrm{i} T_{e}=10 \mathrm{~s}$. Najveće spuštanje težišta $\eta$ sile $H_{w}$ bilo je za $T_{e}=2 \mathrm{~s}$.

Najveći pomaci $\mathrm{u}_{1}, \mathrm{u}_{2}$ (Slika 5.36) bili su za $\mathrm{T}_{\mathrm{e}}=10 \mathrm{~s}$. Najmanji pomak $\mathrm{u}_{1}$ bio je za $\mathrm{T}_{\mathrm{e}}=5 \mathrm{~s}, \mathrm{a} \mathrm{u}_{2}$ za $\mathrm{T}_{\mathrm{e}}=10 \mathrm{~s}$.

Maksimalne deformacije $\varepsilon_{1}$, $\varepsilon_{2}$ (Slika 5.37) se malo razlikuju za sve razmatrane $\mathrm{T}_{\mathrm{e}}$.

Može se globalno zaključiti da je za harmonijsku pobudu dovoljan mali broj perioda da pokrene gibanje vode. Tlakovi vode ovise o trajanju harmonijske pobude. Nerezonantne pobude mogu biti nepovoljnije pri kraćem nego pri duljem trajanju. Rezonantne pobude su vjerojatno nepovoljnije ako duže traju. 


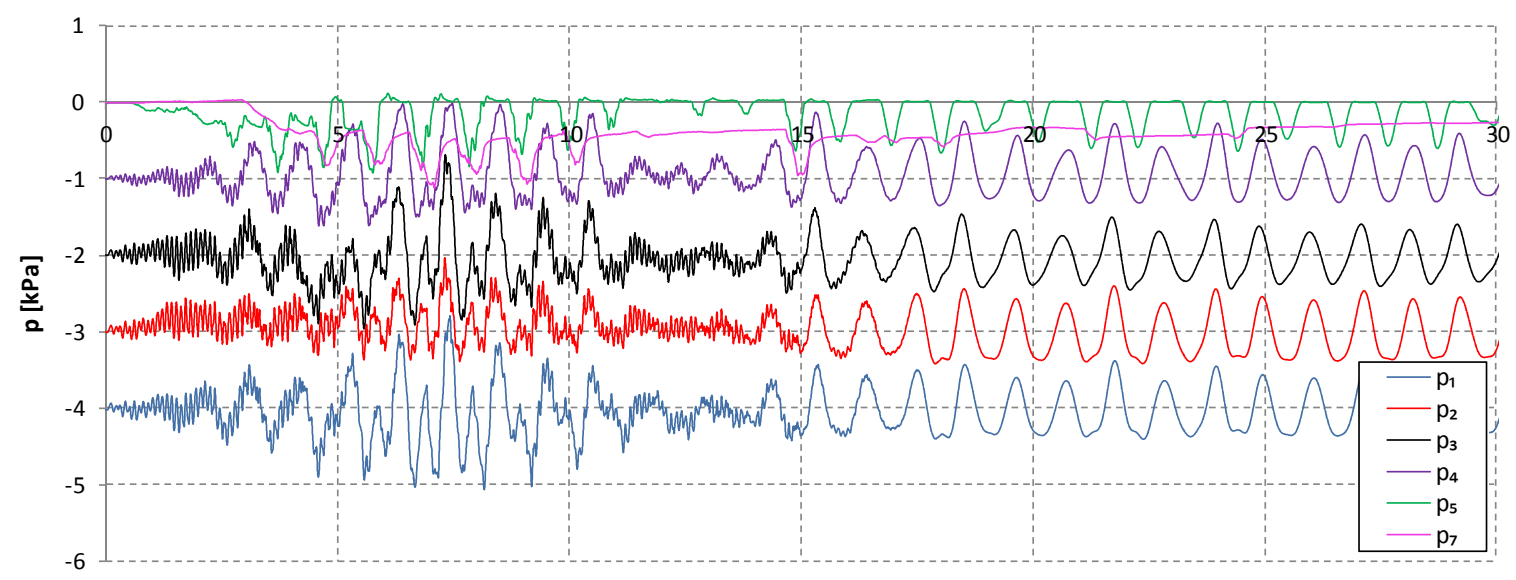

$\mathrm{t}[\mathrm{s}]$

(a) $\mathrm{T}_{\mathrm{e}}=10 \mathrm{~s}$

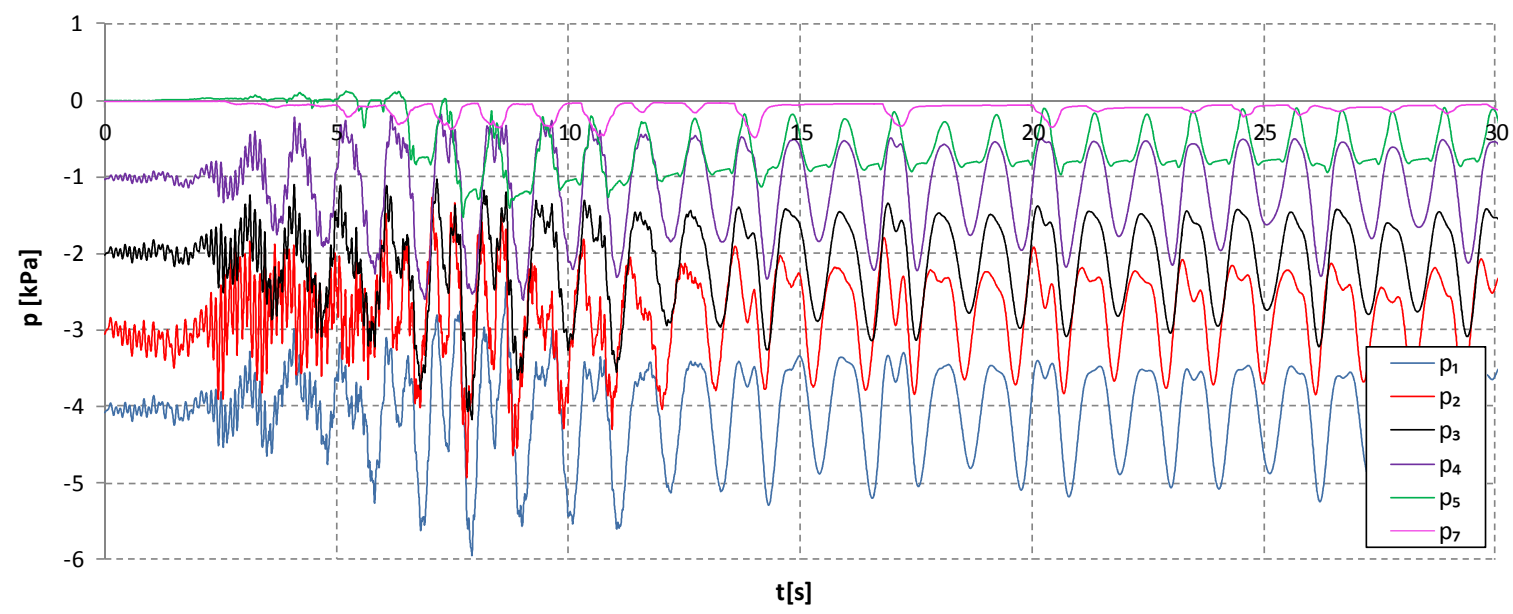

(b) $\mathrm{T}_{\mathrm{e}}=5 \mathrm{~s}$

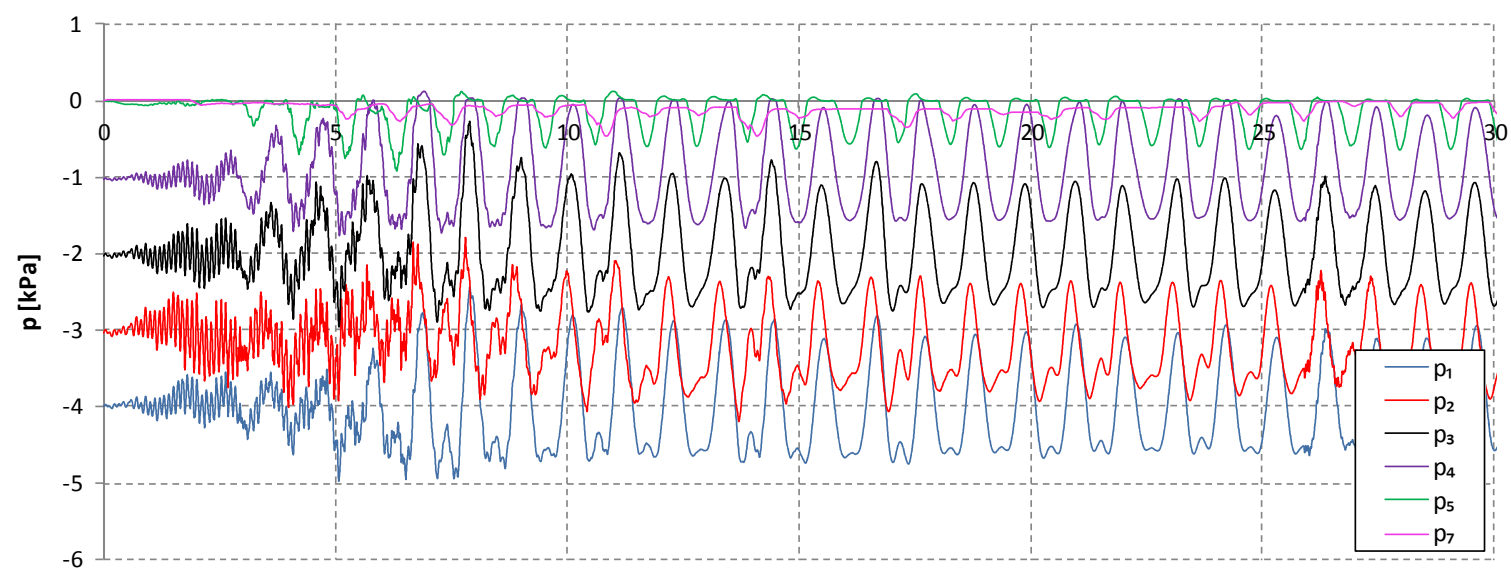

$\mathrm{t}[\mathrm{s}]$

(c) $\mathrm{T}_{\mathrm{e}}=2 \mathrm{~s}$

Slika 5.33. Tlakovi vode na prednju stijenku rezervoara R1 


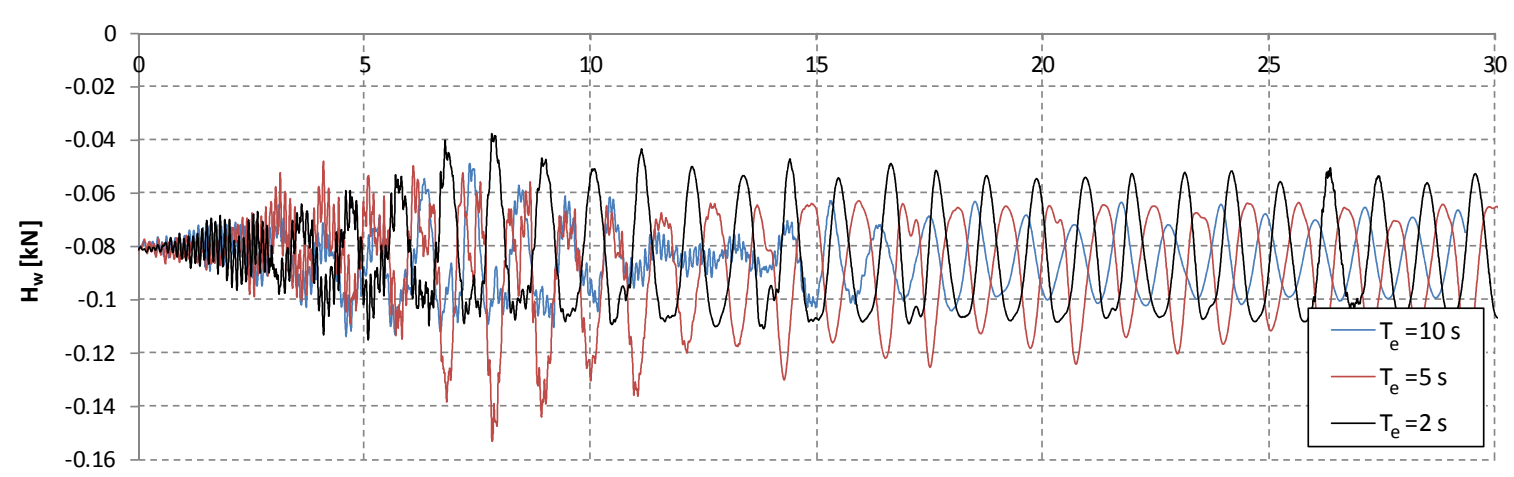

$\mathrm{t}[\mathrm{s}]$

Slika 5.34. Rezultantna sila vode na prednju stijenku rezervoara R1

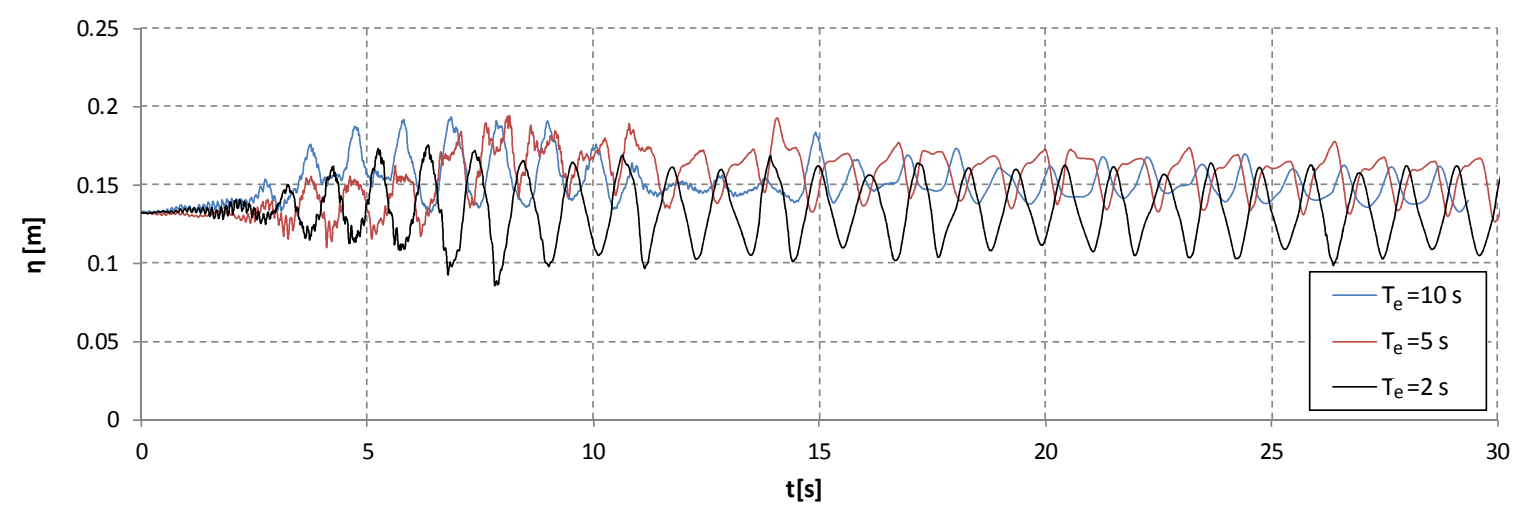

Slika 5.35. Težište rezultantne sile na prednju stijenku rezervoara R1

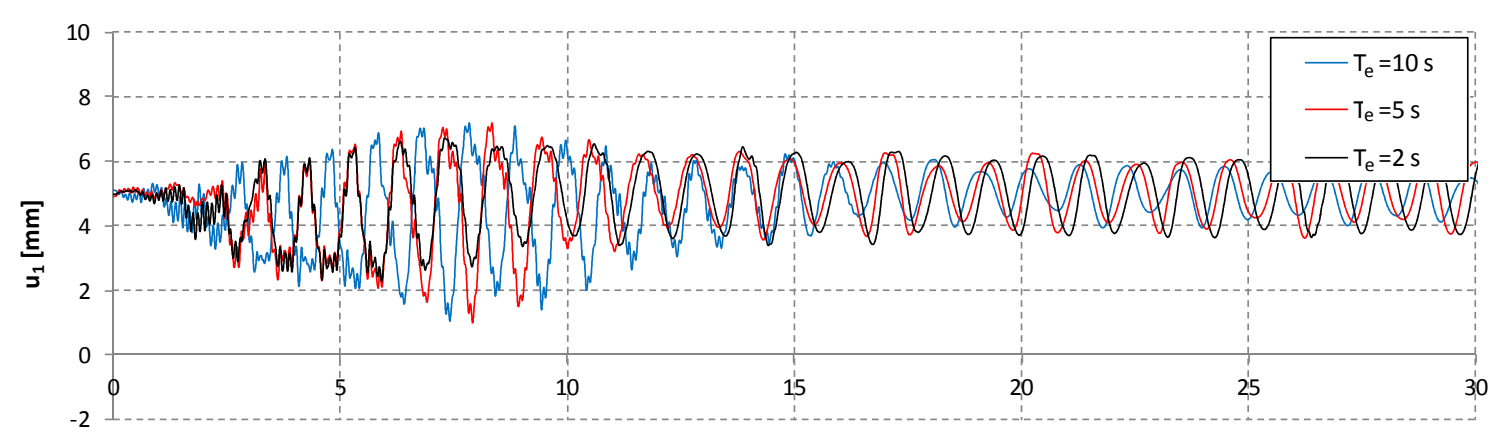

$\mathrm{t}[\mathrm{s}]$

(a) Pomak $u_{1}$

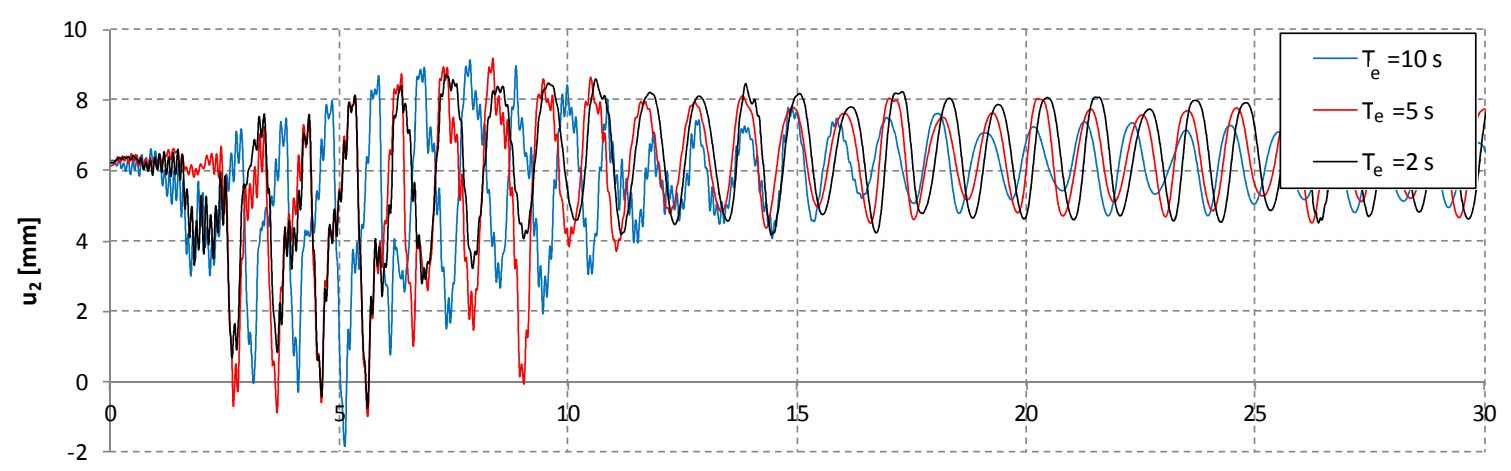

$\mathrm{t}[\mathrm{s}]$

(b) Pomak $\mathrm{u}_{2}$

Slika 5.36. Horizontalni pomak prednje stijenke rezervoara $\mathrm{R} 1$ 


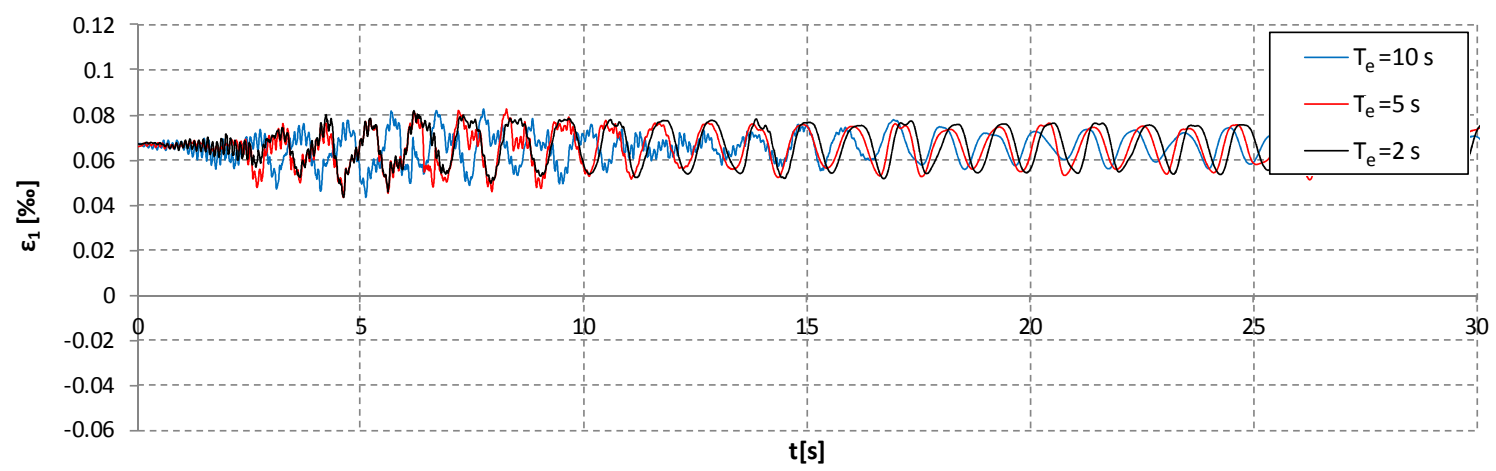

(a) Deformacija $\varepsilon_{1}$

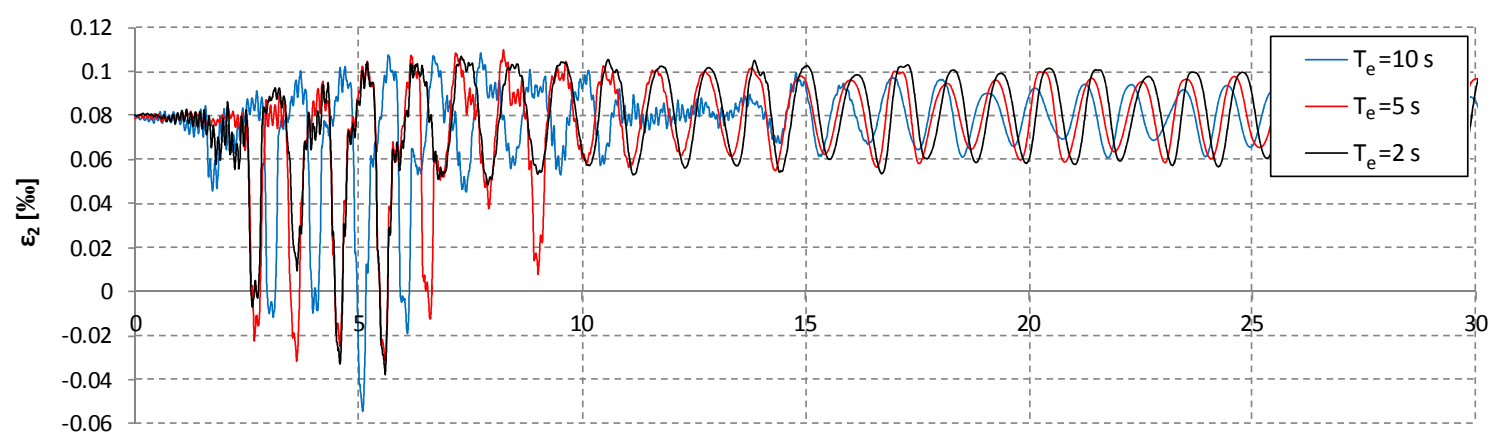

$\mathrm{t}[\mathrm{s}]$

(b) Deformacija $\varepsilon_{2}$

Slika 5.37. Deformacija prednje stijenke rezervoara R1 


\subsection{Zaključci}

Prikazani su rezultati eksperimentalnog ispitivanja ponašanja otvorenog pravokutnog rezervoara s vodom pri potresu pomoću potresne platforme, pri čemu dolazi do većih pomaka vode u rezervoaru. Ostvarena su dva postavljena cilja: (i) dan je doprinos poznavanju ponašanja predmetnih rezervoara u uvjetima potresa, te (ii) proširena je eksperimentalna baza za provjeru numeričkih modela za simulaciju dinamičke interakcije sustava voda - rezervoar. $\mathrm{Na}$ temelju provedenih eksperimentalnih testova, za analizirane rezervoare može se zaključiti niže navedeno:

- S povećanjem krutosti bočnih stijenki rezervoara:

- Povećavaju se hidrodinamički tlakovi i hidrodinamička sila na njih.

- Podiže se težište rezultantne sile vode u odnosu na težište hidrostatičke sile.

- Smanjuju se relativni pomaci i povećavaju deformacije/naprezanja stijenki rezervoara.

- Prvi periodi slobodnih oscilacija sustava voda- rezervoar malo ovise o krutosti stijenki rezervoara i dominantno su određeni gabaritima vode u rezervoaru. Razlog tomu je što čak i vrlo meke stijenke rezervoara još uvijek imaju daleko veću krutost od krutosti same vode.

- Ako se period harmonijske pobude približava prvom periodu slobodnih oscilacija vode u rezervoaru, čak i za vrlo mala maksimalna ubrzanja podloge može doći do sljedećeg:

- Vrlo visokog uzdizanja vode u rezervoaru u odnosu na hidrostatičko stanje te do zapljuskivanja stijenki rezervoara.

- Hidrodinamički tlakovi vode i hidrodinamička sila vode na stijenke rezervoara mogu višestruko premašiti hidrostatičke vrijednosti.

- Težište ukupne sile vode na stijenke rezervoara može se drastično podići i biti nekoliko puta više od težišta hidrostatičke sile, odnosno može biti blizu početne razine vode $\mathrm{u}$ rezervoaru.

- Stvarni i umjetni akcelelogrami potresa mogu biti nepovoljniji od nerezonantnih harmonijskih ubrzanja podloge. Oni mogu prouzročiti visoke hidrodinamičke tlakove vode na stijenke rezervoara čak i za relativno nisko maksimalno ubrzanje podloge.

- S povećanjem visine vode u rezervoaru:

- Povećava se ukupna hidrostatička i hidrodinamička sila vode na sijenke rezervoara. 
- Odnos ukupne i hidrostatičke sile vode se malo mijenja.

- Smanjuje se odnos visine težišta ukupne sile vode u odnosu na visinu težišta hidrostatičke sile.

- S povećanjem amplitude harmonijske pobude povećava se hidrodinamička sila vode $\mathrm{i}$ podiže njeno težište, ali ne proporcionalno.

- Dovoljan je mali broj perioda harmonijske pobude da pokrene gibanje vode $\mathrm{u}$ rezervoaru. Nerezonantne pobude mogu biti nepovoljnije pri kraćem nego pri duljem trajanju. Rezonantne pobude su vjerojatno nepovoljnije ako traju duže. 


\section{6 \\ PROVJERA RAZVIJENOG NUMERIČKOG MODELA}

\subsection{Općenito}

Razvijeni numerički model za međudjelovanje konstrukcije i tekućine, koji je prikazan u Poglavlju 4, namijenjen je analizi konstrukcija koje su u doticaju s tekućinom pri dinamičkom opterećenju (potresu). Osim što je numerički model provjeren na rezultatima prikazanima u Poglavlju 4, provjeren je i na rezultatima eksperimentalnih ispitivanja provedenih u okviru ove disertacije.

U ovom poglavlju prikazani su osnovni podaci o numeričkim analizama, koje su provedene sa ciljem provjere pouzdanosti i primjene razvijenog 3D numeričkog modela za međudjelovanje konstrukcije i tekućine. Provedeno je nekoliko numeričkih testova istovjetnih eksperimentalnim testovima iz Poglavlja 5. Zatim je prikazana usporedba rezultata dobivenih razvijenim numeričkim modelom za simulaciju međudjelovanja konstrukcije i tekućine i rezultata eksperimentalnog ispitivanja. Izvršena je usporedba promjene slobodnog vodnog lica, tlakova vode na stijenke rezervoara i pomaka deformabilnih stijenki rezervoara tijekom različitih dinamičkih pobuda. 


\subsection{Osnovni podaci o provedenim numeričkim analizama}

Dimenzije i svojstva modeliranih rezervoara R1, R2 i R3 odgovaraju dimenzijama eksperimentalno ispitanih rezervoara (Potpoglavlje 5.2). U svim provedenim numeričkim analizama usvojena je razina vode $\mathrm{h}=0.4 \mathrm{~m}$.

\subsubsection{Prostorna diskretizacija}

Početni razmak čestica vode i rubnih (virtualnih) čestica je $0.05 \mathrm{~m}$ i jednoliko su raspoređene (Slika 6.1). Ukupan broj čestica, uključujući rubne čestice, je 13016.

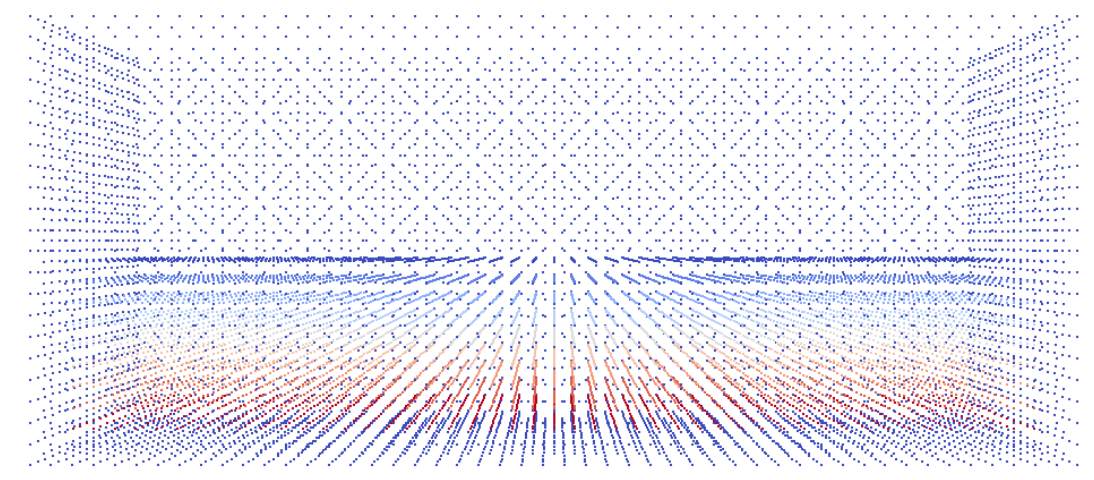

Slika 6.1. Početni razmještaj čestica

Na Slici 6.2 je prikazana prostorna diskretizacija deformabilne prednje stijenke rezervoara, koja je modelirana kao ljuskasta konstrukcija. Svi rubni čvorovi ljuske su modelirani kao upeti, osim čvorova na gornjem rubu ljuske. Kao što je vidljivo, upotrijebljena je relativno gusta mreža pravilnih konačnih elemenata (320 elemenata s 1353 čvora).
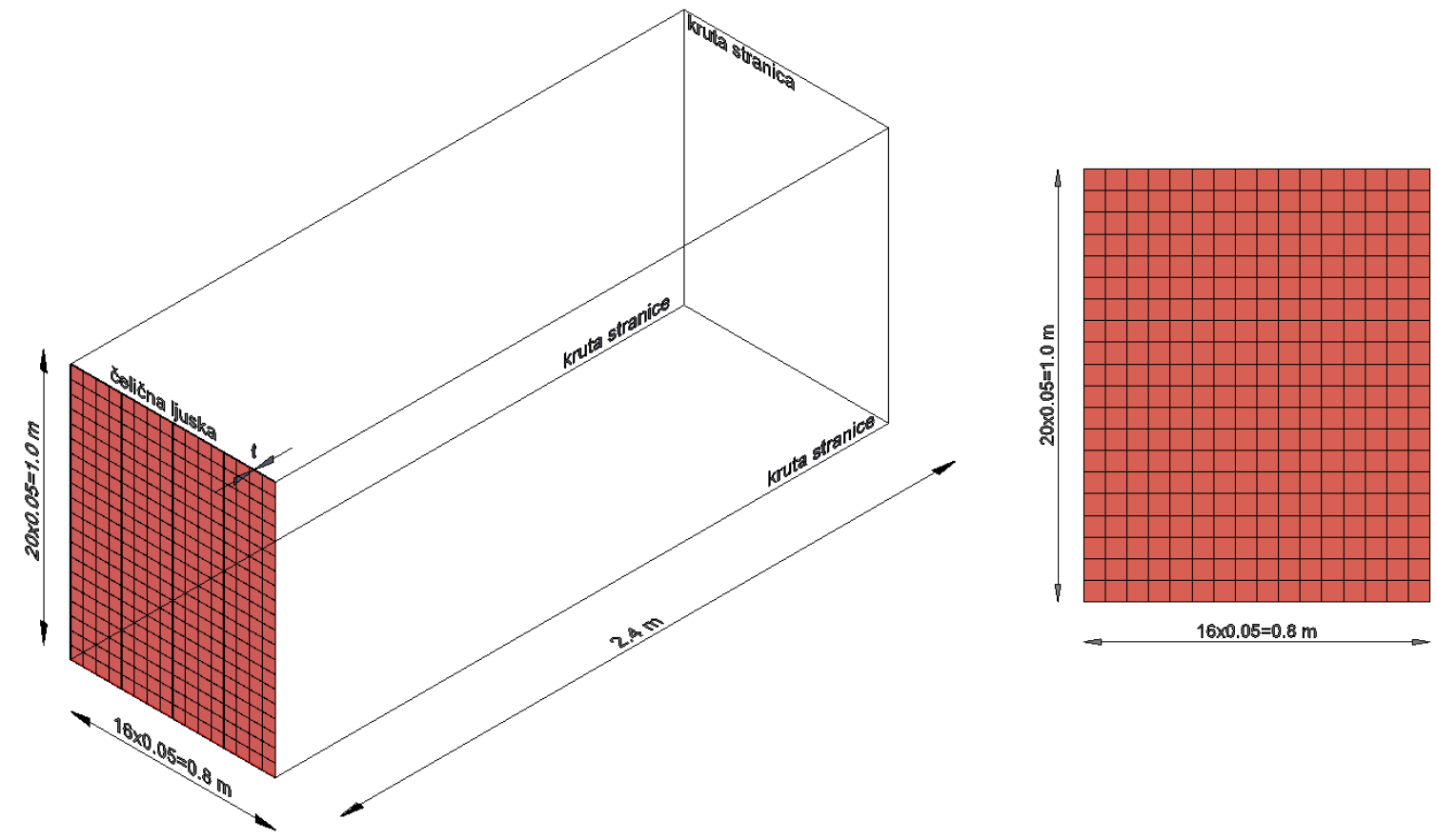

Slika 6.2. Prostorna diskretizacija čelične ljuske 


\subsubsection{Materijalne karakteristike}

Rezervoari su djelomično ispunjeni vodom. U svim numeričkim testovima usvojena je početna gustoća vode $\rho_{0}=1000 \mathrm{~kg} / \mathrm{m}^{3}$ i brzina zvuka u vodi $\mathrm{c}=1430 \mathrm{~m} / \mathrm{s}$. Prednja stijenka rezervoara modelirana je kao čelična ljuska. Usvojen je elastoplastični model materijala. Materijalne karakteristike čelične ljuske prikazane su u Tablici 6.1.

Tablica 6.1. Materijalne karakteristike čelične ljuske

\begin{tabular}{lc}
\hline \multicolumn{1}{c}{ Svojstvo } & Vrijednost \\
\hline \hline Modul elastičnosti [GPa] & 205 \\
\hline Granica razvlačenja [MPa] & 240 \\
\hline Vlačna čvrstoća [MPa] & 370 \\
\hline Poissonov koeficijent & 0.3 \\
\hline Gustoća $\left[\mathrm{kg} / \mathrm{m}^{3}\right]$ & 7850 \\
\hline
\end{tabular}




\subsection{Usporedba promjene vodnog lica}

Usporedba promjene vodnog lica izvršena je na primjeru rezervoara R3 (rezervoar sa svim krutim stijenkama), napunjenog do dubine $\mathrm{h}=0.4 \mathrm{~m}$ i izloženog harmonijskoj pobudi prema Slici 5.3. $\mathrm{sa} \mathrm{a}_{0}=0.5 \mathrm{~g}, \mathrm{~T}_{\mathrm{p}}=2.5 \mathrm{~s}$ i $\mathrm{T}_{\mathrm{e}}=10 \mathrm{~T}_{\mathrm{p}}$. $\mathrm{T}_{\mathrm{p}}=2.5 \mathrm{~s}$ je prvi period slobodnih oscilacija vode $\mathrm{u}$ rezervoaru $\mathrm{i}$ harmonijska pobuda $\mathrm{s}$ tim periodom uzrokuje velike promjene vodnog lica i tlakove na stijenke rezervoara (Potpoglavlje 5.6.3).

Na Slici 6.3. prikazana je usporedba numeričkih i eksperimentalnih rezultata za promjenu razine vode na prednjoj stijenci rezervoara u vremenu. Može se uočiti vrlo dobro poklapanje numeričkih i eksperimentalnih rezultata. Manja odstupanja numeričkih rezultata od eksperimentalnih, posebno ona koja se odnose na maksimalno uzdizanje vode u rezervoaru, mogu se pripisati korištenju relativno malog broja čestica vode.

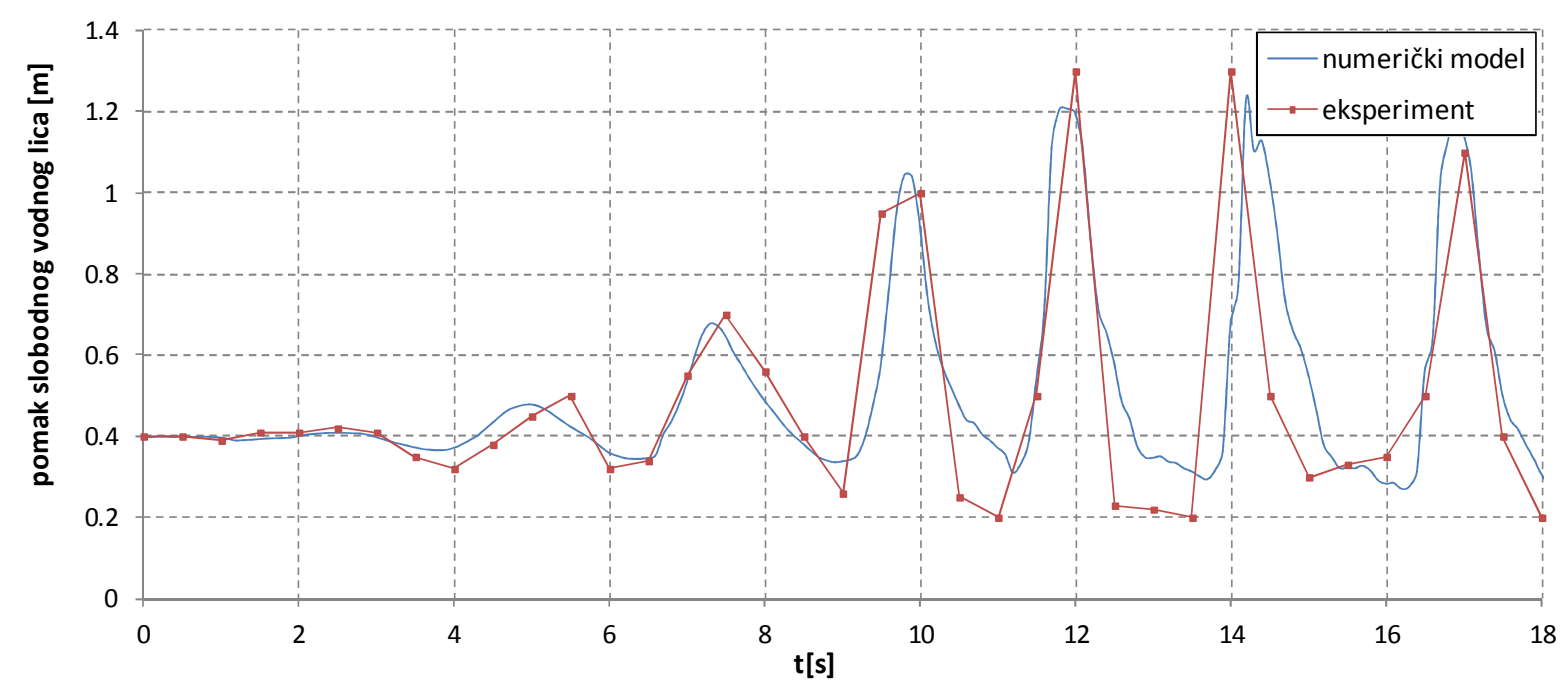

Slika 6.3. Usporedba promjene razine vode na prednjoj stijenci rezervoara

$\mathrm{Na}$ Slici 6.4. je prikazana usporedba promjene slobodnog vodnog lica u nekim vremenima između eksperimentalnih ispitivanja i provedene numeričke analize. Prednja stijenka rezervoara je desna stranica rezervoara na fotografijama. Može se uočiti vrlo dobro podudaranje eksperimentalnih i numeričkih rezultata. 

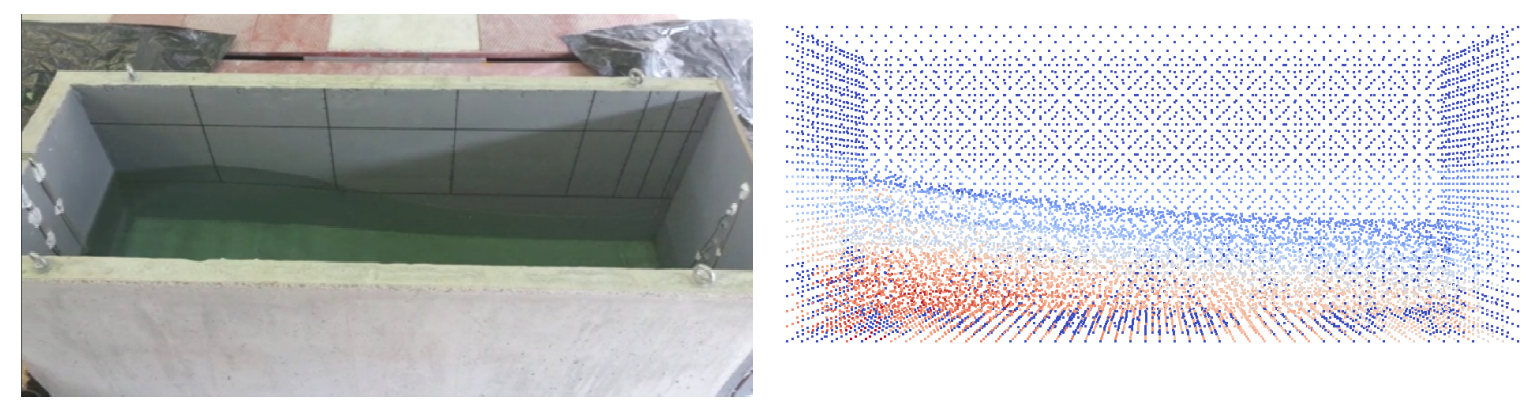

(a) $\mathrm{t}=4.0$
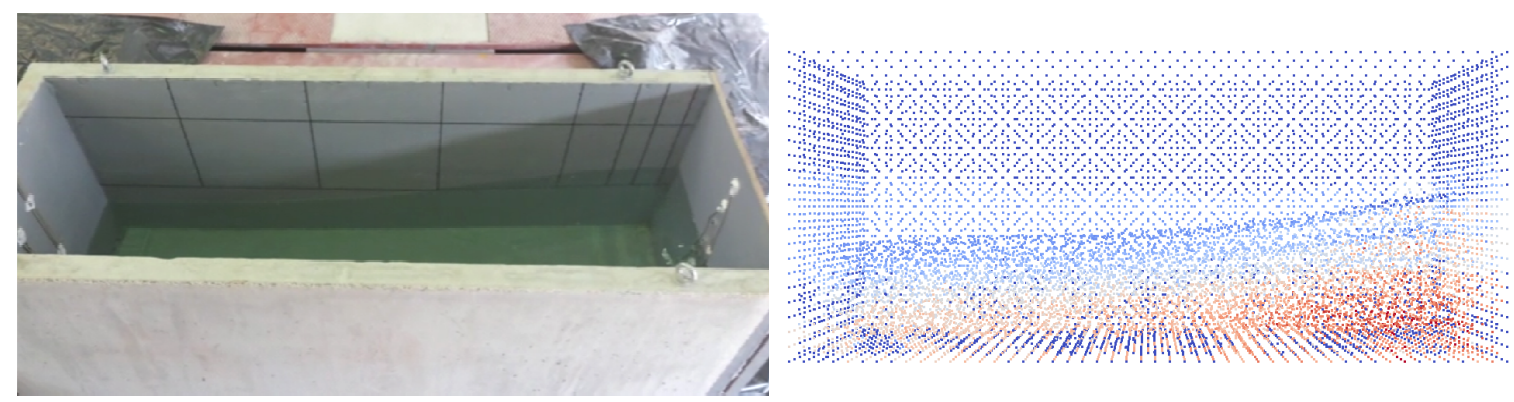

(b) $\mathrm{t}=4.5 \mathrm{~s}$
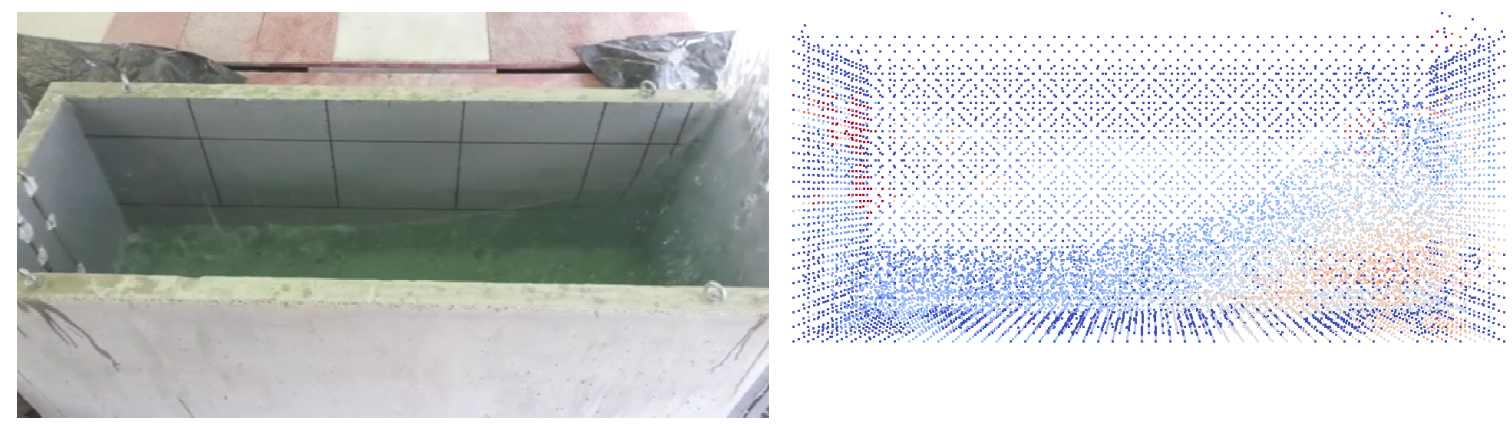

(c) $\mathrm{t}=9.5 \mathrm{~s}$
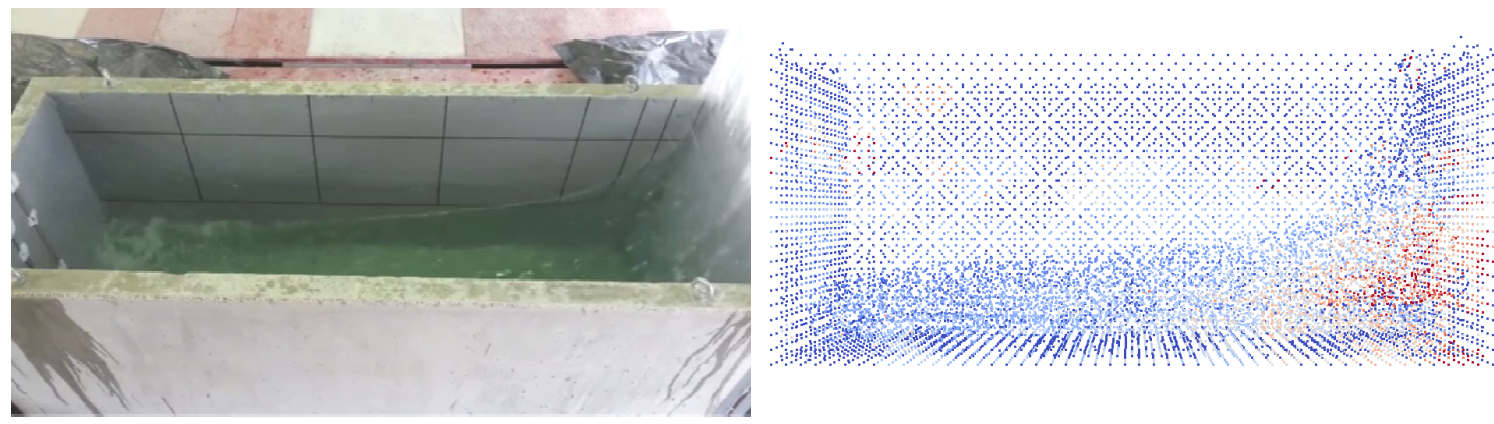

(d) $\mathrm{t}=12.0 \mathrm{~s}$

Slika 6.4. Usporedba promjene vodnog lica 


\subsection{Usporedba tlakova vode na prednju stijenku rezervoara}

\subsubsection{Tlakovi na krutu stijenku rezervoara}

Usporedba tlakova vode na prednju stijenku rezervoara izvršena je na primjeru rezervoara R3 (rezervoar sa svim krutim stijenkama), napunjenog vodom do visine $h=0.4 \mathrm{~m} \mathrm{i}$ izloženog harmonijskoj pobudi prema Slici 5.3. $\mathrm{sa} \mathrm{a}_{0}=0.5 \mathrm{~g}$ i $\mathrm{Te}=10 \mathrm{~T}_{\mathrm{p}}$.

Usporedba tlakova vode na dnu (točka 1) prednje stijenke za harmonijsku pobudu $\mathrm{s}$ $\mathrm{T}_{\mathrm{p}}=0.5 \mathrm{~s}$ prikazana je na Slici 6.5 , za harmonijsku pobudu $\mathrm{s} \mathrm{T}_{\mathrm{p}}=1.0 \mathrm{~s}$ na Slici 6.6 i za pobudu $\mathrm{s}$ $\mathrm{T}_{\mathrm{p}}=2.5 \mathrm{~s}$ na Slici 6.7. Za pobudu $\mathrm{s} \mathrm{T}_{\mathrm{p}}=2.5 \mathrm{~s}$ prikazana je usporedba tlakova u svim drugim točkama po visini stijenke (Slika 6.8 - Slika 6.16), u kojima su se tijekom eksperimentalnog ispitivanja zabilježili tlakovi vode (Potpoglavlje 5.6.3).

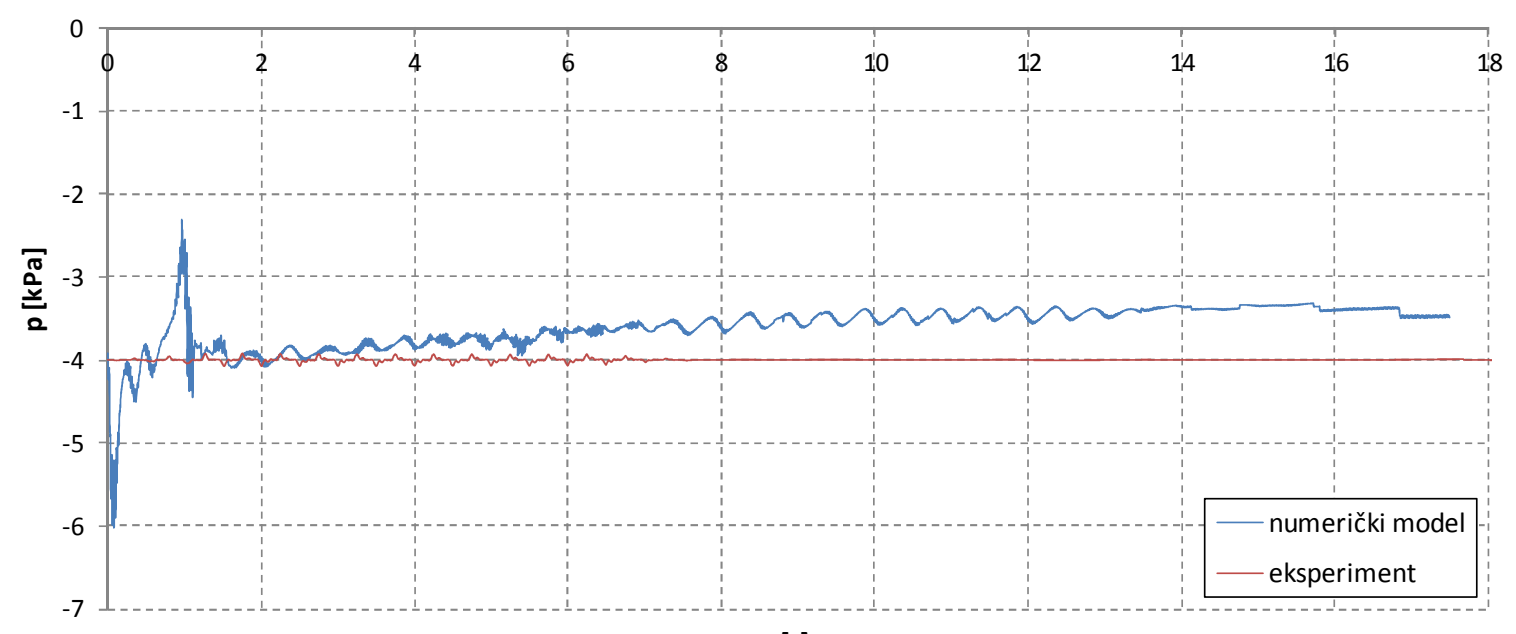

$\mathbf{t}[\mathbf{s}]$

Slika 6.5. Tlakovi vode u točki 1 rezervoara $R 3$ za $T_{p}=0.5 \mathrm{~s}$

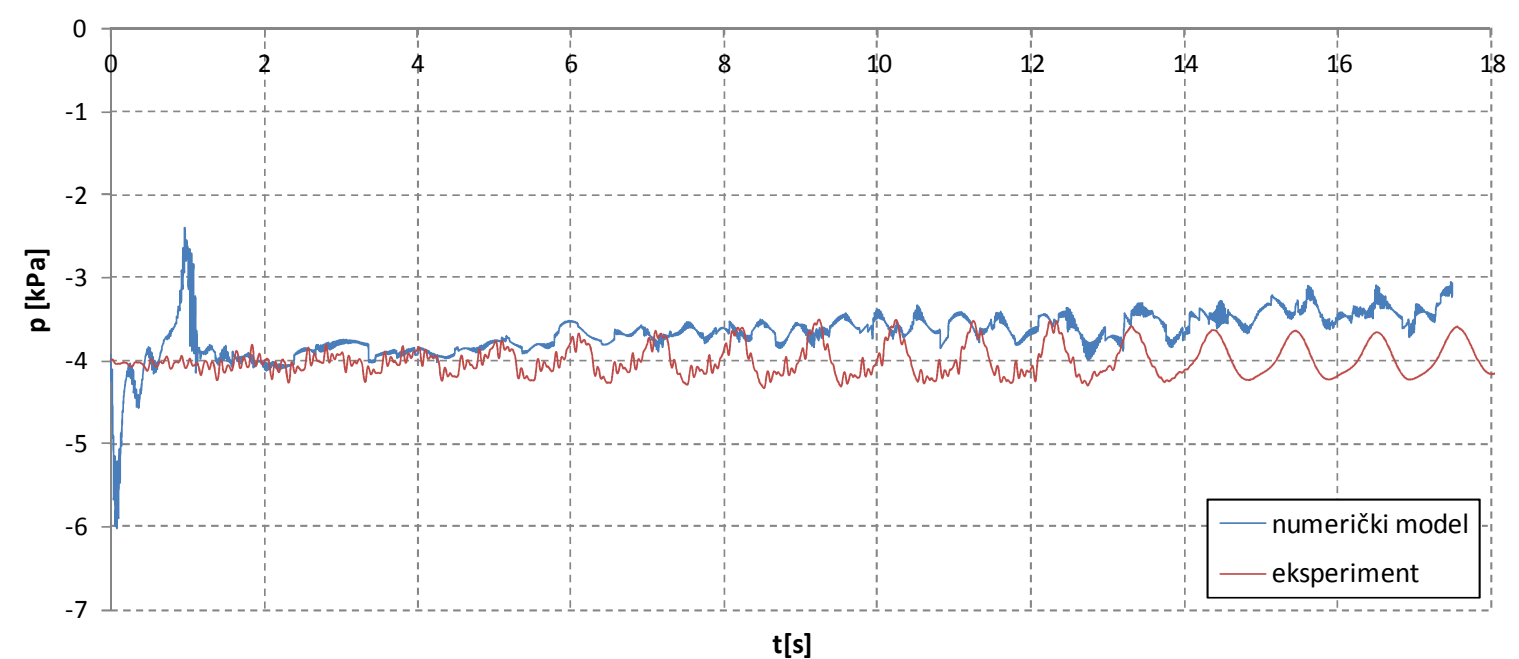

Slika 6.6. Tlakovi vode u točki 1 rezervoara $R 3$ za $T_{p}=1.0 \mathrm{~s}$ 


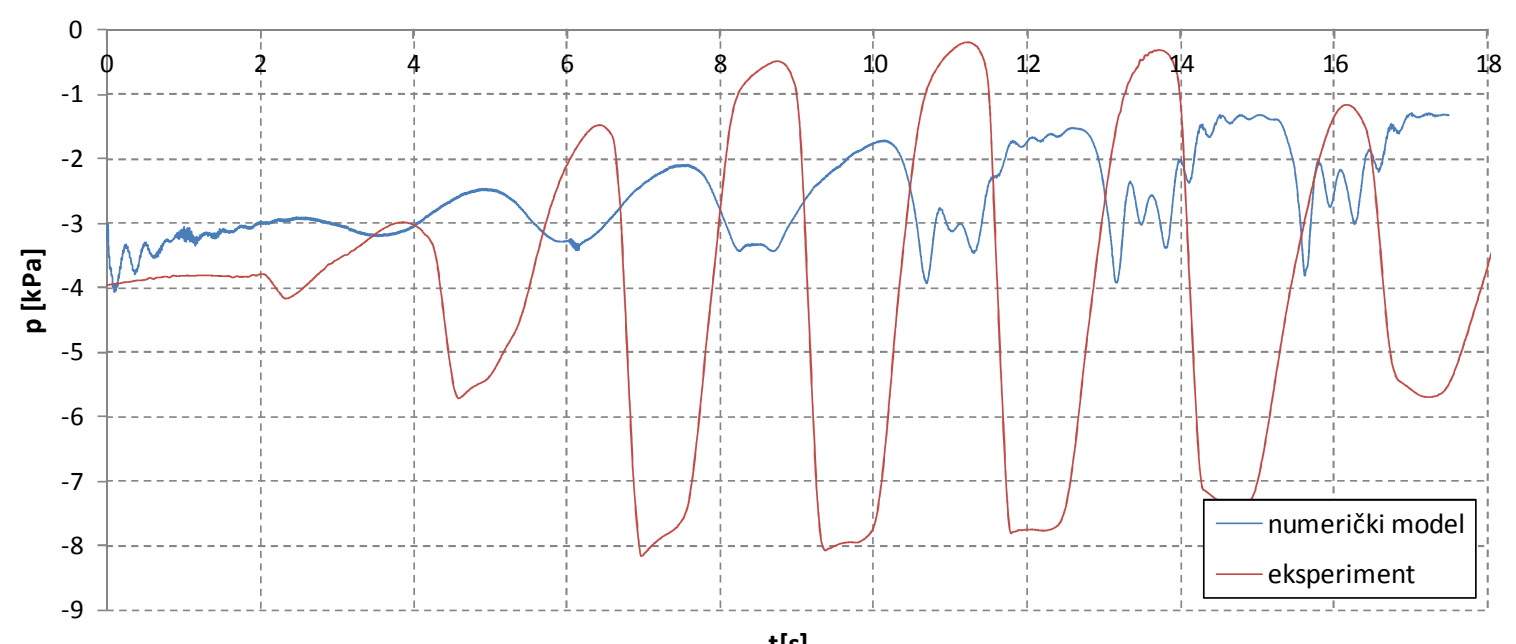

$t[s]$

Slika 6.7. Tlakovi vode $u$ točki 1 rezervoara $R 3$ za $T_{p}=2.5 \mathrm{~s}$

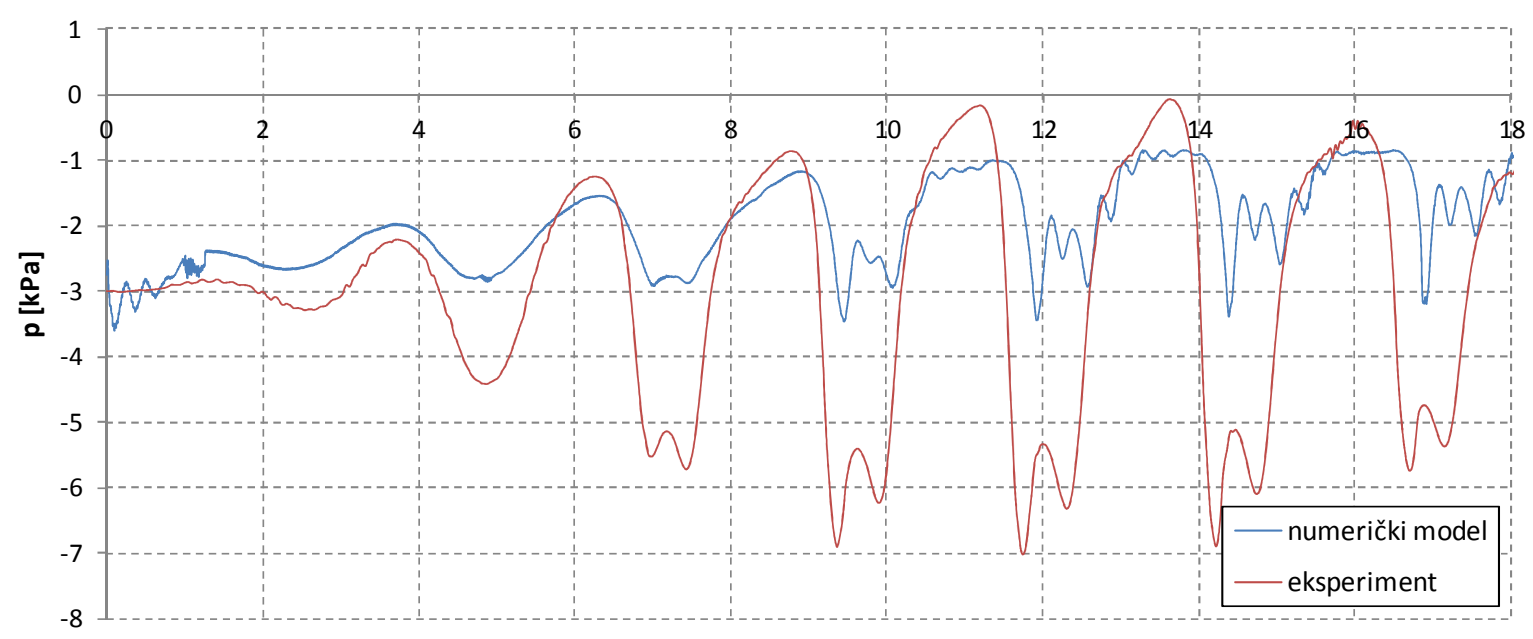

$\mathrm{t}[\mathrm{s}]$

Slika 6.8. Tlakovi vode $u$ točki 2 rezervoara $R 3$ za $T_{p}=2.5 \mathrm{~s}$

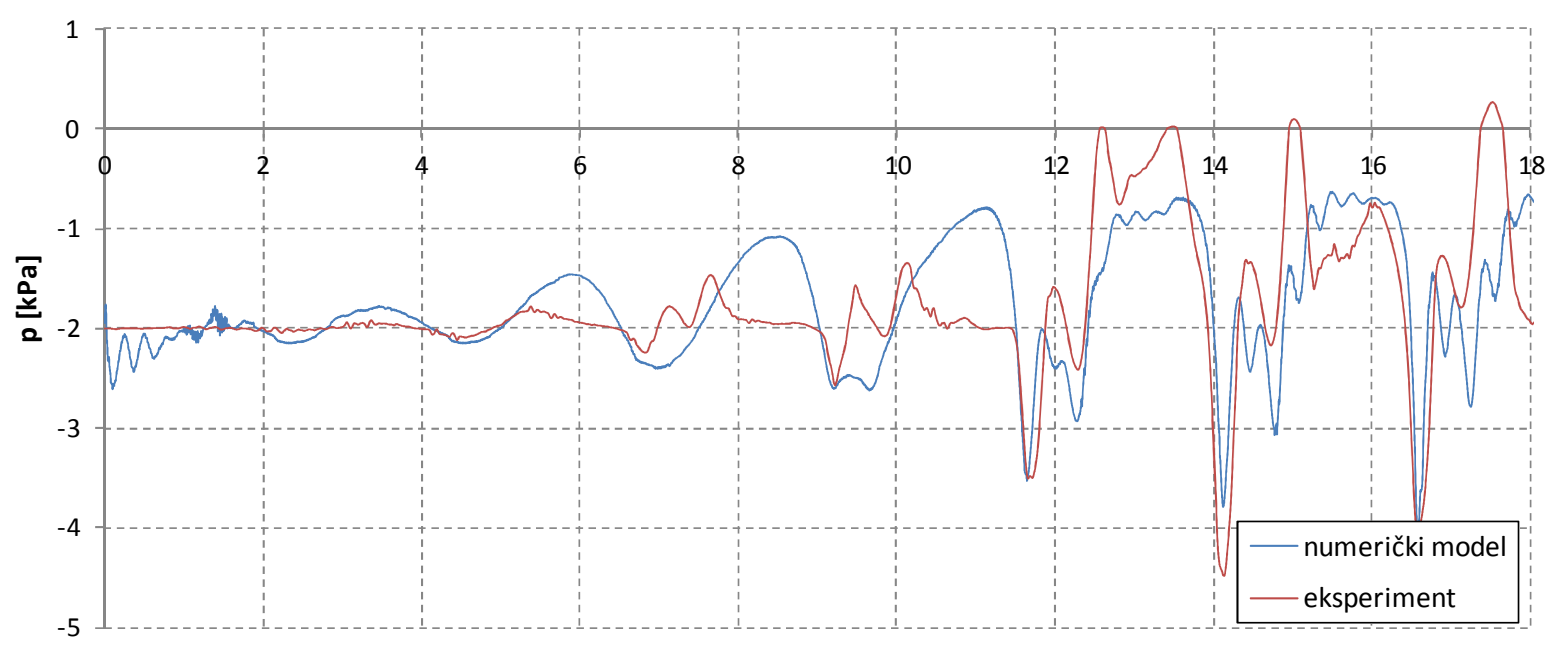

$\mathrm{t}[\mathrm{s}]$

Slika 6.9. Tlakovi vode $u$ točki 3 rezervoara $R 3$ za $T_{p}=2.5 \mathrm{~s}$ 


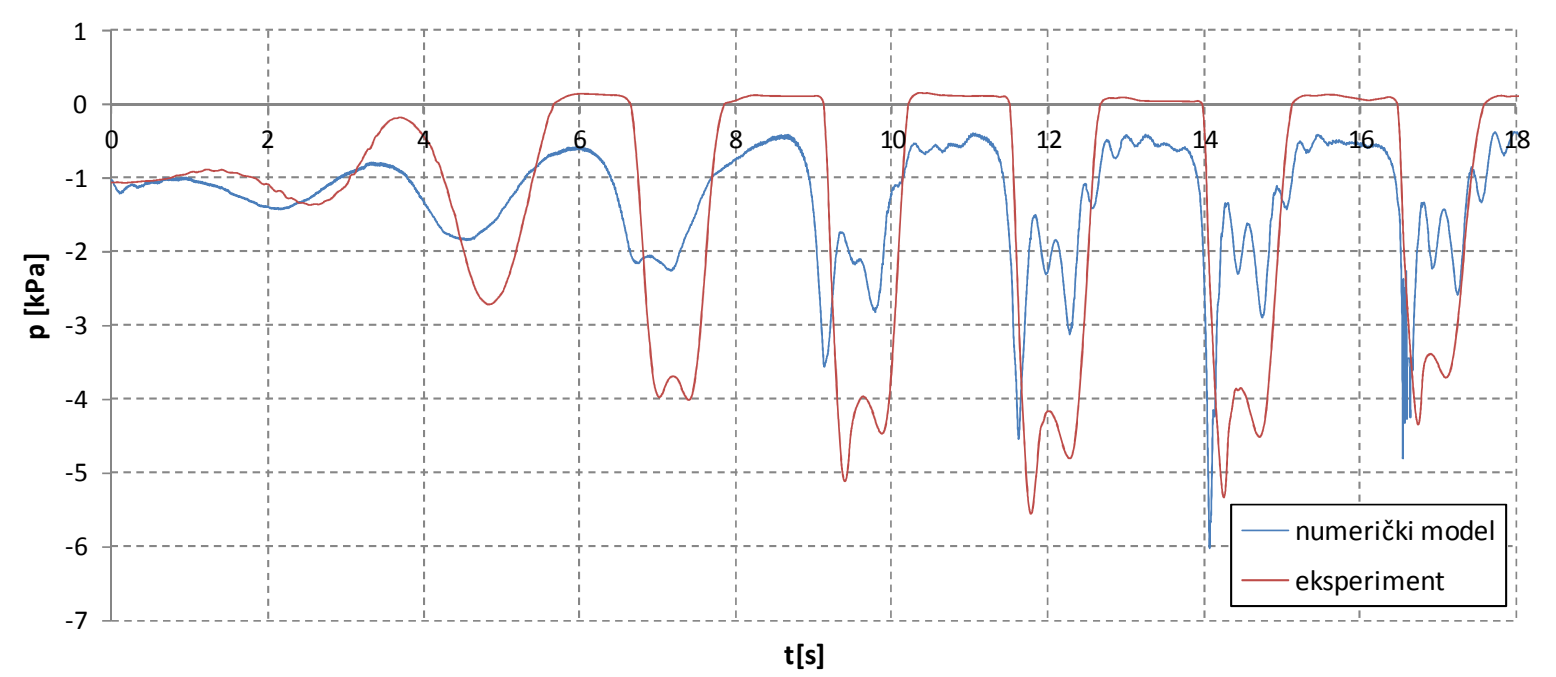

Slika 6.10. Tlakovi vode u točki 4 rezervoara $R 3$ za $T_{p}=2.5 \mathrm{~s}$

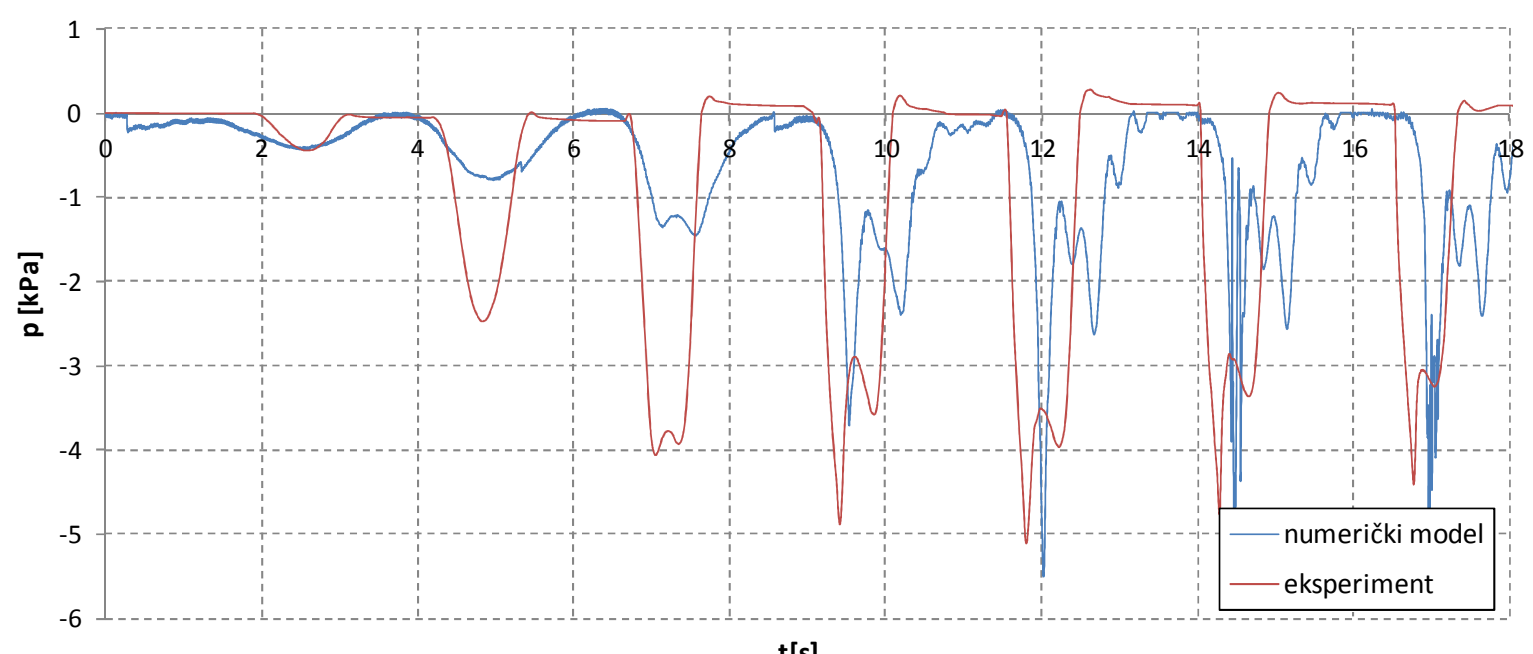

$\mathrm{t}[\mathrm{s}]$

Slika 6.11. Tlakovi vode u točki 5 rezervoara $R 3$ za $T_{p}=2.5 \mathrm{~s}$

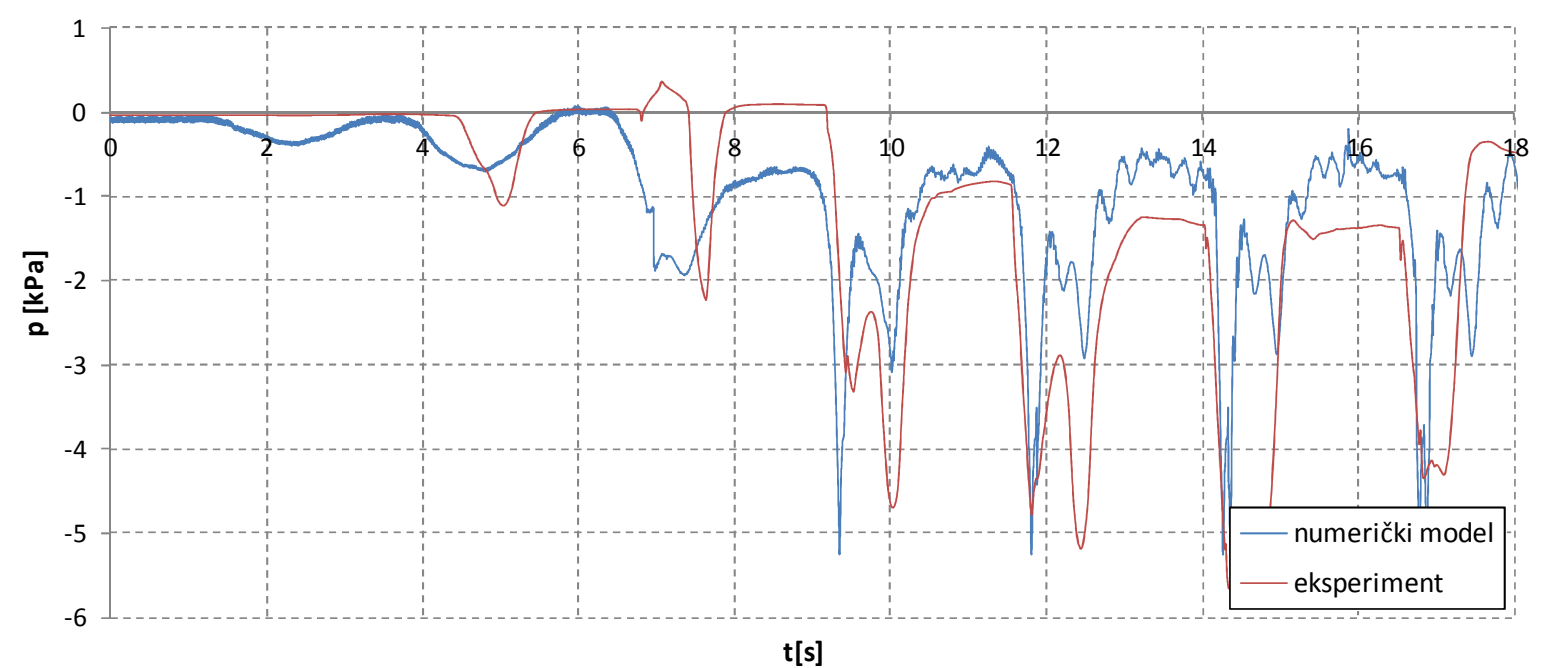

Slika 6.12. Tlakovi vode $u$ točki 6 rezervoara $R 3$ za $T_{p}=2.5 \mathrm{~s}$ 


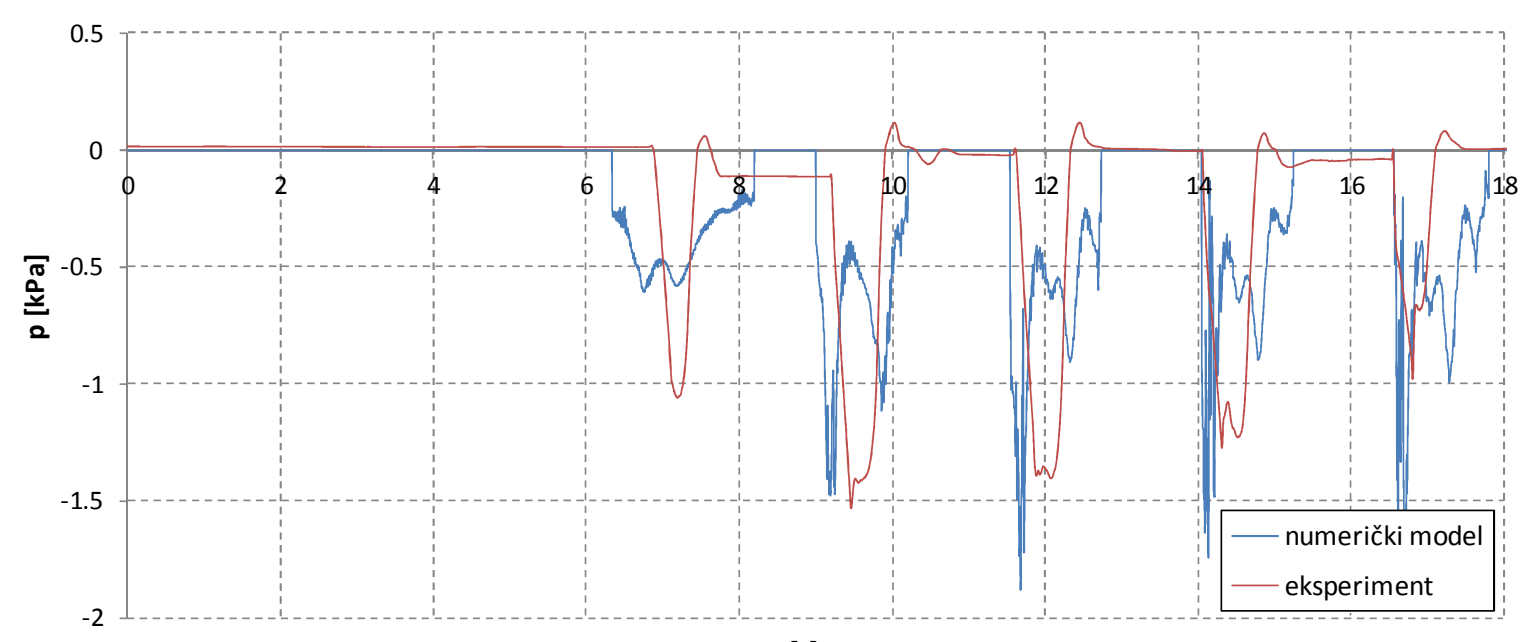

$\mathrm{t}[\mathrm{s}]$

Slika 6.13. Tlakovi vode $u$ točki 7 rezervoara $R 3$ za $T_{p}=2.5 \mathrm{~s}$

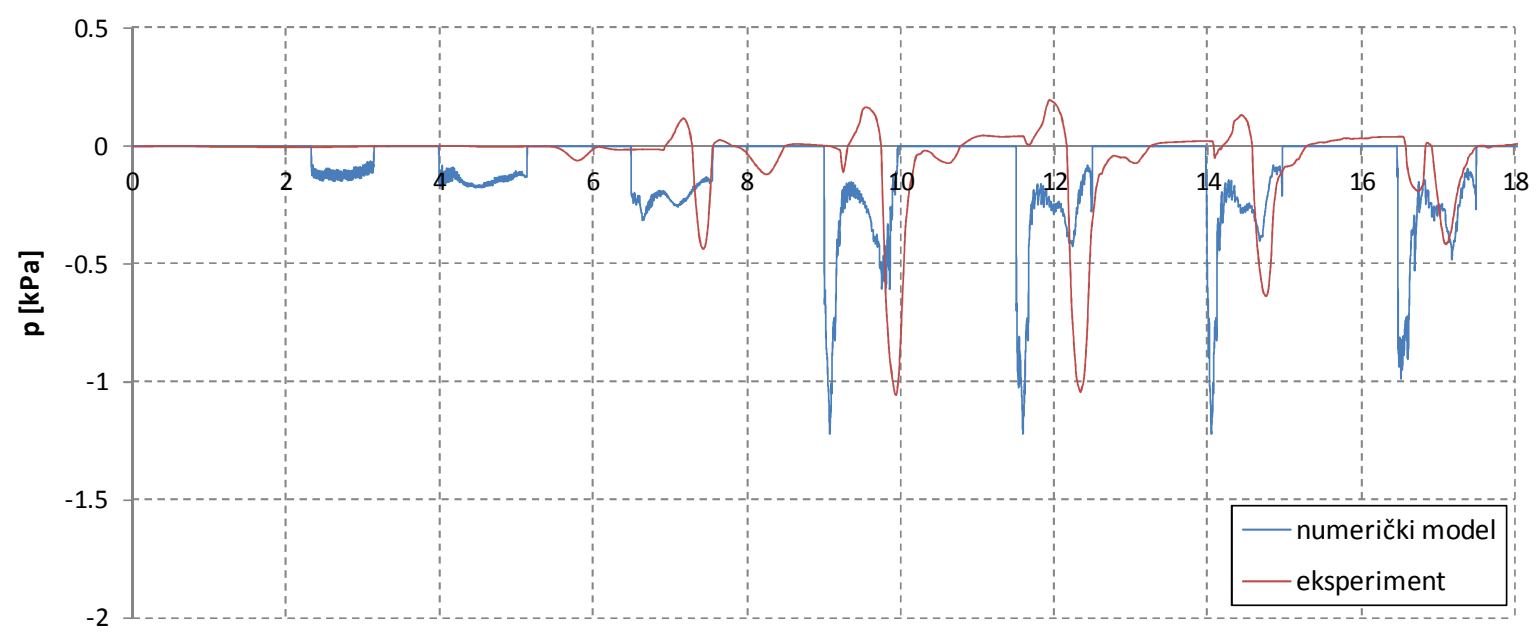

$\mathrm{t}[\mathrm{s}]$

Slika 6.14. Tlakovi vode $\mathrm{u}$ točki 8 rezervoara $\mathrm{R} 3 \mathrm{za} \mathrm{T}_{\mathrm{p}}=2.5 \mathrm{~s}$

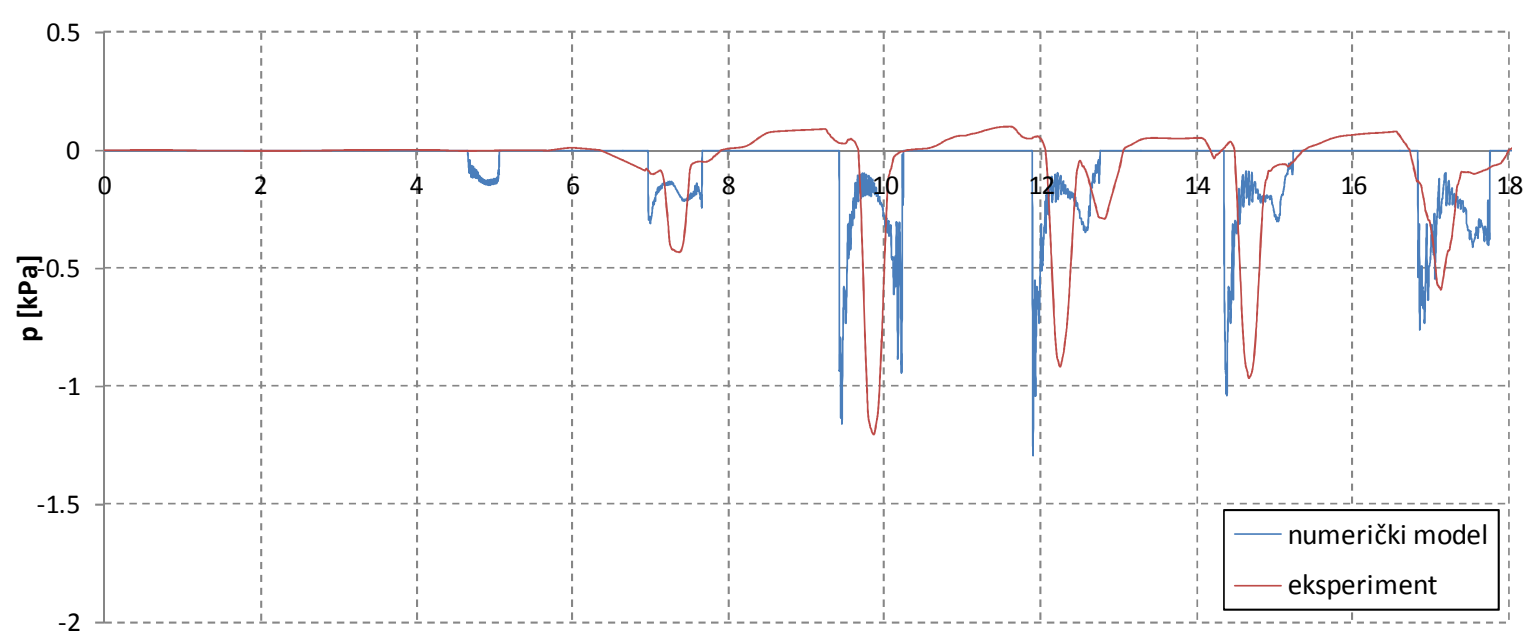

$\mathrm{t}[\mathrm{s}]$

Slika 6.15. Tlakovi vode u točki 9 rezervoara $R 3$ za $T_{p}=2.5 \mathrm{~s}$ 


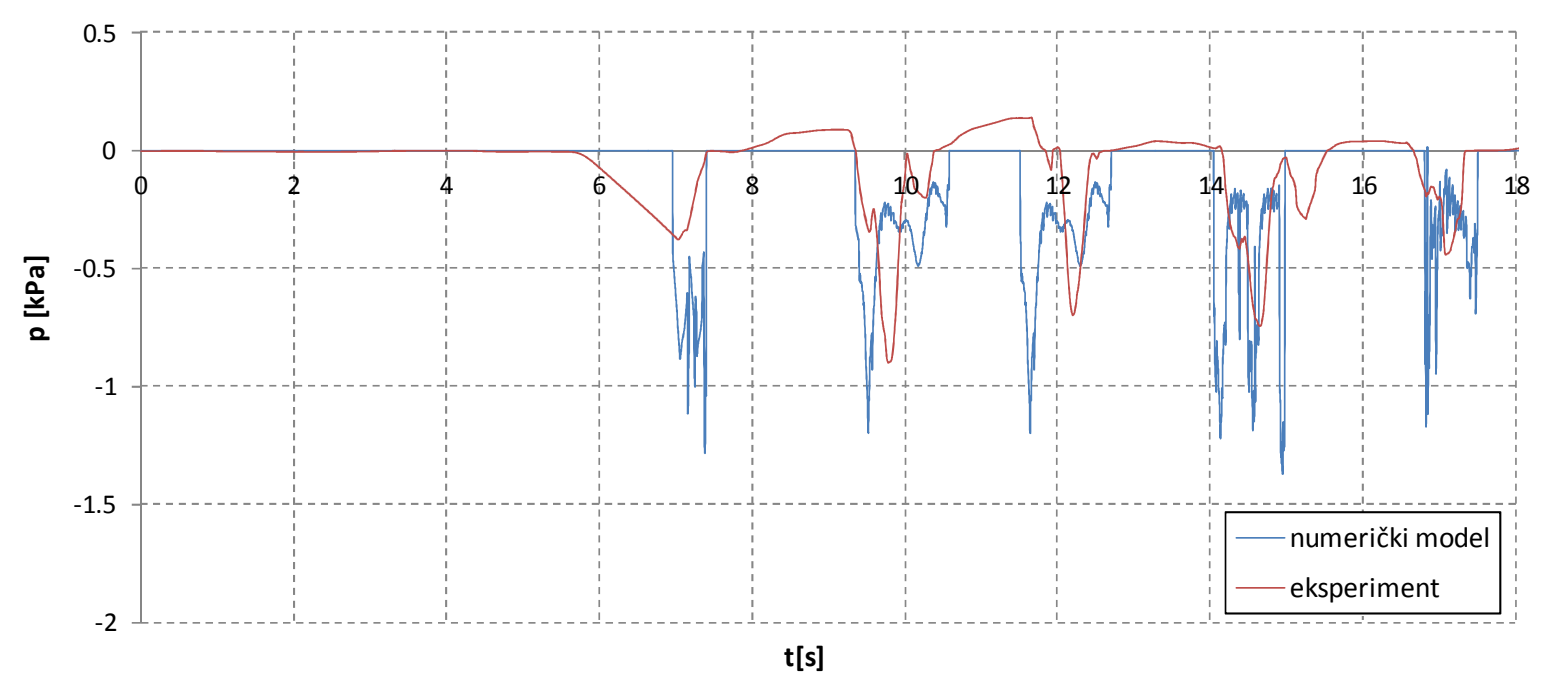

Slika 6.16. Tlakovi vode u točki 10 rezervoara $R 3$ za $T_{p}=2.5 \mathrm{~s}$

Iz prikazanih dijagrama se može uočiti relativno dobro podudaranje numeričkih i eksperimentalnih rezultata. Značajno odstupanje numeričkih rezultata od eksperimentalnih je u točkama koje su pri dnu rezervoara (Slika 6.5.-Slika 6.8.), gdje je negativan utjecaj ruba računalne domene tekućine najveći. Međutim, podudaranje numeričkih i eksperimentalnih rezultata u ostalim točkama po visini je vrlo dobro.

\subsubsection{Tlakovi na deformabilnu stijenku rezervoara}

Izvršena je i usporedba tlakova vode na deformabilnu stijenku rezervoara na primjeru rezervoara $\mathrm{R} 1$, napunjenog do visine $\mathrm{h}=0.4 \mathrm{~m}$. Usvojene su tri različite dinamičke pobude koje odgovaraju pobudama iz Potpoglavlja 5.6.4 (harmonijsko ubrzanje, umjetni akcelerogram i akcelerogram potresa Petrovac).

Usporedba tlakova vode u točki udaljenoj $40 \mathrm{~cm}$ od dna (točka 5) za harmonijsku pobudu $\left(\mathrm{a}_{0}=0.16 \mathrm{~g}, \mathrm{~T}_{\mathrm{p}}=1.0 \mathrm{~s}, \mathrm{Te}=10 \mathrm{~s}\right)$ prikazana je na Slici $6.17 \mathrm{a}$, za umjetni akcelerogram na Slici 2.17b, a za akcelerogram potresa Petrovac na Slici 6.17c. Tlakovi vode na deformabilnu stijenku rezervoara R1 dobiveni numeričkim modelom se dobro slažu s eksperimentalnim rezultatima u pogledu maksimalnih vrijednosti. Međutim, mogu se uočiti neprirodne oscilacije tlakova dobivenih numeričkim modelom koji su posljedica korištenja usvojene formulacije (odnosno jednadžbe stanja). 


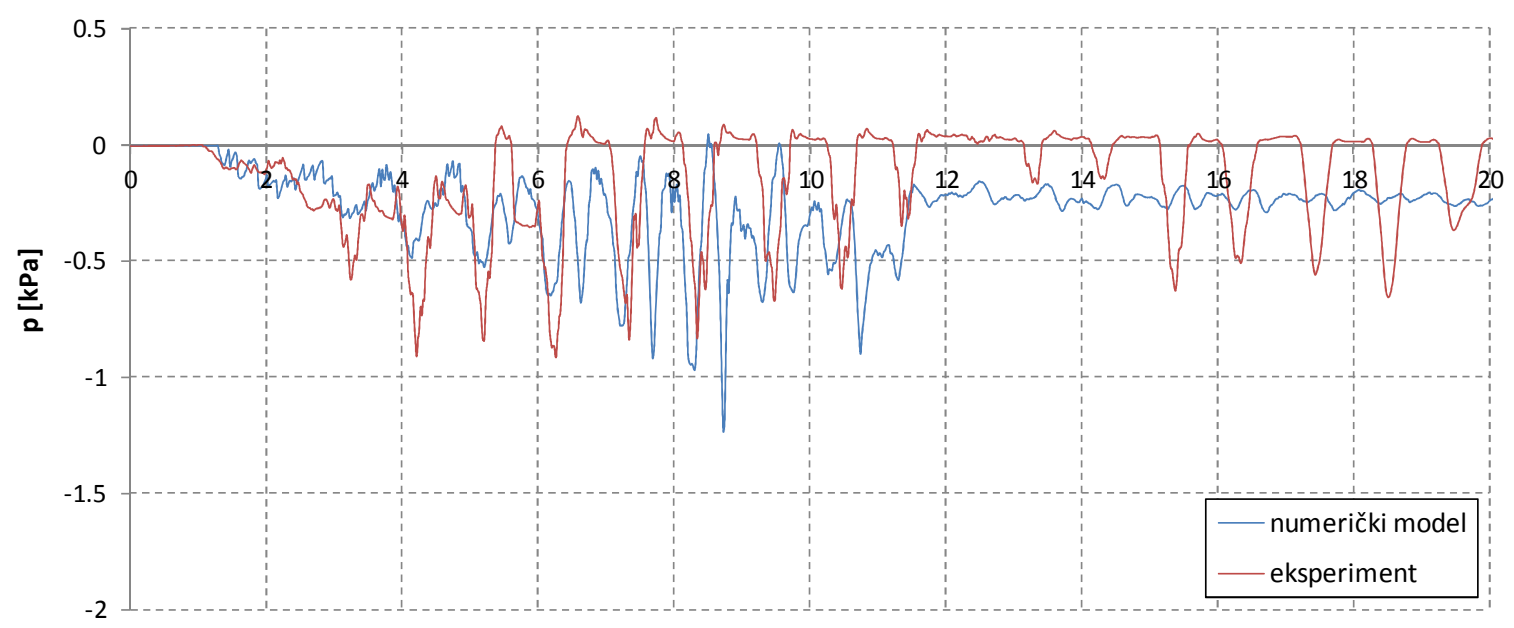

$\mathrm{t}[\mathrm{s}]$

(a) Harmonijsko ubrzanje

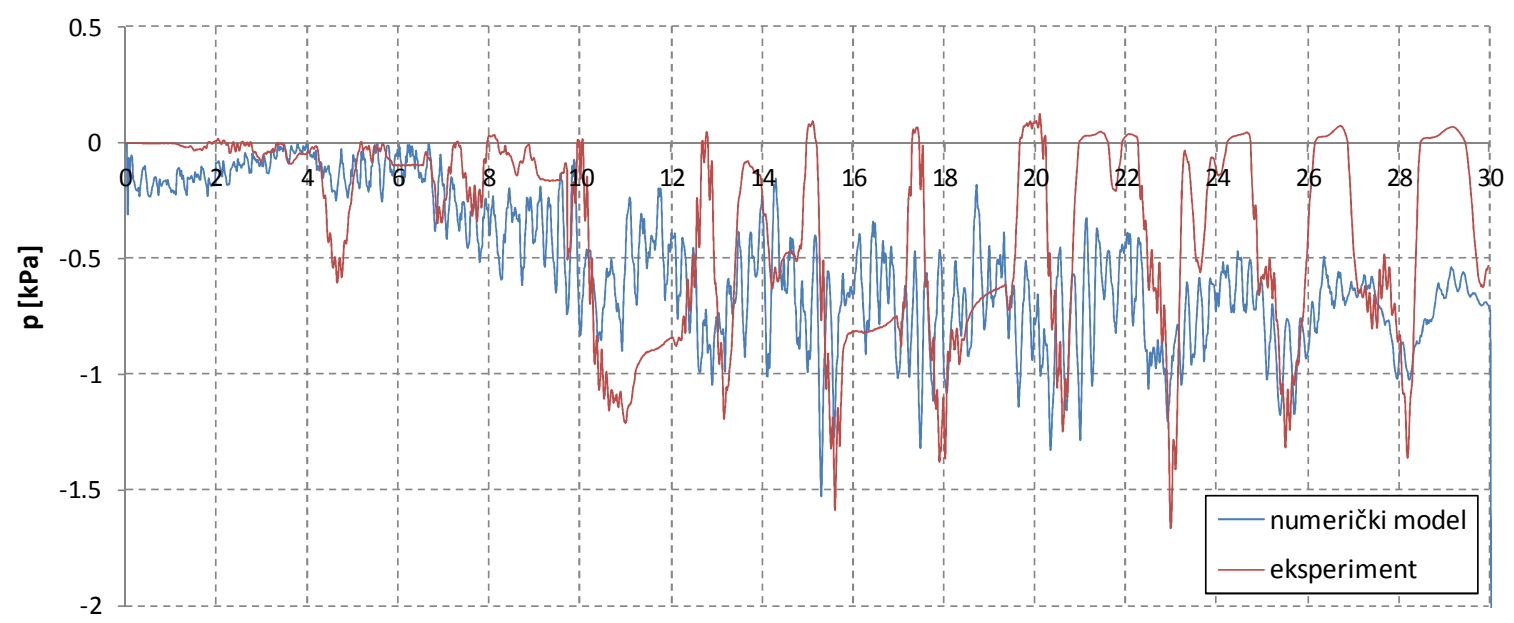

$\mathrm{t}[\mathrm{s}]$

(b) Umjetni akcelerogram

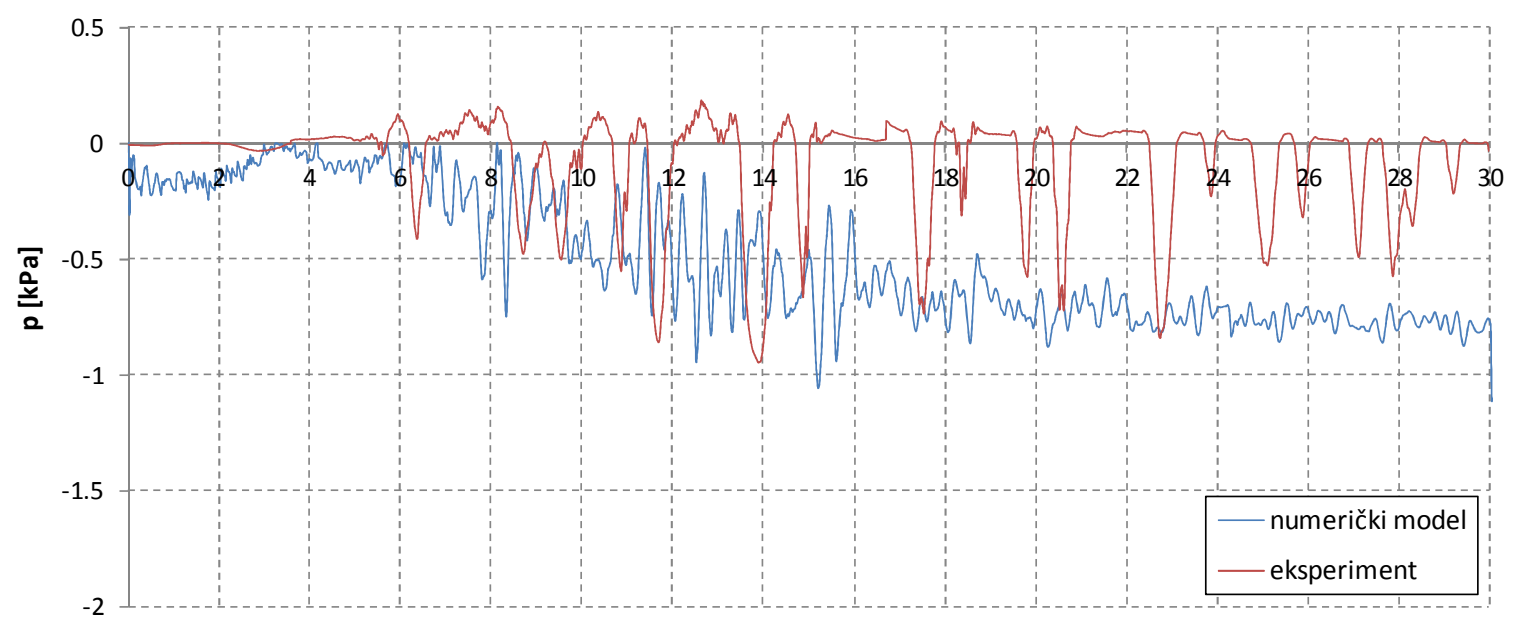

$\mathrm{t}[\mathrm{s}]$

(c) Potres Petrovac

Slika 6.17. Tlakovi vode u točki 5 rezervoara R1 


\subsection{Usporedba pomaka stijenke rezervoara}

U nastavku je prikazana usporedba pomaka deformabilnog čeličnog lima dobivenih numeričkim i eksperimentalnim testovima. Usporedba je izvršena u dvije točke po visini rezervoara $\left(\mathrm{u}_{1}, \mathrm{u}_{2}\right)$ koje odgovaraju mjernim mjestima tijekom eksperimentalnog ispitivanja (Slika 5.4b).

\subsubsection{Pomaci deformabilne stijenke rezervoara $R 1$}

Usporedba pomaka deformabilne stijenke rezervoara R1 (debljina lima $1 \mathrm{~mm}$ ) izvršenja je na primjeru dinamičkih pobuda iz Potpoglavlja 5.6.4. (harmonijsko ubrzanje, umjetni akcelerogram i akcelerogram potresa Petrovac). Na Slici 6.18. prikazana je usporedba horizontalnog pomaka $\mathrm{u}_{1}$, a na Slici 6.19. usporedba horizontalnog pomaka $\mathrm{u}_{2}$.

Vidljivo je dobro poklapanje horizontalnih pomaka deformabilne ljuske dobivenih numeričkim modelom $\mathrm{s}$ rezultatima eksperimentalnih testova. Horizontalni pomak deformabilne ljuske $\mathrm{u}_{2}$ ima manje odstupanje od eksperimentalno izmjerenih pomaka $\mathrm{u}$ odnosu na pomak $\mathrm{u}_{1}$. U slučaju svih dinamičkih pobuda kojima je rezervoar R1 bio izložen, horizontalni pomak $\mathrm{u}_{1}$ dobiven numeričkim modelom je nešto veći od izmjerenog pomaka tijekom eksperimentalnih testova. 


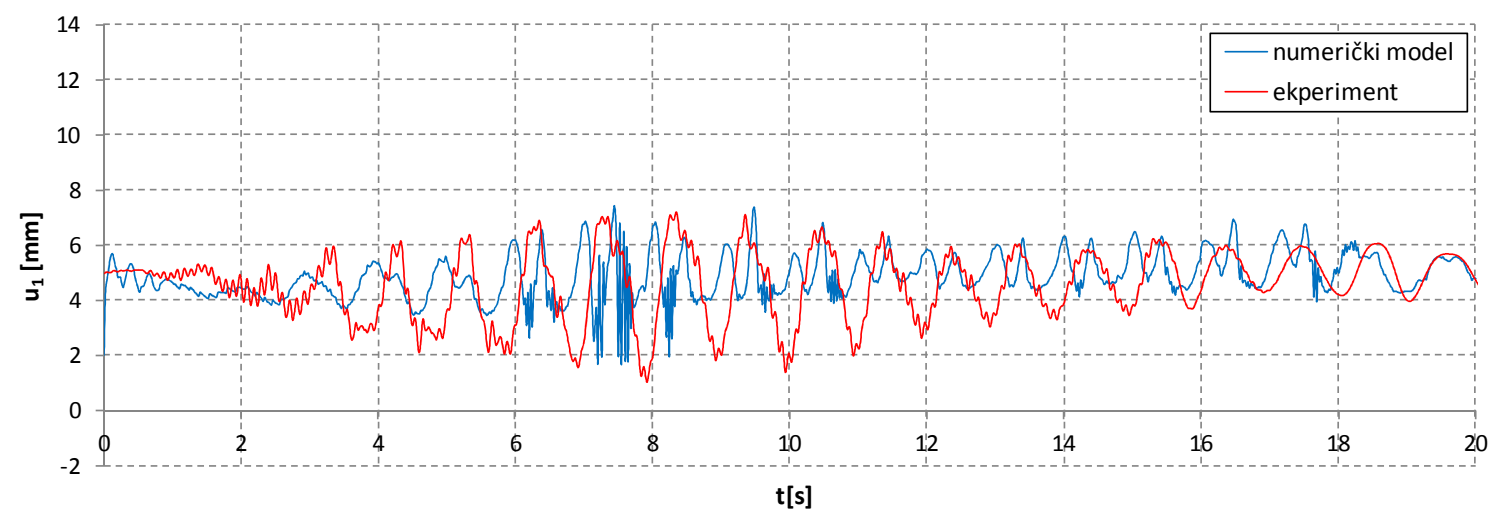

(a) Harmonijsko ubrzanje

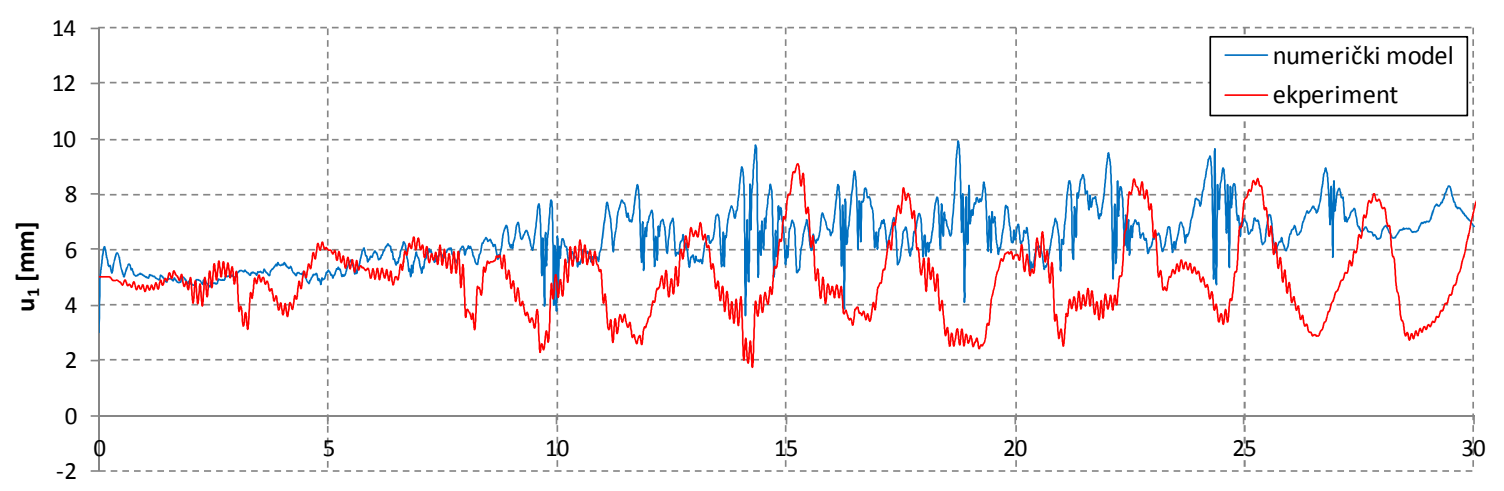

$\mathrm{t}[\mathrm{s}]$

(b) Umjetni akcelerogram

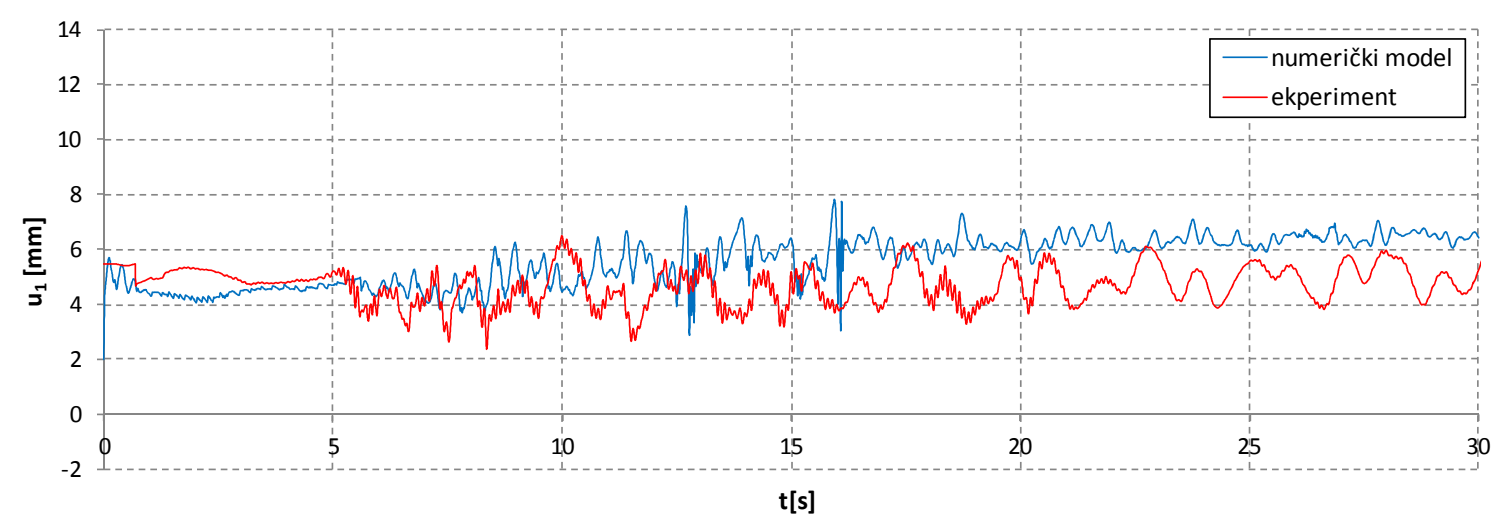

(c) Potres Petrovac

Slika 6.18. Horizontalni pomak $\mathrm{u}_{1}$ prednje stijenke rezervoara $\mathrm{R} 1$ 


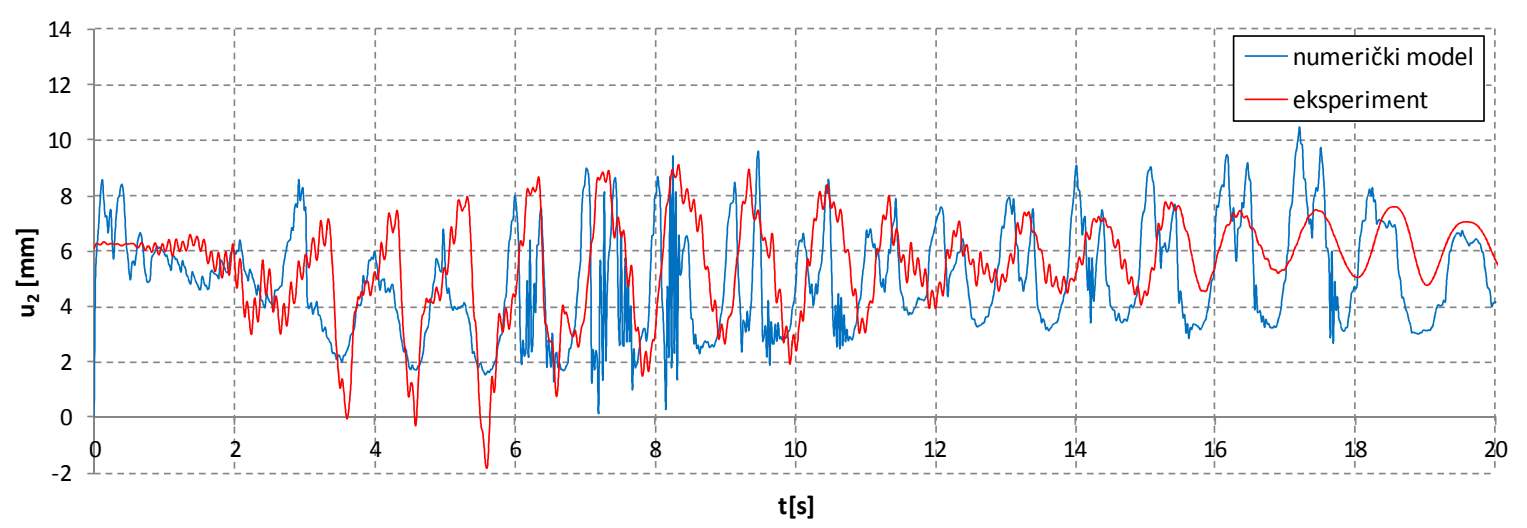

(a) Harmonijsko ubrzanje

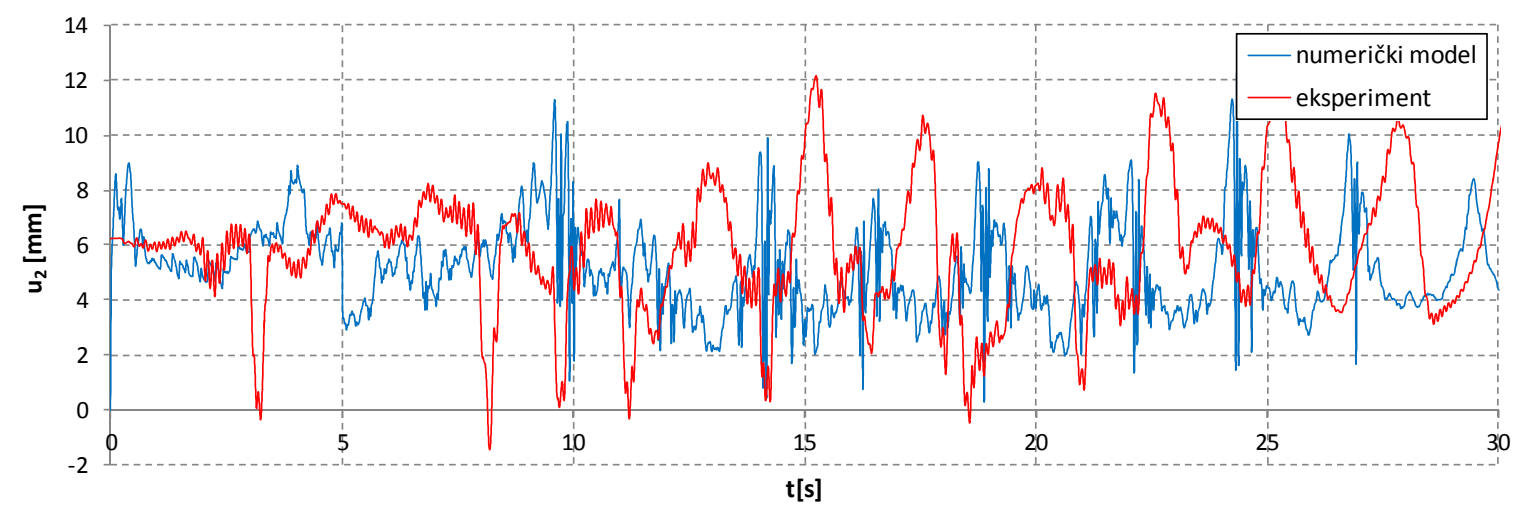

(b) Umjetni akcelerogram

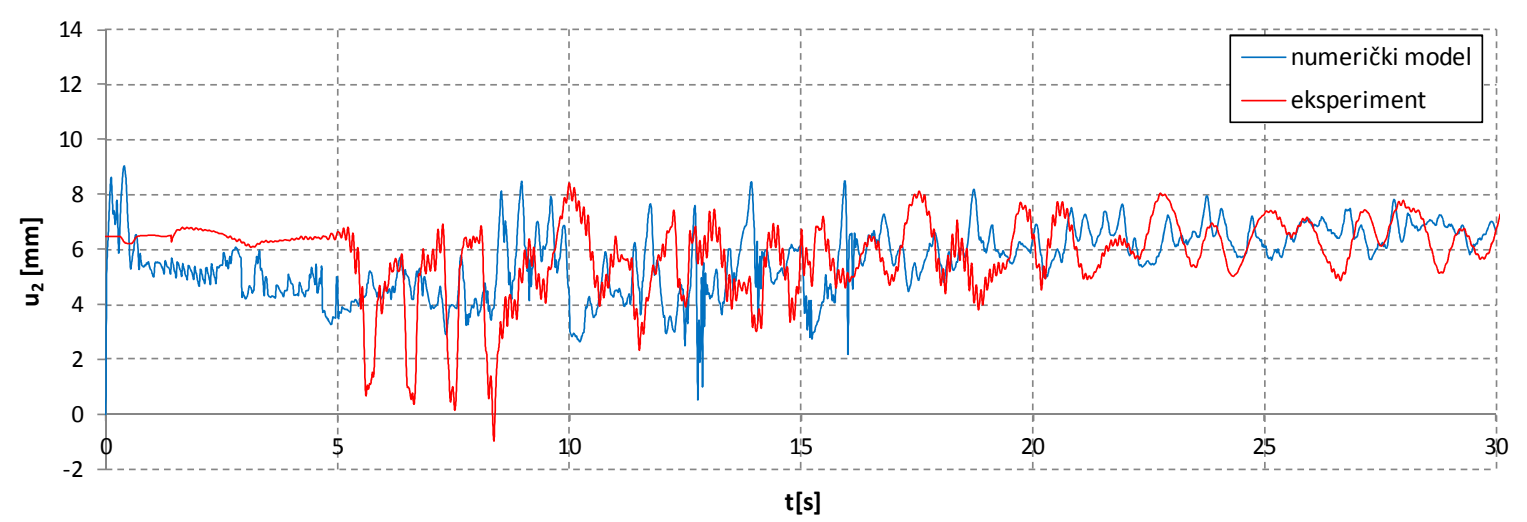

(c) Potres Petrovac

Slika 6.19. Horizontalni pomak $\mathrm{u}_{2}$ prednje stijenke rezervoara $\mathrm{R} 1$ 


\subsubsection{Pomaci deformabilne stijenke rezervoara $R 2$}

Usporedba pomaka deformabilne stijenke rezervoara R2 (debljina lima $2 \mathrm{~mm}$ ) izvršenja je na primjeru dinamičkih pobuda iz Potpoglavlja 5.6.6. (harmonijska ubrzanja s različitim amplitudama). Na Slici 6.20. prikazana je usporedba horizontalnog pomaka $\mathrm{u}_{1}$, a na Slici 6.21. usporedba horizontalnog pomaka $\mathrm{u}_{2}$.

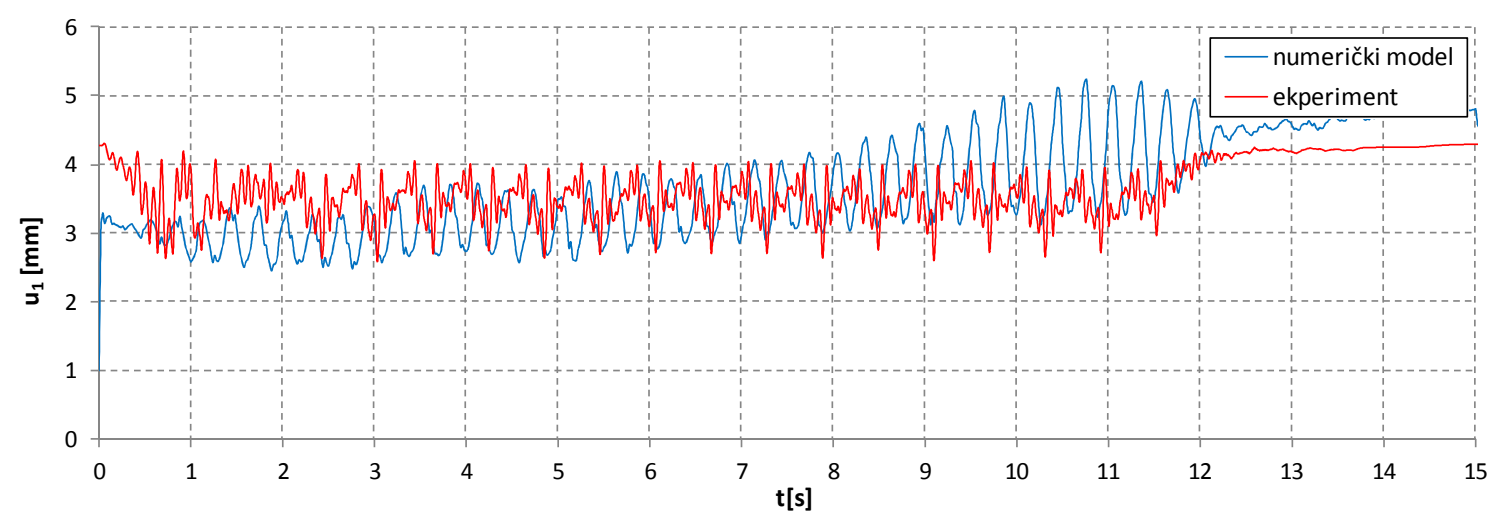

(a) $\mathrm{a}_{0}=0.1 \mathrm{~g}$

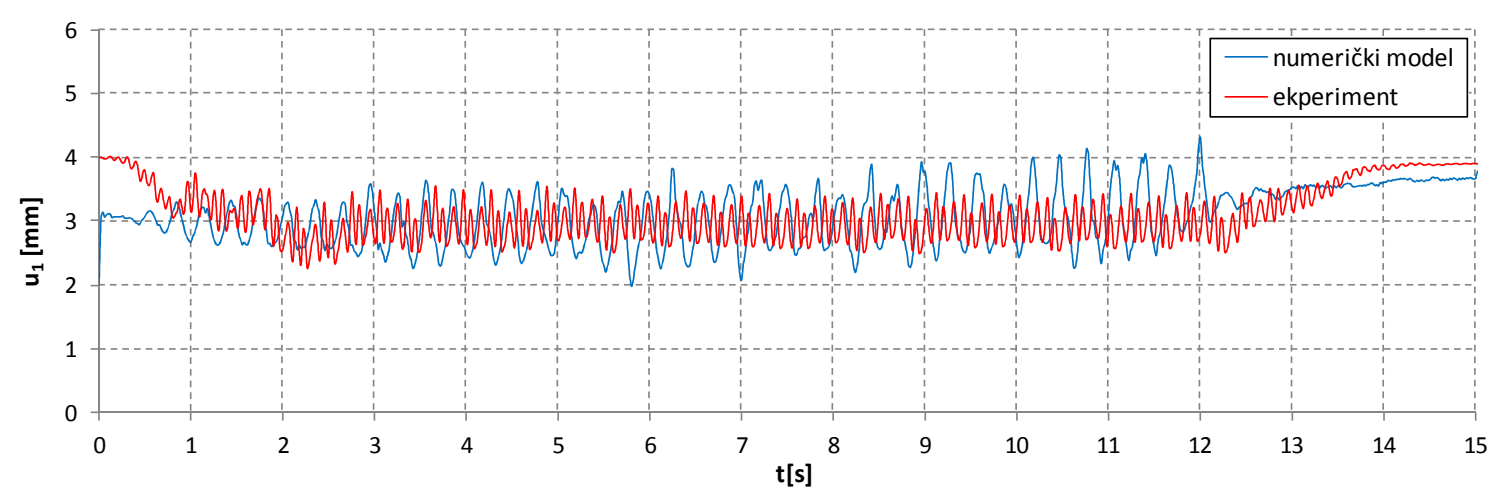

(b) $\mathrm{a}_{0}=0.2 \mathrm{~g}$

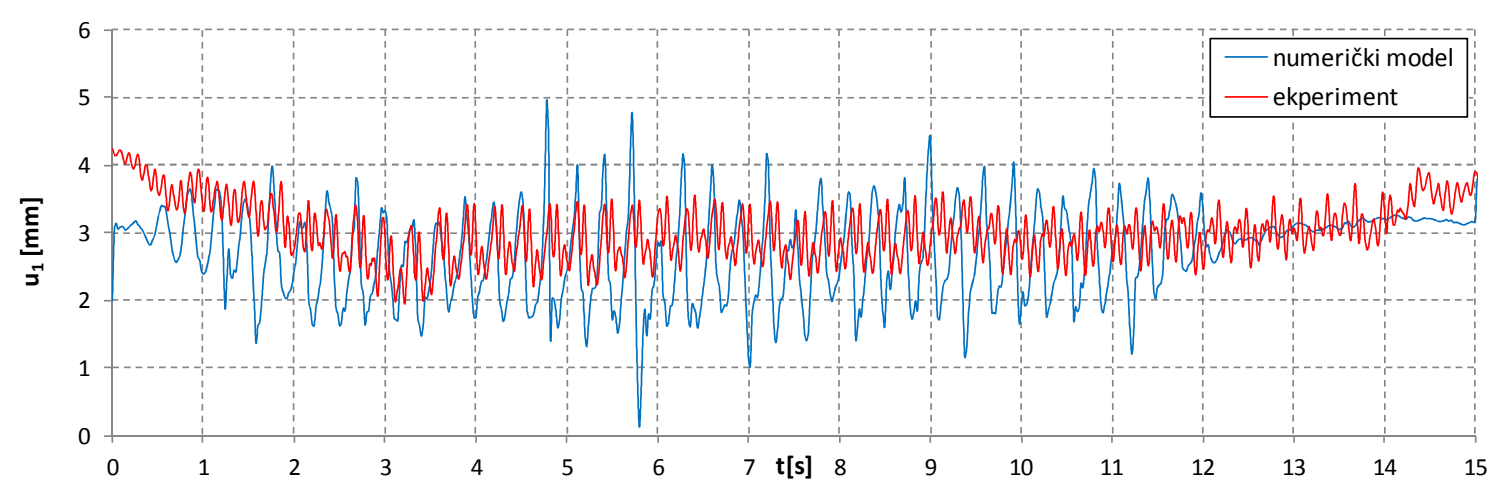

(c) $\mathrm{a}_{0}=0.5 \mathrm{~g}$

Slika 6.20. Horizontalni pomak $\mathrm{u}_{1}$ prednje stijenke rezervoara $\mathrm{R} 2$ 


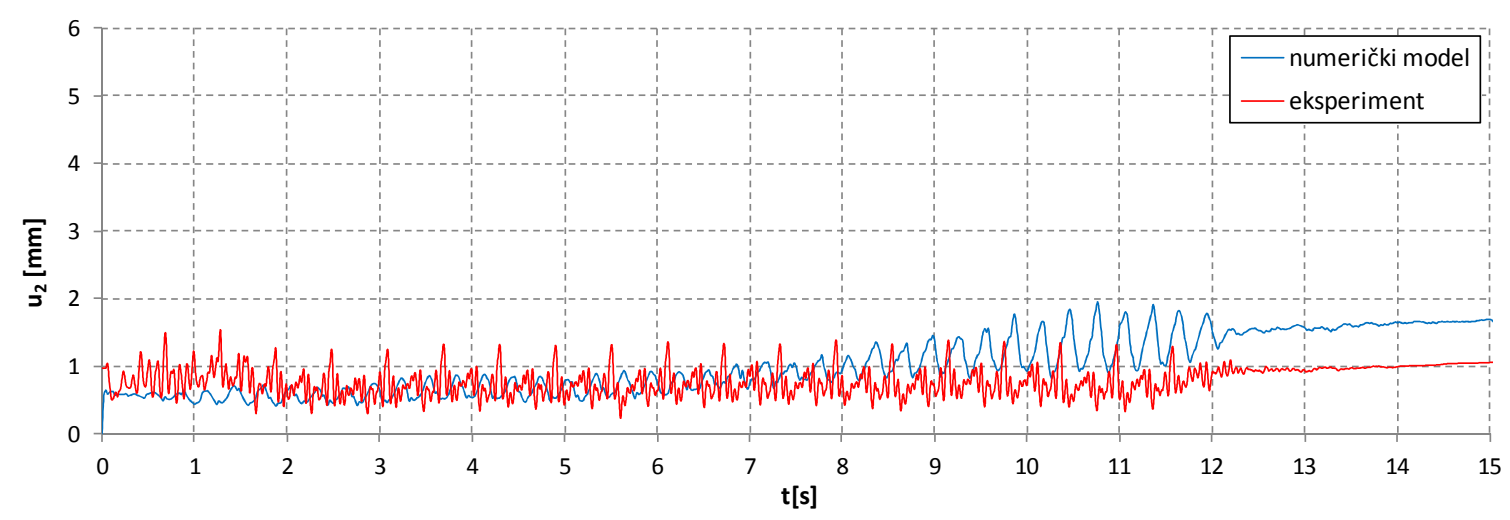

(a) $\mathrm{a}_{0}=0.1 \mathrm{~g}$

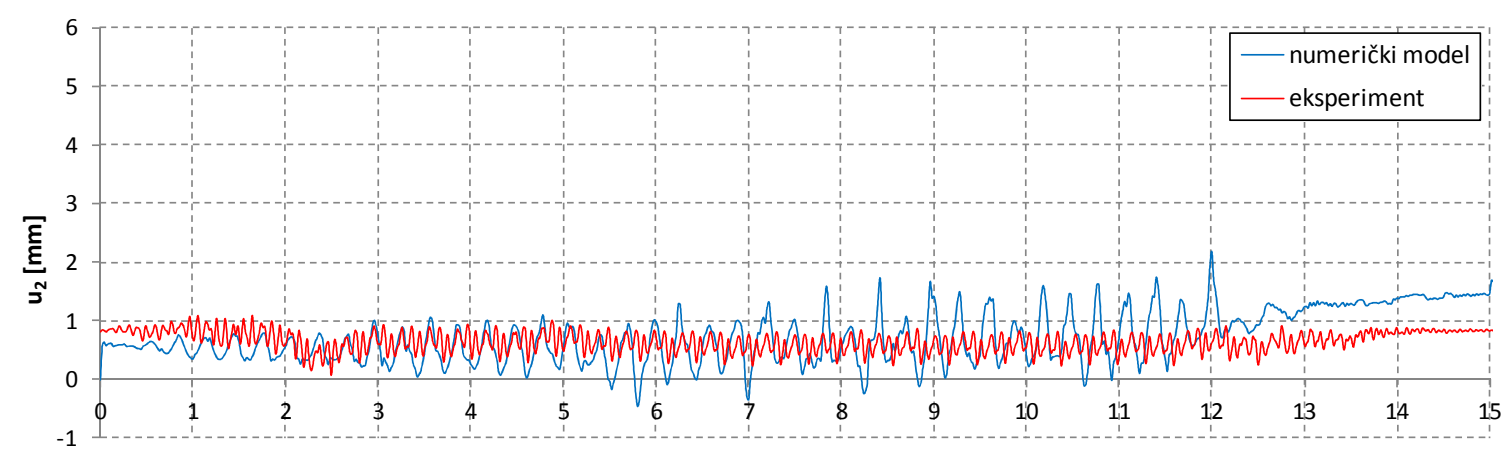

$\mathrm{t}[\mathrm{s}]$

(b) $\mathrm{a}_{0}=0.2 \mathrm{~g}$

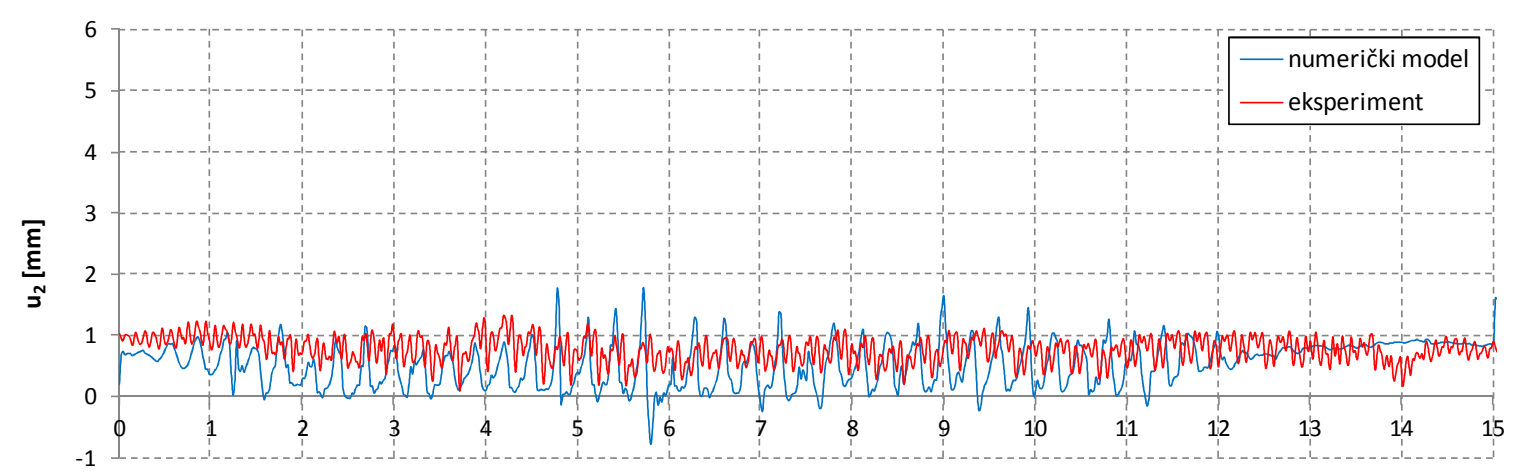

$\mathrm{t}[\mathrm{s}]$

(c) $\mathrm{a}_{0}=0.5 \mathrm{~g}$

Slika 6.21. Horizontalni pomak $\mathrm{u}_{2}$ prednje stijenke rezervoara $\mathrm{R} 2$

Vidljivo je dobro poklapanje horizontalnih pomaka deformabilne ljuske dobivenih numeričkim modelom s rezultatima eksperimentalnih testova. Manja odstupanja rezultata su u slučaju harmonijske pobude sa maksimalnom amplitudom $\mathrm{a}_{0}=0.5 \mathrm{~g}$, što je vjerojatno posljedica oscilacija tlakova vode na stijenke rezervoara. $U$ odnosu na pomake deformabilne stijenke rezervoara R1 iz prethodne točke, pomaci deformabilne stijenke rezervoara R2 su bliži izmjerenim rezultatima tijekom eksperimentalnih testova. 


\section{ZAKLJUČCI I PRAVCI DALJNJIH ISTRAŽIVANJA}

\subsection{Uvod}

Kako je naglašeno u uvodu, građevinske konstrukcije koje su u direktnom dodiru s fluidom (tekućinom), kao što su brane, spremnici tekućina (rezervoari), izvanobalne konstrukcije, cjevovodi, vodotornjevi itd., vrlo su česte u inženjerskoj praksi. Numerički modeli za realnu simulaciju ovih konstrukcija moraju uključivati interakciju tekućine i konstrukcije da bi ovaj kompleksan sustav bio realno modeliran. Ovaj problem je naročito naglašen u dinamičkim/seizmičkim uvjetima.

Tijekom povijesti dogodile su se brojne nesreće uzrokovane djelovanjem tekućine (zraka ili kapljevine) na konstrukcije. Na primjer, most Tacoma Narrows se srušio u studenom 1940. Godine pod relativno blagim udarima vjetra koji je inducirao torzijske vibracije rasponske konstrukcije. Bez sigurne opskrbe vodom nekontrolirani požari uzrokovali su znatno više štete od samog potresa 1906. godine u San Francisku (SAD) ili 1995. godine u Kobeu (Japan). Rušenje rezervoara koji sadržava izrazito zapaljive tvari može dovesti do katastrofalnih i teško gasivih požara, kao što se dogodilo nakon potresa u Niigati (1964), potresa na Aljasci (1964), ili nakon potresa u Turskoj (1999), pri čemu je poginulo preko 1700 osoba. Lista ovih nesreća je veoma dugačka.

Zašto su se dogodile ove katastrofe? U većem broju slučajeva razlozi su greške u pretpostavkama ili proračunu. Neke su greške bile obični previd i nisu se smjele dogoditi, ali 
neke su bile "sofisticirane" jer su projektanti tek nakon događaja uvidjeli da griješe u logici razmišljanja. Iako se iz takvih događaja puno naučio, nažalost, oni su bili plaćeni velikim materijalnim štetama i ljudskim životima.

Računalo i računalne simulacije znatno su promijenili pristup u dizajniranju i proračunu konstrukcija. Međutim unijeli su i dodatnu nepoznanicu u ovaj proces. Korištenjem nedovoljno testiranih računalnih programa ili (još opasnije) korištenjem računalnih programa koje korisnik ne razumije dovoljno (ili ne razumije suštinski), moguće je napraviti i veće greške nego što su ih radili inženjeri koristeći samo šiber (ili samo abak). Svaki računalni model/program ima svoje pretpostavke na kojima je sazdan, svoje mogućnosti i svoja ograničenja, čega treba biti u potpunosti svjestan prije početka njegova korištenja.

\subsection{Zaključci}

Model i računalni program prikazani u ovom radu namijenjeni su računalnoj simulaciji ponašanja konstrukcija koje su u doticaju s tekućinom u uvjetima seizmičkog (dinamičkog) opterećenja. $\mathrm{Na}$ temelju proučenih primjera iz literature i usporedbom s izvršenim eksperimentalnim testovima, može se reći da razvijeni model predstavlja moćno oruđe u pokušaju sagledavanja realnog ponašanja konstrukcije u doticaju s tekućinom pri dinamičkim opterećenjima.

Izloženi model numeričke simulacije je prije svega jednostavan za razumijevanje i korištenje. Osim moguće analize međudjelovanja tekućine i konstrukcije, na vrlo jednostavan način se mogu analizirati i pojedinačna polja.

Primijenjeni numerički modeli simulacije ponašanja čelika pod statičkim i dinamičkim opterećenjem opisuju njegove dominantne nelinearne efekte: tečenje u tlaku i vlaku. Dodatna prednost je ta što se opis materijala temelji na osnovnim parametrima dobivenim iz jednoosnog testa.

Numerički model tekućine u potpunosti zadovoljava situacije kada nema priljeva ni odljeva tekućine. Naime, prikazani numerički model može vrlo dobro opisati globalne hidrodinamičke tlakove, globalnu pojavu kavitacije i sl. Prikazani model može također, do određene razine, opisati i turbulenciju, kovitlanje i slične pojave, što u ovom radu nije bilo primarno. Načelno, prikazani model može obuhvatiti i slučajeve s priljevom i odljevom tekućine, što također u ovom radu nije bio primarni interes. 
Dobro slaganje dobivenih numeričkih rezultata modela proračuna s nekim poznatim analitičkim, numeričkim i eksperimentalnim rezultatima, upućuju na valjanost razvijenog modela i računalnog programa (softwarea). Naknadna testiranja razvijenog modela na rezultatima ispitivanja složenih inženjerskih konstrukcija pripomogla bi da se izloženi model kvalitetnije valorizira i eventualno, prema potrebi, daljnje unaprijedi.

\subsection{Pravci daljnjih istraživanja}

Kako se razvijeni numerički model za međudjelovanje konstrukcije i tekućine zasniva na pristupu zasebnih rješenja, svako daljnje poboljšanje modela za konstrukciju ili tekućinu predstavlja i poboljšanje modela za međudjelovanje. Osim toga, moguća su poboljšanja u načinu povezivanja modela za konstrukciju i modela za tekućinu.

Neki mogući pravci daljnjih istraživanja navedeni su u nastavku.

\subsubsection{Modeliranje konstrukcije}

Postojeći model za analizu ljuskastih konstrukcija je, dodavanjem rotacijske krutosti oko normale na srednju plohu ljuske, postao kompatibilan za povezivanje s modelom za analizu štapnih konstrukcija. Proširenje modela za konstrukciju bi omogućilo adekvatno modeliranje većeg broja različitih građevina koje su $\mathrm{u}$ kontaktu $\mathrm{s}$ tekućinom (npr. vodotornjevi).

Model materijala čelika zasniva se na jednostavnom Von Misesovom modelu tečenja. Ovaj model se može unaprijediti uvođenjem rezidualnih naprezanja i praćenjem ponašanja pri visokim nivoima naprezanja metodama mehanike loma. Na ovaj način bi se mogli simulirati i razne posude pod tlakom, što u ovom radu nije razmatrano.

Iako je rad koncentriran na čelične ljuskaste konstrukcije, jednako efikasno se mogu analizirati i armirano betonske konstrukcije. Model materijala za betonske konstrukcije detaljno je opisan [73], a ovaj rad se direktno nastavlja na njega. I ovaj model se može unaprijediti npr. uvođenjem modela fiksnih neortogonalnih pukotina, čime bi se realističnije opisalo nelinearno ponašanje betona. Za adekvatnu simulaciju ponašanja armiranog betona pred lom, neophodno je uzeti u obzir klizanje armaturnog čelika.

\subsubsection{Modeliranje tekućine}

Veliki utjecaj na točnost i stabilnost rješenja u metodi hidrodinamike izglađenih čestica ima odabir jezgrene (kernel) funkcije. Atomske bazne funkcije algebarskog tipa zbog 
svojih svojstava (normaliziranost, kompaktnost, beskonačna derivabilnost i dr.) bi mogle biti prikladne za jezgrene funkcije. U tijeku je implementacija atomskih baznih funkcija algebarskog tipa drugog, četvrtog i šestog reda kao jezgrenih funkcija u postojeći model za tekućinu.

Pokazalo se da korišteni model za tekućinu ima problema s oscilacijama u polju tlakova. U okviru ovoga rad predložena je moguća korekcija kako bi te oscilacije bile što manje. Daljnje poboljšanje može biti da se istraže mogućnosti nekih drugih korekcija. Osim toga, umjesto korištene jednadžbe stanja, moguće je izračunavati tlakove koristeći Poissonovu jednadžbu (tzv. nestišljiva formulacija metode hidrodinamike izglađenih čestica). Prema dostupnoj literaturi, takav pristup doprinio bi realnijoj simulaciji tlakova u tekućini.

Nedostatak modela za tekućinu je potreba za moćnim računalom i izrazito dugo vrijeme trajanja proračuna pri analizama realnih sustava s velikim brojem stupnjeva slobode. U ovome radu, numerički testovi su provedeni na relativno malim sustavima. U budućnosti se planira paralelizacija kôda, kako bi se mogli rješavati i veliki inženjerski problemi.

\subsubsection{Modeliranje međudjelovanja konstrukcije i tekućine}

Pri modeliranju međudjelovanja pomoću pristupa sa zasebnim rješenjima nužno je zadovoljiti uvjete kompatibilnosti brzina i sila na plohi međudjelovanja. U ovome radu rubne čestice smještene na plohi međudjelovanja gibaju se zajedno s plohom konstrukcije koja je u kontaktu s tekućinom. Time je u potpunosti zadovoljen uvjet kompatibilnosti pomaka i posredno uvjet kompatibilnosti brzine na plohi međudjelovanja. Međutim, kompatibilnost sila na plohi međudjelovanja nije potpuno zadovoljena. Sila kojom tekućina djeluje na konstrukciju je posljedica tlakova u česticama tekućine koje se nalaze uz plohu međudjelovanja, dok sila kojom konstrukcija djeluje na tekućinu je posljedica povećanja gustoće kada se čestica tekućine približi rubnim česticama (dinamički rubni uvjeti). Primjena zakona o akciji i reakciji bi vodila do kompatibilnosti sila na plohi međudjelovanja i poboljšanja modeliranja međudjelovanja konstrukcije i tekućine. Istovremeno, poboljšanje bi se odnosilo i na model za tekućinu zbog promjene rubnih uvjeta na spoju s konstrukcijom. Taj pristup bi se mogao primijeniti i na opisivanje krutih granica u modelu za tekućinu.

U ovome radu model za konstrukciju i model za tekućinu su tzv. labavo povezani, čime je model za međudjelovanje pouzdan za primjenu samo u problemima pri relativno malim pomacima konstrukcije. Uvođenjem iteracijskog postupka rješavanja na plohi 
međudjelovanja, ovim modelom bi se mogli realno simulirati i problemi kod kojih se javljaju veliki pomaci konstrukcije.

\subsubsection{Općenita poboljšanja}

Iako je većina simulacija prikazanih u ovom radu kreirana predprocesorom razvijenim pod AutoCAD-om u aplikaciji VBA (Visual Basic for Application), a prikazani rezultati su vizualizirani AutoCAD-om i Paraview-om, sam software je i dalje neprilagođen korisniku, jer je potrebno kreirati alfa-numeričke ulazne datoteke za pokretanje simulacije. Nakon izvršenja analize program stvara itlazne datoteke (dxf za AutoCAD i vtk za Paraview), koje se onda pregledavaju navedenim komercijalnim programima. Svaka promjena zahtijeva potpuno ponavljanje postupka. Dakle, razvijeni numerički model bi trebalo dodatno opskrbiti automatskim pred i post-procesorom kojima bi se omogućila jednostavnija i vremenski manje zahtjevna upotreba većem broju istraživača.

$\mathrm{S}$ ciljem još boljeg poznavanja ponašanja konstrukcija koje su u kontaktu s tekućinama, posebice na većim i složenijim sustavima, potrebno je izvršiti još eksperimentalnih ispitivanja. 


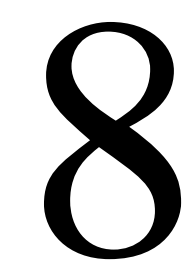

\section{LITERATURA}

[1] Krausmann E., STREST - Report on lessons learned from recent catastrophic events: WP2 - State-of-the-art and lessons learned, Publications Office of the European Union, 2014, http://publications.jrc.ec.europa.eu/repository/handle/JRC95650

[2] Dowell E.H., Hall K.C., Modelling of fluid-structure interaction, Annual Review of Fluid Mechanics, 33, pp 445-490, 2001.

[3] Chakrabarti S.K., Numerical Models in Fluid Structure Interaction, Advances in Fluid Mechanics, WIT Press, 2005.

[4] Jo J.C., Fluid structure interactions, Korea institute of Nuclear safety, Republic of Korea.

[5] Westergaard, H.M., Water pressures on dams during earthquakes. Trans. ASCE 58, 605-42, 1933.

[6] Huang H.C., Static and Dynamic Analysis of Plates and Shells, Springer-Verlag, 1989.

[7] Radnić J., Harapin A., Matešan D., Model for Static Analyses of Concrete Shells, International Journal for Engineering Modelling, 14(3-4), pp 93-99, 2000.

[8] Radnić J., Harapin A., Matešan D., Geometrical nonlinearity model in static analysis of shells, Gradjevinar, 55(10), pp 583-589, 2003. (in Croatian) 
[9] Liu G.R., Liu M.B., Smoothed particle Hydrodynamics - a meshfree particle method, World Scientific Publishing co., Singapur, 2003.

[10] Colagrossi, A., Landrini, M., Numerical simulation of interfacial flows by Smoothed Particle Hydrodynamics, Journal of Computational Physics, 191, pp 448-475, 2003.

[11] Kelager M., Lagrangian Fluid Dynamics Using Smoothed Particle Hydrodynamics, DIKU, University of Copenhagen, 2006.

[12] Crespo A.J.C., Gómez-Gesteira M., Dalrymple R.A., Boundary Conditions Generated by Dynamic Particles in SPH Methods, Tech Science Press, 5(3), pp 173-184, 2007.

[13] Gómez-Gesteira M., Rogers B.D., Dalrymple R.A., Crespo A.J.C., Narayanaswamy M., The User Guide for the SPHysics code, 2010. Online: https://wiki.manchester.ac.uk/sphysics/index.php/SPHYSICS_Reference

[14] Ashwell D.G., Gallagher R.H., Finite elements for thin shells and curved members, John Wiley and Sons, London, 1976.

[15] Zienkiewicz O.C., The finite elementh method, McGraw-Hill Book Company, London, 1976.

[16] Ahmad S., Irons B.M., Zienkiewicz O.C., Analysis of Thick and Thin Shell Structures, International Journal for Numerical Methods in Engineering, 2, pp 419-451, 1970.

[17] Zienkiewicz O.C., Taylor R.L., Too J.M., Reduced Integration Technique in General Analysis of Plates and Shells, International Journal for Numerical Methods in Engineering, 3, pp 275-290, 1971.

[18] Owen D.R.J., Hinton E., Finite Element Programming, Academic Press, London, 1977.

[19] Owen D.R.J., Hinton E., Finite Elements in Plasticity, Pineridge Press, Swansea, UK, 1980.

[20] Owen D.R.J., Figueiras J.A., Damjanić F.B., Finite Elements Analysis of Reinforced and Prestressed Concrete Structures Including Thermal Loading, Computer Methods in Applied Mechanics and Engineering, 41, pp 323-366, 1983.

[21] Figueiras J.A., Owen D.R.J., Analysis of Elasto-Plastic and Geometrically Nonlinear Anisotopic Plates and Shell, Finite Element Software for Plates and Shells, Swansea, pp 235-322, 1984. 
[22] Noh W.F., CEL:A time-dependent two-space dimensional coupled EulerianLagrangian code, In Methods in Computational Physics, 3. Academic Press: New York, pp 117-179, 1964.

[23] Hirt C.W., Amsden A.A., Cook J.L., An arbitrary Lagrangian-Eulerian computing method for all flow speeds, Journal of Computational Physics, 14, pp 227-253, 1974.

[24] Donea J., Fasoli-Stella P., Giuliani S., Lagrangian and Eulerian finite element techniques for transient fluid-structure interaction problems, Trans. 4th Int. Conf. on Structural Mechanics in Reactor Technology, Paper B1/2, San Francisco, 1977.

[25] Belytschko T., Kennedy J.M., Computer methods for subassembly simulation, Nuclear Engineering and Design, 49, pp17-38, 1978.

[26] Bazilevs Y., Takizawa K., Tezduyar T.E., New directions and challenging computations in fluid dynamics modeling with stabilized and multiscale methods, Mathematical models \& methods in applied sciences, 25(12), pp 2217-2226, 2015.

[27] Zhao C., Chen J., Xu Q. et al., Investigation on sloshing and vibration mitigation of water storage tank of AP1000, Annals of nuclear energy, 90, pp 331-342, 2016.

[28] Kayser-Herold O., Matthies H.G., Least squares finite element methods for fluidstructure interaction problems, Computers \& Structures, 83, pp 191-207, 2005.

[29] Onate E., Idelsohn S.R., Del Pin F., Aubry R., The particle finite element method. An overview, International Journal of Computational Methods, 1(2), pp 267-307, 2004.

[30] Onate E., Franci A., and Carbonell J.M., A particle finite element method for analysis of industrial forming processes, Computational Mechanics, DOI: 10.1007/s00466-0141016-2.

[31] Gingold R.A., Monaghan J.J., Smoothed particle hydrodynamics: theory and application to non-spherical stars, Monthly Notices of the Royal Astronomical Society, 181, pp 375-389, 1977.

[32] Lucy L.B., A numerical approach to the testing of the fission hypothesis, Astronomical Journal, 82, pp 1013-1024, 1977.

[33] Monaghan J. J., Kos A., Solitary waves on a cretan beach, Journal of Waterway, Port, Coastal, and Ocean Engineering, 145, pp 145-154, 1999.

[34] Oger G., Doring M., Alessandrini B. and Ferrant, P., Two-dimensional SPH simulations of wedge water entries, Journal of Computational Physics, 213, pp 803822, 2006. 
[35] Le Touz D., Oger G., Alessandrini B., Smoothed Particle Hydrodynamics simulation of fast ship flows, 27th Symposium on Naval Hydrodynamics, Seoul, Korea, 2008.

[36] Delorme L., Colagrossi A., Souto-Iglesias A., Zamora Rodriguez, R., Botia-Vera, E., A set of canonical problems in sloshing, Part I: Pressure field in forced rollcomparison between experimental results and SPH, Ocean Engineering, 36, pp 168$178,2009$.

[37] Gómez-Gesteira M., Rogers B. D., Dalrymple R. A., Crespo, A. J. C., State-of-the-art of classical SPH for free-surface flows, Journal of Hydraulic Reseach, 48, pp 6-27, 2010 .

[38] Gómez-Gesteira M., Rogers B. D., Violeau D., Grassa J. M., Crespo A. J. C., Foreword: SPH for free-surface flows, Journal of Hydraulic Research, 48, pp 3-5, 2010.

[39] Zhang A., Cao X.-Y., Ming F., Zhang Z.-F., Investigation on a damaged ship model sinking into water based on three dimensional SPH method. Applied Ocean Research, 42, pp 24-31, 2013.

[40] Husain S. M., Muhammed J. R., Karunarathna H. U., Reeve, D. E., Investigation of pressure variations over stepped spillways using smooth particle hydrodynamics, Advances in Water Resources, 66, pp 52-69,2014.

[41] Farahani R. J., Dalrymple R. A., Hérault A., Bilotta G., Three-dimensional SPH modeling of a bar/rip channel system, Journal of Waterway, Port, Coastal and Ocean Engineering, 140(1), pp 82-99, 2014.

[42] Lind S.J., Stansby P.K., Rogers B.D., Incompressible-compressible flows with a transient discontinuous interface using smoothed particle hydrodynamics (SPH), Journal of computational physics, 309, pp 129-147, 2016.

[43] Wang W., Chen G., Yin K. et al., Modeling of landslide generated impulsive waves considering complex topography in reservoir area, Environmental Earth Sciences, 75(5), article number: 372, 2016.

[44] Wall W.A., Mok D.P., Ramm E., Interactive Substructuring Schemes for Fluid Structure Interaction, Analysis and Simulation of Multifield Problems, lecture Notes in Applied and Computational Mechanics, pp 349-360, 2003. 
[45] Attaway S.W., Heinstein M.W., Swegle J.W., Coupling of smoothed particle hydrodynamics with the finite element method. Post-SMIRT Impact IV Seminar, Berlin, Nuclear Engineering and Design, 150, 1994.

[46] Johnson G.R., Linking of Lagrangian particle methods to standard nite element methods for high velocity impact computations, Post-SMIRT Impact IV Seminar, Berlin. Nuclear Engineering and Design, 150, $1994 .$.

[47] Johnson G.R., Stryk R.A., Beissel S.R., SPH for high velocity impact computations, Computer Methods in Applied Mechanics and Engineering, 139, pp 347-374, 1996.

[48] Hegen D., Element free Galerkin methods in combination with nite element approaches, Computer Methods in Applied Mechanics and Engineering, 135, pp 143$166,1996$.

[49] Rabczuk T., Belytschko T., Application of mesh free methods to static fracture of reinforced concrete structures, International Journal of Fracture, 137(1-4), pp 19-49, 2006.

[50] Karutz H. Adaptive Kopplung der Elementfreien Galerkin Methode mit der Methode der Finiten Elemente bei Rissfortschrittsproblemen, Dissertation, Institut fuer Statik und Dynamik der Ruhr Universitaet Bochum, VDI-Verlag, 18, 255, 2000.

[51] Belytschko T., Xiao S.P., A bridging domain method for coupling continua with molecular dynamics, Computer Methods in Applied Mechanics and Engineering, 193, pp1645-1669, 2004.

[52] Wagner G.J., Liu W.K., Coupling of atomic and continuum simulations using a bridging scale decomposition, Journal of Computational Physics, 190, pp 249-274, 2003.

[53] Liu W.K., Karpov E.G., Zhang S., Park H.S., An introduction to computational nanomechanics and materials, Computer Methods in Applied Mechanics and Engineering, 193, pp 1529-1578, 2004.

[54] Kadowaki H., Liu W.K., Bridging multi-scale method for localization problems, Computer Methods in Applied Mechanics and Engineering, 193(30-32), pp 3267$3302,2004$.

[55] Kadowaki H., Liu WK., A multiscale approach for the micropolar continuum model, Computer Modeling in Engineering and Sciences, 7(3), pp 269-282, 2005. 
[56] Nguyen-Thoi T., Phung-Van P., Rabczuk T. et al,. An application of the ES-FEM in solid domain for dynamic analysis of 2D fluid-solid interaction problems, International journal of computational methods, 10(1), Article Number: 1340003, 2013.

[57] Ullah Z., Coombs W. M., Augarde, C. E., An adaptive finite element/meshless coupled method based on local maximum entropy shape functions for linear and nonlinear problems, Computer methods in applied mechanics and engineering, 27, pp 111-132, 2013.

[58] Mitsume N., Yoshimura S., Murotani K. et al., MPS-FEM partitioned coupling approach for fluid-structure interaction with free surface flow, International journal of computational methods, 11(4), Article Number: 1350101, 2014.

[59] Vuyst T.D., Vignjevic R., Campbell, J.C., Coupling between meshless and Finite Element Methods, International Journal of Impact Engineering, 31(8), pp 1054-1064, 2005 .

[60] Groenenboom P.H.L., Cartwright, B.K., Hydrodynamics and fluid-structure interaction by coupled SPH-FE method, Journal of Hydraulic Research, 48, pp 61-73, 2010 .

[61] Fourey G., Oger G., Touz’e D.L., Alessandrini B., Violent fluid-structure interaction simulations using a coupled SPH/FEM method, WCCM/APCOM 2010.

[62] Fourey G., Touz'e D.L., Alessandrini B., Development of a sph-fem coupling methodology for modeling strong fluid-structure interactions, International Conference on Particle based Methods: Fundamentals and Applications, Barcelona, Spain, 2011.

[63] Fourey G., Oger G., Touz’e D. L., Alessandrini, B., Weak coupling strategy between FE and SPH methods for FSI simulations, Proceedings of 2nd International Conference on Violent Flows, Nantes, France, 25th-27th September, pp 205-212, 2012

[64] Yang Q., Jones V., McCue L., Free-surface flow interactions with deformable structures using an SPH-FEM model, Ocean engineering, 55, pp 136-147, 2012.

[65] Yang Q., Jones V., Kumar P. et al., Validation of a SPH-FEM Model for Seal Dynamics of Surface Effect Ships Naval engineers journal, 125(4), pp 91-121, 2013. 
[66] Jian W., Liang D., Shao S. et al., Smoothed Particle Hydrodynamics Simulations of Dam-Break Flows Around Movable Structures, International journal of offshore and polar engineering, 26(1), pp 33-40, 2016.

[67] Du Y., Ma L., Zheng J.Y., Fracture of Cylindrical Shells Subjected to Internal Explosion: Numerical Simulation, 14th International Conference on Pressure Vessel Technology (ICPVT) Location: Chinese Pressure Vessel Inst, 2015.

[68] Ming F. R., Zhang A.M., Xue Y. Z. et al., Damage characteristics of ship structures subjected to shockwaves of underwater contact explosions, Ocean engineering, 117, pp 359-382, 2016.

[69] Dilip K.P., Efficient dynamic solutions for single and coupled multiple field problems, PhD Thesis, University College of Swansea, 1982.

[70] Bathe K.J., Zhang H., Wang M.H., Finite element analysis of incompressible and compressible fluid flows with free surfaces and structural interactions, Computers \& Structures; 56(2/3), pp 193-213, 1995.

[71] Degroote J., Bathe, K. J., Vierendeels J., Performance of a new partitioned procedure versus a monolithic procedure in fluid-structure interaction, Computers and Structures, 87, pp 793-801, 2009.

[72] Hou G., Wang J., Layto, A., Numerical Methods for Fluid-Structure Interaction - A Review, Communications in Computational Physics, 12(2), pp 337-377, 2012.

[73] Harapin A., Numerička simulacija dinamičkog međudjelovanja tekućine i konstrukcije, Doktorska disertacija, Građevinski fakultet Sveučilišta u Splitu, Split, 2000.

[74] Kozulić V., Numerička analiza konstrukcija sastavljenih od ljuski i stupova, Magistarski rad, Građevinski fakultet Sveučilišta u Splitu, Split, 1993.

[75] Jović V., Uvod u inženjersko numeričko modeliranj, Aquarius Engineering, Split, 1993.

[76] Radnić, J.; Matešan, D.; Harapin, A.: Model geometrijske nelinearnosti u statičkoj analizi ljusaka, Građevinar, 55(10), pp. 583-589, 2003.

[77] Nagtegaal, J.C.; De Jong, J.E.: Some Computational Aspects of Elasto-plastic Large Strain Analysis, International Journal for Numerical Methods in Engineering; 17, pp. 15-41, 1981. 
[78] Hughes T.J.R., Pister K.S. and Taylor R.L., Implicit-explicit finite elements in nonlinear transient analysi, Comp. Meth. Apl. Mech. Engng., Vol. 17/18, pp. 159-182, 1979.

[79] Hughes T.J.R. and. Liu W.K, Implicit-explicit finite elements in transient analysis: stability theor, Jour. of Apl. Mech., 45, pp. 371-374, 1978.

[80] Mark R. and Reisa J.D., Photoelastic analysis of folded-plate structures, Proceeding of the American Society of Civil Engineers, Vol. 93, no. 4, pp. 79-94, 1967.

[81] Zienkiewitcz O.C., The finite element method, Third edition, McGraw-Hill, London, 1977.

[82] Gingold R.A., Monaghan J.J., Kernel estimates as a basis for general particle methods in hydrodynamic, Journal of Computational Physics, 46, pp. 429-453, 1982.

[83] Von Neumann J., Richtmyer R.D., A method for the Numerical Calculation of Hydrodynamic Shocks, Journal of Applied Physics, 21 pp.232-237, 1950.

[84] Lattanzio J.C., Monaghan J.J., Pongracic H., Schwarz P., Controlling penetration, SIAM, Journal for Scientific and Statistic Computation, 7, pp. 591-598, 1986,

[85] J.J. Monaghan, Smoothed Particle Hydrodynamics, Annual Review of Astronomy and Astrophysics, 30, pp. 543-574, 1992.

[86] Rogers, B. and Dalrymple, R. A., SPH modeling of breaking waves, In Proc. 29th International Conference on Coastal Engineering, pp. 415-427, 2004.

[87] Rogers, B. and Dalrymple, R. A., SPH modeling of tsunami waves, In Advanced Numerical Models for Simulating Tsunami Waves and Run up, pp. 75-100, 2008.

[88] Pope, S.B., Turbulent flows, Cambridge University Press, 2000.

[89] Gotoh H., Shao S.D., Memita T., SPH-LES model for numerical investigation of wave interaction with partially immersed breakwater, Coastal Engineering Journal, 46(1), pp. 39-63, 2004.

[90] Lo E., Shao S., Simulation of near-shore solitary wave mechanics by an incompressible SPH method, Applied Ocean Research, 24, pp. 275-286, 2002.

[91] Dalrymple R. A., Rogers B. D., Numerical modeling of water waves with the SPH method, Coastal Engineering, 53(2/3), pp. 141-147, 2006.

[92] Cole R. H., Underwater Explosions, Princeton, NJ: Princeton University Press, 1948.

[93] Batchelor G.K., An Introduction to Fluid Dynamics, Cambridge University Press, 2000. 
[94] Courant R., Friedrichs K., Lewy H., On the Partial Difference Equations of Mathematical Physics, IBM Journal of Research and Development, 11(2), pp. 215234, 1967.

[95] Monaghan J.J., Simulation Free Surface Flows with SPH, Jornal of Computational Physics, 110, pp. 399-406, 1994.

[96] Monaghan J.J., On the problem of penetration in particle methods, Journal of Computational Physics, 82, pp. 1-15, 1989.

[97] Dalrymple R.A., Knio O., SPH Modelling of Water Waves, Proc. Coastal Dynamics, Lund, 2001.

[98] Gong K, Liu H. Water entry of a wedge based on SPH model with an improved boundary treatment, J Hydrodyn Ser B, 21(6), pp. 750-757, 2009.

[99] Verlet L., Computer "Experiments" on Classical Fluids. I. Thermodynamical Properties of Lennard-Jones Molecules, Physical Review, 159, pp. 98-103, 1967.

[100] Leimkuhler B., Reversible adaptive regularization I: Perturbed Kepler motion and classical atomic trajectories, Coastal Engineering, 53(2/3), pp. 141-147, 1997.

[101] Monaghan J.J., Smoothed particle hydrodynamics, Reports on Progress in Physics, 68, pp. 1703-1759, 2005.

[102] Capone G. et al., Accuracy and stability of numerical schemes in SPH, Proc., SPHERIC 2nd Int. Workshop, Universidad Politecnica de Madrid, Spain, 2007.

[103] Antuono M, Colagrossi A, Marrone S, Molteni D., Free surface flows solved by means of SPH schemes with numerical diffusive term, Comput Phys Commun, 18, pp. 53249, 2010.

[104] Shepard D., A two dimensional function for irregularly spaced data, In ACM National Conference, 1968.

[105] Dilts G.A., Moving-Least-Squares-Particle Hydrodynamics-I.Consistency and stability, International Journal for Numerical Methods in Engineering, 44, pp. 1115$1155,1999$.

[106] Liu W.K. et al., Moving least square Kernel Galerkin method (I) methodology and convergence, Computer Methods in Applied Mechanics and Engineering, 143, pp. 113-154, 1997.

[107] Bonet J., Lok T.-S.L., Variational and momentum preservation aspects of Smoothed Particle Hydrodynamics formulations, Computer Methods in Applied Mechanics and Engineering, 180, pp. 97-115, 1999. 
[108] Wang, J.D., Zhou, D., Liu, W.Q., Sloshing of Liquid in Rigid Cylindrical Container with a Rigid Annular Baffle, Part II: Lateral Excitation, Shock and Vibration, 19(6), pp. 1205-1222, 2012.

[109] Lee, C.S., Cho, J.R., Kim, W.S., Noh, B.J., Kim, M.H., Lee, J.M., Evaluation of sloshing resistance performance for LNG carrier insulation system based on fluidstructure interaction analysis, International Journal of Naval Architecture and Ocean Engineering, 5, pp. 1-20, 2013.

[110] Mahdavi, A. and Talebbeydokhti N., A hybrid solid boundary treatment algorithm for smoothed particle hydrodynamics, Scientia Iranica A, 22(4), pp. 1457-1469, 2015.

[111] Sabahi, H. and Nikseresht A.H., Comparison of ISPH and WCSPH methods to solve fluid-structure interaction problems, Scientia Iranica B, 23(6), pp. 2595-2605, 2016.

[112] Chopra, A.K., Hydrodynamic pressures on dams during earthquake, Department of Civil Engineering, University of California, Berkeley, Report No. 66-2, pp. 1-14, 1966.

[113] Housner, G.W., Dynamic pressures on accelerated fluid container, Bulletin of the Seismological Society of America, 47(1), pp. 15-35, 1957.

[114] Chwang, A.T., Hydrodynamic pressures on sloping dams during earthquakes: Part 2, Exact Theory, Journal of Fluid Mechanics, 87(2), pp. 342-348, 1978.

[115] Petrov, A.A., Moiseev, N.N., Numerical methods of calculating the natural frequencies of vibrations of a bounded volume of fluid, Computing Center of Academy of sciences of the USSR, Moscow, 1966. (na ruskom jeziku).

[116] Brzović, D., Šunjić, G., Radnić J. and Harapin, A., Numerical Model for FluidStructure Coupled Problems under Seismic Load, Materials with Complex Behaviour II, Advanced Structured Materials, ed. A. Öchsner et al., Springer in Germany, 16, pp. 175-198, 2012.

[117] Velestos A.S., Shivakumar P., Sloshing response of layered liquids in rigid tanks, Earthquake Engng. Struct. Dyn, 22, pp. 801-821, 1993.

[118] Su, T.C., Lou, Y.K., Flipse, J.E., Bridges, T.J., A Numerical Analysis of Large Amplitude Liquid Sloshing in Baffled Container, US Department of Transportation, Final Report, MA-RD-940-82046, 1982.

[119] Lou, Y.K., Su, T.C., Flipse, J.E., A Nonlinear Analysis of Liquid Sloshing in Rigid Container, US Department of Commerce, Final Report, MA-79-SAC-B0018, 1980. 
[120] Ibrahim, R.A., Liquid Sloshing Dynamics: Theory and Applications. Cambridge University Press., 2000.

[121] Koshizuka, S., Nobe, A., Oka, Y., Numerical analysis of breaking waves using the moving particle semi-implicit method, Int. J. Numer. Meth. Fluids, 26, pp. 751-769, 1998.

[122] Akyildiz, H., Ünal, E., Experimental investigation of pressure distribution on a rectangular tank

[123] Hou, G., Wang J., Layton, A., NumericalMethods for Fluid-Structure Interaction - A Review, Commun. Comput. Phys., 12(2), pp. 337-377, 2012.

[124] Hubner, B., Walhorn, E., Dinkler, D., A monolithic approach to fluid-structure interaction using space-time finite elements, Computer Methods in Applied Mechanics and Engineering, 193 , pp. 2087-2104, 2004.

[125] Ryzhakov, P. B., Rossi, R., Idelsohn, S. R. and Onate, E., A monolithic Lagrangian approach for fluid-structure interaction problems, Computational Mechanics, 46, pp. 883-899, 2010.

[126] Lim, W.Z., Xiao, R.Y., Hong, T., Chin, C.S., Partitioned Methods in Computational Modelling on Fluid-Structure Interactions of Concrete Gravity-Dam, Computer and Information Science, 6(4), pp. 154-168, 2013.

[127] Richter, R., Numerical methods for fluid-structure interaction problems, Heidelberg, 2010 .

[128] Lee, C.J.K., Noguchi, H., Koshizuka, S., Fluid-shell structure interaction analysis by coupled particle and finite element method, Computers and Structures, 85, pp. 688697, 2007.

[129] Eswaran M. and Ujjwal K. Saha, Sloshing of liquids in partially filled tanks - a review of experimental investigations, Ocean Systems Engineering, 1(2), pp. 131-155, 2011.

[130] Cho, K. and Cho, S., Seismic response of cylindrical steel tanks considering fluidstructure interaction, Steel Structures, 7, pp. 147-152, 2007.

[131] Chiba, M., Nonlinear hydroelastic vibration of a cylindrical tank with elastic bottom containing liquid. Part I Experiment, J Fluid Struct, 6(2), pp. 181-206, 1992.

[132] De Angelis, M., Giannini, R., Paolacci, F., Experimental investigation on the seismic response of a steel liquid storage tank equipped with floating roof by shaking table tests, Earthquake Engineering \& Structural Dynamics, 39(4) pp, 377-396, 2009. 
[133] Burkacki D., Jankowski R., Experimental study on steel tank model using shaking table, Civil and environmental engineering reports, 14 (3), pp. 37-47, 2014.

[134] Park, J. H., Bae, D., Koh, C., Experimental Study on the Dynamic Behavior of a Cylindrical Liquid Storage Tank subjected to Seismic Excitation, International journal of steel structures, 16(3), PP. 935-945, 2016.

[135] HRN EN 206-1:2006, Concrete - Part 1: Specification, performance, production and conformity (includes amendments A1:2004 and A2:2005).

[136] ENV 1998-1-1/2/3 Eurocode 8: Design of for earthquake resistance - part 1: general rules, seismic actions and rules for buildings. Brusseles: European Committee for Standardization, 2004.

[137] European

Strong-Motion

Data

(ISESD), http://www.isesd.hi.is/ESD_Local/frameset.htm

[138] Ibrahim, R.A., Liquid Sloshing Dynamics: Theory and Applications, Cambridge University Press, 2005. 